\title{
STRUCTURAL MICROMETEOROID AND RADIATION SHIELDING FOR INTERPLANETARY SPACECRAFT
}

\author{
A Thesis \\ presented to \\ the Faculty of California Polytechnic State University \\ San Luis Obispo
}

\author{
In Partial Fulfillment \\ of the Requirements for the Degree \\ Master of Science in Aerospace Engineering
}

by

Jared Allen Ruekberg

April 2015 
(C)2015

Jared Allen Ruekberg

ALL RIGHTS RESERVED 


\section{COMMITTEE MEMBERSHIP}

TITLE:

Structural Micrometeoroid and Radiation Shielding for Interplanetary Spacecraft

AUTHOR: $\quad$ Jared Allen Ruekberg

DATE SUBMITTED: April 2015

COMMITTEE CHAIR: $\quad$ Faysal Kolkailah, Ph.D.

Professor of Aerospace Engineering

COMMITTEE MEMBER: Kira Abercromby, Ph.D.

Assistant Professor of Aerospace Engineering

COMMITTEE MEMBER: Eltahry Elghandour, Ph.D.

Lecturer of Civil Engineering

COMMITTEE MEMBER: Eric Christiansen, Ph.D.

NASA Micrometeoroid and Orbital Debris Protection Lead 


\begin{abstract}
Structural Micrometeoroid and Radiation Shielding for Interplanetary Spacecraft Jared Allen Ruekberg
\end{abstract}

This paper focused on two significant space forces that can affect the success of a spacecraft: the radiation and micrometeoroid environments. Both are looked at in the context of the region of space between Earth and Mars. The goal was create reference environments, to provide context to results of environmental modeling, and to provide recommendations to assist in early design decisions of interplanetary spacecraft.

The radiation section of this report used NASA's OLTARIS program to generate data for analysis. The area of focus was on the radiation effects for crewed missions, therefore effective dose equivalent was the metric used to compare different models of radiation and shielding. Test spheres with one, two, or three different materials layers were compared, along with modifiers such as alloys or weight vs. thickness emphasis. Results were compared to limits set by the European and Russian Space Agencies to provide context. The results hinged heavily on the intensity of the Solar Particle Events (SPEs), with testing using additional temporary radiation shielding proving to be a requirement for feasible shielding masses. Differences in shield material effectiveness were found to be negligible for thin Galactic Cosmic Rays (GCRs) and thick SPEs. Thick shields were found to perform better when the more efficient shield was on the outside of the test sphere.

The micrometeoroid section used equations and programs from multiple sources to generate state vectors, flux, and finally impact models for four different case studies. Impacts 
were generated with mass, velocity, and impact angle/location statistics. The mass and velocity results were run through statistical software to generate information such as mean and standard deviation with confidence intervals. Also looked at were higher mass impacts, limited to above $10^{-3}$ grams as opposed to above $10^{-6}$ for the regular case. The results of this show that very thin monolithic shields $(0.1 \mathrm{~cm}-0.25 \mathrm{~cm})$ could protect against the average $10^{-6}$ impact. The Ram, Nadir, and Anti-sun faces received the highest quantity of impacts and Wake received the least. When looking at the worst cases average mass and velocity for the high mass impacts significantly higher shielding was required to prevent penetration (up to $5 \mathrm{~cm}$ for some cases). However, the test cases had probabilities of no high mass impacts greater than $46 \%$ of the time, with shorter mission having greater chances of no high mass impacts. 


\section{ACKNOWLEDGMENTS}

I would like to thank my parents, who gave me the love and support to follow my

dreams. I would also like to thank all the teachers along the way who guided me to my goals.

Finally I would like to thank my friends who served as advanced readers and helped shaped the final form of this document. 


\section{TABLE OF CONTENTS}

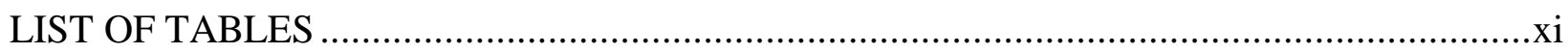

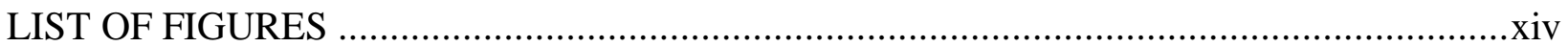

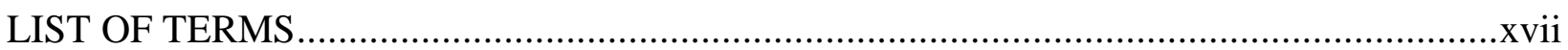

\section{CHAPTER}

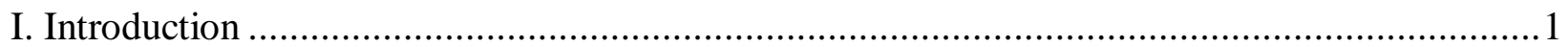

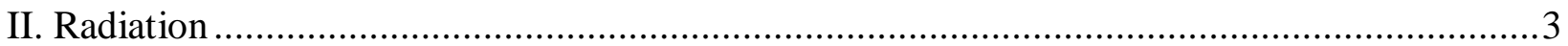

Radiation Background ................................................................................................

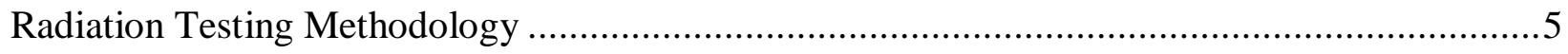

Effective Dose Equivalent and Effects on Crew Health ............................................... 10

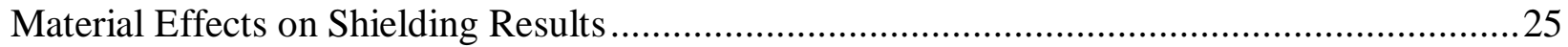

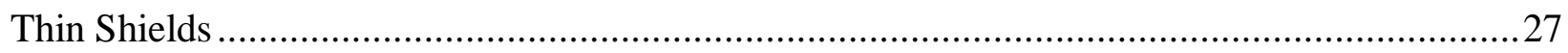

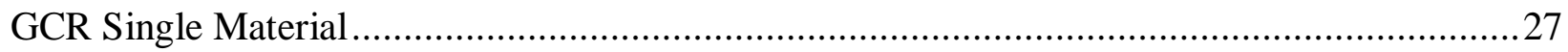

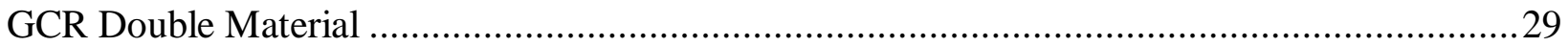

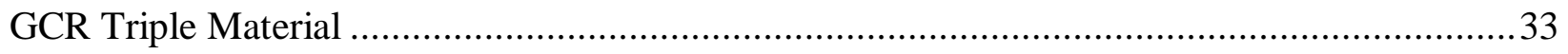

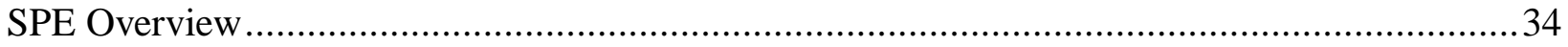

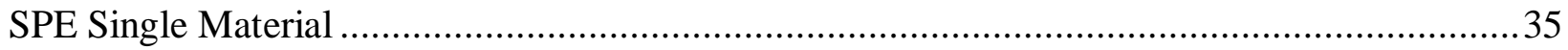


SPE Double Material

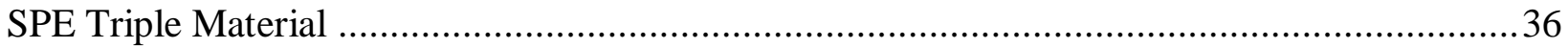

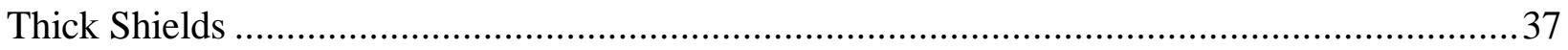

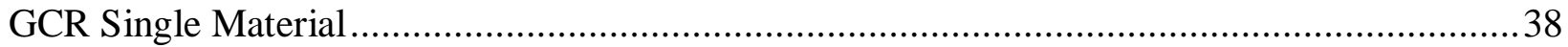

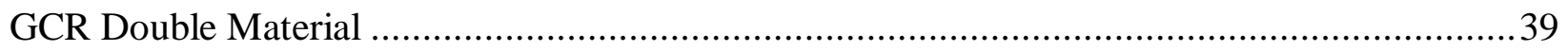

GCR Triple Material ............................................................................................ 43

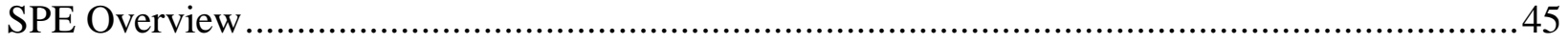

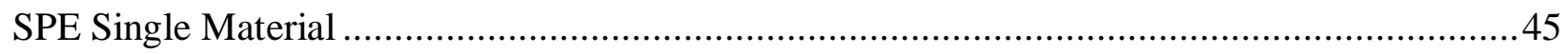

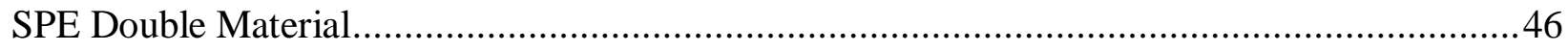

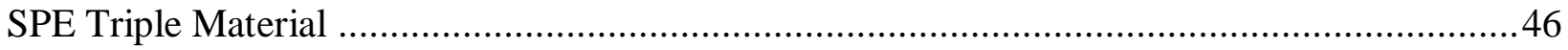

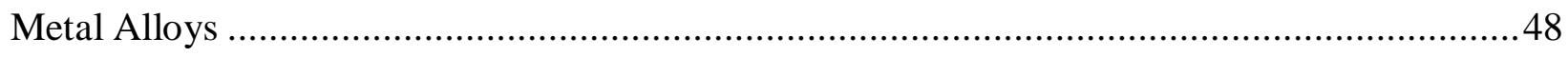

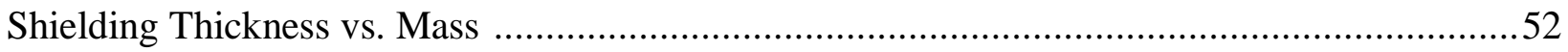

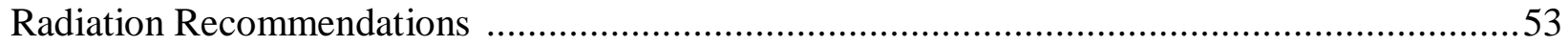

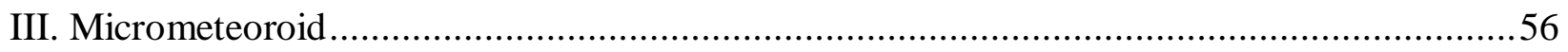

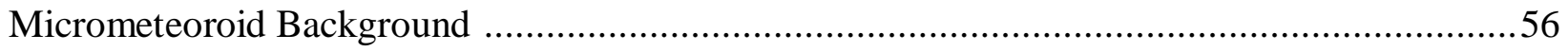

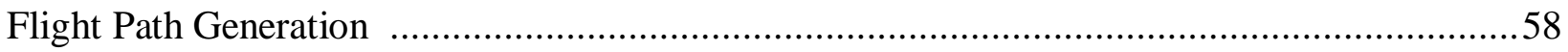


Flux Generation

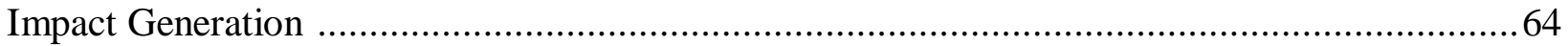

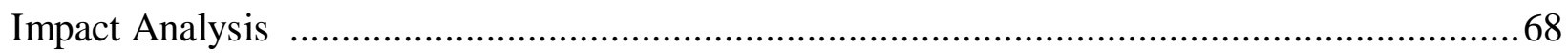

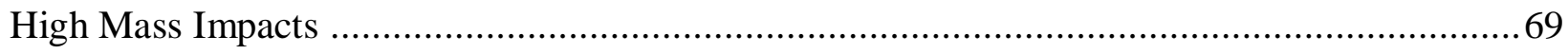

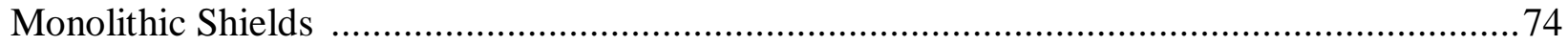

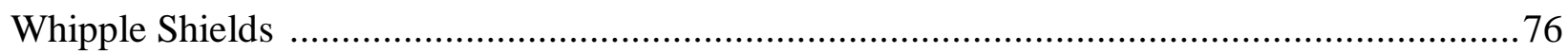

Effect of Minimum Mass on Mass Distribution ........................................................... 79

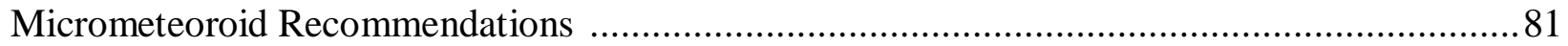

IV. Combined Shielding ….................................................................................... 83

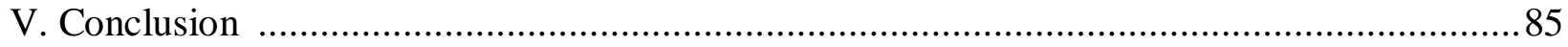

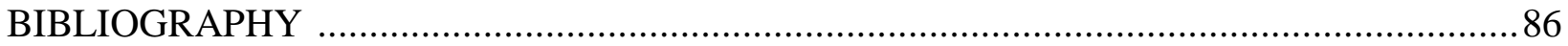

\section{APPENDICES}

A. Carbon Fiber Test Spheres for EDE Comparisons ….................................................. 88

B. Material Effect Plots ................................................................................................ 90

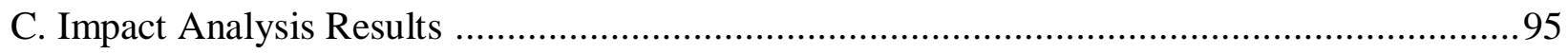

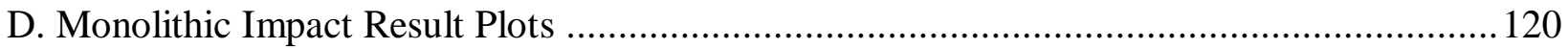

E. Whipple Impact Critical Diameter Plots ............................................................. 130 


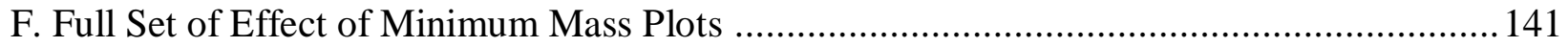




\section{LIST OF TABLES}

1. European and Russian Space Agency Radiation Limits .11

2. Organ Dose Equivalent Variance for 1 Inch Thick Aluminum Sphere Exposed to 1956 Solar Minimum Year 13

3. Organ Dose Equivalent Variance for 1 Inch Thick Aluminum Sphere Exposed to 1956 Solar Minimum Year with Averaged SPE Event 14

4. Result and Limit Comparison, 1 Inch Thick Aluminum Spheres 15

5. Limit Pass/Fail for 1 Inch Thick Aluminum Spheres 15

6. Aluminum First Pass 16

7. Carbon Fiber First Pass 17

8. Aluminum and Polyethylene First Pass 17

9. Carbon Fiber, Water, and Aluminum First Pass 18

10. Aluminum 50\% Reduced SPE First Pass 20

11. Aluminum $70 \%$ Reduced SPE First Pass 20

12. Carbon Fiber 50\% Reduced SPE First Pass .21

13. Carbon Fiber 70\% Reduced SPE First Pass 21

14. Aluminum Total Passes .23 
15. Carbon Fiber Total Passes

16. Aluminum Total Passes, 168 Day Mission Duration .24

17. Aluminum Total Passes, 210 Day Mission Duration .24

18. Aluminum Total Passes, 501 Day Mission Duration with Single SPE Event 24

19. Aluminum Total Passes, 501 Day Mission Duration with Double SPE Event .24

20. Material Effectiveness Rankings for Thick and Thin Spheres .27

21. Best Radiation Material Per Category .54

22. First Five State Vectors for Mariner 9. .61

23. Constants for Grun Interplanetary Flux Equation .62

24. Sample Flux for Mariner 9 V1 65

25. Impact Statistics on the Wake Face for Mariner 9 V11

26. Mariner 9 Averaged Results .68

27. Ram Face Averaged Results 69

28. MRO High Mass Impact Results .70

29. Mariner 9 High Mass Impact Results 70

30. Hohmann1 High Mass Impact Results 70

31. Hohmann2 High Mass Impact Results .71 
32. High Mass Impact Percentage Results

33. MRO High Mass Impacts Mass and Velocity Results .73

34. Mariner 9 High Mass Impacts Mass and Velocity Results .73

35. Hohmann1 High Mass Impacts Mass and Velocity Results .73

36. Hohmann2 High Mass Impacts Mass and Velocity Results .73

37. Overall High Mass Impacts Mass and Velocity Results .74

38. Material Specific Properties for Aluminum 6061-T6 and Titanium Ti-6Al-4V .76

39. Bin Ranges and Colors for Whipple Shield Results .77 


\section{LIST OF FIGURES}

1. Solar Particle Event Results on Tissue Shielded with 1/16 Inch Thick Polypropylene

2. Comparison of SPE Environments Used

3. Diagram of Rays for Transport Module .7

4. Comparison of Tissue Models for Aluminum Spheres for GCR Solar Minimum,

Maximum, and SPE Environments 10

5. ISO Standard Shipping Container Dimensions 19

6. Results of Scaling Material Test .26

7. Thin Single Material Comparison for GCR .28

8. Thin Double Material Comparison for GCR 30

9. Thin Double Material Order Comparisons .31

10. Aluminum and Water Hybrid Shields for 1991 Solar Maximum per Year

11. Thin Triple Material Comparison for GCR .34

12. Thin Single Material Comparison for SPE .35

13. Thin Double Material Comparison for SPE .36

14. Thin Triple Material Comparison for SPE .37

15. Thick Single Material Comparison for GCR .39 
16. Thick Double Material Comparison for GCR

17. Thick Double Material Order Comparisons 42

18. Aluminum and Water Hybrid Shield Percentage Comparison

19. Thick Triple Material Comparison for GCR 44

20. Thick Single Material Comparison for SPE .45

21. Thick Double Material Comparison for SPE .46

22. Thick Triple Material Comparison for SPE .47

23. Aluminum Alloy Comparison for Multiple Environments .49

24. Titanium Alloy Comparison for Multiple Environments .51

25. Thickness vs. Area Density Comparison for 1991 Solar Max Year .53

26. Monolithic and Whipple Shields .56

27. Impact Dynamics on Monolithic and Whipple Shields .57

28. Spacecraft Flight Path and Acting Forces .58

29. Hohmann Transfer Orbits 60

30. Faces of a Spacecraft .63

31. Visual Reference for Impact Statistics .67

32. Impact Results Plot for Aluminum Shield .75 
33. Impact Results Plot for Titanium Shield

34. Critical Particle Diameter for Modulated Bumper Thickness

35. Critical Particle Diameter for Modulated Wall Thickness

36. Mean Varying with Minimum Mass 80

37. 10\% Quartile Varying with Minimum Mass 80

38. 90\% Quartile Varying with Minimum Mass .81

39. Critical Particle Diameter for $0.75 \mathrm{~cm}$ Wall Thickness .83 


\section{LIST OF TERMS}

$\mathrm{Al} \quad=$ Aluminum

AU $\quad=$ Astronomical Unit, unit of distance based on the distance between the Earth and Sun

BFO $=$ Blood Forming Organs

$\mathrm{CF}=$ Carbon Fiber

EDE $\quad=$ Effective Dose Equivalent, tissue weighted sum of equivalent doses representing stochastic health effects

ESA $\quad=$ European Space Agency

GCR $\quad=$ Galactic Cosmic Rays

$\mathrm{H} 2 \mathrm{O}=$ Water

Kevlar $\quad=$ Synthetic fiber often woven into sheets, has high tensile strength to weight ratio

MAX = Male Adult voXel 2005, model used to determine EDE results

MEMR2 = Meteoroid Engineering Model Release 2, NASA program for determining the flux of meteoroids

MRO = Mars Reconnaissance Orbiter

NCRP = National Council on Radiation Protection and Measurements

Nomex $\quad=$ Flame resistant synthetic material often used in both fiber and sheet forms 


$\begin{array}{ll}\text { OLTARIS } & =\text { On-Line Tool for the Assessment of Radiation in Space, NASA software } \\ \mathrm{PE} & =\text { Polyethylene } \\ \mathrm{RSA} & =\text { Russian Space Agency } \\ \mathrm{SPE} & =\text { Solar Particle Events } \\ \mathrm{Sv} & =\text { Sievert, metric derived unit of ionizing dose } \\ \mathrm{Ti} & \quad \text { chitanium } \\ \mathrm{eV} & =\text { Electron Volt, unit of energy equal to one volt multiplied by the elementary }\end{array}$




\section{Introduction}

When designing a product on Earth, the environment it will be used in is an important consideration when trying to maximize the efficiency and lifespan of the product. If the operational environment is warm, is cooling of the machine going to be required? Similarly, will it need to be heated if it will be operating in the cold? Will it need to be coated to prevent the effects of humidity? Will it need dampening for vibration? These questions are an important part of the design process.

The space environment is no different, though a bit more extreme than most of those on earth. An orbit can induce both extreme heat and extreme cold on a spacecraft, with the added difficulty of dispersing heat without convection. Coatings might be required to reduce the effects of atomic oxygen or radiation. Since there will be a large amount of vibration on launch, so how can it be dampened? Ignoring any of these factors could result in reduced performance or even early failure of a spacecraft.

This paper chose to look at two of these environments in detail: radiation and micrometeoroid. The focus was on only the interplanetary versions of each environment, away from the benefits and complications of planetary bodies. As there are comparatively few spacecraft that pass beyond the orbit of earth, the environments are less well known and engineers are forced to rely more on modeling than field testing.

Therefore the first goal of this paper was to generate environmental models for use in the preliminary design of interplanetary spacecraft. For example, a systems engineer looking to lay out requirements for a mission from Earth to Mars could use the data in this paper, with modifiers for mission specific parameters such as travel duration, to set tentative limits and other specifications for the varying subsystem groups. This baseline could be refined after the project had advanced further through the planning and design phases.

The second goal of the paper was to provide context for the results generated by the models. Without understanding how results can interact with the spacecraft and its crew, accurate design decisions cannot be made. Providing context also allows for verification of models. Had the results of the tests run for this paper come back with exposures on the level of $100 \mathrm{~Sv}$, it would be a sign of an error somewhere in the process as the career limits

for spacefarers as set by the European and Russian Space Agencies (discussed later in the radiation section) is $1 \mathrm{~Sv}^{8}$ 
The third goal of the paper was to provide a few solid recommendations for easily implementation. While the attached data in this paper can be used to build other models for simulations, sometimes a simple set of recommendations can be helpful. This is especially true for the early planning stages where one might not have the need or ability to run in depth calculations. The recommendations may also give ideas for other, non-structural, methods of shielding spacecraft. 


\section{Radiation}

\section{Radiation Background}

Outside the safety of our planet's electromagnetic field, radiation can cause both short- and long-term problems for spacefaring humans in addition to damaging electrical components. This radiation comes in three main types from two general sources, each interacting with the others.

The first type of common space radiation is Galactic Cosmic Rays (GCRs). These high energy particles are the far flung results of supernova explosions, neutron stars, pulsars, and other high energy phenomena. They enter the heliosphere (immense magnetic field bubble that contains our solar system) from all directions. GCRs are mostly comprised of high energy protons (roughly $85 \%$ ) and alpha particles (helium nuclei, $14 \%$ ). ${ }^{5}$ Electrons and heavier nuclei compose the rest.

The second common source of space radiation is the sun. The sun emits a constant flow of charged particles. This process is cyclic, with fluctuations between high and low activity over a solar cycle period of around eleven years. This outward flow of particles interacts with the inbound GCRs. When the flow of solar wind peaks at a solar maximum, the GCR flow dwindles to a lesser intensity as fewer particles are able to enter the heliosphere. The reverse happens at solar minimum, with an increased GCR intensity due to a slacking of the solar wind flow. However, due to its low energy (on the range of $100 \mathrm{eV}$ to $3.5 \mathrm{KeV}$ ), solar wind is easy to shield against. ${ }^{5}$ Even with minimal shielding the radiation can only penetrate a few microns of skin.

Solar Particle Events (SPEs), the third type of radiation, are a much more dangerous form of sun based radiation. These events occur when localized areas of the sun let out large bursts of wide frequency radiation, during solar flares for example. Unlike GCRs, which have a fairly constant and predictable flow, SPEs are dangerously variable. The timing of SPEs is unpredictable, though they average one a month. Between the last SPE large enough to be detected by terrestrial sensors in solar cycle 21 and the first in cycle 22 there was a 65 month dead zone. ${ }^{5}$ This was followed by 11 of these large events in the next year. SPEs are more likely in periods of high solar activity during the solar cycle. 
The intensity of the SPEs can also vary, ranging up to several GeV. Several SPEs powerful enough to do significant damage to equipment and crew have been observed since 1955. These include February 1956, November 1960, August 1972, and several events in the fall months of 1989..$^{5,18}$ Figure 1 shows the effective dose equivalent (EDE, in units of $\mathrm{mSv}$ ) for each of these events on a human male model (MAX, see next section) wearing a 1/16 inch thick polypropylene layer. The results ranged from just over half a Sv at the lower end to over three Sv, from career ending to possibly lethal. The variability of SPEs is another reason they are such a risk.

For some events there were two models from different sources. For example there were models of the Feburary 1956 event from both Webber and LaRC (the Langley Research Center). One 1956, the November 1960, and one 1972 were from the LaRC. The 1989 events were all from the National Oceanic and Atmospheric Administration (NOAA). The Webber model was from a paper written by W.R. Webber of the aerospace division of Boeing in 1963. The King model was written by J.H. King for the Journal of Spacecraft and Rockets in 1974.

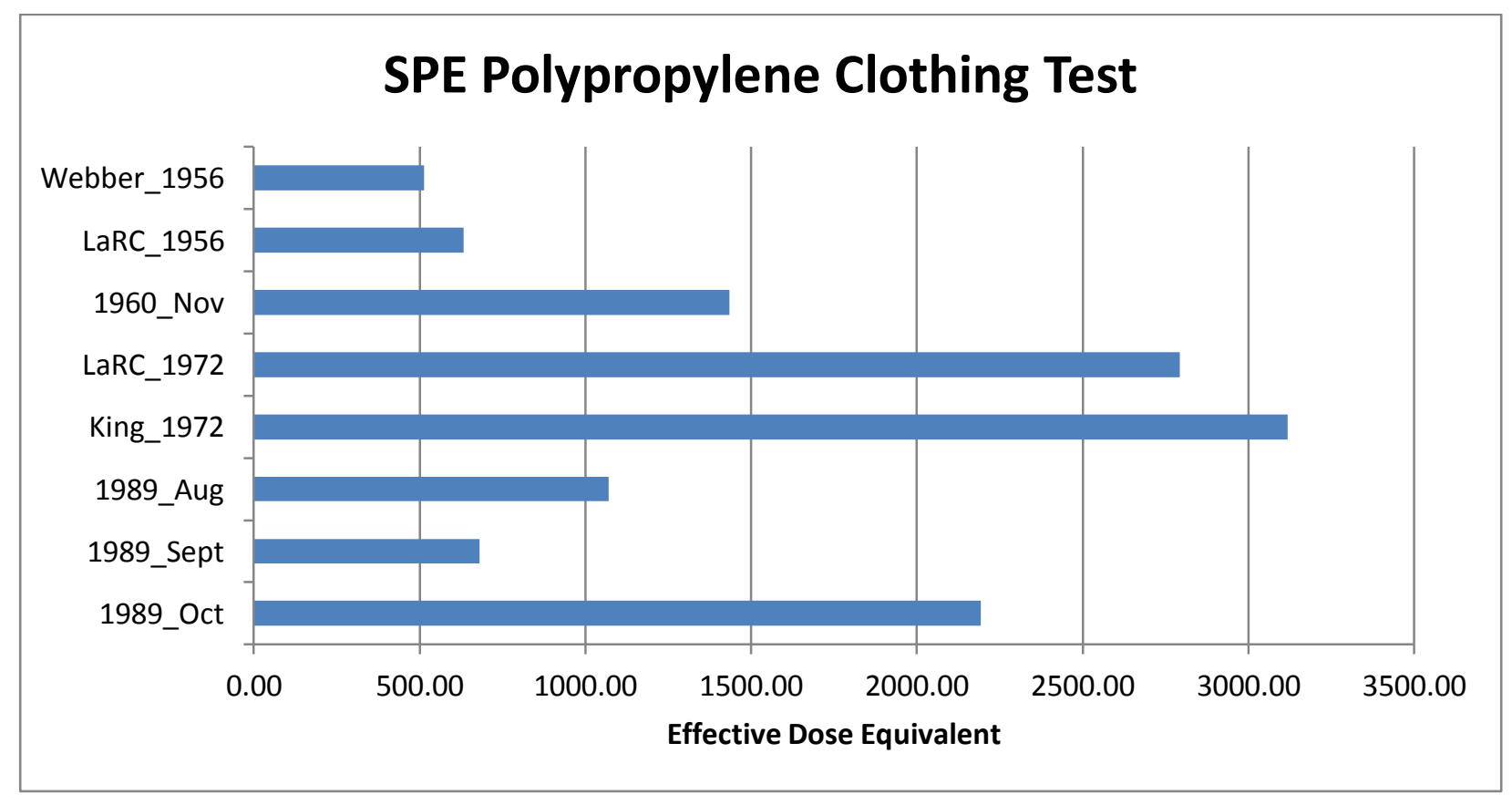

Figure 1. Solar Particle Event Results on Tissue Shielded with 1/16 Inch Thick Polypropylene 


\section{Radiation Testing Methodology}

The radiation analysis performed for this thesis utilized NASA's On-Line Tool for the Assessment of Radiation in Space (OLTARIS).$^{18}$ OLTARIS is an online toolset that utilizes HZETRN (High Charge and Energy Transport) to study the effects of space radiation on biological, silicon, and shielding materials.

OLTARIS is designed to work in a modular fashion. After determining the input boundaries (GCR, SPE, trapped protons, etc.) it starts by calculating the energy spectrum for that particular environment. The spectra from SPEs are calculated using different equations for each preset (ex. Webber 1956, November 1960, September 1989, etc). For those who wish to look at these equations, they can be found on pages 9-11 of OLTARIS: On-Line Tool for the Assessment of Radiation in Space. ${ }^{21}$ Due to the ITAR controls on some of this material, they cannot be listed here.

The GCR model used in OLTARIS was developed by O'Neill in $2010 .{ }^{21}$ The model uses data from balloon and satellite measured energy spectra. The model provides a single value of the deceleration parameter, which describes the modulation of the solar cycle and determines the GCR differential energy spectrum for a range of elements. It is possible to choose any start and end dates for calculations after the year 1951, but in the experiments below two of the preset scenarios were used.

For the GCR tests, data was collected from both the 1956 solar minimum and the 1991 solar maximum of the Badhwar-O'Neill 2010 model. The SPE tests were mostly done with an "averaged" case of two February 1956 events (Webber and LaRC) and two August 1972 events (LaRC and King). The four cases and the average can be seen in Fig. 2. This composite SPE environment was recommended as a worst case event by Xapsos et al, which was also the recommendation source for the GCR years. ${ }^{24}$ Additional tests were done with pure Webber 1956 or King 1972, to give bounds to the averaged data.

All of these cases looked at the interplanetary radiation environment between 1 and 2 AU. There was not shielding from planetary sources such as the Van Allen Belts.

It is estimated that the uncertainty of the GCR spectrum given by the OLTARIS models is approximately

$15 \%{ }^{18}$ The uncertainty in the SPE spectrum could be much higher. The error from the transport codes is expected 
to be less than $25 \%$. For thicker shields, this accuracy drops further due to uncertainties in the radiation physics models. Though even for the thickest shields, the uncertainty is less than a figure of two.

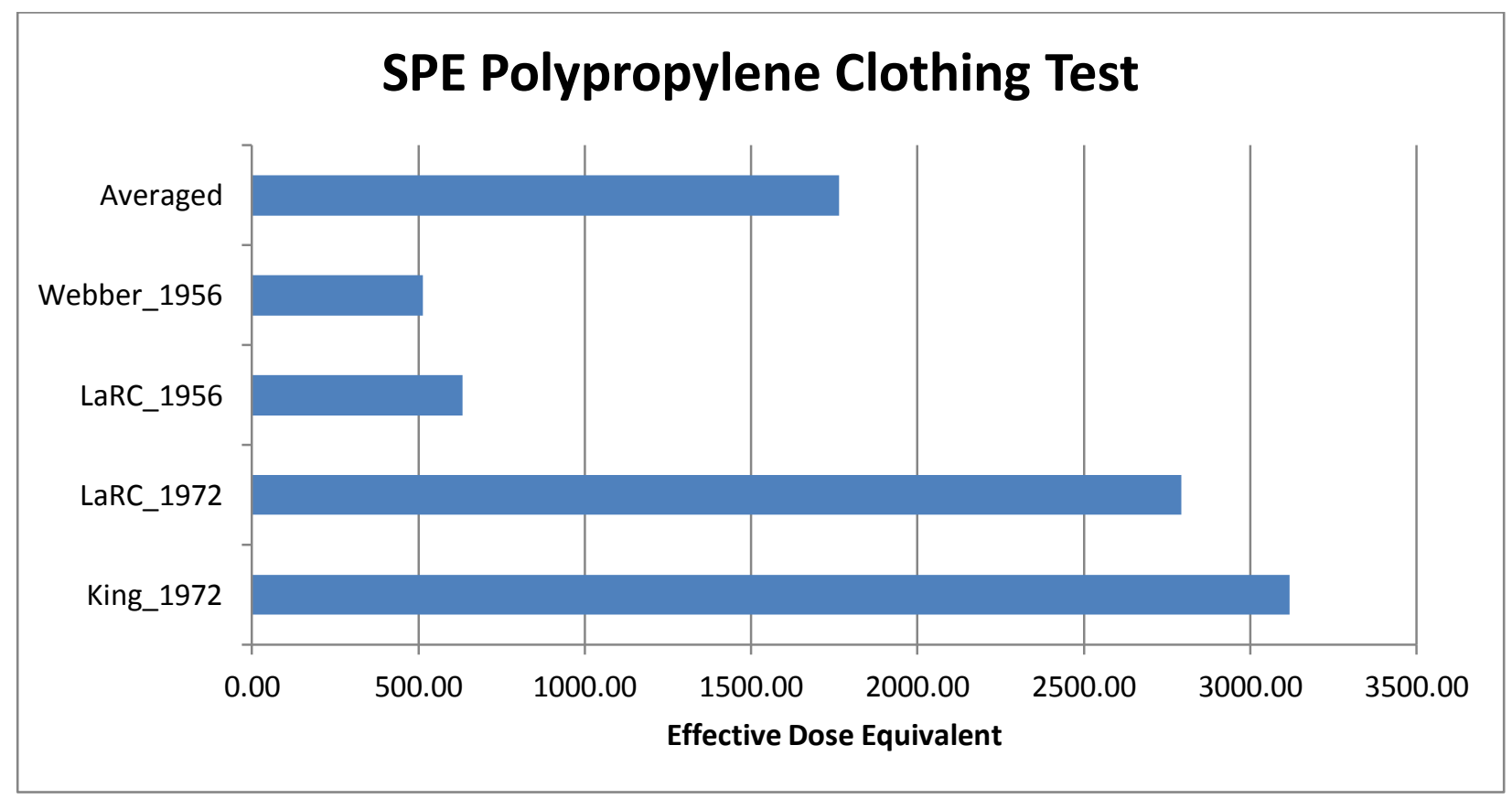

Figure 2. Comparison of SPE Environments Used

After the energy spectra were calculated, OLTARIS next propagated the particles through a combination of structure/shielding and tissue as part of the particle transport module. ${ }^{21}$ The test geometries used for this paper were spheres of varying thickness as seen in Fig. 3. Test rays radiated out from a single point (the target point) and into the test sphere at different angles. Due to the difference in angle for each ray, the total amount of shielding the ray would pass through was variable. OLTARIS also had the option of performing analysis on plates, but this method was incapable of performing the effective dose equivalent calculations desired. The majority of the spheres were set at specific thicknesses between 0.1 inches and 20 inches. A few special cases were done with spheres of up to 10 meters, but this was done as a solo test to see if the EDE could be reduced down to terrestrial limits.

In cases where there was more than one test material, the listed order of the materials was the order the radiation had to pass through. For example an aluminum and carbon fiber shield had aluminum on the outside and carbon fiber on the inside. For each set thickness level, the total thickness was divided evenly between the materials (rounding down). In the carbon fiber and aluminum hybrid shield at the twenty inch thick level, ten inches of carbon 
fiber was sandwiched next to ten inches of aluminum on the inside. Meanwhile the Kevlar-water-aluminum hybrid had three 6.66 inch thick layers (one for each material) for the same twenty inch thick level. The exception to this was a set of tests done to evaluate the effectiveness of the hybridization. These tests had ratios of 1/4-3/4 in addition to the standard $1 / 2-1 / 2$ or $1 / 3-1 / 3-1 / 3$.

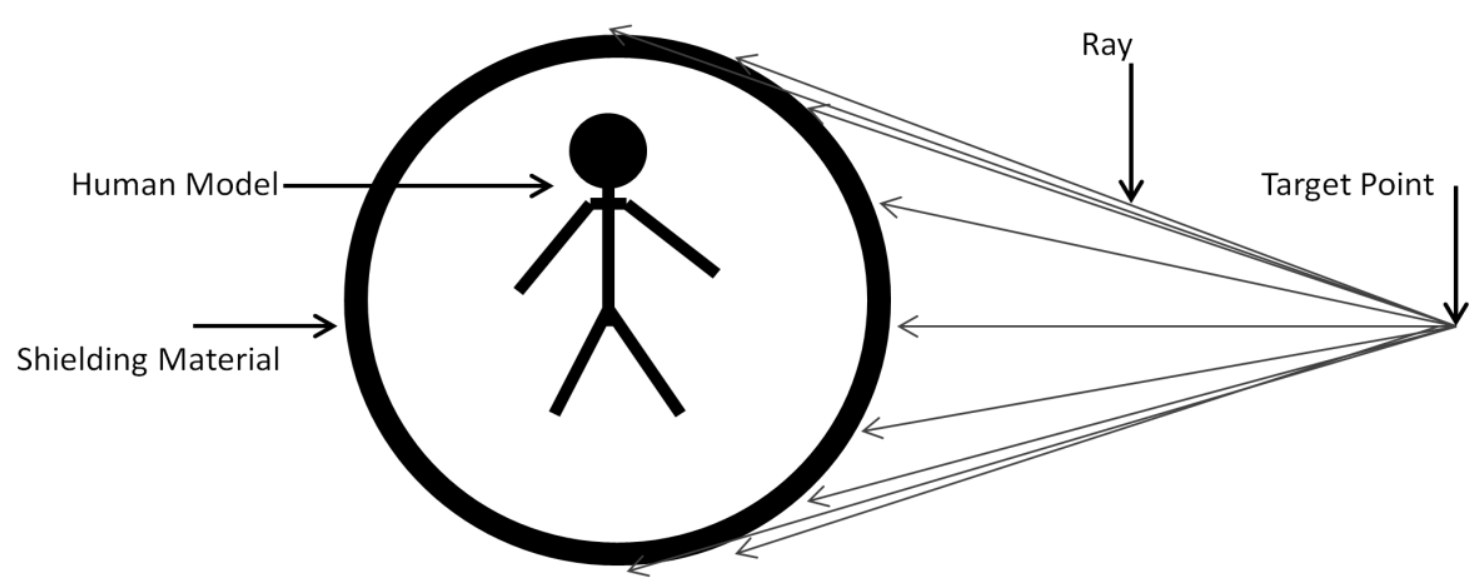

Figure 3. Diagram of Rays for Transport Module

The transport module used by OLTARIS is a modified version of HZETRN2005. ${ }^{21}$ The algorithms provide an approximate numerical solution to the linearized Boltzmann transport equation. Both the Continuous Slowing Down Approximation (CSDA) and straight ahead approximation are used. These assumptions allow the flow of particle interactions to be expressed as a continuous, one dimensional flow. The equation used was:

$$
\left[\frac{\delta}{\delta x}-\frac{1}{A_{j}} \frac{\delta}{\delta E} S_{j}(E)+\sigma_{j}(E)\right] \phi_{j}(x, E)=\sum_{k} \int_{E}^{\infty} d E^{\prime} \sigma_{k \rightarrow j}\left(E^{\prime} \rightarrow E\right) \phi_{k}\left(x, E^{\prime}\right)
$$

with the boundary condition:

$$
\phi_{j}(0, E)=f_{j}(E)
$$

where $\phi_{j}(x, E)$ is the flux or fluence of type $j$ particles at depth $x$ with kinetic energy $E$. $A_{j}$ is the atomic mass number of a type $j$ particle, $S_{j}(E)$ is the stopping power of a type $j$ ion with kinetic energy $E, \sigma_{j}(E)$ is the total 
macroscopic cross section for a type $j$ particle with kinetic energy $E$, and $\sigma_{k \rightarrow j}\left(E^{\prime} \rightarrow E\right)$ is the macroscopic production cross section for interactions in which a type $k$ particle with kinetic energy $E^{\prime}$ produce a type $j$ particle with the kinetic energy $E$. The left side of the equation is known as the Boltzmann operator and the right either the scattering kernel or collision operator. Further discussion of this equation can be found on page 14 of OLTARIS: OnLine Tool for the Assessment of Radiation in Space. ${ }^{21}$ The end result is a flux or fluence spectrum as a function of particles and energies.

These spectra are used to calculate the dose equivalent, which looks at the stochastic effects (ex. cancer mortality) of the radiation on humans. To calculate the effective dose equivalent (EDE), the doses for multiple organs are weighted and averaged together. The weights factor in organ size and susceptibility to damaging effects of radiation. OLTARIS uses four different models for this calculation: Computerized Anatomical Female (CAF), Computerized Anatomical Male (CAM), Female Adult voXel (FAX), and Male Adult voXel (MAX) . They vary slightly; for example the different organs considered for males and females (testes and prostate vs. ovaries and uterus). Another example is that the CAF and CAM models combine the colon, small intestine, and large intestine together into one organ for calculations, while the FAX and MAX separate out the small intestine. The one used for this paper was MAX. The output of the model is a value in milliSieverts (mSv) that can be compared to limits. The higher the value, the more damage was done. When two comparison tests were run using sets of aluminum and carbon fiber spheres, the four models diverged at very thin values, but converged at thicker values. This can be seen in the aluminum spheres in Fig. 4. The MAX data icon is often buried under the one for FAX as the results are so close. For the GCR plots it's nearly invisible, only showing up at very thin points. It returns values higher than FAX for SPE thin shields, but all four shields quickly converge with increasing thickness.

The carbon fiber spheres can be seen in Appendix A. 


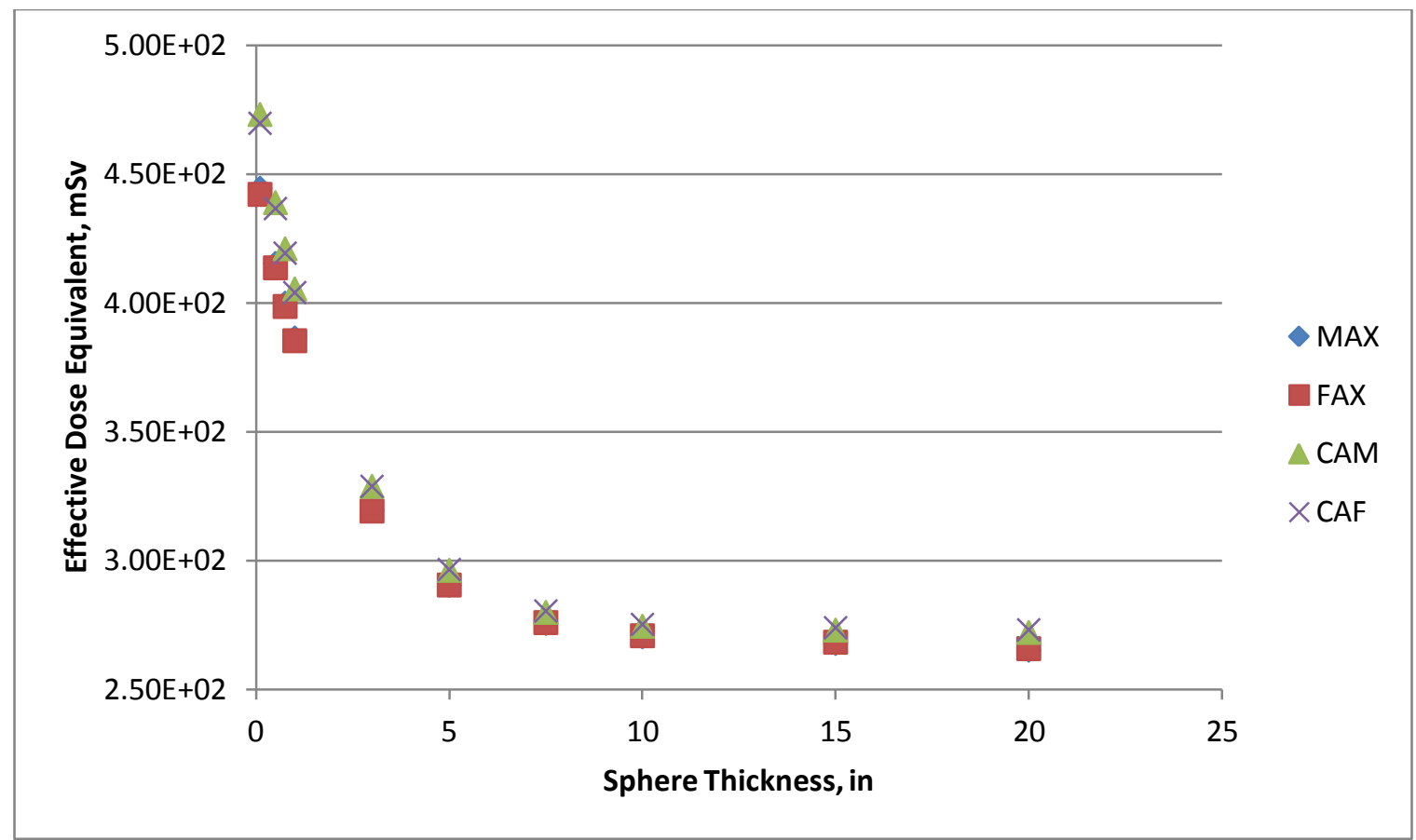

a) GCR Solar Minimum

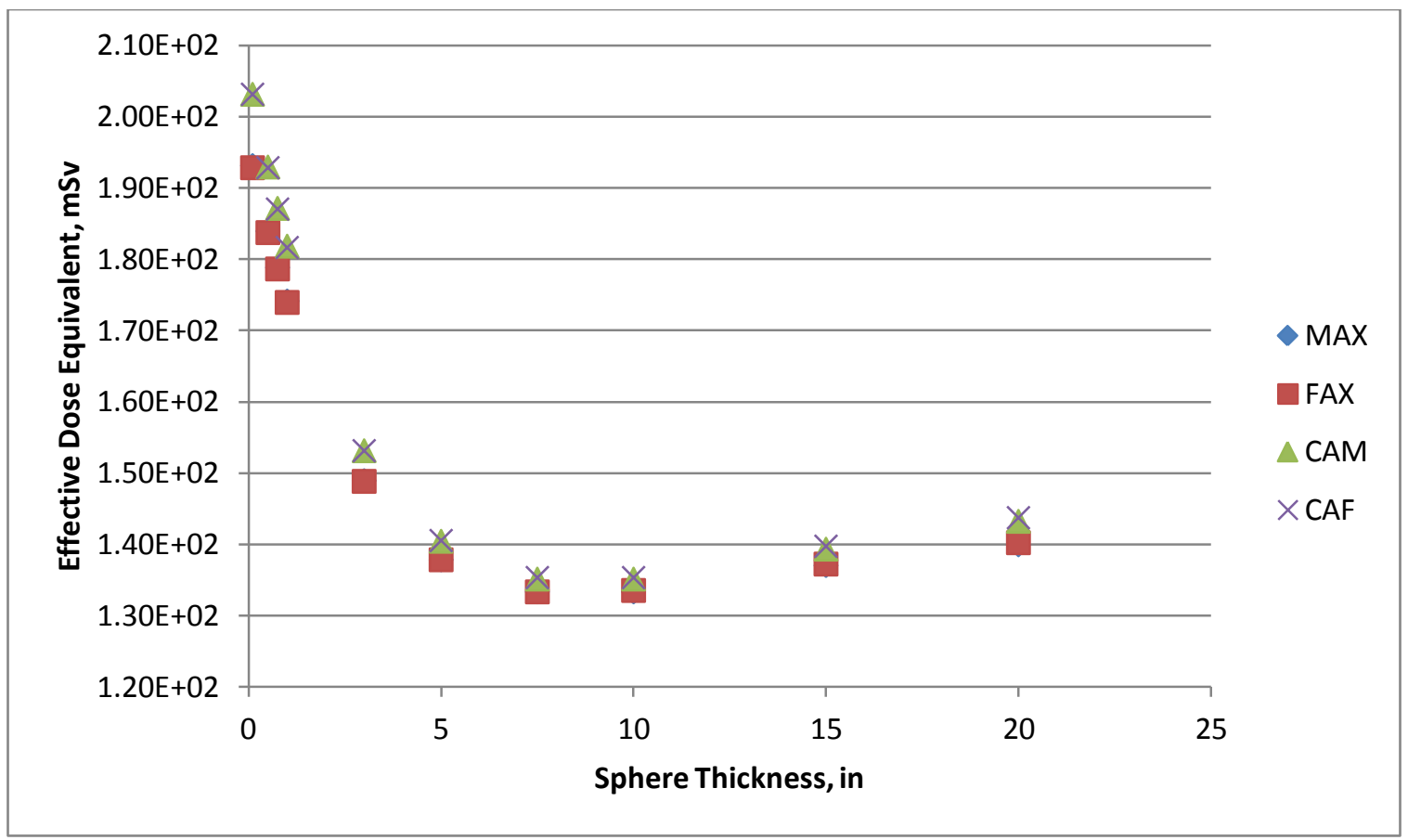

b) GCR Solar Maximum 


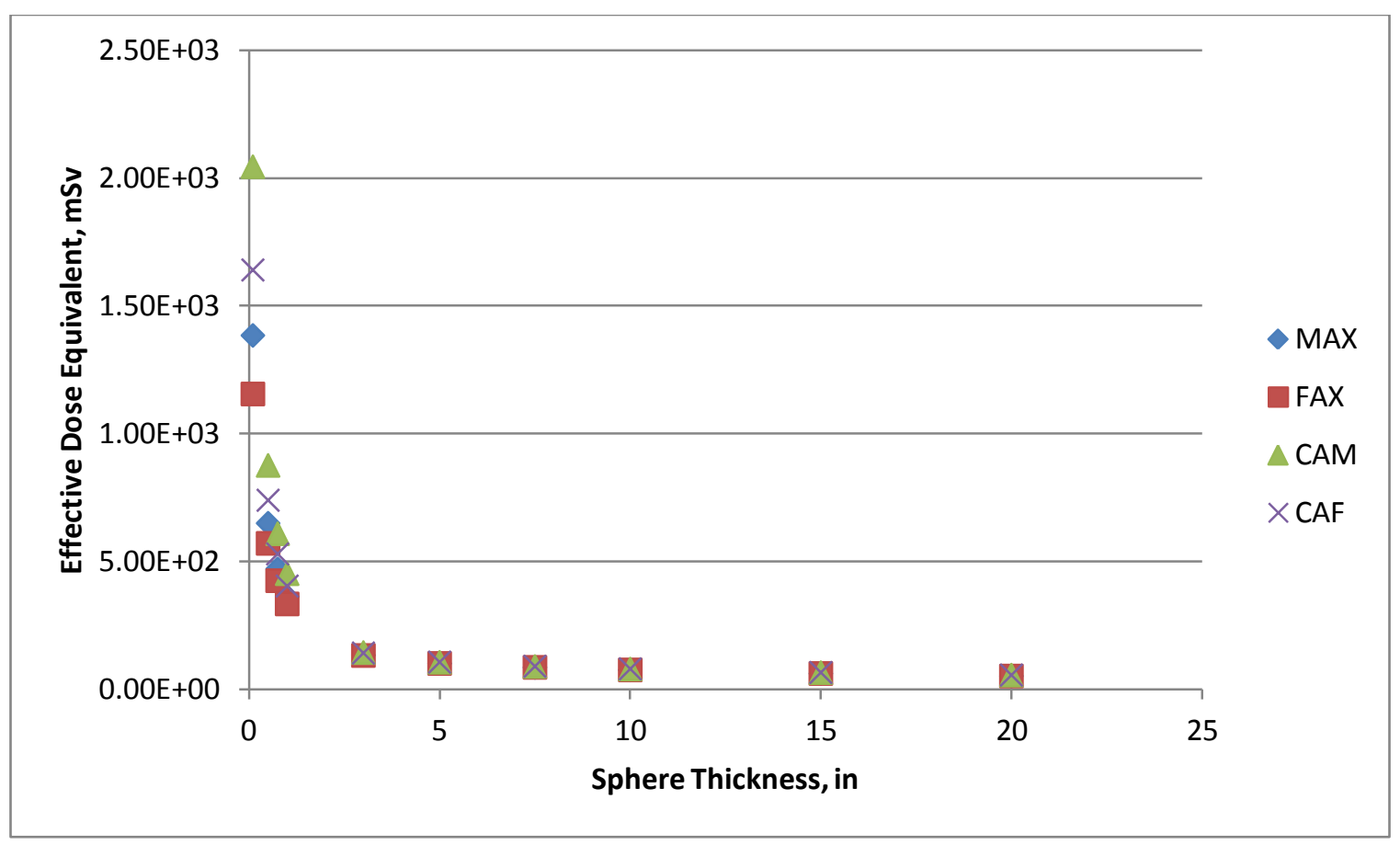

c) Solar Particle Event

Figure 4. Comparison of Tissue Models for Aluminum Spheres for GCR Solar Minimum, Maximum, and SPE Environments

\section{Effective Dose Equivalent and Effects on Crew Health}

There is no ironclad guide to how much radiation is required before detrimental effects can occur in the human body. There are too many influencing factors such as age, gender, and family history. Present guidelines have evolved over time as more knowledge of the radiation effects on the human body has accumulated. The initial guideline, written by the National Academy of Sciences (NAS) in 1970, used a doubling dose limitation. ${ }^{8}$ A doubling dose is the amount of radiation required to double the incidents of stochastic events (randomized negative effects, such as cancer). By looking at the natural probability of cancer over a period of 20 years following radiation exposure, NAS determined an estimated doubling dose of $3.82 \mathrm{~Sv}$. This was later rounded to 4 Sv. However, over time it was discovered that leukemia was not the only major risk from radiation exposure as was previously believed. This discovery came from examining the survivors of the nuclear bombs dropped on Japan.

In the early 1980's NASA turned to the National Council on Radiation Protection and Measurements (NCRP) to refine its dose limits. ${ }^{8}$ They returned with Report 98, which laid out age and gender dependent dose 
limits based on a $3 \%$ increase in cancer mortality rates. For a comparison, the US nuclear industry uses age dependent career limits of the individual's age x $10 \mathrm{mSv}$. NCRP estimated that workers who reached their respective dose limit would see an increased risk of $3 \%$. However, most space based risks are short term ( $<2$ years), while terrestrial workers can spread out their limit over long careers. Most radiation workers receive an average of 1-2 $\mathrm{mSv}$ per year, compared to an average of $80 \mathrm{mSv}$ absorbed during a 6 month ISS mission. ${ }^{8}$ To achieve only $1-2 \mathrm{mSv}$ of space based radiation would require somewhere between 5-10 meters of aluminum shielding material or equivalent.

To put into perspective the mass required for that amount of shielding, the density of pure aluminum is $2700 \mathrm{~kg} / \mathrm{m}^{3}$. Therefore, a 7.5 meter thick aluminum shield wall would have an area density of $20,250 \mathrm{~kg} / \mathrm{m}^{2}$. That would require an entire Delta IV Medium rocket just to launch a square meter of the shield. ${ }^{10}$ Given the expense and risk of a rocket launch, clearly this is infeasible with modern rocketry limitations.

One way this could be possible would be to use mass already in orbit such as part of the moon or an asteroid. A 10 meter thick shield test with lunar regolith reduced the absorbed radiation down to 1.16 and $0.86 \mathrm{mSv}$ under averaged SPE conditions, with the variation coming between solar max and min. However this would add other complications outside the scope of this paper.

Other international organizations have their own limits for space based radiation exposure. Table 1 below contains the limits set by the European Space Agency (ESA) and the Russian Space Agency (RSA). ${ }^{8}$

Table 1. European and Russian Space Agency Radiation Limits

\begin{tabular}{|c|c|c|}
\hline Limit & ESA (Sv) & RSA (Sv) \\
\hline Career & 1 & 1 \\
\hline Blood Forming Organs (BFOs) & 0.25 for 30 Day Period & 0.15 for Acute (Single Event) \\
& 0.5 Annually & 0.25 for 30 Day Period \\
& & 0.5 Annually \\
\hline Eye & 0.5 for 30 Day Period & 0.5 for 30 Day Period \\
& 1 Annually & 2 Career \\
\hline Skin & & 1.5 for 30 Day Period \\
& 1.5 for 30 Day Period & 3 Annually \\
& 3 Annually & 6 Career \\
\hline
\end{tabular}


With the exception of the career category, the limits in Table 1 are organ specific. This is necessary as dosage can vary from organ to organ based on size, location, and susceptibility.

To compare against the limits in Table 1, several assumptions were made. The most important assumption was that this would be the only major radiation exposure the crewmember experienced. This would be their first and only spaceflight. Also they would not have had significant terrestrial radiation exposure, such as working as an Xray technician or in the nuclear industry. With the rarity of flights and proper screening, this seemed a valid assumption. If there were repeated flights or the crewmember was exposed to significant terrestrial radiation, much thicker shielding would be required to stay below limits. While repeated long-term spaceflight may one day be possible, the required mass of shielding to prevent significant damage to crewmember health and welfare is currently impractical.

The second assumption was that there would only be one major (above approximately $500 \mathrm{mSv}$ ) SPE per year. While there could be several less intense events, they would sum up to be the equivalent of a major event. All the SPEs from OLTARIS were considered major events. So while they might be referred to as weak further down this paper, it is only in the context of comparing them to the other major SPEs from OLTARIS.

Table 2 below shows a sample organ variance, based on the GCR results on a 1 inch thick aluminum sphere for 1956 solar minimum. The results are in dose equivalent (in units of mSv), which represents the stochastic health effects. Dose equivalent takes into account both the size of the organ as well as its susceptibility. The skin is large, which is why its dose equivalent value is high. The eye is much smaller, but much more impacted by radiation, which is why its dose equivalent is also high. The higher the number, the more damaging radiation effects the organ is receiving. Meanwhile, the adrenals and pancreas have relatively low dose equivalents. They both end up falling into the remainder category for effective dose equivalent calculations, along with several other middle to low dose equivalent organs. ${ }^{21}$ As this was a male model (MAX) there were testes and prostate but no ovaries or uterus in the shown data. 
Table 2. Organ Dose Equivalent Variance for 1 Inch Thick Aluminum Sphere Exposed to 1956 Solar

Minimum Year

\begin{tabular}{|c|c|c|c|}
\hline Organ & $\begin{array}{c}\text { Dose Eq. Per Year } \\
(\mathbf{m S v})\end{array}$ & Organ & $\begin{array}{c}\text { Dose Eq. Per Year } \\
(\mathbf{m S v})\end{array}$ \\
\hline EDE & 386.40 & Testes & 431.20 \\
\hline Adrenals & 333.70 & Thymus & 378.80 \\
\hline Bladder & 347.00 & Thyroid & 391.90 \\
\hline Brain & 427.50 & Prostate & 341.30 \\
\hline Colon & 361.20 & Small Intestine & 356.80 \\
\hline Heart & 378.20 & Breast & 398.70 \\
\hline Hippocampus & 413.30 & Salivary glands & 444.60 \\
\hline Kidneys & 349.50 & Esophagus & 367.40 \\
\hline Liver & 358.10 & Muscle & 416.60 \\
\hline Lungs & 398.50 & BFO & 372.00 \\
\hline Pancreas & 334.10 & Bone & 397.50 \\
\hline Skin & 529.30 & Lens & 494.00 \\
\hline Spleen & 364.90 & Retina & 447.60 \\
\hline Stomach & 362.10 & Trachea & 395.60 \\
\hline
\end{tabular}

The results of Table 2 above seem to be compliant with the limits in Table 1 . The BFOs are under the 0.5 $\mathrm{mSv}$ annual limit $(0.372 \mathrm{mSv})$, the eye (lens) is under half the limit $(0.494 \mathrm{mSv} v \mathrm{ss} .1 \mathrm{mSv})$, and the skin is a fraction of its limit ( $0.529 \mathrm{mSv}$ vs. $3 \mathrm{mSv})$. But this chart only covers the more constant GCR. SPEs must be accounted for, as they can have a significant effect on the totals. In Table 3 below, the "averaged" SPE values were added to the dose equivalent totals.

With the addition of SPEs, the EDE doubles, the dose to the skin quadruples, and the BFO and eyes are pushed well above their limits. Clearly this amount of shielding would not be sufficient without significant risk to crew health and welfare. However, as stated above, SPEs can have wildly variable impacts. Just among the sets provided by OLTARIS, the EDE can range from a little over half a Sv (Webber 1956) to over 3 Sv (King 1972) with minimal shielding. This can be seen in Table 1 several pages previously. While these were strong SPE events, they are a possibility the spacecraft might face. 
Table 3. Organ Dose Equivalent Variance for 1 Inch Thick Aluminum Sphere Exposed to 1956 Solar Minimum Year with Averaged SPE Event

\begin{tabular}{|c|c|c|c|}
\hline Organ & $\begin{array}{c}\text { Dose Eq. Per Year } \\
(\mathbf{m S v})\end{array}$ & Organ & $\begin{array}{c}\text { Dose Eq. Per Year } \\
(\mathbf{m S v})\end{array}$ \\
\hline EDE & 748.60 & Testes & 1069.70 \\
\hline Adrenals & 496.50 & Thymus & 634.90 \\
\hline Bladder & 553.50 & Thyroid & 740.70 \\
\hline Brain & 835.90 & Prostate & 524.10 \\
\hline Colon & 605.20 & Small Intestine & 584.00 \\
\hline Heart & 649.10 & Breast & 767.60 \\
\hline Hippocampus & 760.30 & Salivary glands & 1143.20 \\
\hline Kidneys & 555.30 & Esophagus & 601.40 \\
\hline Liver & 586.20 & Muscle & 868.00 \\
\hline Lungs & 729.00 & BFO & 664.80 \\
\hline Pancreas & 497.80 & Bone & 783.30 \\
\hline Skin & 2079.30 & Lens & 1551.00 \\
\hline Spleen & 611.00 & Retina & 1016.00 \\
\hline Stomach & 600.60 & Trachea & 736.70 \\
\hline
\end{tabular}

Therefore a second test was in order. This time there were three levels of SPEs. The lower bound was set with the Webber 1956 data set. The upper bound used the King 1972 data set. These models were chosen based on the results shown previously in Fig. 1. For the midpoint the "averaged" SPE was used (see Fig. 2). Both solar minimum and maximum GCR values for this test were used with aluminum spheres. These tests were performed for numerous thicknesses, such as the 1 inch thick sphere shown in Table 4 on the next page. Table 4 shows the six environmental combinations (solar maximum or minimum and low, high, or averaged SPE) for the organs listed in the ESA/RSA limits.

The results in Table 4 were then analyzed to see which values were under the ESA/RSA limits. For easy comparison, this led to a pass/fail system. If an organ was under its limit, it passed. This led to a few cases where a category was only slightly above the limit, but still failed. An example was the BFO for GCR max + SPE 1972 category. If this testing was performed again, additional thicknesses such as 1.5 or 2 inches would provide better resolution. 
Table 4. Result and Limit Comparison, 1 Inch Thick Aluminum Spheres

\begin{tabular}{|c|c|c|c|}
\hline Organ & $\begin{array}{c}\text { GCR min + } \\
\text { SPE 1956 }(\mathbf{m S v})\end{array}$ & $\begin{array}{c}\text { GCR } \mathbf{~ m i n}+ \\
\text { SPE 1972 }(\mathbf{m S v})\end{array}$ & $\begin{array}{c}\text { GCR min + } \\
\text { SPE averaged (mSv) }\end{array}$ \\
\hline $\begin{array}{c}\text { Effective Dose } \\
\text { Equivalent }\end{array}$ & 495.60 & 837.10 & 748.60 \\
\hline $\begin{array}{c}\text { Blood Forming } \\
\text { Organs (BFOs) }\end{array}$ & 462.65 & 705.00 & 664.80 \\
\hline Eye & 774.70 & 2167.00 & 1551.00 \\
\hline Skin & 914.90 & 3118.30 & 2079.30 \\
\hline Organ & GCR max + & GCR $\mathbf{m a x}+$ & GCR max + \\
SPE 1956 $(\mathbf{m S v})$ & SPE 1972 (mSv) & SPE averaged (mSv) \\
\hline $\begin{array}{c}\text { Effective Dose } \\
\text { Equivalent }\end{array}$ & 283.30 & 624.80 & 536.30 \\
\hline $\begin{array}{c}\text { Blood Forming } \\
\text { Organs (BFOs) }\end{array}$ & 258.95 & 501.30 & 461.10 \\
\hline Eye & 497.10 & 1889.40 & 1273.40 \\
\hline Skin & 614.10 & 2817.50 & 1778.50 \\
\hline
\end{tabular}

Table 5. Limit Pass/Fail for 1 Inch Thick Aluminum Spheres

\begin{tabular}{|c|c|c|c|}
\hline Organ & $\begin{array}{c}\text { GCR min + } \\
\text { SPE } 1956\end{array}$ & $\begin{array}{c}\text { GCR min + } \\
\text { SPE } 1972\end{array}$ & $\begin{array}{c}\text { GCR min + } \\
\text { SPE averaged }\end{array}$ \\
\hline $\begin{array}{c}\text { Effective Dose } \\
\text { Equivalent }\end{array}$ & Pass & Pass & Pass \\
\hline $\begin{array}{l}\text { Blood Forming } \\
\text { Organs (BFOs) }\end{array}$ & Pass & Fail & Fail \\
\hline Eye & Pass & Fail & Fail \\
\hline Skin & Pass & Fail & Pass \\
\hline Organ & $\begin{array}{c}\text { GCR max + } \\
\text { SPE } 1956\end{array}$ & $\begin{array}{c}\text { GCR max + } \\
\text { SPE } 1972\end{array}$ & $\begin{array}{c}\text { GCR max + } \\
\text { SPE averaged }\end{array}$ \\
\hline $\begin{array}{c}\text { Effective Dose } \\
\text { Equivalent }\end{array}$ & Pass & Pass & Pass \\
\hline $\begin{array}{l}\text { Blood Forming } \\
\text { Organs (BFOs) }\end{array}$ & Pass & Fail & Pass \\
\hline Eye & Pass & Fail & Fail \\
\hline Skin & Pass & Pass & Pass \\
\hline
\end{tabular}


The results in Table 4 were then analyzed to see which values were under the ESA/RSA limits. For easy comparison, this led to a pass/fail system. If an organ was under its limit, it passed. This led to a few cases where a category was only slightly above the limit, but still failed. An example was the BFO for GCR max + SPE 1972 category. If this testing was performed again, additional thicknesses such as 1.5 or 2 inches would provide better resolution.

Looking at the results in Table 5, we can see that SPE intensity can play a significant role in staying under radiation limits. While the weakest SPE conditions (1956) passed under all the limits for both solar maximum and minimum, the worst case only passed under 2 and 1 categories, respectively. Table 5 also pointed out a benefit of breaking down radiation limits to include major organs when designing radiation shielding for living crewmembers. The eye failed in 4 out of 6 categories, the ones listed in red in Table 4 . If this held true in further testing (and it did, as will be discussed below), it highlighted an area to focus on. Perhaps special eye drops could be developed that hinder radiation absorption or goggles that would further block some of the radiation. Either way, finding a way to mitigate radiation damage to the more at risk categories would lessen overall shielding required.

Table 6. Aluminum First Pass

\begin{tabular}{|c|c|c|c|}
\hline Organ & $\begin{array}{c}\text { GCR min }+ \\
\text { SPE 1956 }\end{array}$ & $\begin{array}{c}\text { GCR min + } \\
\text { SPE 1972 }\end{array}$ & $\begin{array}{c}\text { GCR min + } \\
\text { SPE averaged }\end{array}$ \\
\hline $\begin{array}{c}\text { Effective Dose } \\
\text { Equivalent }\end{array}$ & 0.1 & 1 & 1 \\
\hline $\begin{array}{c}\text { Blood Forming } \\
\text { Organs (BFOs) }\end{array}$ & 1 & 1 & 1 \\
\hline Eye & 1 & 3 & 3 \\
\hline Skin & 0.5 & 3 & 1 \\
\hline Organ & GCR max + & GCR max + & GCR max + \\
SPE 1956 & SPE 1972 & 0.5 \\
\hline $\begin{array}{c}\text { Effective Dose } \\
\text { Equivalent }\end{array}$ & 0.1 & 1 & 1 \\
\hline $\begin{array}{c}\text { Blood Forming } \\
\text { Organs (BFOs) }\end{array}$ & 0.1 & 3 & 3 \\
\hline Eye & 0.5 & 3 & 1 \\
\hline Skin & 0.5 & 1 & \\
\hline
\end{tabular}


Table 7. Carbon Fiber First Pass

\begin{tabular}{|c|c|c|c|}
\hline Organ & $\begin{array}{c}\text { GCR min + } \\
\text { SPE 1956 }\end{array}$ & $\begin{array}{c}\text { GCR min + } \\
\text { SPE 1972 }\end{array}$ & $\begin{array}{c}\text { GCR min + } \\
\text { SPE averaged }\end{array}$ \\
\hline $\begin{array}{c}\text { Effective Dose } \\
\text { Equivalent }\end{array}$ & 0.1 & 3 & 1 \\
\hline $\begin{array}{c}\text { Blood Forming } \\
\text { Organs (BFOs) }\end{array}$ & 3 & 3 & 3 \\
\hline Eye & 1 & 3 & 3 \\
\hline Skin & 0.5 & 3 & 3 \\
\hline Organ & GCR max + & GCR max + \\
SPE $\mathbf{1 9 5 6}$ & SPE 1972 & $\begin{array}{c}\text { GCR max + } \\
\text { SPE averaged }\end{array}$ \\
\hline $\begin{array}{c}\text { Effective Dose } \\
\text { Equivalent }\end{array}$ & 0.1 & 1 & 1 \\
\hline $\begin{array}{c}\text { Blood Forming } \\
\text { Organs (BFOs) }\end{array}$ & 0.1 & 3 & 3 \\
\hline Eye & 1 & 3 & 3 \\
\hline Skin & 0.5 & 3 & \\
\hline
\end{tabular}

Table 8. Aluminum and Polyethylene First Pass

\begin{tabular}{|c|c|c|c|}
\hline Organ & $\begin{array}{c}\text { GCR min + } \\
\text { SPE 1956 }\end{array}$ & $\begin{array}{c}\text { GCR min + } \\
\text { SPE 1972 }\end{array}$ & $\begin{array}{c}\text { GCR min + } \\
\text { SPE averaged }\end{array}$ \\
\hline $\begin{array}{c}\text { Effective Dose } \\
\text { Equivalent }\end{array}$ & 0.1 & 3 & 1 \\
\hline $\begin{array}{c}\text { Blood Forming } \\
\text { Organs (BFOs) }\end{array}$ & 1 & 3 & 3 \\
\hline Eye & 1 & 3 & 3 \\
\hline Skin & 0.5 & 3 & 1 \\
\hline Organ & GCR max + & GCR max + & GCR max + \\
SPE 1956 & SPE 1972 & 0.5 \\
\hline $\begin{array}{c}\text { Effective Dose } \\
\text { Equivalent }\end{array}$ & 0.1 & 1 & 3 \\
\hline $\begin{array}{c}\text { Blood Forming } \\
\text { Organs (BFOs) }\end{array}$ & 0.1 & 3 & 3 \\
\hline Eye & 1 & 3 & 1 \\
\hline Skin & 0.5 & 3 & \\
\hline
\end{tabular}


Table 9. Carbon Fiber, Water, and Aluminum First Pass

\begin{tabular}{|c|c|c|c|}
\hline Organ & $\begin{array}{c}\text { GCR min + } \\
\text { SPE 1956 }\end{array}$ & $\begin{array}{c}\text { GCR min + } \\
\text { SPE 1972 }\end{array}$ & $\begin{array}{c}\text { GCR min + } \\
\text { SPE averaged }\end{array}$ \\
\hline $\begin{array}{c}\text { Effective Dose } \\
\text { Equivalent }\end{array}$ & 0.1 & 3 & 1 \\
\hline $\begin{array}{c}\text { Blood Forming } \\
\text { Organs (BFOs) }\end{array}$ & 1 & 3 & 3 \\
\hline Eye & 1 & 3 & 3 \\
\hline Skin & 0.5 & 3 & 1 \\
\hline Organ & GCR max + & GCR max + & GCR max + \\
SPE $\mathbf{1 9 5 6}$ & SPE $\mathbf{1 9 7 2}$ & 1 \\
\hline $\begin{array}{c}\text { Effective Dose } \\
\text { Equivalent }\end{array}$ & 0.1 & 1 & 3 \\
\hline $\begin{array}{c}\text { Blood Forming } \\
\text { Organs (BFOs) }\end{array}$ & 0.1 & 3 & 3 \\
\hline Eye & 1 & 3 & 1 \\
\hline Skin & 0.5 & 3 & \\
\hline
\end{tabular}

Expanding on this idea, multiple thicknesses of shielding were tested to determine the minimum thickness required for a pass. The test was run on multiple materials to see how material composition affected the pass rate. Two single material, one double material, and one triple material shields were used. The materials were tested on $0.1,0.5,1$, and 3 inch thick spheres.

Looking at Tables 6-9, several trends emerged. The lowest SPE categories (1956) required only 1 inch of shielding across all the different material compositions of shield (with one exception, which was a very close failure). The most destructive category, conversely, had no passes with under an inch thick of shielding.

To visualize the difference between 1 and 3 inches of shielding, consider the example of a spacecraft the size of an ISO standard 40-foot shipping container (see Fig. 5 for dimensions). A purely parasitic shield (serves no purpose other than to shield) of pure aluminum is used. The 1 inch thick shield would end up with a mass of approximately 9,200 $\mathrm{kg}$ while the 3 inch thick shield would be over $27,000 \mathrm{~kg}$. For context, the payload mass capability of a Delta 4 Heavy to LEO is $28,790 \mathrm{~kg} .{ }^{10}$ The 3 inch thick shield would take up nearly an entire rocket by itself when items such as the payload interface were factored in. Clearly, requiring 3 inches of shielding is not 
possible from a practical perspective. Therefore reducing the required shielding for SPEs, especially reducing the parasitic mass, becomes another priority.

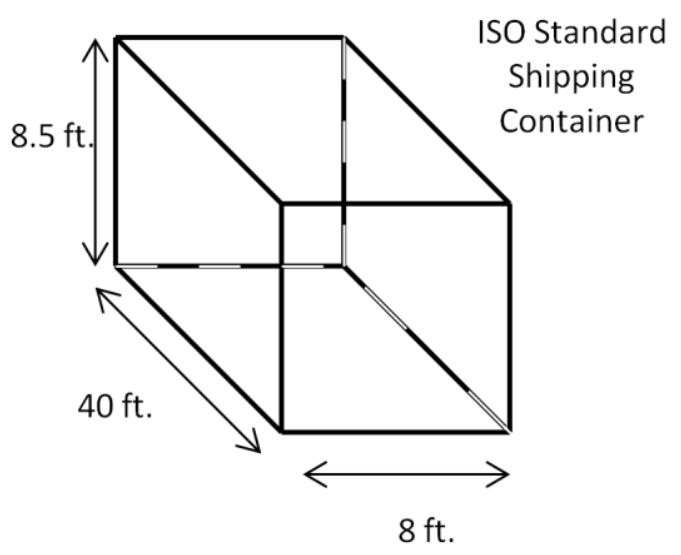

Figure 5. ISO Standard Shipping Container Dimensions

After further research, the concept was proposed by NASA's Advanced Explorations Systems RadWorks Storm Shelter Team that it was possible to reduce the effects of SPE with temporary shielding. ${ }^{20}$ This extra mass could be cannibalized from other sources and then returned after the solar event ends. This would lessen the static and parasitic shielding mass required for the vessel. The four ideas proposed in the paper were a deployable group shelter; a wearable, sleeping bag style shelter; an individual crew quarter shelter; and a deployable individual shelter. Each had a different preparation time, effectiveness, and effect on normal operations. A larger shelter, such as the group shelter, would take longer to set up and trap the crew inside, but could provide the best protection. It would work by repurposing structural floor and ceiling panels from other parts of the spacecraft. If the panels are honeycomb cored, they could also be filled with water for extra protection. On the other hand, the sleeping bag style shelter would be quick to deploy and would allow for some operations to continue while providing less protection. Such a shield would work by filling layers of bladders with water.

The RadWorks team reduced SPE intensity by $50 \%$ with their designs and theorized it was possible to reduce it by $70 \% .{ }^{18}$ Aluminum and carbon fiber test cases were run to see how this reduction would affect the shielding requirements. One case study used the 50\% intensity SPE environment; the other used the 70\% reduction. These test results can be seen in Tables 10-13. 
Table 10. Aluminum 50\% Reduced SPE First Pass

\begin{tabular}{|c|c|c|c|}
\hline Organ & $\begin{array}{c}\text { GCR min + } \\
\text { SPE 1956 }\end{array}$ & $\begin{array}{c}\text { GCR min + } \\
\text { SPE 1972 }\end{array}$ & $\begin{array}{c}\text { GCR min + } \\
\text { SPE averaged }\end{array}$ \\
\hline $\begin{array}{c}\text { Effective Dose } \\
\text { Equivalent }\end{array}$ & 0.1 & 0.5 & 0.1 \\
\hline $\begin{array}{c}\text { Blood Forming } \\
\text { Organs (BFOs) }\end{array}$ & 0.1 & 3 & 3 \\
\hline Eye & 0.5 & 3 & 3 \\
\hline Skin & 0.5 & 1 & 0.5 \\
\hline Organ & $\begin{array}{c}\text { GCR max }+ \\
\text { SPE 1956 }\end{array}$ & $\begin{array}{c}\text { GCR max }+ \\
\text { SPE 1972 }\end{array}$ & $\begin{array}{c}\text { GCR max + } \\
\text { SPE averaged }\end{array}$ \\
\hline $\begin{array}{c}\text { Effective Dose } \\
\text { Equivalent }\end{array}$ & 0.1 & 0.5 & 0.1 \\
\hline $\begin{array}{c}\text { Blood Forming } \\
\text { Organs (BFOs) }\end{array}$ & 0.1 & 1 & 0.5 \\
\hline Eye & 0.5 & 3 & 1 \\
\hline Skin & 0.5 & 1 & 0.5 \\
\hline
\end{tabular}

Table 11. Aluminum 70\% Reduced SPE First Pass

\begin{tabular}{|c|c|c|c|}
\hline Organ & $\begin{array}{c}\text { GCR min + } \\
\text { SPE 1956 }\end{array}$ & $\begin{array}{c}\text { GCR min + } \\
\text { SPE 1972 }\end{array}$ & $\begin{array}{c}\text { GCR min + } \\
\text { SPE averaged }\end{array}$ \\
\hline $\begin{array}{c}\text { Effective Dose } \\
\text { Equivalent }\end{array}$ & 0.1 & 0.1 & 0.1 \\
\hline $\begin{array}{c}\text { Blood Forming } \\
\text { Organs (BFOs) }\end{array}$ & 0.1 & 1 & 1 \\
\hline Eye & 0.5 & 1 & 1 \\
\hline Skin & 0.5 & 1 & 0.5 \\
\hline Organ & GCR max + & GCR max + & GCR max + \\
SPE 1972 & SPE averaged \\
\hline $\begin{array}{c}\text { Effective Dose } \\
\text { Equivalent }\end{array}$ & 0.1 & 0.1 & 0.1 \\
\hline $\begin{array}{c}\text { Blood Forming } \\
\text { Organs (BFOs) }\end{array}$ & 0.1 & 0.5 & 0.1 \\
\hline Eye & 0.1 & 1 & 1 \\
\hline Skin & 0.1 & 0.5 & 0.5 \\
\hline
\end{tabular}


Table 12. Carbon Fiber 50\% Reduced SPE First Pass

\begin{tabular}{|c|c|c|c|}
\hline Organ & $\begin{array}{c}\text { GCR min + } \\
\text { SPE 1956 }\end{array}$ & $\begin{array}{c}\text { GCR min + } \\
\text { SPE 1972 }\end{array}$ & $\begin{array}{c}\text { GCR min + } \\
\text { SPE averaged }\end{array}$ \\
\hline $\begin{array}{c}\text { Effective Dose } \\
\text { Equivalent }\end{array}$ & 0.1 & 1 & 0.5 \\
\hline $\begin{array}{c}\text { Blood Forming } \\
\text { Organs (BFOs) }\end{array}$ & 0.5 & 3 & 3 \\
\hline Eye & 1 & 3 & 3 \\
\hline Skin & 0.5 & 1 & 1 \\
\hline Organ & GCR max + & GCR max + & GCR max + \\
SPE $\mathbf{1 9 5 6}$ & SPE 1972 & 0.1 \\
\hline $\begin{array}{c}\text { Effective Dose } \\
\text { Equivalent }\end{array}$ & 0.1 & 0.5 & 0.5 \\
\hline $\begin{array}{c}\text { Blood Forming } \\
\text { Organs (BFOs) }\end{array}$ & 0.1 & 1 & 1 \\
\hline Eye & 0.5 & 3 & 1 \\
\hline Skin & 0.5 & 1 & \\
\hline
\end{tabular}

Table 13. Carbon Fiber 70\% Reduced SPE First Pass

\begin{tabular}{|c|c|c|c|}
\hline Organ & $\begin{array}{c}\text { GCR min + } \\
\text { SPE } 1956\end{array}$ & $\begin{array}{c}\text { GCR min + } \\
\text { SPE } 1972\end{array}$ & $\begin{array}{c}\text { GCR min + } \\
\text { SPE averaged }\end{array}$ \\
\hline $\begin{array}{c}\text { Effective Dose } \\
\text { Equivalent }\end{array}$ & 0.1 & 0.5 & 0.1 \\
\hline $\begin{array}{l}\text { Blood Forming } \\
\text { Organs (BFOs) }\end{array}$ & 0.5 & 3 & 3 \\
\hline Eye & 0.5 & 3 & 3 \\
\hline Skin & 0.5 & 1 & 0.5 \\
\hline Organ & $\begin{array}{c}\text { GCR max + } \\
\text { SPE } 1956\end{array}$ & $\begin{array}{c}\text { GCR max + } \\
\text { SPE } 1972\end{array}$ & $\begin{array}{c}\text { GCR max + } \\
\text { SPE averaged }\end{array}$ \\
\hline $\begin{array}{c}\text { Effective Dose } \\
\text { Equivalent }\end{array}$ & 0.1 & 0.1 & 0.1 \\
\hline $\begin{array}{l}\text { Blood Forming } \\
\text { Organs (BFOs) }\end{array}$ & 0.1 & 0.5 & 0.1 \\
\hline Eye & 0.5 & 3 & 1 \\
\hline Skin & 0.5 & 1 & 0.5 \\
\hline
\end{tabular}


For the aluminum spheres at $70 \%$ reduction, the maximum required thickness to pass in all categories dropped from three inches to one inch. The carbon fiber cases still had a few categories that required three inches of shielding, but the total required dropped from 8 and 6 categories for solar minimum and maximum respectively down to 4 and 1. These failures were all in the eye and BFO categories for the average and high SPE cases. If additional non-structural shielding could be applied to shore up the eyes and BFOs then it could be possible to properly shield with less than 1 inch.

For missions shorter than one year, or if additional non-structural shielding/anti-absorption methods are applied, perhaps the thinner shielding will suffice. Under the lightest of the tested SPE conditions (1956), both solar maximum and minimum managed to pass all categories under 0.5 inches of shielding for both $50 \%$ and $70 \%$ SPE reductions with both test materials (with the one exception of the eye for carbon fiber 50\%). The aluminum case for GCR max + SPE 1956 even manages to pass at the 0.1 inch thick amount of shielding. Though a higher risk, design for the lower intensity might be possible with current technology. These requirements are much more easily multipurposed from other subsystems such as thermal or structure. Using the ISO visualization example above, shields of 0.5 inches and 0.1 inches would require $4,600 \mathrm{~kg}$ and $920 \mathrm{~kg}$ respectively.

For another comparison of the data, a new style of table was developed. Examples of this can be seen in Tables 14 and Table 15. Instead of the style of the tables above, which show every category with its minimum required thickness, the following tables look at how many categories are in compliance at each thickness level (i.e. if the 0.5 inch thickness shows 18 , then 18 of the 24 categories are in compliance with the relevant limits). While not as descriptive as the above tables, it allows for comparisons. Previously, one would have to flip back and forth between tables and compare category by category to deduce the changes. The total pass method also allows for risk comparisons. Is it acceptable to have only 22 successes with a thinner shielding amount, knowing the two failures were from the unlikely worst case scenario? Or is a $100 \%$ pass rate a necessity? The answers to that would depend on mission conditions outside the scope of this paper. 
Table 14. Aluminum Total Passes

\begin{tabular}{|c|c|c|c|}
\hline & Regular SPE & $50 \%$ Reduced SPE & $70 \%$ Reduced SPE \\
\hline 0.1 & 3 & 6 & 11 \\
\hline 0.5 & 5 & 15 & 17 \\
\hline 1 & 10 & 19 & 24 \\
\hline 3 & 24 & 24 & 24 \\
\hline
\end{tabular}

Table 15. Carbon Fiber Total Passes

\begin{tabular}{|c|c|c|c|}
\hline & Regular SPE & $50 \%$ Reduced SPE & $70 \%$ Reduced SPE \\
\hline 0.1 & 3 & 4 & 7 \\
\hline 0.5 & 5 & 11 & 16 \\
\hline 1 & 10 & 19 & 19 \\
\hline 3 & 24 & 24 & 24 \\
\hline
\end{tabular}

As expected, the numbers continue to rise as one moves down and to the right of the chart. But while some are large increases, e.g. aluminum 1 inch thick from 50\% to 70\%, others show little improvement, e.g. the carbon fiber version of that same transition.

The results above are for the general case of one year. While they might be useful in the early mission planning stages, once the total trip time is fine-tuned the numbers can be adjusted accordingly. The GCR values were directly time scalable. For example, to create a six month mission simply divide the yearly GCR results by 2 and add the SPE. Due to Mars' prominence in the interplanetary discussions of today, it was chosen for the hypothetical test cases.

After looking at several alternative duration options, three were selected. Two represented one-way trips. The first was 168 days; the duration of travel of the Mariner 9 probe. ${ }^{17}$ This was the first spacecraft to orbit another planet and one of the shortest duration trips to the red planet that wasn't a flyby. The second chosen duration was from the Mars Reconnaissance Orbiter. At 210 days, it sits squarely in the middle of the 6-8 month estimated trip time. The final trip time selected was 501 days, taken from a mission proposed by Inspiration Mars for $2018 .^{12}$ This timing was for a round trip mission, flying to Mars and returning to Earth. Since the duration was longer than a year, two different tests were done with the 501 day duration. The first assumed there would be one major SPE event, the 
second assumed two. For the two year test with two SPEs the standard three SPE intensities (1956, 1972, and averaged) were doubled. A possibility not explored in this paper would be trying the double SPE event with different intensities, which would lead to six different combinations. Also, the tests over a year were compared against double the one year limits for the BFO, eye, and skin categories. The results are listed in Tables 16-19.

Table 16. Aluminum Total Passes, 168 Day Mission Duration

\begin{tabular}{|c|c|c|c|}
\hline & Regular SPE & $50 \%$ Reduced SPE & $70 \%$ Reduced SPE \\
\hline 0.1 & 8 & 15 & 16 \\
\hline 0.5 & 18 & 22 & 24 \\
\hline 1 & 24 & 24 & 24 \\
\hline
\end{tabular}

Table 17. Aluminum Total Passes, 210 Day Mission Duration

\begin{tabular}{|c|c|c|c|}
\hline & Regular SPE & $50 \%$ Reduced SPE & $70 \%$ Reduced SPE \\
\hline 0.1 & 4 & 14 & 16 \\
\hline 0.5 & 16 & 21 & 23 \\
\hline 1 & 22 & 24 & 24 \\
\hline 3 & 24 & 24 & 24 \\
\hline
\end{tabular}

Table 18. Aluminum Total Passes, 501 Day Mission Duration with Single SPE Event

\begin{tabular}{|c|c|c|c|}
\hline & Regular SPE & 50\% Reduced SPE & 70\% Reduced SPE \\
\hline 0.1 & 3 & 8 & 12 \\
\hline 0.5 & 9 & 17 & 22 \\
\hline 1 & 19 & 24 & 24 \\
\hline 3 & 24 & 24 & 24 \\
\hline
\end{tabular}

Table 19. Aluminum Total Passes, 501 Day Mission Duration with Double SPE Event

\begin{tabular}{|c|c|c|c|}
\hline & Regular SPE & $50 \%$ Reduced SPE & $70 \%$ Reduced SPE \\
\hline 0.1 & 1 & 3 & 6 \\
\hline 0.5 & 6 & 9 & 14 \\
\hline 1 & 10 & 19 & 23 \\
\hline 3 & 24 & 24 & 24 \\
\hline
\end{tabular}


The shortest mission (Mariner 9) returned the highest pass rates per thickness, as expected due to its short duration. It was the only one of the four durations tested that succeeded in passing all categories without requiring more than an inch of thickness. The 210 day test (MRO) was worse by 0-2 passes per category, with the exception of the thinnest regular SPE data set.

Three of the four tests (Mariner 9, MRO, and 501 day single SPE) passed fully at 1 inch thick in the reduced SPE categories. Even without any other reduction, the pass rate was still above 80\%. The final test (501 day double SPE) showed the importance in developing temporary shielding. The regular SPE pass rates were 30$60 \%$ of the $50 \%$ reduced category at thicknesses below three inches.

\section{Material Effects on Shielding Results}

Now that baseline results had been run using a few common materials, it was possible to expand out into other combinations of materials. By extrapolation, it was possible to estimate how swapping a material would affect the EDE. To test the accuracy of the extrapolation, four sets of materials were compared. This was accomplished by dividing the base material by the scaled material for all tested thicknesses (e.g. if Nomex was being scaled to the effectiveness of titanium, the titanium would be divided by the Nomex). This percentage was multiplied by the original thicknesses (e.g. 0.1 inch, 0.5 inch, 1 inch, etc.). These modified thicknesses were run through OLTARIS to get single year EDE. Tests were run with two SPE and two GCR solar maximum comparisons. The results of both tests can be seen in Fig. 6 . The thickness count was the ten thicknesses used in the calculation, with 1 as the thinnest (0.1 in) and 10 the thickest (20 in). The results of the test showed the linear scaling was more accurate for thin shield GCR calculations and thick shield SPE calculations. The maximum error of the four tests was around twenty percent. 


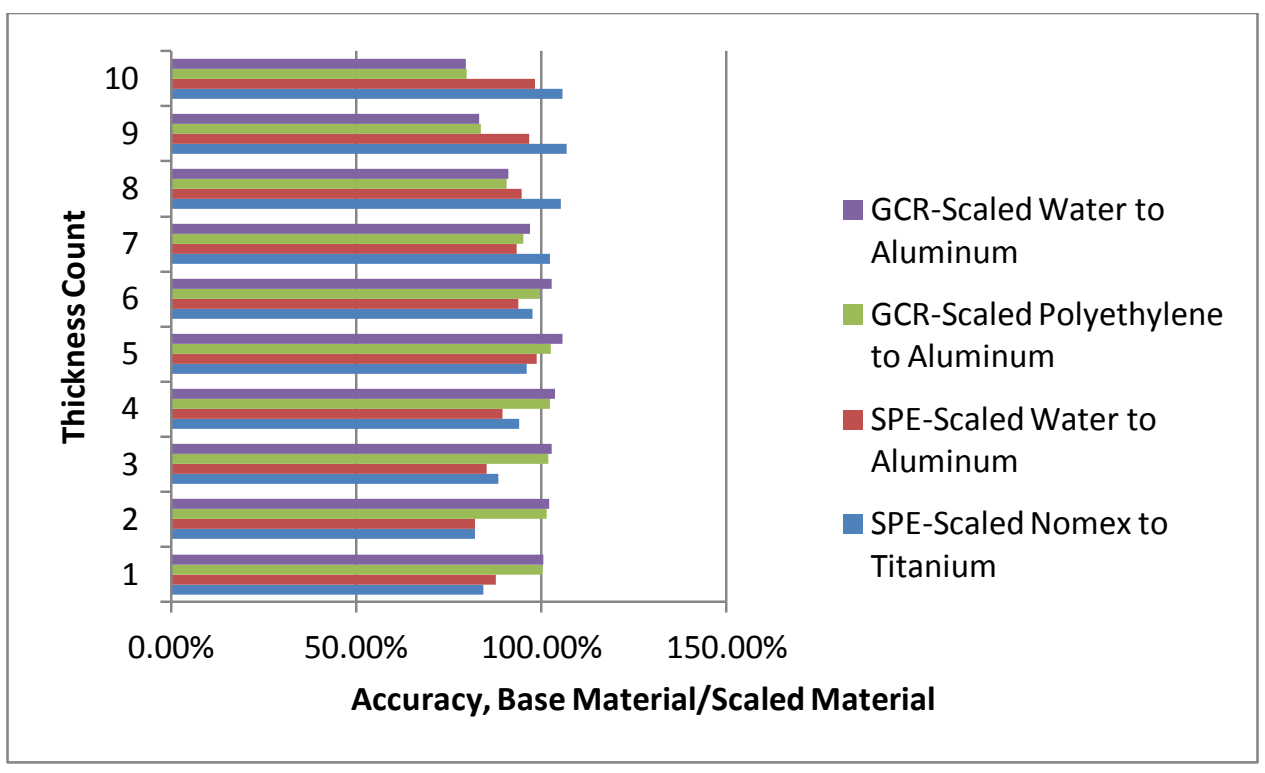

Figure 6. Results of Scaling Material Test

Plots of entire data sets can be found in Appendix B. The following plots are cropped for readability and to more easily show trends. Also, GCR and SPE data values are separated in this section, both to allow for clearer viewing and to see how each was affected by material(s) selection.

SPE material effectiveness rankings didn't change much with thickness over the course of the tested spheres. However, for GCRs it was discovered that the question of which material has the highest shielding absorptivity varied depending on material thickness. As the thickness increases the shielding effectiveness order inverts, usually in the 5 to 10 inch thick range. For example, for 3 inch thick spheres aluminum returned the lowest EDE of the tested materials, followed by Kevlar and carbon fiber, and with polyethylene and water returning the highest EDE. But by the last data point (20 in thick spheres), the order of effectiveness had significantly shifted. Materials that were most efficient for thin shields now were the lest effective and vice versa. Now polyethylene had the lowest EDE, followed by water, Kevlar, and carbon fiber. Aluminum returned the relative highest EDE for thick shields. A sample of this can be seen in Table 20, with the same order for both solar minimum and maximum. 
Table 20. Material Effectiveness Rankings for Thick and Thin Spheres

\begin{tabular}{|c|c|c|}
\hline MateriallThickness & 3 inches thick & 20 inches thick \\
\hline Water & 5 & 2 \\
\hline Aluminum & 1 & 5 \\
\hline Carbon fiber & 3 & 4 \\
\hline Polyethylene & 4 & 3 \\
\hline Kevlar & 2 & 1 \\
\hline
\end{tabular}

Due to this, the shields are broken into two sections for analysis. The first covers shields less than 3 inches thick. As shown in the previous section, 3 inches was the maximum thickness required for limit compliance. However, for materials that return higher EDEs per thickness, longer duration missions, or for repeated exposure missions the second section will look at 10, 15, and 20 inch thick spheres. Grouping the data this way excludes the 5 and 7.5 inch thick data sets, but as the GCR EDE values drift toward a focal point in this range as the trends reverse, this data is not as useful for trends. If the data is needed, it can still be found in Appendix B.

\section{Thin Shields}

This section covers shields of thickness $0.1,0.5,0.75,1$, and 3 inches thick. While not as protective as the thicker shields, the reduced mass requirement makes them much more feasible to implement.

\section{GCR Single Material}

A comparison of all single material spheres tested can be seen in Fig. 7. At first glance, one material can be seen to be breaking the general trend. Despite increasing thickness, polyurethane barely seemed to drop. When the hard data is looked at, polyurethane at the thickest test sphere taken (20 inches) had EDE values measuring $92.44 \%$ and $93.96 \%$ of the thinnest shield ( 0.1 in) for solar minimum and maximum respectively. So while it may be useful for other factors such as micrometeoroid shielding or insulation, polyurethane is clearly not a good choice strictly as a radiation shielding material. Therefore it will be excluded occasionally from the following discussion to prevent distortion. 


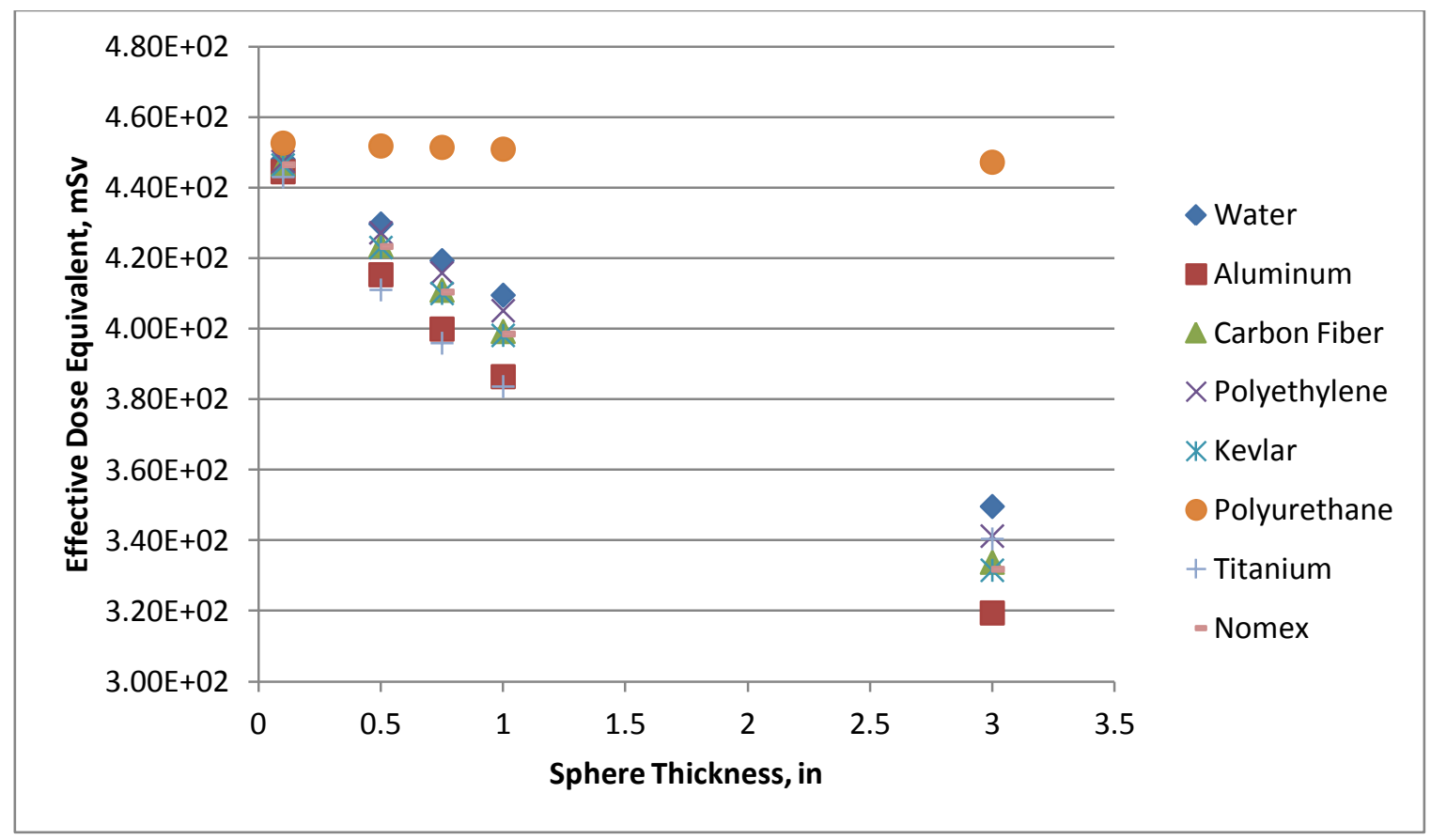

a) 1956 Solar Minimum Single Material Comparison

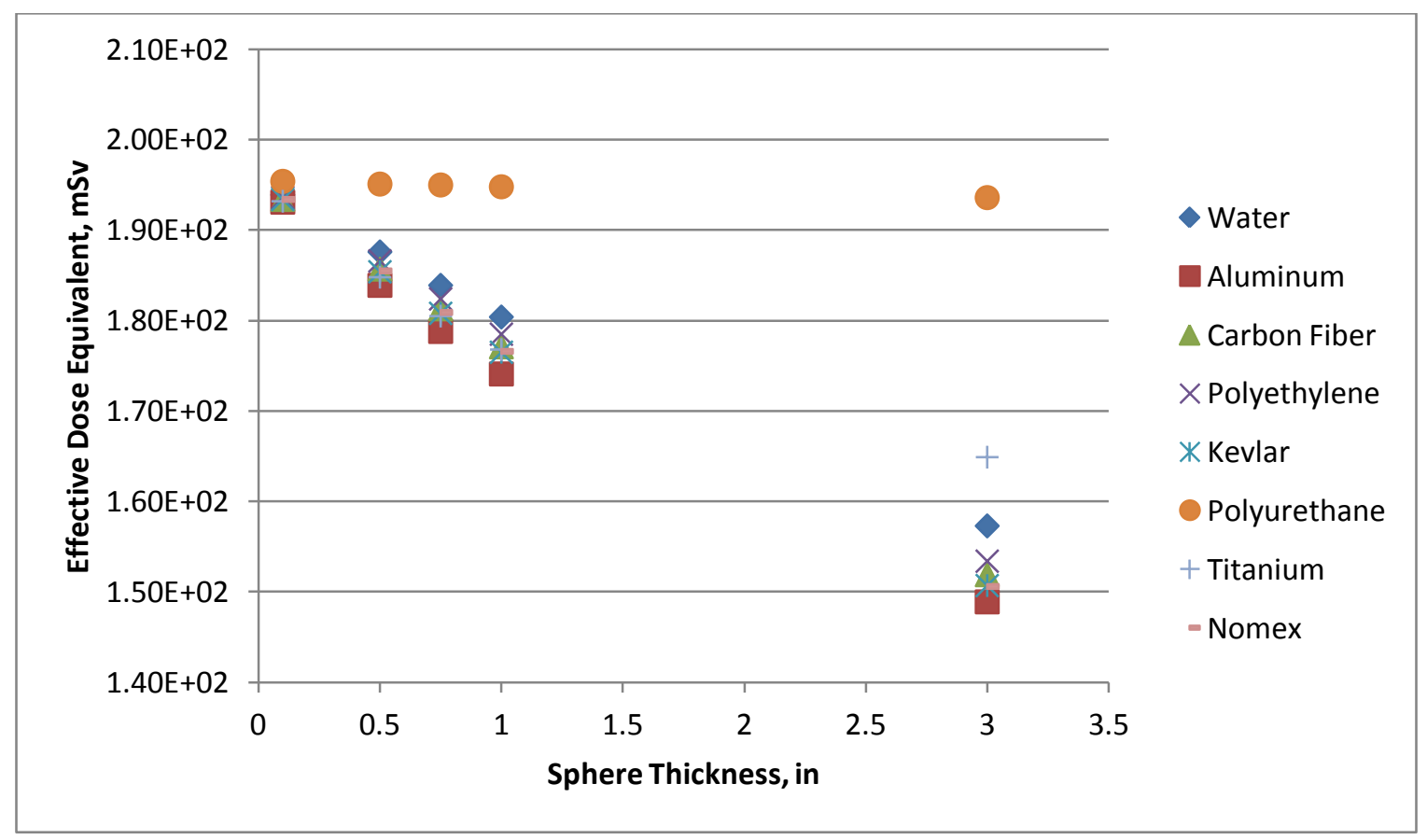

b) 1991 Solar Maximum Single Material Comparison

Figure 7. Thin Single Material Comparison for GCR 
For both solar maximum and minimum thin shields, the order from top to bottom was fairly constant. Water returned the highest EDE values, followed by polyethylene. Next was carbon fiber, Nomex, and Kevlar, all clumped closely together. Aluminum returned the lowest EDE values for the majority of cases, only occasionally

beaten by the variably effective titanium. While it returned values even lower than aluminum for the solar minimum case, it slowly rose from between aluminum and the clump of several materials to reaching the clump at 1 inch of shielding. At three inches it was returning values even higher than water. So while titanium might be a wise choice as a radiation shield at thinner values, it drops in effectiveness at thicker shields (as will be seen in the next section).

\section{GCR Double Material}

The tested double material shields were aluminum and one of four other materials (water, polyethylene, carbon fiber, or titanium). Results (seen in Fig. 8) show that material composition seemed to have a minimal effect on the thin double material shields. 3 of the 4 shields tested stayed within $10 \mathrm{~Sv}$ of each other for solar minimum, and amazingly within $2 \mathrm{~Sv}$ for solar maximum. The outlier was the aluminum and titanium shield, which returned the lowest EDE up to 1 inch for both solar max and min, but started to rise by the 3 inch thick test.

As all of the tests were aluminum hybrids, the second material played a strong role in the relative order of the hybrid shields. Shields hybridized with water or polyethylene returned higher mSv than those hybridized with carbon fiber or titanium. 


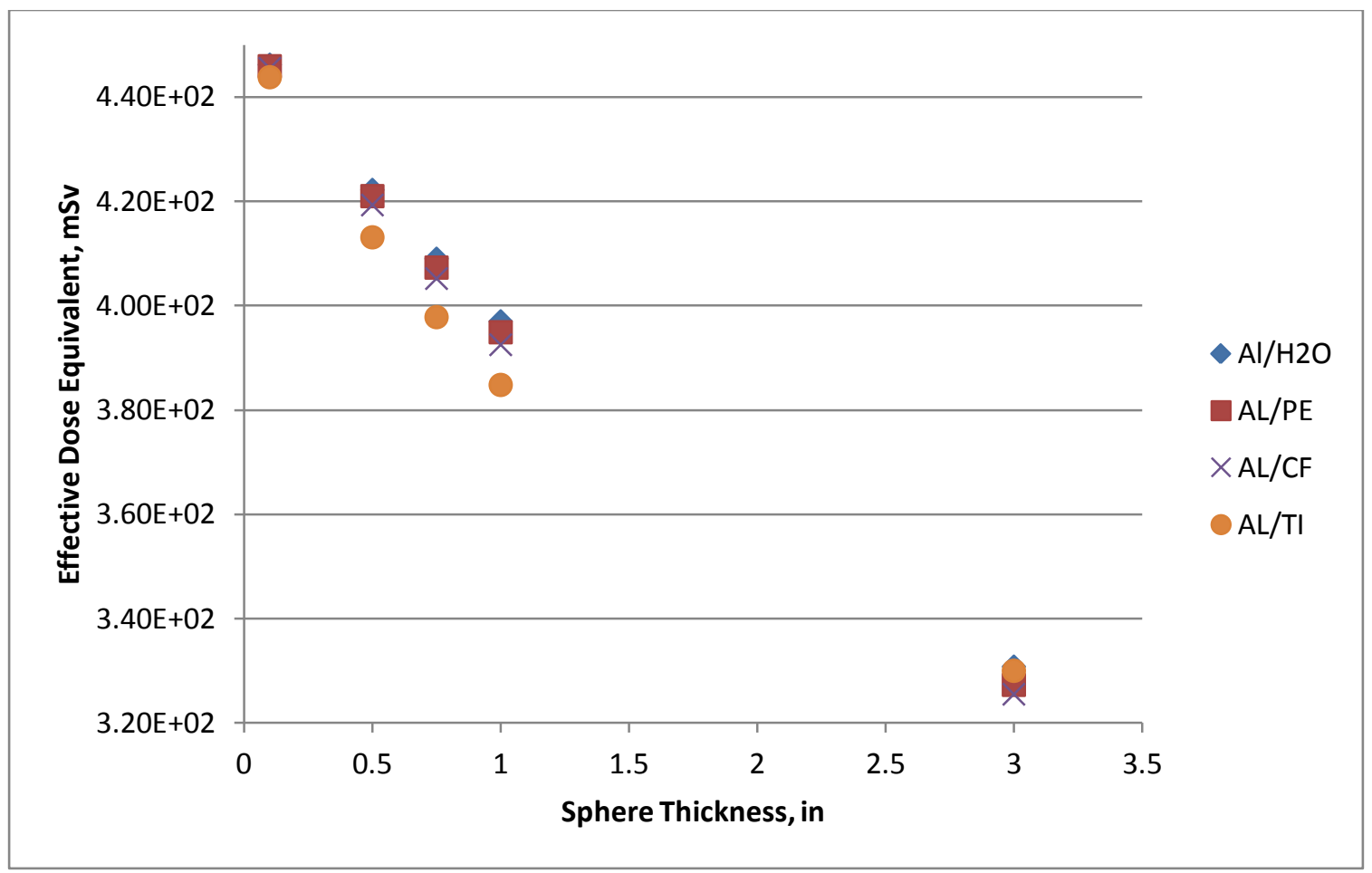

a) 1956 Solar Minimum Double Material Comparison

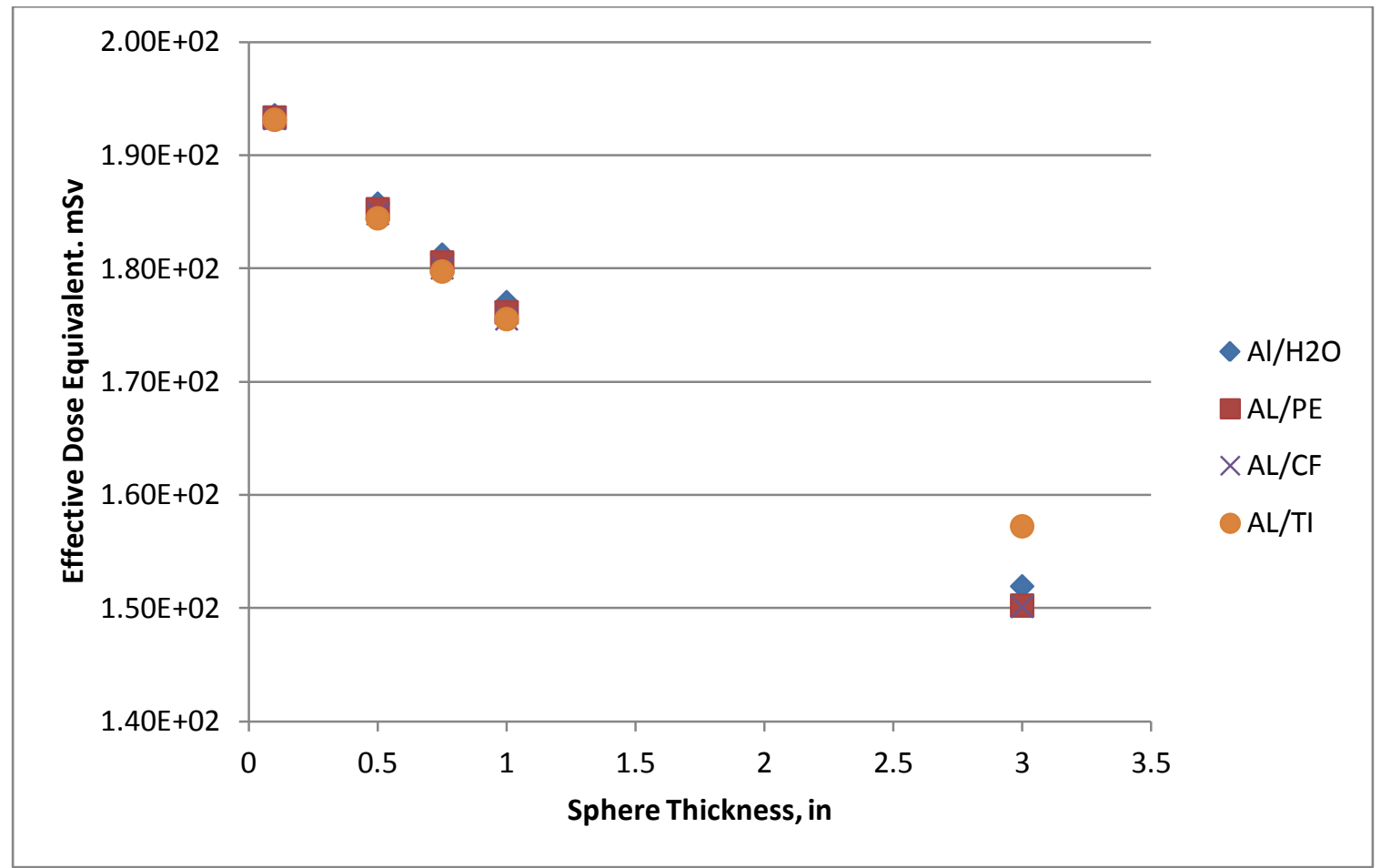

b) 1991 Solar Maximum Double Material Comparison

Figure 8. Thin Double Material Comparison for GCR 


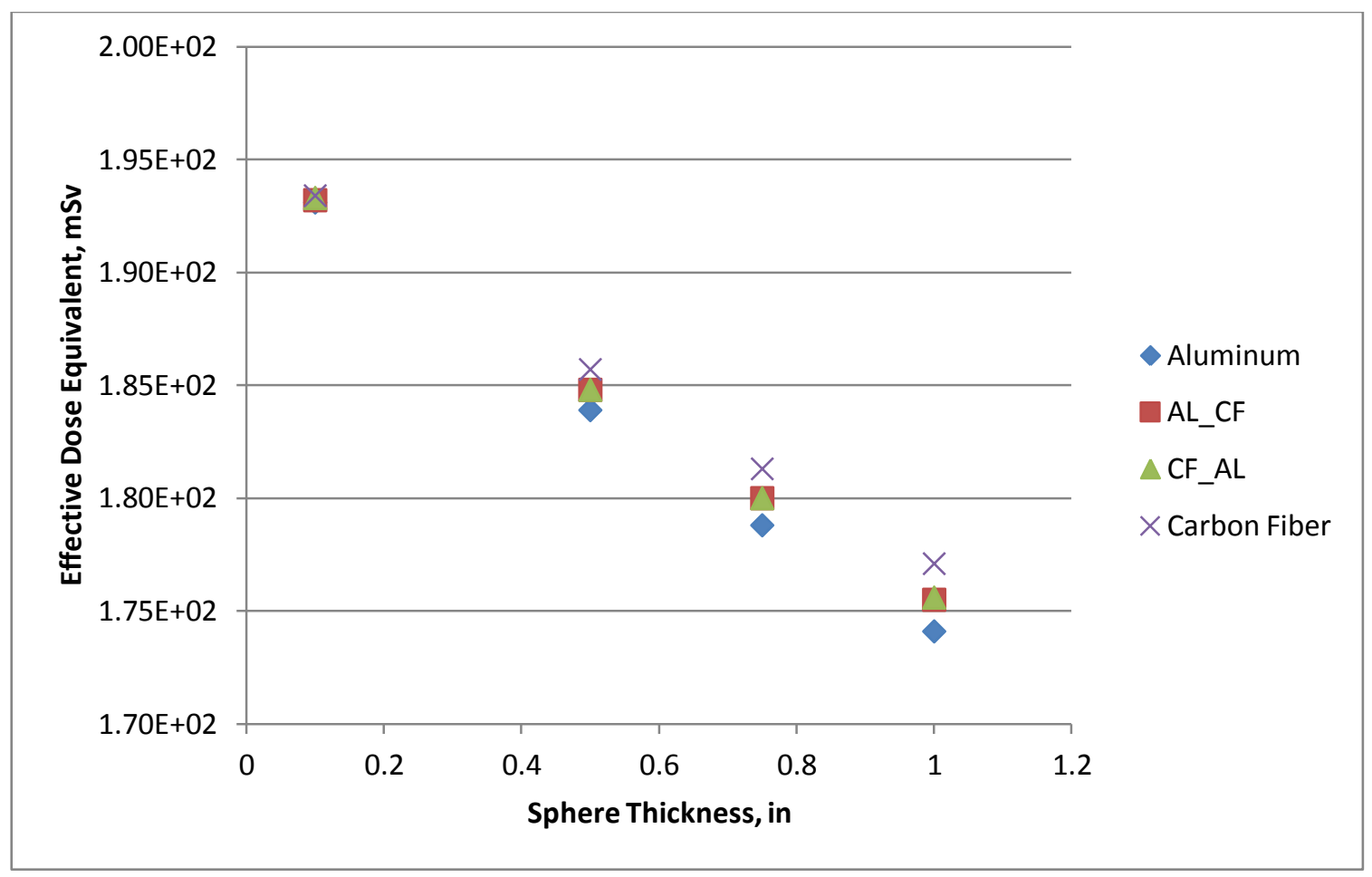

a) Aluminum and Carbon Fiber Hybrid Shields for 1991 Solar Maximum per Year

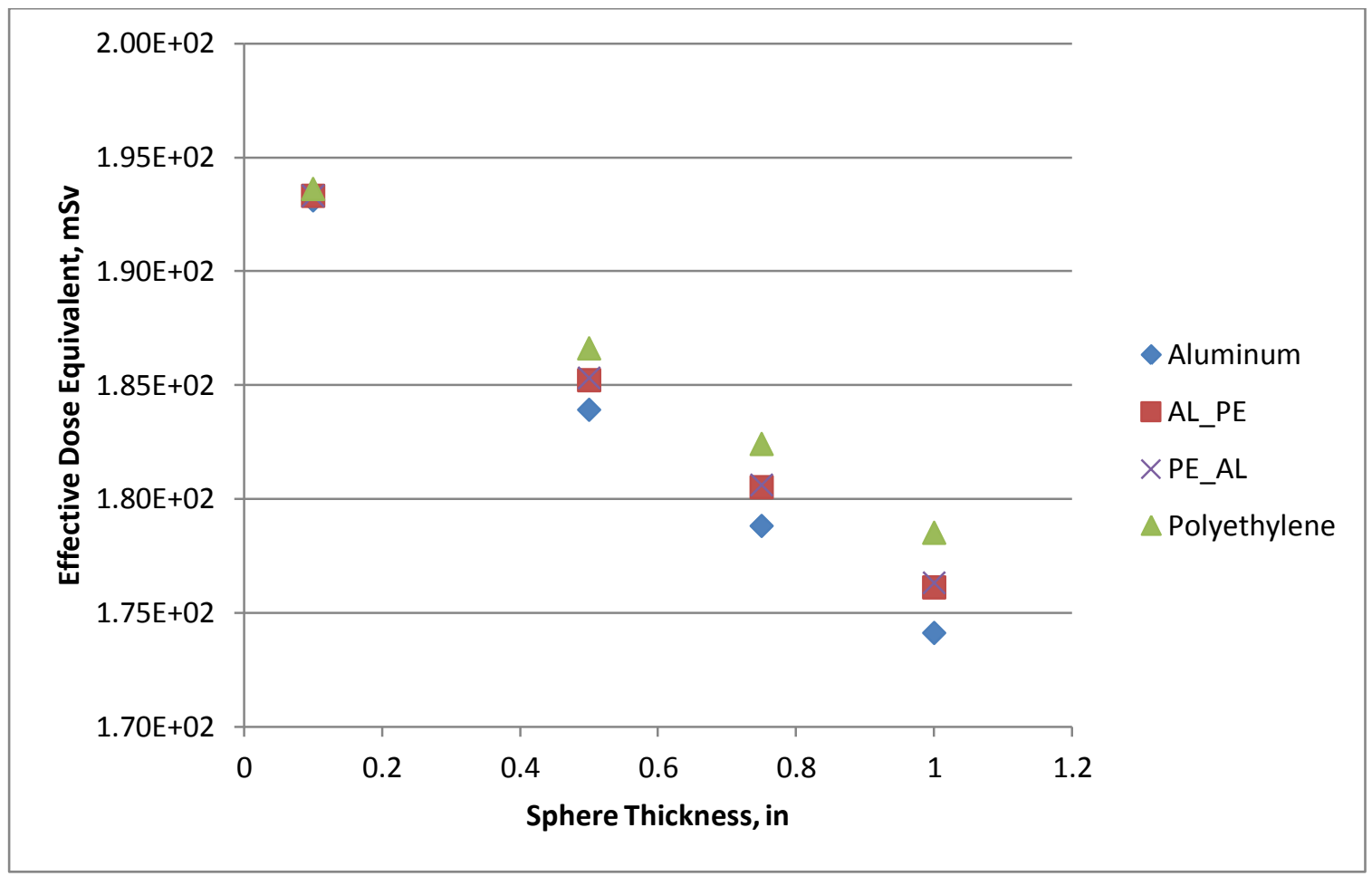

b) Aluminum and Polyethylene Hybrid Shields for 1991 Solar Maximum per Year

Figure 9. Thin Double Material Order Comparisons 
Order of the materials didn't have much of an influence in the two test cases seen in Fig. 9. The plot shows both hybrid shields centered between both pure shields at each data point. The data set for 3 inches thick was removed for ease of viewing. When hybrids of uneven proportions were tested, the hybrids ordered themselves closest to the majority material, as seen in Fig. 10.

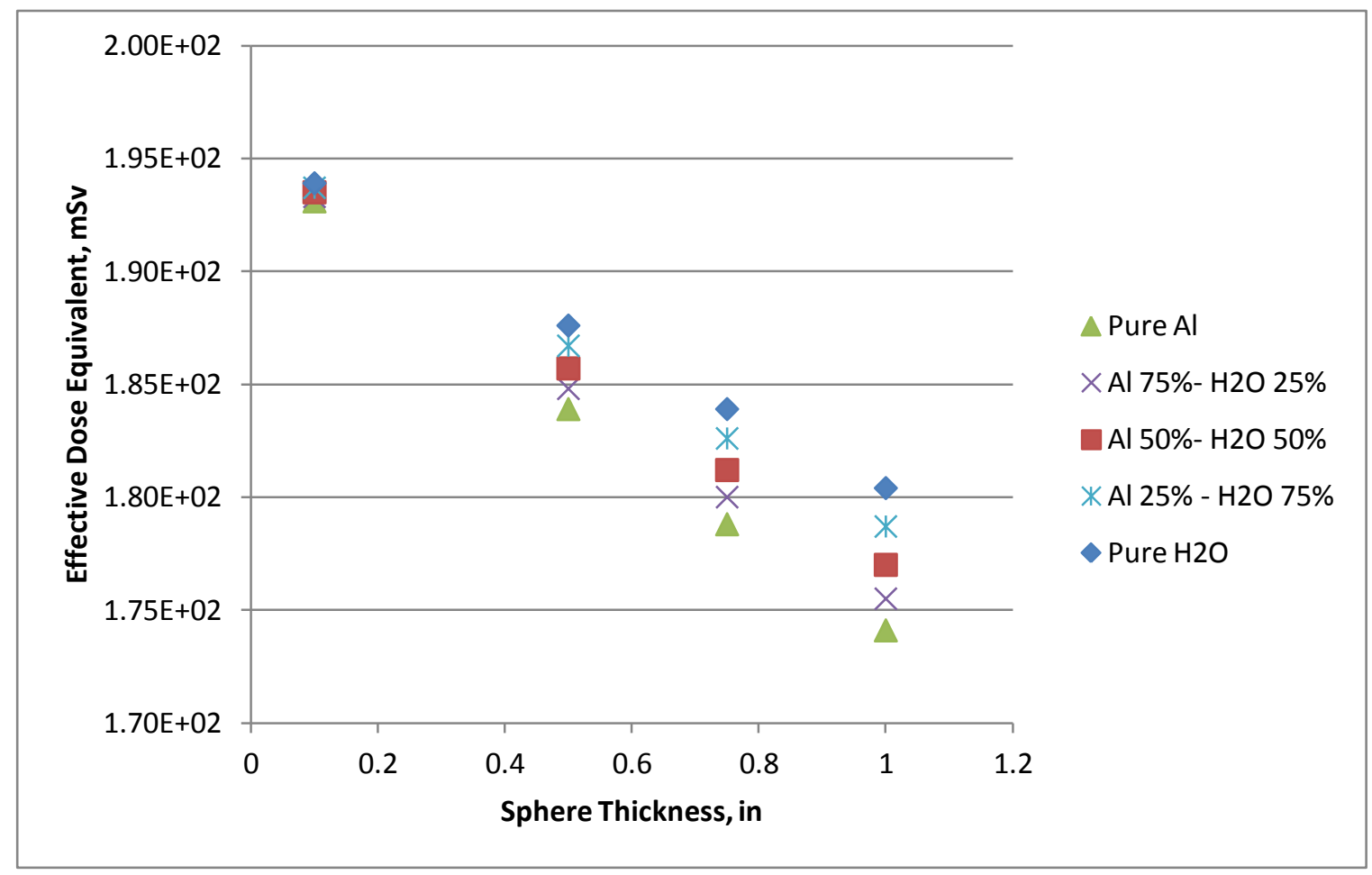

Figure 10. Aluminum and Water Hybrid Shields for 1991 Solar Maximum per Year

Data from the single material versions of each wall were combined and divided by two at each data point to determine if these methods could be used for approximating a multi-layer wall. For example, results from the 1 inch thick aluminum and carbon fiber spheres were summed and divided by 2 to compare against the 1 inch thick aluminum-carbon fiber test sphere. Results were promising for thin shields, as the highest difference was 0.79\% (for aluminum and water shields). Therefore it may be possible to estimate other combinations of thin double material shields with a small margin for error. 


\section{GCR Triple Material}

Three different sets of walls were constructed for the triple material tests. Each had a unique core (water, polyethylene, or polyurethane) while the outside walls were either aluminum and Kevlar or aluminum and carbon fiber. The outside materials could be on either side, yielding twelve total different walls. However, comparisons up to the 3 inch thick level showed less than a 1\% difference in EDE between the different orders of outside walls. Therefore the plots in Fig. 11 only show six sets of test results, the ones with aluminum on the outside.

4 of the 6 shields in Fig. 11 are clumped closely together, to within around $2 \mathrm{mSv}$. The outliers had polyurethane as a center material. As shown in the single material tests above, it did not absorb appreciably more radiation as the material thickened.

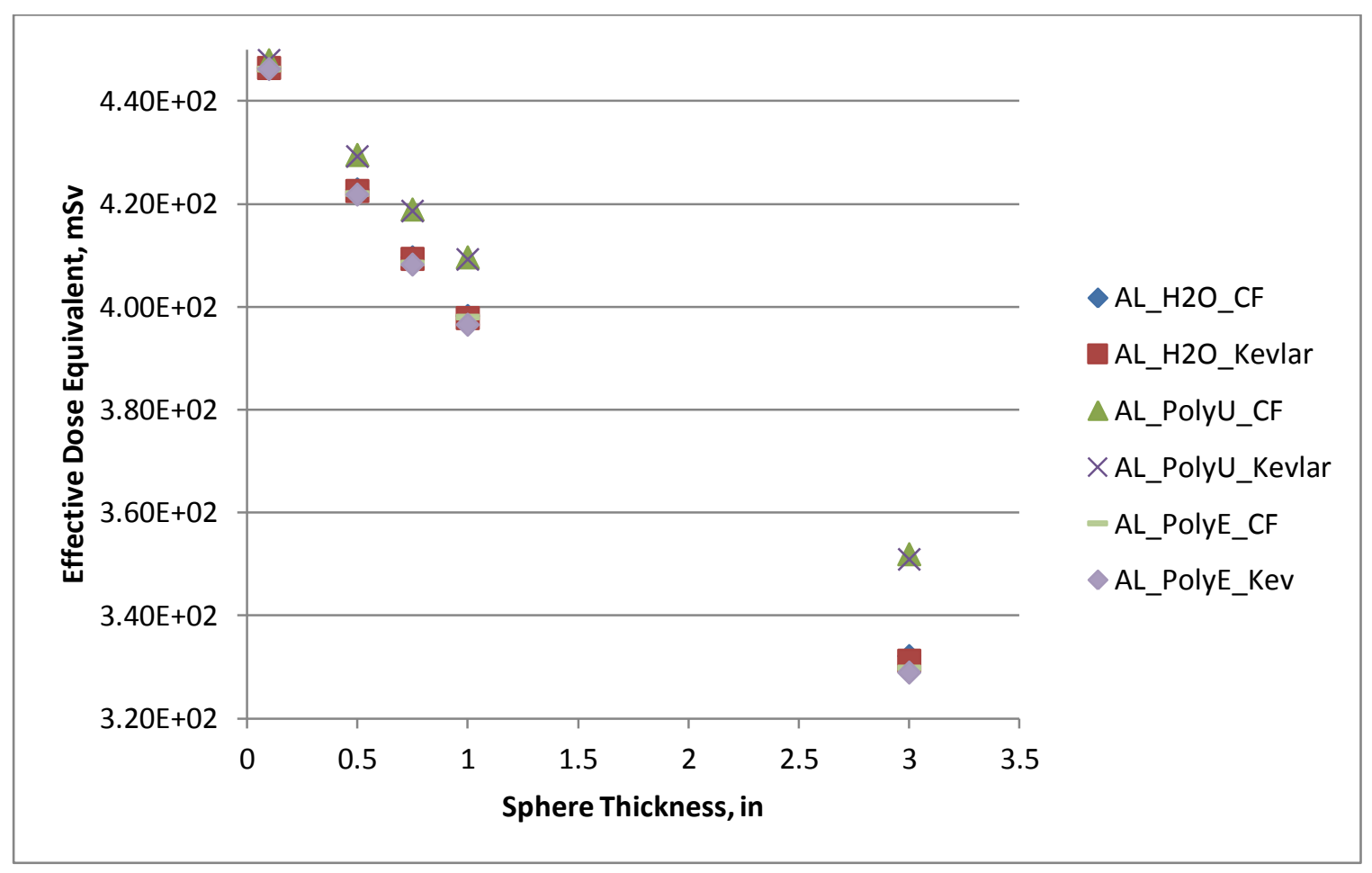

a) Solar Minimum Triple Material Comparison 


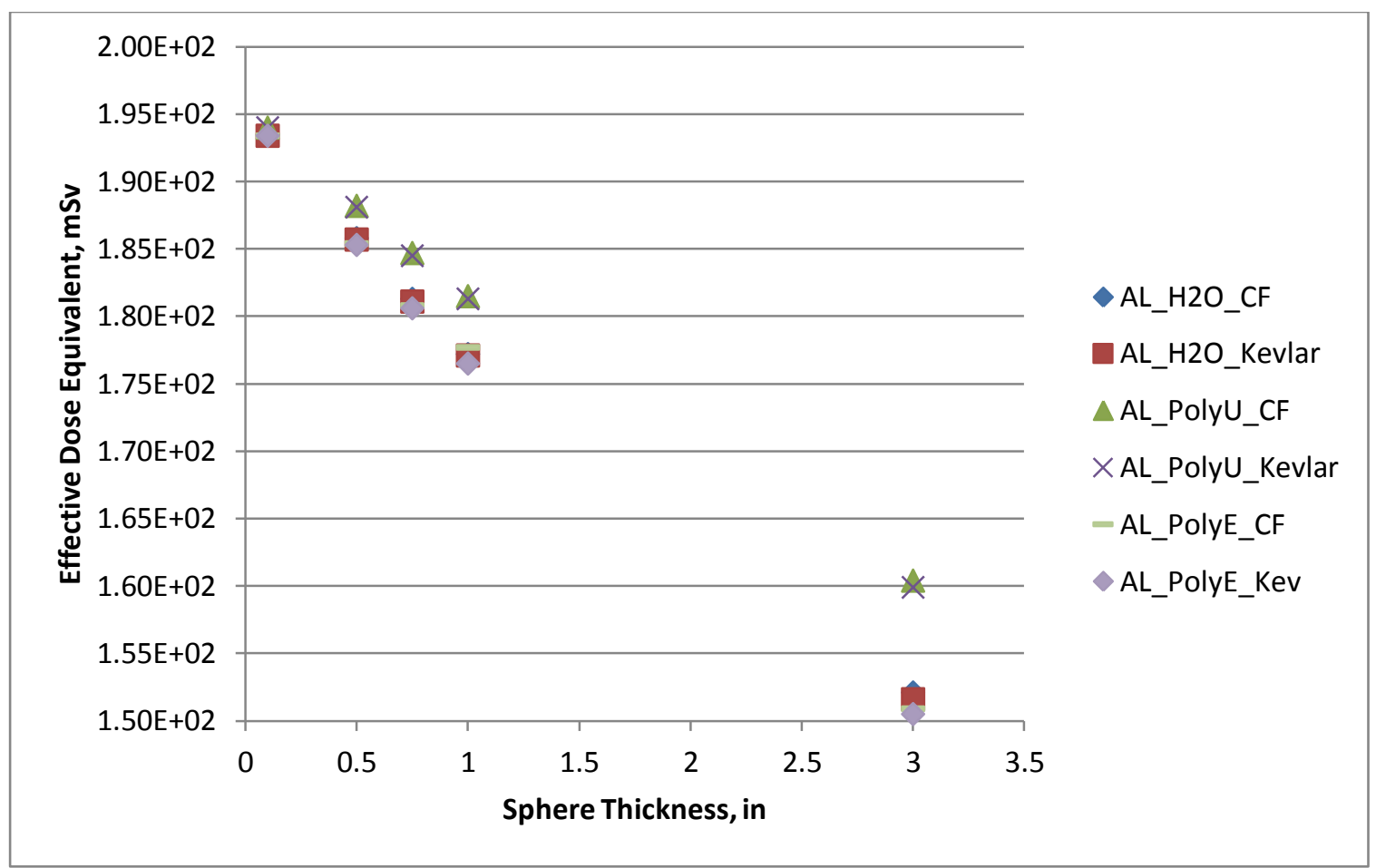

\section{b) Solar Maximum Triple Material Comparison}

Figure 11. Thin Triple Material Comparison for GCR

Similarly to the double material shields, data from the single material versions of each wall were combined and divided by three at each data point to determine if this method could be used for approximating a multilayer wall. For example, results from the 1 inch thick aluminum, water, and carbon fiber spheres were summed and divided by 3 to compare against the 1 inch thick aluminum-water-carbon fiber test sphere. Results were also promising as the water and polyethylene centered walls had calculated data within $1 \%$ of the tested for both solar maximum and minimum. The polyurethane results stayed within 5\% and 3\% for solar minimum and maximum respectively.

\section{SPE Overview}

Unlike GCR shields, which deviate as the shield thickened, SPE shield results converge together as the shields thicken. They also start at a higher EDE for the minimum thickness shield and drop steeply to a much lower EDE at the thickest shield when compared to GCR results. There was no drastic order rotation as seen in GCR cases. 
SPE Single Material

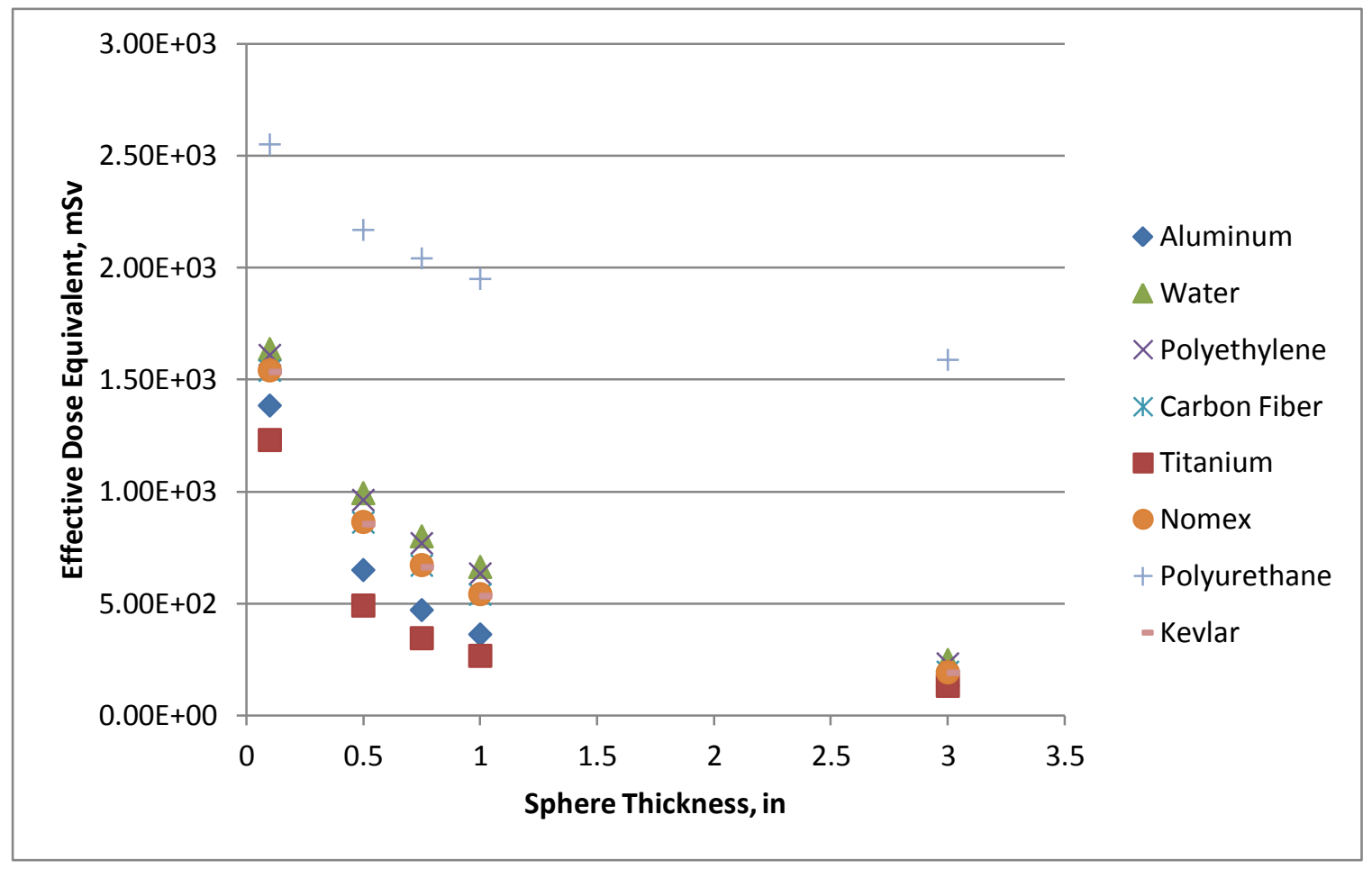

Figure 12. Thin Single Material Comparison for SPE

Between the thinnest and thickest data points, the order of EDE stays fairly constant as can be seen in Fig. 12. Polyurethane had the highest EDE at each data point, just like with the GCR tests. In fact, the order is almost the same as the thin GCR tests. Water and polyethylene both returned high mSv values, followed by a clump of Nomex, Kevlar, and carbon fiber. Aluminum and titanium produced the lowest results, though titanium's efficiency decreased with increasing thickness.

\section{SPE Double Material}

The results of the double material tests can be seen in Fig. 13. While checking to see if order of materials was important, most stayed in the 1-2\% difference range. There was one outlier though. The titanium and aluminum hybrid rose all the way up to a $13 \%$ difference for 3 inch thick shields. However, this drop in accuracy was just premature compared to the other tested combinations. By the time the titanium and aluminum hybrid reached the 20 inch thick sphere in the thick shields section, it was in the same 19-23\% error range as the other combinations. It 
was also noticed that all four combinations of shields returned lower EDE values when aluminum was the outside material.

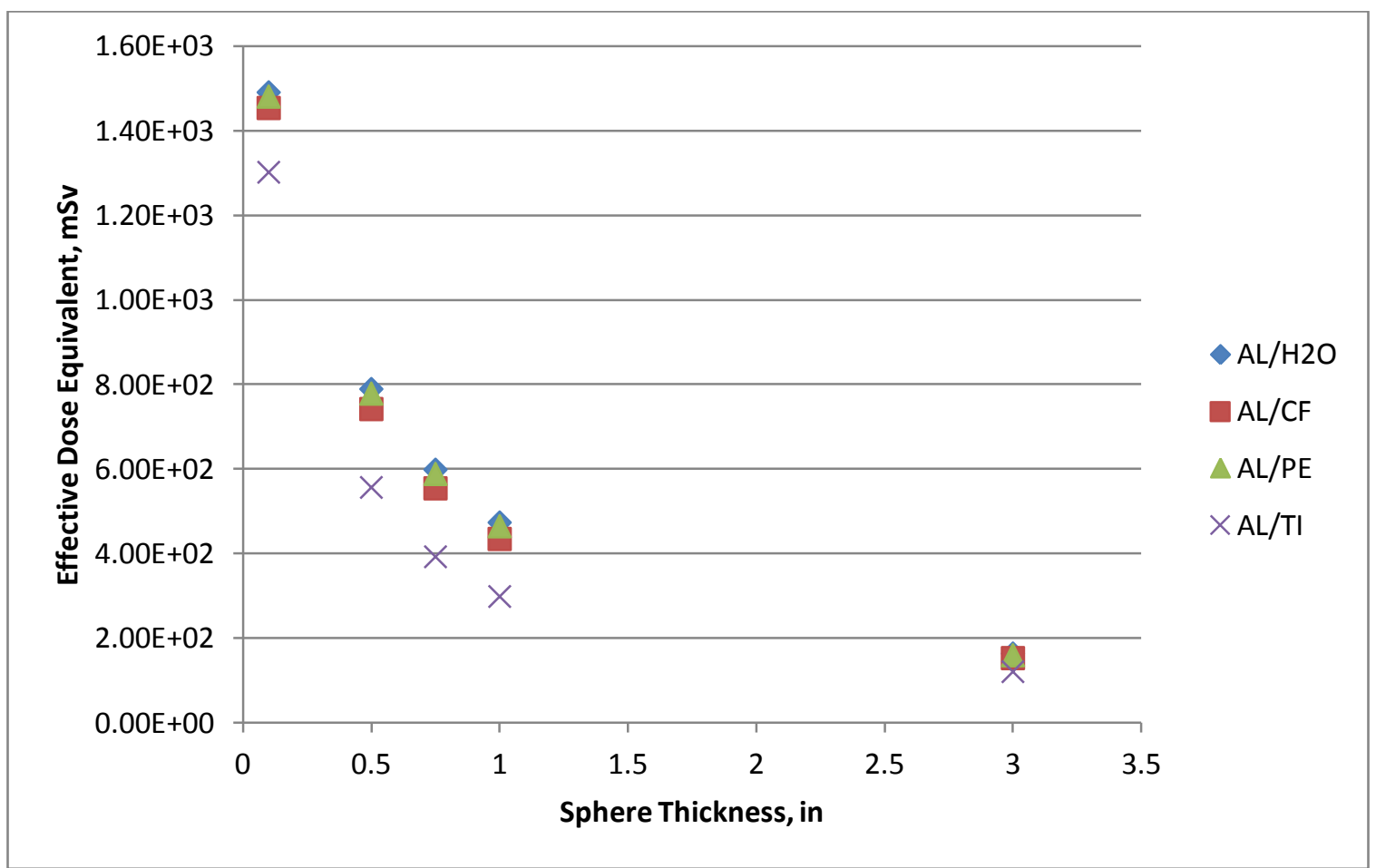

Figure 13. Thin Double Material Comparison for SPE

Unlike the GCR shields, attempts to predict SPE levels by the sum and divide method were much less effective. While aluminum-water managed to stay within $1 \%$ difference, all the other tested combinations ranged from 4\%-14\% different. Also unlike the GCR shields, there was not a constant increase in error as the thickness increased. Some, like carbon fiber-aluminum, peaked in error in the middle of the testing range before dropping. This wasn't even consistent between different orders of materials, as aluminum-carbon fiber continued to rise in error with increasing thickness.

\section{SPE Triple Material}

Similarly to the GCR results, the tested shields with the polyurethane centers returned the highest EDE values. In this case though, the polyethylene centered shields narrowly returned lower EDE values than the water cored ones. This can be seen in Fig. 14 . 


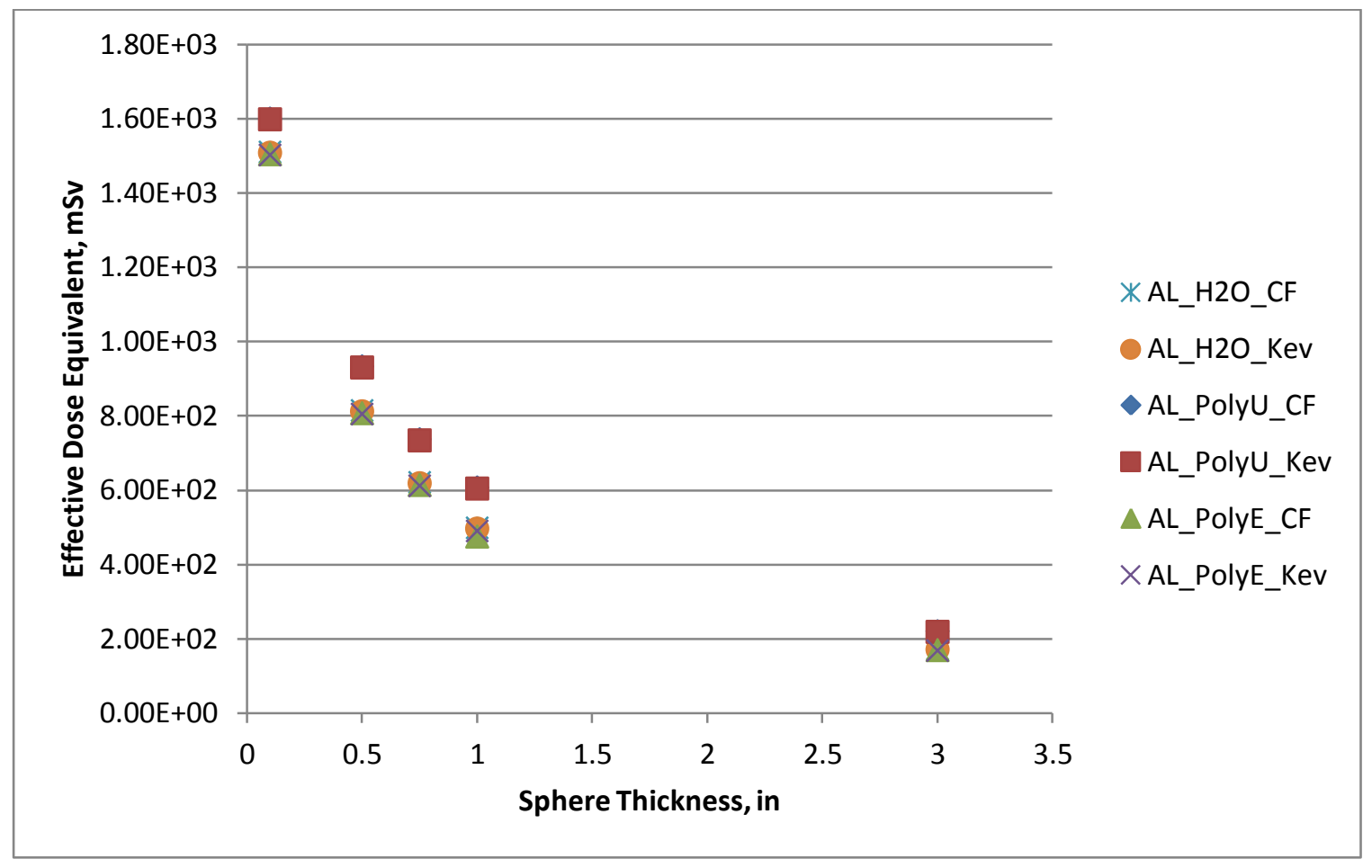

Figure 14. Thin Triple Material Comparison for SPE

With regard to flipping the interior and exterior wall materials, those with water or polyurethane cores made the transition with less than a $2 \%$ difference. In fact, those cases only rose above the $2 \%$ difference at the 3 inch thick shields. The difference at 1 inch thick or less was less than $0.01 \%$. Polyethylene retains a similar degree of accuracy up to 0.75 inch thick shields, but the accuracy drops after that. While the carbon fiber difference was only up to $4 \%$, the Kevlar difference was just under $18 \%$.

\section{Thick Shields}

The thick shields section covers shields of 10, 15, and 20 inches thick. While not feasible with current methods, they one day could be used with advances in rocketry or for shields that cover only a small section of the spacecraft. These shields are more useful for long duration missions or when crewmembers may be exposed to multiple spaceflights. Depending on material composition, thicker material shields were not always determined to be 
beneficial. When predicting EDE by looking at the single material versions of the individual layers, multi-layer thick proved slightly less accurate than multi-layer thin shields.

\section{GCR Single Material}

Looking at the results in Fig. 15, though polyurethane remains the worst radiation shielding material in terms of EDE, much of the rest of the order has flipped between the thick and thin shields. Aluminum and titanium, some of the best thin shield materials, now return some of the highest EDE values. Titanium even manages to return higher values than polyurethane for the solar maximum case. The other materials are still loosely clumped at the 10 inch thick data point, but spread out afterward. Polyethylene and water return the lowest values, followed by Nomex, Kevlar, and carbon fiber.

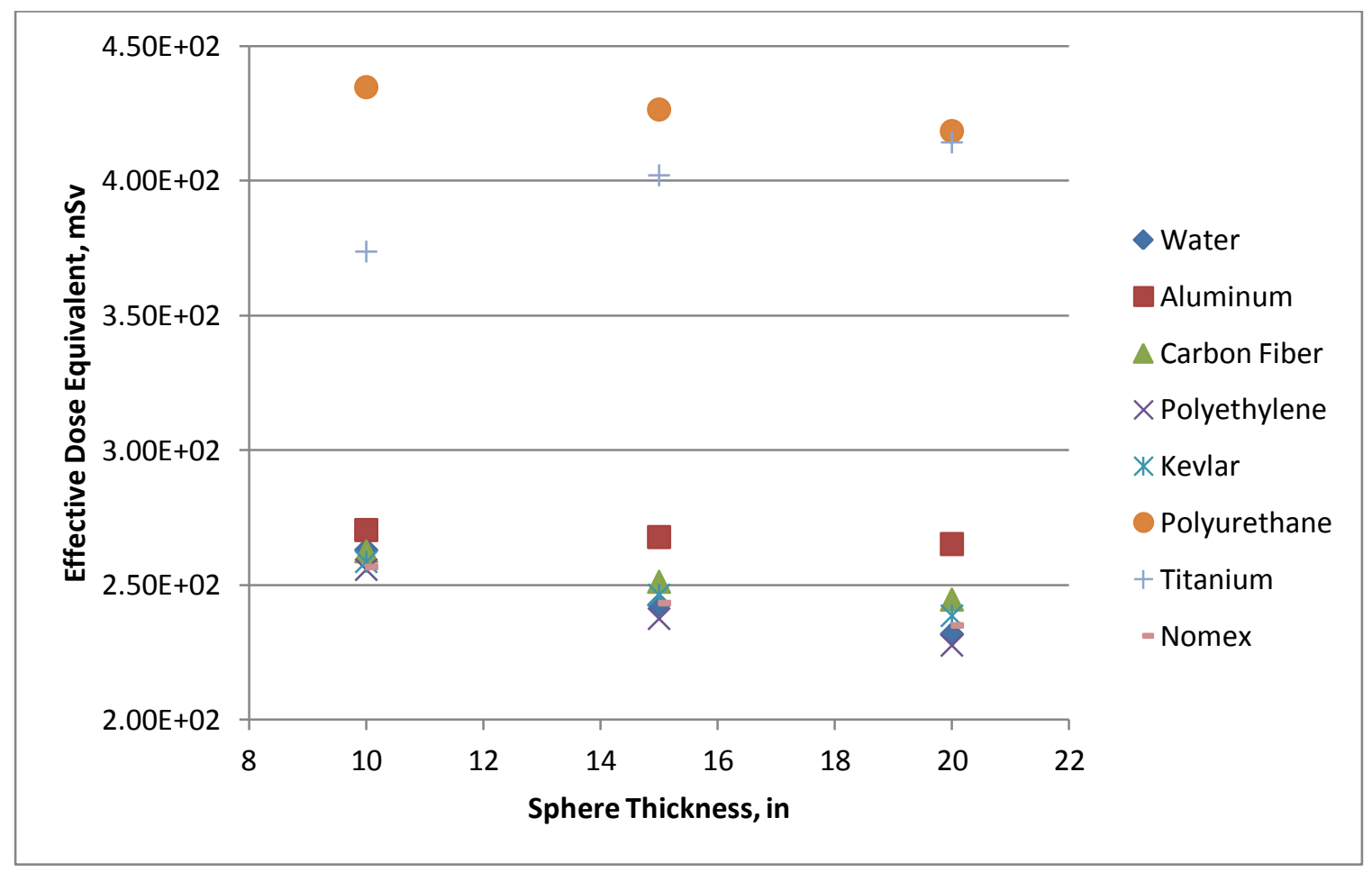

a) 1956 Solar Minimum Single Material Comparison 


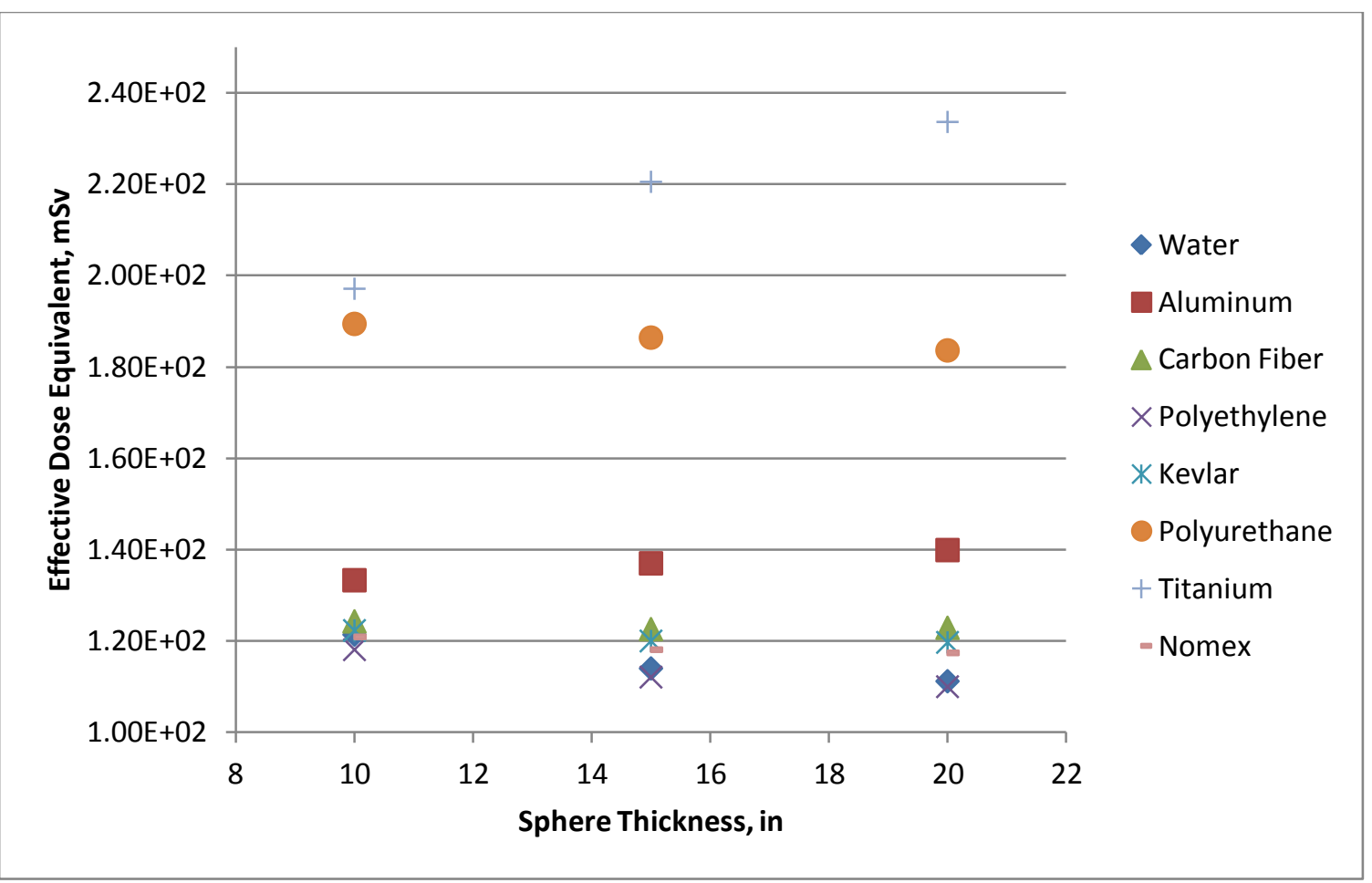

b) 1991 Solar Maximum Single Material Comparison

Figure 15. Thick Single Material Comparison for GCR

\section{GCR Double Material}

When looking at the four tested shield combinations in Fig. 16, one clearly stands out from the others. The aluminum and titanium shield actually had rising EDE values as the thickness increased. This happened for both solar maximum and minimum after the 5 inch thick data set. The other data sets stay fairly close together, within 10 $\mathrm{mSv}$ at 10 inch thick shields up to just over $20 \mathrm{mSv}$ for the 20 inch thick shields. Aluminum hybrids with water and polyethylene returned close lower values, followed by the carbon fiber hybrid. 


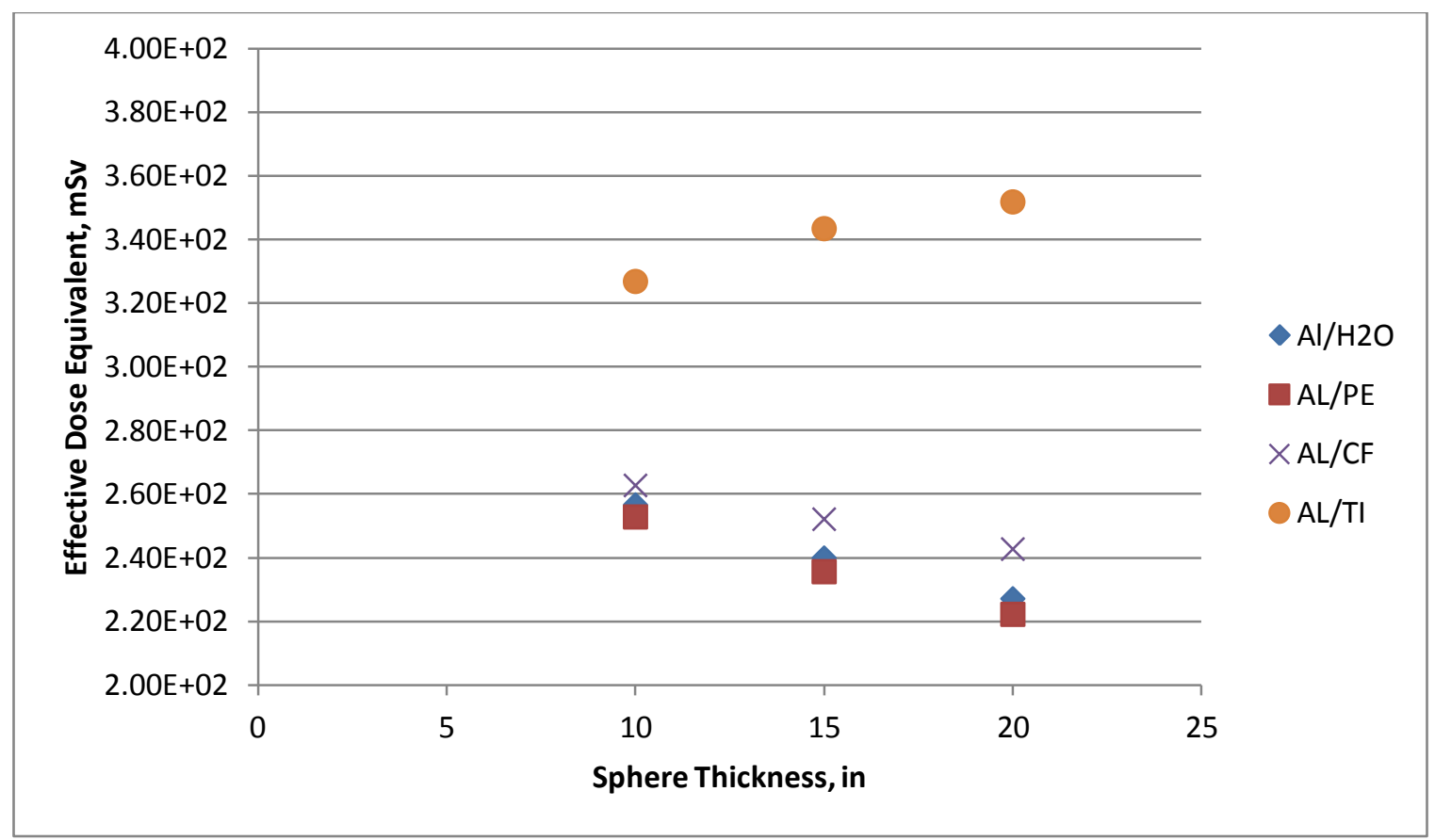

a) 1956 Solar Minimum Double Material Comparison

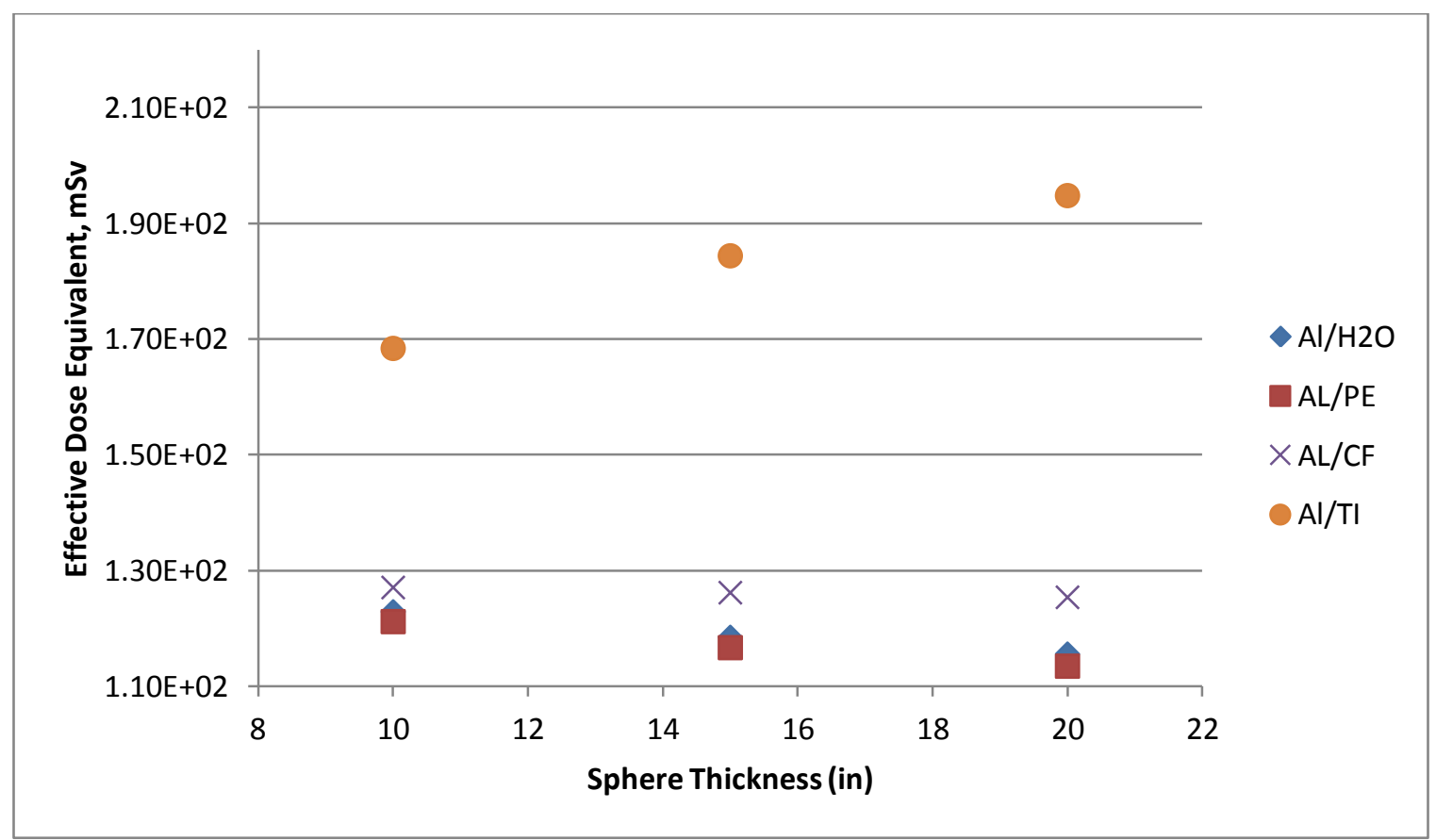

b) 1991 Solar Maximum Double Material Comparison

Figure 16. Thick Double Material Comparison for GCR 
The variance when looking at order of materials in two material shields ranged from aluminum and polyethylene at the high end at $13 \%$ for solar maximum down to aluminum and titanium at $4 \%$ for solar minimum. The effectiveness of a hybrid shield improved when the more efficient of the two materials was placed on the outside. As seen in Fig. 17, the aluminum and water shield returned lower EDE values when water was on the outside, as water was more efficient than aluminum for thick shields. Similarly, the titanium and aluminum shield performed more efficiently than when aluminum was on the outside, for in this case aluminum was the better performer. Material order also came into play when trying to predict the shield effectiveness by the sum and divide method. Shields with aluminum on the inside ranged from $1 \%-5 \%$ worst case error, while those with aluminum on the outside ranged from $4 \%-10 \%$.

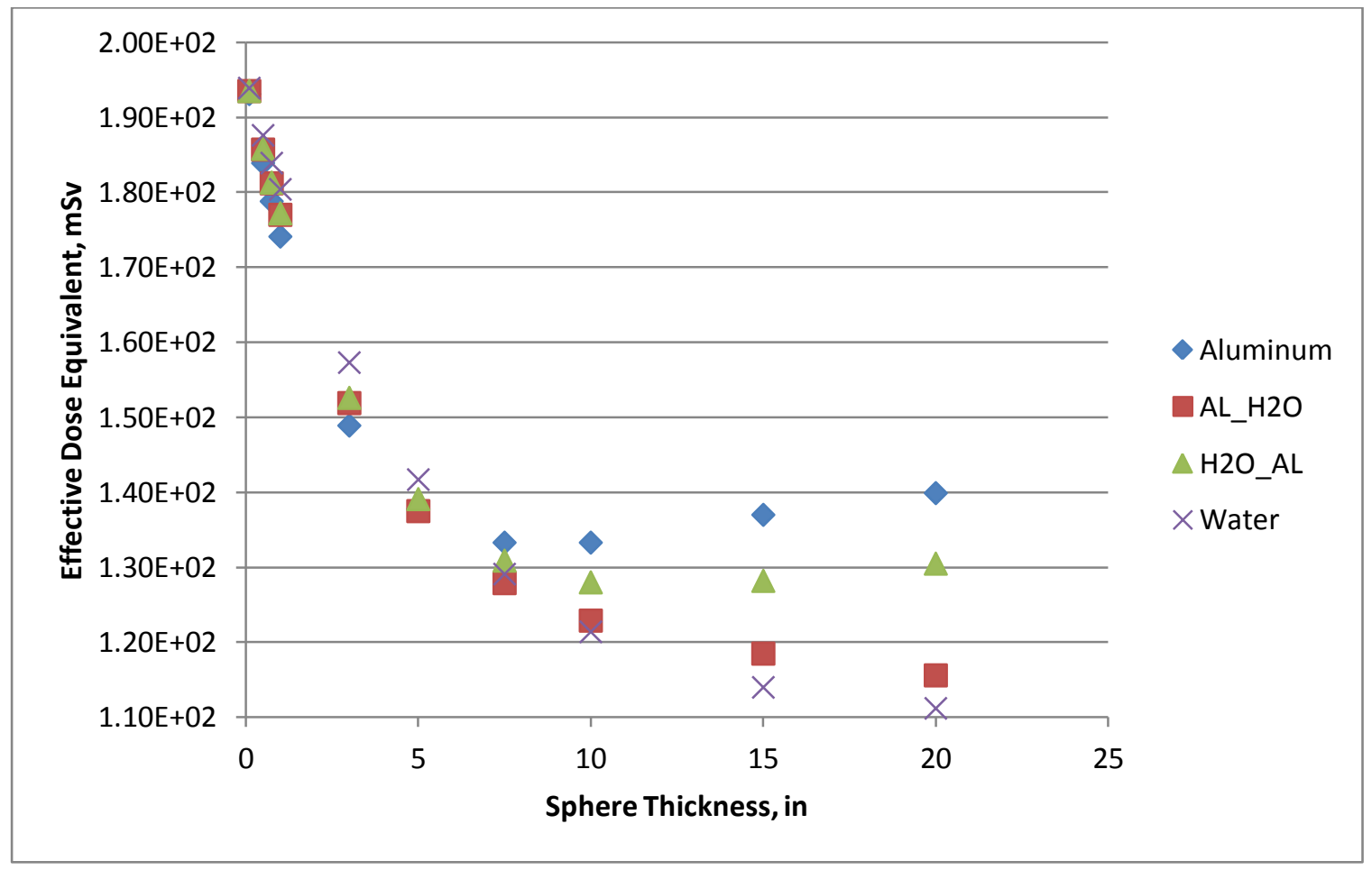

a) Aluminum and Water Hybrid Shields for 1991 Solar Maximum per Year 


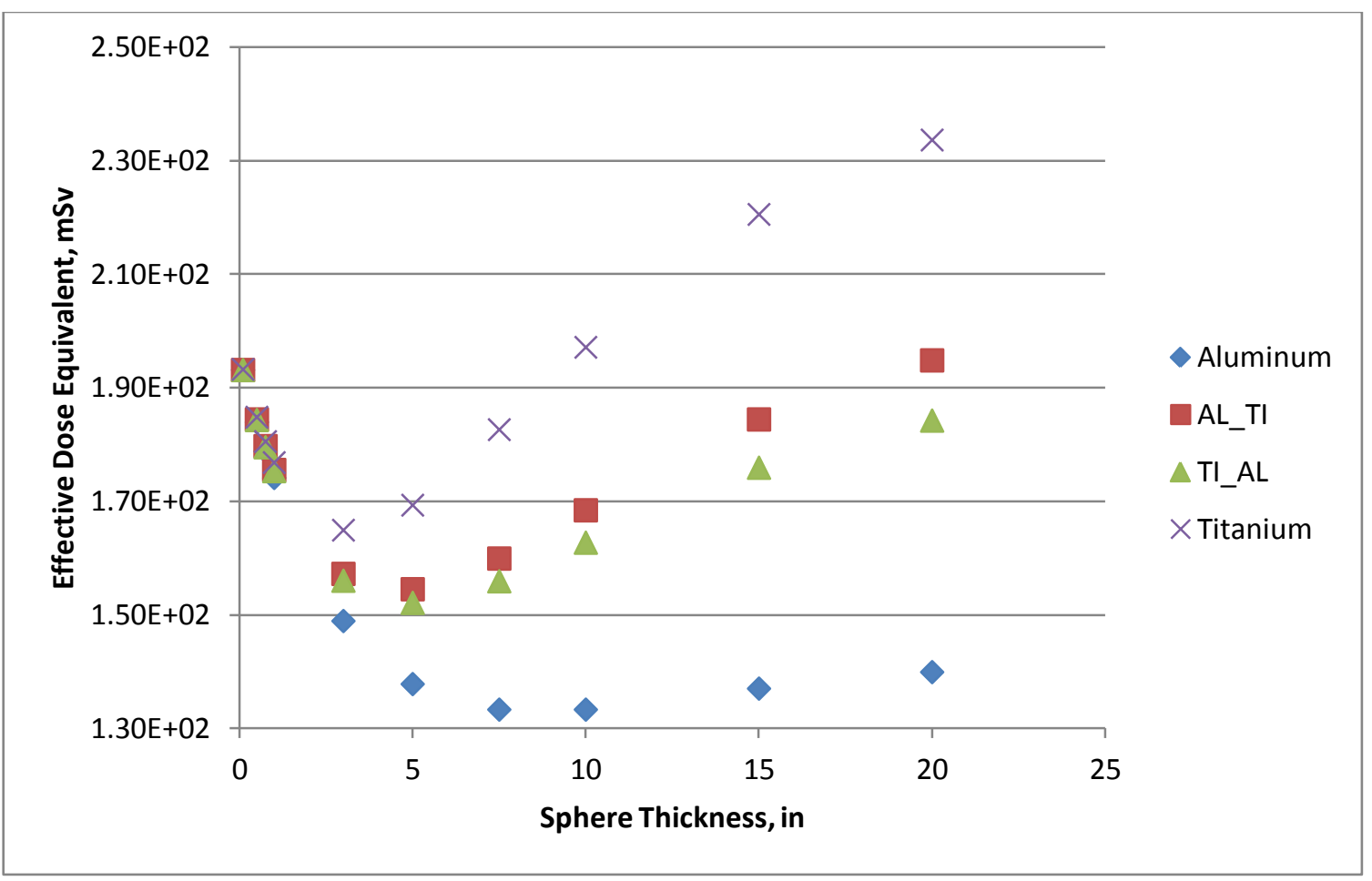

\section{b) Aluminum and Titanium Hybrid Shields for 1991 Solar Maximum per Year}

\section{Figure 17. Thick Double Material Order Comparisons}

For thicker shields with consistent orders, material relative thickness had less of an impact. Consider the case of an aluminum and water shield for 1991 solar maximum per year data (Fig. 18) with the materials in that order. Data was taken for shields of pure water and aluminum, as well as hybrids of 25-75, 50-50, and 75-25 percent. Before the rotation thickness, the returned EDEs are even spaced out between the two pure shields, with the 25-75 shields closer to their larger respective material and the 50-50 shield in the center. After the reflection thickness (the 7.5 inch data points for this scenario) all three hybrids stay closer to the more efficient pure shield (water). Even the hybrid with the highest concentration was only slightly above a third (35.5\%) of the way between the two pure shields. 


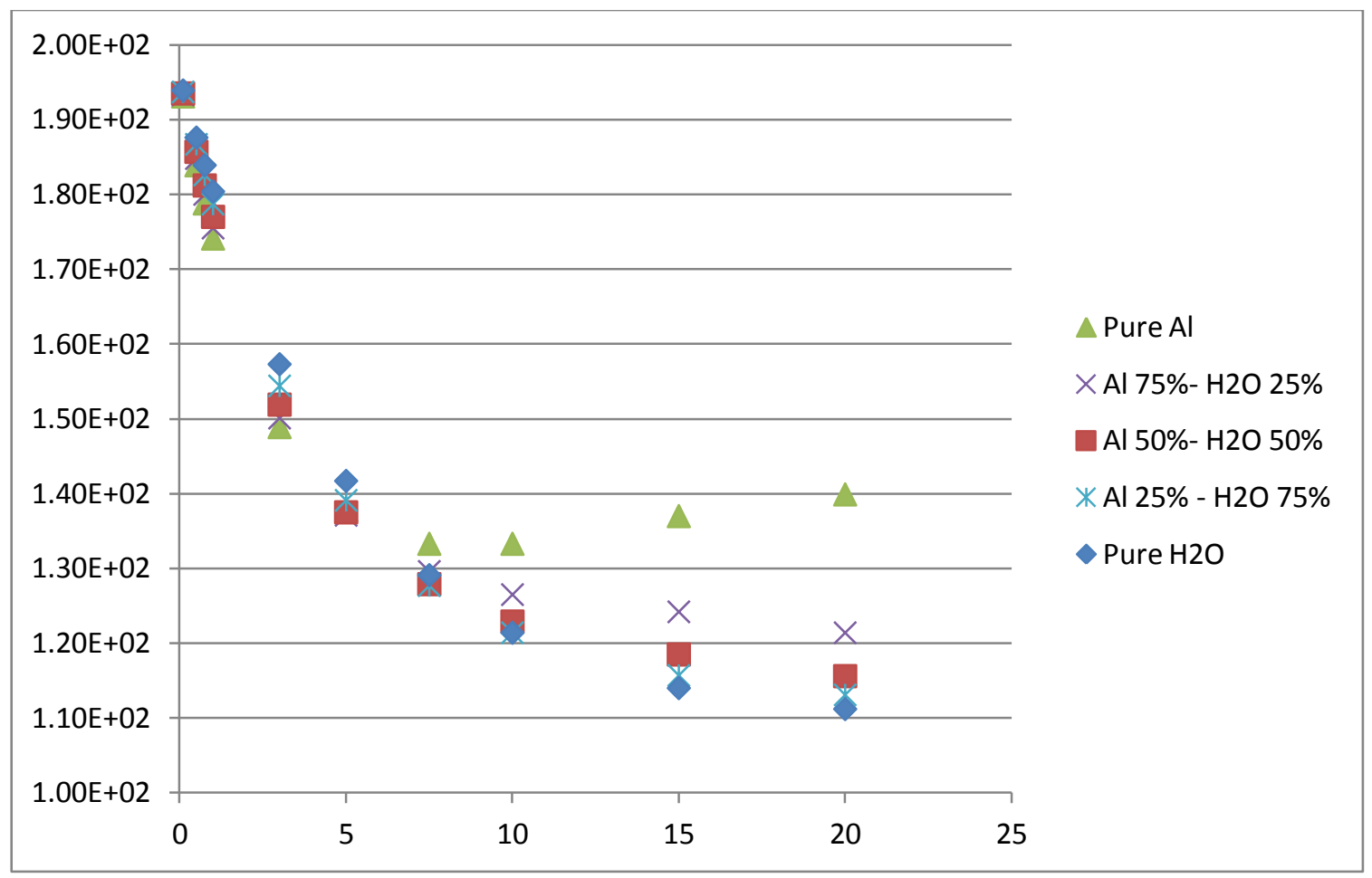

Figure 18. Aluminum and Water Hybrid Shield Percentage Comparison

\section{GCR Triple Material}

For both solar maximum and minimum shields, triple material shields with polyurethane centers were the least effective as seen in Fig. 19. Polyethylene centers had the best results overall, though there was some overlap with water centers. The shields that used Kevlar had better results than those using carbon fiber.

Attempts to estimate effectiveness by the sum and divide method were accurate to within 3\%-6\% for water and polyethylene cores at the thickest case of (20 inches). The polyurethane cored models had a much higher worst case error at $18 \%-23 \%$. This skew is most likely due to the high EDE values of pure polyurethane, which did not reduce much with thickness. This inflated the total calculated value. So while calculating EDE of multilayer shields by adding the component walls materials and dividing them by the thickness fraction, the basic material curve must be known to prevent data skew. 


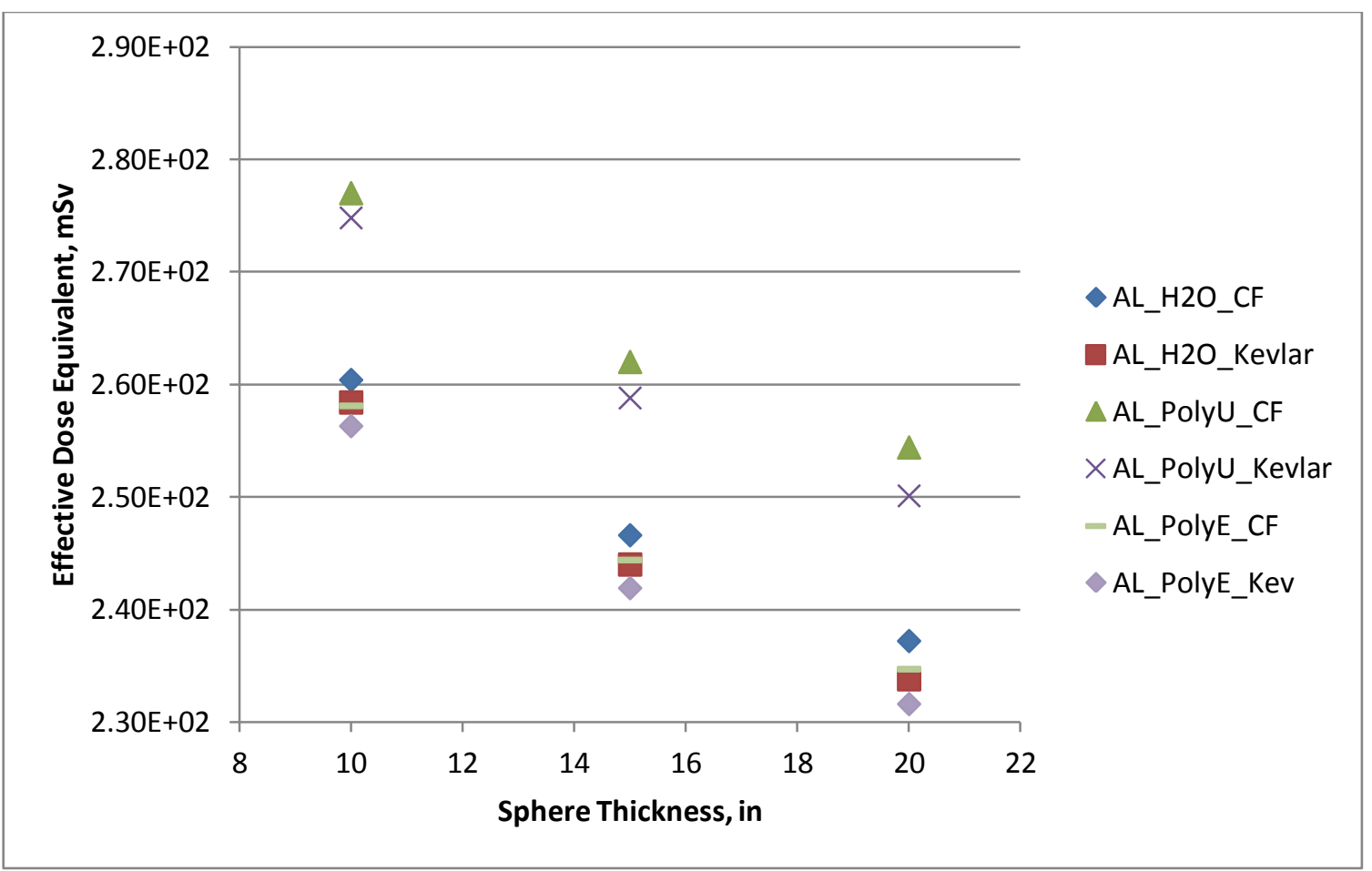

a) 1956 Solar Minimum Triple Material Comparison

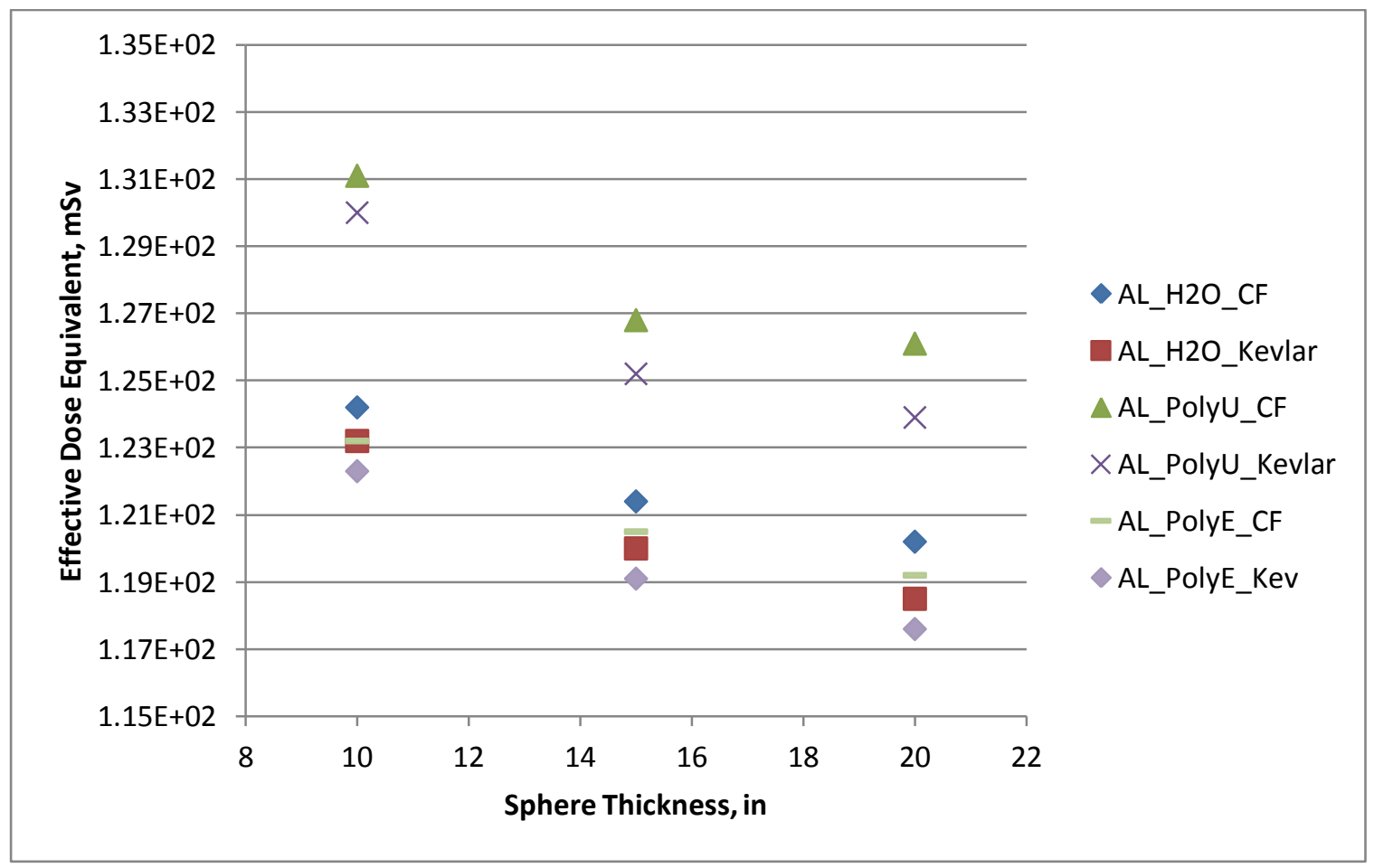

a) 1991 Solar Maximum Triple Material Comparison

Figure 19. Thick Triple Material Comparison for GCR 


\section{SPE Overview}

SPE shields converge with increasing thickness. The results in the figures below can seem to be quite different, but they really only differ by less than $25 \mathrm{mSV}$. This is a tiny difference compared to the over $400 \mathrm{mSv}$ difference between some of the thin shields.

\section{SPE Single Material}

Polyurethane was also a tested material in Fig. 20, but the values were over an order of magnitude greater than all the other tested shields. By excluding it, the graph becomes much less distorted. While titanium presents as the next least efficient material with water close after, the order of the rest of the tested shields jumbles between points. However, the greatest gap between the top and bottom elements is only $15.4 \mathrm{mSv}$. By the 20 inch shields and excluding titanium, all the other materials fit in a $6.46 \mathrm{mSv}$ range.

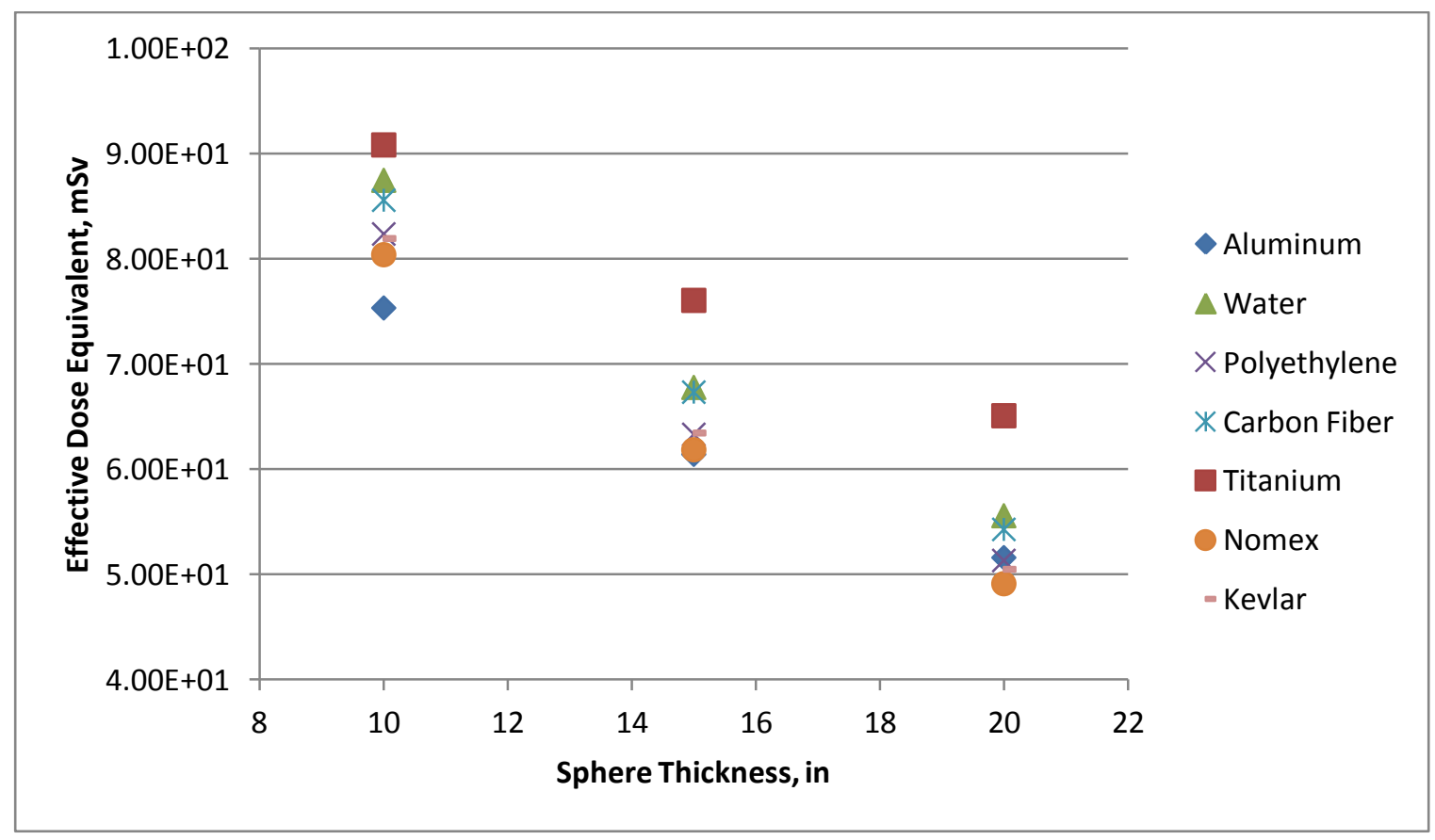

Figure 20. Thick Single Material Comparison for SPE 
SPE Double Material

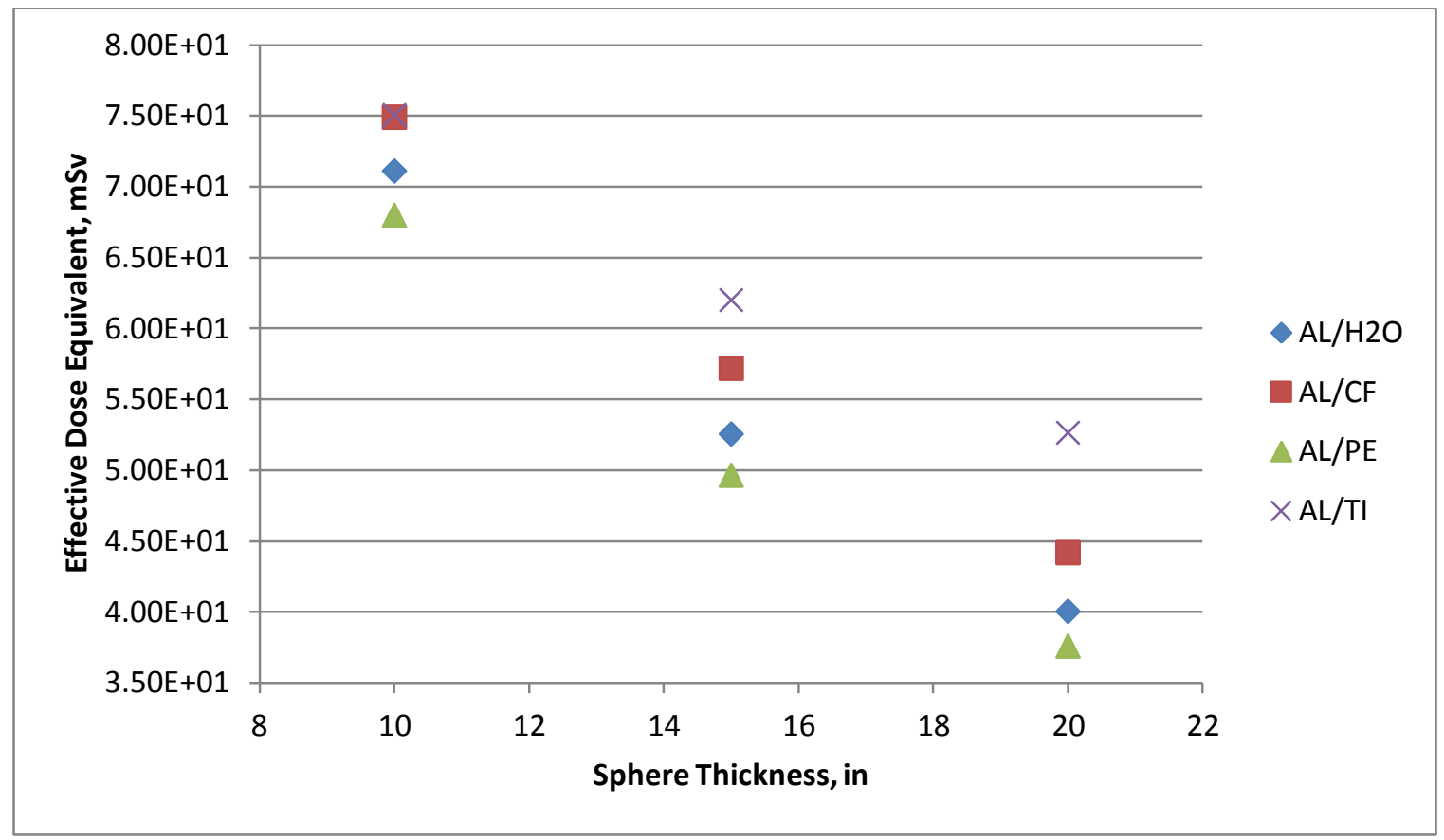

Figure 21. Thick Double Material Comparison for SPE

The order of effectiveness stayed the same between the three thicknesses tested in Fig. 21, though aluminum and titanium shield was less than $1 \mathrm{mSv}$ higher than aluminum and carbon fiber shield for 10 inch thick test spheres. All but the aluminum and titanium shield stayed within $1 \mathrm{mSv}$ of each other for all three thicknesses. The aluminum and titanium combination however became less efficient than the others at each step.

A significant difference was noted when looking at the order of materials. Flipping the outer and inner materials resulted in differences of $8 \%-10 \%$ at 10 inches thickness and $19 \%-22 \%$ at maximum thickness.

\section{SPE Triple Material}

Similarly to other plots, the polyurethane cored triple material hybrid shields in Fig. 22 were less efficient that the other two core types. The shields with Kevlar were also slightly more efficient than those with carbon fiber. The polyethylene shields narrowly but consistently beat out the water cored shields. But the difference between the most efficient polyethylene and the least efficient water was still less than $3 \mathrm{mSv}$. 


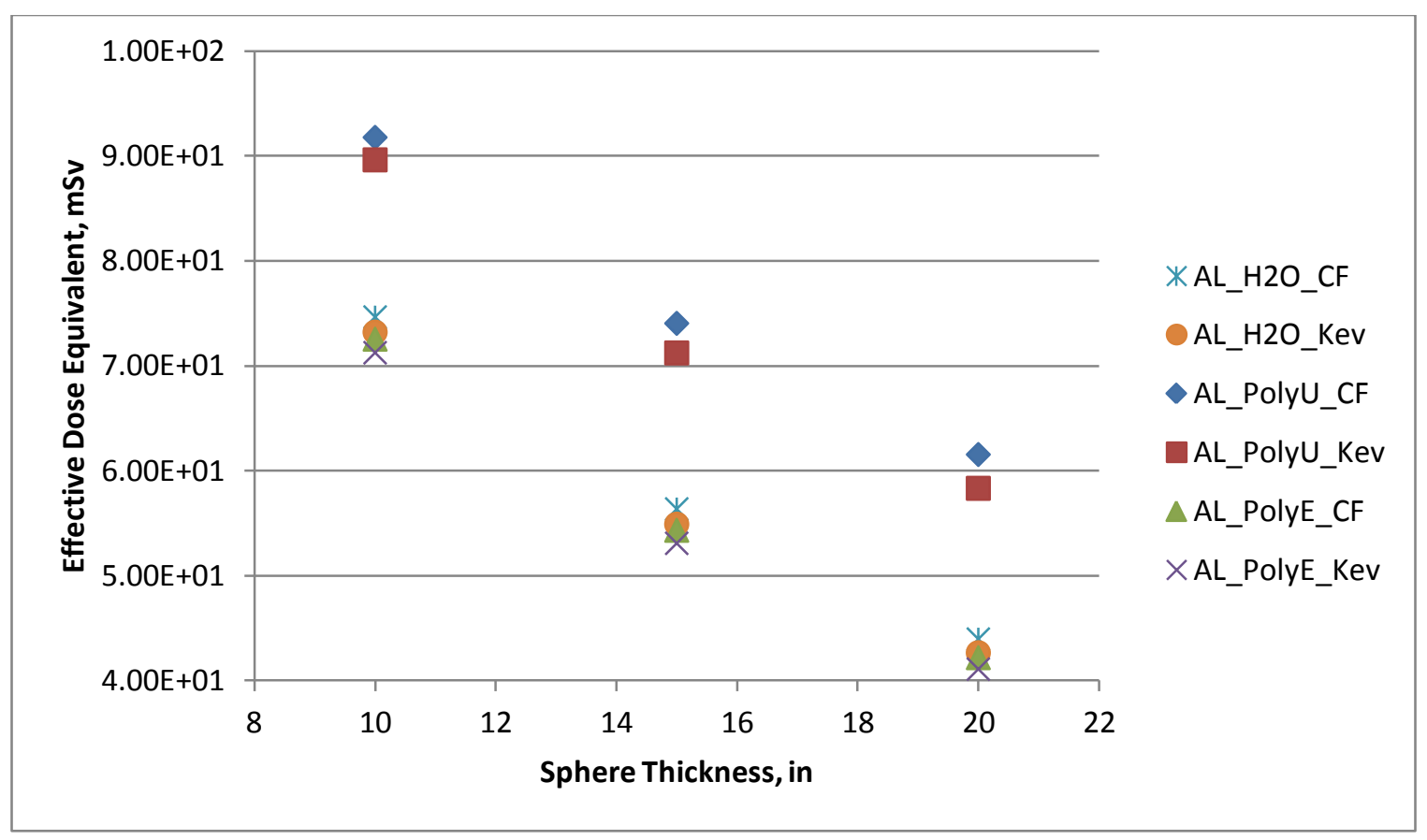

Figure 22. Thick Triple Material Comparison for SPE

Material order was much more important for thicker shields than thinner. Polyurethane shields had the lowest maximum difference in order with $12 \%$ and $14 \%$ for carbon fiber and Kevlar respectively. The other four had maximum errors in the $17 \%-18 \%$ range.

The error for using the sum and divide method was fairly consistent for two of the tested cores. Water and polyethylene cores had maximum errors in the $22 \%-25 \%$ range. The polyurethane cores on the other hand had massive errors of $486 \%$ and $510 \%$ for carbon fiber and Kevlar respectively. This large error is most likely due to polyurethane's trend of not decreasing significantly with increasing shielding.

A second sum and divide calculation was done ignoring the central material and treating the calculated shield as a two layer hybrid. These results were surprisingly similar to the triple material shield results, with only a maximum 1\%-2\% difference for polyethylene cores and 2\%-4\% for water cores. The polyurethane cores dropped to a much more useful error. 


\section{Metal Alloys}

Though the tests above were done with pure materials, most metals used these days are alloys. Therefore another set of tests were done to determine the effects of alloyed materials on shielding effectiveness. The first test was done with aluminum and aluminum-lithium alloy 2195 , which is used in spacecraft structures such as the space shuttle external tank. ${ }^{1}$ While aluminum, copper, and lithium are the majority components $(93.8 \%, 4 \%$, and $1 \%$ in the tested sample respectively), the metal also contains small quantities of magnesium $(0.5 \%)$, manganese $(0.3 \%)$, and silver $(0.4 \%)$. The results of the test for solar maximum and minimum, as well as SPE, can be seen below in Fig. 23.

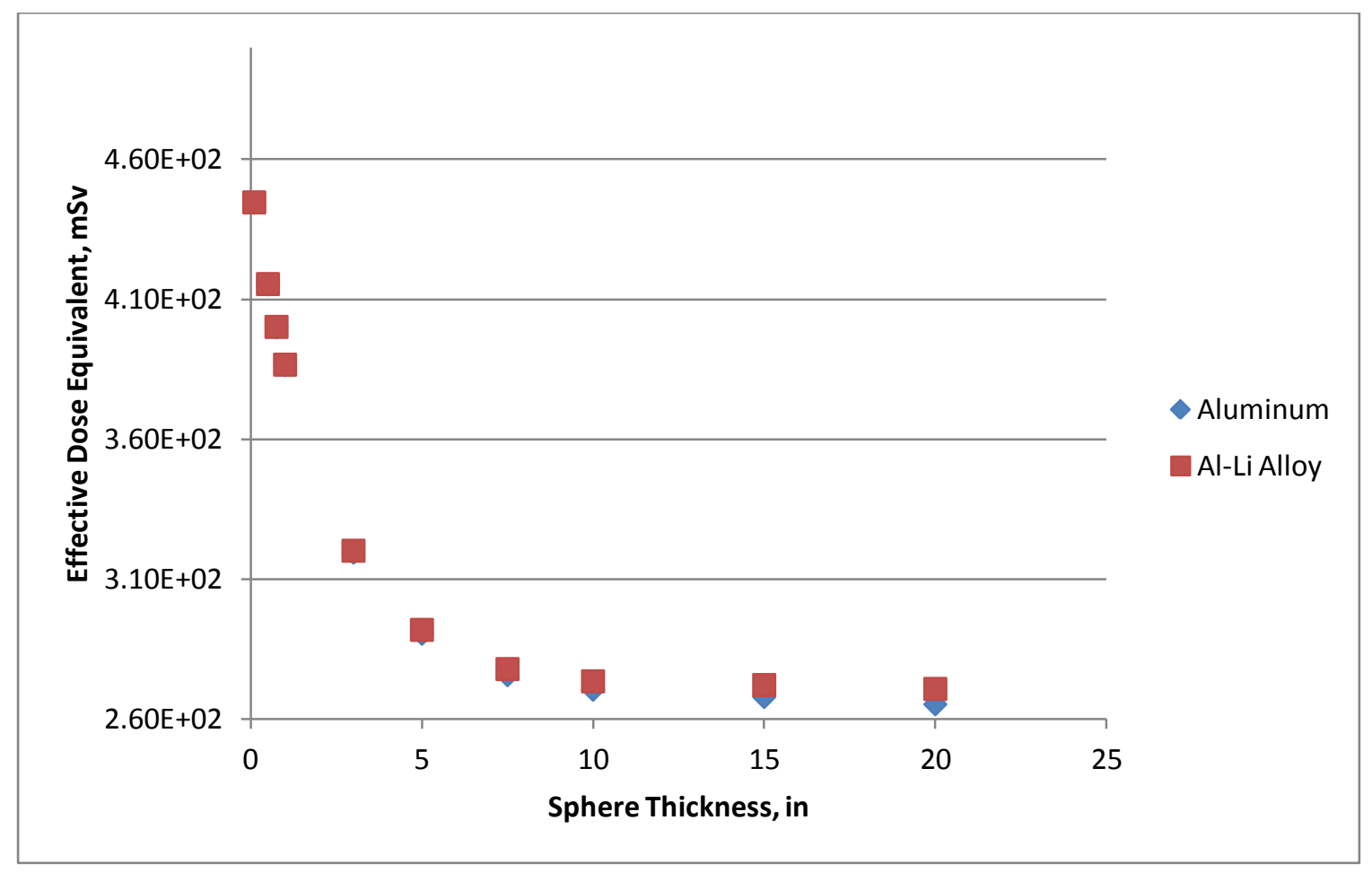

a) Aluminum Alloy Comparison for 1956 Solar Minimum 


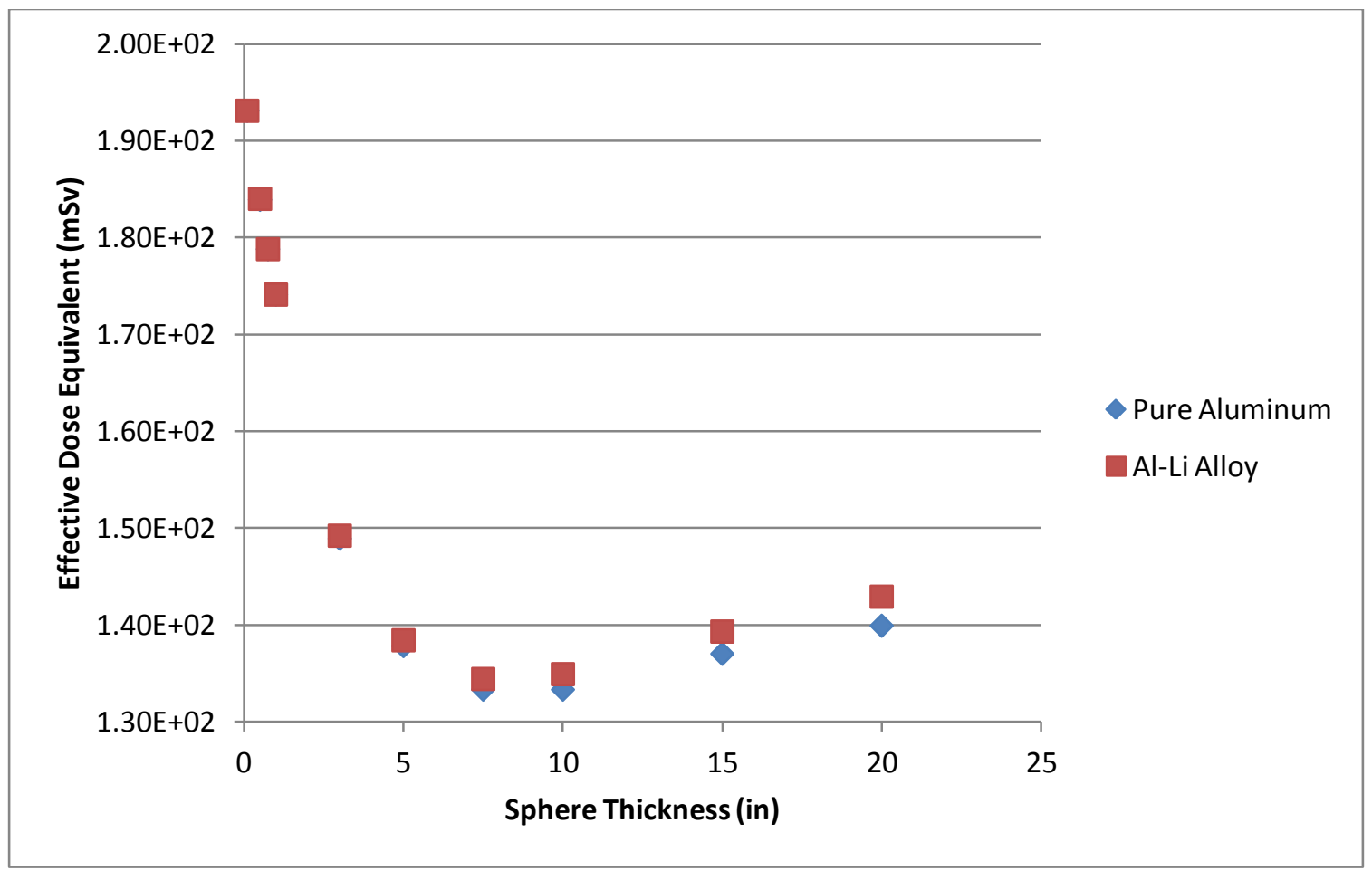

b) Aluminum Alloy Comparison for 1991 Solar Maximum

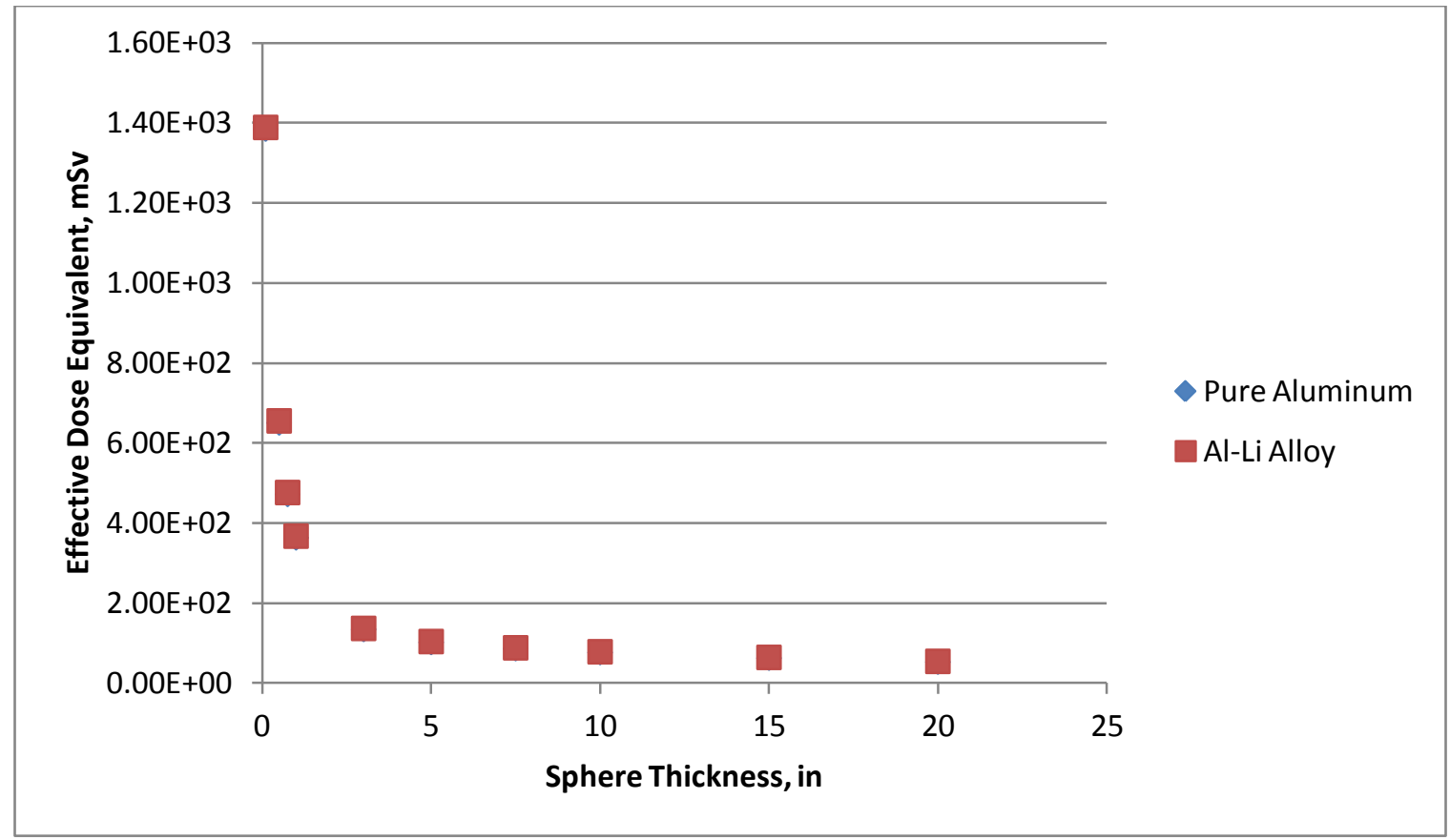

c) Aluminum Alloy Comparison for Averaged SPE

Figure 23. Aluminum Alloy Comparison for Multiple Environments 
As can be seen in the plots in Fig. 23 above, the difference between the pure and alloy shields is negligible until it reaches the thick shield region. For both solar maximum and minimum GCR shields the difference for the alloy was less than $1 \%$ up to 7.5 inch thick shields. For the thickest shields, the worst case difference was just a tenth over $2 \%$. For the SPE data the difference was under $2 \%$ up to 3 inch thick shields, with the thickest tested shields having a difference of less than $3.5 \%$.

The second test was done with titanium and Ti-6A-4V titanium alloy. ${ }^{3}$ The alloy contained $90 \%$ titanium, $6 \%$ aluminum, and $4 \%$ vanadium. Similarly to the aluminum alloy results, the difference seen in Fig. 24 between pure titanium and its alloy were less than $1 \%$ up to 3 inch thick shields. The worst case tested difference was $3 \%$. The SPE results were only able to maintain the $1 \%$ difference up to 1 inch thick shields, but the worst case difference was only $2.6 \%$.

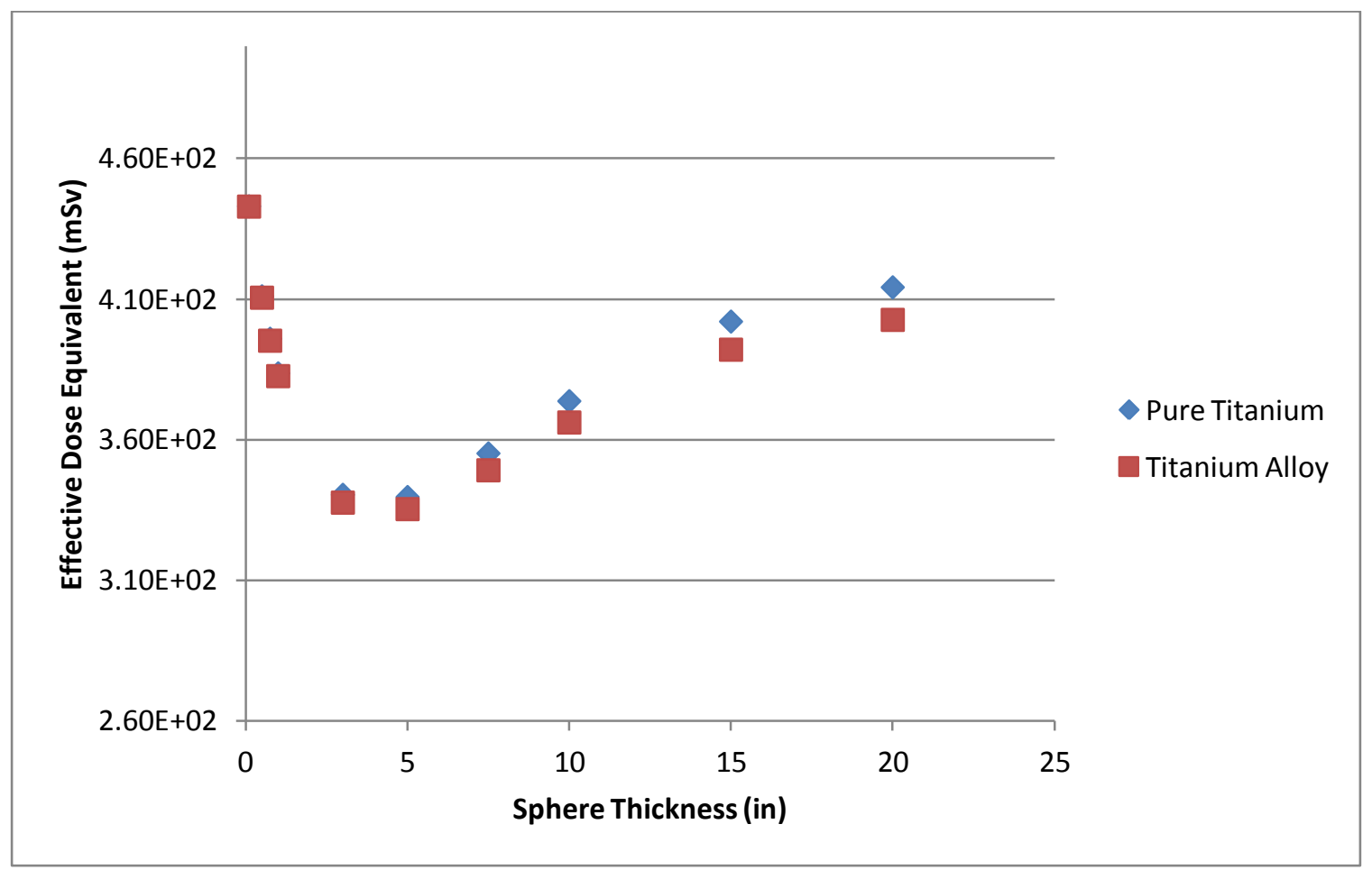

a) Titanium Alloy Comparison for 1956 Solar Minimum 


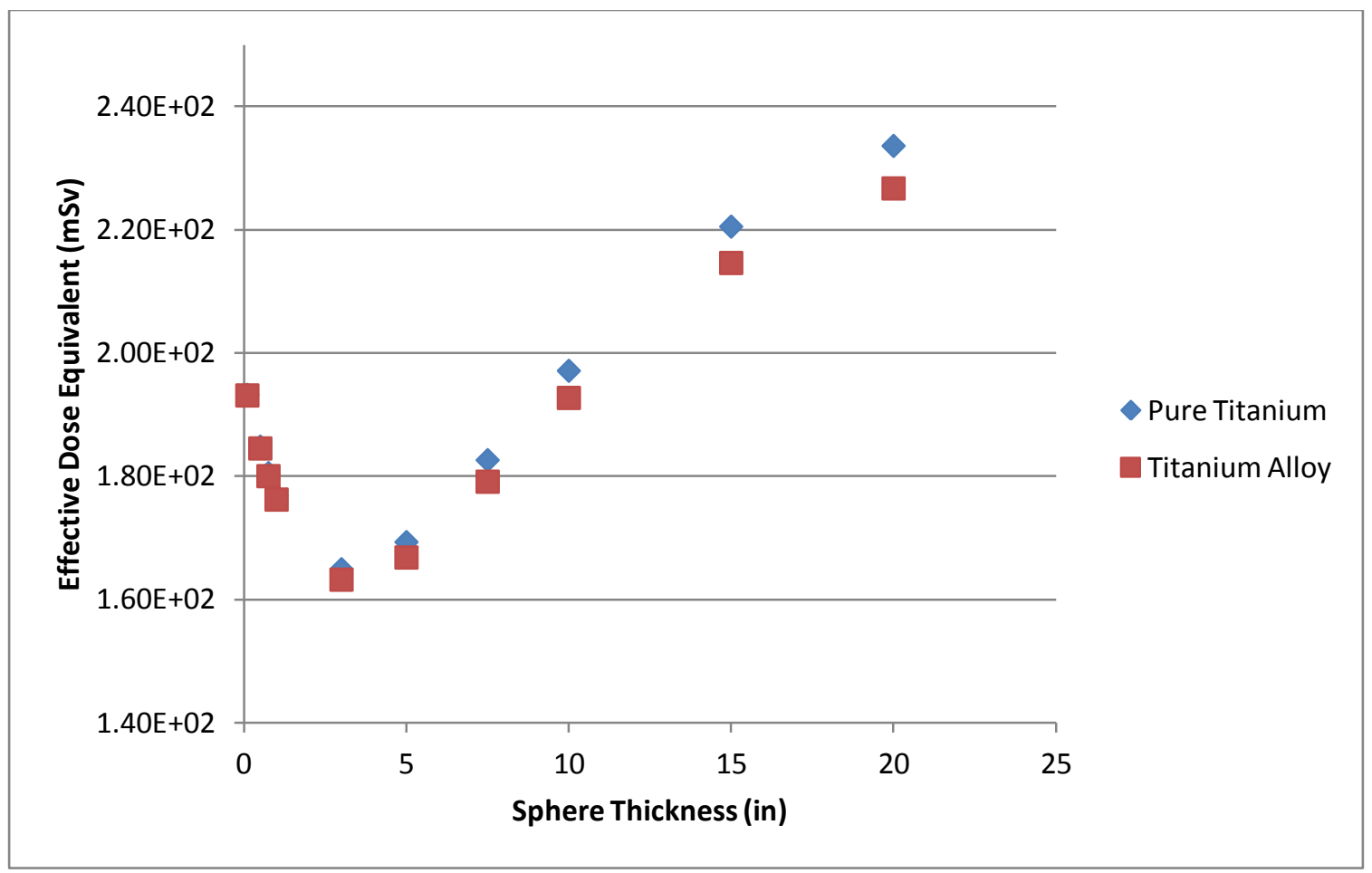

b) Titanium Alloy Comparison for 1991 Solar Maximum

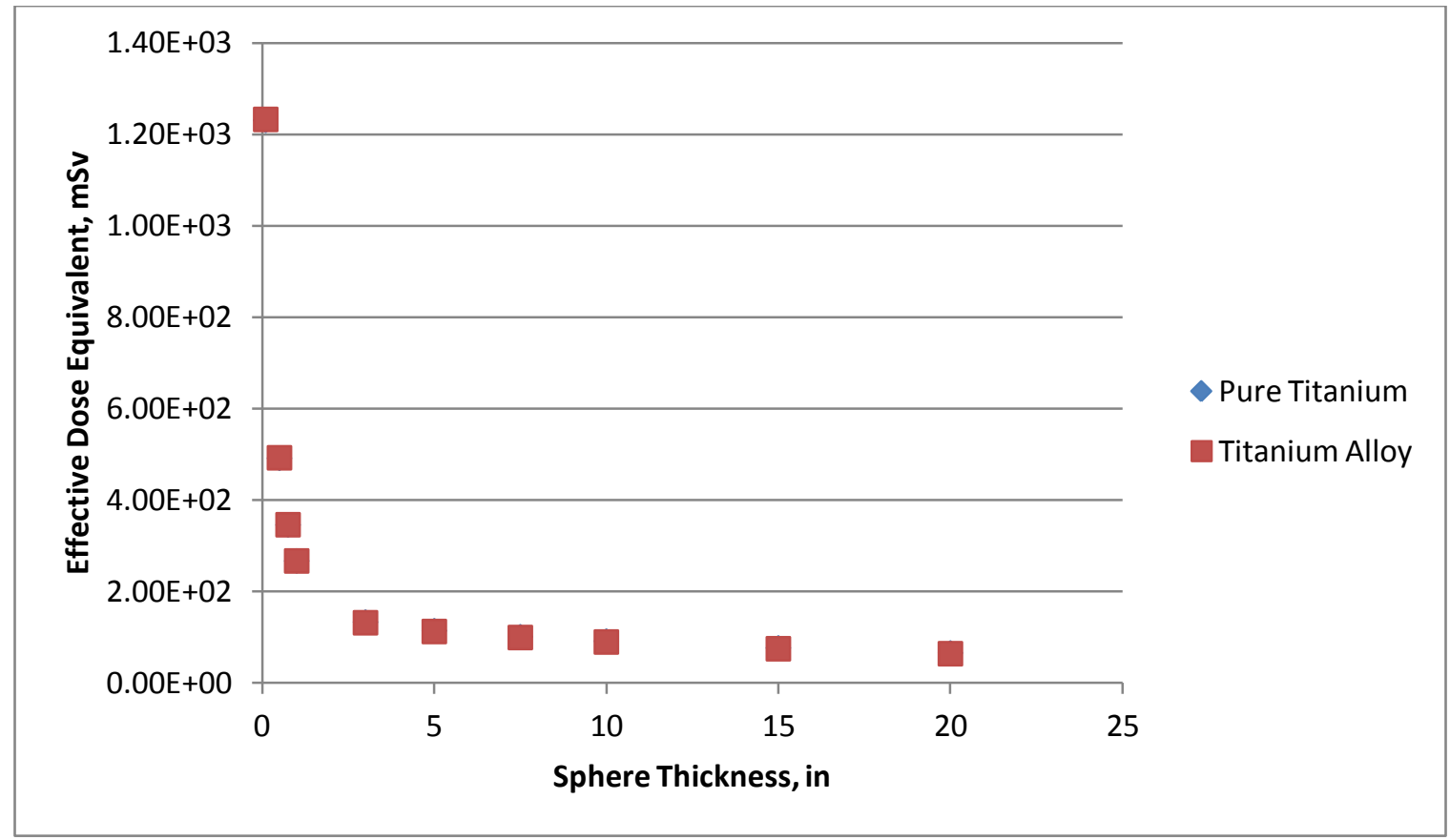

c) Titanium Alloy Comparison for Averaged SPE

Figure 24. Titanium Alloy Comparison for Multiple Environments 


\section{Shielding Thickness vs. Mass}

The design of spacecraft is all about compromise, about picking not the best option but the one that allows for greatest overall effectiveness. What this requires is prioritization. In this paper for example, the yardstick with which the effective dose equivalent was measured was thickness in inches. By using thickness, the emphasis was on using existing structural components to see if the shielding was sufficient and how much needed to be added to be compliant. It was also a useful metric when spacecraft size is a critical design requirement, such as when a specific launch faring must be used.

But this was not the only possible priority. Another was to use the measure of areal density (typically grams per centimeter squared) instead of inches thick. In this case, the priority shifts from size to mass. This is more useful when missions have a tightly regulated mass budget or the shielding required goes above what material is needed for other subsystems. In the former case, reducing the parasitic mass at the expense of volume may be necessary. A comparison between the two methods can be seen in Fig. 25 below.

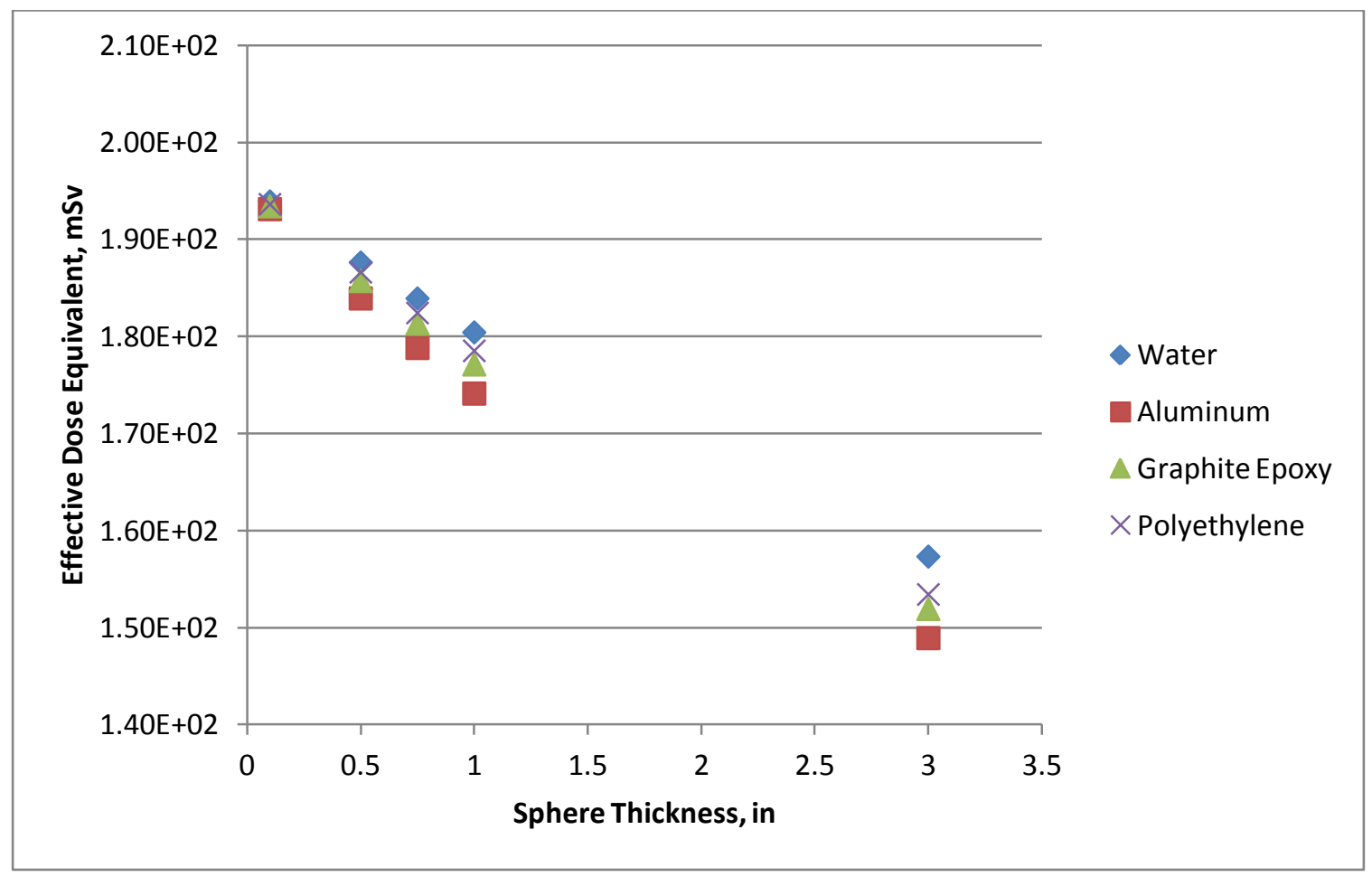

a) 1991 Single Material Comparison, Thickness 


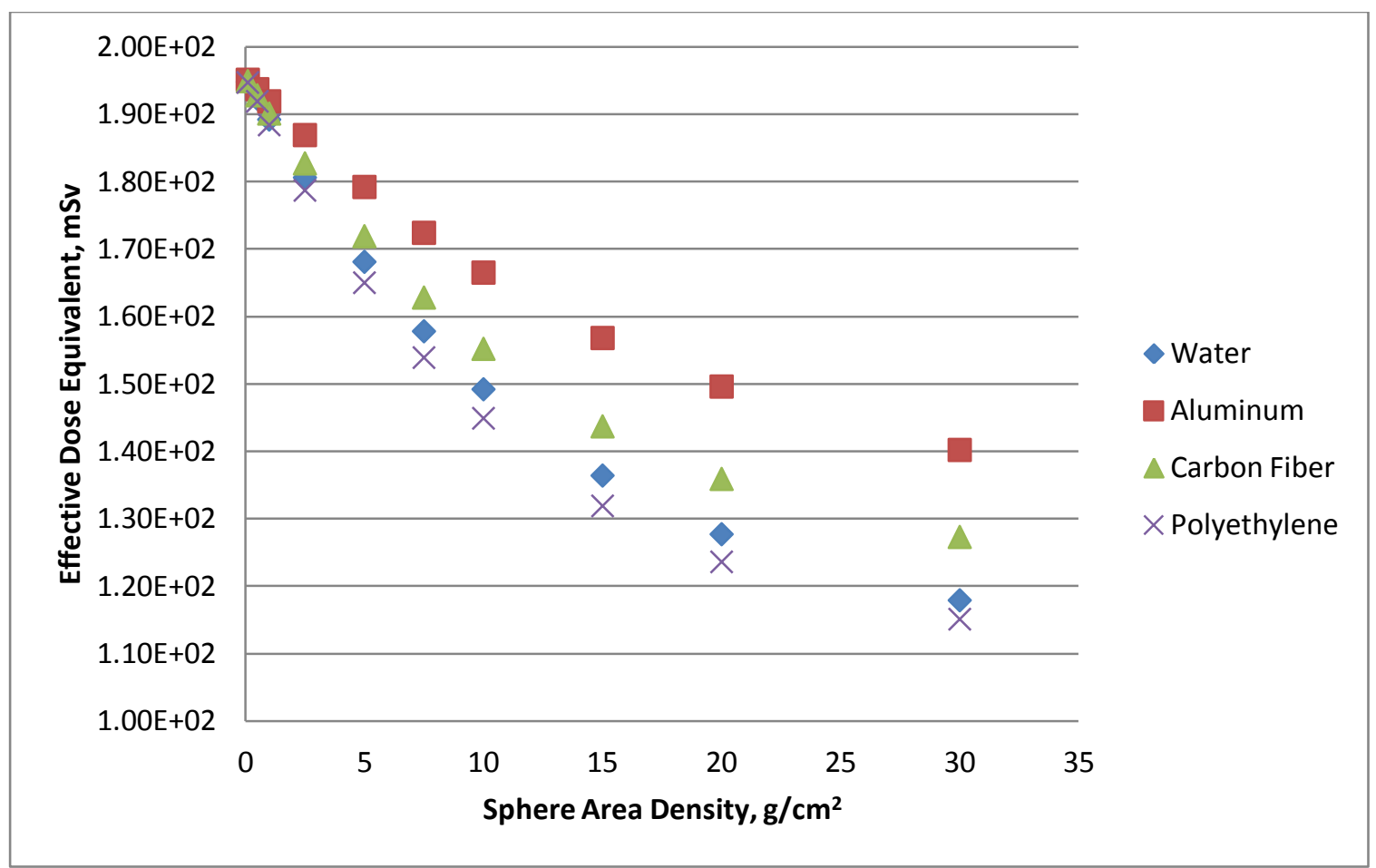

b) 1991 Single Material Comparison, Area Density

Figure 25. Thickness vs. Area Density Comparison for 1991 Solar Max Year

Though this is but a single comparison, it is easy to see how much effect the switch can make. Aluminum, the most efficient shield when only thickness is considered, suffers greatly from its high density and is therefore less useful when mass is the concern. The significantly lighter polyethylene $\left(1 \mathrm{~g} / \mathrm{cm}^{2} \mathrm{vs} .2 .7 \mathrm{~g} / \mathrm{cm}^{2}\right.$ for aluminum $)$ is able to use the extra material to become the most efficient of the four materials shown.

\section{Radiation Recommendations}

From the results above, GCRs and SPEs require different types of shielding. This is due to the differing intensity, energy, and types of particles that compose each flavor of radiation. While GCRs could be brought below limits with thin shields, it took significantly more shielding thickness to reduce the risk from SPEs. Limitations on launch vehicle size and mass will likely be the driving factors in radiation design, preventing the thick shields required to bring down the intensity of SPEs. As shown in the examples in the previous sections, launching an inch 
or more of shield material could take up most or all of a rocket's capacity. While it could be possible to launch the interplanetary spaceship in pieces and assemble it in space (a la the International Space Station), doing so would add a significant factors of risk and complexity in addition to the mass required for the interconnects.

The most practical option would be to reduce the amount of radiation the shield needs to absorb. The use of temporary shields is a must and should be factored into the overall design. Non-structural shielding for particularly vulnerable organs, such as the eyes, should also be employed to reduce the total necessary structural shielding mass. By lowering the damage to the most vulnerable organs, the overall shielding requirement could be lowered.

If a "best" material must be selected for each category, the results can be seen in Table 21 below. There was some variation, but useful trends come through. For thin $(<1$ inch $)$ shields aluminum and titanium were the best for almost every category. The thin SPE triple material category swapped order at every point, making it impossible to point out a most efficient material. For the thick (>10 inches) shields, polyethylene became the "best material. It was the most efficient in five of the six categories, narrowly beaten out by aluminum and Nomex for single material thick shields. Though as the total difference between most and least efficient for those cases was less than $5 \mathrm{mSv}$.

Table 21. Best Radiation Material Per Category

\begin{tabular}{|c|c|c|}
\hline GCR & $<1$ Inch Thick & $>10$ Inches Thick \\
\hline Single Material & $\begin{array}{c}\text { Solar Minimum-Titanium } \\
\text { Solar Maximum-Aluminum }\end{array}$ & Polyethylene \\
\hline Double Material & Aluminum-Titanium & Aluminum-Polyethylene \\
\hline Triple Material & Aluminum-Polyethylene-Kevlar & Aluminum-Polyethylene-Kevlar \\
\hline SPE & Titanium & $\begin{array}{c}\text { At 10 Inches-Aluminum } \\
\text { After 10 Inches-Nomex }\end{array}$ \\
\hline Single Material & Aluminum-Titanium & Aluminum-Polyethylene \\
\hline Double Material & Variable, Thickness Dependent & Aluminum-Polyethylene-Kevlar \\
\hline Triple Material & & \\
\hline
\end{tabular}

From the results of the material effects section, total thickness is more important than the material in most cases (with the exception for materials such as polyurethane that defy the common trend). With the exception of thin 
SPE shields, for most shields the difference between the most and least efficient material was less than $30-40 \mathrm{mSv}$ at each thickness level.

While for thin shields the majority of the mass might be dictated by what is needed for structure and other subsystems, for thick shields it would be recommended to look at shielding by mass instead of thickness. Though it is not currently feasible to shield an entire spacecraft with a thick shield, they still might have a use as storm shelters from SPEs. Thick SPE shields did not deviate much based on material, therefore a lighter material such as polyethylene could be substituted for a similar thickness of metal with a significant reduction of mass.

For multi-material walls, when looking at material order in thinner shields there was not much difference. However, thick shields performed better when the more efficient material was on the outside of the spacecraft. 


\section{Micrometeoroid}

\section{Micrometeoroid Background}

Despite the common misconception, space is not actually completely empty. In between the stars and planets are a multitude of objects. Some are large, such as comets and asteroids. Others are imperceptibly tiny, the dust that floats in empty space. But due to the velocities on the cosmic scale even this dust, commonly known as micrometeoroids, can still wreak havoc on a spacecraft if not properly taken into account during design. For earth orbiting satellites, micrometeoroids are often overshadowed by orbital debris with higher masses. While less catastrophic, the multitude of lesser micrometeoroid impacts can still damage the outer faces of a spacecraft.

Structural shielding for orbital debris and micrometeoroids most often falls into two different categories.

The first is monolithic shielding, in which the shield is all one solid layer, even if there are multiple materials. ${ }^{6}$ These shields work best for low velocity impacts (the ballistic regime). The second common type of impact shield is a Whipple shield. These shields use two different layers, a bumper and a wall, with a gap between. Whipple shields

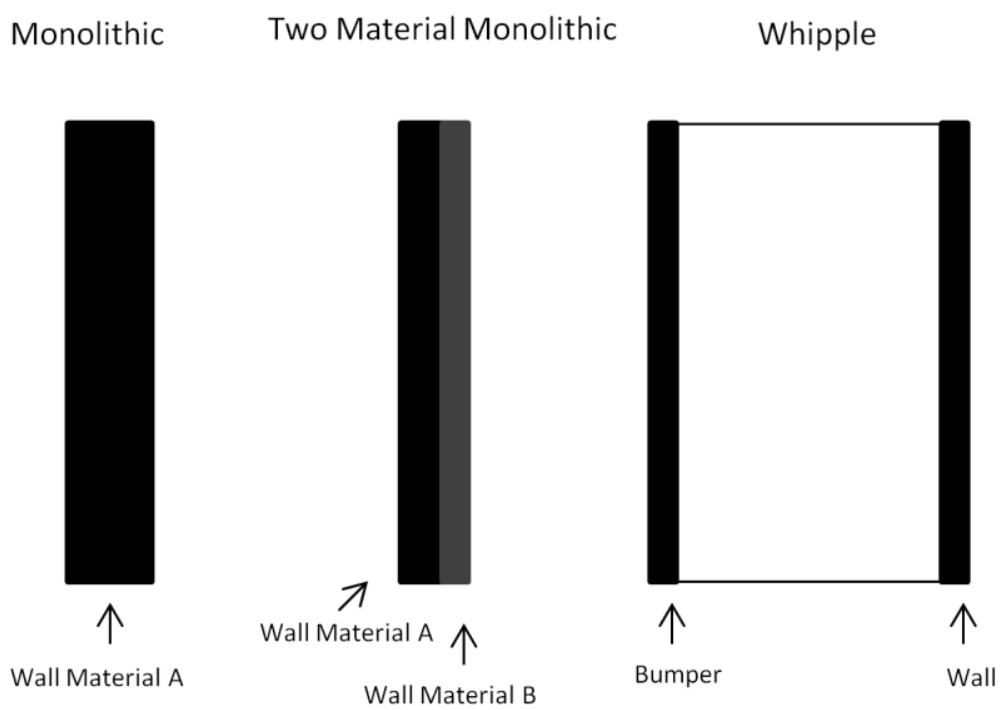

(a)

(b)

(c)

Figure 26. Monolithic and Whipple Shields 
work better for high velocity, low mass impacts as the particle will often vaporize on impact with the bumper, allowing the wall to absorb the smaller particles. A sample of these shields can be seen in Fig. 26.

The two shields react differently to impacts, as seen in Fig. 27. When a projectile impacts a monolithic shield (a), it will either spall (indent) the wall (b) or break through (c). When a particle impacts a Whipple shield (d), it impacts the bumper and breaks into smaller pieces (e) that the wall can absorb more easily (f). It is possible to have multiple layers of bumpers and walls in a Whipple shield, each one breaking the particles into smaller and smaller pieces.

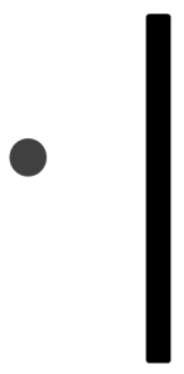

(a)

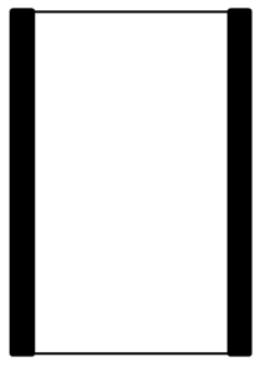

(d)

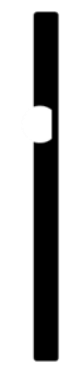

(b)

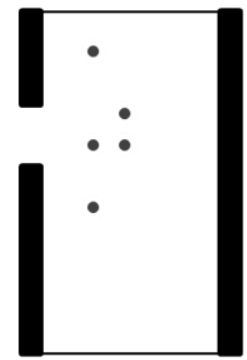

(e)

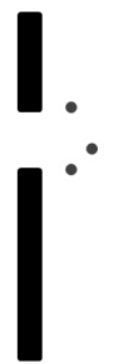

(c)

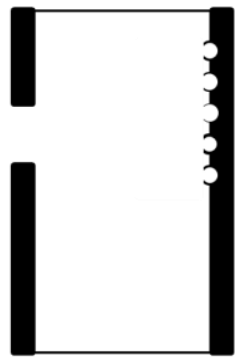

(f)

Figure 27. Impact Dynamics on Monolithic and Whipple Shields

It is possible to design separate, stand-alone micrometeoroid shielding for a spacecraft. However, this would result in a significant increase in parasitic mass and volume. A more efficient approach is to use already existing structural, thermal, or other resilient subsystem components and patch in micrometeoroid shields over vulnerable points. 


\section{Flight Path Generation}

Plotting the course of an interplanetary spacecraft is not as simple as drawing a line between two points.

The planets are constantly moving, so the straight line destination would arrive at empty space. The total time required for the trip must be factored in to determine the final location. Even with the time factored in, the path will still not be a straight line. The gravitational pull of the sun (and sometime other celestial bodies) curves the ultimate trajectory. Unless the spacecraft is within the sphere of influence of a planet or moon, the main acceleration driver is the sun. The sun's gravitational field pulls the spacecraft inward as shown in Fig. 28.

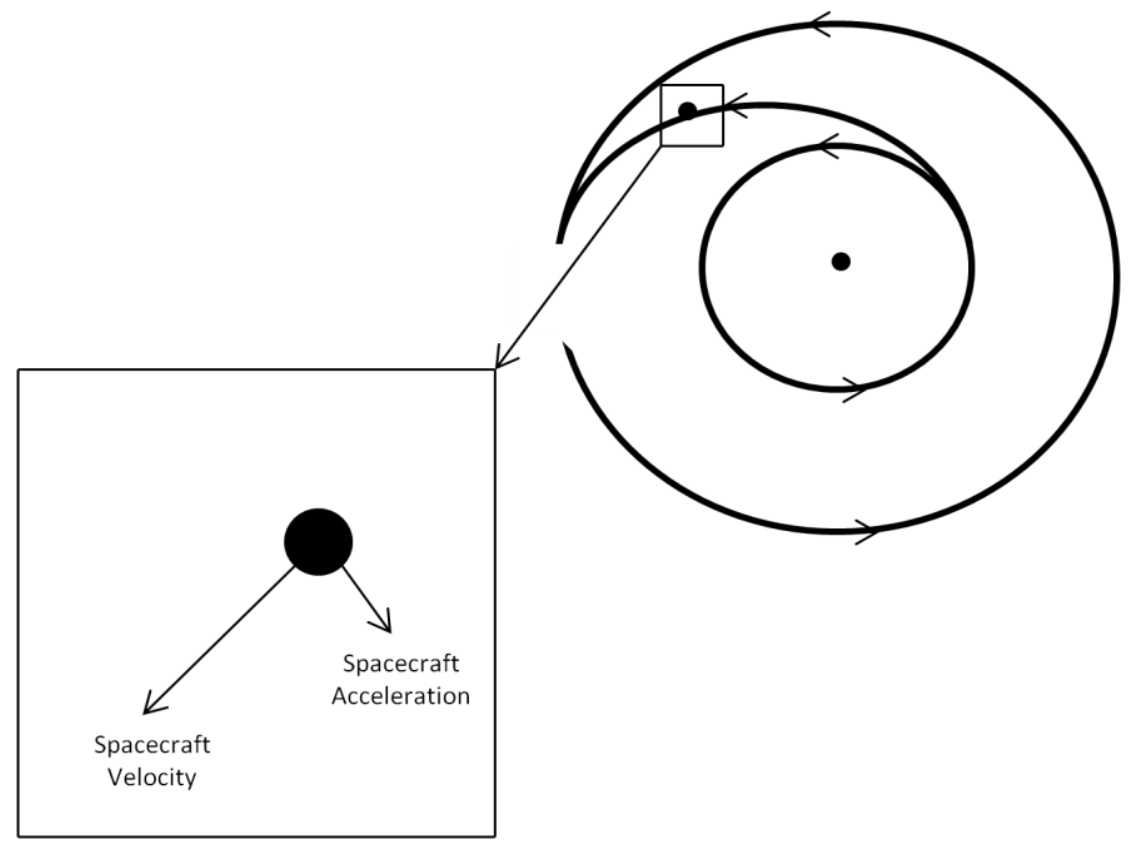

Figure 28. Spacecraft Flight Path and Acting Forces

To determine the impact characteristics of various test spaceflights, flight path trajectories first needed to be calculated. In order to interface with NASA's MEMR2 program and get the micrometeoroid flux (see next section), state vectors with position and velocity in the $\mathrm{X}, \mathrm{Y}$, and $\mathrm{Z}$ directions needed to be calculated with their respective Julian dates. After being unable to locate a source of state vectors for historical flights, it became necessary to generate them with Matlab code. ${ }^{14}$ The start and end times of the missions were known (this will be discussed below), allowing for the approximation of the flight path. Using equations and algorithms from Curtis' Orbital Mechanics for Engineering Students, it was possible to calculate the required initial velocity of the spacecraft to arrive at its destination. ${ }^{9}$ 


$$
V_{1}=\frac{1}{g}\left(\boldsymbol{r}_{2}-f \boldsymbol{r}_{1}\right)
$$

$$
V_{2}=\frac{1}{g}\left(\dot{\mathrm{g}} \boldsymbol{r}_{2}-\boldsymbol{r}_{\mathbf{1}}\right)
$$

$V_{l}$ and $V_{2}$ were the initial and final velocities while $g, \dot{g}$, and $f$ are values from the Lagrange functions. As the arrival and departure dates are known, the position vectors $\left(\boldsymbol{r}_{\mathbf{1}}\right.$ and $\left.\boldsymbol{r}_{\mathbf{2}}\right)$ could either be calculated or looked up. The final required component to iterate out the state vectors was acceleration. The acceleration equation chosen was for simple two body orbital parameters. What this meant was that the sun (the larger body) was the sole acting acceleration on the spacecraft (the smaller body) with its gravitational pull. The influence of the other planets was assumed to be insignificant, allowing for simplified calculations. Acceleration was calculated using;

$$
\ddot{\boldsymbol{r}}=-\frac{u}{r^{2}} \widehat{\boldsymbol{u}}_{r}
$$

where $\ddot{\boldsymbol{r}}$ was the acceleration vector $\left(\mathrm{km} / \mathrm{s}^{2}\right), r$ was the scalar distance between the spacecraft and the sun $(\mathrm{km}), u$ was the gravitational parameter $\left(\mathrm{km}^{3} / \mathrm{s}^{2}\right)$, and $\widehat{\boldsymbol{u}}_{r}$ was the unit vector of $\boldsymbol{r}$. The position, velocity, and acceleration equations were iterated through over the time between departure and arrival to generate state vectors. The code could calculate state vectors multiple times per day. This could be useful for a short duration mission such as to the moon, where a slight difference in position and velocity could be critical. It is also useful for more advanced calculations that benefit from a finer micrometeoroid model. However, a single check per day was the standard used throughout the testing due to the longer travel times.

Four state vector sets were created using the orbit generator program. Two followed the same one-way historical missions from the Radiation section, using the start and end times of Mariner 9 and Mars Reconnaissance Orbiter (MRO.) Mainer 9 was selected due to its short travel duration, while MRO was chosen as it fit into the 4-6 month range that is commonly discussed for Mars missions. ${ }^{17}$ The other two state vectors were more generalized 
Hohmann transfers. A Hohmann transfer is the most efficient two impulse maneuver for transferring between two circular, coplanar orbits. ${ }^{9}$ The orbits of the planets in our solar system are not perfectly circular or coplanar, but they are close enough to allow for this assumption. The transfer flight path is an ellipse tangent to both circular orbits, as seen in Fig. 29. If going from the inner to outer planet (such as Earth to Mars), the spacecraft will travel from Point 1 to Point 2 (only half the ellipse is traveled). Likewise, travel from an outer planet to an inner planet travels from Point 2 to Point 1.

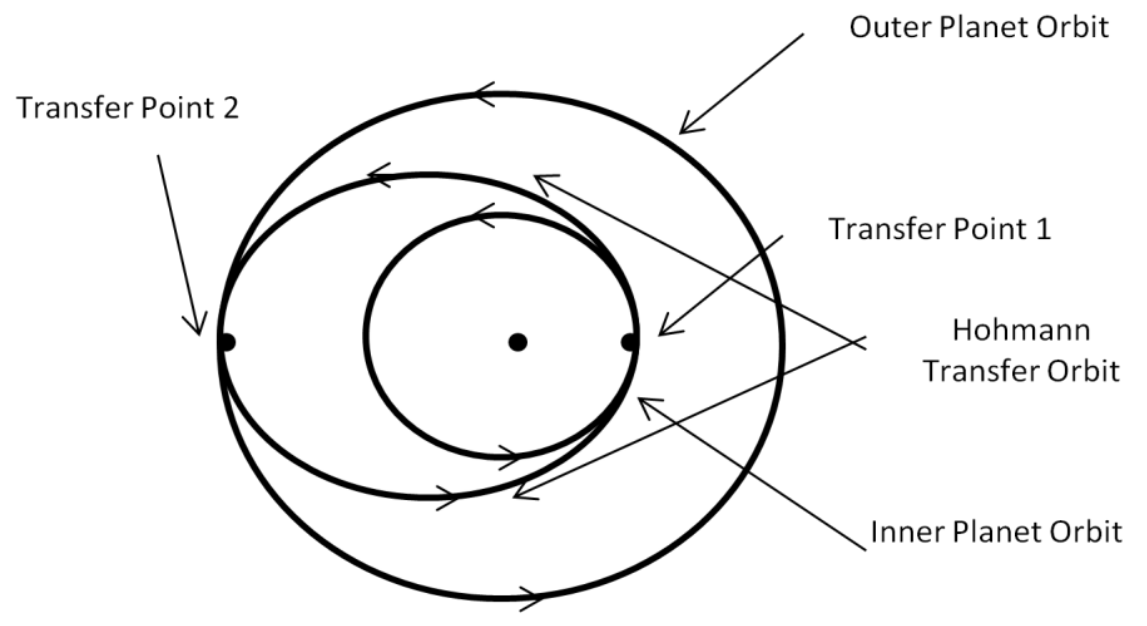

Figure 29. Hohmann Transfer Orbits

Backtracking is required to find the proper angle between the two planets that will have the departure and arrival location line up. The total flight time between the planets can be calculated by looking at the semimajor axis. As we are assuming the orbits to be circular, the radius will be the same at all points of the orbit. The semimajor axis is simply the average of the two radii. With the semimajor axis we can calculate the orbital period. By comparing the orbital periods of the transfer and destination orbits, it becomes possible to find the required angle between them. In the case of an Earth to Mars trip, the required travel time was 258.8 days and the angle was 135 degrees.

To find the dates with the required angle between the planets, additional Matlab code was used to plot the state vectors of the two interested planets over a two year cycle and calculate the angle between them. As above, an $\mathrm{X}-\mathrm{Y}$ co-planar assumption was used as the $\mathrm{Z}$ displacement is several orders of magnitude lower for all solar system planets (besides Pluto). Possible dates were selected by perusing the angle results. The first selected Hohmann 
transfer left Earth on November 24, 2000 and arrived on Mars at August 8, 2001 (Hohmann1). The second Hohmann transfer left Earth November 29, 2015 and reached Mars on August 13, 2016 (Hohmann2).

The results of the state vector were in the Earth Centered Inertial (ECI) J2000 reference frame. They were cut into a .txt file with the first six lines left blank (MEMRS is designed to ignore headers of that length). The first column was the Julian date, followed by the position vectors (X, Y, and Z) and velocities (X, Y, and Z). A sample of the first five state vectors from Mariner 9 can be seen in Table 22 below. Please note that in the real .txt file the Julian date would not have been repeated, it is there only for comprehension of the split data set.

Table 22. First Five State Vectors for Mariner 9

\begin{tabular}{|c|c|c|c|}
\hline Julian Date & Rx $(\mathrm{km})$ & Ry $(\mathrm{km})$ & $\mathrm{Rz}(\mathrm{km})$ \\
\hline 2441101.50 & -55941917.06 & -140950162.95 & -9787.20 \\
\hline 2441102.53 & -53367324.10 & -142034516.31 & -71935.95 \\
\hline 2441103.56 & -50777595.43 & -143078586.67 & -134064.30 \\
\hline 2441104.59 & -48173491.72 & -144082151.81 & -196154.69 \\
\hline 2441105.62 & -45555777.26 & -145045008.51 & -258189.66 \\
\hline
\end{tabular}

Table 22. First Five State Vectors for Mariner 9 (cont)

\begin{tabular}{|c|c|c|c|}
\hline Julian Date & Vx $(\mathrm{km} / \mathrm{s})$ & $\mathrm{Vy}(\mathrm{km} / \mathrm{s})$ & $\mathrm{Vz}(\mathrm{km} / \mathrm{s})$ \\
\hline 2441101.50 & 29.80 & -12.55 & -0.72 \\
\hline 2441102.53 & 29.97 & -12.08 & -0.72 \\
\hline 2441103.56 & 30.14 & -11.62 & -0.72 \\
\hline 2441104.59 & 30.30 & -11.14 & -0.72 \\
\hline 2441105.62 & 30.45 & -10.67 & -0.72 \\
\hline
\end{tabular}

\section{Flux Generation}

The calculated state vectors were fed into NASA's MEMR2 program, which outputted flux (in units of particles per meter squared per year) for each. ${ }^{15}$ The flux is the micrometeoroid environment the spacecraft would face. MEMR2 looks at only the sporadic complex, the background micrometeoroid environment. These particles are 
the results of thousands of years of collisions and breakups, gravitational effects, and Poynting-Robertson drag (the loss of angular momentum due to solar radiation). On the time scale, this environment is fairly constant, with negligible difference between the dawn of spaceflight and today. It is quite different than the orbital debris environment, which has grown at an alarming rate over that time.

MEMR2 uses the Grun model, a set of equations from the paper "Collisional Balance of the Meteoric Complex" by Grun et al. in $1985 .{ }^{14}$ These equations model the flux as a function of mass. The model also includes an averaged meteor shower component. The model used was for interplanetary spacecraft, removing components of shielding or gravitational focusing found around celestial bodies such as planets. While there would be some influence at both ends of the spaceflight that could be modeled separately for better accuracy, this was not done for the work in this paper. Grun's interplanetary flux model equation and its constants can be seen in Equation 6 and Table 23 below. ${ }^{11}$ The flux $F_{2}$,in units of number of particles/(meter ${ }^{2}$ second), is dependent on mass $m$ (in grams) and radius $r_{0}$. For the interplanetary use $r_{0}$ is equal to $1 \mathrm{AU}$.

$$
F_{2}\left(m, r_{0}\right)=\left(c_{4} m^{\gamma_{4}}+c_{5}\right)^{\gamma_{5}}+c_{6}\left(m+c_{7} m^{\gamma_{6}}+c_{8} m^{\gamma_{7}}\right)^{\gamma_{8}}+c_{9}\left(m+c_{10} m^{\gamma_{9}}\right)^{\gamma_{10}}
$$

Table 23. Constants for Grun Interplanetary Flux Equation

\begin{tabular}{|c|c|c|c|}
\hline Constant & Value & Constant & Value \\
\hline $\mathrm{C}_{4}$ & $2.2^{*} 10^{3}$ & $\gamma_{4}$ & 0.306 \\
\hline $\mathrm{C}_{5}$ & 15 & $\mathrm{\gamma}_{5}$ & -4.38 \\
\hline $\mathrm{C}_{6}$ & $1.3 * 10^{-9}$ & $\mathrm{\gamma}_{6}$ & 2 \\
\hline $\mathrm{C}_{7}$ & $10^{11}$ & $\mathrm{\gamma}_{7}$ & -0.36 \\
\hline $\mathrm{C}_{8}$ & $10^{27}$ & $\mathrm{\gamma}_{8}$ & 2 \\
\hline $\mathrm{C}_{9}$ & $1.3^{*} 10^{-16}$ & $\mathrm{\gamma}_{9}$ & -0.85 \\
\hline $\mathrm{C}_{10}$ & $10^{6}$ & $\mathrm{\gamma}_{10}$ & \\
\hline
\end{tabular}


MEMR2 outputted flux per velocity for nine different faces of the satellite. In order they were Ram, Wake, Port, Starboard, Zenith, Nadir, Earth, Sun, and Antisun. The first six can be seen in Fig. 60, while the last three are dependent on the orientation of the spacecraft relative to the Earth and Sun. As the flux is face specific, to use this data it must be assumed the spacecraft has some form of attitude control that keeps the faces steady. The data below will be less useful for spacecraft that are spin stabilized or allowed to tumble.

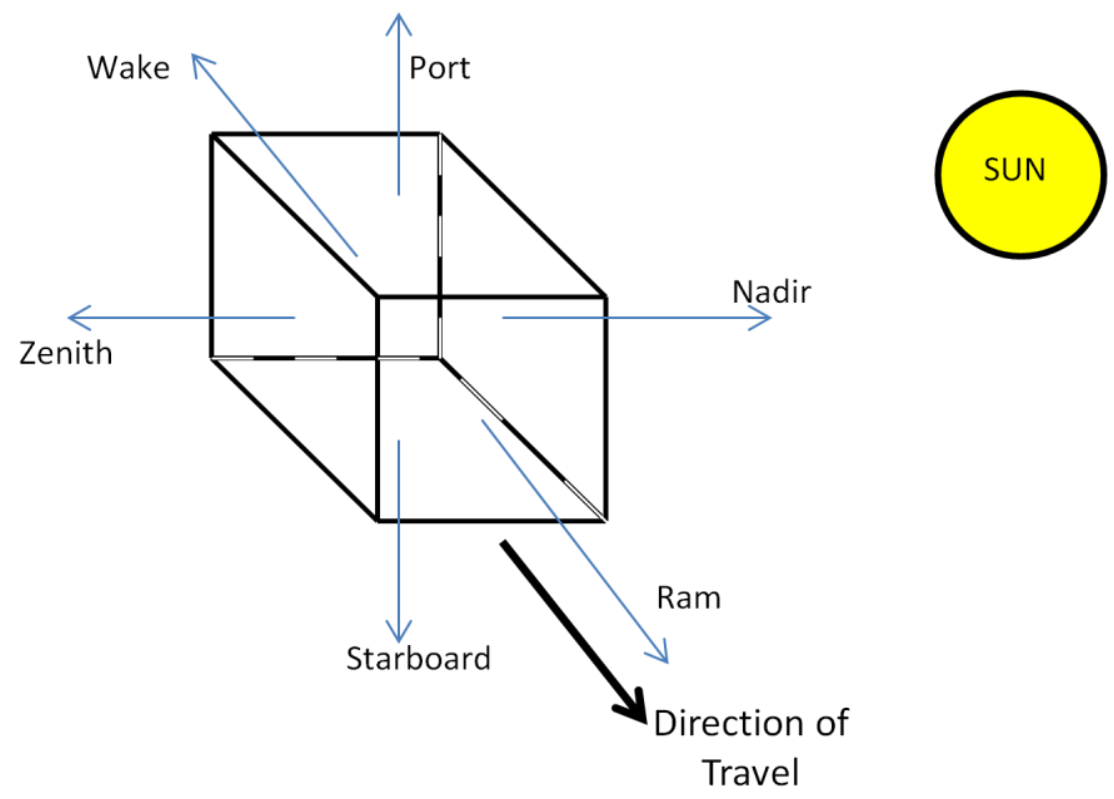

Figure 30. Faces of a Spacecraft

For known mission parameters (such as a two week visit to the ISS), the state vectors can be calculated down to the minute. While not all of these would be used in MEMR2, several thousand would give an extremely accurate map of the micrometeoroid flux. However due to the more generalized nature of the test cases and their duration (several months instead of weeks), it was decided to use a more coarse model of fewer draws but perform several sets of draws to allow comparison. Each draw was a single state vector with Julian date, position, and velocity values taken from the parent state vector set. Part of the deciding factor was also the significantly increased preparation and code run time required for a large increase in the number of draws.

Using the "random" run type MEMR2 took twenty random draws from the input state vectors and calculated flux for each. To prevent data skew, three sets of random draws were performed for each state vector. This may not seem like a lot compared to the thousands listed above, but the percentages of tested state vectors work 
out similarly. For a two week ISS mission, the recommended number of draws is 1500 out of the 20,160 minute state vectors. ${ }^{7}$ This is $7.4 \%$ of the total. Drawing 20 out of the 164 state vectors for Mariner 9 is $12.2 \%$ of the total. For the longest mission, the 501 round trip, twenty draws is only $4 \%$. But using all three draw sets gives a better resolution of $12 \%$.

Each data sets had a minimum mass of $10^{-6}$ grams. A similar second flux data set was generated with a $10^{-3}$ minimum mass for all four state vectors. The interplanetary mode of the program was used, with a resolution of 1 degree $x 1$ degree $x 2 \mathrm{~km} / \mathrm{s}$. What this means is the flux will be looked at in 1 degree angular increments and the "bins" that the flux will be divided into will be $2 \mathrm{~km} / \mathrm{s}$ wide. For example, the $1 \mathrm{~km} / \mathrm{s}$ bin includes everything from $0-2 \mathrm{~km} / \mathrm{s}$ and the $3 \mathrm{~km} / \mathrm{s}$ bin contains everything from $2-4 \mathrm{~km} / \mathrm{s}$. The results were in the body fixed frame.

Each MEMR2 output had all the fluxes together in one document. After each run of MEMR2, the output was manually separated out into the twenty different data sets. The header information and velocities with zero flux were also removed, leaving only the velocity and flux for each face in a .txt file. A sample of this for the first Mariner 9 state vector can be seen in Table 24.

\section{Impact Generation}

Generating impacts and impact related statistics was done with a tiered system of Matlab code. The top tier code set universal variables such as the number of runs and the area of each face. It also rotated through the fluxes for each run through the second tier code. Finally, it collated the results into a master output list.

The second tier code calculated the probability of an impact based on flux, area, and time. It then compared these values against a randomly generated uniform probability by subtracting the randomized value from the calculated. Afterward negative "hits" were tabulated.

The hits were separated out into the nine different listed faces above. For each hit eight different values were calculated by a several different third tier codes. The first two were the step (out of twenty) and total number of hits so far in the step. The third was the velocity, taken from MEMR2. Fourth was the mass, generated using mass 
Table 24. Sample Flux for Mariner 9 V1

\begin{tabular}{|c|c|c|c|c|c|}
\hline $\begin{array}{l}\text { Velocity } \\
(\mathrm{km} / \mathrm{s})\end{array}$ & $\begin{array}{c}\text { Ram } \\
\text { (particles } / \mathrm{m}^{2}- \\
\text { year) }\end{array}$ & $\begin{array}{c}\text { Wake } \\
\text { (particles } / \mathrm{m}^{2}- \\
\text { year) }\end{array}$ & $\begin{array}{c}\text { Port } \\
\text { (particles } / \mathrm{m}^{2}- \\
\text { year) }\end{array}$ & $\begin{array}{c}\text { Starboard } \\
\text { (particles } / \mathrm{m}^{2}- \\
\text { year) }\end{array}$ & $\begin{array}{c}\text { Zenith } \\
\text { (particles } / \mathrm{m}^{2} \text { - } \\
\text { year) }\end{array}$ \\
\hline 1 & $2.36 \mathrm{E}-04$ & $3.11 \mathrm{E}-05$ & $2.54 \mathrm{E}-04$ & $2.53 \mathrm{E}-04$ & $8.95 \mathrm{E}-05$ \\
\hline 3 & $4.69 \mathrm{E}-03$ & $9.22 \mathrm{E}-04$ & $7.35 \mathrm{E}-03$ & $7.21 \mathrm{E}-03$ & $1.32 \mathrm{E}-03$ \\
\hline 5 & $3.10 \mathrm{E}-02$ & $7.70 \mathrm{E}-03$ & $6.11 \mathrm{E}-02$ & $5.96 \mathrm{E}-02$ & $5.78 \mathrm{E}-03$ \\
\hline 7 & $3.97 \mathrm{E}-02$ & $7.41 \mathrm{E}-03$ & $5.71 \mathrm{E}-02$ & $5.59 \mathrm{E}-02$ & $1.47 \mathrm{E}-02$ \\
\hline 9 & 4.67E-02 & $5.82 \mathrm{E}-03$ & $4.25 \mathrm{E}-02$ & $4.21 \mathrm{E}-02$ & $2.53 \mathrm{E}-02$ \\
\hline 11 & $6.04 \mathrm{E}-02$ & $6.76 \mathrm{E}-03$ & $4.82 \mathrm{E}-02$ & $4.80 \mathrm{E}-02$ & $3.50 \mathrm{E}-02$ \\
\hline 13 & 7.29E-02 & $7.78 \mathrm{E}-03$ & $5.44 \mathrm{E}-02$ & $5.41 \mathrm{E}-02$ & $4.41 \mathrm{E}-02$ \\
\hline 15 & $8.20 \mathrm{E}-02$ & $8.60 \mathrm{E}-03$ & 5.94E-02 & 5.92E-02 & $5.06 \mathrm{E}-02$ \\
\hline 17 & $8.72 \mathrm{E}-02$ & 8.93E-03 & $6.04 \mathrm{E}-02$ & $6.01 \mathrm{E}-02$ & $5.58 \mathrm{E}-02$ \\
\hline 19 & $9.02 \mathrm{E}-02$ & $9.08 \mathrm{E}-03$ & $6.02 \mathrm{E}-02$ & $5.99 \mathrm{E}-02$ & $5.93 \mathrm{E}-02$ \\
\hline 21 & $8.89 \mathrm{E}-02$ & $8.71 \mathrm{E}-03$ & $5.62 \mathrm{E}-02$ & $5.58 \mathrm{E}-02$ & $6.06 \mathrm{E}-02$ \\
\hline 23 & $8.55 \mathrm{E}-02$ & $8.11 \mathrm{E}-03$ & $5.07 \mathrm{E}-02$ & $5.03 \mathrm{E}-02$ & $6.06 \mathrm{E}-02$ \\
\hline 25 & 7.99E-02 & 7.42E-03 & $4.51 \mathrm{E}-02$ & $4.48 \mathrm{E}-02$ & 5.82E-02 \\
\hline 27 & $7.18 \mathrm{E}-02$ & $6.47 \mathrm{E}-03$ & $3.82 \mathrm{E}-02$ & 3.79E-02 & 5.37E-02 \\
\hline 29 & $6.26 \mathrm{E}-02$ & $5.50 \mathrm{E}-03$ & $3.16 \mathrm{E}-02$ & $3.13 \mathrm{E}-02$ & 4.79E-02 \\
\hline 31 & $5.21 \mathrm{E}-02$ & 4.44E- 03 & $2.47 \mathrm{E}-02$ & $2.44 \mathrm{E}-02$ & $4.08 \mathrm{E}-02$ \\
\hline 33 & $4.11 \mathrm{E}-02$ & 3.33E-03 & $1.83 \mathrm{E}-02$ & $1.81 \mathrm{E}-02$ & $3.24 \mathrm{E}-02$ \\
\hline 35 & $3.14 \mathrm{E}-02$ & $2.46 \mathrm{E}-03$ & $1.36 \mathrm{E}-02$ & $1.35 \mathrm{E}-02$ & $2.44 \mathrm{E}-02$ \\
\hline 37 & $2.22 \mathrm{E}-02$ & $1.63 \mathrm{E}-03$ & $9.22 \mathrm{E}-03$ & $9.12 \mathrm{E}-03$ & $1.68 \mathrm{E}-02$ \\
\hline 39 & $1.50 \mathrm{E}-02$ & $9.71 \mathrm{E}-04$ & $6.20 \mathrm{E}-03$ & $6.14 \mathrm{E}-03$ & $1.03 \mathrm{E}-02$ \\
\hline 41 & $9.83 \mathrm{E}-03$ & 5.19E-04 & $4.28 \mathrm{E}-03$ & $4.25 \mathrm{E}-03$ & $5.38 \mathrm{E}-03$ \\
\hline 43 & $6.75 \mathrm{E}-03$ & $2.06 \mathrm{E}-04$ & $2.95 \mathrm{E}-03$ & $2.95 \mathrm{E}-03$ & $2.34 \mathrm{E}-03$ \\
\hline 45 & $6.02 \mathrm{E}-03$ & $8.58 \mathrm{E}-05$ & $2.58 \mathrm{E}-03$ & $2.58 \mathrm{E}-03$ & $1.29 \mathrm{E}-03$ \\
\hline 47 & $6.18 \mathrm{E}-03$ & $5.26 \mathrm{E}-05$ & $2.52 \mathrm{E}-03$ & $2.53 \mathrm{E}-03$ & $1.18 \mathrm{E}-03$ \\
\hline 49 & $5.01 \mathrm{E}-03$ & $2.31 \mathrm{E}-05$ & $1.94 \mathrm{E}-03$ & $1.94 \mathrm{E}-03$ & $9.23 \mathrm{E}-04$ \\
\hline 51 & $4.58 \mathrm{E}-03$ & $1.70 \mathrm{E}-05$ & $1.75 \mathrm{E}-03$ & $1.76 \mathrm{E}-03$ & $8.38 \mathrm{E}-04$ \\
\hline 53 & $3.74 \mathrm{E}-03$ & $1.37 \mathrm{E}-05$ & $1.43 \mathrm{E}-03$ & $1.43 \mathrm{E}-03$ & $6.83 \mathrm{E}-04$ \\
\hline 55 & $3.36 \mathrm{E}-03$ & 1.13E-05 & $1.28 \mathrm{E}-03$ & $1.28 \mathrm{E}-03$ & $6.12 \mathrm{E}-04$ \\
\hline 57 & $2.40 \mathrm{E}-03$ & $8.05 \mathrm{E}-06$ & $9.12 \mathrm{E}-04$ & $9.14 \mathrm{E}-04$ & $4.38 \mathrm{E}-04$ \\
\hline 59 & $1.34 \mathrm{E}-03$ & $4.48 \mathrm{E}-06$ & $5.08 \mathrm{E}-04$ & 5.09E-04 & 2.44E-04 \\
\hline 61 & $6.08 \mathrm{E}-04$ & $2.04 \mathrm{E}-06$ & $2.31 \mathrm{E}-04$ & $2.32 \mathrm{E}-04$ & $1.11 \mathrm{E}-04$ \\
\hline 63 & $8.25 \mathrm{E}-05$ & $2.77 \mathrm{E}-07$ & $3.14 \mathrm{E}-05$ & $3.14 \mathrm{E}-05$ & $1.50 \mathrm{E}-05$ \\
\hline
\end{tabular}




\begin{tabular}{|c|c|c|c|c|}
\hline $\begin{array}{c}\text { Velocity } \\
(\mathrm{km} / \mathrm{s})\end{array}$ & $\begin{array}{c}\text { Nadir } \\
\text { (particles } / \mathrm{m}^{2} \text {-year) }\end{array}$ & $\begin{array}{c}\text { Earth } \\
\text { (particles } / \mathrm{m}^{2} \text {-year) }\end{array}$ & $\begin{array}{c}\text { Sun } \\
\text { (particles } / \mathrm{m}^{2} \text {-year) }\end{array}$ & $\begin{array}{c}\text { Anti-Sun } \\
\text { (particles } / \mathrm{m}^{2} \text {-year) }\end{array}$ \\
\hline 1 & $3.90 \mathrm{E}-04$ & $1.10 \mathrm{E}-04$ & $8.03 \mathrm{E}-05$ & $4.15 \mathrm{E}-04$ \\
\hline 3 & $2.60 \mathrm{E}-02$ & $1.56 \mathrm{E}-03$ & $1.20 \mathrm{E}-03$ & 2.62E-02 \\
\hline 5 & $2.65 \mathrm{E}-01$ & $6.59 \mathrm{E}-03$ & $5.29 \mathrm{E}-03$ & 2.64E-01 \\
\hline 7 & $2.16 \mathrm{E}-01$ & $1.62 \mathrm{E}-02$ & $1.36 \mathrm{E}-02$ & $2.17 \mathrm{E}-01$ \\
\hline 9 & $1.05 \mathrm{E}-01$ & $2.79 \mathrm{E}-02$ & $2.33 \mathrm{E}-02$ & $1.09 \mathrm{E}-01$ \\
\hline 11 & $9.81 \mathrm{E}-02$ & $3.85 \mathrm{E}-02$ & 3.23E-02 & $1.05 \mathrm{E}-01$ \\
\hline 13 & $1.05 \mathrm{E}-01$ & 4.83E-02 & $4.08 \mathrm{E}-02$ & $1.13 \mathrm{E}-01$ \\
\hline 15 & $1.16 \mathrm{E}-01$ & $5.52 \mathrm{E}-02$ & 4.69E-02 & $1.26 \mathrm{E}-01$ \\
\hline 17 & $1.24 \mathrm{E}-01$ & $6.03 \mathrm{E}-02$ & $5.17 \mathrm{E}-02$ & $1.33 \mathrm{E}-01$ \\
\hline 19 & $1.28 \mathrm{E}-01$ & $6.38 \mathrm{E}-02$ & $5.51 \mathrm{E}-02$ & $1.38 \mathrm{E}-01$ \\
\hline 21 & $1.27 \mathrm{E}-01$ & $6.48 \mathrm{E}-02$ & 5.64E-02 & $1.37 \mathrm{E}-01$ \\
\hline 23 & $1.23 \mathrm{E}-01$ & $6.43 \mathrm{E}-02$ & $5.64 \mathrm{E}-02$ & $1.32 \mathrm{E}-01$ \\
\hline 25 & $1.15 \mathrm{E}-01$ & $6.14 \mathrm{E}-02$ & $5.43 \mathrm{E}-02$ & $1.24 \mathrm{E}-01$ \\
\hline 27 & $1.04 \mathrm{E}-01$ & $5.65 \mathrm{E}-02$ & 5.02E-02 & $1.12 \mathrm{E}-01$ \\
\hline 29 & $9.04 \mathrm{E}-02$ & $5.02 \mathrm{E}-02$ & 4.47E-02 & $9.74 \mathrm{E}-02$ \\
\hline 31 & 7.52E-02 & 4.26E- 02 & $3.81 \mathrm{E}-02$ & $8.11 \mathrm{E}-02$ \\
\hline 33 & 5.83E-02 & 3.40E-02 & 3.02E-02 & $6.29 \mathrm{E}-02$ \\
\hline 35 & 4.35E-02 & $2.58 \mathrm{E}-02$ & $2.27 \mathrm{E}-02$ & $4.70 \mathrm{E}-02$ \\
\hline 37 & 2.95E-02 & $1.81 \mathrm{E}-02$ & $1.56 \mathrm{E}-02$ & $3.19 \mathrm{E}-02$ \\
\hline 39 & $1.78 \mathrm{E}-02$ & $1.16 \mathrm{E}-02$ & $9.40 \mathrm{E}-03$ & $1.95 \mathrm{E}-02$ \\
\hline 41 & $9.31 \mathrm{E}-03$ & $6.73 \mathrm{E}-03$ & $4.75 \mathrm{E}-03$ & $1.04 \mathrm{E}-02$ \\
\hline 43 & $3.82 \mathrm{E}-03$ & $3.81 \mathrm{E}-03$ & $1.85 \mathrm{E}-03$ & $4.55 \mathrm{E}-03$ \\
\hline 45 & $1.80 \mathrm{E}-03$ & $2.93 \mathrm{E}-03$ & 8.03E-04 & $2.45 \mathrm{E}-03$ \\
\hline 47 & $1.43 \mathrm{E}-03$ & $2.94 \mathrm{E}-03$ & $6.68 \mathrm{E}-04$ & 2.09E-03 \\
\hline 49 & $9.80 \mathrm{E}-04$ & $2.39 \mathrm{E}-03$ & 5.04E-04 & $1.52 \mathrm{E}-03$ \\
\hline 51 & $8.59 \mathrm{E}-04$ & $2.18 \mathrm{E}-03$ & 4.54E-04 & $1.35 \mathrm{E}-03$ \\
\hline 53 & $6.99 \mathrm{E}-04$ & $1.78 \mathrm{E}-03$ & $3.70 \mathrm{E}-04$ & $1.10 \mathrm{E}-03$ \\
\hline 55 & $6.19 \mathrm{E}-04$ & $1.60 \mathrm{E}-03$ & $3.30 \mathrm{E}-04$ & $9.78 \mathrm{E}-04$ \\
\hline 57 & 4.42E-04 & $1.14 \mathrm{E}-03$ & $2.36 \mathrm{E}-04$ & $6.99 \mathrm{E}-04$ \\
\hline 59 & $2.46 \mathrm{E}-04$ & $6.37 \mathrm{E}-04$ & $1.31 \mathrm{E}-04$ & $3.89 \mathrm{E}-04$ \\
\hline 61 & $1.12 \mathrm{E}-04$ & $2.90 \mathrm{E}-04$ & $5.98 \mathrm{E}-05$ & $1.77 \mathrm{E}-04$ \\
\hline 63 & $1.52 \mathrm{E}-05$ & 3.93E-05 & $8.11 \mathrm{E}-06$ & $2.40 \mathrm{E}-05$ \\
\hline
\end{tabular}


equations from Tribble. ${ }^{23}$ The last four generated qualities were angle up, angle around, $\mathrm{X}$, and $\mathrm{Y} . \mathrm{X}$ and $\mathrm{Y}$ were measured from the bottom left corner of the face. Pictorial references of these can be seen in Fig. 31. Each of the last four values was randomly generated by a uniform distribution between the boundaries. While the last four didn't end up getting used in this thesis, they have use for anyone trying to test their own shield or testing to see how often a particular area of a face (ex. an optical lens) would be hit compared to the rest of the face.
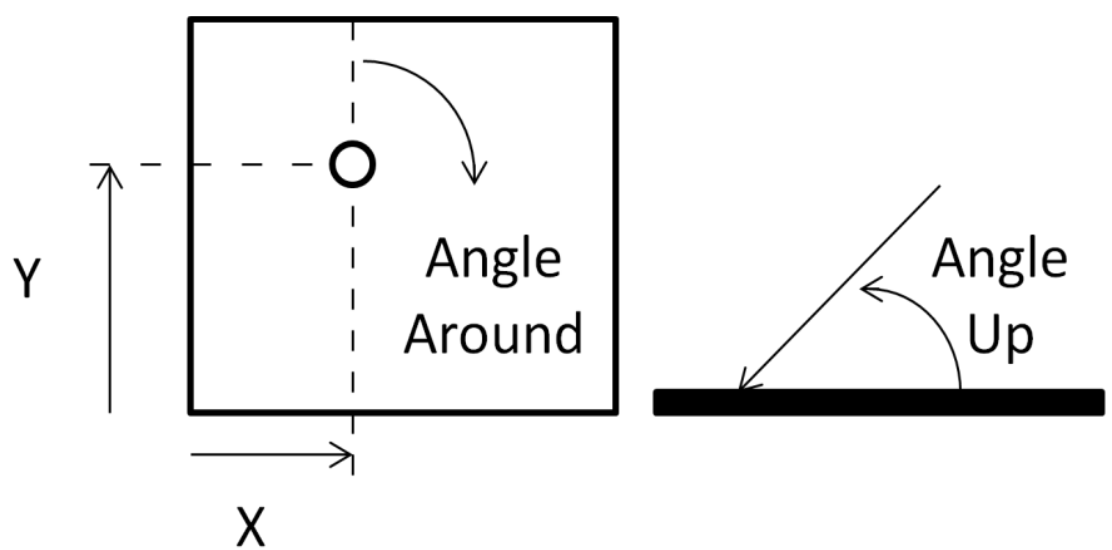

Figure 31. Visual Reference for Impact Statistics

Table 25. Impact Statistics on the Wake Face for Mariner 9 V11

\begin{tabular}{|c|c|c|c|c|c|c|c|}
\hline Step & $\begin{array}{c}\text { Hit } \\
\text { Number }\end{array}$ & $\begin{array}{c}\text { Velocity } \\
(\mathrm{km} / \mathrm{s})\end{array}$ & $\begin{array}{c}\text { Mass } \\
\text { (grams) }\end{array}$ & $\begin{array}{c}\text { Angle Up } \\
\text { (degrees) }\end{array}$ & $\begin{array}{c}\text { Angle } \\
\text { Around } \\
\text { (degrees) }\end{array}$ & $\begin{array}{c}\mathrm{X} \\
(\text { meter })\end{array}$ & $\begin{array}{c}\mathrm{Y} \\
\text { (meter) }\end{array}$ \\
\hline 2 & 1 & 19.00 & $5.00 \mathrm{E}-06$ & 85.06 & 2.46 & 1.51 & 0.12 \\
\hline 2 & 2 & 35.00 & $7.00 \mathrm{E}-06$ & 74.07 & 296.25 & 0.44 & 1.26 \\
\hline 2 & 3 & 37.00 & $5.00 \mathrm{E}-06$ & 31.60 & 153.20 & 2.86 & 2.04 \\
\hline 9 & 1 & 21.00 & $5.00 \mathrm{E}-05$ & 22.07 & 49.21 & 2.43 & 2.21 \\
\hline 9 & 2 & 29.00 & $3.00 \mathrm{E}-06$ & 55.27 & 4.54 & 2.17 & 1.87 \\
\hline 11 & 1 & 29.00 & $4.00 \mathrm{E}-06$ & 60.77 & 209.57 & 2.42 & 1.37 \\
\hline 12 & 1 & 7.00 & $2.00 \mathrm{E}-06$ & 34.78 & 46.98 & 1.58 & 2.57 \\
\hline 15 & 1 & 29.00 & $1.00 \mathrm{E}-06$ & 60.78 & 116.36 & 3.043 & 2.03 \\
\hline 17 & 1 & 9.00 & $3.00 \mathrm{E}-06$ & 33.95 & 15.63 & 2.35 & 0.90 \\
\hline 19 & 1 & 19.00 & $7.00 \mathrm{E}-06$ & 4.31 & 124.90 & 1.28 & 0.38 \\
\hline 19 & 1 & 35.00 & $1.00 \mathrm{E}-06$ & 78.83 & 84.99 & 2.31 & 0.18 \\
\hline
\end{tabular}


A sample of impact results can be seen in Table 25, taken from the wake face of the V11 Mariner 9 data set. For this case the $\mathrm{X}$ and $\mathrm{Y}$ values run from 0 to 3.16 meters as the goal was to have each face be 10 square meters. While the mass values might seems low, remember that the space shuttle windows were sensitive to impacts as small as 100 microns $\left(\sim 10^{-6.3}\right)$ grams. ${ }^{7}$ Radiators can suffer penetrations from particles of 150 microns $\left(\sim 10^{-5.8}\right)$ grams. Optics and solar arrays can suffer reduced performance from even small particles.

\section{Impact Analysis}

The mass and velocity results of the impacts were subjected to additional analysis. A JMP graphical summary was performed on the impacts for each face. ${ }^{13}$ From this the mean, median, and standard deviation with a 95\% confidence interval were acquired. These values were compared inside different versions (ex. all V1s) and overall for each orbital path. A total listing of results can be found in Appendix C, but two samples are listed below in Tables 26 and 27. For both tables, $\mathrm{N}$ is the averaged number of impacts.

Table 26. Mariner 9 Averaged Results

\begin{tabular}{|c|c|c|c|c|c|c|c|}
\hline \multicolumn{2}{|c|}{} & \multicolumn{3}{c|}{ Mass (grams) } & \multicolumn{3}{c|}{ Velocity (km/s) } \\
\hline Face & $\mathrm{N}$ & Mean & Median & StDev & Mean & Median & StDev \\
\hline Ram & 142.11 & $8.78 \mathrm{E}-06$ & $2.78 \mathrm{E}-06$ & $3.49 \mathrm{E}-05$ & 21.03 & 20.33 & 10.86 \\
\hline Wake & 9.56 & $7.56 \mathrm{E}-06$ & $3.56 \mathrm{E}-06$ & $1.16 \mathrm{E}-05$ & 19.76 & 21.00 & 9.65 \\
\hline Port & 81.44 & $8.56 \mathrm{E}-06$ & $2.89 \mathrm{E}-06$ & $3.29 \mathrm{E}-05$ & 19.42 & 18.56 & 10.03 \\
\hline Starboard & 88.22 & $7.33 \mathrm{E}-06$ & $2.67 \mathrm{E}-06$ & $1.90 \mathrm{E}-05$ & 19.27 & 18.33 & 10.36 \\
\hline Zenith & 91.00 & $5.67 \mathrm{E}-06$ & $2.56 \mathrm{E}-06$ & $1.20 \mathrm{E}-05$ & 23.83 & 23.67 & 8.95 \\
\hline Nadir & 182.56 & $7.44 \mathrm{E}-06$ & $2.44 \mathrm{E}-06$ & $2.69 \mathrm{E}-05$ & 19.32 & 19.22 & 10.49 \\
\hline Earth & 63.22 & $5.89 \mathrm{E}-06$ & $2.67 \mathrm{E}-06$ & $1.11 \mathrm{E}-05$ & 23.36 & 23.22 & 9.33 \\
\hline Sun & 86.00 & $7.22 \mathrm{E}-06$ & $2.78 \mathrm{E}-06$ & $2.13 \mathrm{E}-05$ & 22.78 & 22.44 & 8.93 \\
\hline Antisun & 187.56 & $7.44 \mathrm{E}-06$ & $2.78 \mathrm{E}-06$ & $2.69 \mathrm{E}-05$ & 19.05 & 18.78 & 10.17 \\
\hline
\end{tabular}


Table 27. Ram Face Averaged Results

\begin{tabular}{|c|c|c|c|c|c|c|c|}
\hline \multicolumn{2}{|c|}{} & \multicolumn{3}{c|}{ Mass (grams) } & \multicolumn{3}{c|}{ Velocity (km/s) } \\
\hline Orbit & N & Mean & Median & StDev & Mean & Median & StDev \\
\hline Hohmann1 & 299.67 & $6.89 \mathrm{E}-06$ & $2.67 \mathrm{E}-06$ & $2.51 \mathrm{E}-05$ & 22.79 & 21.44 & 12.77 \\
\hline Hohmann2 & 239.44 & $7.11 \mathrm{E}-06$ & $2.67 \mathrm{E}-06$ & $2.76 \mathrm{E}-05$ & 22.79 & 22.11 & 12.35 \\
\hline Mariner 9 & 142.11 & $8.78 \mathrm{E}-06$ & $2.78 \mathrm{E}-06$ & $3.49 \mathrm{E}-05$ & 21.03 & 20.33 & 10.86 \\
\hline MRO & 169.11 & $6.22 \mathrm{E}-06$ & $2.67 \mathrm{E}-06$ & $1.49 \mathrm{E}-05$ & 21.21 & 20.56 & 11.26 \\
\hline
\end{tabular}

The first table (26) shows the averaged results for each face. Right away we can see that some faces received significantly more impacts than others. Ram, Nadir, and Antisun were in the top three for all four flight paths. Similarly, the wake face always received the fewest impacts. The mean masses stayed in the upper $10^{-6}$ to low $10^{-5}$ range for most cases, but there were outliers ranging from $1.72 * 10^{-5}$ for MRO Zenith down to $4.67 * 10^{-6}$ for Hohmann2's wake face. The mean velocities also stayed within the same range, with the sole exception of the MRO Wake face, which clocked only a $12.84 \mathrm{~km} / \mathrm{s}$ average velocity. However, due to impact physics it was expected that Wake face would have the lowest average impact velocity of the 9 faces. In three of the four cases it does, the last (Mariner 9) has five different faces with close low velocities.

The second table (27) showed that the means and medians were close for the same face across all four orbital paths. Surprisingly, three of the four even had the same median mass. It also showed that longer duration missions have higher numbers of impacts.

\section{High Mass Impacts}

As mentioned in the flux generation section above, a second flux set was created for each state vector with a $10^{-3}$ gram minimum mass limit. The goal was to isolate high mass impacts, the ones that had the greatest likelihood of damaging a spacecraft. When running the initial code it quickly became apparent that data storage and analysis similar to the $10^{-6}$ data would be impossible. Each run produced very few impacts, many had none. Due to this, a new testing method was devised. Each flux set was run fifty times and the results recorded. The tables below 
Table 28. MRO High Mass Impact Results

\begin{tabular}{|c|c|c|c|c|}
\hline & Flux Set 1 & Flux Set 2 & Flux Set 3 & Average \\
\hline $\begin{array}{c}\text { Total Impacts } \\
\text { (over 50 runs) }\end{array}$ & 22 & 26 & 23 & 24 \\
\hline $\begin{array}{c}\text { Runs with 0 } \\
\text { Impacts }\end{array}$ & 31 & 30 & 32 & 31 \\
\hline $\begin{array}{c}\text { Runs with 1 } \\
\text { Impact }\end{array}$ & 16 & 15 & 13 & 15 \\
\hline $\begin{array}{c}\text { Runs with 2 } \\
\text { Impacts }\end{array}$ & 3 & 1 & 5 & 1 \\
\hline $\begin{array}{c}\text { Runs with 3 } \\
\text { Impacts }\end{array}$ & 0 & 0 & 4 \\
\hline
\end{tabular}

Table 29. Mariner 9 High Mass Impact Results

\begin{tabular}{|c|c|c|c|c|}
\hline & Flux Set 1 & Flux Set 2 & Flux Set 3 & Average \\
\hline $\begin{array}{c}\text { Total Impacts } \\
\text { (over 50 runs) }\end{array}$ & 17 & 14 & 17 & 16 \\
\hline $\begin{array}{c}\text { Runs with 0 } \\
\text { Impacts }\end{array}$ & 35 & 40 & 36 & 37 \\
\hline $\begin{array}{c}\text { Runs with 1 } \\
\text { Impact }\end{array}$ & 14 & 8 & 11 & 11 \\
\hline $\begin{array}{c}\text { Runs with 2 } \\
\text { Impacts }\end{array}$ & 0 & 0 & 3 & 2 \\
\hline $\begin{array}{c}\text { Runs with 3 } \\
\text { Impacts }\end{array}$ & 1 & 3 & 0 & 1 \\
\hline
\end{tabular}

Table 30. Hohmann1 High Mass Impact Results

\begin{tabular}{|c|c|c|c|c|}
\hline & Flux Set 1 & Flux Set 2 & Flux Set 3 & Average \\
\hline $\begin{array}{c}\text { Total Impacts } \\
\text { (over 50 runs) }\end{array}$ & 38 & 37 & 42 & 39 \\
\hline $\begin{array}{c}\text { Runs with 0 } \\
\text { Impacts }\end{array}$ & 23 & 28 & 21 & 24 \\
\hline $\begin{array}{c}\text { Runs with 1 } \\
\text { Impact }\end{array}$ & 18 & 11 & 17 & 16 \\
\hline $\begin{array}{c}\text { Runs with 2 } \\
\text { Impacts }\end{array}$ & 7 & 7 & 11 & 3 \\
\hline $\begin{array}{c}\text { Runs with 3 } \\
\text { Impacts }\end{array}$ & 2 & 4 & 1 & 9 \\
\hline
\end{tabular}


Table 31. Hohmann2 High Mass Impact Results

\begin{tabular}{|c|c|c|c|c|}
\hline & Flux Set 1 & Flux Set 2 & Flux Set 3 & Average \\
\hline $\begin{array}{c}\text { Total Impacts } \\
\text { (over 50 runs) }\end{array}$ & 29 & 32 & 27 & 30 \\
\hline $\begin{array}{c}\text { Runs with 0 } \\
\text { Impacts }\end{array}$ & 26 & 29 & 31 & 29 \\
\hline $\begin{array}{c}\text { Runs with 1 } \\
\text { Impact }\end{array}$ & 20 & 12 & 14 & 5 \\
\hline $\begin{array}{c}\text { Runs with 2 } \\
\text { Impacts }\end{array}$ & 3 & 7 & 1 & 2 \\
\hline $\begin{array}{c}\text { Runs with 3 } \\
\text { Impacts }\end{array}$ & 1 & 0 & 1 & 1 \\
\hline $\begin{array}{c}\text { Runs with 4 } \\
\text { Impacts }\end{array}$ & 0 & 2 & 3 & 5 \\
\hline
\end{tabular}

(28-31) look at the total number of impacts for each of the four main state vectors. The average column of these tables was rounded up as it is impossible to have a fraction of an impact. Also included is the quantity of impacts per individual run. Same as above, Hohmann1 is the 2000-2001 state vector and Hohmann2 is the 20152016 state vector.

Using the average values from each flight path in Tables $28-31$, it is possible to calculate the impact probabilities with a mass of $10^{-3}$ grams on a $60 \mathrm{~m}^{2}$ cube. The average number of impacts per run $(\mathrm{N})$, was calculated by:

$$
N=\frac{\text { total number of impacts }}{\text { number of runs }}
$$

For these calculations the number of runs was always 50, while the number of impact varied by flight path. The probability of no impact (PNI) was calculated using:

$$
P N I=e^{-N}
$$


Additionally, the probability of 1 or more impacts was found by subtracting the PNI value from 1 . Finally, the probabilities of exactly $\mathrm{X}$ impacts were found using:

$$
\text { Probability } X \text { impacts }=N^{X} * \frac{e^{-N}}{X !}
$$

These equations were used to calculated the values found in Table 32. While they all had the same surface area, the duration for each flight path varied as listed in the Flight Path Generation section above. The percentages in Table 32 were all rounded up.

Table 32. High Mass Impact Percentage Results

\begin{tabular}{|c|c|c|c|c|}
\hline & MRO & Mariner 9 & Hohmann1 & Hohmann2 \\
\hline $\begin{array}{c}\text { Average Number of } \\
\text { Impacts Per Run (N) }\end{array}$ & 0.48 & 0.32 & 0.78 & 0.60 \\
\hline $\begin{array}{c}\text { Probability of No } \\
\text { Impact (PNI) }\end{array}$ & $62 \%$ & $73 \%$ & $46 \%$ & $55 \%$ \\
\hline $\begin{array}{c}\text { Probability of 1+ } \\
\text { Impacts }\end{array}$ & $38 \%$ & $27 \%$ & $54 \%$ & $45 \%$ \\
\hline $\begin{array}{c}\text { Probability of } \\
\text { Exactly 1 Impact }\end{array}$ & $30 \%$ & $24 \%$ & $36 \%$ & $33 \%$ \\
\hline $\begin{array}{c}\text { Probability of } \\
\text { Exactly 2 Impacts }\end{array}$ & $8 \%$ & $4 \%$ & $14 \%$ & $10 \%$ \\
\hline $\begin{array}{c}\text { Probability of } \\
\text { Exactly 3 Impacts }\end{array}$ & $2 \%$ & $1 \%$ & $4 \%$ & $2 \%$ \\
\hline
\end{tabular}

Looking at the percentages above in Table 32, as expected the Hohmann missions had the highest probability of one or more impacts and Mariner 9 the lowest due to the difference in total trip time (164 days vs. 257 days). The probability of a mission with no impacts above $10^{-3}$ grams was above half for three of the four cases, with the outlier, Hohmann1, having only $46 \%$. The highest number of impacts per run of all the runs was a single run of 4 in flux set 3 for the Hohmann2 state vector.

While the quantity of impacts is important, the quality of the impacts can be more so. The tables below (33-37) show the average mass and velocity results of each state vector. They also include the worst case mass and velocity combinations for future reference. The first value in those columns with a slash is the velocity, the second the mass of the impact. 
Table 33. MRO High Mass Impacts Mass and Velocity Results

\begin{tabular}{|c|c|c|c|c|}
\hline & $\begin{array}{c}\text { Flux Set } \\
1\end{array}$ & Flux Set 2 & Flux Set 3 & Average \\
\hline Average Mass $(\mathrm{g})$ & 0.00732 & 0.00504 & 0.00561 & 0.00599 \\
\hline Average Velocity $(\mathrm{km} / \mathrm{s})$ & 19 & 20.846 & 16.826 & 18.891 \\
\hline Worst Case Mass Combination $(\mathrm{km} / \mathrm{s}$ and g) & $19 / 0.06$ & $17 / 0.02$ & $7 / 0.06$ & \\
\hline $\begin{array}{c}\text { Worst Case Velocity Combination } \\
(\mathrm{km} / \mathrm{s} \text { and g) }\end{array}$ & $35 / 0.009$ & $35 / 0.002$ & $37 / 0.001$ & \\
\hline
\end{tabular}

Table 34. Mariner 9 High Mass Impacts Mass and Velocity Results

\begin{tabular}{|c|c|c|c|c|}
\hline & Flux Set 1 & Flux Set 2 & Flux Set 3 & Average \\
\hline Average Mass (g) & 0.00259 & 0.00257 & 0.00561 & 0.00359 \\
\hline Average Velocity (km/s) & 24.765 & 26.286 & 16.826 & 22.626 \\
\hline Worst Case Mass Combination (km/s and g) & $19 / 0.01$ & $33 / 0.007$ & $7 / 0.06$ & \\
\hline $\begin{array}{c}\text { Worst Case Velocity Combination } \\
(\mathrm{km} / \mathrm{s} \text { and g) }\end{array}$ & $39 / 0.001$ & $47 / 0.005$ & $37 / 0.001$ & \\
\hline
\end{tabular}

Table 35. Hohmann1 High Mass Impacts Mass and Velocity Results

\begin{tabular}{|c|c|c|c|c|}
\hline & Flux Set 1 & Flux Set 2 & Flux Set 3 & Average \\
\hline Average Mass (g) & 0.00279 & 0.00315 & 0.00460 & 0.00351 \\
\hline Average Velocity (km/s) & 21.053 & 23.848 & 23 & 22.634 \\
\hline Worst Case Mass Combination (km/s and g) & $43 / 0.01$ & $27 / 0.02$ & $21 / 0.04$ & \\
\hline $\begin{array}{c}\text { Worst Case Velocity Combination } \\
(\mathrm{km} / \mathrm{s} \text { and g) }\end{array}$ & $43 / 0.01$ & $47 / 0.001$ & $49 / 0.001$ & \\
\hline
\end{tabular}

Table 36. Hohmann2 High Mass Impacts Mass and Velocity Results

\begin{tabular}{|c|c|c|c|c|}
\hline & Flux Set 1 & Flux Set 2 & Flux Set 3 & Average \\
\hline Average Mass (g) & 0.00314 & 0.00331 & 0.00267 & 0.00304 \\
\hline Average Velocity (km/s) & 21.966 & 21.812 & 19.592 & 21.124 \\
\hline Worst Case Mass Combination (km/s and g) & $33 / 0.01$ & $35 / 0.009$ & $17 / 0.007$ & \\
\hline $\begin{array}{c}\text { Worst Case Velocity Combination } \\
(\mathrm{km} / \mathrm{s} \text { and g) }\end{array}$ & $39 / 0.003$ & $35 / 0.009$ & $69 / 0.002$ & \\
\hline
\end{tabular}


Table 37. Overall High Mass Impacts Mass and Velocity Results

\begin{tabular}{|c|c|c|c|c|}
\hline & MRO & Mariner 9 & Hohmann1 & Hohmann2 \\
\hline Average Mass (g) & 0.00599 & 0.00359 & 0.00351 & 0.00304 \\
\hline Average Velocity (km/s) & 18.891 & 22.626 & 22.634 & 21.124 \\
\hline Worst Case Mass Combination (km/s and g) & $19 / 0.06$ & $7 / 0.06$ & $21 / 0.04$ & $33 / 0.01$ \\
\hline $\begin{array}{c}\text { Worst Case Velocity Combination } \\
(\mathrm{km} / \mathrm{s} \text { and g) }\end{array}$ & $37 / 0.001$ & $47 / 0.005$ & $49 / 0.001$ & $69 / 0.002$ \\
\hline
\end{tabular}

All four cases have velocity averages in the $18-23 \mathrm{~km} / \mathrm{s}$ range. Three of the average masses were similar, with MRO being significantly higher than the others. This skew was due to several very high mass impacts, for example 2 of the 3 highest recorded masses are the worst cases for MRO. As seen in Table 33, it was one of the two flight paths that had all three flux sets with a worst case mass above $10^{-2}$ grams (the other was Hohmann1).

When looking at the worst cases, there were no doubly bad impacts. That is to say that those with the highest masses tended to have low to average velocities and vice versa. The Hohmann 2 case for worst case mass has a higher velocity than the average, but it also has the lowest of the worst case mass masses. While one of the highest worst case masses $(19 \mathrm{~km} / \mathrm{s} / 0.06$ grams $)$ is very close to the average velocity for its state vector $(18.891 \mathrm{~km} / \mathrm{s})$, the other $(7 \mathrm{~km} / \mathrm{s} / 0.06$ grams $)$ is less than a third of its average velocity $(22.626 \mathrm{~km} / \mathrm{s})$. Among the worst case velocities only one had a higher than average mass (Mariner 9), but it was also the second slowest of the set.

Among all the tested versions, only 2 had both the worst case mass and velocity on the same impact. In both cases, the worst case mass was low (43 km/s/0.01 grams and $35 \mathrm{~km} / \mathrm{s} / 0.009$ grams) compared to the other versions.

\section{Monolithic Shields}

With the goal of providing context to environmental results, a series of charts were created to gauge the danger of mass/velocity combinations to different thicknesses of material. Using equations from Christiansen and Ryan, simulations were run for aluminum and titanium monolithic shields. ${ }^{6,19}$ Both materials were subjected to impacts with a density of $2.35 \mathrm{~g} / \mathrm{cm}^{3}$, taken as an average from Britt et al. ${ }^{4}$ This density put it in the clay range of 
impacts. The material specific qualities used for calculations are in the Table 38 below. The values were taken from data sheets provided by Aerospace Specification Metals Inc on their website., ${ }^{2,3}$

The mass/velocity combinations were compared against 10 different shields per material, ranging in thickness from 0.1 to $5 \mathrm{~cm}$. The full set of plots can be seen in Appendix D, but one plot for each material can be seen in Fig. 32 and Fig. 33 on the following pages.

The mass points on the $\mathrm{Y}$ axis are 54 masses ranging from $10^{-6}$ grams up to 0.9 grams. The green areas are free from spallation, the yellow and red have incipient and detached spalling respectively, and the blue has perforation. Mass seems to be more damaging than velocity, for maximum velocity impacts can be received up to at least 10 mass points in the plots above (corresponding to $10^{-5}$ grams). However, the highest mass impacts spall even at the lowest velocities.

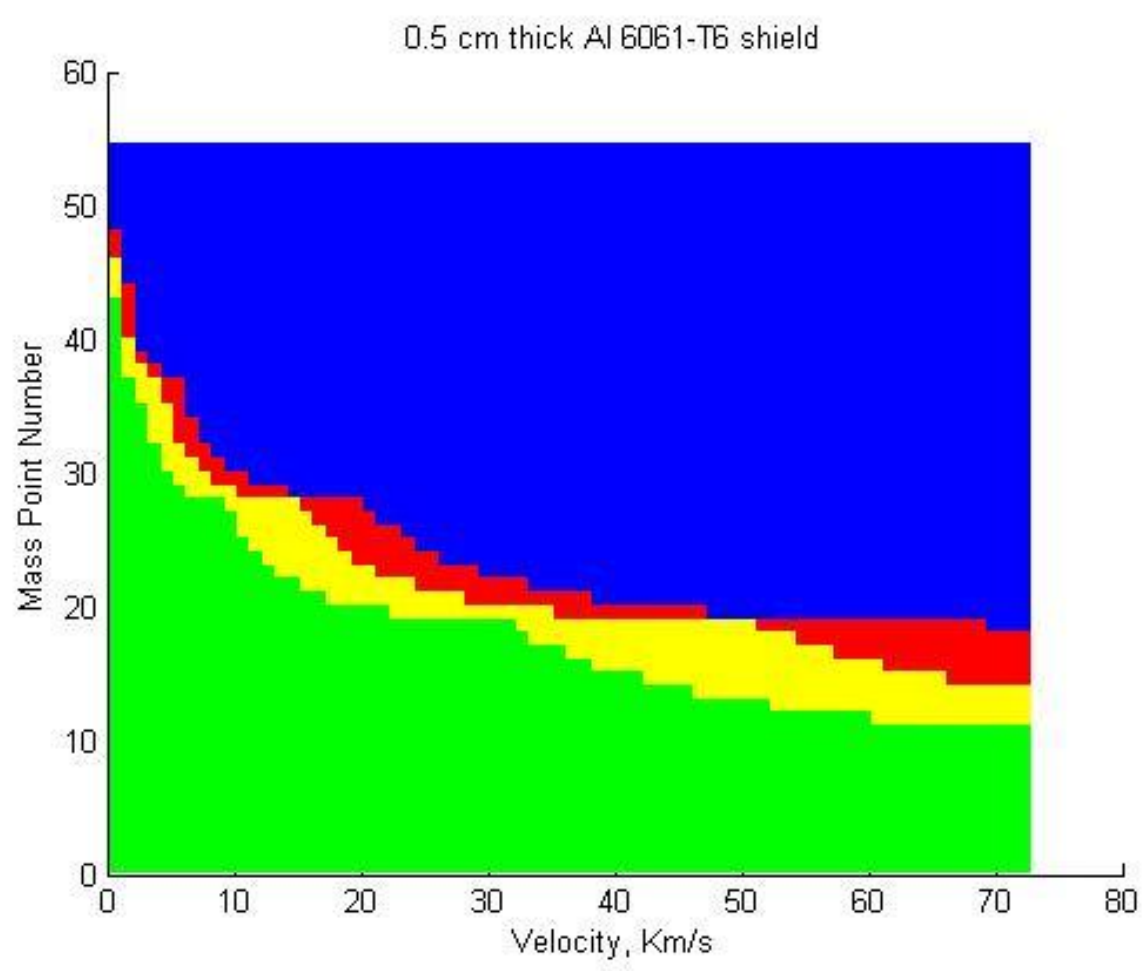

Figure 32. Impact Results Plot for Aluminum Shield 


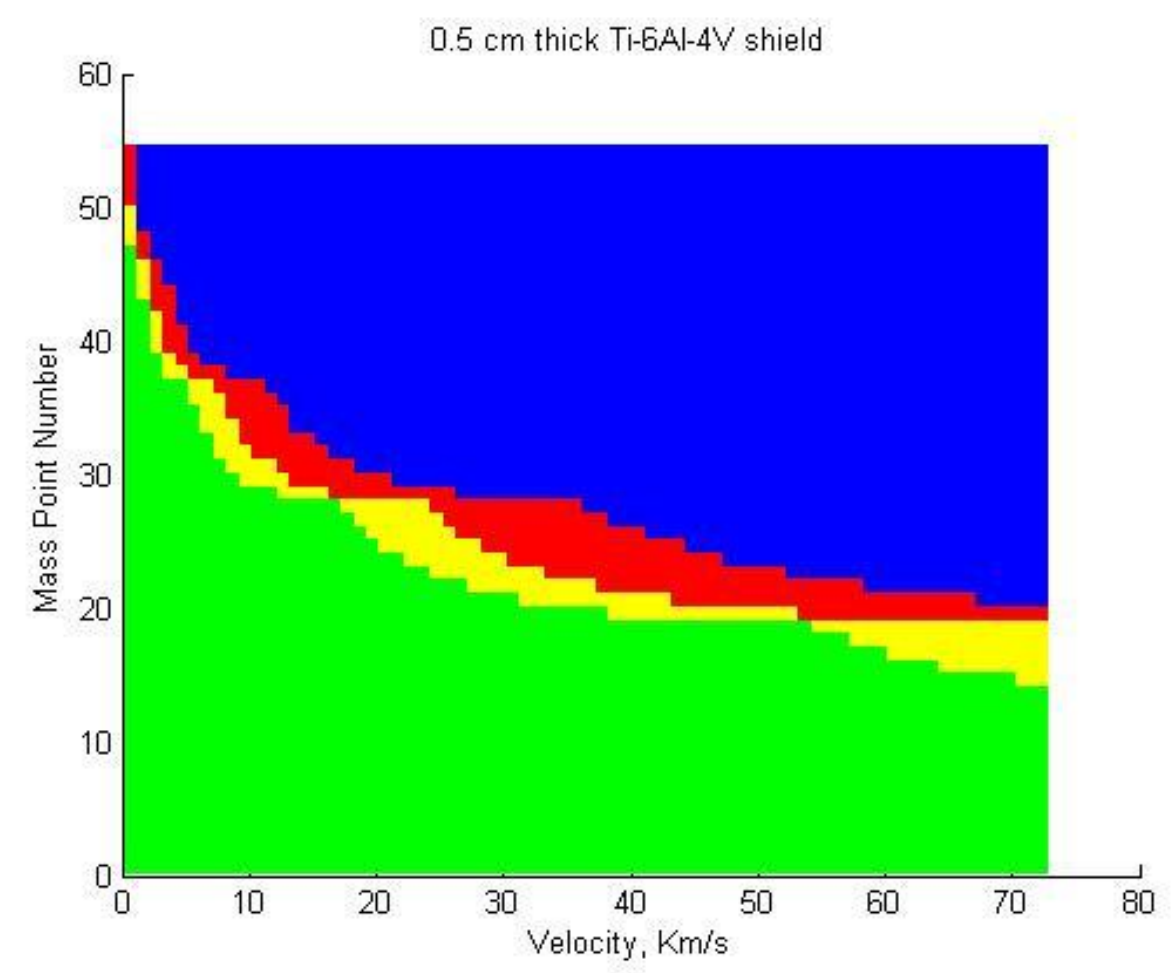

Figure 33. Impact Results Plot for Titanium Shield

Table 38. Material Specific Properties for Aluminum 6061-T6 and Titanium Ti-6Al-4V

\begin{tabular}{|c|c|c|}
\hline Material & Aluminum 6061-T6 & Titanium Ti-6Al-4V (grade 5) \\
\hline Brinell Hardness $(\mathrm{HB})$ & 95 & 334 \\
\hline Density $\left(\mathrm{g} / \mathrm{cm}^{\wedge} 3\right)$ & 2.7 & 4.43 \\
\hline Speed of Sound in Material $(\mathrm{km} / \mathrm{s})$ & 6.42 & 6.07 \\
\hline
\end{tabular}

\section{Whipple Shields}

Attempts to perform similar charts for Whipple shields provided much less general results. For single wall shields there are five main variables: wall material, wall thickness, impact particle material, impact particle mass, and impact particle velocity. In any one set of tests three would have to be held constant while two could vary. In the case of the tests above, particle and wall material were always held constant, wall thickness was varied by different runs, and mass and velocity the main variables in each run. Whipple shields have all those variables too, but add 
bumper material and thickness as well as wall separation distance (and sometimes fill material or multiple layers). The additional variables require more variables to be made constant. This made it difficult to create a generalized reference case.

However, it is possible to draw recommendations even from a less general reference case. Similar to the monolithic shielding section above, two sets of plots were created. Both used the same particle and material properties as the aluminum monolithic impacts above, with both wall and bumper being aluminum. Due to working with different equations, the plots created focused on critical particle diameter for increasing impact velocity and spacing between the bumper and wall. The spacing ran up to $20 \mathrm{~cm}$ and the velocity up to $70 \mathrm{~km} / \mathrm{s}$. Impacts with a velocity of less than $7 \mathrm{~km} / \mathrm{s}$ used different equations that those above to account for the shatter and deformation regimes. In the first set of plots, the wall thickness was held at $0.5 \mathrm{~cm}$ while the bumper thickness rose from $0.1 \mathrm{~cm}$ to $5 \mathrm{~cm}$. In the second set, the bumper thickness was held constant at $0.5 \mathrm{~cm}$ while the wall thickness varied. For the plots the results were assigned a color based on what critical particle diameter "bin" they fell into. Table 39 below lists the bins and each respective color.

\section{Table 39. Bin Ranges and Colors for Whipple Shield Results}

\begin{tabular}{|c|c|}
\hline Color & Critical Particle Diameter $(\mathrm{cm})$ \\
\hline Blue & $\mathrm{X} \geq 2$ \\
\hline Green & $2>\mathrm{X} \geq 1$ \\
\hline Yellow & $1>\mathrm{X} \geq 0.5$ \\
\hline Red & $0.5>\mathrm{X} \geq 0.1$ \\
\hline Black & $\mathrm{X}<0.1$ \\
\hline
\end{tabular}

The results showed that increasing the bumper thickness was not a very effective way to increase critical particle diameter in the vaporization range $(>7 \mathrm{~km} / \mathrm{s})$. At lower velocities it performed similar to the varying wall thickness results, though with less dependence on spacing. Even at maximum tested bumper thickness $(5 \mathrm{~cm})$, the majority of the vaporization range had a critical particle diameter between $0.1 \mathrm{~cm}$ and $0.5 \mathrm{~cm}$ (red) with a smattering of black and yellow on either end. 
Increasing the wall diameter with a fixed bumper thickness produced more fruitful results. Already by 0.5 $\mathrm{cm}$ thick there were results with a critical particle diameter greater than $1 \mathrm{~cm}$ (green), though these were for low velocity and wide spacing. By the time the plot of the thickest tested wall was reached $(5 \mathrm{~cm})$, the critical diameter is above $1 \mathrm{~cm}$ (blue and green) for nearly two thirds of the plot. The rest was yellow a small spattering of red only at very thin spacing.

Another example of how increasing wall thickness is more fruitful is Fig. 34 and Fig. 35. In Fig. 34 and Fig. 35 the wall and bumper thickness flips between $0.5 \mathrm{~cm}$ and $1 \mathrm{~cm}$. Fig. 35 (the one with the thicker wall) performs significantly better.

This may beg the question, why increase bumper thickness while keeping wall thickness the same? Increasing wall thickness produces better results for thinner materials. The answer is that not all Whipple shields are designed that way. Many satellite designs have a central core that payloads and other electronics are mounted on. This area is encased in outer panels. A particle penetrating the outer panel and impacting the protective case of a component can act like a Whipple shield. While not intentionally designed to be a Whipple shield, studying how it acts like one can predict how the spacecraft will react to damage.

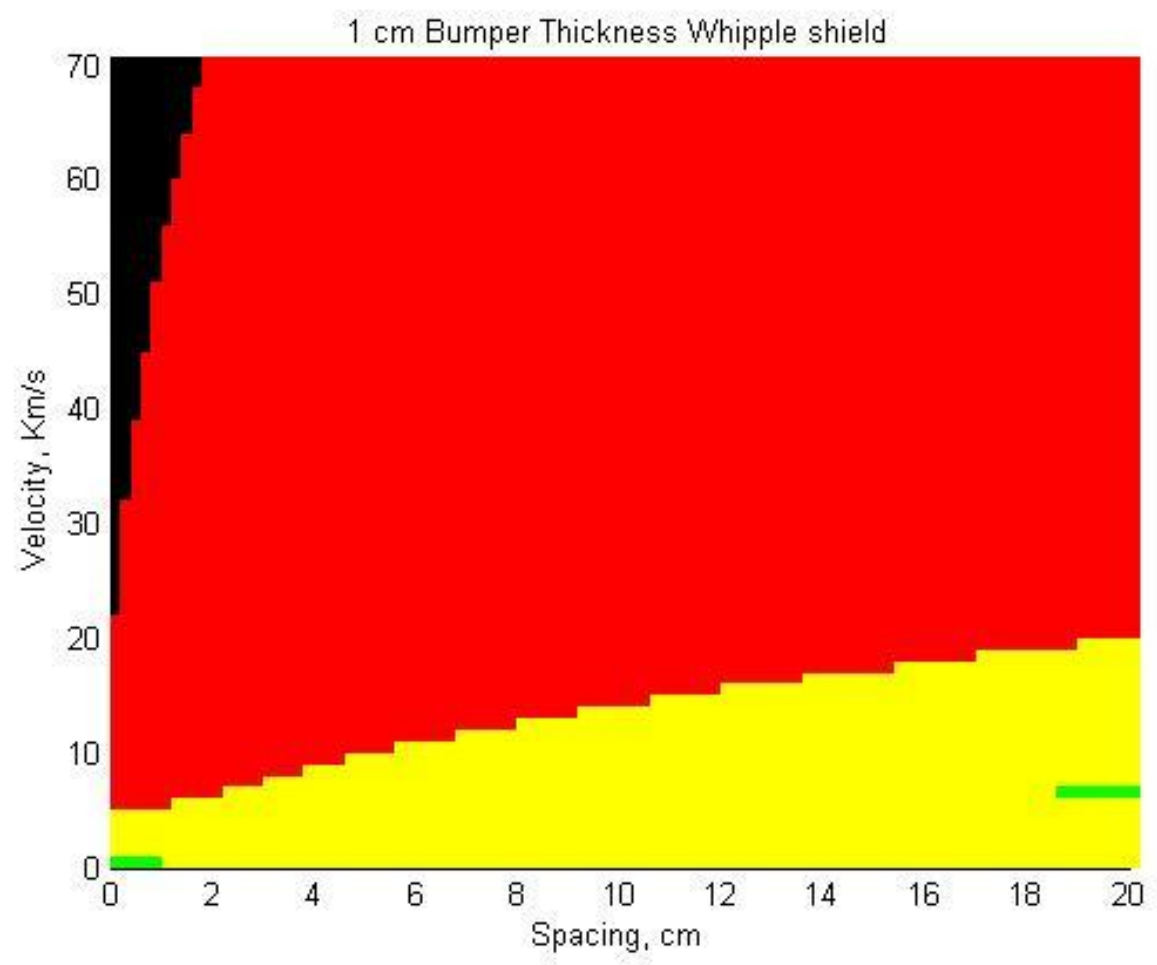

Figure 34. Critical Particle Diameter for Modulated Bumper Thickness 


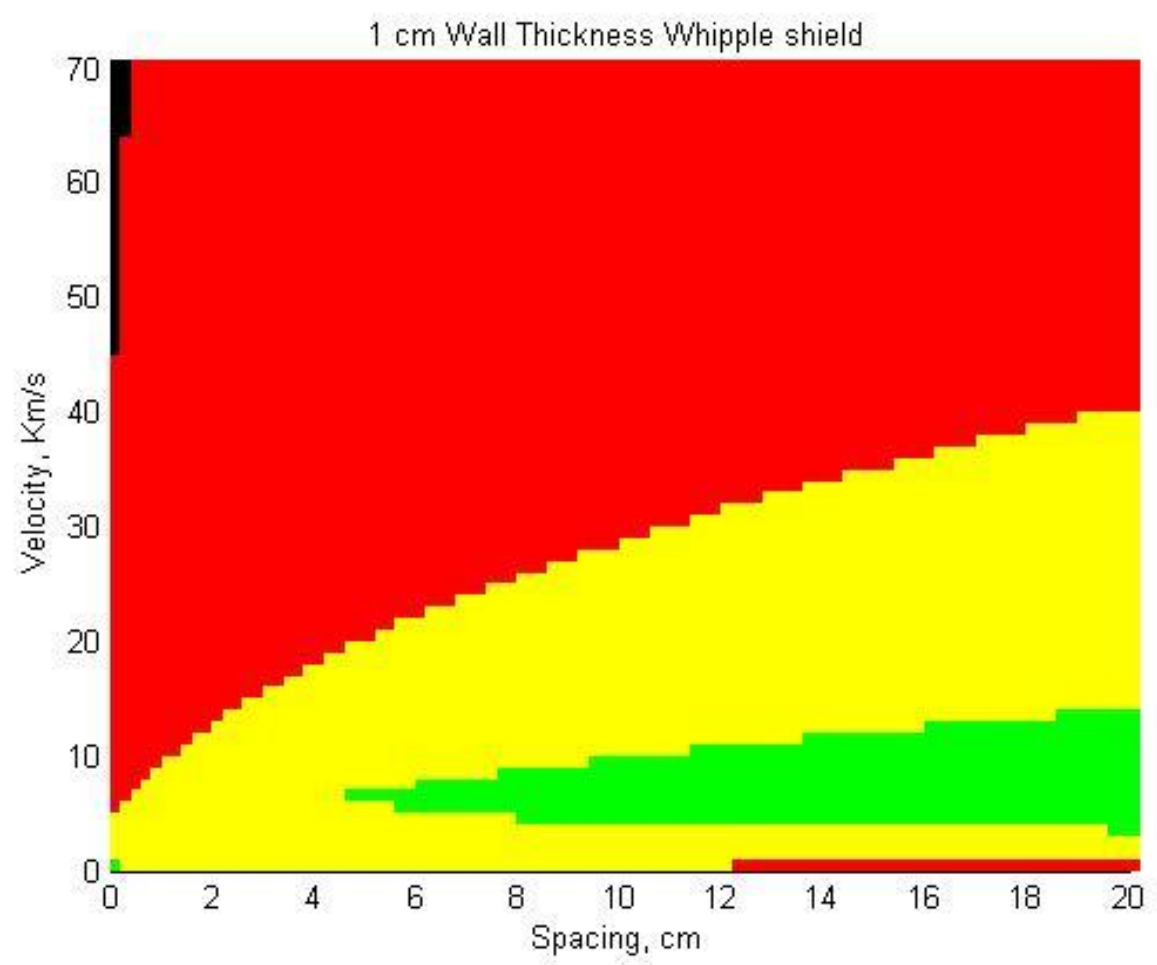

Figure 35. Critical Particle Diameter for Modulated Wall Thickness

\section{Effect of Minimum Mass on Mass Distribution}

A decision that must be made while analyzing the micrometeoroid environment is how low the mass floor should be? How light can a particle be before its effect is no longer significant? Choosing too high can artificially suppress the damage that could result from the magnitude of lesser impact, especially on delicate systems such as solar arrays and optics. On the other hand, choosing too low can obfuscate the significant impacts in the data. Worse, depending on how extensive the model is, it can push them out all together.

To provide a guide to selecting the minimum mass, the mass code written for the sections above was repurposed. 1000 masses were generated using the MATLAB mass model for each minimum mass ranging from $10^{-1}$ to $10^{-15}$, with the exponent changing by one for each set. These masses were analyzed in JMP to look at not only the mean and standard deviations changed, but also how several quartiles changed. ${ }^{13}$ While all the plots can be seen in Appendix E, samples of the mean as well as the 10\% and 90\% quartiles are posted below in Fig. 36, 37, and 38. 


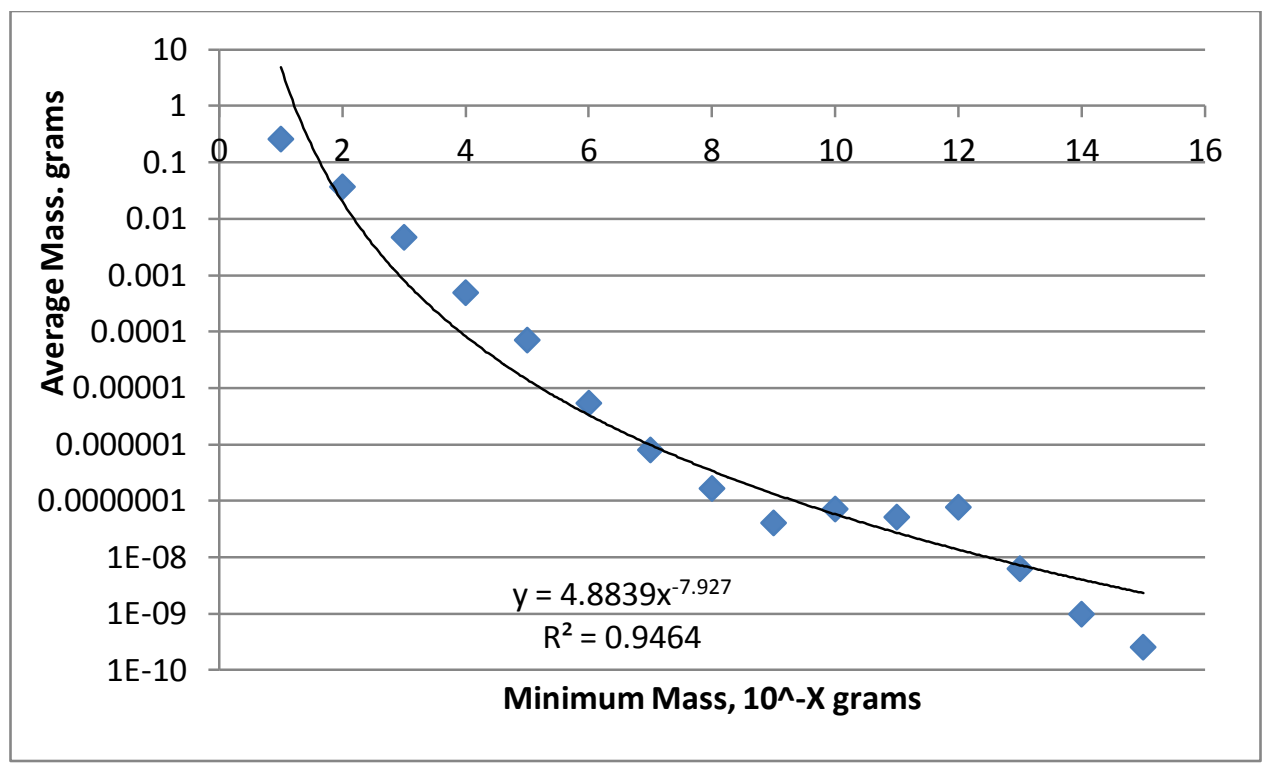

Figure 36. Mean Varying with Minimum Mass

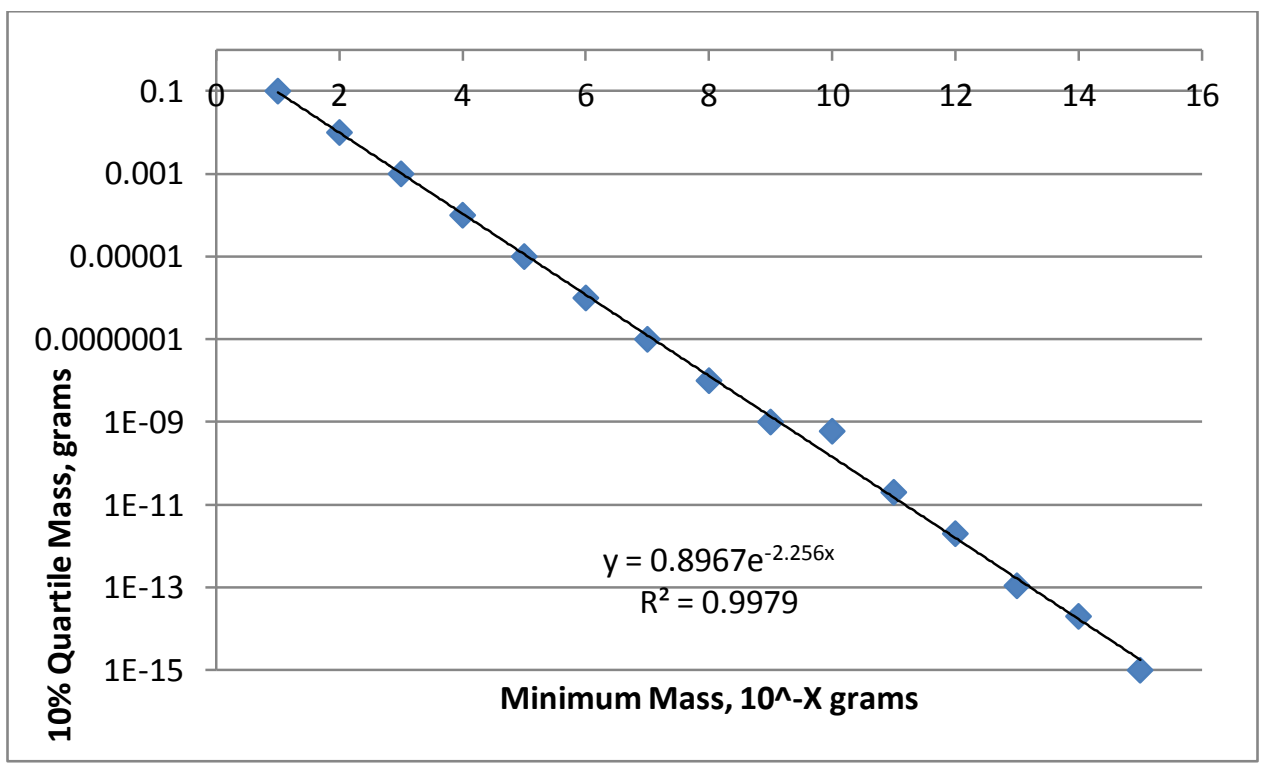

Figure 37. 10\% Quartile Varying with Minimum Mass 


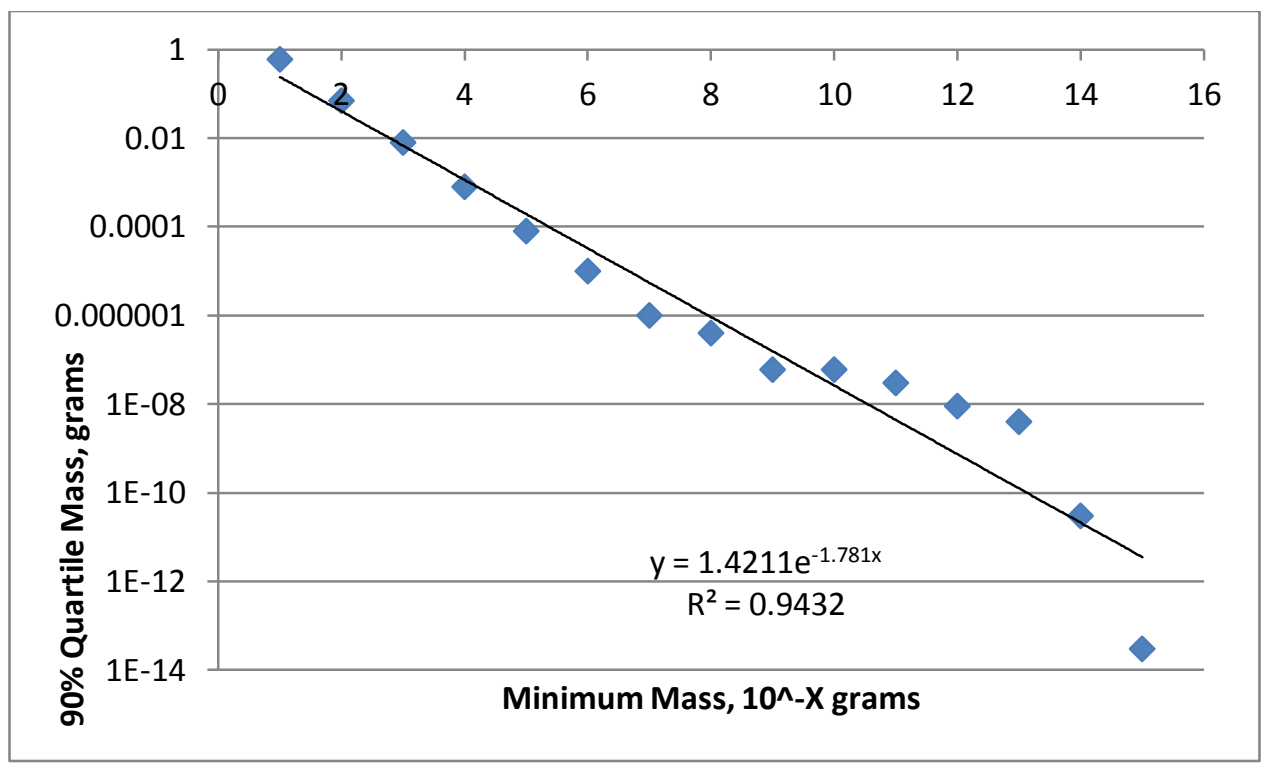

Figure 38. 90\% Quartile Varying with Minimum Mass

While the mean has a gradual curve, all the quartiles below $90 \%$ run fairly close to a straight line. In the $10 \%$ quartile, the data is almost a perfectly straight line; in the ones below it is. This shows how influential each step of lowering the minimum mass can be. The plots of higher quartiles $(100 \%, 99.5 \%$, and $97.5 \%)$ form jagged peaks and valleys as they are driven by only a few values.

\section{Micrometeoroid Recommendations}

Even thin shields can protect against the average micrometeoroid environment. When averaging the four mass and velocity results at the $10^{-6}$ level from Table 27 (ram face), the results were $7.25^{*} 10^{-6}$ grams and $22 \mathrm{~km} / \mathrm{s}$. When comparing these to the aluminum monolithic shields from the Monolithic Shields section, even the thinnest shield $(0.1 \mathrm{~cm})$ will prevent penetration. The next highest lever $(0.25 \mathrm{~cm})$ does not even suffer spallation.

The high mass impacts on the other hand, required very high levels of shielding to avoid penetration. Two values from Table 37 were used. $69 \mathrm{~km} / \mathrm{s}$ and 0.002 grams was chosen for high velocity and $19 \mathrm{~km} / \mathrm{s}$ and 0.06 grams was chosen for high mass. When compared against the aluminum charts, the higher mass was the most threatening. It took up to the $2.5 \mathrm{~cm}$ thick shield to prevent penetration and only the thickest $(5 \mathrm{~cm})$ was able to avoid spallation. The high velocity impact only took $1.5 \mathrm{~cm}$ to avoid penetration and $2.5 \mathrm{~cm}$ to prevent spallation. 
If a surface of the spacecraft is vulnerable to impacts on objects that cannot be shielded (radiator, solar array, optics) the first choice for location would be on the wake face. This face received significantly fewer impacts than the others, nearly up to an order of magnitude less compared to some of the more hit cases. The next best faces were port, starboard, and zenith. While not useful for long in an interplanetary mission, the earth face received the second lowest amount of hits for all four missions. The sun case was also low for three of the four, in Hohmann1 it spiked up above port and starboard.

When changing the minimum mass, one must be aware that the smallest mass setting will be the overwhelming majority of impacts. So while some sensors might require lower, it would be recommended to stay at $10^{-6}$ grams as a minimum. If modeling a part of the skip with more robust components, it might be wise to raise the minimum higher to check for catastrophic impacts. For crewed missions, it would be extremely important to run a high mass analysis of particles that could endanger crew safety. 


\section{Combined Shielding}

Some readers might wonder why two distinct forms of space environmental shielding were included in the same paper. This is due to the mindset of a spacecraft engineer to "double dip" components as much as possible. For example, running both electrical and data systems through one set of conduits saves the mass and complexity of extra tubing and brackets. Both micrometeoroid and radiation shielding don't have to stand alone; they can be combined into a single shield or even be composed of component from other systems such as structures.

On the simple end thin shields of aluminum were very efficient at shielding against both GCR radiation and average micrometeoroid environments. These are commonly seen as the outer panels of spacecraft. From the radiation section, a shield that was 0.5 inches thick of aluminum would be sufficient for the least intense SPE conditions for either of the temporary shielding reductions. If that shield is broken in two it can act like the $0.5 \mathrm{~cm}$

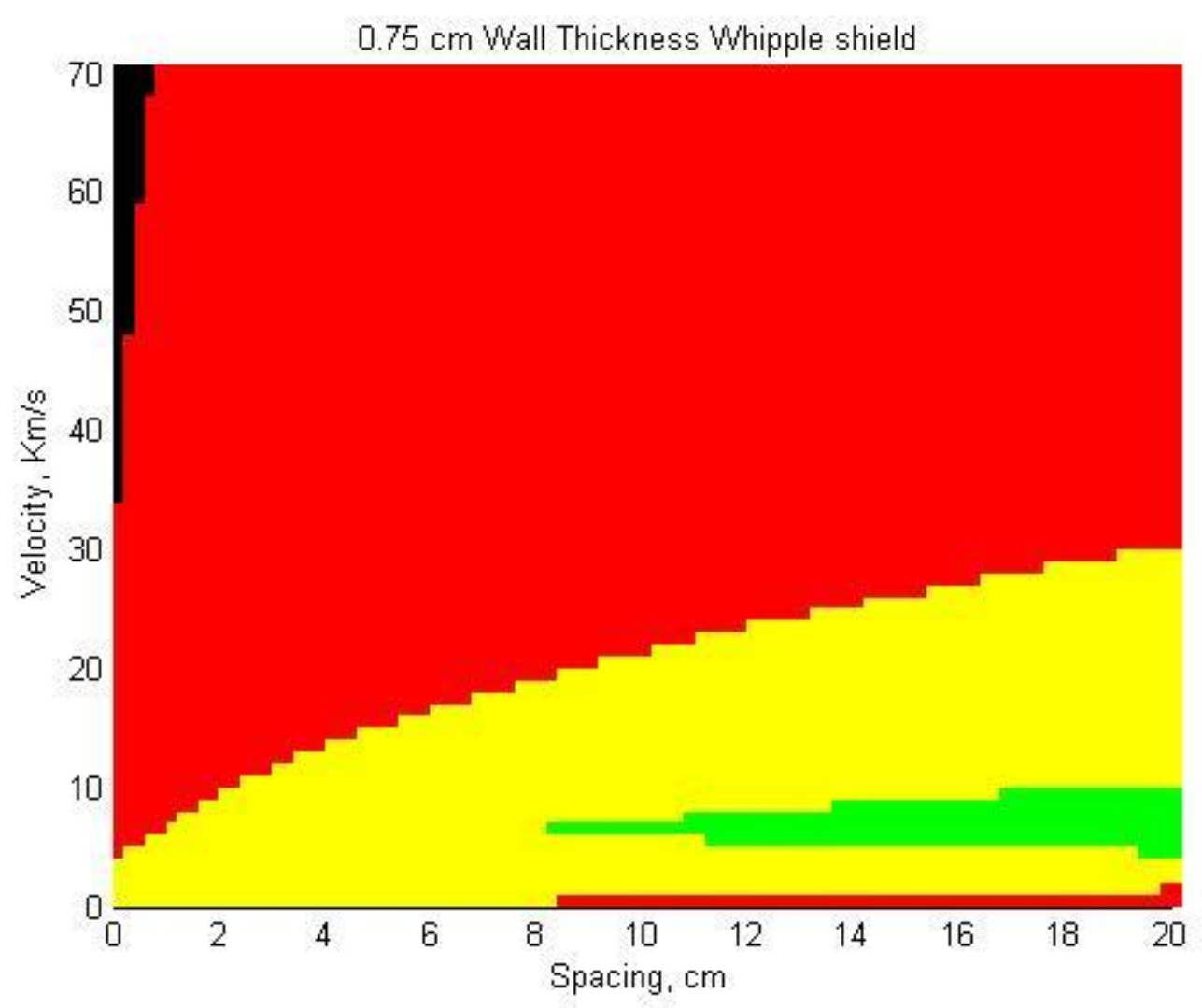

Figure 39. Critical Particle Diameter for $0.75 \mathrm{~cm}$ Wall Thickness 
bumper and $0.75 \mathrm{~cm}$ wall Whipple shield from the micrometeoroid section. The critical particle diameters for the majority of this plot are somewhere between $0.1 \mathrm{~cm}$ to $1 \mathrm{~cm}$. If we assume the impacting particles are spheres with a density of $2.35 \mathrm{~g} / \mathrm{cm}^{2}$, the red section can handle particles between $10^{-2}$ grams and 1.23 grams, while the yellow goes all the way up to 9.84 grams. All of the average particle masses from the micrometeoroid section fell significantly below this range, most were between $10^{-6}$ grams and $10^{-5}$ grams. Even the worst case masses never broke 0.06 grams, which was on the low end of the red bin.

While sufficient for micrometeoroids, such a shield might not protect against orbital debris, which tend to be slower but higher mass. Protection against those would require thicker shields, which would also be more useful against SPES. For example, a Stuffed Whipple shield (third material in the center instead of a gap), would act like a triple material shield from the radiation section.

This mindset of using items for multiple purposes is the result of monetary and logistical restrictions placed on satellites and other spacecraft, subsystem teams are forced to work closely together. A choice by one team can have significant effect on all the others. Say the thermal team want to put in a huge, incredibly complicated cooling system. The effectiveness of that oversized cooling system would have to weighed against its mass, volume, and power draw. In addition, it could be possible for the system be overly effective and actually cool other subsystem too much. If a smaller, less efficient system could meet all the requirements given by the other subsystem teams, it would be most likely used even though it is not the "best" option. That is the mindset of spacecraft design--not picking the best choice but the choice that allows for the most other better choices. If the radiation and micrometeoroid shielding can be combined into one system, that leave more mass for other subsystems to make better choices. 


\section{Conclusion}

The project was successful in its goal of providing model data for the micrometeoroid and radiation environments. The conclusions and recommendations drawn from the data will hopefully be useful for those in the early stages of interplanetary mission design. But like any project, there is room to expand on the work. One recommendation would be a finer (shorter duration state vectors and more draws) flux model to generate micrometeoroid results with. Additional runs could be made with different materials and thickness of micrometeoroid shields to allow for a better recommendation. The radiation section could have also looked at dose, which would be more useful for those missions where no crewmembers are aboard. Other mission lengths or shield combinations could further round out the model. These are ideas for those who would wish to continue this work.

For those who would use my data, there is one final note. Verification has been extremely difficult. Searches for scholarly literature on the subject revealed minimal comparable data. This is one reason I undertook this project to begin with. Sadly, I lack the millions to send out a spacecraft to ensure my models are sound. The code I used from others has been verified by each individually, but my combined method is much more intricate. My state vector codes were verified by endpoint, but there could be variance along the way. Verification of my impact chance code would have required redoing flux for an earth orbiting satellite and even then comparing results would not be conclusive. So while my results have been common sense verified (no mission returning $100 \mathrm{~Sv}$ of radiation, every run is not returning a $1 \mathrm{~kg}$ impact on several faces), fine-tune verification is beyond my capability.

The data is still useful without $100 \%$ verification as it was created for the early design stages. At that point rough ranges can be more useful than hard numbers. Design is still fluid. When the project matures, then mission specific models can be built.

For those working toward sending spacecraft out beyond the reach of Earth, I wish you luck. For humanity's greatest challenge is to seed ourselves across the stars. 


\section{BIBLOIGRAPHY}

1. American Specification Metals Inc, "Aluminum-Lithium Alloy 2195," URL: http://www.matweb.com/search/datasheet.aspx?matguid=4363dafc7f5545688506d8b4af1 e9468\&ckck=1, Cited 10/27/2014

2. American Specification Metals Inc Website, "Aluminum 6061-T6," URL: http://asm.matweb.com/search/SpecificMaterial.asp?bassnum=MA6061T6, Cited $10 / 27 / 2014$

3. American Specification Metals Inc Website, "Titanium Ti-6Al-4V (Grade 5), Annealed," URL: http://asm.matweb.com/search/SpecificMaterial.asp?bassnum=MTP641, Cited $10 / 27 / 2014$

4. Britt, D.T., Yeomans, D., Housen, K., and Consolmango, G., "Asteroid Density, Porosity, and Structure," Pasadena, CA: Jet Propulsion Laboratory, NASA, 2003

5. Clement, C.H. (ed), Sasaki, M. (ed). Dietze, G., Bartlett, D.T., Cucinotta ,F.A., Pelliccioni, M., Sato, T., Petrov, V., Reitz, G., McAulay, I.R., Xianghong, J., and Cool, D.A., "Assessment of Radiation Exposure of Astronauts in Space," The International Commission on Radiological Protection, 03 July, 2012

6. Christiansen Phd., Eric L., "Handbook for Designing MMOD Protection," NASA/TM2009-214785

7. Cooke, William J., Koehler, and Moorhead Phd., Althea, "NASA Meteoroid Engineering Model Release 2.0, NASA Marshall Space Flight Center, Huntsville Alabama, January 2013

8. Cucinotta Ph.D., Farnacis A., "Radiation Risk Acceptability and Limitations," 12 December, 2010

9. Curtis, Howard D., "Orbital Mechanics for Engineering Studies", $2^{\text {nd }}$ ed., Elsevier, New York, 2009

10. "Delta IV Launch Services User's Guide," June 2013,pp 2-10

11. Grun, E., Zook, H.A., Fechtig, H., and Giese, R.H., "Collisional Balance of the Meteoritic Complex," Icarus, Vol. 60, Dec. 1984, pp. 244-272

12. Inspiration Mars Website, "Overview," URL: http://inspirationmars.org/, Cited 2/02/15

13. JMP Pro, Ver. 11.0.0, SAS Institute Inc., 2013

14. MATLAB, software package, Ver. 7.10.0.499 (R2010a), MathWorks, 2010

15. MEMR2, Meteoroid Engineering Model Release 2.0, software package, George C. Marshall Space Flight Center, Huntsville, Alabama, January 2013

16. Microsoft Office Excel, Ver. 12.0.6715.5000,Microsoft, 2007

17. NASA's Mars Exploration Website, "Programs and Missions," URL: http://mars.jpl.nasa.gov/programmissions/missions/, Cited 2/02/15 
18. OLTARIS, "On-Line Tool for the Assessment of Radiation In Space," software package, Version 3.5, 12/12/2014

19. Ryan, Shannon and Christiansen, Eric L., "Micrometeoroid and Orbital Debris (MMOD) Shield Ballistic Limit Analysis Program," NASA/TM-2009-214789

20. Simon, Matthew A., Clowdsley, Martha, and Walker, Steven, "Habitat Design Considerations for Implementing Solar Particle Event Radiation Protection," NASA Report Number NF1676L-15543, 2013

21. Singleterry Jr, Robert C, Blattnig, Steve R., Clowdsley, Martha S., Qualls, Garry D., Sandridge, Christopher A., Simonsen, Lisa C., Norbury, John W, et al., "OLTARIS: OnLine Tool for the Assessment of Radiation in Space," NASA/TP-2010-216722, July 2010

22. Thelivesky.com, URL: http://theskylive.com/mars-tracker, Cited 21 January, 2015

23. Tribble, Alan C., The Space Environment, Princeton University Press, New York, 2003

24. Xapsos, M. A., Barth, J.L., Stassinopoulos, E. G., Burke, E. A., and Gee, G.B., "Space Environment Effects: Model for Emission of Solar Protons (ESP)--Cumulative and Worst-Case Event Fluences," NASA/TP-1999-209763 


\section{Appendices}

Appendix A Carbon Fiber Test Spheres for EDE Comparisons

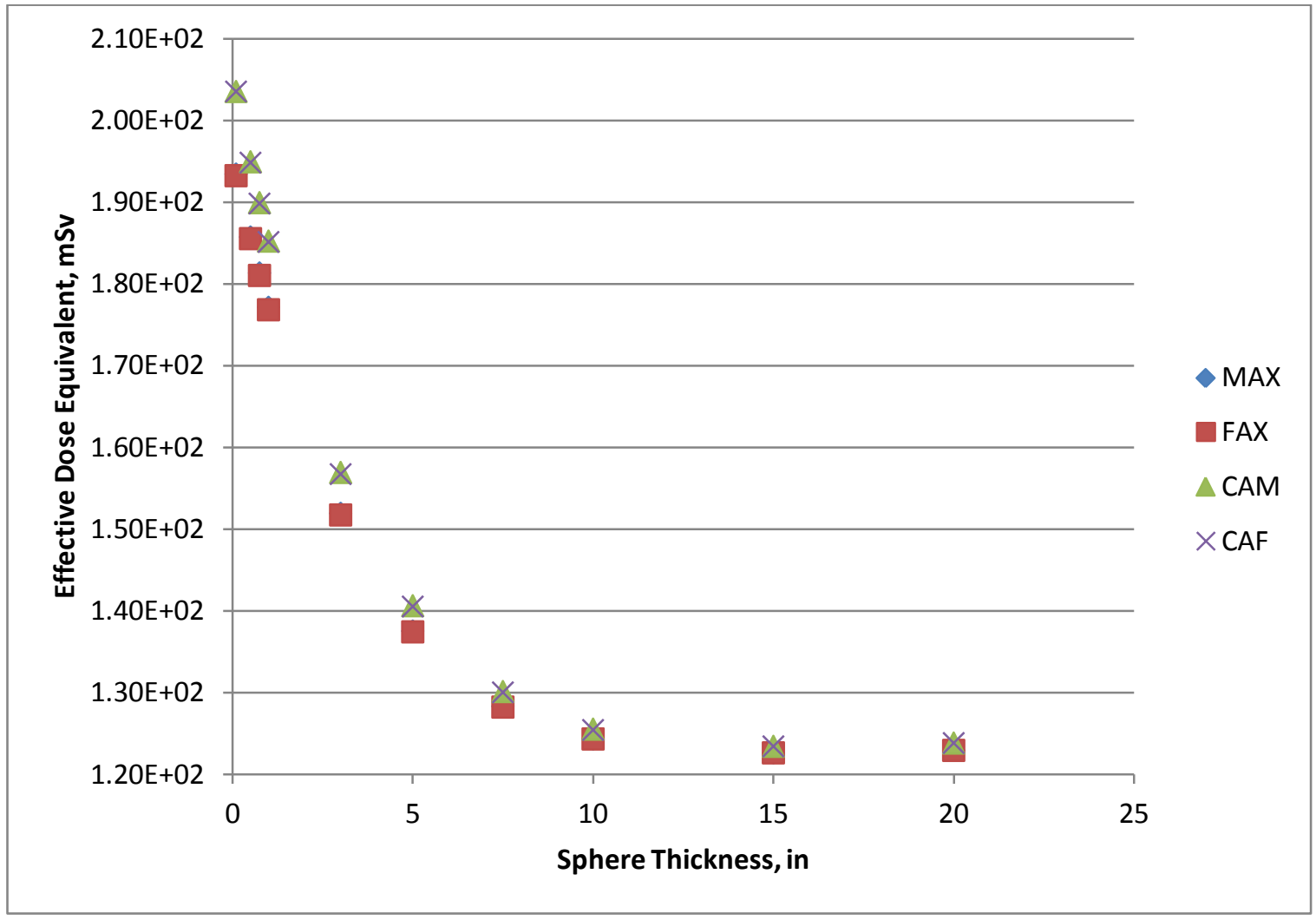

a) Galactic Cosmic Rays, 1956 Solar Minimum 


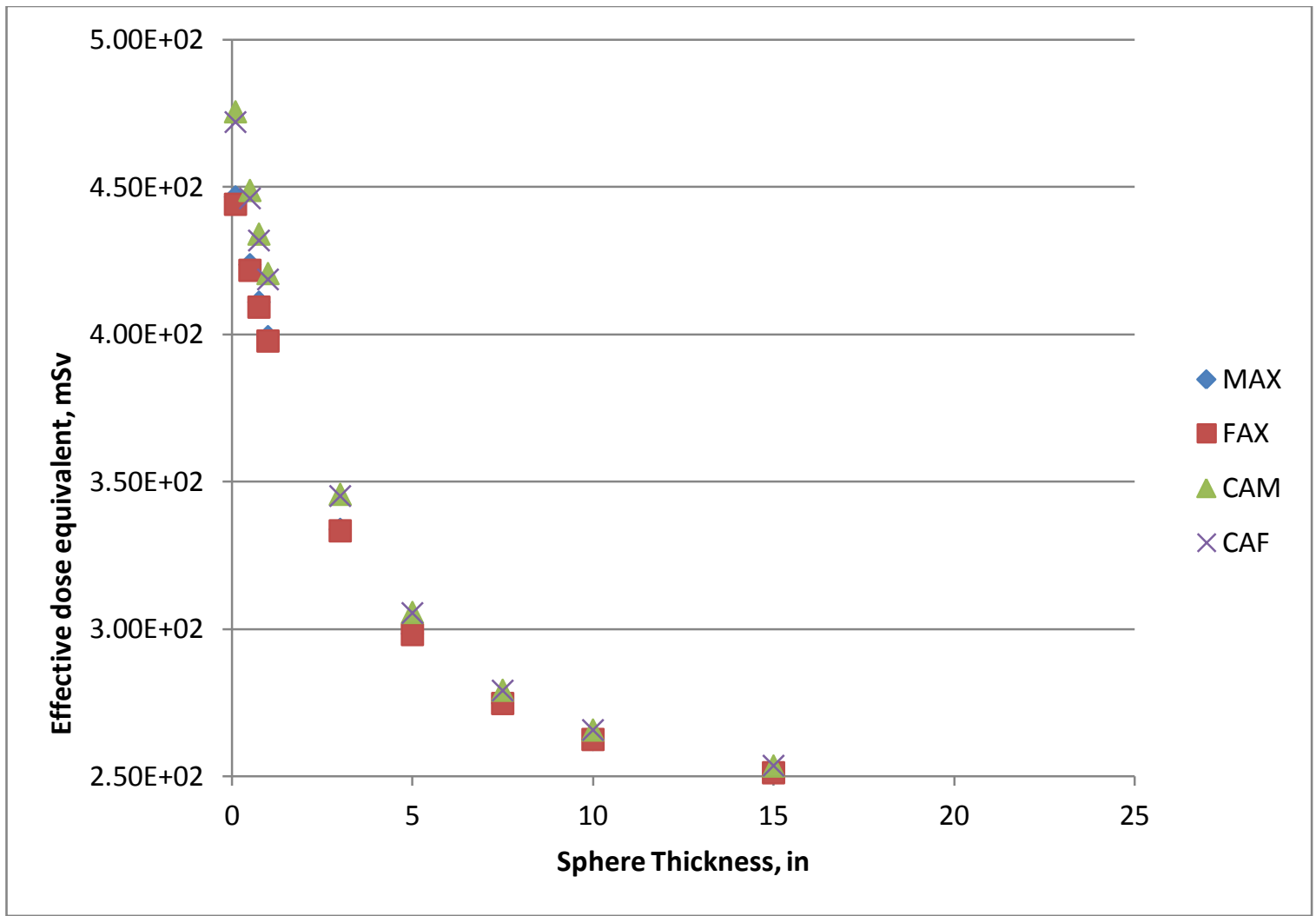

b) Galactic Cosmic Rays, 1991 Solar Maximum

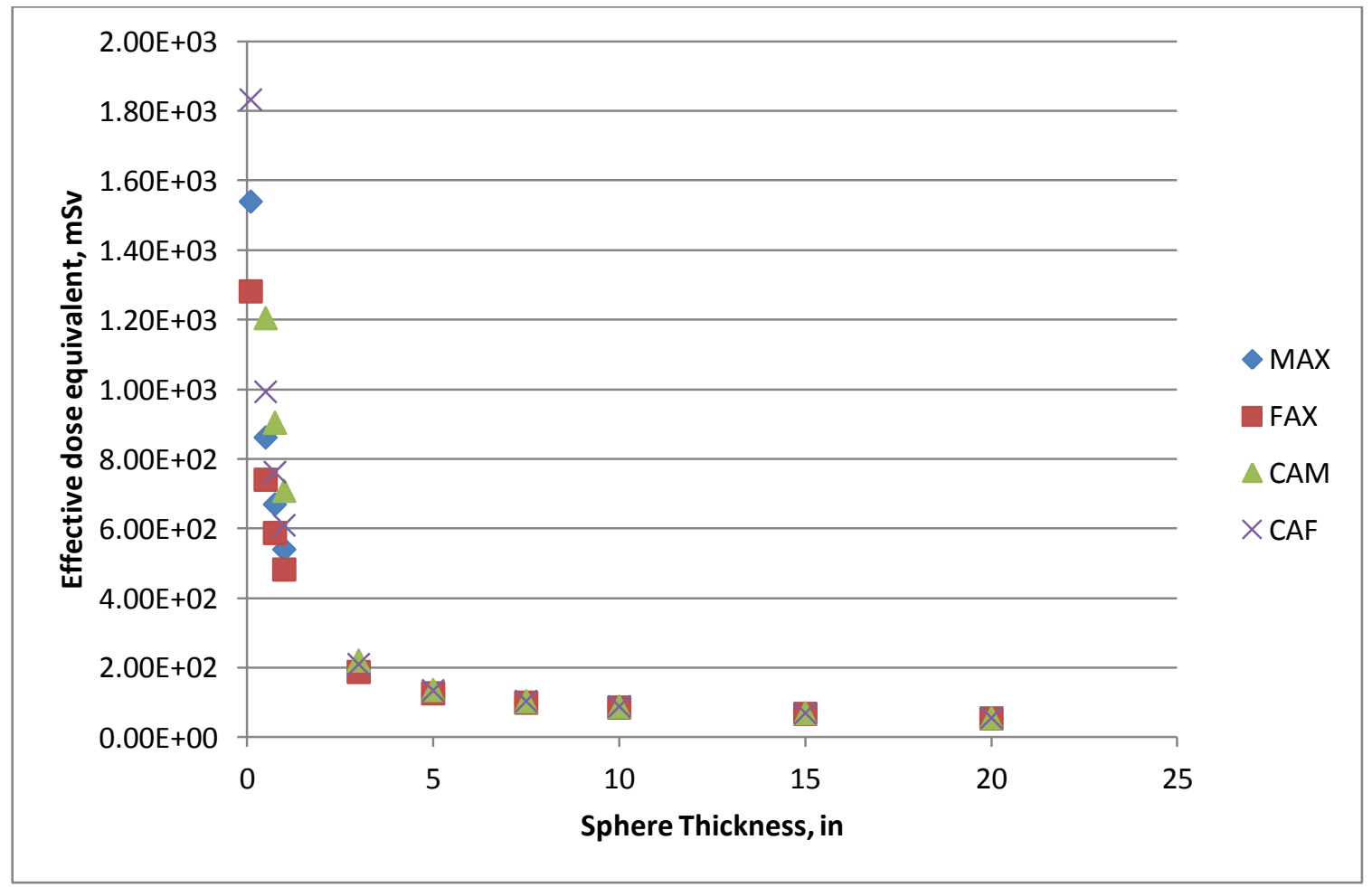

c) Averaged Solar Particle Event 
Appendix B Material Effect Plots

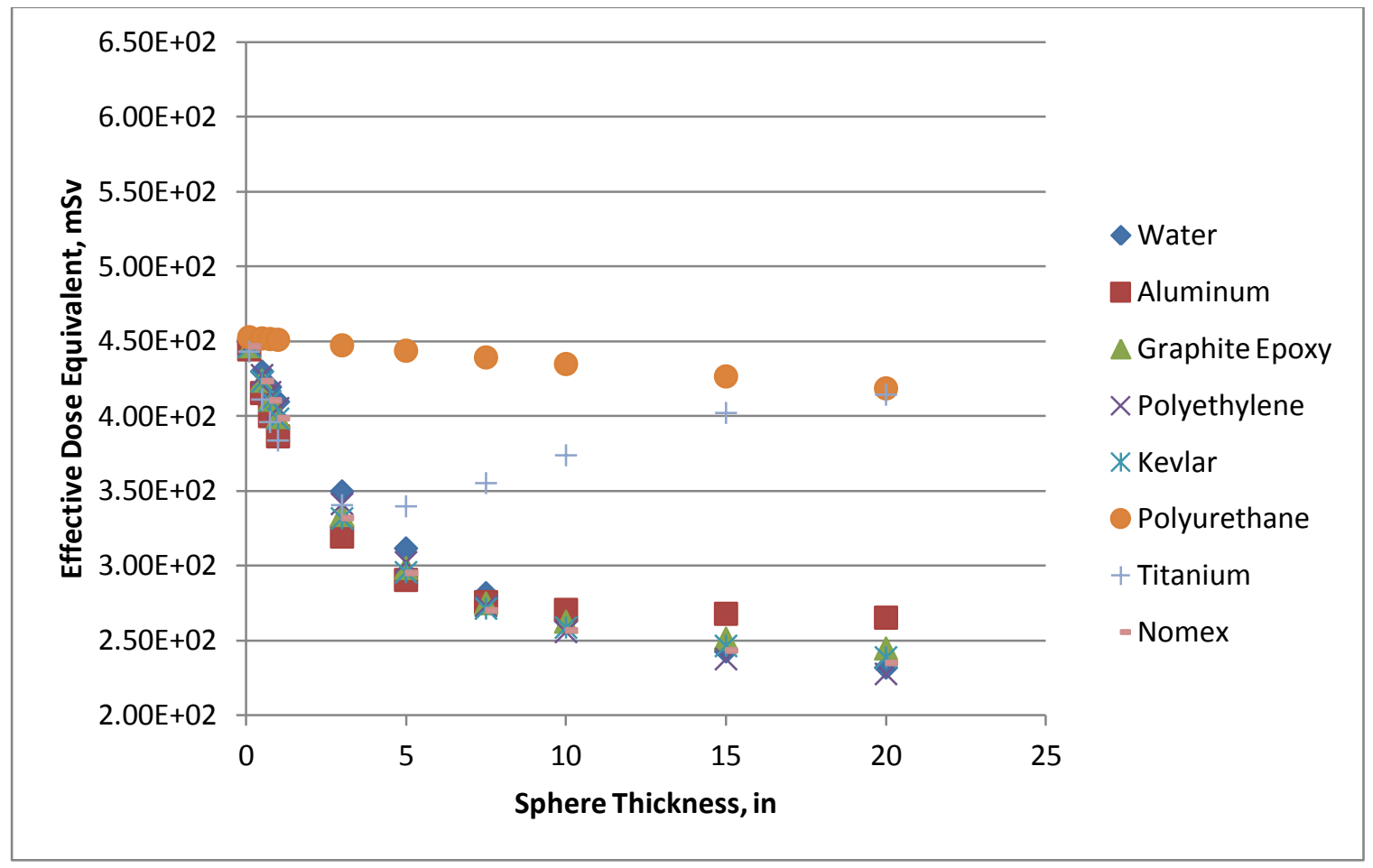

a) Single Material Comparison, 1956 Solar Minimum

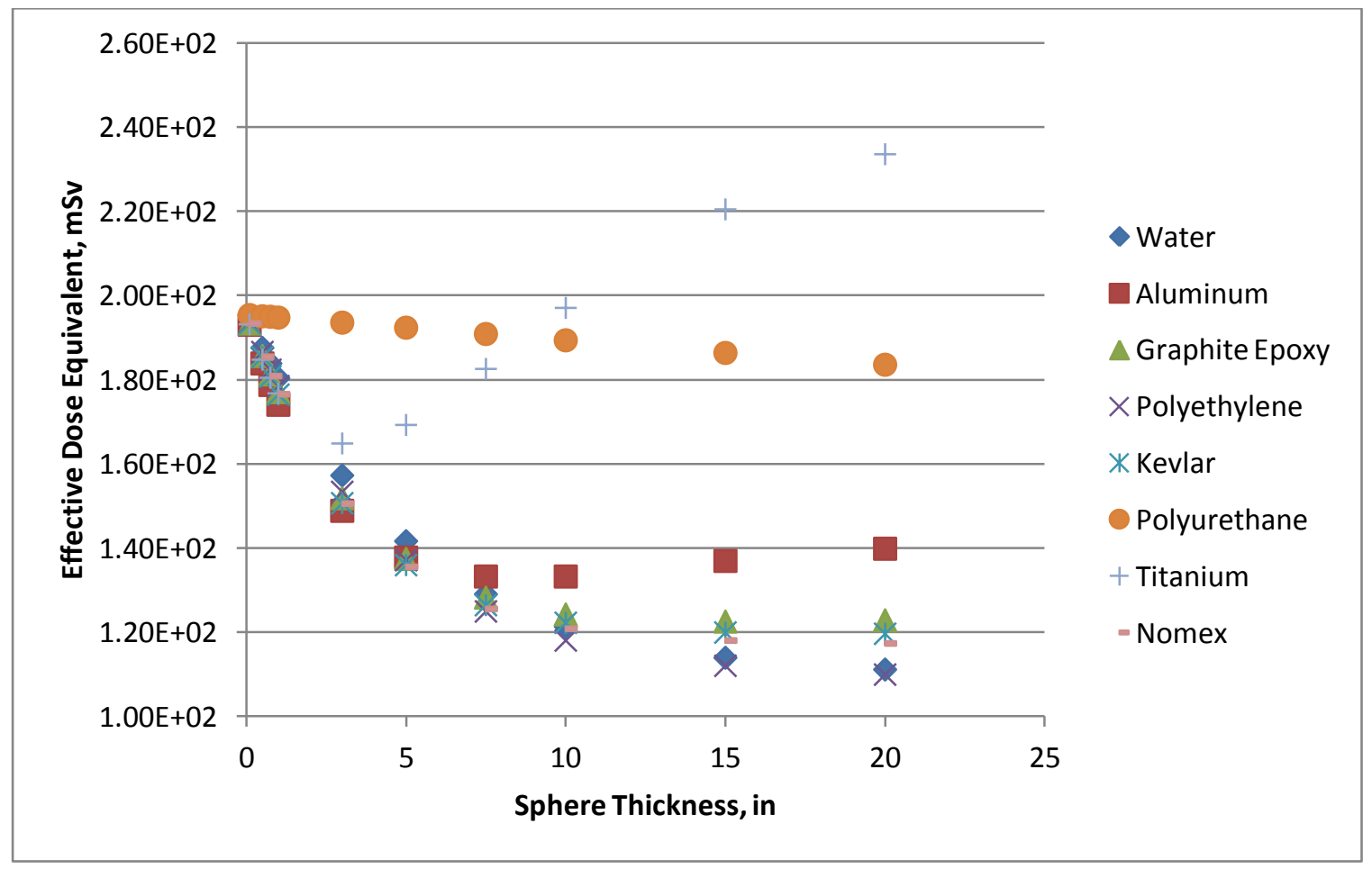

b) Single Material Comparison, 1991 Solar Maximum 


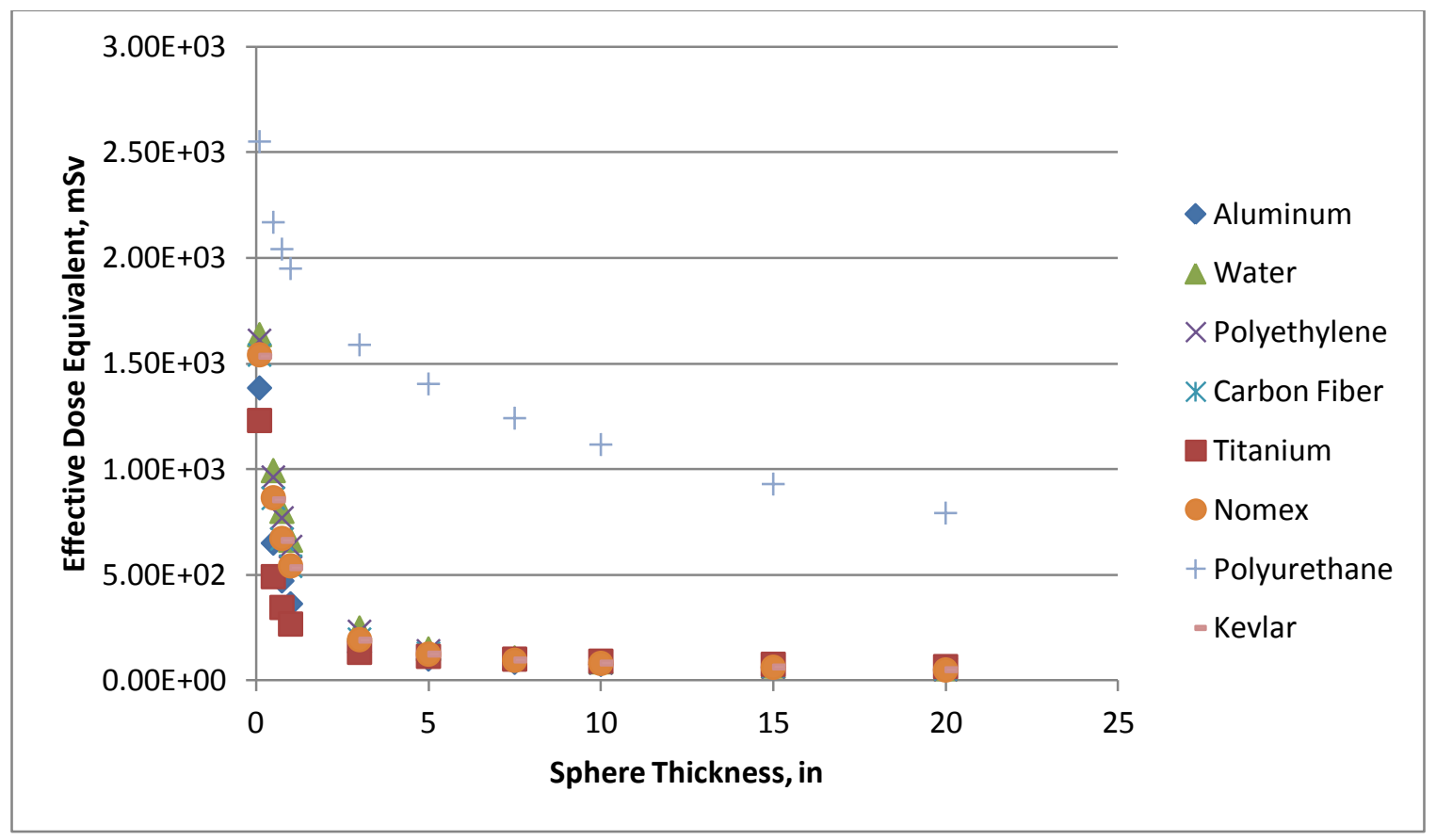

c) Single Material Comparison, Averaged Solar Particle Event

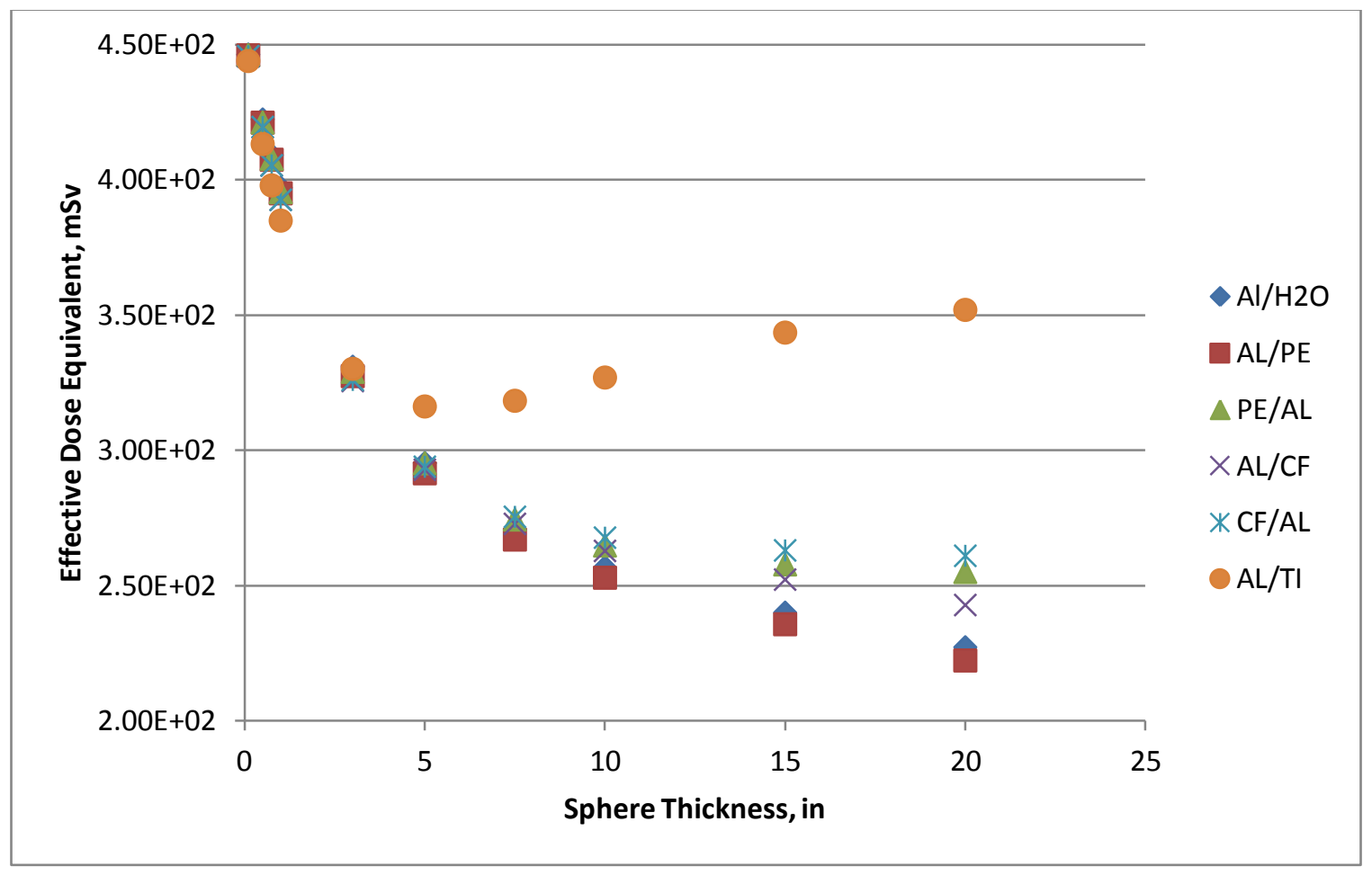

d) Double Material Comparison, 1956 Solar Minimum 


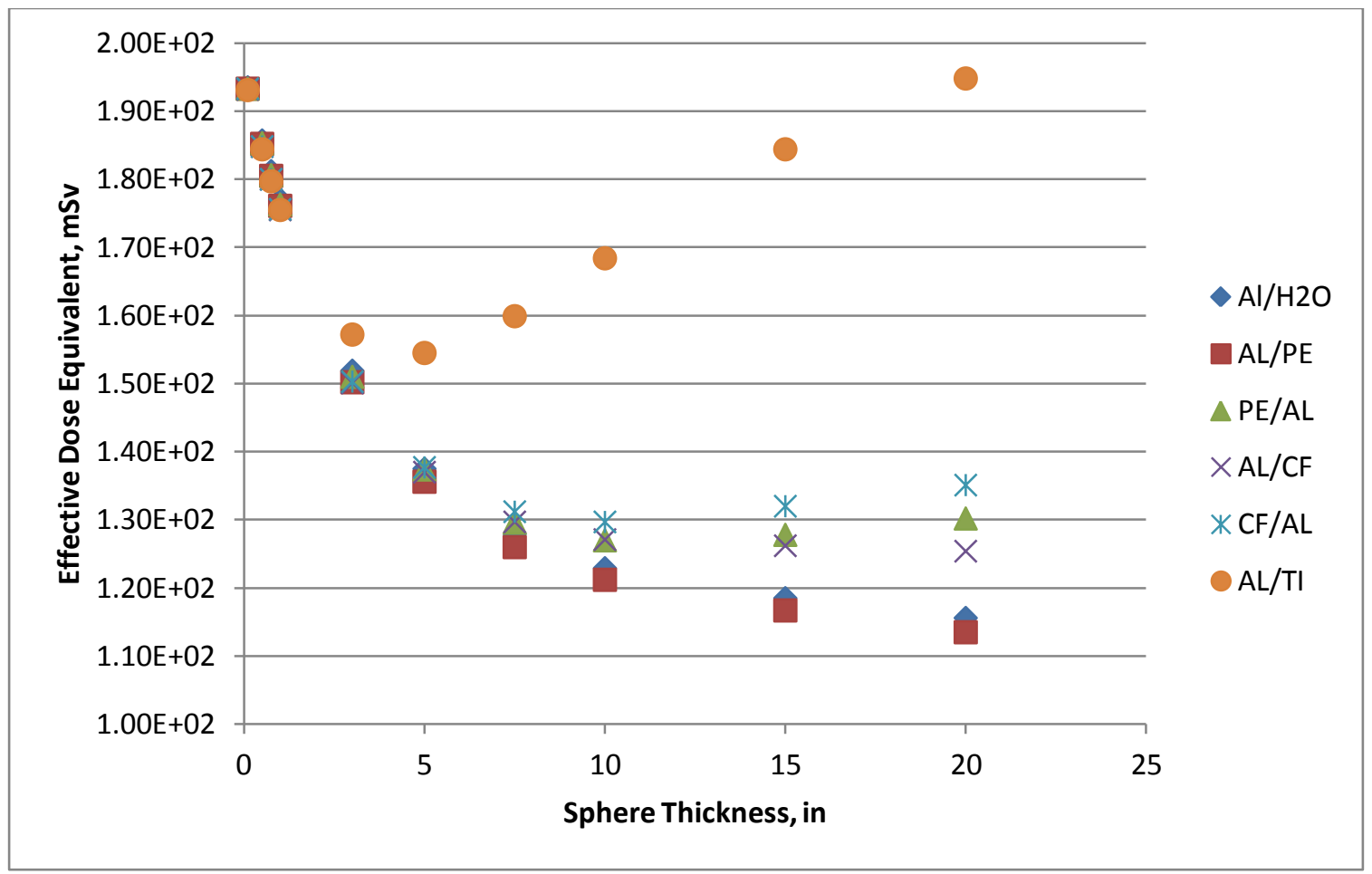

e) Double Material Comparison, 1991 Solar Maximum

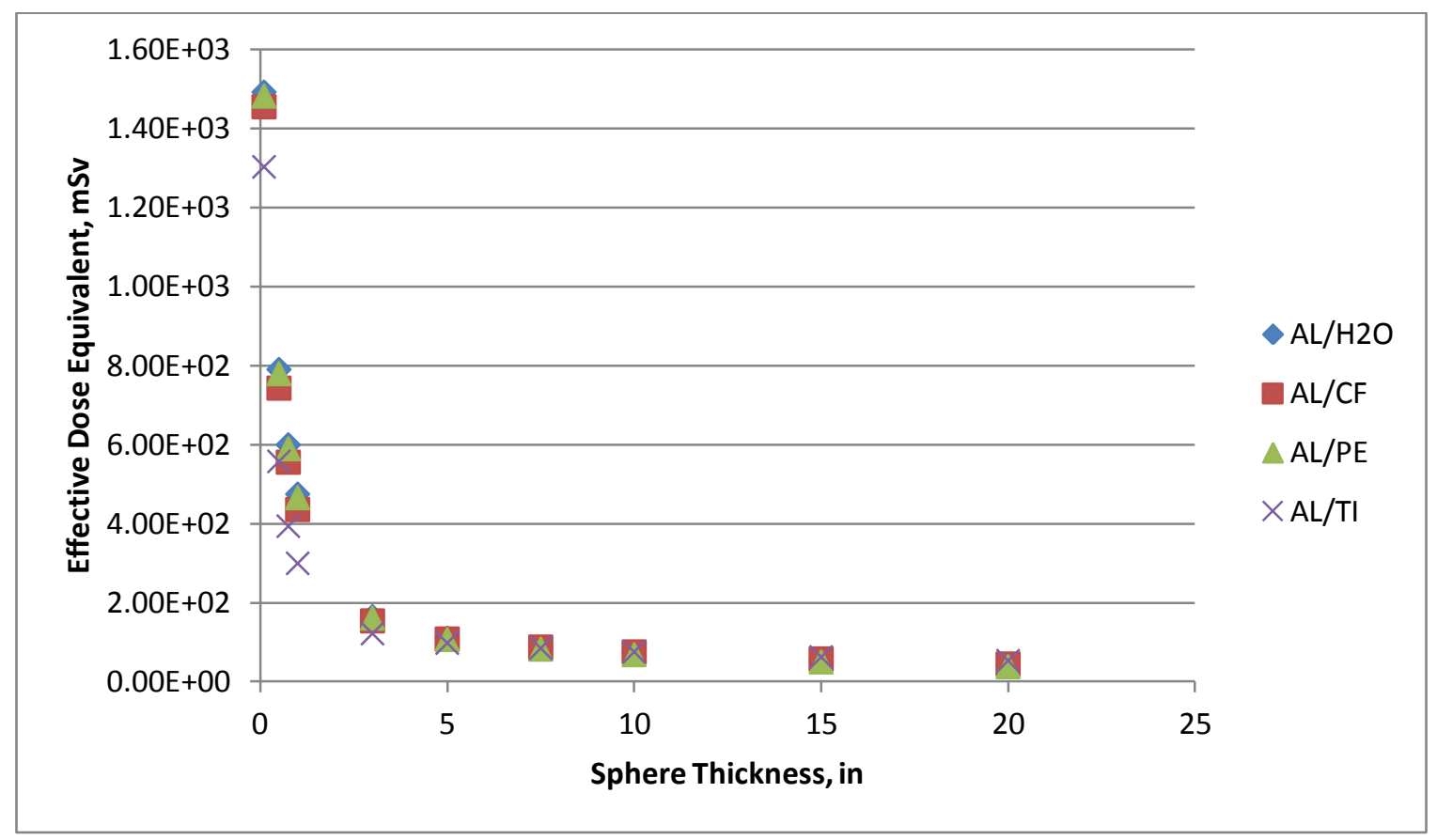

f) Double Material Comparison, Averaged Solar Particle Event 


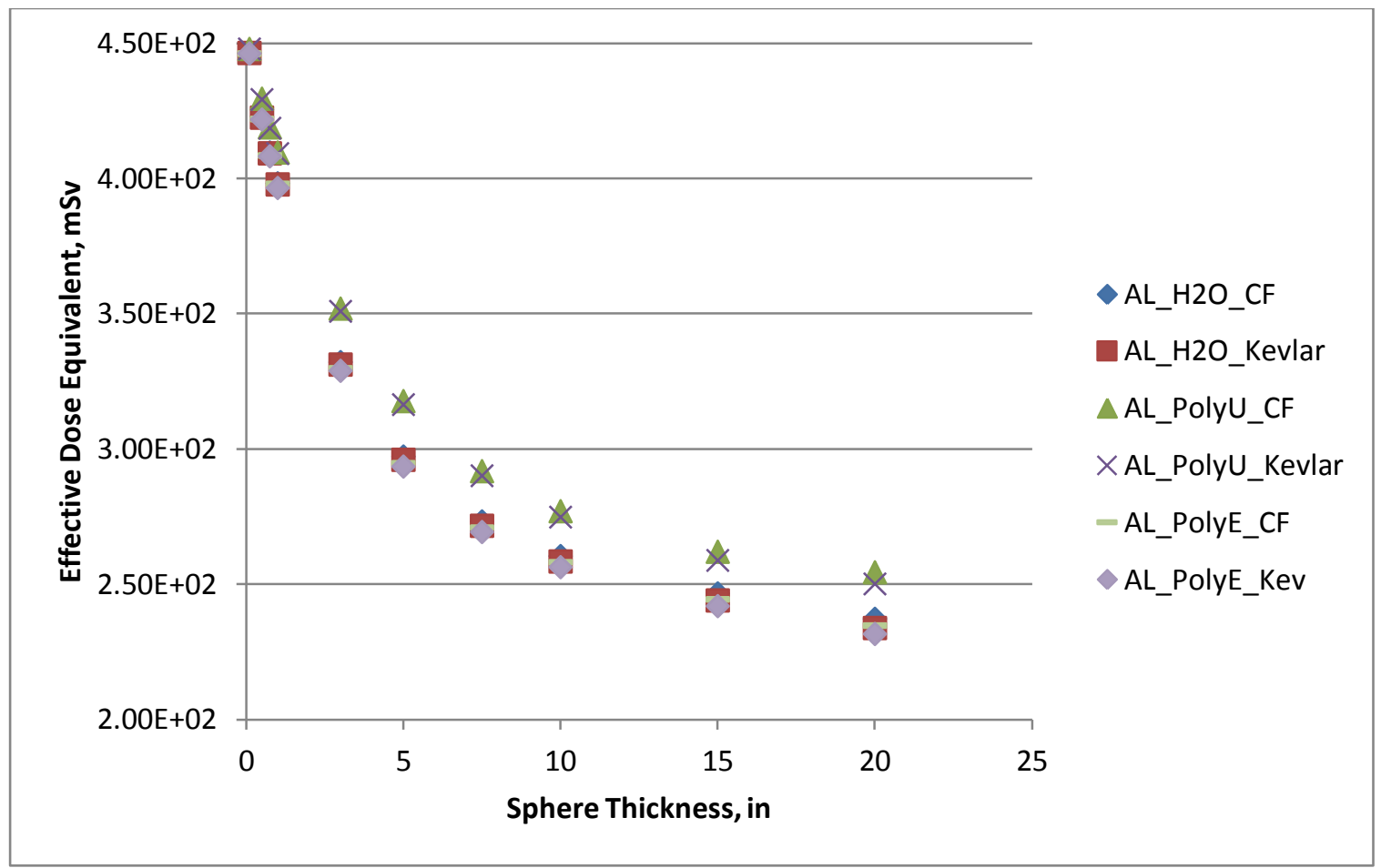

g) Triple Material Comparison, 1956 Solar Minimum

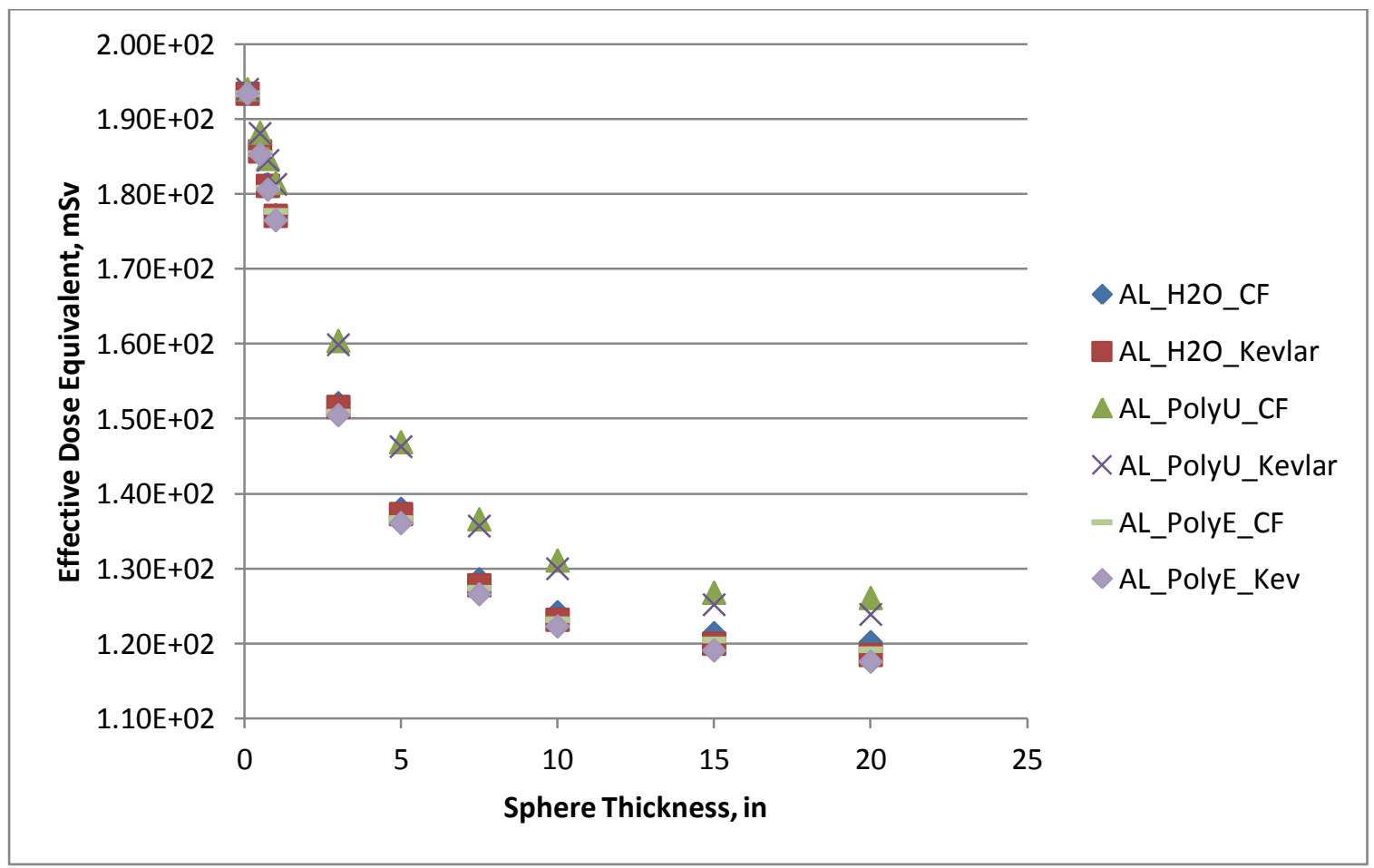

h) Triple Material Comparison, 1991 Solar Maximum 


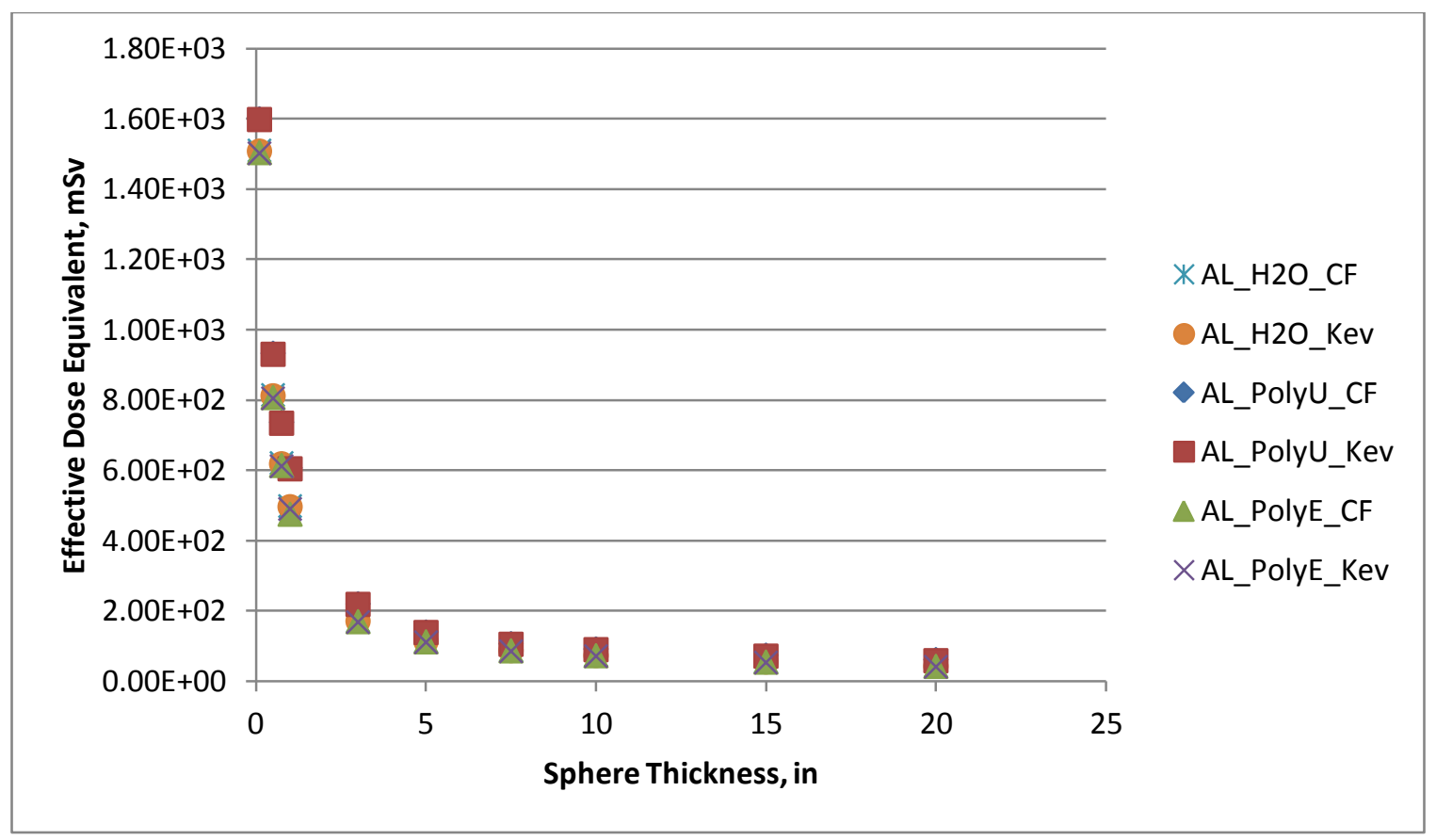

i) Triple Material Comparison, Averaged Solar Particle Event 


\section{Appendix C Impact Analysis Results}

In the version column in the following tables, the first number denotes the flux set and the second the impact set. For example V23 is the third impact run of the second set of flux values. The V_"number"_ave datasets are averages of the three different impact sets for each flux set. The Vtotave is the average off all nine impact sets. These values are unitless.

The number of impacts category is a count and is also unitless. The rest of the categories are either in units of grams (for mass) or $\mathrm{km} / \mathrm{s}$ (for velocity). These values were not listed in the tables to save space.

\section{Mariner 9}

\section{Ram Mass}

\begin{tabular}{|c|c|c|c|c|c|c|c|c|c|c|}
\hline Version & $\begin{array}{l}\text { Number of } \\
\text { Impacts }\end{array}$ & Mean & $\begin{array}{l}95 \% \text { CI for } \\
\text { Mean, Low }\end{array}$ & $\begin{array}{l}95 \% \text { CI for } \\
\text { Mean, High }\end{array}$ & Median & $\begin{array}{l}95 \% \text { CI for } \\
\text { Median, } \\
\text { Low }\end{array}$ & $\begin{array}{l}95 \% \text { CI for } \\
\text { Median, } \\
\text { High }\end{array}$ & StDev & $\begin{array}{l}95 \% \text { CI for } \\
\text { StDev, } \\
\text { Low }\end{array}$ & $\begin{array}{c}95 \% \text { CI for } \\
\text { Stdev, } \\
\text { High }\end{array}$ \\
\hline $\mathrm{V} 11$ & 135.00 & $7.00 \mathrm{E}-06$ & $5.00 \mathrm{E}-06$ & $1.00 \mathrm{E}-05$ & $3.00 \mathrm{E}-06$ & $2.00 \mathrm{E}-06$ & $4.00 \mathrm{E}-06$ & $1.60 \mathrm{E}-05$ & $1.40 \mathrm{E}-05$ & $1.80 \mathrm{E}-05$ \\
\hline V12 & 139.00 & $7.00 \mathrm{E}-06$ & $4.00 \mathrm{E}-06$ & $1.00 \mathrm{E}-05$ & $3.00 \mathrm{E}-06$ & $2.00 \mathrm{E}-06$ & $4.00 \mathrm{E}-06$ & $1.60 \mathrm{E}-05$ & $1.40 \mathrm{E}-05$ & $1.80 \mathrm{E}-05$ \\
\hline V13 & 132.00 & $1.40 \mathrm{E}-05$ & $2.00 \mathrm{E}-06$ & $2.50 \mathrm{E}-05$ & $3.00 \mathrm{E}-06$ & $2.00 \mathrm{E}-06$ & $4.00 \mathrm{E}-06$ & $6.70 \mathrm{E}-05$ & $5.90 \mathrm{E}-05$ & $7.60 \mathrm{E}-05$ \\
\hline $\mathrm{V} 21$ & 134.00 & $5.00 \mathrm{E}-06$ & $4.00 \mathrm{E}-06$ & $7.00 \mathrm{E}-06$ & $3.00 \mathrm{E}-06$ & $2.00 \mathrm{E}-06$ & $4.00 \mathrm{E}-06$ & $9.00 \mathrm{E}-06$ & $8.00 \mathrm{E}-06$ & $1.00 \mathrm{E}-05$ \\
\hline $\mathrm{V} 22$ & 152.00 & $1.30 \mathrm{E}-05$ & $2.00 \mathrm{E}-06$ & $2.40 \mathrm{E}-05$ & $3.00 \mathrm{E}-06$ & $2.00 \mathrm{E}-06$ & $3.00 \mathrm{E}-06$ & $7.00 \mathrm{E}-05$ & $6.30 \mathrm{E}-05$ & $7.80 \mathrm{E}-05$ \\
\hline V23 & 147.00 & $6.00 \mathrm{E}-06$ & $4.00 \mathrm{E}-06$ & $8.00 \mathrm{E}-06$ & $3.00 \mathrm{E}-06$ & $2.00 \mathrm{E}-06$ & $3.00 \mathrm{E}-06$ & $1.20 \mathrm{E}-05$ & $1.10 \mathrm{E}-05$ & $1.40 \mathrm{E}-05$ \\
\hline V31 & 159.00 & $5.00 \mathrm{E}-06$ & $4.00 \mathrm{E}-06$ & $7.00 \mathrm{E}-06$ & $2.00 \mathrm{E}-06$ & $2.00 \mathrm{E}-06$ & $3.00 \mathrm{E}-06$ & $1.00 \mathrm{E}-05$ & $9.00 \mathrm{E}-06$ & $1.10 \mathrm{E}-05$ \\
\hline V32 & 150.00 & $1.00 \mathrm{E}-05$ & $1.00 \mathrm{E}-06$ & $2.00 \mathrm{E}-05$ & $2.00 \mathrm{E}-06$ & $2.00 \mathrm{E}-06$ & $3.00 \mathrm{E}-06$ & $5.80 \mathrm{E}-05$ & $5.20 \mathrm{E}-05$ & $6.50 \mathrm{E}-05$ \\
\hline V33 & 141.00 & $1.20 \mathrm{E}-05$ & $3.00 \mathrm{E}-06$ & $2.10 \mathrm{E}-05$ & $3.00 \mathrm{E}-06$ & $2.00 \mathrm{E}-06$ & $4.00 \mathrm{E}-06$ & $5.60 \mathrm{E}-05$ & $5.00 \mathrm{E}-05$ & $6.30 \mathrm{E}-05$ \\
\hline V1ave & 135.33 & $9.33 \mathrm{E}-06$ & $3.67 \mathrm{E}-06$ & $1.50 \mathrm{E}-05$ & $3.00 \mathrm{E}-06$ & $2.00 \mathrm{E}-06$ & $4.00 \mathrm{E}-06$ & $3.30 \mathrm{E}-05$ & $2.90 \mathrm{E}-05$ & $3.73 \mathrm{E}-05$ \\
\hline V2ave & 144.33 & $8.00 \mathrm{E}-06$ & $3.33 \mathrm{E}-06$ & $1.30 \mathrm{E}-05$ & $3.00 \mathrm{E}-06$ & $2.00 \mathrm{E}-06$ & $3.33 \mathrm{E}-06$ & $3.03 \mathrm{E}-05$ & $2.73 \mathrm{E}-05$ & $3.40 \mathrm{E}-05$ \\
\hline V3ave & 150.00 & $9.00 \mathrm{E}-06$ & $2.67 \mathrm{E}-06$ & $1.60 \mathrm{E}-05$ & $2.33 \mathrm{E}-06$ & $2.00 \mathrm{E}-06$ & $3.33 \mathrm{E}-06$ & $4.13 \mathrm{E}-05$ & $3.70 \mathrm{E}-05$ & $4.63 \mathrm{E}-05$ \\
\hline Vtotave & 143.22 & $8.78 \mathrm{E}-06$ & $3.22 \mathrm{E}-06$ & $1.47 \mathrm{E}-05$ & $2.78 \mathrm{E}-06$ & $2.00 \mathrm{E}-06$ & $3.56 \mathrm{E}-06$ & $3.49 \mathrm{E}-05$ & $3.11 \mathrm{E}-05$ & $3.92 \mathrm{E}-05$ \\
\hline
\end{tabular}

Ram Velocity

\begin{tabular}{|c|c|c|c|c|c|c|c|c|c|c|}
\hline Version & $\begin{array}{l}\text { Number of } \\
\text { Impacts }\end{array}$ & Mean & $\begin{array}{l}95 \% \text { CI for } \\
\text { Mean, Low }\end{array}$ & $\begin{array}{c}95 \% \text { CI for } \\
\text { Mean, } \\
\text { High }\end{array}$ & Median & $\begin{array}{l}\text { 95\% CI for } \\
\text { Median, } \\
\text { Low }\end{array}$ & $\begin{array}{l}95 \% \text { CI for } \\
\text { Median, } \\
\text { High }\end{array}$ & StDev & $\begin{array}{c}95 \% \text { CI for } \\
\text { StDev, } \\
\text { Low }\end{array}$ & $\begin{array}{c}95 \% \text { CI for } \\
\text { Stdev, } \\
\text { High }\end{array}$ \\
\hline V11 & 135.00 & 22.96 & 21.00 & 24.92 & 21.00 & 19.00 & 25.00 & 11.52 & 10.29 & 13.09 \\
\hline V12 & 129.00 & 21.81 & 19.96 & 23.66 & 21.00 & 19.00 & 23.00 & 10.61 & 9.46 & 12.10 \\
\hline V13 & 132.00 & 20.99 & 19.37 & 22.60 & 21.00 & 19.00 & 22.46 & 9.36 & 8.35 & 10.65 \\
\hline V21 & 134.00 & 21.03 & 19.14 & 22.92 & 21.00 & 19.00 & 23.00 & 11.06 & 9.88 & 12.57 \\
\hline V22 & 152.00 & 19.55 & 17.78 & 21.33 & 17.00 & 17.00 & 21.00 & 11.09 & 9.97 & 12.51 \\
\hline V23 & 147.00 & 19.75 & 18.14 & 21.36 & 19.00 & 17.00 & 21.00 & 9.90 & 8.88 & 11.18 \\
\hline V31 & 159.00 & 21.45 & 19.67 & 23.24 & 21.00 & 19.00 & 23.00 & 11.38 & 10.25 & 12.79 \\
\hline V32 & 150.00 & 20.88 & 19.07 & 22.69 & 21.00 & 19.00 & 23.00 & 11.24 & 10.09 & 12.67 \\
\hline V33 & 141.00 & 20.86 & 18.93 & 22.78 & 21.00 & 17.00 & 23.00 & 11.56 & 10.35 & 13.10 \\
\hline V1ave & 132.00 & 21.92 & 20.11 & 23.72 & 21.00 & 19.00 & 23.49 & 10.50 & 9.37 & 11.94 \\
\hline V2ave & 144.33 & 20.11 & 18.35 & 21.87 & 19.00 & 17.67 & 21.67 & 10.68 & 9.58 & 12.09 \\
\hline V3ave & 150.00 & 21.06 & 19.22 & 22.90 & 21.00 & 18.33 & 23.00 & 11.39 & 10.23 & 12.85 \\
\hline Vtotave & 142.11 & 21.03 & 19.23 & 22.83 & 20.33 & 18.33 & 22.72 & 10.86 & 9.72 & 12.29 \\
\hline
\end{tabular}


Wake Mass

\begin{tabular}{|c|c|c|c|c|c|c|c|c|c|c|}
\hline Version & $\begin{array}{l}\text { Number of } \\
\text { Impacts }\end{array}$ & Mean & $\begin{array}{l}95 \% \text { CI for } \\
\text { Mean, Low }\end{array}$ & $\begin{array}{l}95 \% \text { CI for } \\
\text { Mean, } \\
\text { High }\end{array}$ & Median & $\begin{array}{l}95 \% \text { CI for } \\
\text { Median, } \\
\text { Low }\end{array}$ & $\begin{array}{l}95 \% \text { CI for } \\
\text { Median, } \\
\text { High }\end{array}$ & StDev & $\begin{array}{l}95 \% \text { CI for } \\
\text { StDev, } \\
\text { Low }\end{array}$ & $\begin{array}{c}95 \% \text { CI for } \\
\text { Stdev, } \\
\text { High }\end{array}$ \\
\hline V11 & 11.00 & $8.00 \mathrm{E}-06$ & $-1.00 \mathrm{E}-06$ & $1.70 \mathrm{E}-05$ & $4.00 \mathrm{E}-06$ & $2.00 \mathrm{E}-06$ & $7.00 \mathrm{E}-06$ & $1.40 \mathrm{E}-05$ & $1.00 \mathrm{E}-05$ & $2.50 \mathrm{E}-05$ \\
\hline V12 & 12.00 & $4.00 \mathrm{E}-06$ & $2.00 \mathrm{E}-06$ & $6.00 \mathrm{E}-06$ & $2.00 \mathrm{E}-06$ & $1.00 \mathrm{E}-06$ & $6.00 \mathrm{E}-06$ & $3.00 \mathrm{E}-06$ & $2.00 \mathrm{E}-06$ & $6.00 \mathrm{E}-06$ \\
\hline V13 & 10.00 & $8.00 \mathrm{E}-06$ & $1.00 \mathrm{E}-06$ & $1.50 \mathrm{E}-05$ & $5.00 \mathrm{E}-06$ & $2.00 \mathrm{E}-06$ & $1.10 \mathrm{E}-05$ & $9.00 \mathrm{E}-06$ & $6.00 \mathrm{E}-06$ & $1.70 \mathrm{E}-05$ \\
\hline V21 & 4.00 & $5.00 \mathrm{E}-06$ & $1.00 \mathrm{E}-06$ & $9.00 \mathrm{E}-06$ & $4.00 \mathrm{E}-06$ & $3.00 \mathrm{E}-06$ & $9.00 \mathrm{E}-06$ & $3.00 \mathrm{E}-06$ & $3.00 \mathrm{E}-06$ & $1.00 \mathrm{E}-05$ \\
\hline V22 & 14.00 & $1.30 \mathrm{E}-05$ & $-2.00 \mathrm{E}-06$ & $2.80 \mathrm{E}-05$ & $2.00 \mathrm{E}-06$ & $1.00 \mathrm{E}-06$ & $5.00 \mathrm{E}-06$ & $2.60 \mathrm{E}-05$ & $1.90 \mathrm{E}-05$ & $4.30 \mathrm{E}-05$ \\
\hline V23 & 6.00 & $2.00 \mathrm{E}-06$ & $0.00 \mathrm{E}+00$ & $4.00 \mathrm{E}-06$ & $1.00 \mathrm{E}-06$ & $1.00 \mathrm{E}-06$ & $4.00 \mathrm{E}-06$ & $2.00 \mathrm{E}-06$ & $1.00 \mathrm{E}-06$ & $4.00 \mathrm{E}-06$ \\
\hline V31 & 11.00 & $4.00 \mathrm{E}-06$ & $2.00 \mathrm{E}-06$ & $6.00 \mathrm{E}-06$ & $2.00 \mathrm{E}-06$ & $1.00 \mathrm{E}-06$ & $7.00 \mathrm{E}-06$ & $3.00 \mathrm{E}-06$ & $2.00 \mathrm{E}-06$ & $6.00 \mathrm{E}-06$ \\
\hline V32 & 6.00 & $1.30 \mathrm{E}-05$ & $-7.00 \mathrm{E}-06$ & $3.20 \mathrm{E}-05$ & $7.00 \mathrm{E}-06$ & $1.00 \mathrm{E}-06$ & $3.60 \mathrm{E}-05$ & $1.90 \mathrm{E}-05$ & $1.20 \mathrm{E}-05$ & $4.60 \mathrm{E}-05$ \\
\hline V33 & 12.00 & $1.10 \mathrm{E}-05$ & $-5.00 \mathrm{E}-06$ & $2.70 \mathrm{E}-05$ & $5.00 \mathrm{E}-06$ & $1.00 \mathrm{E}-06$ & 7.00E-06 & $2.50 \mathrm{E}-05$ & $1.80 \mathrm{E}-05$ & $4.20 \mathrm{E}-05$ \\
\hline V1ave & 11.00 & $6.67 \mathrm{E}-06$ & $6.67 \mathrm{E}-07$ & $1.27 \mathrm{E}-05$ & $3.67 \mathrm{E}-06$ & $1.67 \mathrm{E}-06$ & $8.00 \mathrm{E}-06$ & $8.67 \mathrm{E}-06$ & $6.00 \mathrm{E}-06$ & $1.60 \mathrm{E}-05$ \\
\hline V2ave & 8.00 & $6.67 \mathrm{E}-06$ & $-3.33 \mathrm{E}-07$ & $1.37 \mathrm{E}-05$ & $2.33 \mathrm{E}-06$ & $1.67 \mathrm{E}-06$ & $6.00 \mathrm{E}-06$ & $1.03 \mathrm{E}-05$ & 7.67E-06 & $1.90 \mathrm{E}-05$ \\
\hline V3ave & 9.67 & 9.33E-06 & $-3.33 \mathrm{E}-06$ & $2.17 \mathrm{E}-05$ & 4.67E-06 & $1.00 \mathrm{E}-06$ & 1.67E-05 & $1.57 \mathrm{E}-05$ & $1.07 \mathrm{E}-05$ & $3.13 \mathrm{E}-05$ \\
\hline Vtotave & 9.56 & $7.56 \mathrm{E}-06$ & $-1.00 \mathrm{E}-06$ & $1.60 \mathrm{E}-05$ & $3.56 \mathrm{E}-06$ & $1.44 \mathrm{E}-06$ & $1.02 \mathrm{E}-05$ & $1.16 \mathrm{E}-05$ & $8.11 \mathrm{E}-06$ & $2.21 \mathrm{E}-05$ \\
\hline
\end{tabular}

\section{Wake Velocity}

\begin{tabular}{|c|c|c|c|c|c|c|c|c|c|c|}
\hline Version & $\begin{array}{l}\text { Number of } \\
\text { Impacts }\end{array}$ & Mean & $\begin{array}{l}95 \% \text { CI for } \\
\text { Mean, Low }\end{array}$ & $\begin{array}{l}95 \% \text { CI for } \\
\text { Mean, } \\
\text { High }\end{array}$ & Median & $\begin{array}{l}95 \% \text { CI for } \\
\text { Median, } \\
\text { Low }\end{array}$ & $\begin{array}{l}\text { 95\% CI for } \\
\text { Median, } \\
\text { High }\end{array}$ & StDev & $\begin{array}{c}95 \% \text { CI for } \\
\text { StDev, } \\
\text { Low }\end{array}$ & $\begin{array}{c}95 \% \text { CI for } \\
\text { Stdev, } \\
\text { High }\end{array}$ \\
\hline V11 & 11.00 & 24.46 & 17.55 & 31.36 & 29.00 & 18.18 & 35.00 & 10.28 & 7.18 & 18.04 \\
\hline V12 & 12.00 & 15.83 & 10.43 & 21.24 & 18.00 & 7.53 & 22.47 & 8.51 & 6.03 & 14.44 \\
\hline V13 & 10.00 & 18.00 & 12.07 & 23.93 & 17.00 & 11.63 & 25.05 & 8.29 & 5.70 & 15.13 \\
\hline V21 & 4.00 & 17.50 & -3.19 & 38.19 & 15.00 & 5.00 & 35.00 & 13.00 & 7.36 & 48.47 \\
\hline V22 & 14.00 & 22.29 & 14.29 & 30.28 & 24.00 & 8.79 & 31.00 & 13.85 & 10.04 & 22.31 \\
\hline V23 & 6.00 & 20.00 & 11.32 & 28.68 & 23.00 & 9.29 & 26.86 & 8.27 & 5.16 & 20.28 \\
\hline V32 & 6.00 & 21.33 & 11.91 & 30.76 & 23.00 & 10.00 & 29.57 & 8.98 & 5.61 & 22.03 \\
\hline V33 & 12.00 & 17.83 & 12.46 & 23.21 & 19.00 & 11.00 & 24.47 & 8.46 & 5.99 & 14.37 \\
\hline V1ave & 11.00 & 19.43 & 13.35 & 25.51 & 21.33 & 12.45 & 27.51 & 9.02 & 6.30 & 15.87 \\
\hline V2ave & 8.00 & 19.93 & 7.48 & 32.38 & 20.67 & 7.69 & 30.95 & 11.71 & 7.52 & 30.35 \\
\hline V3ave & 9.67 & 19.93 & 13.39 & 26.48 & 21.00 & 12.00 & 27.68 & 8.21 & 5.54 & 16.34 \\
\hline Vtotave & 9.56 & 19.76 & 11.40 & 28.12 & 21.00 & 10.71 & 28.71 & 9.65 & 6.46 & 20.86 \\
\hline
\end{tabular}

Port Mass

\begin{tabular}{|c|c|c|c|c|c|c|c|c|c|c|}
\hline Version & $\begin{array}{l}\text { Number of } \\
\text { Impacts }\end{array}$ & Mean & $\begin{array}{l}95 \% \text { CI for } \\
\text { Mean, Low }\end{array}$ & $\begin{array}{c}95 \% \text { CI for } \\
\text { Mean, } \\
\text { High }\end{array}$ & Median & $\begin{array}{l}95 \% \text { CI for } \\
\text { Median, } \\
\text { Low }\end{array}$ & $\begin{array}{l}95 \% \text { CI for } \\
\text { Median, } \\
\text { High }\end{array}$ & StDev & $\begin{array}{c}95 \% \text { CI for } \\
\text { StDev, } \\
\text { Low }\end{array}$ & $\begin{array}{c}95 \% \text { CI for } \\
\text { Stdev, } \\
\text { High }\end{array}$ \\
\hline V11 & 71.00 & $7.00 \mathrm{E}-06$ & $4.00 \mathrm{E}-06$ & $1.10 \mathrm{E}-05$ & $3.00 \mathrm{E}-06$ & $2.00 \mathrm{E}-06$ & $3.00 \mathrm{E}-06$ & $1.50 \mathrm{E}-05$ & $1.30 \mathrm{E}-05$ & $1.80 \mathrm{E}-05$ \\
\hline V12 & 76.00 & $6.00 \mathrm{E}-06$ & $4.00 \mathrm{E}-06$ & $8.00 \mathrm{E}-06$ & $3.00 \mathrm{E}-06$ & $2.00 \mathrm{E}-06$ & $4.00 \mathrm{E}-06$ & $1.00 \mathrm{E}-05$ & $8.00 \mathrm{E}-06$ & $1.10 \mathrm{E}-05$ \\
\hline V13 & 78.00 & $6.00 \mathrm{E}-06$ & $4.00 \mathrm{E}-06$ & $9.00 \mathrm{E}-06$ & $3.00 \mathrm{E}-06$ & $4.00 \mathrm{E}-06$ & $5.00 \mathrm{E}-06$ & $1.10 \mathrm{E}-05$ & $1.00 \mathrm{E}-05$ & $1.30 \mathrm{E}-05$ \\
\hline V21 & 67.00 & $5.00 \mathrm{E}-06$ & $3.00 \mathrm{E}-06$ & $8.00 \mathrm{E}-06$ & $3.00 \mathrm{E}-06$ & $1.00 \mathrm{E}-06$ & $4.00 \mathrm{E}-06$ & $9.00 \mathrm{E}-06$ & $8.00 \mathrm{E}-06$ & $1.10 \mathrm{E}-05$ \\
\hline V22 & 91.00 & $1.60 \mathrm{E}-05$ & $-4.00 \mathrm{E}-06$ & $3.50 \mathrm{E}-05$ & $3.00 \mathrm{E}-06$ & $3.00 \mathrm{E}-06$ & $4.00 \mathrm{E}-06$ & $9.40 \mathrm{E}-05$ & $8.20 \mathrm{E}-05$ & $1.11 \mathrm{E}-04$ \\
\hline V23 & 81.00 & $1.30 \mathrm{E}-05$ & $-2.00 \mathrm{E}-06$ & $2.80 \mathrm{E}-05$ & $3.00 \mathrm{E}-06$ & $2.00 \mathrm{E}-06$ & $4.00 \mathrm{E}-06$ & $6.70 \mathrm{E}-05$ & $5.80 \mathrm{E}-05$ & $7.90 \mathrm{E}-05$ \\
\hline V31 & 87.00 & $8.00 \mathrm{E}-06$ & $3.00 \mathrm{E}-06$ & $1.30 \mathrm{E}-05$ & $3.00 \mathrm{E}-06$ & $2.00 \mathrm{E}-06$ & $3.00 \mathrm{E}-06$ & $2.40 \mathrm{E}-05$ & $2.10 \mathrm{E}-05$ & $2.80 \mathrm{E}-05$ \\
\hline V32 & 101.00 & $5.00 \mathrm{E}-06$ & $3.00 \mathrm{E}-06$ & $7.00 \mathrm{E}-06$ & $2.00 \mathrm{E}-06$ & $2.00 \mathrm{E}-06$ & $3.00 \mathrm{E}-06$ & $1.00 \mathrm{E}-05$ & $9.00 \mathrm{E}-06$ & $1.10 \mathrm{E}-05$ \\
\hline V33 & 81.00 & $1.10 \mathrm{E}-05$ & $-1.00 \mathrm{E}-06$ & $2.40 \mathrm{E}-05$ & $3.00 \mathrm{E}-06$ & $2.00 \mathrm{E}-06$ & $4.00 \mathrm{E}-06$ & $5.60 \mathrm{E}-05$ & $4.80 \mathrm{E}-05$ & $6.60 \mathrm{E}-05$ \\
\hline V1ave & 75.00 & $6.33 \mathrm{E}-06$ & $4.00 \mathrm{E}-06$ & $9.33 \mathrm{E}-06$ & $3.00 \mathrm{E}-06$ & $2.67 \mathrm{E}-06$ & $4.00 \mathrm{E}-06$ & $1.20 \mathrm{E}-05$ & $1.03 \mathrm{E}-05$ & $1.40 \mathrm{E}-05$ \\
\hline V2ave & 79.67 & $1.13 \mathrm{E}-05$ & $-1.00 \mathrm{E}-06$ & $2.37 \mathrm{E}-05$ & $3.00 \mathrm{E}-06$ & $2.00 \mathrm{E}-06$ & $4.00 \mathrm{E}-06$ & $5.67 \mathrm{E}-05$ & $4.93 \mathrm{E}-05$ & $6.70 \mathrm{E}-05$ \\
\hline V3ave & 89.67 & $8.00 \mathrm{E}-06$ & $1.67 \mathrm{E}-06$ & $1.47 \mathrm{E}-05$ & $2.67 \mathrm{E}-06$ & $2.00 \mathrm{E}-06$ & $3.33 \mathrm{E}-06$ & $3.00 \mathrm{E}-05$ & $2.60 \mathrm{E}-05$ & $3.50 \mathrm{E}-05$ \\
\hline Vtotave & 81.44 & $8.56 \mathrm{E}-06$ & $1.56 \mathrm{E}-06$ & $1.59 \mathrm{E}-05$ & $2.89 \mathrm{E}-06$ & $2.22 \mathrm{E}-06$ & $3.78 \mathrm{E}-06$ & $3.29 \mathrm{E}-05$ & $2.86 \mathrm{E}-05$ & $3.87 \mathrm{E}-05$ \\
\hline
\end{tabular}


Port Velocity

\begin{tabular}{|c|c|c|c|c|c|c|c|c|c|c|}
\hline & $\begin{array}{c}\text { Number of } \\
\text { Impacts }\end{array}$ & Mean & $\begin{array}{c}\text { 95\% CI for } \\
\text { Mean, Low }\end{array}$ & $\begin{array}{c}\text { 95\% CI for } \\
\text { Mean, } \\
\text { High }\end{array}$ & Median & $\begin{array}{c}\text { Median, } \\
\text { Low }\end{array}$ & $\begin{array}{c}\text { M5\% CI for } \\
\text { Median, } \\
\text { High }\end{array}$ & $\begin{array}{c}\text { 95\% CI for } \\
\text { StDev, } \\
\text { Low }\end{array}$ & $\begin{array}{c}\text { 95\% CI for } \\
\text { Stdev, } \\
\text { High }\end{array}$ \\
\hline V11 & 71.00 & 18.32 & 15.88 & 20.77 & 17.00 & 13.00 & 19.42 & 10.33 & 8.86 & 12.37 \\
\hline V12 & 76.00 & 20.55 & 18.09 & 23.02 & 19.00 & 17.00 & 23.00 & 10.80 & 9.31 & 12.85 \\
\hline V13 & 78.00 & 18.95 & 16.42 & 21.48 & 17.00 & 15.00 & 19.00 & 11.20 & 0.68 & 13.30 \\
\hline V21 & 67.00 & 19.12 & 16.69 & 21.55 & 19.00 & 15.00 & 23.00 & 9.96 & 8.51 & 12.00 \\
\hline V22 & 91.00 & 17.09 & 15.50 & 18.68 & 17.00 & 15.00 & 19.00 & 7.64 & 6.67 & 8.95 \\
\hline V23 & 81.00 & 20.24 & 18.08 & 22.39 & 21.00 & 17.00 & 23.00 & 9.76 & 8.45 & 11.55 \\
\hline V31 & 87.00 & 21.28 & 19.12 & 23.43 & 21.00 & 17.00 & 25.00 & 10.10 & 8.79 & 11.87 \\
\hline V32 & 101.00 & 20.15 & 18.12 & 22.17 & 19.00 & 17.00 & 21.00 & 10.25 & 9.01 & 11.90 \\
\hline V33 & 81.00 & 19.05 & 16.78 & 21.32 & 17.00 & 15.43 & 19.00 & 10.25 & 8.88 & 12.12 \\
\hline V1ave & 75.00 & 19.28 & 16.80 & 21.75 & 17.67 & 15.00 & 20.47 & 10.78 & 6.28 & 12.84 \\
\hline V2ave & 79.67 & 18.81 & 16.75 & 20.87 & 19.00 & 15.67 & 21.67 & 9.12 & 7.88 & 10.83 \\
\hline V3ave & 89.67 & 20.16 & 18.01 & 22.31 & 19.00 & 16.48 & 21.67 & 10.20 & 8.89 & 11.97 \\
\hline Vtotave & 81.44 & 19.42 & 17.19 & 21.64 & 18.56 & 15.71 & 21.27 & 10.03 & 7.68 & 11.88 \\
\hline
\end{tabular}

Starboard Mass

\begin{tabular}{|c|c|c|c|c|c|c|c|c|c|c|}
\hline Version & $\begin{array}{c}\text { Number of } \\
\text { Impacts }\end{array}$ & Mean & $\begin{array}{l}95 \% \text { CI for } \\
\text { Mean, Low }\end{array}$ & $\begin{array}{l}95 \% \text { CI for } \\
\text { Mean, } \\
\text { High }\end{array}$ & Median & $\begin{array}{l}95 \% \text { CI for } \\
\text { Median, } \\
\text { Low }\end{array}$ & $\begin{array}{l}95 \% \text { CI for } \\
\text { Median, } \\
\text { High }\end{array}$ & StDev & $\begin{array}{c}95 \% \text { CI for } \\
\text { StDev, } \\
\text { Low } \\
\end{array}$ & $\begin{array}{c}95 \% \text { CI for } \\
\text { Stdev, } \\
\text { High }\end{array}$ \\
\hline V11 & 79.00 & $6.00 \mathrm{E}-06$ & $3.00 \mathrm{E}-06$ & $9.00 \mathrm{E}-06$ & $2.00 \mathrm{E}-06$ & $2.00 \mathrm{E}-06$ & $3.00 \mathrm{E}-06$ & $1.30 \mathrm{E}-05$ & $1.10 \mathrm{E}-05$ & $1.50 \mathrm{E}-05$ \\
\hline V12 & 85.00 & $9.00 \mathrm{E}-06$ & $2.00 \mathrm{E}-06$ & $1.60 \mathrm{E}-05$ & $3.00 \mathrm{E}-06$ & $2.00 \mathrm{E}-06$ & $4.00 \mathrm{E}-06$ & $3.40 \mathrm{E}-05$ & $2.90 \mathrm{E}-05$ & $4.00 \mathrm{E}-05$ \\
\hline V13 & 90.00 & $6.00 \mathrm{E}-06$ & $3.00 \mathrm{E}-06$ & $8.00 \mathrm{E}-06$ & $2.00 \mathrm{E}-06$ & $2.00 \mathrm{E}-06$ & $4.00 \mathrm{E}-06$ & $1.20 \mathrm{E}-05$ & $1.10 \mathrm{E}-05$ & $1.40 \mathrm{E}-05$ \\
\hline V21 & 72.00 & $1.00 \mathrm{E}-05$ & $5.00 \mathrm{E}-06$ & $1.40 \mathrm{E}-05$ & $3.00 \mathrm{E}-06$ & $2.00 \mathrm{E}-06$ & $4.00 \mathrm{E}-06$ & $2.00 \mathrm{E}-05$ & $1.70 \mathrm{E}-05$ & $2.40 \mathrm{E}-05$ \\
\hline V22 & 79.00 & $6.00 \mathrm{E}-06$ & $3.00 \mathrm{E}-06$ & $9.00 \mathrm{E}-06$ & $3.00 \mathrm{E}-06$ & $2.00 \mathrm{E}-06$ & $4.00 \mathrm{E}-06$ & $1.20 \mathrm{E}-05$ & $1.00 \mathrm{E}-05$ & $1.40 \mathrm{E}-05$ \\
\hline V23 & 95.00 & $7.00 \mathrm{E}-06$ & $5.00 \mathrm{E}-06$ & $1.00 \mathrm{E}-05$ & $3.00 \mathrm{E}-06$ & $2.00 \mathrm{E}-06$ & $5.00 \mathrm{E}-06$ & $1.30 \mathrm{E}-05$ & $1.10 \mathrm{E}-05$ & $1.50 \mathrm{E}-05$ \\
\hline V32 & 96.00 & $6.00 \mathrm{E}-06$ & $3.00 \mathrm{E}-06$ & $9.00 \mathrm{E}-06$ & $2.00 \mathrm{E}-06$ & $2.00 \mathrm{E}-06$ & $4.00 \mathrm{E}-06$ & $1.50 \mathrm{E}-05$ & $1.30 \mathrm{E}-05$ & $1.80 \mathrm{E}-05$ \\
\hline V33 & 105.00 & $9.00 \mathrm{E}-06$ & $1.00 \mathrm{E}-06$ & $1.60 \mathrm{E}-05$ & $2.00 \mathrm{E}-06$ & $2.00 \mathrm{E}-06$ & $4.00 \mathrm{E}-06$ & $4.00 \mathrm{E}-05$ & $3.50 \mathrm{E}-05$ & $4.60 \mathrm{E}-05$ \\
\hline V1ave & 84.67 & $7.00 \mathrm{E}-06$ & $2.67 \mathrm{E}-06$ & $1.10 \mathrm{E}-05$ & $2.33 \mathrm{E}-06$ & $2.00 \mathrm{E}-06$ & $3.67 \mathrm{E}-06$ & $1.97 \mathrm{E}-05$ & $1.70 \mathrm{E}-05$ & $2.30 \mathrm{E}-05$ \\
\hline V2ave & 82.00 & 7.67E-06 & $4.33 \mathrm{E}-06$ & $1.10 \mathrm{E}-05$ & $3.00 \mathrm{E}-06$ & $2.00 \mathrm{E}-06$ & 4.33E-06 & $1.50 \mathrm{E}-05$ & $1.27 \mathrm{E}-05$ & $1.77 \mathrm{E}-05$ \\
\hline V3ave & 98.00 & 7.33E-06 & $3.00 \mathrm{E}-06$ & $1.17 \mathrm{E}-05$ & $2.67 \mathrm{E}-06$ & $2.33 \mathrm{E}-06$ & $4.67 \mathrm{E}-06$ & $2.23 \mathrm{E}-05$ & $1.93 \mathrm{E}-05$ & $2.57 \mathrm{E}-05$ \\
\hline Vtotave & 88.22 & $7.33 \mathrm{E}-06$ & $3.33 \mathrm{E}-06$ & $1.12 \mathrm{E}-05$ & $2.67 \mathrm{E}-06$ & $2.11 \mathrm{E}-06$ & $4.22 \mathrm{E}-06$ & $1.90 \mathrm{E}-05$ & $1.63 \mathrm{E}-05$ & $2.21 \mathrm{E}-05$ \\
\hline
\end{tabular}

\section{Starboard Velocity}

\begin{tabular}{|c|c|c|c|c|c|c|c|c|c|c|}
\hline & $\begin{array}{c}\text { Number of } \\
\text { Impacts }\end{array}$ & Mean & $\begin{array}{c}\text { 95\% CI for } \\
\text { Mean, Low }\end{array}$ & $\begin{array}{c}\text { 95\% CI for } \\
\text { Mean, } \\
\text { High }\end{array}$ & Median & $\begin{array}{c}\text { Median, } \\
\text { Low }\end{array}$ & $\begin{array}{c}\text { M5\% CI for } \\
\text { Median, } \\
\text { High }\end{array}$ & $\begin{array}{c}\text { 95\% CI for } \\
\text { StDev, } \\
\text { Low }\end{array}$ & $\begin{array}{c}\text { 95\% CI for } \\
\text { Stdev, } \\
\text { High }\end{array}$ \\
\hline V11 & 79.00 & 18.32 & 16.07 & 20.56 & 17.00 & 15.00 & 20.33 & 10.03 & 8.67 & 11.89 \\
\hline V12 & 85.00 & 19.45 & 17.07 & 21.83 & 17.00 & 15.00 & 19.06 & 11.03 & 9.59 & 12.99 \\
\hline V13 & 90.00 & 19.13 & 17.25 & 21.02 & 19.00 & 17.00 & 21.00 & 9.01 & 7.86 & 10.56 \\
\hline V21 & 72.00 & 20.06 & 17.62 & 22.49 & 19.00 & 15.44 & 21.00 & 10.37 & 8.91 & 12.41 \\
\hline V22 & 79.00 & 18.67 & 16.48 & 20.87 & 17.00 & 15.67 & 11.62 & 9.80 & 8.47 & 11.62 \\
\hline V23 & 95.00 & 18.24 & 16.37 & 20.11 & 19.00 & 17.00 & 21.00 & 9.19 & 8.04 & 10.72 \\
\hline V31 & 93.00 & 18.14 & 15.86 & 20.42 & 17.00 & 15.00 & 19.80 & 11.05 & 9.66 & 12.92 \\
\hline V32 & 96.00 & 19.79 & 17.64 & 21.94 & 19.00 & 17.00 & 21.00 & 10.61 & 9.29 & 12.36 \\
\hline V33 & 105.00 & 21.65 & 19.30 & 24.00 & 21.00 & 17.00 & 23.00 & 12.13 & 10.68 & 14.04 \\
\hline V1ave & 84.67 & 18.97 & 16.80 & 21.14 & 17.67 & 15.67 & 20.13 & 10.02 & 8.71 & 11.81 \\
\hline V2ave & 82.00 & 18.99 & 16.82 & 21.16 & 18.33 & 16.04 & 17.87 & 9.78 & 8.47 & 11.58 \\
\hline V3ave & 98.00 & 19.86 & 17.60 & 22.12 & 19.00 & 16.33 & 21.27 & 11.26 & 9.88 & 13.10 \\
\hline Vtotave & 88.22 & 19.27 & 17.07 & 21.47 & 18.33 & 16.01 & 19.76 & 10.36 & 9.02 & 12.17 \\
\hline
\end{tabular}




\section{Zenith Mass}

\begin{tabular}{|c|c|c|c|c|c|c|c|c|c|c|}
\hline Version & $\begin{array}{l}\text { Number of } \\
\text { Impacts }\end{array}$ & Mean & $\begin{array}{l}95 \% \text { CI for } \\
\text { Mean, Low }\end{array}$ & $\begin{array}{c}95 \% \text { CI for } \\
\text { Mean, } \\
\text { High }\end{array}$ & Median & $\begin{array}{l}95 \% \text { CI for } \\
\text { Median, } \\
\text { Low }\end{array}$ & $\begin{array}{l}95 \% \text { CI for } \\
\text { Median, } \\
\text { High }\end{array}$ & StDev & $\begin{array}{c}95 \% \text { CI for } \\
\text { StDev, } \\
\text { Low }\end{array}$ & $\begin{array}{c}95 \% \text { CI for } \\
\text { Stdev, } \\
\text { High }\end{array}$ \\
\hline V11 & 81.00 & $5.00 \mathrm{E}-06$ & $3.00 \mathrm{E}-06$ & $7.00 \mathrm{E}-06$ & $3.00 \mathrm{E}-06$ & $3.00 \mathrm{E}-06$ & $4.00 \mathrm{E}-06$ & $1.00 \mathrm{E}-05$ & $8.00 \mathrm{E}-06$ & $1.10 \mathrm{E}-05$ \\
\hline V12 & 79.00 & $6.00 \mathrm{E}-06$ & $4.00 \mathrm{E}-06$ & $9.00 \mathrm{E}-06$ & $3.00 \mathrm{E}-06$ & $2.00 \mathrm{E}-06$ & $5.00 \mathrm{E}-06$ & $1.00 \mathrm{E}-05$ & $9.00 \mathrm{E}-06$ & $1.20 \mathrm{E}-05$ \\
\hline V13 & 90.00 & $7.00 \mathrm{E}-06$ & $3.00 \mathrm{E}-06$ & $1.00 \mathrm{E}-05$ & $2.00 \mathrm{E}-06$ & $2.00 \mathrm{E}-06$ & $2.00 \mathrm{E}-06$ & $1.60 \mathrm{E}-05$ & $1.40 \mathrm{E}-05$ & $1.80 \mathrm{E}-05$ \\
\hline V21 & 92.00 & $5.00 \mathrm{E}-06$ & $4.00 \mathrm{E}-06$ & $6.00 \mathrm{E}-06$ & $2.00 \mathrm{E}-06$ & $2.00 \mathrm{E}-06$ & $3.00 \mathrm{E}-06$ & $7.00 \mathrm{E}-06$ & $6.00 \mathrm{E}-06$ & $8.00 \mathrm{E}-06$ \\
\hline V22 & 83.00 & $5.00 \mathrm{E}-06$ & $3.00 \mathrm{E}+06$ & $7.00 \mathrm{E}-06$ & $3.00 \mathrm{E}-06$ & $2.00 \mathrm{E}-06$ & $3.00 \mathrm{E}-06$ & $9.00 \mathrm{E}-06$ & $8.00 \mathrm{E}-06$ & $1.00 \mathrm{E}-05$ \\
\hline V23 & 96.00 & $4.00 \mathrm{E}-06$ & $3.00 \mathrm{E}-06$ & $6.00 \mathrm{E}-06$ & $2.00 \mathrm{E}-06$ & $2.00 \mathrm{E}-06$ & $3.00 \mathrm{E}-06$ & $8.00 \mathrm{E}-06$ & $7.00 \mathrm{E}-06$ & $9.00 \mathrm{E}-06$ \\
\hline V31 & 110.00 & $8.00 \mathrm{E}-06$ & $2.00 \mathrm{E}-06$ & $1.30 \mathrm{E}-05$ & $3.00 \mathrm{E}-06$ & $2.00 \mathrm{E}-06$ & $3.00 \mathrm{E}-06$ & $2.90 \mathrm{E}-05$ & $2.60 \mathrm{E}-05$ & $3.40 \mathrm{E}-05$ \\
\hline V32 & 92.00 & $5.00 \mathrm{E}-06$ & $3.00 \mathrm{E}-06$ & $6.00 \mathrm{E}-06$ & $2.00 \mathrm{E}-06$ & $2.00 \mathrm{E}-06$ & $3.00 \mathrm{E}-06$ & $8.00 \mathrm{E}-06$ & $7.00 \mathrm{E}-06$ & $1.00 \mathrm{E}-05$ \\
\hline V33 & 96.00 & $6.00 \mathrm{E}-06$ & $4.00 \mathrm{E}-06$ & $8.00 \mathrm{E}-06$ & $3.00 \mathrm{E}-06$ & $2.00 \mathrm{E}-06$ & $4.00 \mathrm{E}-06$ & $1.10 \mathrm{E}-05$ & $1.00 \mathrm{E}-05$ & $1.30 \mathrm{E}-05$ \\
\hline V1ave & 83.33 & $6.00 \mathrm{E}-06$ & $3.33 \mathrm{E}-06$ & $8.67 \mathrm{E}-06$ & $2.67 \mathrm{E}-06$ & $2.33 \mathrm{E}-06$ & $3.67 \mathrm{E}-06$ & $1.20 \mathrm{E}-05$ & $1.03 \mathrm{E}-05$ & $1.37 \mathrm{E}-05$ \\
\hline V2ave & 90.33 & $4.67 \mathrm{E}-06$ & $1.00 \mathrm{E}+06$ & $6.33 \mathrm{E}-06$ & $2.33 \mathrm{E}-06$ & $2.00 \mathrm{E}-06$ & $3.00 \mathrm{E}-06$ & $8.00 \mathrm{E}-06$ & $7.00 \mathrm{E}-06$ & $9.00 \mathrm{E}-06$ \\
\hline V3ave & 99.33 & $6.33 \mathrm{E}-06$ & $3.00 \mathrm{E}-06$ & $9.00 \mathrm{E}-06$ & $2.67 \mathrm{E}-06$ & $2.00 \mathrm{E}-06$ & 3.33E-06 & $1.60 \mathrm{E}-05$ & $1.43 \mathrm{E}-05$ & $1.90 \mathrm{E}-05$ \\
\hline Vtotave & 91.00 & $5.67 \mathrm{E}-06$ & $3.33 \mathrm{E}+05$ & $8.00 \mathrm{E}-06$ & $2.56 \mathrm{E}-06$ & $2.11 \mathrm{E}-06$ & 3.33E-06 & $1.20 \mathrm{E}-05$ & $1.06 \mathrm{E}-05$ & $1.39 \mathrm{E}-05$ \\
\hline
\end{tabular}

\section{Zenith Velocity}

\begin{tabular}{|c|c|c|c|c|c|c|c|c|c|c|}
\hline Version & $\begin{array}{c}\text { Number of } \\
\text { Impacts }\end{array}$ & Mean & $\begin{array}{c}\text { 95\% CI for } \\
\text { Mean, Low }\end{array}$ & $\begin{array}{c}\text { 95\% CI for } \\
\text { Mean, } \\
\text { High }\end{array}$ & Median & $\begin{array}{c}\text { Median, } \\
\text { Low }\end{array}$ & $\begin{array}{c}\text { M5\% CI for } \\
\text { Median, } \\
\text { High }\end{array}$ & $\begin{array}{c}\text { 95\% CI for } \\
\text { StDev, } \\
\text { Low }\end{array}$ & $\begin{array}{c}\text { 95\% CI for } \\
\text { Stdev, } \\
\text { High }\end{array}$ \\
\hline V11 & 81.00 & 23.79 & 22.10 & 25.48 & 25.00 & 21.00 & 27.00 & 7.64 & 6.62 & 9.04 \\
\hline V12 & 79.00 & 24.32 & 22.37 & 26.26 & 23.00 & 21.00 & 27.00 & 8.69 & 7.51 & 10.30 \\
\hline V13 & 90.00 & 24.53 & 22.77 & 26.31 & 23.00 & 21.00 & 27.00 & 8.49 & 7.40 & 9.95 \\
\hline V21 & 92.00 & 23.20 & 21.22 & 25.17 & 25.00 & 21.24 & 25.00 & 9.54 & 8.33 & 11.16 \\
\hline V22 & 83.00 & 24.69 & 22.51 & 26.87 & 25.00 & 21.17 & 27.00 & 9.98 & 8.66 & 11.78 \\
\hline V23 & 96.00 & 24.25 & 22.34 & 26.17 & 25.00 & 21.00 & 29.00 & 9.45 & 8.28 & 11.01 \\
\hline V31 & 110.00 & 22.46 & 21.00 & 23.91 & 22.00 & 19.00 & 25.00 & 7.69 & 6.79 & 8.87 \\
\hline V32 & 92.00 & 23.00 & 21.21 & 24.84 & 22.00 & 21.00 & 25.00 & 8.76 & 7.65 & 10.25 \\
\hline V33 & 96.00 & 24.27 & 22.19 & 26.35 & 23.00 & 19.00 & 27.00 & 10.27 & 9.00 & 11.97 \\
\hline V1ave & 83.33 & 24.21 & 22.41 & 26.02 & 23.67 & 21.00 & 27.00 & 8.27 & 7.18 & 9.76 \\
\hline V2ave & 90.33 & 24.04 & 22.02 & 26.07 & 25.00 & 21.14 & 27.00 & 9.66 & 8.42 & 11.32 \\
\hline V3ave & 99.33 & 23.24 & 21.47 & 25.03 & 22.33 & 19.67 & 25.67 & 8.91 & 7.81 & 10.36 \\
\hline Vtotave & 91.00 & 23.83 & 21.97 & 25.71 & 23.67 & 20.60 & 26.56 & 8.95 & 7.80 & 10.48 \\
\hline
\end{tabular}

Nadir Mass

\begin{tabular}{|c|c|c|c|c|c|c|c|c|c|c|}
\hline Version & $\begin{array}{c}\text { Number of } \\
\text { Impacts }\end{array}$ & Mean & $\begin{array}{l}95 \% \text { CI for } \\
\text { Mean, Low }\end{array}$ & $\begin{array}{c}95 \% \text { CI for } \\
\text { Mean, } \\
\text { High }\end{array}$ & Median & $\begin{array}{l}\text { 95\% CI for } \\
\text { Median, } \\
\text { Low }\end{array}$ & $\begin{array}{l}95 \% \text { CI for } \\
\text { Median, } \\
\text { High }\end{array}$ & StDev & $\begin{array}{c}95 \% \text { CI for } \\
\text { StDev, } \\
\text { Low }\end{array}$ & $\begin{array}{c}95 \% \text { CI for } \\
\text { Stdev, } \\
\text { High }\end{array}$ \\
\hline V11 & 198.00 & $9.00 \mathrm{E}-06$ & $5.00 \mathrm{E}-06$ & $1.30 \mathrm{E}-05$ & $3.00 \mathrm{E}-06$ & $2.00 \mathrm{E}-06$ & $3.00 \mathrm{E}-06$ & $2.60 \mathrm{E}-05$ & $2.40 \mathrm{E}-05$ & $2.90 \mathrm{E}-05$ \\
\hline V12 & 194.00 & $7.00 \mathrm{E}-06$ & $4.00 \mathrm{E}-06$ & $1.00 \mathrm{E}-05$ & $3.00 \mathrm{E}-06$ & $2.00 \mathrm{E}-06$ & $4.00 \mathrm{E}-06$ & $2.30 \mathrm{E}-05$ & $2.10 \mathrm{E}-05$ & $2.60 \mathrm{E}-05$ \\
\hline V13 & 176.00 & $6.00 \mathrm{E}-06$ & $4.00 \mathrm{E}-06$ & $8.00 \mathrm{E}-06$ & $2.00 \mathrm{E}-06$ & $2.00 \mathrm{E}-06$ & $3.00 \mathrm{E}-06$ & $1.50 \mathrm{E}-05$ & $1.30 \mathrm{E}-05$ & $1.60 \mathrm{E}-05$ \\
\hline V21 & 198.00 & $6.00 \mathrm{E}-06$ & $3.00 \mathrm{E}-06$ & $9.00 \mathrm{E}-06$ & $2.00 \mathrm{E}-06$ & $2.00 \mathrm{E}-06$ & $3.00 \mathrm{E}-06$ & $2.20 \mathrm{E}-05$ & $2.00 \mathrm{E}-05$ & $2.40 \mathrm{E}-05$ \\
\hline V22 & 169.00 & $8.00 \mathrm{E}-06$ & $4.00 \mathrm{E}-06$ & $1.20 \mathrm{E}-05$ & $3.00 \mathrm{E}-06$ & $2.00 \mathrm{E}-06$ & $4.00 \mathrm{E}-06$ & $2.60 \mathrm{E}-05$ & $2.40 \mathrm{E}-05$ & $2.90 \mathrm{E}-05$ \\
\hline V23 & 191.00 & $9.00 \mathrm{E}-06$ & $4.00 \mathrm{E}-06$ & $1.40 \mathrm{E}-05$ & $3.00 \mathrm{E}-06$ & $2.00 \mathrm{E}-06$ & $3.00 \mathrm{E}-06$ & $3.70 \mathrm{E}-05$ & $3.40 \mathrm{E}-05$ & $4.10 \mathrm{E}-05$ \\
\hline V31 & 147.00 & $5.00 \mathrm{E}-06$ & $4.00 \mathrm{E}-06$ & $7.00 \mathrm{E}-06$ & $2.00 \mathrm{E}-06$ & $2.00 \mathrm{E}-06$ & $3.00 \mathrm{E}-06$ & $9.00 \mathrm{E}-06$ & $8.00 \mathrm{E}-06$ & $1.00 \mathrm{E}-05$ \\
\hline V32 & 184.00 & $9.00 \mathrm{E}-06$ & $3.00 \mathrm{E}-06$ & $1.40 \mathrm{E}-05$ & $2.00 \mathrm{E}-06$ & $2.00 \mathrm{E}-06$ & $3.00 \mathrm{E}-06$ & $3.90 \mathrm{E}-05$ & $3.50 \mathrm{E}-05$ & $4.30 \mathrm{E}-05$ \\
\hline V33 & 186.00 & $8.00 \mathrm{E}-06$ & $2.00 \mathrm{E}-06$ & $1.40 \mathrm{E}-05$ & $2.00 \mathrm{E}-06$ & $2.00 \mathrm{E}-06$ & $3.00 \mathrm{E}-06$ & $4.50 \mathrm{E}-05$ & $4.10 \mathrm{E}-05$ & $5.00 \mathrm{E}-05$ \\
\hline V1ave & 189.33 & 7.33E-06 & $4.33 \mathrm{E}-06$ & $1.03 \mathrm{E}-05$ & $2.67 \mathrm{E}-06$ & $2.00 \mathrm{E}-06$ & $3.33 \mathrm{E}-06$ & $2.13 \mathrm{E}-05$ & $1.93 \mathrm{E}-05$ & $2.37 \mathrm{E}-05$ \\
\hline V2ave & 186.00 & 7.67E-06 & $3.67 \mathrm{E}-06$ & $1.17 \mathrm{E}-05$ & $2.67 \mathrm{E}-06$ & $2.00 \mathrm{E}-06$ & $3.33 \mathrm{E}-06$ & $2.83 \mathrm{E}-05$ & $2.60 \mathrm{E}-05$ & $3.13 \mathrm{E}-05$ \\
\hline V3ave & 172.33 & 7.33E-06 & $3.00 \mathrm{E}-06$ & $1.17 \mathrm{E}-05$ & $2.00 \mathrm{E}-06$ & $2.00 \mathrm{E}-06$ & $3.00 \mathrm{E}-06$ & $3.10 \mathrm{E}-05$ & $2.80 \mathrm{E}-05$ & $3.43 \mathrm{E}-05$ \\
\hline Vtotave & 182.56 & $7.44 \mathrm{E}-06$ & $3.67 \mathrm{E}-06$ & $1.12 \mathrm{E}-05$ & $2.44 \mathrm{E}-06$ & $2.00 \mathrm{E}-06$ & $3.22 \mathrm{E}-06$ & $2.69 \mathrm{E}-05$ & $2.44 \mathrm{E}-05$ & $2.98 \mathrm{E}-05$ \\
\hline
\end{tabular}


Nadir Velocity

\begin{tabular}{|c|c|c|c|c|c|c|c|c|c|c|}
\hline Version & $\begin{array}{l}\text { Number of } \\
\text { Impacts }\end{array}$ & Mean & $\begin{array}{l}95 \% \text { CI for } \\
\text { Mean, Low }\end{array}$ & $\begin{array}{c}95 \% \text { CI for } \\
\text { Mean, } \\
\text { High }\end{array}$ & Median & $\begin{array}{l}95 \% \text { CI for } \\
\text { Median, } \\
\text { Low }\end{array}$ & $\begin{array}{l}95 \% \text { CI for } \\
\text { Median, } \\
\text { High }\end{array}$ & StDev & $\begin{array}{c}95 \% \text { CI for } \\
\text { StDev, } \\
\text { Low }\end{array}$ & $\begin{array}{c}95 \% \text { CI for } \\
\text { Stdev, } \\
\text { High }\end{array}$ \\
\hline V11 & 198.00 & 18.49 & 17.06 & 19.91 & 19.00 & 16.48 & 21.00 & 10.14 & 9.23 & 11.25 \\
\hline V12 & 194.00 & 19.53 & 17.98 & 21.07 & 19.00 & 17.00 & 21.00 & 10.91 & 9.92 & 12.12 \\
\hline V13 & 176.00 & 18.94 & 17.41 & 20.48 & 19.00 & 15.00 & 21.00 & 10.30 & 9.32 & 11.50 \\
\hline V21 & 198.00 & 20.39 & 18.99 & 21.80 & 21.00 & 19.00 & 23.00 & 10.00 & 9.10 & 11.09 \\
\hline V22 & 169.00 & 18.88 & 17.31 & 20.45 & 19.00 & 17.00 & 21.00 & 10.33 & 9.34 & 11.57 \\
\hline V23 & 191.00 & 19.44 & 17.92 & 20.96 & 19.00 & 17.00 & 21.00 & 10.68 & 9.71 & 11.87 \\
\hline V32 & 184.00 & 19.49 & 17.85 & 21.13 & 19.00 & 17.00 & 21.00 & 11.30 & 10.25 & 12.59 \\
\hline V33 & 186.00 & 18.83 & 17.36 & 20.30 & 19.00 & 17.00 & 21.00 & 10.18 & 9.24 & 11.33 \\
\hline V1ave & 189.33 & 18.98 & 17.49 & 20.48 & 19.00 & 16.16 & 21.00 & 10.45 & 9.49 & 11.62 \\
\hline V2ave & 186.00 & 19.57 & 18.07 & 21.07 & 19.67 & 17.67 & 21.67 & 10.34 & 9.38 & 11.51 \\
\hline V3ave & 172.33 & 19.39 & 17.78 & 21.01 & 19.00 & 17.00 & 21.67 & 10.70 & 9.67 & 11.97 \\
\hline Vtotave & 182.56 & 19.32 & 17.78 & 20.85 & 19.22 & 16.94 & 21.44 & 10.49 & 9.51 & 11.70 \\
\hline
\end{tabular}

Earth Mass

\begin{tabular}{|c|c|c|c|c|c|c|c|c|c|c|}
\hline Version & $\begin{array}{l}\text { Number of } \\
\text { Impacts }\end{array}$ & Mean & $\begin{array}{l}95 \% \text { CI for } \\
\text { Mean, Low }\end{array}$ & $\begin{array}{c}95 \% \text { CI for } \\
\text { Mean, } \\
\text { High }\end{array}$ & Median & $\begin{array}{l}95 \% \text { CI for } \\
\text { Median, } \\
\text { Low }\end{array}$ & $\begin{array}{l}95 \% \text { CI for } \\
\text { Median, } \\
\text { High }\end{array}$ & StDev & $\begin{array}{c}95 \% \text { CI for } \\
\text { StDev, } \\
\text { Low }\end{array}$ & $\begin{array}{c}95 \% \text { CI for } \\
\text { Stdev, } \\
\text { High }\end{array}$ \\
\hline V11 & 69.00 & $4.00 \mathrm{E}-06$ & $3.00 \mathrm{E}-06$ & $6.00 \mathrm{E}-06$ & $2.00 \mathrm{E}-06$ & $2.00 \mathrm{E}-06$ & $4.00 \mathrm{E}-06$ & $5.00 \mathrm{E}-06$ & $5.00 \mathrm{E}-06$ & $7.00 \mathrm{E}-06$ \\
\hline V12 & 68.00 & $7.00 \mathrm{E}-06$ & $3.00 \mathrm{E}-06$ & $1.10 \mathrm{E}-05$ & $3.00 \mathrm{E}-06$ & $2.00 \mathrm{E}-06$ & $4.00 \mathrm{E}-06$ & $1.50 \mathrm{E}-05$ & $1.30 \mathrm{E}-05$ & $1.80 \mathrm{E}-05$ \\
\hline V13 & 73.00 & $5.00 \mathrm{E}-06$ & $4.00 \mathrm{E}-06$ & $7.00 \mathrm{E}-06$ & $3.00 \mathrm{E}-06$ & $2.00 \mathrm{E}-06$ & $4.00 \mathrm{E}-06$ & $7.00 \mathrm{E}-06$ & $6.00 \mathrm{E}-06$ & $9.00 \mathrm{E}-06$ \\
\hline V21 & 59.00 & $4.00 \mathrm{E}-06$ & $3.00 \mathrm{E}-06$ & $4.00 \mathrm{E}-06$ & $2.00 \mathrm{E}-06$ & $2.00 \mathrm{E}-06$ & $4.00 \mathrm{E}-06$ & $3.00 \mathrm{E}-06$ & $2.00 \mathrm{E}-06$ & $3.00 \mathrm{E}-06$ \\
\hline V22 & 80.00 & $5.00 \mathrm{E}-06$ & $3.00 \mathrm{E}-06$ & $7.00 \mathrm{E}-06$ & $3.00 \mathrm{E}-06$ & $2.00 \mathrm{E}-06$ & $3.00 \mathrm{E}-06$ & $9.00 \mathrm{E}-06$ & $8.00 \mathrm{E}-06$ & $1.10 \mathrm{E}-05$ \\
\hline $\mathrm{V} 23$ & 75.00 & $1.00 \mathrm{E}-05$ & $4.00 \mathrm{E}-06$ & $1.60 \mathrm{E}-05$ & $3.00 \mathrm{E}-06$ & $2.00 \mathrm{E}-06$ & $4.00 \mathrm{E}-06$ & $2.60 \mathrm{E}-05$ & $2.20 \mathrm{E}-05$ & $3.10 \mathrm{E}-05$ \\
\hline V32 & 45.00 & $5.00 \mathrm{E}-06$ & $3.00 \mathrm{E}-06$ & $8.00 \mathrm{E}-06$ & $3.00 \mathrm{E}-06$ & $2.00 \mathrm{E}-06$ & $5.00 \mathrm{E}-06$ & $8.00 \mathrm{E}-06$ & $7.00 \mathrm{E}-06$ & $1.00 \mathrm{E}-05$ \\
\hline V33 & 53.00 & $9.00 \mathrm{E}-06$ & $3.00 \mathrm{E}-06$ & $1.50 \mathrm{E}-05$ & $3.00 \mathrm{E}-06$ & $3.00 \mathrm{E}-06$ & $4.00 \mathrm{E}-06$ & $2.10 \mathrm{E}-05$ & $1.80 \mathrm{E}-05$ & $2.60 \mathrm{E}-05$ \\
\hline V1ave & 70.00 & $5.33 \mathrm{E}-06$ & $3.33 \mathrm{E}-06$ & $8.00 \mathrm{E}-06$ & $2.67 \mathrm{E}-06$ & $2.00 \mathrm{E}-06$ & $4.00 \mathrm{E}-06$ & $9.00 \mathrm{E}-06$ & $8.00 \mathrm{E}-06$ & $1.13 \mathrm{E}-05$ \\
\hline V2ave & 71.33 & $6.33 \mathrm{E}-06$ & $3.33 \mathrm{E}-06$ & $9.00 \mathrm{E}-06$ & $2.67 \mathrm{E}-06$ & $2.00 \mathrm{E}-06$ & $3.67 \mathrm{E}-06$ & $1.27 \mathrm{E}-05$ & $1.07 \mathrm{E}-05$ & $1.50 \mathrm{E}-05$ \\
\hline V3ave & 48.33 & $6.00 \mathrm{E}-06$ & $2.67 \mathrm{E}-06$ & $9.67 \mathrm{E}-06$ & $2.67 \mathrm{E}-06$ & $2.00 \mathrm{E}-06$ & 3.67E-06 & $1.17 \mathrm{E}-05$ & $1.00 \mathrm{E}-05$ & $1.47 \mathrm{E}-05$ \\
\hline Vtotave & 63.22 & $5.89 \mathrm{E}-06$ & $3.11 \mathrm{E}-06$ & 8.89E-06 & $2.67 \mathrm{E}-06$ & $2.00 \mathrm{E}-06$ & $3.78 \mathrm{E}-06$ & $1.11 \mathrm{E}-05$ & $9.56 \mathrm{E}-06$ & $1.37 \mathrm{E}-05$ \\
\hline
\end{tabular}

Earth Velocity

\begin{tabular}{|c|c|c|c|c|c|c|c|c|c|c|}
\hline Version & $\begin{array}{c}\text { Number of } \\
\text { Impacts }\end{array}$ & Mean & $\begin{array}{c}\text { 95\% CI for } \\
\text { Mean, Low }\end{array}$ & $\begin{array}{c}\text { 95\% CI for } \\
\text { Mean, } \\
\text { High }\end{array}$ & Median & $\begin{array}{c}\text { Median, } \\
\text { Low }\end{array}$ & $\begin{array}{c}\text { M5\% CI for } \\
\text { Median, } \\
\text { High }\end{array}$ & $\begin{array}{c}\text { 95\% CI for } \\
\text { StDev, } \\
\text { Low }\end{array}$ & $\begin{array}{c}\text { 95\% CI for } \\
\text { Stdev, } \\
\text { High }\end{array}$ \\
\hline V11 & 69.00 & 22.88 & 20.62 & 25.15 & 21.00 & 19.00 & 25.00 & 9.43 & 8.08 & 11.33 \\
\hline V12 & 69.00 & 22.56 & 20.24 & 24.88 & 23.00 & 19.00 & 25.00 & 9.58 & 8.17 & 11.53 \\
\hline V13 & 73.00 & 23.52 & 21.42 & 25.62 & 23.00 & 19.00 & 25.00 & 8.99 & 7.74 & 10.75 \\
\hline V21 & 59.00 & 23.27 & 21.09 & 25.45 & 23.00 & 19.00 & 25.00 & 8.37 & 7.08 & 10.22 \\
\hline V22 & 80.00 & 23.18 & 21.15 & 25.20 & 23.00 & 19.00 & 27.00 & 9.09 & 7.87 & 10.77 \\
\hline V23 & 75.00 & 24.84 & 22.62 & 27.06 & 25.00 & 21.00 & 27.86 & 9.66 & 8.32 & 11.51 \\
\hline V31 & 47.00 & 23.17 & 20.54 & 25.80 & 23.00 & 17.00 & 25.00 & 8.95 & 7.44 & 11.24 \\
\hline V32 & 45.00 & 24.02 & 20.72 & 27.33 & 23.00 & 18.07 & 27.00 & 10.99 & 9.10 & 13.89 \\
\hline V33 & 53.00 & 22.77 & 20.32 & 25.23 & 25.00 & 19.00 & 25.20 & 8.90 & 7.47 & 11.01 \\
\hline V1ave & 70.33 & 22.99 & 20.76 & 25.22 & 22.33 & 19.00 & 25.00 & 9.34 & 7.99 & 11.20 \\
\hline V2ave & 71.33 & 23.76 & 21.62 & 25.90 & 23.67 & 19.67 & 26.62 & 9.04 & 7.76 & 10.83 \\
\hline V3ave & 48.33 & 23.32 & 20.53 & 26.12 & 23.67 & 18.02 & 25.73 & 9.61 & 8.00 & 12.05 \\
\hline Vtotave & 63.33 & 23.36 & 20.97 & 25.75 & 23.22 & 18.90 & 25.78 & 9.33 & 7.92 & 11.36 \\
\hline
\end{tabular}


Sun Mass

\begin{tabular}{|c|c|c|c|c|c|c|c|c|c|c|}
\hline Version & $\begin{array}{l}\text { Number of } \\
\text { Impacts }\end{array}$ & Mean & $\begin{array}{l}95 \% \text { CI for } \\
\text { Mean, Low }\end{array}$ & $\begin{array}{c}95 \% \text { CI for } \\
\text { Mean, } \\
\text { High }\end{array}$ & Median & $\begin{array}{l}95 \% \text { CI for } \\
\text { Median, } \\
\text { Low }\end{array}$ & $\begin{array}{l}95 \% \text { CI for } \\
\text { Median, } \\
\text { High }\end{array}$ & StDev & $\begin{array}{c}95 \% \text { CI for } \\
\text { StDev, } \\
\text { Low }\end{array}$ & $\begin{array}{c}95 \% \text { CI for } \\
\text { Stdev, } \\
\text { High }\end{array}$ \\
\hline V11 & 95.00 & $6.00 \mathrm{E}-06$ & $4.00 \mathrm{E}-06$ & $8.00 \mathrm{E}-06$ & $3.00 \mathrm{E}-06$ & $2.00 \mathrm{E}-06$ & $5.00 \mathrm{E}-06$ & $1.00 \mathrm{E}-05$ & $9.00 \mathrm{E}-06$ & $1.20 \mathrm{E}-05$ \\
\hline V12 & 91.00 & $7.00 \mathrm{E}-06$ & $4.00 \mathrm{E}-06$ & $1.10 \mathrm{E}-05$ & $2.00 \mathrm{E}-06$ & $1.00 \mathrm{E}-06$ & $3.00 \mathrm{E}-06$ & $1.70 \mathrm{E}-05$ & $1.50 \mathrm{E}-05$ & $2.00 \mathrm{E}-05$ \\
\hline V13 & 71.00 & $6.00 \mathrm{E}-06$ & $3.00 \mathrm{E}-06$ & $8.00 \mathrm{E}-06$ & $3.00 \mathrm{E}-06$ & $2.00 \mathrm{E}-06$ & $4.00 \mathrm{E}-06$ & $1.10 \mathrm{E}-05$ & $1.00 \mathrm{E}-05$ & $1.40 \mathrm{E}-05$ \\
\hline V21 & 85.00 & $7.00 \mathrm{E}-06$ & $4.00 \mathrm{E}-06$ & $9.00 \mathrm{E}-06$ & $3.00 \mathrm{E}-06$ & $2.00 \mathrm{E}-06$ & $4.00 \mathrm{E}-06$ & $1.40 \mathrm{E}-05$ & $1.20 \mathrm{E}-05$ & $1.60 \mathrm{E}-05$ \\
\hline V22 & 85.00 & $9.00 \mathrm{E}-06$ & $5.00 \mathrm{E}-06$ & $1.30 \mathrm{E}-05$ & $3.00 \mathrm{E}-06$ & $2.00 \mathrm{E}-06$ & $4.00 \mathrm{E}-06$ & $1.80 \mathrm{E}-05$ & $1.60 \mathrm{E}-05$ & $2.20 \mathrm{E}-05$ \\
\hline V23 & 86.00 & $1.50 \mathrm{E}-05$ & $-6.00 \mathrm{E}-06$ & $3.50 \mathrm{E}-05$ & $3.00 \mathrm{E}-06$ & $2.00 \mathrm{E}-06$ & $4.00 \mathrm{E}-06$ & $9.70 \mathrm{E}-05$ & $8.40 \mathrm{E}-05$ & $1.14 \mathrm{E}-04$ \\
\hline V31 & 93.00 & $4.00 \mathrm{E}-06$ & $3.00 \mathrm{E}-06$ & $5.00 \mathrm{E}-06$ & $2.00 \mathrm{E}-06$ & $2.00 \mathrm{E}-06$ & $3.00 \mathrm{E}-06$ & $7.00 \mathrm{E}-06$ & $6.00 \mathrm{E}-06$ & $8.00 \mathrm{E}-06$ \\
\hline V32 & 84.00 & $4.00 \mathrm{E}-06$ & $3.00 \mathrm{E}-06$ & $5.00 \mathrm{E}-06$ & $3.00 \mathrm{E}-06$ & $2.00 \mathrm{E}-06$ & $3.00 \mathrm{E}-06$ & $4.00 \mathrm{E}-06$ & $4.00 \mathrm{E}-06$ & $5.00 \mathrm{E}-06$ \\
\hline V33 & 84.00 & $7.00 \mathrm{E}-06$ & $4.00 \mathrm{E}-06$ & $1.00 \mathrm{E}-05$ & $3.00 \mathrm{E}-06$ & $2.00 \mathrm{E}-06$ & $4.00 \mathrm{E}-06$ & $1.40 \mathrm{E}-05$ & $1.20 \mathrm{E}-05$ & $1.60 \mathrm{E}-05$ \\
\hline V1ave & 85.67 & $6.33 \mathrm{E}-06$ & $3.67 \mathrm{E}-06$ & $9.00 \mathrm{E}-06$ & $2.67 \mathrm{E}-06$ & $1.67 \mathrm{E}-06$ & $4.00 \mathrm{E}-06$ & $1.27 \mathrm{E}-05$ & $1.13 \mathrm{E}-05$ & $1.53 \mathrm{E}-05$ \\
\hline V2ave & 85.33 & $1.03 \mathrm{E}-05$ & $1.00 \mathrm{E}-06$ & $1.90 \mathrm{E}-05$ & $3.00 \mathrm{E}-06$ & $2.00 \mathrm{E}-06$ & $4.00 \mathrm{E}-06$ & $4.30 \mathrm{E}-05$ & $3.73 \mathrm{E}-05$ & $5.07 \mathrm{E}-05$ \\
\hline V3ave & 87.00 & $5.00 \mathrm{E}-06$ & $3.33 \mathrm{E}-06$ & $6.67 \mathrm{E}-06$ & $2.67 \mathrm{E}-06$ & $2.00 \mathrm{E}-06$ & 3.33E-06 & $8.33 \mathrm{E}-06$ & 7.33E-06 & $9.67 \mathrm{E}-06$ \\
\hline Vtotave & 86.00 & 7.22E-06 & $2.67 \mathrm{E}-06$ & $1.16 \mathrm{E}-05$ & $2.78 \mathrm{E}-06$ & $1.89 \mathrm{E}-06$ & $3.78 \mathrm{E}-06$ & $2.13 \mathrm{E}-05$ & $1.87 \mathrm{E}-05$ & $2.52 \mathrm{E}-05$ \\
\hline
\end{tabular}

Sun Velocity

\begin{tabular}{|c|c|c|c|c|c|c|c|c|c|c|}
\hline Version & $\begin{array}{c}\text { Number of } \\
\text { Impacts }\end{array}$ & Mean & $\begin{array}{c}\text { 95\% CI for } \\
\text { Mean, Low }\end{array}$ & $\begin{array}{c}\text { 95\% CI for } \\
\text { Mean, } \\
\text { High }\end{array}$ & Median & $\begin{array}{c}\text { Median, } \\
\text { Low }\end{array}$ & $\begin{array}{c}\text { M5\% CI for } \\
\text { Median, } \\
\text { High }\end{array}$ & $\begin{array}{c}\text { 95\% CI for } \\
\text { StDev, } \\
\text { Low }\end{array}$ & $\begin{array}{c}\text { 95\% CI for } \\
\text { Stdev, } \\
\text { High }\end{array}$ \\
\hline V11 & 95.00 & 23.04 & 21.24 & 24.85 & 23.00 & 21.00 & 25.00 & 8.87 & 7.77 & 10.35 \\
\hline V12 & 91.00 & 21.57 & 19.78 & 23.37 & 21.00 & 19.00 & 23.00 & 8.63 & 7.53 & 10.10 \\
\hline V13 & 71.00 & 23.96 & 21.61 & 26.30 & 25.00 & 19.00 & 27.42 & 9.91 & 8.50 & 11.87 \\
\hline V21 & 85.00 & 23.78 & 21.91 & 25.65 & 25.00 & 22.95 & 25.06 & 8.66 & 7.53 & 10.21 \\
\hline V22 & 85.00 & 22.55 & 20.68 & 24.42 & 21.00 & 19.00 & 25.00 & 8.68 & 7.54 & 10.22 \\
\hline V23 & 86.00 & 21.98 & 20.13 & 23.83 & 22.00 & 19.00 & 24.07 & 8.63 & 7.51 & 10.16 \\
\hline V31 & 93.00 & 22.72 & 20.91 & 24.53 & 23.00 & 21.00 & 25.00 & 8.78 & 7.67 & 10.26 \\
\hline V32 & 84.00 & 22.95 & 21.14 & 24.77 & 21.00 & 21.00 & 25.00 & 8.35 & 7.25 & 9.85 \\
\hline V33 & 84.00 & 22.43 & 20.29 & 24.57 & 21.00 & 19.00 & 23.85 & 9.86 & 8.57 & 11.63 \\
\hline V1ave & 85.67 & 22.86 & 20.87 & 24.84 & 23.00 & 19.67 & 25.14 & 9.14 & 7.93 & 10.77 \\
\hline V2ave & 85.33 & 22.77 & 20.91 & 24.63 & 22.67 & 20.32 & 24.71 & 8.66 & 7.52 & 10.19 \\
\hline V3ave & 87.00 & 22.70 & 20.78 & 24.62 & 21.67 & 20.33 & 24.62 & 9.00 & 7.83 & 10.58 \\
\hline Vtotave & 86.00 & 22.78 & 20.85 & 24.70 & 22.44 & 20.11 & 24.82 & 8.93 & 7.76 & 10.52 \\
\hline
\end{tabular}

Antisun Mass

\begin{tabular}{|c|c|c|c|c|c|c|c|c|c|c|}
\hline Version & $\begin{array}{l}\text { Number of } \\
\text { Impacts }\end{array}$ & Mean & $\begin{array}{l}95 \% \text { CI for } \\
\text { Mean, Low }\end{array}$ & $\begin{array}{l}95 \% \text { CI for } \\
\text { Mean, } \\
\text { High }\end{array}$ & Median & $\begin{array}{l}95 \% \text { CI for } \\
\text { Median, } \\
\text { Low }\end{array}$ & $\begin{array}{l}\text { 95\% CI for } \\
\text { Median, } \\
\text { High }\end{array}$ & StDev & $\begin{array}{c}95 \% \text { CI for } \\
\text { StDev, } \\
\text { Low }\end{array}$ & $\begin{array}{c}95 \% \text { CI for } \\
\text { Stdev, } \\
\text { High }\end{array}$ \\
\hline V11 & 169.00 & $7.00 \mathrm{E}-06$ & $5.00 \mathrm{E}-06$ & $9.00 \mathrm{E}-06$ & $3.00 \mathrm{E}-06$ & $2.00 \mathrm{E}-06$ & $4.00 \mathrm{E}-06$ & $1.50 \mathrm{E}-05$ & $1.40 \mathrm{E}-05$ & $1.70 \mathrm{E}-05$ \\
\hline V12 & 177.00 & $1.10 \mathrm{E}-05$ & $3.00 \mathrm{E}-06$ & $1.90 \mathrm{E}-05$ & $3.00 \mathrm{E}-06$ & $2.00 \mathrm{E}-06$ & $4.00 \mathrm{E}-06$ & $5.40 \mathrm{E}-05$ & $4.90 \mathrm{E}-05$ & $6.00 \mathrm{E}-05$ \\
\hline V13 & 205.00 & $1.30 \mathrm{E}-05$ & $4.00 \mathrm{E}-06$ & $2.30 \mathrm{E}-05$ & $3.00 \mathrm{E}-06$ & $2.00 \mathrm{E}-06$ & $3.00 \mathrm{E}-06$ & $6.90 \mathrm{E}-05$ & $6.30 \mathrm{E}-05$ & $7.60 \mathrm{E}-05$ \\
\hline V21 & 181.00 & $4.00 \mathrm{E}-06$ & $3.00 \mathrm{E}-06$ & $5.00 \mathrm{E}-06$ & $3.00 \mathrm{E}-06$ & $2.00 \mathrm{E}-06$ & $3.00 \mathrm{E}-06$ & $7.00 \mathrm{E}-06$ & $6.00 \mathrm{E}-06$ & $8.00 \mathrm{E}-06$ \\
\hline V22 & 202.00 & $6.00 \mathrm{E}-06$ & $5.00 \mathrm{E}-06$ & $7.00 \mathrm{E}-06$ & $3.00 \mathrm{E}-06$ & $3.00 \mathrm{E}-06$ & $4.00 \mathrm{E}-06$ & $1.00 \mathrm{E}-05$ & $9.00 \mathrm{E}-06$ & $1.10 \mathrm{E}-05$ \\
\hline V23 & 195.00 & $5.00 \mathrm{E}-06$ & $4.00 \mathrm{E}-06$ & $7.00 \mathrm{E}-06$ & $3.00 \mathrm{E}-06$ & $2.00 \mathrm{E}-06$ & $3.00 \mathrm{E}-06$ & $1.20 \mathrm{E}-05$ & $1.10 \mathrm{E}-05$ & $1.30 \mathrm{E}-05$ \\
\hline V32 & 191.00 & $6.00 \mathrm{E}-06$ & $5.00 \mathrm{E}-06$ & $8.00 \mathrm{E}-06$ & $3.00 \mathrm{E}-06$ & $3.00 \mathrm{E}-06$ & $4.00 \mathrm{E}-06$ & $1.20 \mathrm{E}-05$ & $1.10 \mathrm{E}-05$ & $1.40 \mathrm{E}-05$ \\
\hline V33 & 182.00 & $5.00 \mathrm{E}-06$ & $4.00 \mathrm{E}-06$ & $7.00 \mathrm{E}-06$ & $2.00 \mathrm{E}-06$ & $2.00 \mathrm{E}-06$ & $3.00 \mathrm{E}-06$ & $1.00 \mathrm{E}-05$ & $9.00 \mathrm{E}-06$ & $1.10 \mathrm{E}-05$ \\
\hline V1ave & 183.67 & $1.03 \mathrm{E}-05$ & $4.00 \mathrm{E}-06$ & $1.70 \mathrm{E}-05$ & $3.00 \mathrm{E}-06$ & $2.00 \mathrm{E}-06$ & $3.67 \mathrm{E}-06$ & $4.60 \mathrm{E}-05$ & $4.20 \mathrm{E}-05$ & $5.10 \mathrm{E}-05$ \\
\hline V2ave & 192.67 & $5.00 \mathrm{E}-06$ & $4.00 \mathrm{E}-06$ & $6.33 \mathrm{E}-06$ & $3.00 \mathrm{E}-06$ & $2.33 \mathrm{E}-06$ & $3.33 \mathrm{E}-06$ & $9.67 \mathrm{E}-06$ & $8.67 \mathrm{E}-06$ & $1.07 \mathrm{E}-05$ \\
\hline V3ave & 186.33 & $7.00 \mathrm{E}-06$ & $3.67 \mathrm{E}-06$ & $5.57 \mathrm{E}-06$ & $2.33 \mathrm{E}-06$ & $2.33 \mathrm{E}-06$ & $3.33 \mathrm{E}-06$ & $2.50 \mathrm{E}-05$ & $2.27 \mathrm{E}-05$ & $2.80 \mathrm{E}-05$ \\
\hline Vtotave & 187.56 & $7.44 \mathrm{E}-06$ & $3.89 \mathrm{E}-06$ & $9.63 \mathrm{E}-06$ & $2.78 \mathrm{E}-06$ & $2.22 \mathrm{E}-06$ & $3.44 \mathrm{E}-06$ & $2.69 \mathrm{E}-05$ & $2.44 \mathrm{E}-05$ & $2.99 \mathrm{E}-05$ \\
\hline
\end{tabular}




\section{Antisun Velocity}

\begin{tabular}{|c|c|c|c|c|c|c|c|c|c|c|}
\hline Version & $\begin{array}{c}\text { Number of } \\
\text { Impacts }\end{array}$ & Mean & $\begin{array}{l}95 \% \text { CI for } \\
\text { Mean, Low }\end{array}$ & $\begin{array}{c}95 \% \text { CI for } \\
\text { Mean, } \\
\text { High }\end{array}$ & Median & $\begin{array}{l}95 \% \text { CI for } \\
\text { Median, } \\
\text { Low }\end{array}$ & $\begin{array}{c}95 \% \text { CI for } \\
\text { Median, } \\
\text { High }\end{array}$ & StDev & $\begin{array}{c}95 \% \text { CI for } \\
\text { StDev, } \\
\text { Low }\end{array}$ & $\begin{array}{c}95 \% \text { CI for } \\
\text { Stdev, } \\
\text { High }\end{array}$ \\
\hline V11 & 169.00 & 18.79 & 17.21 & 20.36 & 19.00 & 17.00 & 21.00 & 10.38 & 9.38 & 11.62 \\
\hline V12 & 177.00 & 18.75 & 17.40 & 20.11 & 19.00 & 17.00 & 21.00 & 9.14 & 8.28 & 10.21 \\
\hline V13 & 205.00 & 18.72 & 17.27 & 20.16 & 19.00 & 17.00 & 21.00 & 10.48 & 9.56 & 11.61 \\
\hline V21 & 181.00 & 20.11 & 18.55 & 21.66 & 19.00 & 17.00 & 21.00 & 10.59 & 9.60 & 11.81 \\
\hline V22 & 202.00 & 18.76 & 17.33 & 20.20 & 19.00 & 17.00 & 21.00 & 10.33 & 9.41 & 11.45 \\
\hline V23 & 195.00 & 18.76 & 17.28 & 20.25 & 17.00 & 15.00 & 21.00 & 10.51 & 9.56 & 11.67 \\
\hline V31 & 186.00 & 17.72 & 16.38 & 19.06 & 17.00 & 15.30 & 19.00 & 9.29 & 8.43 & 10.34 \\
\hline V32 & 191.00 & 20.20 & 18.73 & 21.68 & 21.00 & 17.00 & 23.00 & 10.34 & 9.39 & 11.49 \\
\hline V33 & 182.00 & 19.60 & 18.07 & 21.14 & 19.00 & 17.00 & 21.00 & 10.46 & 9.49 & 11.66 \\
\hline V1ave & 183.67 & 18.75 & 17.29 & 20.21 & 19.00 & 17.00 & 21.00 & 10.00 & 9.07 & 11.15 \\
\hline V2ave & 192.67 & 19.21 & 17.72 & 20.70 & 18.33 & 16.33 & 21.00 & 10.48 & 9.52 & 11.64 \\
\hline V3ave & 186.33 & 19.18 & 17.73 & 20.63 & 19.00 & 16.43 & 21.00 & 10.03 & 9.10 & 11.16 \\
\hline Vtotave & 187.56 & 19.05 & 17.58 & 20.51 & 18.78 & 16.59 & 21.00 & 10.17 & 9.23 & 11.32 \\
\hline
\end{tabular}

\section{Mars Reconnaissance Orbiter}

\section{Ram Mass}

\begin{tabular}{|c|c|c|c|c|c|c|c|c|c|c|}
\hline Version & $\begin{array}{l}\text { Number of } \\
\text { Impacts }\end{array}$ & Mean & $\begin{array}{l}95 \% \text { CI for } \\
\text { Mean, Low }\end{array}$ & $\begin{array}{l}95 \% \text { CI for } \\
\text { Mean, High }\end{array}$ & Median & $\begin{array}{l}95 \% \text { CI for } \\
\text { Median, } \\
\text { Low }\end{array}$ & $\begin{array}{l}95 \% \text { CI for } \\
\text { Median, } \\
\text { High }\end{array}$ & StDev & $\begin{array}{c}95 \% \text { CI for } \\
\text { StDev, } \\
\text { Low }\end{array}$ & $\begin{array}{c}95 \% \text { CI for } \\
\text { Stdev, } \\
\text { High }\end{array}$ \\
\hline V11 & 177.00 & $9.00 \mathrm{E}-06$ & $3.00 \mathrm{E}-06$ & $1.50 \mathrm{E}-05$ & $3.00 \mathrm{E}-06$ & $2.00 \mathrm{E}-06$ & $4.00 \mathrm{E}-06$ & $3.90 \mathrm{E}-05$ & $3.50 \mathrm{E}-05$ & $4.40 \mathrm{E}-05$ \\
\hline V12 & 158.00 & $5.00 \mathrm{E}-06$ & $4.00 \mathrm{E}-06$ & $6.00 \mathrm{E}-06$ & $3.00 \mathrm{E}-06$ & $2.00 \mathrm{E}-06$ & $4.00 \mathrm{E}-06$ & $7.00 \mathrm{E}-06$ & $6.00 \mathrm{E}-06$ & $8.00 \mathrm{E}-06$ \\
\hline V13 & 176.00 & $8.00 \mathrm{E}-06$ & $5.00 \mathrm{E}-06$ & $1.10 \mathrm{E}-05$ & $3.00 \mathrm{E}-06$ & $2.00 \mathrm{E}-06$ & $4.00 \mathrm{E}-06$ & $2.00 \mathrm{E}-05$ & $1.90 \mathrm{E}-05$ & $2.30 \mathrm{E}-05$ \\
\hline V21 & 164.00 & $6.00 \mathrm{E}-06$ & $4.00 \mathrm{E}-06$ & $8.00 \mathrm{E}-06$ & $3.00 \mathrm{E}-06$ & $2.00 \mathrm{E}-06$ & $3.00 \mathrm{E}-06$ & $1.20 \mathrm{E}-05$ & $1.10 \mathrm{E}-05$ & $1.40 \mathrm{E}-05$ \\
\hline V22 & 174.00 & $5.00 \mathrm{E}-06$ & $3.00 \mathrm{E}-06$ & $6.00 \mathrm{E}-06$ & $3.00 \mathrm{E}-06$ & $2.00 \mathrm{E}-06$ & $3.00 \mathrm{E}-06$ & $9.00 \mathrm{E}-06$ & $8.00 \mathrm{E}-06$ & $1.00 \mathrm{E}-05$ \\
\hline V23 & 170.00 & $6.00 \mathrm{E}-06$ & $4.00 \mathrm{E}-06$ & $8.00 \mathrm{E}-06$ & $2.00 \mathrm{E}-06$ & $2.00 \mathrm{E}-06$ & $3.00 \mathrm{E}-06$ & $1.40 \mathrm{E}-05$ & $1.20 \mathrm{E}-05$ & $1.50 \mathrm{E}-05$ \\
\hline V32 & 155.00 & $5.00 \mathrm{E}-06$ & $3.00 \mathrm{E}-06$ & $6.00 \mathrm{E}-06$ & $3.00 \mathrm{E}-06$ & $2.00 \mathrm{E}-06$ & $3.00 \mathrm{E}-06$ & $9.00 \mathrm{E}-06$ & $8.00 \mathrm{E}-06$ & $1.00 \mathrm{E}-05$ \\
\hline V33 & 158.00 & $7.00 \mathrm{E}-06$ & $5.00 \mathrm{E}-06$ & $9.00 \mathrm{E}-06$ & $2.00 \mathrm{E}-06$ & $2.00 \mathrm{E}-06$ & $3.00 \mathrm{E}-06$ & $1.30 \mathrm{E}-05$ & $1.20 \mathrm{E}-05$ & $1.50 \mathrm{E}-05$ \\
\hline V1ave & 170.33 & $7.33 \mathrm{E}-06$ & $4.00 \mathrm{E}-06$ & $1.07 \mathrm{E}-05$ & $3.00 \mathrm{E}-06$ & $2.00 \mathrm{E}-06$ & $4.00 \mathrm{E}-06$ & $2.20 \mathrm{E}-05$ & $2.00 \mathrm{E}-05$ & $2.50 \mathrm{E}-05$ \\
\hline V2ave & 169.33 & $5.67 \mathrm{E}-06$ & $3.67 \mathrm{E}-06$ & 7.33E-06 & $2.67 \mathrm{E}-06$ & $2.00 \mathrm{E}-06$ & $3.00 \mathrm{E}-06$ & $1.17 \mathrm{E}-05$ & $1.03 \mathrm{E}-05$ & $1.30 \mathrm{E}-05$ \\
\hline V3ave & 167.67 & $5.67 \mathrm{E}-06$ & $3.67 \mathrm{E}-06$ & $7.00 \mathrm{E}-06$ & $2.33 \mathrm{E}-06$ & $2.00 \mathrm{E}-06$ & $3.00 \mathrm{E}-06$ & $1.10 \mathrm{E}-05$ & $1.00 \mathrm{E}-05$ & $1.23 \mathrm{E}-05$ \\
\hline Vtotave & 169.11 & $6.22 \mathrm{E}-06$ & $3.78 \mathrm{E}-06$ & 8.33E-06 & $2.67 \mathrm{E}-06$ & $2.00 \mathrm{E}-06$ & $3.33 \mathrm{E}-06$ & $1.49 \mathrm{E}-05$ & $1.34 \mathrm{E}-05$ & $1.68 \mathrm{E}-05$ \\
\hline
\end{tabular}

Ram Velocity

\begin{tabular}{|c|c|c|c|c|c|c|c|c|c|c|}
\hline Version & $\begin{array}{c}\text { Number of } \\
\text { Impacts }\end{array}$ & Mean & $\begin{array}{c}\text { 95\% CI for } \\
\text { Mean, Low }\end{array}$ & $\begin{array}{c}\text { 95\% CI for } \\
\text { Mean, } \\
\text { High }\end{array}$ & Median & $\begin{array}{c}\text { M5\% CI for } \\
\text { Median, } \\
\text { Low }\end{array}$ & $\begin{array}{c}\text { 95\% CI for } \\
\text { Median, } \\
\text { High }\end{array}$ & $\begin{array}{c}\text { 95\% CI for } \\
\text { StDev, } \\
\text { Low }\end{array}$ & $\begin{array}{c}\text { 95\% CI for } \\
\text { Stdev, } \\
\text { High }\end{array}$ \\
\hline V11 & 177.00 & 21.81 & 20.04 & 23.59 & 21.00 & 17.00 & 23.00 & 11.95 & 10.82 & 13.35 \\
\hline V12 & 158.00 & 19.79 & 18.02 & 21.55 & 19.00 & 15.44 & 21.00 & 11.23 & 10.11 & 12.63 \\
\hline V13 & 176.00 & 21.76 & 19.90 & 23.62 & 19.00 & 17.00 & 21.00 & 12.50 & 11.31 & 13.96 \\
\hline V21 & 164.00 & 20.90 & 19.18 & 22.63 & 21.00 & 17.00 & 23.00 & 11.19 & 10.09 & 12.55 \\
\hline V22 & 174.00 & 21.86 & 20.23 & 23.50 & 23.00 & 19.00 & 23.00 & 10.92 & 9.88 & 12.21 \\
\hline V23 & 170.00 & 20.78 & 19.12 & 22.44 & 21.00 & 19.00 & 23.00 & 10.97 & 9.92 & 12.28 \\
\hline V31 & 190.00 & 20.80 & 19.30 & 22.30 & 21.00 & 19.00 & 21.01 & 10.49 & 9.53 & 11.67 \\
\hline V32 & 155.00 & 21.83 & 20.02 & 23.63 & 21.00 & 19.00 & 23.00 & 11.37 & 10.23 & 12.80 \\
\hline V33 & 158.00 & 21.38 & 19.69 & 23.07 & 19.00 & 19.00 & 23.00 & 10.75 & 9.68 & 12.09 \\
\hline V1ave & 170.33 & 21.12 & 19.32 & 22.92 & 19.67 & 16.48 & 21.67 & 11.89 & 10.75 & 13.31 \\
\hline V2ave & 169.33 & 21.18 & 19.51 & 22.85 & 21.67 & 18.33 & 23.00 & 11.03 & 9.96 & 12.35 \\
\hline V3ave & 167.67 & 21.34 & 19.67 & 23.00 & 20.33 & 19.00 & 22.34 & 10.87 & 9.81 & 12.18 \\
\hline Vtotave & 169.11 & 21.21 & 19.50 & 22.92 & 20.56 & 17.94 & 22.33 & 11.26 & 10.18 & 12.61 \\
\hline
\end{tabular}


Wake Mass

\begin{tabular}{|c|c|c|c|c|c|c|c|c|c|c|}
\hline Version & $\begin{array}{l}\text { Number of } \\
\text { Impacts }\end{array}$ & Mean & $\begin{array}{l}95 \% \text { CI for } \\
\text { Mean, Low }\end{array}$ & $\begin{array}{c}95 \% \text { CI for } \\
\text { Mean, } \\
\text { High }\end{array}$ & Median & $\begin{array}{l}95 \% \text { CI for } \\
\text { Median, } \\
\text { Low }\end{array}$ & $\begin{array}{l}95 \% \text { CI for } \\
\text { Median, } \\
\text { High }\end{array}$ & StDev & $\begin{array}{c}95 \% \text { CI for } \\
\text { StDev, } \\
\text { Low }\end{array}$ & $\begin{array}{c}95 \% \text { CI for } \\
\text { Stdev, } \\
\text { High }\end{array}$ \\
\hline V11 & 11.00 & $5.00 \mathrm{E}-06$ & $2.00 \mathrm{E}-06$ & $7.00 \mathrm{E}-06$ & $3.00 \mathrm{E}-06$ & $1.00 \mathrm{E}-06$ & $9.00 \mathrm{E}-06$ & $4.00 \mathrm{E}-06$ & $3.00 \mathrm{E}-06$ & $7.00 \mathrm{E}-06$ \\
\hline V12 & 20.00 & $4.00 \mathrm{E}-06$ & $2.00 \mathrm{E}-06$ & $6.00 \mathrm{E}-06$ & $2.00 \mathrm{E}-06$ & $1.00 \mathrm{E}-06$ & $5.00 \mathrm{E}-06$ & $5.00 \mathrm{E}-06$ & $3.00 \mathrm{E}-06$ & $7.00 \mathrm{E}-06$ \\
\hline V13 & 9.00 & $5.00 \mathrm{E}-06$ & 0 & $9.00 \mathrm{E}-06$ & $1.00 \mathrm{E}-06$ & $1.00 \mathrm{E}-06$ & $7.00 \mathrm{E}-06$ & $6.00 \mathrm{E}-06$ & $4.00 \mathrm{E}-06$ & $1.20 \mathrm{E}-05$ \\
\hline V21 & 10.00 & $4.00 \mathrm{E}-06$ & $2.00 \mathrm{E}-06$ & $6.00 \mathrm{E}-06$ & $3.00 \mathrm{E}-06$ & $1.00 \mathrm{E}-06$ & $5.00 \mathrm{E}-06$ & $3.00 \mathrm{E}-06$ & $2.00 \mathrm{E}-06$ & $5.00 \mathrm{E}-06$ \\
\hline V22 & 8.00 & $7.00 \mathrm{E}-06$ & $4.00 \mathrm{E}-06$ & $9.00 \mathrm{E}-06$ & $7.00 \mathrm{E}-06$ & $3.00 \mathrm{E}-06$ & $1.00 \mathrm{E}-05$ & $3.00 \mathrm{E}-06$ & $2.00 \mathrm{E}-06$ & $6.00 \mathrm{E}-06$ \\
\hline V23 & 15.00 & $1.30 \mathrm{E}-05$ & $-1.00 \mathrm{E}-06$ & $2.70 \mathrm{E}-05$ & $3.00 \mathrm{E}-06$ & $1.00 \mathrm{E}-06$ & $1.00 \mathrm{E}-05$ & $2.60 \mathrm{E}-05$ & $1.90 \mathrm{E}-05$ & $4.10 \mathrm{E}-05$ \\
\hline V32 & 16.00 & $3.00 \mathrm{E}-06$ & $2.00 \mathrm{E}-06$ & $4.00 \mathrm{E}-06$ & $2.00 \mathrm{E}-06$ & $1.00 \mathrm{E}-06$ & $3.00 \mathrm{E}-06$ & $3.00 \mathrm{E}-06$ & $2.00 \mathrm{E}-06$ & $3.00 \mathrm{E}-06$ \\
\hline V33 & 12.00 & $3.00 \mathrm{E}-06$ & $1.00 \mathrm{E}-06$ & $4.00 \mathrm{E}-06$ & $2.00 \mathrm{E}-06$ & $1.00 \mathrm{E}-06$ & $3.00 \mathrm{E}-06$ & $2.00 \mathrm{E}-06$ & $1.00 \mathrm{E}-06$ & $3.00 \mathrm{E}-06$ \\
\hline V1ave & 13.33 & $4.67 \mathrm{E}-06$ & $1.33 \mathrm{E}-06$ & $7.33 \mathrm{E}-06$ & $2.00 \mathrm{E}-06$ & $1.00 \mathrm{E}-06$ & $7.00 \mathrm{E}-06$ & $5.00 \mathrm{E}-06$ & $3.33 \mathrm{E}-06$ & $8.67 \mathrm{E}-06$ \\
\hline V2ave & 11.00 & $8.00 \mathrm{E}-06$ & $1.67 \mathrm{E}-06$ & $1.40 \mathrm{E}-05$ & 4.33E-06 & $1.67 \mathrm{E}-06$ & $8.33 \mathrm{E}-06$ & $1.07 \mathrm{E}-05$ & 7.67E-06 & $1.73 \mathrm{E}-05$ \\
\hline V3ave & 15.00 & $5.00 \mathrm{E}-06$ & $2.00 \mathrm{E}-06$ & $7.00 \mathrm{E}-06$ & $3.00 \mathrm{E}-06$ & $1.33 \mathrm{E}-06$ & $5.00 \mathrm{E}-06$ & $6.00 \mathrm{E}-06$ & $4.33 \mathrm{E}-06$ & $8.67 \mathrm{E}-06$ \\
\hline Vtotave & 13.11 & 5.89E-06 & $1.67 \mathrm{E}-06$ & $9.44 \mathrm{E}-06$ & $3.11 \mathrm{E}-06$ & $1.33 \mathrm{E}-06$ & $6.78 \mathrm{E}-06$ & $7.22 \mathrm{E}-06$ & $5.11 \mathrm{E}-06$ & $1.16 \mathrm{E}-05$ \\
\hline
\end{tabular}

Wake Velocity

\begin{tabular}{|c|c|c|c|c|c|c|c|c|c|c|}
\hline Version & $\begin{array}{c}\text { Number of } \\
\text { Impacts }\end{array}$ & Mean & $\begin{array}{c}\text { 95\% CI for } \\
\text { Mean, Low }\end{array}$ & $\begin{array}{c}\text { 95\% CI for } \\
\text { Mean, } \\
\text { High }\end{array}$ & Median & $\begin{array}{c}\text { Median, } \\
\text { Low }\end{array}$ & $\begin{array}{c}\text { M5\% CI for } \\
\text { Median, } \\
\text { High }\end{array}$ & $\begin{array}{c}\text { 95\% CI for } \\
\text { StDev, } \\
\text { Low }\end{array}$ & $\begin{array}{c}\text { 95\% CI for } \\
\text { Stdev, } \\
\text { High }\end{array}$ \\
\hline V11 & 11.00 & 16.64 & 9.43 & 23.84 & 13.00 & 7.00 & 27.33 & 10.73 & 7.50 & 18.82 \\
\hline V12 & 20.00 & 11.00 & 6.86 & 15.14 & 7.00 & 5.00 & 12.53 & 8.85 & 6.73 & 12.93 \\
\hline V13 & 9.00 & 13.67 & 7.42 & 19.91 & 11.00 & 5.46 & 22.09 & 8.12 & 5.49 & 15.56 \\
\hline V21 & 10.00 & 13.20 & 6.97 & 19.44 & 10.00 & 5.00 & 21.69 & 8.72 & 6.00 & 15.91 \\
\hline V22 & 8.00 & 10.25 & 3.57 & 16.93 & 7.00 & 5.00 & 14.03 & 8.00 & 5.29 & 16.27 \\
\hline V23 & 15.00 & 11.13 & 7.15 & 15.12 & 9.00 & 5.75 & 17.51 & 7.19 & 5.26 & 11.34 \\
\hline V31 & 17.00 & 12.77 & 8.67 & 16.86 & 9.00 & 7.00 & 20.95 & 7.97 & 5.93 & 12.12 \\
\hline V32 & 16.00 & 12.88 & 8.02 & 17.73 & 9.00 & 6.53 & 15.95 & 9.11 & 6.73 & 14.09 \\
\hline V33 & 12.00 & 14.00 & 8.03 & 19.97 & 11.00 & 7.00 & 20.47 & 9.40 & 6.66 & 15.96 \\
\hline V1ave & 13.33 & 13.77 & 7.90 & 19.63 & 10.33 & 5.82 & 20.65 & 9.23 & 6.57 & 15.77 \\
\hline V2ave & 11.00 & 11.53 & 5.89 & 17.16 & 8.67 & 5.25 & 17.74 & 7.97 & 5.52 & 14.51 \\
\hline V3ave & 15.00 & 13.21 & 8.24 & 18.19 & 9.67 & 6.84 & 19.13 & 8.82 & 6.44 & 14.06 \\
\hline Vtotave & 13.11 & 12.84 & 7.35 & 18.33 & 9.56 & 5.97 & 19.17 & 8.67 & 6.18 & 14.78 \\
\hline
\end{tabular}

Port Mass

\begin{tabular}{|c|c|c|c|c|c|c|c|c|c|c|}
\hline Version & $\begin{array}{l}\text { Number of } \\
\text { Impacts }\end{array}$ & Mean & $\begin{array}{l}95 \% \text { CI for } \\
\text { Mean, Low }\end{array}$ & $\begin{array}{l}95 \% \text { CI for } \\
\text { Mean, } \\
\text { High }\end{array}$ & Median & $\begin{array}{l}95 \% \text { CI for } \\
\text { Median, } \\
\text { Low }\end{array}$ & $\begin{array}{l}95 \% \text { CI for } \\
\text { Median, } \\
\text { High }\end{array}$ & StDev & $\begin{array}{c}95 \% \text { CI for } \\
\text { StDev, } \\
\text { Low }\end{array}$ & $\begin{array}{c}95 \% \text { CI for } \\
\text { Stdev, } \\
\text { High }\end{array}$ \\
\hline V11 & 108.00 & $6.00 \mathrm{E}-06$ & $2.00 \mathrm{E}-06$ & $1.00 \mathrm{E}-05$ & $2.00 \mathrm{E}-06$ & $2.00 \mathrm{E}-06$ & $3.00 \mathrm{E}-06$ & $2.10 \mathrm{E}-05$ & $1.80 \mathrm{E}-05$ & $2.40 \mathrm{E}-05$ \\
\hline V12 & 103.00 & $9.00 \mathrm{E}-06$ & $4.00 \mathrm{E}-06$ & $1.40 \mathrm{E}-05$ & $3.00 \mathrm{E}-06$ & $2.00 \mathrm{E}-06$ & $4.00 \mathrm{E}-06$ & $2.60 \mathrm{E}-05$ & $2.20 \mathrm{E}-05$ & $3.00 \mathrm{E}-05$ \\
\hline V13 & 102.00 & $8.00 \mathrm{E}-06$ & $5.00 \mathrm{E}-06$ & $1.00 \mathrm{E}-05$ & $3.00 \mathrm{E}-06$ & $2.00 \mathrm{E}-06$ & $4.00 \mathrm{E}-06$ & $1.40 \mathrm{E}-05$ & $1.30 \mathrm{E}-05$ & $1.70 \mathrm{E}-05$ \\
\hline V21 & 107.00 & $4.00 \mathrm{E}-06$ & $3.00 \mathrm{E}-06$ & $6.00 \mathrm{E}-06$ & $2.00 \mathrm{E}-06$ & $1.00 \mathrm{E}-06$ & $3.00 \mathrm{E}-06$ & $7.00 \mathrm{E}-06$ & $6.00 \mathrm{E}-06$ & $8.00 \mathrm{E}-06$ \\
\hline V22 & 97.00 & $6.00 \mathrm{E}-06$ & $4.00 \mathrm{E}-06$ & $8.00 \mathrm{E}-06$ & $3.00 \mathrm{E}-06$ & $2.00 \mathrm{E}-06$ & $4.00 \mathrm{E}-06$ & $1.00 \mathrm{E}-05$ & $9.00 \mathrm{E}-06$ & $1.20 \mathrm{E}-05$ \\
\hline V23 & 103.00 & $6.00 \mathrm{E}-06$ & $4.00 \mathrm{E}-06$ & $9.00 \mathrm{E}-06$ & $3.00 \mathrm{E}-06$ & $2.00 \mathrm{E}-06$ & $4.00 \mathrm{E}-06$ & $1.30 \mathrm{E}-05$ & $1.10 \mathrm{E}-05$ & $1.50 \mathrm{E}-05$ \\
\hline V31 & 103.00 & $6.00 \mathrm{E}-06$ & $4.00 \mathrm{E}-06$ & $8.00 \mathrm{E}-06$ & $3.00 \mathrm{E}-06$ & $2.00 \mathrm{E}-06$ & $4.00 \mathrm{E}-06$ & $9.00 \mathrm{E}-06$ & $8.00 \mathrm{E}-06$ & $1.10 \mathrm{E}-05$ \\
\hline V32 & 100.00 & $4.00 \mathrm{E}-06$ & $3.00 \mathrm{E}-06$ & $6.00 \mathrm{E}-06$ & $2.00 \mathrm{E}-06$ & $2.00 \mathrm{E}-06$ & $3.00 \mathrm{E}-06$ & $8.00 \mathrm{E}-06$ & $7.00 \mathrm{E}-06$ & $1.00 \mathrm{E}-05$ \\
\hline V33 & 98.00 & $6.00 \mathrm{E}-06$ & $4.00 \mathrm{E}-06$ & $9.00 \mathrm{E}-06$ & $3.00 \mathrm{E}-06$ & $2.00 \mathrm{E}-06$ & $4.00 \mathrm{E}-06$ & $1.30 \mathrm{E}-05$ & $1.10 \mathrm{E}-05$ & $1.50 \mathrm{E}-05$ \\
\hline V1ave & 104.33 & $7.67 \mathrm{E}-06$ & $3.67 \mathrm{E}-06$ & $1.13 \mathrm{E}-05$ & $2.67 \mathrm{E}-06$ & $2.00 \mathrm{E}-06$ & $3.67 \mathrm{E}-06$ & $2.03 \mathrm{E}-05$ & $1.77 \mathrm{E}-05$ & $2.37 \mathrm{E}-05$ \\
\hline V2ave & 102.33 & 5.33E-06 & $3.67 \mathrm{E}-06$ & 7.67E-06 & $2.67 \mathrm{E}-06$ & $1.67 \mathrm{E}-06$ & $3.67 \mathrm{E}-06$ & $1.00 \mathrm{E}-05$ & $8.67 \mathrm{E}-06$ & $1.17 \mathrm{E}-05$ \\
\hline V3ave & 100.33 & $5.33 \mathrm{E}-06$ & $3.67 \mathrm{E}-06$ & 7.67E-06 & $2.67 \mathrm{E}-06$ & $2.00 \mathrm{E}-06$ & $3.67 \mathrm{E}-06$ & $1.00 \mathrm{E}-05$ & $8.67 \mathrm{E}-06$ & $1.20 \mathrm{E}-05$ \\
\hline Vtotave & 102.33 & $6.11 \mathrm{E}-06$ & $3.67 \mathrm{E}-06$ & $8.89 \mathrm{E}-06$ & $2.67 \mathrm{E}-06$ & $1.89 \mathrm{E}-06$ & $3.67 \mathrm{E}-06$ & $1.34 \mathrm{E}-05$ & $1.17 \mathrm{E}-05$ & $1.58 \mathrm{E}-05$ \\
\hline
\end{tabular}


Port Velocity

\begin{tabular}{|c|c|c|c|c|c|c|c|c|c|c|}
\hline Version & $\begin{array}{l}\text { Number of } \\
\text { Impacts }\end{array}$ & Mean & $\begin{array}{l}95 \% \text { CI for } \\
\text { Mean, Low }\end{array}$ & $\begin{array}{c}95 \% \text { CI for } \\
\text { Mean, } \\
\text { High }\end{array}$ & Median & $\begin{array}{l}95 \% \text { CI for } \\
\text { Median, } \\
\text { Low }\end{array}$ & $\begin{array}{l}95 \% \text { CI for } \\
\text { Median, } \\
\text { High }\end{array}$ & StDev & $\begin{array}{c}95 \% \text { CI for } \\
\text { StDev, } \\
\text { Low }\end{array}$ & $\begin{array}{c}95 \% \text { CI for } \\
\text { Stdev, } \\
\text { High }\end{array}$ \\
\hline V11 & 108.00 & 17.98 & 16.31 & 19.66 & 17.00 & 15.00 & 19.00 & 8.79 & 7.75 & 10.14 \\
\hline V12 & 103.00 & 19.62 & 17.69 & 21.56 & 19.00 & 17.00 & 21.00 & 9.91 & 8.72 & 11.48 \\
\hline V13 & 102.00 & 18.63 & 16.54 & 20.72 & 17.00 & 14.30 & 21.00 & 10.65 & 9.36 & 12.35 \\
\hline V21 & 107.00 & 19.84 & 17.74 & 21.95 & 17.00 & 17.00 & 21.00 & 10.99 & 9.69 & 12.70 \\
\hline V22 & 97.00 & 20.92 & 18.89 & 22.85 & 21.00 & 17.79 & 23.00 & 9.60 & 8.41 & 11.18 \\
\hline V23 & 103.00 & 18.55 & 16.62 & 20.49 & 17.00 & 15.00 & 19.00 & 9.90 & 8.71 & 11.47 \\
\hline V32 & 100.00 & 20.68 & 18.65 & 22.71 & 21.00 & 19.00 & 23.00 & 10.24 & 9.00 & 11.90 \\
\hline V33 & 98.00 & 18.35 & 16.51 & 20.18 & 19.00 & 15.00 & 21.00 & 9.15 & 8.02 & 10.65 \\
\hline V1ave & 104.33 & 18.74 & 16.84 & 20.64 & 17.67 & 15.43 & 20.33 & 9.78 & 8.61 & 11.33 \\
\hline V2ave & 102.33 & 19.77 & 17.75 & 21.76 & 18.33 & 16.60 & 21.00 & 10.16 & 8.93 & 11.78 \\
\hline V3ave & 100.33 & 19.57 & 17.61 & 21.53 & 19.67 & 16.33 & 21.62 & 9.89 & 8.68 & 11.48 \\
\hline Vtotave & 102.33 & 19.36 & 17.40 & 21.31 & 18.56 & 16.12 & 20.99 & 9.94 & 8.74 & 11.53 \\
\hline
\end{tabular}

Starboard Mass

\begin{tabular}{|c|c|c|c|c|c|c|c|c|c|c|}
\hline Version & $\begin{array}{l}\text { Number of } \\
\text { Impacts }\end{array}$ & Mean & $\begin{array}{l}95 \% \text { CI for } \\
\text { Mean, Low }\end{array}$ & $\begin{array}{c}95 \% \text { CI for } \\
\text { Mean, } \\
\text { High }\end{array}$ & Median & $\begin{array}{l}95 \% \text { CI for } \\
\text { Median, } \\
\text { Low }\end{array}$ & $\begin{array}{l}95 \% \text { CI for } \\
\text { Median, } \\
\text { High }\end{array}$ & StDev & $\begin{array}{l}95 \% \text { CI for } \\
\text { StDev, } \\
\text { Low }\end{array}$ & $\begin{array}{c}95 \% \text { CI for } \\
\text { Stdev, } \\
\text { High }\end{array}$ \\
\hline V11 & 94.00 & $5.00 \mathrm{E}-06$ & $3.00 \mathrm{E}-06$ & $8.00 \mathrm{E}-06$ & $3.00 \mathrm{E}-06$ & $2.00 \mathrm{E}-06$ & $3.00 \mathrm{E}-06$ & $1.10 \mathrm{E}-05$ & $1.00 \mathrm{E}-05$ & $1.30 \mathrm{E}-05$ \\
\hline V12 & 73.00 & $7.00 \mathrm{E}-06$ & $3.00 \mathrm{E}-06$ & $1.00 \mathrm{E}-05$ & $2.00 \mathrm{E}-06$ & $3.00 \mathrm{E}-06$ & $4.00 \mathrm{E}-06$ & $1.50 \mathrm{E}-05$ & $1.30 \mathrm{E}-05$ & $1.80 \mathrm{E}-05$ \\
\hline V13 & 98.00 & $8.00 \mathrm{E}-06$ & $1.00 \mathrm{E}-06$ & $1.40 \mathrm{E}-05$ & $2.00 \mathrm{E}-06$ & $2.00 \mathrm{E}-06$ & $3.00 \mathrm{E}-06$ & $3.10 \mathrm{E}-05$ & $2.70 \mathrm{E}-05$ & $3.60 \mathrm{E}-05$ \\
\hline V21 & 74.00 & $4.50 \mathrm{E}-05$ & $-3.50 \mathrm{E}-05$ & $1.26 \mathrm{E}-04$ & $2.00 \mathrm{E}-06$ & $2.00 \mathrm{E}-06$ & $3.00 \mathrm{E}-06$ & $3.48 \mathrm{E}-04$ & $3.00 \mathrm{E}-04$ & $4.16 \mathrm{E}-04$ \\
\hline V22 & 80.00 & $5.00 \mathrm{E}-06$ & $3.00 \mathrm{E}-06$ & $7.00 \mathrm{E}-06$ & $2.00 \mathrm{E}-06$ & $2.00 \mathrm{E}-06$ & $4.00 \mathrm{E}-06$ & $9.00 \mathrm{E}-06$ & $8.00 \mathrm{E}-06$ & $1.00 \mathrm{E}-05$ \\
\hline $\mathrm{V} 23$ & 92.00 & $5.00 \mathrm{E}-06$ & $3.00 \mathrm{E}-06$ & $6.00 \mathrm{E}-06$ & $3.00 \mathrm{E}-06$ & $2.00 \mathrm{E}-06$ & $4.00 \mathrm{E}-06$ & $8.00 \mathrm{E}-06$ & $7.00 \mathrm{E}-06$ & $9.00 \mathrm{E}-06$ \\
\hline V32 & 100.00 & $5.00 \mathrm{E}-06$ & $3.00 \mathrm{E}-06$ & $7.00 \mathrm{E}-06$ & $3.00 \mathrm{E}-06$ & $2.00 \mathrm{E}-06$ & $3.00 \mathrm{E}-06$ & $9.00 \mathrm{E}-06$ & $8.00 \mathrm{E}-06$ & $1.00 \mathrm{E}-05$ \\
\hline V33 & 102.00 & $6.00 \mathrm{E}-06$ & $4.00 \mathrm{E}-06$ & $8.00 \mathrm{E}-06$ & $3.00 \mathrm{E}-06$ & $2.00 \mathrm{E}-06$ & $4.00 \mathrm{E}-06$ & $9.00 \mathrm{E}-06$ & $8.00 \mathrm{E}-06$ & $1.10 \mathrm{E}-05$ \\
\hline V1ave & 88.33 & $6.67 \mathrm{E}-06$ & $2.33 \mathrm{E}-06$ & $1.07 \mathrm{E}-05$ & $2.33 \mathrm{E}-06$ & $2.33 \mathrm{E}-06$ & $3.33 \mathrm{E}-06$ & $1.90 \mathrm{E}-05$ & $1.67 \mathrm{E}-05$ & $2.23 \mathrm{E}-05$ \\
\hline V2ave & 82.00 & $1.83 \mathrm{E}-05$ & $-9.67 \mathrm{E}-06$ & $4.63 \mathrm{E}-05$ & $2.33 \mathrm{E}-06$ & $2.00 \mathrm{E}-06$ & $3.67 \mathrm{E}-06$ & $1.22 \mathrm{E}-04$ & $1.05 \mathrm{E}-04$ & $1.45 \mathrm{E}-04$ \\
\hline V3ave & 92.00 & $5.33 \mathrm{E}-06$ & $3.33 \mathrm{E}-06$ & $7.67 \mathrm{E}-06$ & $3.00 \mathrm{E}-06$ & $2.00 \mathrm{E}-06$ & $3.33 \mathrm{E}-06$ & $9.67 \mathrm{E}-06$ & $8.33 \mathrm{E}-06$ & $1.13 \mathrm{E}-05$ \\
\hline Vtotave & 87.44 & $1.01 \mathrm{E}-05$ & $-1.33 \mathrm{E}-06$ & $2.16 \mathrm{E}-05$ & $2.56 \mathrm{E}-06$ & $2.11 \mathrm{E}-06$ & $3.44 \mathrm{E}-06$ & $5.01 \mathrm{E}-05$ & $4.33 \mathrm{E}-05$ & $5.96 \mathrm{E}-05$ \\
\hline
\end{tabular}

\section{Starboard Velocity}

\begin{tabular}{|c|c|c|c|c|c|c|c|c|c|c|}
\hline Version & $\begin{array}{l}\text { Number of } \\
\text { Impacts }\end{array}$ & Mean & $\begin{array}{l}95 \% \text { CI for } \\
\text { Mean, Low }\end{array}$ & $\begin{array}{c}95 \% \text { CI for } \\
\text { Mean, } \\
\text { High }\end{array}$ & Median & $\begin{array}{l}\text { 95\% CI for } \\
\text { Median, } \\
\text { Low }\end{array}$ & $\begin{array}{c}\text { 95\% CI for } \\
\text { Median, } \\
\text { High }\end{array}$ & StDev & $\begin{array}{c}95 \% \text { CI for } \\
\text { StDev, } \\
\text { Low }\end{array}$ & $\begin{array}{c}95 \% \text { CI for } \\
\text { Stdev, } \\
\text { High }\end{array}$ \\
\hline V11 & 94.00 & 18.64 & 16.60 & 20.68 & 19.00 & 15.00 & 21.00 & 9.97 & 8.72 & 11.64 \\
\hline V12 & 73.00 & 18.53 & 16.34 & 20.73 & 17.00 & 15.00 & 21.00 & 9.41 & 8.10 & 11.25 \\
\hline V13 & 98.00 & 17.98 & 16.01 & 19.95 & 17.00 & 15.00 & 19.00 & 9.82 & 8.61 & 11.43 \\
\hline V21 & 74.00 & 17.68 & 15.39 & 19.97 & 15.00 & 13.00 & 19.00 & 9.88 & 8.51 & 11.79 \\
\hline V22 & 80.00 & 17.55 & 15.06 & 20.04 & 15.00 & 13.00 & 19.00 & 11.17 & 9.67 & 13.24 \\
\hline V23 & 92.00 & 18.74 & 16.78 & 20.70 & 17.00 & 15.00 & 19.00 & 9.48 & 8.28 & 11.10 \\
\hline V31 & 74.00 & 18.19 & 15.89 & 20.49 & 17.00 & 15.00 & 21.00 & 9.91 & 8.53 & 11.82 \\
\hline V32 & 100.00 & 21.14 & 18.86 & 23.42 & 19.00 & 17.00 & 23.00 & 11.48 & 10.08 & 13.34 \\
\hline V33 & 102.00 & 20.43 & 18.26 & 22.60 & 19.00 & 17.00 & 23.00 & 11.04 & 9.70 & 12.80 \\
\hline V1ave & 88.33 & 18.38 & 16.32 & 20.45 & 17.67 & 15.00 & 20.33 & 9.74 & 8.48 & 11.44 \\
\hline V2ave & 82.00 & 17.99 & 15.74 & 20.24 & 15.67 & 13.67 & 19.00 & 10.18 & 8.82 & 12.04 \\
\hline V3ave & 92.00 & 19.92 & 17.67 & 22.17 & 18.33 & 16.33 & 22.33 & 10.81 & 9.44 & 12.65 \\
\hline Vtotave & 87.44 & 18.76 & 16.58 & 20.95 & 17.22 & 15.00 & 20.56 & 10.24 & 8.91 & 12.04 \\
\hline
\end{tabular}




\section{Zenith Mass}

\begin{tabular}{|c|c|c|c|c|c|c|c|c|c|c|}
\hline Version & $\begin{array}{l}\text { Number of } \\
\text { Impacts }\end{array}$ & Mean & $\begin{array}{l}95 \% \text { CI for } \\
\text { Mean, Low }\end{array}$ & $\begin{array}{c}95 \% \text { CI for } \\
\text { Mean, } \\
\text { High }\end{array}$ & Median & $\begin{array}{l}95 \% \text { CI for } \\
\text { Median, } \\
\text { Low }\end{array}$ & $\begin{array}{l}95 \% \text { CI for } \\
\text { Median, } \\
\text { High }\end{array}$ & StDev & $\begin{array}{c}95 \% \text { CI for } \\
\text { StDev, } \\
\text { Low }\end{array}$ & $\begin{array}{c}95 \% \text { CI for } \\
\text { Stdev, } \\
\text { High }\end{array}$ \\
\hline V11 & 91.00 & $5.00 \mathrm{E}-06$ & $3.00 \mathrm{E}-06$ & $7.00 \mathrm{E}-06$ & $2.00 \mathrm{E}-06$ & $2.00 \mathrm{E}-06$ & $3.00 \mathrm{E}-06$ & $9.00 \mathrm{E}-06$ & $8.00 \mathrm{E}-06$ & $1.10 \mathrm{E}-05$ \\
\hline V12 & 96.00 & $9.00 \mathrm{E}-06$ & $1.00 \mathrm{E}-06$ & $1.80 \mathrm{E}-05$ & $2.00 \mathrm{E}-06$ & $2.00 \mathrm{E}-06$ & $3.00 \mathrm{E}-06$ & $4.20 \mathrm{E}-05$ & $3.70 \mathrm{E}-05$ & $4.90 \mathrm{E}-05$ \\
\hline V13 & 94.00 & $1.60 \mathrm{E}-05$ & $1.00 \mathrm{E}-06$ & $3.10 \mathrm{E}-05$ & $3.00 \mathrm{E}-06$ & $2.00 \mathrm{E}-06$ & $4.00 \mathrm{E}-06$ & $7.40 \mathrm{E}-05$ & $6.40 \mathrm{E}-05$ & $8.60 \mathrm{E}-05$ \\
\hline V21 & 87.00 & $9.80 \mathrm{E}-05$ & $-8.50 \mathrm{E}-05$ & $2.81 \mathrm{E}-04$ & $3.00 \mathrm{E}-06$ & $2.00 \mathrm{E}-06$ & $4.00 \mathrm{E}-06$ & $8.57 \mathrm{E}-04$ & $7.46 \mathrm{E}-04$ & $1.01 \mathrm{E}-03$ \\
\hline V22 & 93.00 & $5.00 \mathrm{E}-06$ & $3.00 \mathrm{E}-06$ & $6.00 \mathrm{E}-06$ & $3.00 \mathrm{E}-06$ & $2.00 \mathrm{E}-06$ & $4.00 \mathrm{E}-06$ & $7.00 \mathrm{E}-06$ & $7.00 \mathrm{E}-06$ & $9.00 \mathrm{E}-06$ \\
\hline V23 & 85.00 & $5.00 \mathrm{E}-06$ & $2.00 \mathrm{E}-06$ & $7.00 \mathrm{E}-06$ & $2.00 \mathrm{E}-06$ & $2.00 \mathrm{E}-06$ & $3.00 \mathrm{E}-06$ & $1.00 \mathrm{E}-05$ & $9.00 \mathrm{E}-06$ & $1.20 \mathrm{E}-05$ \\
\hline V31 & 92.00 & $4.00 \mathrm{E}-06$ & $3.00 \mathrm{E}-06$ & $6.00 \mathrm{E}-06$ & $2.00 \mathrm{E}-06$ & $1.00 \mathrm{E}-06$ & $2.00 \mathrm{E}-06$ & $8.00 \mathrm{E}-06$ & $7.00 \mathrm{E}-06$ & $9.00 \mathrm{E}-06$ \\
\hline V32 & 95.00 & $6.00 \mathrm{E}-06$ & $4.00 \mathrm{E}-06$ & $8.00 \mathrm{E}-06$ & $3.00 \mathrm{E}-06$ & $2.00 \mathrm{E}-06$ & $4.00 \mathrm{E}-06$ & $1.00 \mathrm{E}-05$ & $9.00 \mathrm{E}-06$ & $1.20 \mathrm{E}-05$ \\
\hline V33 & 89.00 & $7.00 \mathrm{E}-06$ & $2.00 \mathrm{E}-06$ & $1.20 \mathrm{E}-05$ & $3.00 \mathrm{E}-06$ & $2.00 \mathrm{E}-06$ & $3.00 \mathrm{E}-06$ & $2.30 \mathrm{E}-05$ & $2.00 \mathrm{E}-05$ & $2.70 \mathrm{E}-05$ \\
\hline V1ave & 93.67 & $1.00 \mathrm{E}-05$ & $1.67 \mathrm{E}-06$ & $1.87 \mathrm{E}-05$ & $2.33 \mathrm{E}-06$ & $2.00 \mathrm{E}-06$ & $3.33 \mathrm{E}-06$ & 4.17E-05 & $3.63 \mathrm{E}-05$ & $4.87 \mathrm{E}-05$ \\
\hline V2ave & 88.33 & $3.60 \mathrm{E}-05$ & $-2.67 \mathrm{E}-05$ & $9.80 \mathrm{E}-05$ & $2.67 \mathrm{E}-06$ & $2.00 \mathrm{E}-06$ & $3.67 \mathrm{E}-06$ & $2.91 \mathrm{E}-04$ & $2.54 \mathrm{E}-04$ & $3.43 \mathrm{E}-04$ \\
\hline V3ave & 92.00 & $5.67 \mathrm{E}-06$ & $3.00 \mathrm{E}-06$ & $8.67 \mathrm{E}-06$ & $2.67 \mathrm{E}-06$ & $1.67 \mathrm{E}-06$ & $3.00 \mathrm{E}-06$ & $1.37 \mathrm{E}-05$ & $1.20 \mathrm{E}-05$ & $1.60 \mathrm{E}-05$ \\
\hline Vtotave & 91.33 & $1.72 \mathrm{E}-05$ & $-7.33 \mathrm{E}-06$ & $4.18 \mathrm{E}-05$ & $2.56 \mathrm{E}-06$ & $1.89 \mathrm{E}-06$ & 3.33E-06 & $1.16 \mathrm{E}-04$ & $1.01 \mathrm{E}-04$ & $1.36 \mathrm{E}-04$ \\
\hline
\end{tabular}

\section{Zenith Velocity}

\begin{tabular}{|c|c|c|c|c|c|c|c|c|c|c|}
\hline Version & $\begin{array}{c}\text { Number of } \\
\text { Impacts }\end{array}$ & Mean & $\begin{array}{c}\text { 95\% CI for } \\
\text { Mean, Low }\end{array}$ & $\begin{array}{c}\text { 95\% CI for } \\
\text { Mean, } \\
\text { High }\end{array}$ & Median & $\begin{array}{c}\text { Median, } \\
\text { Low }\end{array}$ & $\begin{array}{c}\text { M5\% CI for } \\
\text { Median, } \\
\text { High }\end{array}$ & $\begin{array}{c}\text { 95\% CI for } \\
\text { StDev, } \\
\text { Low }\end{array}$ & $\begin{array}{c}\text { 95\% CI for } \\
\text { Stdev, } \\
\text { High }\end{array}$ \\
\hline V11 & 91.00 & 22.67 & 20.94 & 24.40 & 23.00 & 21.00 & 25.00 & 8.30 & 7.24 & 9.71 \\
\hline V12 & 96.00 & 24.25 & 22.26 & 26.24 & 24.00 & 21.00 & 27.00 & 9.81 & 8.59 & 11.44 \\
\hline V13 & 94.00 & 23.43 & 21.64 & 25.21 & 23.00 & 21.00 & 25.00 & 8.70 & 7.61 & 10.16 \\
\hline V21 & 87.00 & 22.54 & 20.90 & 24.18 & 21.00 & 21.00 & 23.00 & 7.70 & 6.70 & 9.05 \\
\hline V22 & 93.00 & 23.15 & 21.43 & 24.88 & 23.00 & 21.00 & 25.00 & 8.38 & 7.32 & 9.79 \\
\hline V23 & 85.00 & 25.19 & 23.44 & 26.94 & 25.00 & 23.00 & 25.06 & 8.12 & 7.05 & 9.56 \\
\hline V31 & 92.00 & 23.22 & 21.56 & 24.88 & 23.00 & 19.00 & 27.00 & 8.02 & 7.00 & 9.38 \\
\hline V32 & 96.00 & 22.85 & 20.66 & 25.05 & 21.00 & 19.00 & 24.00 & 10.77 & 9.43 & 12.57 \\
\hline V33 & 89.00 & 22.17 & 20.25 & 24.08 & 23.00 & 20.59 & 25.00 & 9.09 & 7.92 & 10.66 \\
\hline V1ave & 93.67 & 23.45 & 21.62 & 25.28 & 23.33 & 21.00 & 25.67 & 8.94 & 7.81 & 10.44 \\
\hline V2ave & 88.33 & 23.63 & 21.92 & 25.33 & 23.00 & 21.67 & 24.35 & 8.07 & 7.03 & 9.47 \\
\hline V3ave & 92.33 & 22.75 & 20.82 & 24.67 & 22.33 & 19.53 & 25.33 & 9.29 & 8.12 & 10.87 \\
\hline Vtotave & 91.44 & 23.27 & 21.45 & 25.09 & 22.89 & 20.73 & 25.12 & 8.76 & 7.65 & 10.26 \\
\hline
\end{tabular}

Nadir Mass

\begin{tabular}{|c|c|c|c|c|c|c|c|c|c|c|}
\hline Version & $\begin{array}{l}\text { Number of } \\
\text { Impacts }\end{array}$ & Mean & $\begin{array}{l}95 \% \text { CI for } \\
\text { Mean, Low }\end{array}$ & $\begin{array}{l}95 \% \text { CI for } \\
\text { Mean, } \\
\text { High }\end{array}$ & Median & $\begin{array}{l}95 \% \text { CI for } \\
\text { Median, } \\
\text { Low }\end{array}$ & $\begin{array}{l}\text { 95\% CI for } \\
\text { Median, } \\
\text { High }\end{array}$ & StDev & $\begin{array}{c}95 \% \text { CI for } \\
\text { StDev, } \\
\text { Low }\end{array}$ & $\begin{array}{c}95 \% \text { CI for } \\
\text { Stdev, } \\
\text { High }\end{array}$ \\
\hline V11 & 236.00 & $4.00 \mathrm{E}-05$ & $-2.60 \mathrm{E}-05$ & $1.07 \mathrm{E}-04$ & $3.00 \mathrm{E}-06$ & $2.00 \mathrm{E}-06$ & $3.00 \mathrm{E}-06$ & $5.21 \mathrm{E}-04$ & $4.77 \mathrm{E}-04$ & $5.72 \mathrm{E}-04$ \\
\hline V12 & 203.00 & $1.00 \mathrm{E}-05$ & $3.00 \mathrm{E}-06$ & $1.70 \mathrm{E}-05$ & $3.00 \mathrm{E}-06$ & $3.00 \mathrm{E}-06$ & $4.00 \mathrm{E}-06$ & $5.00 \mathrm{E}-05$ & $4.60 \mathrm{E}-05$ & $5.50 \mathrm{E}-05$ \\
\hline V13 & 227.00 & $5.00 \mathrm{E}-06$ & $4.00 \mathrm{E}-06$ & $7.00 \mathrm{E}-06$ & $2.00 \mathrm{E}-06$ & $2.00 \mathrm{E}-06$ & $3.00 \mathrm{E}-06$ & $1.00 \mathrm{E}-05$ & $9.00 \mathrm{E}-06$ & $1.10 \mathrm{E}-05$ \\
\hline V21 & 219.00 & $4.00 \mathrm{E}-06$ & $3.00 \mathrm{E}-06$ & $6.00 \mathrm{E}-06$ & $2.00 \mathrm{E}-06$ & $2.00 \mathrm{E}-06$ & $3.00 \mathrm{E}-06$ & $8.00 \mathrm{E}-06$ & $7.00 \mathrm{E}-06$ & $9.00 \mathrm{E}-06$ \\
\hline V22 & 218.00 & $6.00 \mathrm{E}-06$ & $4.00 \mathrm{E}-06$ & $7.00 \mathrm{E}-06$ & $3.00 \mathrm{E}-06$ & $2.00 \mathrm{E}-06$ & $4.00 \mathrm{E}-06$ & $9.00 \mathrm{E}-06$ & $8.00 \mathrm{E}-06$ & $1.00 \mathrm{E}-05$ \\
\hline V23 & 214.00 & $7.00 \mathrm{E}-06$ & $3.00 \mathrm{E}-06$ & $1.10 \mathrm{E}-05$ & $3.00 \mathrm{E}-06$ & $2.00 \mathrm{E}-06$ & $3.00 \mathrm{E}-06$ & $2.90 \mathrm{E}-05$ & $2.70 \mathrm{E}-05$ & $3.20 \mathrm{E}-05$ \\
\hline V31 & 225.00 & $4.00 \mathrm{E}-06$ & $3.00 \mathrm{E}-06$ & $6.00 \mathrm{E}-06$ & $3.00 \mathrm{E}-06$ & $2.00 \mathrm{E}-06$ & $3.00 \mathrm{E}-06$ & $8.00 \mathrm{E}-06$ & $8.00 \mathrm{E}-06$ & $9.00 \mathrm{E}-06$ \\
\hline V32 & 198.00 & $6.00 \mathrm{E}-06$ & $4.00 \mathrm{E}-06$ & $8.00 \mathrm{E}-06$ & $3.00 \mathrm{E}-06$ & $2.00 \mathrm{E}-06$ & $3.00 \mathrm{E}-06$ & $1.20 \mathrm{E}-05$ & $1.10 \mathrm{E}-05$ & $1.40 \mathrm{E}-05$ \\
\hline V33 & 228.00 & $5.00 \mathrm{E}-06$ & $4.00 \mathrm{E}-06$ & $5.00 \mathrm{E}-06$ & $3.00 \mathrm{E}-06$ & $2.00 \mathrm{E}-06$ & $3.00 \mathrm{E}-06$ & $7.00 \mathrm{E}-06$ & $7.00 \mathrm{E}-06$ & $8.00 \mathrm{E}-06$ \\
\hline V1ave & 222.00 & $1.83 \mathrm{E}-05$ & $-6.33 \mathrm{E}-06$ & $4.37 \mathrm{E}-05$ & $2.67 \mathrm{E}-06$ & $2.33 \mathrm{E}-06$ & $3.33 \mathrm{E}-06$ & $1.94 \mathrm{E}-04$ & $1.77 \mathrm{E}-04$ & $2.13 \mathrm{E}-04$ \\
\hline V2ave & 217.00 & $5.67 \mathrm{E}-06$ & $3.33 \mathrm{E}-06$ & $8.00 \mathrm{E}-06$ & $2.67 \mathrm{E}-06$ & $2.00 \mathrm{E}-06$ & $3.33 \mathrm{E}-06$ & $1.53 \mathrm{E}-05$ & $1.40 \mathrm{E}-05$ & $1.70 \mathrm{E}-05$ \\
\hline V3ave & 217.00 & $5.00 \mathrm{E}-06$ & $3.67 \mathrm{E}-06$ & $6.33 \mathrm{E}-06$ & $3.00 \mathrm{E}-06$ & $2.00 \mathrm{E}-06$ & $3.00 \mathrm{E}-06$ & $9.00 \mathrm{E}-06$ & $8.67 \mathrm{E}-06$ & $1.03 \mathrm{E}-05$ \\
\hline Vtotave & 218.67 & $9.67 \mathrm{E}-06$ & $2.22 \mathrm{E}-07$ & $1.93 \mathrm{E}-05$ & $2.78 \mathrm{E}-06$ & $2.11 \mathrm{E}-06$ & $3.22 \mathrm{E}-06$ & $7.27 \mathrm{E}-05$ & $6.67 \mathrm{E}-05$ & $8.00 \mathrm{E}-05$ \\
\hline
\end{tabular}


Nadir Velocity

\begin{tabular}{|c|c|c|c|c|c|c|c|c|c|c|}
\hline Version & $\begin{array}{c}\text { Number of } \\
\text { Impacts }\end{array}$ & Mean & $\begin{array}{c}\text { 95\% CI for } \\
\text { Mean, Low }\end{array}$ & $\begin{array}{c}\text { 95\% CI for } \\
\text { Mean, } \\
\text { High }\end{array}$ & Median & $\begin{array}{c}\text { Median, } \\
\text { Low }\end{array}$ & $\begin{array}{c}\text { M5\% CI for } \\
\text { Median, } \\
\text { High }\end{array}$ & $\begin{array}{c}\text { 95\% CI for } \\
\text { StDev, } \\
\text { Low }\end{array}$ & $\begin{array}{c}\text { 95\% CI for } \\
\text { Stdev, } \\
\text { High }\end{array}$ \\
\hline V11 & 236.00 & 18.47 & 17.19 & 19.74 & 18.00 & 17.00 & 19.00 & 9.97 & 9.14 & 10.96 \\
\hline V12 & 203.00 & 17.93 & 16.52 & 19.33 & 17.00 & 15.00 & 19.00 & 10.17 & 9.26 & 11.26 \\
\hline V13 & 227.00 & 17.99 & 16.65 & 9.33 & 17.00 & 15.00 & 19.00 & 10.25 & 9.39 & 11.29 \\
\hline V21 & 219.00 & 18.99 & 17.63 & 20.36 & 19.00 & 17.00 & 19.94 & 10.26 & 9.38 & 11.32 \\
\hline V22 & 218.00 & 18.14 & 16.86 & 19.41 & 17.00 & 17.00 & 19.00 & 9.56 & 8.74 & 10.56 \\
\hline V23 & 214.00 & 19.08 & 17.78 & 20.38 & 19.00 & 17.00 & 21.00 & 9.65 & 8.81 & 10.66 \\
\hline V31 & 225.00 & 18.32 & 17.00 & 19.65 & 17.00 & 15.00 & 19.00 & 10.05 & 9.20 & 11.07 \\
\hline V32 & 198.00 & 17.08 & 15.69 & 18.47 & 17.00 & 15.00 & 19.00 & 9.89 & 9.01 & 10.98 \\
\hline V33 & 228.00 & 18.98 & 17.66 & 20.31 & 19.00 & 17.00 & 21.00 & 10.16 & 9.30 & 11.19 \\
\hline V1ave & 222.00 & 18.13 & 16.78 & 16.14 & 17.33 & 15.67 & 19.00 & 10.13 & 9.26 & 11.17 \\
\hline V2ave & 217.00 & 18.73 & 17.42 & 20.05 & 18.33 & 17.00 & 19.98 & 9.82 & 8.98 & 10.84 \\
\hline V3ave & 217.00 & 18.13 & 16.79 & 19.47 & 17.67 & 15.67 & 19.67 & 10.03 & 9.17 & 11.08 \\
\hline Vtotave & 218.67 & 18.33 & 17.00 & 18.55 & 17.78 & 16.11 & 19.55 & 9.99 & 9.14 & 11.03 \\
\hline
\end{tabular}

Earth Mass

\begin{tabular}{|c|c|c|c|c|c|c|c|c|c|c|}
\hline Version & $\begin{array}{l}\text { Number of } \\
\text { Impacts }\end{array}$ & Mean & $\begin{array}{l}95 \% \text { CI for } \\
\text { Mean, Low }\end{array}$ & $\begin{array}{c}95 \% \text { CI for } \\
\text { Mean, } \\
\text { High }\end{array}$ & Median & $\begin{array}{l}95 \% \text { CI for } \\
\text { Median, } \\
\text { Low }\end{array}$ & $\begin{array}{l}95 \% \text { CI for } \\
\text { Median, } \\
\text { High }\end{array}$ & StDev & $\begin{array}{l}95 \% \text { CI for } \\
\text { StDev, } \\
\text { Low }\end{array}$ & $\begin{array}{c}95 \% \text { CI for } \\
\text { Stdev, } \\
\text { High }\end{array}$ \\
\hline V11 & 70.00 & $1.70 \mathrm{E}-05$ & $-3.00 \mathrm{E}-06$ & $3.70 \mathrm{E}-05$ & $4.00 \mathrm{E}-06$ & $3.00 \mathrm{E}-06$ & $5.00 \mathrm{E}-06$ & $8.40 \mathrm{E}-05$ & $7.20 \mathrm{E}-05$ & $1.01 \mathrm{E}-04$ \\
\hline V12 & 51.00 & $4.00 \mathrm{E}-06$ & $3.00 \mathrm{E}-06$ & $6.00 \mathrm{E}-06$ & $3.00 \mathrm{E}-06$ & $2.00 \mathrm{E}-06$ & $5.00 \mathrm{E}-06$ & $5.00 \mathrm{E}-06$ & $4.00 \mathrm{E}-06$ & $6.00 \mathrm{E}-06$ \\
\hline V13 & 59.00 & $7.00 \mathrm{E}-06$ & $4.00 \mathrm{E}-06$ & $9.00 \mathrm{E}-06$ & $3.00 \mathrm{E}-06$ & $2.00 \mathrm{E}-06$ & $5.00 \mathrm{E}-06$ & $1.10 \mathrm{E}-05$ & $1.00 \mathrm{E}-05$ & $1.40 \mathrm{E}-05$ \\
\hline V21 & 65.00 & $5.00 \mathrm{E}-06$ & $3.00 \mathrm{E}-06$ & $8.00 \mathrm{E}-06$ & $2.00 \mathrm{E}-06$ & $1.00 \mathrm{E}-06$ & $3.00 \mathrm{E}-06$ & $1.10 \mathrm{E}-05$ & $1.00 \mathrm{E}-05$ & $1.40 \mathrm{E}-05$ \\
\hline V22 & 72.00 & $7.00 \mathrm{E}-06$ & $3.00 \mathrm{E}-06$ & $1.00 \mathrm{E}-05$ & $2.00 \mathrm{E}-06$ & $2.00 \mathrm{E}-06$ & $4.00 \mathrm{E}-06$ & $1.50 \mathrm{E}-05$ & $1.30 \mathrm{E}-05$ & $1.80 \mathrm{E}-05$ \\
\hline $\mathrm{V} 23$ & 79.00 & $5.00 \mathrm{E}-06$ & $4.00 \mathrm{E}-06$ & $6.00 \mathrm{E}-06$ & $3.00 \mathrm{E}-06$ & $2.00 \mathrm{E}-06$ & $4.00 \mathrm{E}-06$ & $5.00 \mathrm{E}-06$ & $4.00 \mathrm{E}-06$ & $6.00 \mathrm{E}-06$ \\
\hline V32 & 77.00 & $6.00 \mathrm{E}-06$ & $3.00 \mathrm{E}-06$ & $8.00 \mathrm{E}-06$ & $3.00 \mathrm{E}-06$ & $2.00 \mathrm{E}-06$ & $4.00 \mathrm{E}-06$ & $1.10 \mathrm{E}-05$ & $9.00 \mathrm{E}-06$ & $1.30 \mathrm{E}-05$ \\
\hline V33 & 59.00 & $6.00 \mathrm{E}-06$ & $3.00 \mathrm{E}-06$ & $8.00 \mathrm{E}-06$ & $3.00 \mathrm{E}-06$ & $2.00 \mathrm{E}-06$ & $4.00 \mathrm{E}-06$ & $1.00 \mathrm{E}-05$ & $8.00 \mathrm{E}-06$ & $1.20 \mathrm{E}-05$ \\
\hline V1ave & 60.00 & $9.33 \mathrm{E}-06$ & $1.33 \mathrm{E}-06$ & $1.73 \mathrm{E}-05$ & $3.33 \mathrm{E}-06$ & $2.33 \mathrm{E}-06$ & $5.00 \mathrm{E}-06$ & $3.33 \mathrm{E}-05$ & $2.87 \mathrm{E}-05$ & $4.03 \mathrm{E}-05$ \\
\hline V2ave & 72.00 & $5.67 \mathrm{E}-06$ & $3.33 \mathrm{E}-06$ & $8.00 \mathrm{E}-06$ & $2.33 \mathrm{E}-06$ & $1.67 \mathrm{E}-06$ & $3.67 \mathrm{E}-06$ & $1.03 \mathrm{E}-05$ & $9.00 \mathrm{E}-06$ & $1.27 \mathrm{E}-05$ \\
\hline V3ave & 69.00 & $6.67 \mathrm{E}-06$ & $3.33 \mathrm{E}-06$ & $9.33 \mathrm{E}-06$ & $3.00 \mathrm{E}-06$ & $2.00 \mathrm{E}-06$ & $4.00 \mathrm{E}-06$ & $1.27 \mathrm{E}-05$ & $1.03 \mathrm{E}-05$ & $1.50 \mathrm{E}-05$ \\
\hline Vtotave & 67.00 & $7.22 \mathrm{E}-06$ & $2.67 \mathrm{E}-06$ & $1.16 \mathrm{E}-05$ & $2.89 \mathrm{E}-06$ & $2.00 \mathrm{E}-06$ & $4.22 \mathrm{E}-06$ & $1.88 \mathrm{E}-05$ & $1.60 \mathrm{E}-05$ & $2.27 \mathrm{E}-05$ \\
\hline
\end{tabular}

Earth Velocity

\begin{tabular}{|c|c|c|c|c|c|c|c|c|c|c|}
\hline Version & $\begin{array}{l}\text { Number of } \\
\text { Impacts }\end{array}$ & Mean & $\begin{array}{l}95 \% \text { CI for } \\
\text { Mean, Low }\end{array}$ & $\begin{array}{l}95 \% \text { CI for } \\
\text { Mean, } \\
\text { High }\end{array}$ & Median & $\begin{array}{l}95 \% \text { CI for } \\
\text { Median, } \\
\text { Low }\end{array}$ & $\begin{array}{l}95 \% \text { CI for } \\
\text { Median, } \\
\text { High }\end{array}$ & StDev & $\begin{array}{c}95 \% \text { CI for } \\
\text { StDev, } \\
\text { Low }\end{array}$ & $\begin{array}{c}95 \% \text { CI for } \\
\text { Stdev, } \\
\text { High }\end{array}$ \\
\hline V11 & 70.00 & 20.97 & 19.03 & 22.91 & 21.00 & 17.70 & 23.00 & 8.13 & 6.97 & 9.76 \\
\hline V12 & 51.00 & 22.41 & 20.10 & 24.72 & 23.00 & 19.00 & 23.00 & 8.22 & 6.88 & 10.22 \\
\hline V13 & 59.00 & 23.41 & 21.49 & 25.33 & 23.00 & 21.00 & 25.00 & 7.36 & 6.23 & 8.99 \\
\hline V21 & 65.00 & 22.75 & 20.53 & 24.98 & 23.00 & 21.00 & 27.00 & 8.98 & 7.66 & 10.86 \\
\hline V22 & 72.00 & 23.11 & 21.05 & 25.18 & 23.00 & 21.00 & 25.00 & 8.79 & 7.55 & 10.52 \\
\hline V23 & 79.00 & 23.32 & 20.40 & 24.23 & 21.00 & 19.00 & 24.33 & 8.54 & 7.38 & 10.13 \\
\hline V32 & 77.00 & 21.78 & 19.97 & 23.59 & 23.00 & 19.00 & 25.00 & 7.96 & 6.87 & 9.46 \\
\hline V33 & 59.00 & 25.54 & 23.06 & 28.02 & 25.00 & 23.00 & 31.00 & 9.51 & 8.05 & 11.62 \\
\hline V1ave & 60.00 & 22.26 & 20.21 & 24.32 & 22.33 & 19.23 & 23.67 & 7.90 & 6.69 & 9.66 \\
\hline V2ave & 72.00 & 23.06 & 20.66 & 24.80 & 22.33 & 20.33 & 25.44 & 8.77 & 7.53 & 10.50 \\
\hline V3ave & 69.00 & 22.93 & 20.81 & 25.06 & 23.00 & 19.67 & 26.33 & 8.78 & 7.51 & 10.57 \\
\hline Vtotave & 67.00 & 22.75 & 20.56 & 24.73 & 22.56 & 19.74 & 25.15 & 8.48 & 7.24 & 10.24 \\
\hline
\end{tabular}


Sun Mass

\begin{tabular}{|c|c|c|c|c|c|c|c|c|c|c|}
\hline Version & $\begin{array}{c}\text { Number of } \\
\text { Impacts }\end{array}$ & Mean & $\begin{array}{l}95 \% \text { CI for } \\
\text { Mean, Low }\end{array}$ & $\begin{array}{l}95 \% \text { CI for } \\
\text { Mean, } \\
\text { High }\end{array}$ & Median & $\begin{array}{l}95 \% \text { CI for } \\
\text { Median, } \\
\text { Low }\end{array}$ & $\begin{array}{l}95 \% \text { CI for } \\
\text { Median, } \\
\text { High }\end{array}$ & StDev & $\begin{array}{c}95 \% \text { CI for } \\
\text { StDev, } \\
\text { Low }\end{array}$ & $\begin{array}{c}95 \% \text { CI for } \\
\text { Stdev, } \\
\text { High }\end{array}$ \\
\hline V11 & 83.00 & $4.00 \mathrm{E}-06$ & $3.00 \mathrm{E}-06$ & $4.00 \mathrm{E}-06$ & $2.00 \mathrm{E}-06$ & $3.00 \mathrm{E}-06$ & $3.00 \mathrm{E}-06$ & $3.00 \mathrm{E}-06$ & $3.00 \mathrm{E}-06$ & $4.00 \mathrm{E}-06$ \\
\hline V12 & 68.00 & $7.00 \mathrm{E}-06$ & $3.00 \mathrm{E}-06$ & $1.10 \mathrm{E}-05$ & $2.00 \mathrm{E}-06$ & $1.00 \mathrm{E}-06$ & $4.00 \mathrm{E}-06$ & $1.70 \mathrm{E}-05$ & $1.50 \mathrm{E}-05$ & $2.00 \mathrm{E}-05$ \\
\hline V13 & 79.00 & $5.00 \mathrm{E}-06$ & $3.00 \mathrm{E}-06$ & $6.00 \mathrm{E}-06$ & $3.00 \mathrm{E}-06$ & $2.00 \mathrm{E}-06$ & $4.00 \mathrm{E}-06$ & $6.00 \mathrm{E}-06$ & $5.00 \mathrm{E}-06$ & $7.00 \mathrm{E}-06$ \\
\hline V21 & 86.00 & $5.00 \mathrm{E}-06$ & $3.00 \mathrm{E}-06$ & $7.00 \mathrm{E}-06$ & $2.00 \mathrm{E}-06$ & $2.00 \mathrm{E}-06$ & $3.00 \mathrm{E}-06$ & $9.00 \mathrm{E}-06$ & $8.00 \mathrm{E}-06$ & $1.10 \mathrm{E}-05$ \\
\hline V22 & 87.00 & $6.00 \mathrm{E}-06$ & $1.00 \mathrm{E}-06$ & $1.00 \mathrm{E}-05$ & $2.00 \mathrm{E}-06$ & $2.00 \mathrm{E}-06$ & $3.00 \mathrm{E}-06$ & $2.10 \mathrm{E}-05$ & $1.80 \mathrm{E}-05$ & $2.50 \mathrm{E}-05$ \\
\hline V23 & 83.00 & $5.00 \mathrm{E}-06$ & $3.00 \mathrm{E}-06$ & $8.00 \mathrm{E}-06$ & $3.00 \mathrm{E}-06$ & $2.00 \mathrm{E}-06$ & $4.00 \mathrm{E}-06$ & $1.10 \mathrm{E}-05$ & $1.00 \mathrm{E}-05$ & $1.30 \mathrm{E}-05$ \\
\hline V31 & 73.00 & $5.00 \mathrm{E}-06$ & $3.00 \mathrm{E}-06$ & $7.00 \mathrm{E}-06$ & $2.00 \mathrm{E}-06$ & $2.00 \mathrm{E}-06$ & $3.00 \mathrm{E}-06$ & $9.00 \mathrm{E}-06$ & $8.00 \mathrm{E}-06$ & $1.10 \mathrm{E}-05$ \\
\hline V32 & 87.00 & $4.00 \mathrm{E}-06$ & $3.00 \mathrm{E}-06$ & $5.00 \mathrm{E}-06$ & $3.00 \mathrm{E}-06$ & $2.00 \mathrm{E}-06$ & $4.00 \mathrm{E}-06$ & $4.00 \mathrm{E}-06$ & $4.00 \mathrm{E}-06$ & $5.00 \mathrm{E}-06$ \\
\hline V33 & 71.00 & $5.00 \mathrm{E}-06$ & $3.00 \mathrm{E}-06$ & $6.00 \mathrm{E}-06$ & $3.00 \mathrm{E}-06$ & $2.00 \mathrm{E}-06$ & $4.00 \mathrm{E}-06$ & $5.00 \mathrm{E}-06$ & $5.00 \mathrm{E}-06$ & $6.00 \mathrm{E}-06$ \\
\hline V1ave & 76.67 & $5.33 \mathrm{E}-06$ & $3.00 \mathrm{E}-06$ & 7.00E-06 & $2.33 \mathrm{E}-06$ & $2.00 \mathrm{E}-06$ & $3.67 \mathrm{E}-06$ & $8.67 \mathrm{E}-06$ & 7.67E-06 & $1.03 \mathrm{E}-05$ \\
\hline V2ave & 85.33 & 5.33E-06 & $2.33 \mathrm{E}-06$ & $8.33 \mathrm{E}-06$ & $2.33 \mathrm{E}-06$ & $2.00 \mathrm{E}-06$ & $3.33 \mathrm{E}-06$ & $1.37 \mathrm{E}-05$ & $1.20 \mathrm{E}-05$ & $1.63 \mathrm{E}-05$ \\
\hline V3ave & 77.00 & 4.67E-06 & $3.00 \mathrm{E}-06$ & $6.00 \mathrm{E}-06$ & $2.67 \mathrm{E}-06$ & $2.00 \mathrm{E}-06$ & $3.67 \mathrm{E}-06$ & $6.00 \mathrm{E}-06$ & $5.67 \mathrm{E}-06$ & 7.33E-06 \\
\hline Vtotave & 79.67 & $5.11 \mathrm{E}-06$ & $2.78 \mathrm{E}-06$ & $7.11 \mathrm{E}-06$ & $2.44 \mathrm{E}-06$ & $2.00 \mathrm{E}-06$ & $3.56 \mathrm{E}-06$ & $9.44 \mathrm{E}-06$ & $8.44 \mathrm{E}-06$ & $1.13 \mathrm{E}-05$ \\
\hline
\end{tabular}

Sun Velocity

\begin{tabular}{|c|c|c|c|c|c|c|c|c|c|c|}
\hline Version & $\begin{array}{l}\text { Number of } \\
\text { Impacts }\end{array}$ & Mean & $\begin{array}{l}95 \% \text { CI for } \\
\text { Mean, Low }\end{array}$ & $\begin{array}{c}95 \% \text { CI for } \\
\text { Mean, } \\
\text { High }\end{array}$ & Median & $\begin{array}{l}95 \% \text { CI for } \\
\text { Median, } \\
\text { Low }\end{array}$ & $\begin{array}{c}95 \% \text { CI for } \\
\text { Median, } \\
\text { High }\end{array}$ & StDev & $\begin{array}{c}95 \% \text { CI for } \\
\text { StDev, } \\
\text { Low }\end{array}$ & $\begin{array}{c}95 \% \text { CI for } \\
\text { Stdev, } \\
\text { High }\end{array}$ \\
\hline V11 & 83.00 & 22.52 & 20.48 & 24.56 & 23.00 & 19.17 & 25.00 & 9.33 & 8.10 & 11.02 \\
\hline V12 & 68.00 & 23.94 & 21.80 & 26.09 & 23.00 & 21.96 & 25.00 & 8.86 & 7.58 & 10.66 \\
\hline V13 & 79.00 & 22.98 & 21.20 & 24.75 & 23.00 & 19.00 & 25.00 & 7.91 & 6.84 & 9.38 \\
\hline V21 & 86.00 & 23.07 & 21.59 & 24.55 & 23.00 & 21.00 & 25.00 & 6.92 & 6.02 & 8.14 \\
\hline V22 & 87.00 & 22.93 & 21.06 & 24.81 & 23.00 & 19.00 & 25.00 & 8.80 & 7.66 & 10.34 \\
\hline V23 & 83.00 & 23.92 & 22.11 & 25.73 & 25.00 & 23.00 & 26.83 & 8.29 & 7.19 & 9.79 \\
\hline V31 & 73.00 & 22.73 & 20.77 & 24.68 & 21.00 & 19.00 & 25.00 & 8.39 & 7.21 & 10.02 \\
\hline V32 & 87.00 & 21.53 & 19.84 & 23.22 & 21.00 & 19.00 & 23.00 & 7.93 & 6.90 & 9.33 \\
\hline V33 & 71.00 & 21.65 & 19.59 & 23.70 & 21.00 & 19.00 & 23.42 & 8.68 & 7.45 & 10.41 \\
\hline V1ave & 76.67 & 23.14 & 21.16 & 25.13 & 23.00 & 20.04 & 25.00 & 8.70 & 7.50 & 10.35 \\
\hline V2ave & 85.33 & 23.31 & 21.58 & 25.03 & 23.67 & 21.00 & 25.61 & 8.00 & 6.96 & 9.42 \\
\hline V3ave & 77.00 & 21.97 & 20.07 & 23.87 & 21.00 & 19.00 & 23.81 & 8.34 & 7.19 & 9.92 \\
\hline Vtotave & 79.67 & 22.81 & 20.94 & 24.68 & 22.56 & 20.01 & 24.81 & 8.35 & 7.22 & 9.90 \\
\hline
\end{tabular}

Antisun Mass

\begin{tabular}{|c|c|c|c|c|c|c|c|c|c|c|}
\hline Version & $\begin{array}{l}\text { Number of } \\
\text { Impacts }\end{array}$ & Mean & $\begin{array}{l}\text { 95\% CI for } \\
\text { Mean, Low }\end{array}$ & $\begin{array}{c}95 \% \text { CI for } \\
\text { Mean, } \\
\text { High }\end{array}$ & Median & $\begin{array}{l}95 \% \text { CI for } \\
\text { Median, } \\
\text { Low }\end{array}$ & $\begin{array}{l}\text { 95\% CI for } \\
\text { Median, } \\
\text { High }\end{array}$ & StDev & $\begin{array}{l}95 \% \text { CI for } \\
\text { StDev, } \\
\text { Low }\end{array}$ & $\begin{array}{c}95 \% \text { CI for } \\
\text { Stdev, } \\
\text { High }\end{array}$ \\
\hline V11 & 235.00 & $6.00 \mathrm{E}-06$ & $5.00 \mathrm{E}-06$ & $7.00 \mathrm{E}-06$ & $3.00 \mathrm{E}-06$ & $3.00 \mathrm{E}-06$ & $4.00 \mathrm{E}-06$ & $1.10 \mathrm{E}-05$ & $1.00 \mathrm{E}-05$ & $1.20 \mathrm{E}-05$ \\
\hline V12 & 231.00 & $7.00 \mathrm{E}-06$ & $4.00 \mathrm{E}-06$ & $1.00 \mathrm{E}-05$ & $3.00 \mathrm{E}-06$ & $2.00 \mathrm{E}-06$ & $3.00 \mathrm{E}-06$ & $2.20 \mathrm{E}-05$ & $2.00 \mathrm{E}-05$ & $2.40 \mathrm{E}-05$ \\
\hline V13 & 235.00 & $5.00 \mathrm{E}-06$ & $4.00 \mathrm{E}-06$ & $7.00 \mathrm{E}-06$ & $3.00 \mathrm{E}-06$ & $2.00 \mathrm{E}-06$ & $4.00 \mathrm{E}-06$ & $1.00 \mathrm{E}-05$ & $9.00 \mathrm{E}-06$ & $1.10 \mathrm{E}-05$ \\
\hline V21 & 234.00 & $8.00 \mathrm{E}-06$ & $4.00 \mathrm{E}-06$ & $1.10 \mathrm{E}-05$ & $3.00 \mathrm{E}-06$ & $2.00 \mathrm{E}-06$ & $3.00 \mathrm{E}-06$ & $2.80 \mathrm{E}-05$ & $2.60 \mathrm{E}-05$ & $3.10 \mathrm{E}-05$ \\
\hline V22 & 242.00 & $1.00 \mathrm{E}-05$ & $4.00 \mathrm{E}-06$ & $1.60 \mathrm{E}-05$ & $2.00 \mathrm{E}-06$ & $2.00 \mathrm{E}-06$ & $3.00 \mathrm{E}-06$ & $4.80 \mathrm{E}-05$ & $4.40 \mathrm{E}-05$ & $5.30 \mathrm{E}-05$ \\
\hline V23 & 238.00 & $6.00 \mathrm{E}-06$ & $4.00 \mathrm{E}-06$ & $7.00 \mathrm{E}-06$ & $3.00 \mathrm{E}-06$ & $2.00 \mathrm{E}-06$ & $3.00 \mathrm{E}-06$ & $1.00 \mathrm{E}-05$ & $1.00 \mathrm{E}-05$ & $1.10 \mathrm{E}-05$ \\
\hline V32 & 250.00 & $1.00 \mathrm{E}-05$ & $4.00 \mathrm{E}-06$ & $1.60 \mathrm{E}-05$ & $3.00 \mathrm{E}-06$ & $3.00 \mathrm{E}-06$ & $4.00 \mathrm{E}-06$ & $5.00 \mathrm{E}-05$ & $4.60 \mathrm{E}-05$ & $5.50 \mathrm{E}-05$ \\
\hline V33 & 211.00 & $1.00 \mathrm{E}-05$ & $5.00 \mathrm{E}-06$ & $1.50 \mathrm{E}-05$ & $2.00 \mathrm{E}-06$ & $2.00 \mathrm{E}-06$ & $3.00 \mathrm{E}-06$ & $3.80 \mathrm{E}-05$ & $3.50 \mathrm{E}-05$ & $4.20 \mathrm{E}-05$ \\
\hline V1ave & 233.67 & $6.00 \mathrm{E}-06$ & $4.33 \mathrm{E}-06$ & $8.00 \mathrm{E}-06$ & $3.00 \mathrm{E}-06$ & $2.33 \mathrm{E}-06$ & $3.67 \mathrm{E}-06$ & $1.43 \mathrm{E}-05$ & $1.30 \mathrm{E}-05$ & $1.57 \mathrm{E}-05$ \\
\hline V2ave & 238.00 & $8.00 \mathrm{E}-06$ & $4.00 \mathrm{E}-06$ & $1.13 \mathrm{E}-05$ & $2.67 \mathrm{E}-06$ & $2.00 \mathrm{E}-06$ & $3.00 \mathrm{E}-06$ & $2.87 \mathrm{E}-05$ & $2.67 \mathrm{E}-05$ & $3.17 \mathrm{E}-05$ \\
\hline V3ave & 233.67 & $9.33 \mathrm{E}-06$ & $4.67 \mathrm{E}-06$ & $1.43 \mathrm{E}-05$ & $2.67 \mathrm{E}-06$ & $2.33 \mathrm{E}-06$ & $3.33 \mathrm{E}-06$ & $3.80 \mathrm{E}-05$ & $3.50 \mathrm{E}-05$ & $4.20 \mathrm{E}-05$ \\
\hline Vtotave & 235.11 & $7.78 \mathrm{E}-06$ & $4.33 \mathrm{E}-06$ & $1.12 \mathrm{E}-05$ & $2.78 \mathrm{E}-06$ & $2.22 \mathrm{E}-06$ & $3.33 \mathrm{E}-06$ & $2.70 \mathrm{E}-05$ & $2.49 \mathrm{E}-05$ & $2.98 \mathrm{E}-05$ \\
\hline
\end{tabular}




\section{Antisun Velocity}

\begin{tabular}{|c|c|c|c|c|c|c|c|c|c|c|}
\hline Version & $\begin{array}{l}\text { Number of } \\
\text { Impacts }\end{array}$ & Mean & $\begin{array}{l}95 \% \text { CI for } \\
\text { Mean, Low }\end{array}$ & $\begin{array}{l}95 \% \text { CI for } \\
\text { Mean, } \\
\text { High }\end{array}$ & Median & $\begin{array}{l}95 \% \text { CI for } \\
\text { Median, } \\
\text { Low }\end{array}$ & $\begin{array}{l}95 \% \text { CI for } \\
\text { Median, } \\
\text { High }\end{array}$ & StDev & $\begin{array}{l}95 \% \text { CI for } \\
\text { StDev, } \\
\text { Low }\end{array}$ & $\begin{array}{c}95 \% \text { CI for } \\
\text { Stdev, } \\
\text { High }\end{array}$ \\
\hline V11 & 235.00 & 17.44 & 16.12 & 18.77 & 17.00 & 15.00 & 17.04 & 10.29 & 9.44 & 11.32 \\
\hline V12 & 231.00 & 18.22 & 16.98 & 19.46 & 17.00 & 15.00 & 21.00 & 9.57 & 8.77 & 10.53 \\
\hline V13 & 235.00 & 18.35 & 17.06 & 19.63 & 17.00 & 15.00 & 19.00 & 10.00 & 9.17 & 10.99 \\
\hline V21 & 234.00 & 19.14 & 17.85 & 20.42 & 19.00 & 17.00 & 21.00 & 9.97 & 9.14 & 10.96 \\
\hline V22 & 242.00 & 18.51 & 17.15 & 19.88 & 19.00 & 17.00 & 19.00 & 10.80 & 9.92 & 11.86 \\
\hline V23 & 238.00 & 18.42 & 17.05 & 19.79 & 17.00 & 15.00 & 19.00 & 10.70 & 9.81 & 11.75 \\
\hline V31 & 240.00 & 19.32 & 17.95 & 20.68 & 19.00 & 15.00 & 21.00 & 10.75 & 9.87 & 11.81 \\
\hline V32 & 250.00 & 17.74 & 16.47 & 19.01 & 17.00 & 15.00 & 19.00 & 10.19 & 9.37 & 11.18 \\
\hline V33 & 211.00 & 17.67 & 16.30 & 19.04 & 17.00 & 15.00 & 19.00 & 10.10 & 9.22 & 11.17 \\
\hline V1ave & 233.67 & 18.00 & 16.72 & 19.29 & 17.00 & 15.00 & 19.01 & 9.95 & 9.12 & 10.95 \\
\hline V2ave & 238.00 & 18.69 & 17.35 & 20.03 & 18.33 & 16.33 & 19.67 & 10.49 & 9.62 & 11.52 \\
\hline V3ave & 233.67 & 18.24 & 16.91 & 19.58 & 17.67 & 15.00 & 19.67 & 10.35 & 9.49 & 11.38 \\
\hline Vtotave & 235.11 & 18.31 & 16.99 & 19.63 & 17.67 & 15.44 & 19.45 & 10.26 & 9.41 & 11.29 \\
\hline
\end{tabular}

\section{Hohmann1}

Ram Mass

\begin{tabular}{|c|c|c|c|c|c|c|c|c|c|c|}
\hline Version & $\begin{array}{l}\text { Number of } \\
\text { Impacts }\end{array}$ & Mean & $\begin{array}{l}95 \% \text { CI for } \\
\text { Mean, Low }\end{array}$ & $\begin{array}{l}\text { 95\% CI for } \\
\text { Mean, High }\end{array}$ & Median & $\begin{array}{l}\text { 95\% CI for } \\
\text { Median, } \\
\text { Low }\end{array}$ & $\begin{array}{c}95 \% \text { CI for } \\
\text { Median, } \\
\text { High }\end{array}$ & StDev & $\begin{array}{l}95 \% \text { CI for } \\
\text { StDev, } \\
\text { Low }\end{array}$ & $\begin{array}{c}95 \% \text { CI for } \\
\text { Stdev, } \\
\text { High }\end{array}$ \\
\hline V11 & 270.00 & $9.00 \mathrm{E}-06$ & $3.00 \mathrm{E}-06$ & $1.40 \mathrm{E}-05$ & $3.00 \mathrm{E}-06$ & $2.00 \mathrm{E}-06$ & $3.00 \mathrm{E}-06$ & $4.40 \mathrm{E}-05$ & $4.10 \mathrm{E}-05$ & $4.80 \mathrm{E}-05$ \\
\hline V12 & 302.00 & $8.00 \mathrm{E}-06$ & $4.00 \mathrm{E}-06$ & $1.20 \mathrm{E}-05$ & $3.00 \mathrm{E}-06$ & $2.00 \mathrm{E}-06$ & $3.00 \mathrm{E}-06$ & $3.40 \mathrm{E}-05$ & $3.10 \mathrm{E}-05$ & $3.70 \mathrm{E}-05$ \\
\hline V13 & 279.00 & $5.00 \mathrm{E}-06$ & $4.00 \mathrm{E}-06$ & $7.00 \mathrm{E}-06$ & $3.00 \mathrm{E}-06$ & $2.00 \mathrm{E}-06$ & $3.00 \mathrm{E}-06$ & $1.10 \mathrm{E}-05$ & $1.00 \mathrm{E}-05$ & $1.20 \mathrm{E}-05$ \\
\hline V21 & 339.00 & $8.00 \mathrm{E}-06$ & $3.00 \mathrm{E}-06$ & $1.40 \mathrm{E}-05$ & $2.00 \mathrm{E}-06$ & $2.00 \mathrm{E}-06$ & $3.00 \mathrm{E}-06$ & $5.10 \mathrm{E}-05$ & $4.70 \mathrm{E}-05$ & $5.50 \mathrm{E}-05$ \\
\hline V22 & 331.00 & $7.00 \mathrm{E}-06$ & $4.00 \mathrm{E}-06$ & $1.00 \mathrm{E}-05$ & $3.00 \mathrm{E}-06$ & $2.00 \mathrm{E}-06$ & $3.00 \mathrm{E}-06$ & $2.90 \mathrm{E}-05$ & $2.70 \mathrm{E}-05$ & $3.10 \mathrm{E}-05$ \\
\hline V23 & 290.00 & $6.00 \mathrm{E}-06$ & $4.00 \mathrm{E}-06$ & $7.00 \mathrm{E}-06$ & $2.00 \mathrm{E}-06$ & $2.00 \mathrm{E}-06$ & $3.00 \mathrm{E}-06$ & $1.20 \mathrm{E}-05$ & $1.10 \mathrm{E}-05$ & $1.30 \mathrm{E}-05$ \\
\hline V31 & 278.00 & $8.00 \mathrm{E}-06$ & $5.00 \mathrm{E}-06$ & $1.10 \mathrm{E}-05$ & $3.00 \mathrm{E}-06$ & $3.00 \mathrm{E}-06$ & $4.00 \mathrm{E}-06$ & $2.50 \mathrm{E}-05$ & $2.30 \mathrm{E}-05$ & $2.70 \mathrm{E}-05$ \\
\hline V32 & 314.00 & $6.00 \mathrm{E}-06$ & $4.00 \mathrm{E}-06$ & $7.00 \mathrm{E}-06$ & $2.00 \mathrm{E}-06$ & $2.00 \mathrm{E}-06$ & $3.00 \mathrm{E}-06$ & $1.30 \mathrm{E}-05$ & $1.20 \mathrm{E}-05$ & $1.40 \mathrm{E}-05$ \\
\hline V33 & 294.00 & $5.00 \mathrm{E}-06$ & $4.00 \mathrm{E}-06$ & $6.00 \mathrm{E}-06$ & $3.00 \mathrm{E}-06$ & $2.00 \mathrm{E}-06$ & $3.00 \mathrm{E}-06$ & $7.00 \mathrm{E}-06$ & $7.00 \mathrm{E}-06$ & $8.00 \mathrm{E}-06$ \\
\hline V1ave & 283.67 & 7.33E-06 & 3.67E-06 & $1.10 \mathrm{E}-05$ & $3.00 \mathrm{E}-06$ & $2.00 \mathrm{E}-06$ & $3.00 \mathrm{E}-06$ & $2.97 \mathrm{E}-05$ & $2.73 \mathrm{E}-05$ & $3.23 \mathrm{E}-05$ \\
\hline V2ave & 320.00 & $7.00 \mathrm{E}-06$ & $3.67 \mathrm{E}-06$ & $1.03 \mathrm{E}-05$ & $2.33 \mathrm{E}-06$ & $2.00 \mathrm{E}-06$ & $3.00 \mathrm{E}-06$ & $3.07 \mathrm{E}-05$ & $2.83 \mathrm{E}-05$ & $3.30 \mathrm{E}-05$ \\
\hline V3ave & 295.33 & $6.33 \mathrm{E}-06$ & $4.33 \mathrm{E}-06$ & $8.00 \mathrm{E}-06$ & $2.67 \mathrm{E}-06$ & $2.33 \mathrm{E}-06$ & $3.33 \mathrm{E}-06$ & $1.50 \mathrm{E}-05$ & $1.40 \mathrm{E}-05$ & $1.63 \mathrm{E}-05$ \\
\hline Vtotave & 299.67 & $6.89 \mathrm{E}-06$ & $3.89 \mathrm{E}-06$ & $9.78 \mathrm{E}-06$ & $2.67 \mathrm{E}-06$ & $2.11 \mathrm{E}-06$ & $3.11 \mathrm{E}-06$ & $2.51 \mathrm{E}-05$ & $2.32 \mathrm{E}-05$ & $2.72 \mathrm{E}-05$ \\
\hline
\end{tabular}

Ram Velocity

\begin{tabular}{|c|c|c|c|c|c|c|c|c|c|c|}
\hline Version & $\begin{array}{l}\text { Number of } \\
\text { Impacts }\end{array}$ & Mean & $\begin{array}{l}95 \% \text { CI for } \\
\text { Mean, Low }\end{array}$ & $\begin{array}{l}95 \% \text { CI for } \\
\text { Mean, } \\
\text { High }\end{array}$ & Median & $\begin{array}{l}95 \% \text { CI for } \\
\text { Median, } \\
\text { Low }\end{array}$ & $\begin{array}{l}\text { 95\% CI for } \\
\text { Median, } \\
\text { High }\end{array}$ & StDev & $\begin{array}{c}95 \% \text { CI for } \\
\text { StDev, } \\
\text { Low }\end{array}$ & $\begin{array}{c}95 \% \text { CI for } \\
\text { Stdev, } \\
\text { High }\end{array}$ \\
\hline V11 & 270.00 & 22.25 & 20.64 & 23.86 & 21.00 & 19.00 & 22.15 & 13.42 & 12.38 & 14.66 \\
\hline V12 & 302.00 & 22.47 & 21.10 & 23.84 & 21.00 & 19.00 & 23.00 & 12.10 & 11.20 & 13.15 \\
\hline V13 & 279.00 & 22.24 & 20.69 & 23.79 & 21.00 & 19.00 & 23.00 & 13.18 & 12.17 & 14.38 \\
\hline V21 & 339.00 & 23.02 & 21.71 & 24.34 & 21.00 & 21.00 & 23.00 & 12.34 & 11.47 & 13.34 \\
\hline V22 & 331.00 & 22.43 & 21.13 & 23.72 & 21.00 & 19.00 & 23.00 & 11.99 & 11.14 & 12.98 \\
\hline V23 & 290.00 & 22.44 & 20.97 & 23.91 & 21.00 & 19.00 & 21.00 & 12.73 & 11.77 & 13.86 \\
\hline V31 & 278.00 & 23.96 & 22.38 & 25.53 & 23.00 & 21.00 & 23.00 & 13.32 & 12.30 & 14.53 \\
\hline V32 & 314.00 & 23.20 & 21.79 & 24.62 & 23.00 & 21.00 & 25.00 & 12.74 & 11.81 & 13.82 \\
\hline V33 & 294.00 & 23.10 & 21.59 & 24.61 & 21.00 & 19.00 & 23.00 & 13.15 & 12.16 & 14.31 \\
\hline V1ave & 283.67 & 22.32 & 20.81 & 23.83 & 21.00 & 19.00 & 22.72 & 12.90 & 11.92 & 14.06 \\
\hline V2ave & 320.00 & 22.63 & 21.27 & 23.99 & 21.00 & 19.67 & 22.33 & 12.35 & 11.46 & 13.39 \\
\hline V3ave & 295.33 & 23.42 & 21.92 & 24.92 & 22.33 & 20.33 & 23.67 & 13.07 & 12.09 & 14.22 \\
\hline Vtotave & 299.67 & 22.79 & 21.33 & 24.25 & 21.44 & 19.67 & 22.91 & 12.77 & 11.82 & 13.89 \\
\hline
\end{tabular}


Wake Mass

\begin{tabular}{|c|c|c|c|c|c|c|c|c|c|c|}
\hline Version & $\begin{array}{l}\text { Number of } \\
\text { Impacts }\end{array}$ & Mean & $\begin{array}{l}95 \% \text { CI for } \\
\text { Mean, Low }\end{array}$ & $\begin{array}{c}95 \% \text { CI for } \\
\text { Mean, } \\
\text { High }\end{array}$ & Median & $\begin{array}{l}95 \% \text { CI for } \\
\text { Median, } \\
\text { Low }\end{array}$ & $\begin{array}{l}95 \% \text { CI for } \\
\text { Median, } \\
\text { High }\end{array}$ & StDev & $\begin{array}{c}95 \% \text { CI for } \\
\text { StDev, } \\
\text { Low }\end{array}$ & $\begin{array}{c}95 \% \text { CI for } \\
\text { Stdev, } \\
\text { High }\end{array}$ \\
\hline V11 & 28.00 & $5.00 \mathrm{E}-06$ & $1.00 \mathrm{E}-06$ & $8.00 \mathrm{E}-06$ & $2.00 \mathrm{E}-06$ & $2.00 \mathrm{E}-06$ & $4.00 \mathrm{E}-06$ & $9.00 \mathrm{E}-06$ & $7.00 \mathrm{E}-06$ & $1.30 \mathrm{E}-05$ \\
\hline V12 & 26.00 & $5.00 \mathrm{E}-06$ & $2.00 \mathrm{E}-06$ & $8.00 \mathrm{E}-06$ & $2.00 \mathrm{E}-06$ & $1.00 \mathrm{E}-06$ & $4.00 \mathrm{E}-06$ & $7.00 \mathrm{E}-06$ & $5.00 \mathrm{E}-06$ & $9.00 \mathrm{E}-06$ \\
\hline V13 & 32.00 & $6.00 \mathrm{E}-06$ & $3.00 \mathrm{E}-06$ & $9.00 \mathrm{E}-06$ & $5.00 \mathrm{E}-06$ & $3.00 \mathrm{E}-06$ & $6.00 \mathrm{E}-06$ & $9.00 \mathrm{E}-06$ & $7.00 \mathrm{E}-06$ & $1.20 \mathrm{E}-05$ \\
\hline V21 & 28.00 & $4.00 \mathrm{E}-06$ & $3.00 \mathrm{E}-06$ & $5.00 \mathrm{E}-06$ & $3.00 \mathrm{E}-06$ & $2.00 \mathrm{E}-06$ & $5.00 \mathrm{E}-06$ & $3.00 \mathrm{E}-06$ & $2.00 \mathrm{E}-06$ & $4.00 \mathrm{E}-06$ \\
\hline V22 & 27.00 & $8.00 \mathrm{E}-06$ & $1.00 \mathrm{E}-06$ & $1.60 \mathrm{E}-05$ & $2.00 \mathrm{E}-06$ & $1.00 \mathrm{E}-06$ & $4.00 \mathrm{E}-06$ & $1.80 \mathrm{E}-05$ & $1.50 \mathrm{E}-05$ & $2.50 \mathrm{E}-05$ \\
\hline V23 & 40.00 & $4.00 \mathrm{E}-06$ & $3.00 \mathrm{E}-06$ & $5.00 \mathrm{E}-06$ & $3.00 \mathrm{E}-06$ & $2.00 \mathrm{E}-06$ & $5.00 \mathrm{E}-06$ & $3.00 \mathrm{E}-06$ & $2.00 \mathrm{E}-06$ & $4.00 \mathrm{E}-06$ \\
\hline V32 & 34.00 & $4.00 \mathrm{E}-06$ & $1.00 \mathrm{E}-06$ & $8.00 \mathrm{E}-06$ & $2.00 \mathrm{E}-06$ & $1.00 \mathrm{E}-06$ & $3.00 \mathrm{E}-06$ & $1.00 \mathrm{E}-05$ & $8.00 \mathrm{E}-06$ & $1.30 \mathrm{E}-05$ \\
\hline V33 & 31.00 & $5.00 \mathrm{E}-06$ & $2.00 \mathrm{E}-06$ & $9.00 \mathrm{E}-06$ & $3.00 \mathrm{E}-06$ & $2.00 \mathrm{E}-06$ & $5.00 \mathrm{E}-06$ & $1.00 \mathrm{E}-05$ & $8.00 \mathrm{E}-06$ & $1.40 \mathrm{E}-05$ \\
\hline V1ave & 28.67 & $5.33 \mathrm{E}-06$ & $2.00 \mathrm{E}-06$ & $8.33 \mathrm{E}-06$ & $3.00 \mathrm{E}-06$ & $2.00 \mathrm{E}-06$ & $4.67 \mathrm{E}-06$ & $8.33 \mathrm{E}-06$ & $6.33 \mathrm{E}-06$ & $1.13 \mathrm{E}-05$ \\
\hline V2ave & 31.67 & $5.33 \mathrm{E}-06$ & $2.33 \mathrm{E}-06$ & $8.67 \mathrm{E}-06$ & $2.67 \mathrm{E}-06$ & $1.67 \mathrm{E}-06$ & $4.67 \mathrm{E}-06$ & $8.00 \mathrm{E}-06$ & $6.33 \mathrm{E}-06$ & $1.10 \mathrm{E}-05$ \\
\hline V3ave & 34.33 & $7.33 \mathrm{E}-06$ & $-3.33 \mathrm{E}-07$ & $1.53 \mathrm{E}-05$ & $2.33 \mathrm{E}-06$ & $1.33 \mathrm{E}-06$ & $3.67 \mathrm{E}-06$ & $2.30 \mathrm{E}-05$ & $1.87 \mathrm{E}-05$ & $3.03 \mathrm{E}-05$ \\
\hline Vtotave & 31.56 & $6.00 \mathrm{E}-06$ & $1.33 \mathrm{E}-06$ & $1.08 \mathrm{E}-05$ & $2.67 \mathrm{E}-06$ & $1.67 \mathrm{E}-06$ & 4.33E-06 & $1.31 \mathrm{E}-05$ & $1.04 \mathrm{E}-05$ & $1.76 \mathrm{E}-05$ \\
\hline
\end{tabular}

Wake Velocity

\begin{tabular}{|c|c|c|c|c|c|c|c|c|c|c|}
\hline Version & $\begin{array}{c}\text { Number of } \\
\text { Impacts }\end{array}$ & Mean & $\begin{array}{c}\text { 95\% CI for } \\
\text { Mean, Low }\end{array}$ & $\begin{array}{c}\text { 95\% CI for } \\
\text { Mean, } \\
\text { High }\end{array}$ & Median & $\begin{array}{c}\text { Median, } \\
\text { Low }\end{array}$ & $\begin{array}{c}\text { M5\% CI for } \\
\text { Median, } \\
\text { High }\end{array}$ & $\begin{array}{c}\text { 95\% CI for } \\
\text { StDev, } \\
\text { Low }\end{array}$ & $\begin{array}{c}\text { 95\% CI for } \\
\text { Stdev, } \\
\text { High }\end{array}$ \\
\hline V11 & 28.00 & 15.93 & 12.22 & 19.64 & 13.00 & 11.00 & 19.00 & 9.58 & 7.57 & 13.03 \\
\hline V12 & 26.00 & 16.62 & 11.45 & 21.78 & 11.00 & 7.00 & 21.00 & 12.79 & 10.03 & 17.65 \\
\hline V13 & 32.00 & 18.06 & 13.36 & 22.76 & 15.00 & 9.00 & 21.00 & 13.06 & 10.46 & 17.34 \\
\hline V21 & 28.00 & 17.00 & 12.74 & 21.26 & 14.00 & 9.00 & 24.10 & 11.00 & 8.69 & 14.97 \\
\hline V22 & 27.00 & 15.89 & 12.16 & 19.62 & 15.00 & 8.94 & 21.00 & 9.44 & 7.43 & 12.93 \\
\hline V23 & 40.00 & 19.10 & 15.94 & 22.26 & 18.00 & 13.00 & 23.00 & 9.87 & 8.09 & 12.67 \\
\hline V31 & 38.00 & 16.32 & 13.08 & 19.55 & 15.00 & 10.16 & 21.00 & 9.85 & 8.03 & 12.74 \\
\hline V32 & 34.00 & 17.71 & 14.03 & 21.39 & 15.00 & 12.75 & 19.25 & 10.55 & 8.51 & 13.88 \\
\hline V33 & 31.00 & 18.29 & 13.75 & 22.84 & 19.00 & 8.35 & 23.65 & 12.39 & 9.90 & 16.56 \\
\hline V1ave & 28.67 & 16.87 & 12.34 & 21.40 & 13.00 & 9.00 & 20.33 & 11.81 & 9.35 \\
\hline V2ave & 31.67 & 17.33 & 13.61 & 21.05 & 15.67 & 10.31 & 22.70 & 10.10 & 8.07 & 16.01 \\
\hline V3ave & 34.33 & 17.44 & 13.62 & 21.26 & 16.33 & 10.42 & 21.30 & 10.93 & 8.81 & 14.39 \\
\hline Vtotave & 31.56 & 17.21 & 13.19 & 21.23 & 15.00 & 9.91 & 21.44 & 10.95 & 8.74 & 14.64 \\
\hline
\end{tabular}

Port Mass

\begin{tabular}{|c|c|c|c|c|c|c|c|c|c|c|}
\hline Version & $\begin{array}{l}\text { Number of } \\
\text { Impacts }\end{array}$ & Mean & $\begin{array}{l}95 \% \text { CI for } \\
\text { Mean, Low }\end{array}$ & $\begin{array}{c}95 \% \text { CI for } \\
\text { Mean, } \\
\text { High }\end{array}$ & Median & $\begin{array}{l}95 \% \text { CI for } \\
\text { Median, } \\
\text { Low }\end{array}$ & $\begin{array}{l}\text { 95\% CI for } \\
\text { Median, } \\
\text { High }\end{array}$ & StDev & $\begin{array}{c}95 \% \text { CI for } \\
\text { StDev, } \\
\text { Low }\end{array}$ & $\begin{array}{c}95 \% \text { CI for } \\
\text { Stdev, } \\
\text { High }\end{array}$ \\
\hline V11 & 186.00 & $6.00 \mathrm{E}-06$ & $4.00 \mathrm{E}-06$ & $7.00 \mathrm{E}-06$ & $3.00 \mathrm{E}-06$ & $2.00 \mathrm{E}-06$ & $3.00 \mathrm{E}-06$ & $1.10 \mathrm{E}-05$ & $1.00 \mathrm{E}-05$ & $1.20 \mathrm{E}-05$ \\
\hline V12 & 165.00 & $5.00 \mathrm{E}-06$ & $4.00 \mathrm{E}-06$ & $7.00 \mathrm{E}-06$ & $2.00 \mathrm{E}-06$ & $2.00 \mathrm{E}-06$ & $3.00 \mathrm{E}-06$ & $1.10 \mathrm{E}-05$ & $1.00 \mathrm{E}-05$ & $1.30 \mathrm{E}-05$ \\
\hline V13 & 163.00 & $7.00 \mathrm{E}-06$ & $4.00 \mathrm{E}-06$ & $1.10 \mathrm{E}-05$ & $3.00 \mathrm{E}-06$ & $3.00 \mathrm{E}-06$ & $4.00 \mathrm{E}-06$ & $2.50 \mathrm{E}-05$ & $2.20 \mathrm{E}-05$ & $2.80 \mathrm{E}-05$ \\
\hline V21 & 189.00 & $5.00 \mathrm{E}-06$ & $3.00 \mathrm{E}-06$ & $6.00 \mathrm{E}-06$ & $2.00 \mathrm{E}-06$ & $3.00 \mathrm{E}-06$ & $3.00 \mathrm{E}-06$ & $9.00 \mathrm{E}-06$ & $8.00 \mathrm{E}-06$ & $1.00 \mathrm{E}-05$ \\
\hline V22 & 189.00 & $6.00 \mathrm{E}-06$ & $3.00 \mathrm{E}-06$ & $8.00 \mathrm{E}-06$ & $3.00 \mathrm{E}-06$ & $2.00 \mathrm{E}-06$ & $4.00 \mathrm{E}-06$ & $1.60 \mathrm{E}-05$ & $1.50 \mathrm{E}-05$ & $1.80 \mathrm{E}-05$ \\
\hline V23 & 195.00 & $4.00 \mathrm{E}-06$ & $3.00 \mathrm{E}-06$ & $6.00 \mathrm{E}-06$ & $3.00 \mathrm{E}-06$ & $2.00 \mathrm{E}-06$ & $3.00 \mathrm{E}-06$ & $8.00 \mathrm{E}-06$ & $7.00 \mathrm{E}-06$ & $9.00 \mathrm{E}-06$ \\
\hline V31 & 200.00 & $7.00 \mathrm{E}-06$ & $5.00 \mathrm{E}-06$ & $9.00 \mathrm{E}-06$ & $2.00 \mathrm{E}-06$ & $2.00 \mathrm{E}-06$ & $3.00 \mathrm{E}-06$ & $1.50 \mathrm{E}-05$ & $1.30 \mathrm{E}-05$ & $1.60 \mathrm{E}-05$ \\
\hline V32 & 170.00 & 8.00E-06 & $3.00 \mathrm{E}-06$ & $1.20 \mathrm{E}-05$ & $3.00 \mathrm{E}-06$ & $2.00 \mathrm{E}-06$ & $3.00 \mathrm{E}-06$ & $2.80 \mathrm{E}-05$ & $2.50 \mathrm{E}-05$ & $3.20 \mathrm{E}-05$ \\
\hline V33 & 183.00 & $6.00 \mathrm{E}-06$ & $4.00 \mathrm{E}-06$ & $8.00 \mathrm{E}-06$ & $3.00 \mathrm{E}-06$ & $2.00 \mathrm{E}-06$ & $4.00 \mathrm{E}-06$ & $1.20 \mathrm{E}-05$ & $1.10 \mathrm{E}-05$ & $1.30 \mathrm{E}-05$ \\
\hline V1ave & 171.33 & $6.00 \mathrm{E}-06$ & $4.00 \mathrm{E}-06$ & $8.33 \mathrm{E}-06$ & $2.67 \mathrm{E}-06$ & $2.33 \mathrm{E}-06$ & 3.33E-06 & $1.57 \mathrm{E}-05$ & $1.40 \mathrm{E}-05$ & $1.77 \mathrm{E}-05$ \\
\hline V2ave & 191.00 & $5.00 \mathrm{E}-06$ & $3.00 \mathrm{E}-06$ & $6.67 \mathrm{E}-06$ & $2.67 \mathrm{E}-06$ & $2.33 \mathrm{E}-06$ & $3.33 \mathrm{E}-06$ & $1.10 \mathrm{E}-05$ & $1.00 \mathrm{E}-05$ & $1.23 \mathrm{E}-05$ \\
\hline V3ave & 184.33 & $7.00 \mathrm{E}-06$ & $4.00 \mathrm{E}-06$ & $9.67 \mathrm{E}-06$ & $2.67 \mathrm{E}-06$ & $2.00 \mathrm{E}-06$ & $3.33 \mathrm{E}-06$ & $1.83 \mathrm{E}-05$ & $1.63 \mathrm{E}-05$ & $2.03 \mathrm{E}-05$ \\
\hline Vtotave & 182.22 & $6.00 \mathrm{E}-06$ & $3.67 \mathrm{E}-06$ & $8.22 \mathrm{E}-06$ & $2.67 \mathrm{E}-06$ & $2.22 \mathrm{E}-06$ & $3.33 \mathrm{E}-06$ & $1.50 \mathrm{E}-05$ & $1.34 \mathrm{E}-05$ & $1.68 \mathrm{E}-05$ \\
\hline
\end{tabular}


Port Velocity

\begin{tabular}{|c|c|c|c|c|c|c|c|c|c|c|}
\hline Version & $\begin{array}{l}\text { Number of } \\
\text { Impacts }\end{array}$ & Mean & $\begin{array}{l}95 \% \text { CI for } \\
\text { Mean, Low }\end{array}$ & $\begin{array}{c}95 \% \text { CI for } \\
\text { Mean, } \\
\text { High }\end{array}$ & Median & $\begin{array}{l}95 \% \text { CI for } \\
\text { Median, } \\
\text { Low }\end{array}$ & $\begin{array}{l}95 \% \text { CI for } \\
\text { Median, } \\
\text { High }\end{array}$ & StDev & $\begin{array}{c}95 \% \text { CI for } \\
\text { StDev, } \\
\text { Low }\end{array}$ & $\begin{array}{c}95 \% \text { CI for } \\
\text { Stdev, } \\
\text { High }\end{array}$ \\
\hline V11 & 186.00 & 22.07 & 20.40 & 23.73 & 21.00 & 19.00 & 23.00 & 11.48 & 10.42 & 12.79 \\
\hline V12 & 165.00 & 22.43 & 20.68 & 24.18 & 21.00 & 19.00 & 25.00 & 11.40 & 10.29 & 12.78 \\
\hline V13 & 163.00 & 22.17 & 20.40 & 23.93 & 21.00 & 19.00 & 23.00 & 11.42 & 10.30 & 12.81 \\
\hline V21 & 189.00 & 21.05 & 19.41 & 22.70 & 19.00 & 18.13 & 21.00 & 11.48 & 10.43 & 12.78 \\
\hline V22 & 189.00 & 20.81 & 19.18 & 22.44 & 21.00 & 17.00 & 23.00 & 11.33 & 10.29 & 12.61 \\
\hline V23 & 195.00 & 22.00 & 20.27 & 23.72 & 19.00 & 17.69 & 23.00 & 12.20 & 11.10 & 13.55 \\
\hline V31 & 200.00 & 21.24 & 19.47 & 23.01 & 19.00 & 17.00 & 21.00 & 12.66 & 11.53 & 14.04 \\
\hline V32 & 170.00 & 21.45 & 19.59 & 23.31 & 21.00 & 17.00 & 23.00 & 12.28 & 11.10 & 13.75 \\
\hline V33 & 183.00 & 22.50 & 20.71 & 24.29 & 21.00 & 20.54 & 23.46 & 12.26 & 11.12 & 13.66 \\
\hline V1ave & 171.33 & 22.22 & 20.49 & 23.95 & 21.00 & 19.00 & 23.67 & 11.43 & 10.33 & 12.79 \\
\hline V2ave & 191.00 & 21.29 & 19.62 & 22.95 & 19.67 & 17.61 & 22.33 & 11.67 & 10.61 & 12.98 \\
\hline V3ave & 184.33 & 21.73 & 19.92 & 23.53 & 20.33 & 18.18 & 22.49 & 12.40 & 11.25 & 13.82 \\
\hline Vtotave & 182.22 & 21.74 & 20.01 & 23.48 & 20.33 & 18.26 & 22.83 & 11.83 & 10.73 & 13.20 \\
\hline
\end{tabular}

Starboard Mass

\begin{tabular}{|c|c|c|c|c|c|c|c|c|c|c|}
\hline Version & $\begin{array}{c}\text { Number of } \\
\text { Impacts }\end{array}$ & Mean & $\begin{array}{l}95 \% \text { CI for } \\
\text { Mean, Low }\end{array}$ & $\begin{array}{l}95 \% \text { CI for } \\
\text { Mean, } \\
\text { High }\end{array}$ & Median & $\begin{array}{l}95 \% \text { CI for } \\
\text { Median, } \\
\text { Low }\end{array}$ & $\begin{array}{l}95 \% \text { CI for } \\
\text { Median, } \\
\text { High }\end{array}$ & StDev & $\begin{array}{c}95 \% \text { CI for } \\
\text { StDev, } \\
\text { Low } \\
\end{array}$ & $\begin{array}{c}95 \% \text { CI for } \\
\text { Stdev, } \\
\text { High }\end{array}$ \\
\hline V11 & 182.00 & $7.00 \mathrm{E}-06$ & $3.00 \mathrm{E}-06$ & $1.00 \mathrm{E}-05$ & $3.00 \mathrm{E}-06$ & $2.00 \mathrm{E}-06$ & $3.00 \mathrm{E}-06$ & $2.40 \mathrm{E}-05$ & $2.10 \mathrm{E}-05$ & $2.60 \mathrm{E}-05$ \\
\hline V12 & 189.00 & $1.40 \mathrm{E}-05$ & $2.00 \mathrm{E}-06$ & $2.60 \mathrm{E}-05$ & $3.00 \mathrm{E}-06$ & $3.00 \mathrm{E}-06$ & $4.00 \mathrm{E}-06$ & $8.10 \mathrm{E}-05$ & $7.40 \mathrm{E}-05$ & $9.00 \mathrm{E}-05$ \\
\hline V13 & 157.00 & $5.00 \mathrm{E}-06$ & $4.00 \mathrm{E}-06$ & $7.00 \mathrm{E}-06$ & $2.00 \mathrm{E}-06$ & $2.00 \mathrm{E}-06$ & $3.00 \mathrm{E}-06$ & $1.10 \mathrm{E}-05$ & $1.00 \mathrm{E}-05$ & $1.20 \mathrm{E}-05$ \\
\hline V21 & 197.00 & $2.30 \mathrm{E}-05$ & $-7.00 \mathrm{E}-06$ & $5.40 \mathrm{E}-05$ & $2.00 \mathrm{E}-06$ & $2.00 \mathrm{E}-06$ & $3.00 \mathrm{E}-06$ & $2.16 \mathrm{E}-04$ & $1.97 \mathrm{E}-04$ & $2.40 \mathrm{E}-04$ \\
\hline V22 & 153.00 & $6.00 \mathrm{E}-06$ & $4.00 \mathrm{E}-06$ & $8.00 \mathrm{E}-06$ & $3.00 \mathrm{E}-06$ & $2.00 \mathrm{E}-06$ & $3.00 \mathrm{E}-06$ & $1.30 \mathrm{E}-05$ & $1.10 \mathrm{E}-05$ & $1.40 \mathrm{E}-05$ \\
\hline V23 & 173.00 & $8.00 \mathrm{E}-06$ & $3.00 \mathrm{E}-06$ & $1.30 \mathrm{E}-05$ & $3.00 \mathrm{E}-06$ & $2.00 \mathrm{E}-06$ & $4.00 \mathrm{E}-06$ & $3.20 \mathrm{E}-05$ & $2.90 \mathrm{E}-05$ & $3.60 \mathrm{E}-05$ \\
\hline V32 & 166.00 & $7.00 \mathrm{E}-06$ & $4.00 \mathrm{E}-06$ & $1.10 \mathrm{E}-05$ & $3.00 \mathrm{E}-06$ & $2.00 \mathrm{E}-06$ & $4.00 \mathrm{E}-06$ & $2.30 \mathrm{E}-05$ & $2.10 \mathrm{E}-05$ & $2.60 \mathrm{E}-05$ \\
\hline V33 & 179.00 & $6.00 \mathrm{E}-06$ & $4.00 \mathrm{E}-06$ & $7.00 \mathrm{E}-06$ & $3.00 \mathrm{E}-06$ & $2.00 \mathrm{E}-06$ & $4.00 \mathrm{E}-06$ & $1.00 \mathrm{E}-05$ & $9.00 \mathrm{E}-06$ & $1.10 \mathrm{E}-05$ \\
\hline V1ave & 176.00 & $8.67 \mathrm{E}-06$ & $3.00 \mathrm{E}-06$ & $1.43 \mathrm{E}-05$ & $2.67 \mathrm{E}-06$ & $2.33 \mathrm{E}-06$ & $3.33 \mathrm{E}-06$ & $3.87 \mathrm{E}-05$ & $3.50 \mathrm{E}-05$ & $4.27 \mathrm{E}-05$ \\
\hline V2ave & 174.33 & $1.23 \mathrm{E}-05$ & $0.00 \mathrm{E}+00$ & $2.50 \mathrm{E}-05$ & $2.67 \mathrm{E}-06$ & $2.00 \mathrm{E}-06$ & 3.33E-06 & $8.70 \mathrm{E}-05$ & $7.90 \mathrm{E}-05$ & $9.67 \mathrm{E}-05$ \\
\hline V3ave & 176.67 & $6.33 \mathrm{E}-06$ & $4.00 \mathrm{E}-06$ & $8.33 \mathrm{E}-06$ & $3.00 \mathrm{E}-06$ & $2.00 \mathrm{E}-06$ & $3.67 \mathrm{E}-06$ & $1.50 \mathrm{E}-05$ & $1.37 \mathrm{E}-05$ & $1.67 \mathrm{E}-05$ \\
\hline Vtotave & 175.67 & $9.11 \mathrm{E}-06$ & $2.33 \mathrm{E}-06$ & $1.59 \mathrm{E}-05$ & $2.78 \mathrm{E}-06$ & $2.11 \mathrm{E}-06$ & $3.44 \mathrm{E}-06$ & $4.69 \mathrm{E}-05$ & $4.26 \mathrm{E}-05$ & $5.20 \mathrm{E}-05$ \\
\hline
\end{tabular}

\section{Starboard Velocity}

\begin{tabular}{|c|c|c|c|c|c|c|c|c|c|c|}
\hline & $\begin{array}{c}\text { Number of } \\
\text { Impacts }\end{array}$ & Mean & $\begin{array}{c}\text { 95\% CI for } \\
\text { Mean, Low }\end{array}$ & $\begin{array}{c}\text { 95\% CI for } \\
\text { Mean, } \\
\text { High }\end{array}$ & Median & $\begin{array}{c}\text { Median, } \\
\text { Low }\end{array}$ & $\begin{array}{c}\text { M5\% CI for } \\
\text { Median, } \\
\text { High }\end{array}$ & $\begin{array}{c}\text { 95\% CI for } \\
\text { StDev, } \\
\text { Low }\end{array}$ & $\begin{array}{c}\text { 95\% CI for } \\
\text { Stdev, } \\
\text { High }\end{array}$ \\
\hline V11 & 182.00 & 22.45 & 20.61 & 24.29 & 21.00 & 19.00 & 24.38 & 12.56 & 11.39 & 14.00 \\
\hline V12 & 189.00 & 21.77 & 19.93 & 23.61 & 21.00 & 19.00 & 23.00 & 12.82 & 11.65 & 14.26 \\
\hline V13 & 157.00 & 17.83 & 16.27 & 19.39 & 17.00 & 15.00 & 19.00 & 9.92 & 8.93 & 11.15 \\
\hline V21 & 197.00 & 21.69 & 20.20 & 23.18 & 21.00 & 19.00 & 21.00 & 10.58 & 9.63 & 11.74 \\
\hline V22 & 153.00 & 22.50 & 20.54 & 24.46 & 23.00 & 20.79 & 25.00 & 12.27 & 11.03 & 13.82 \\
\hline V23 & 173.00 & 19.41 & 17.73 & 21.08 & 17.00 & 15.00 & 19.00 & 11.17 & 10.11 & 12.49 \\
\hline V31 & 185.00 & 21.49 & 19.89 & 23.09 & 21.00 & 19.00 & 23.00 & 11.02 & 10.00 & 12.27 \\
\hline V32 & 166.00 & 21.45 & 19.65 & 23.24 & 20.00 & 17.00 & 23.00 & 11.69 & 10.55 & 13.10 \\
\hline V33 & 179.00 & 21.87 & 20.11 & 23.64 & 21.00 & 19.00 & 23.00 & 11.96 & 10.83 & 13.34 \\
\hline V1ave & 176.00 & 20.68 & 18.94 & 22.43 & 19.67 & 17.67 & 22.13 & 11.76 & 10.65 & 13.14 \\
\hline V2ave & 174.33 & 21.20 & 19.49 & 22.91 & 20.33 & 18.26 & 21.67 & 11.34 & 10.26 & 12.69 \\
\hline V3ave & 176.67 & 21.60 & 19.88 & 23.32 & 20.67 & 18.33 & 23.00 & 11.56 & 10.46 & 12.91 \\
\hline Vtotave & 175.67 & 21.16 & 19.44 & 22.89 & 20.22 & 18.09 & 22.26 & 11.55 & 10.46 & 12.91 \\
\hline
\end{tabular}




\section{Zenith Mass}

\begin{tabular}{|c|c|c|c|c|c|c|c|c|c|c|}
\hline Version & $\begin{array}{l}\text { Number of } \\
\text { Impacts }\end{array}$ & Mean & $\begin{array}{l}95 \% \text { CI for } \\
\text { Mean, Low }\end{array}$ & $\begin{array}{c}95 \% \text { CI for } \\
\text { Mean, } \\
\text { High }\end{array}$ & Median & $\begin{array}{l}95 \% \text { CI for } \\
\text { Median, } \\
\text { Low }\end{array}$ & $\begin{array}{l}95 \% \text { CI for } \\
\text { Median, } \\
\text { High }\end{array}$ & StDev & $\begin{array}{c}95 \% \text { CI for } \\
\text { StDev, } \\
\text { Low }\end{array}$ & $\begin{array}{c}95 \% \text { CI for } \\
\text { Stdev, } \\
\text { High }\end{array}$ \\
\hline V11 & 196.00 & $4.00 \mathrm{E}-06$ & $3.00 \mathrm{E}-06$ & $6.00 \mathrm{E}-06$ & $2.00 \mathrm{E}-06$ & $2.00 \mathrm{E}-06$ & $3.00 \mathrm{E}-06$ & $9.00 \mathrm{E}-06$ & $8.00 \mathrm{E}-06$ & $1.00 \mathrm{E}-05$ \\
\hline V12 & 229.00 & $7.00 \mathrm{E}-06$ & $2.00 \mathrm{E}-06$ & $1.30 \mathrm{E}-05$ & $3.00 \mathrm{E}-06$ & $2.00 \mathrm{E}-06$ & $3.00 \mathrm{E}-06$ & $4.00 \mathrm{E}-05$ & $3.70 \mathrm{E}-05$ & $4.40 \mathrm{E}-05$ \\
\hline V13 & 217.00 & $6.00 \mathrm{E}-06$ & $4.00 \mathrm{E}-06$ & $8.00 \mathrm{E}-06$ & $2.00 \mathrm{E}-06$ & $2.00 \mathrm{E}-06$ & $3.00 \mathrm{E}-06$ & $1.20 \mathrm{E}-05$ & $1.10 \mathrm{E}-05$ & $1.40 \mathrm{E}-05$ \\
\hline V21 & 264.00 & $6.00 \mathrm{E}-06$ & $4.00 \mathrm{E}-06$ & $8.00 \mathrm{E}-06$ & $3.00 \mathrm{E}-06$ & $2.00 \mathrm{E}-06$ & $3.00 \mathrm{E}-06$ & $1.90 \mathrm{E}-05$ & $1.70 \mathrm{E}-05$ & $2.00 \mathrm{E}-05$ \\
\hline V22 & 251.00 & $5.00 \mathrm{E}-06$ & $4.00 \mathrm{E}-06$ & $6.00 \mathrm{E}-06$ & $2.00 \mathrm{E}-06$ & $2.00 \mathrm{E}-06$ & $3.00 \mathrm{E}-06$ & $1.00 \mathrm{E}-05$ & $9.00 \mathrm{E}-06$ & $1.10 \mathrm{E}-05$ \\
\hline V23 & 262.00 & $6.00 \mathrm{E}-06$ & $4.00 \mathrm{E}-06$ & $7.00 \mathrm{E}-06$ & $3.00 \mathrm{E}-06$ & $2.00 \mathrm{E}-06$ & $4.00 \mathrm{E}-06$ & $1.10 \mathrm{E}-05$ & $1.00 \mathrm{E}-05$ & $1.20 \mathrm{E}-05$ \\
\hline V31 & 274.00 & $8.00 \mathrm{E}-06$ & $4.00 \mathrm{E}-06$ & $1.20 \mathrm{E}-05$ & $3.00 \mathrm{E}-06$ & $2.00 \mathrm{E}-06$ & $3.00 \mathrm{E}-06$ & $3.60 \mathrm{E}-05$ & $3.30 \mathrm{E}-05$ & $4.00 \mathrm{E}-05$ \\
\hline V32 & 254.00 & $5.00 \mathrm{E}-06$ & $4.00 \mathrm{E}-06$ & $6.00 \mathrm{E}-06$ & $3.00 \mathrm{E}-06$ & $2.00 \mathrm{E}-06$ & $4.00 \mathrm{E}-06$ & $1.00 \mathrm{E}-05$ & $9.00 \mathrm{E}-06$ & $1.10 \mathrm{E}-05$ \\
\hline V33 & 259.00 & $7.00 \mathrm{E}-06$ & $4.00 \mathrm{E}-06$ & $9.00 \mathrm{E}-06$ & $3.00 \mathrm{E}-06$ & $2.00 \mathrm{E}-06$ & $3.00 \mathrm{E}-06$ & $2.00 \mathrm{E}-05$ & $1.80 \mathrm{E}-05$ & $2.20 \mathrm{E}-05$ \\
\hline V1ave & 214.00 & $5.67 \mathrm{E}-06$ & $3.00 \mathrm{E}-06$ & $9.00 \mathrm{E}-06$ & $2.33 \mathrm{E}-06$ & $2.00 \mathrm{E}-06$ & $3.00 \mathrm{E}-06$ & $2.03 \mathrm{E}-05$ & $1.87 \mathrm{E}-05$ & $2.27 \mathrm{E}-05$ \\
\hline V2ave & 259.00 & $5.67 \mathrm{E}-06$ & $4.00 \mathrm{E}-06$ & $7.00 \mathrm{E}-06$ & $2.67 \mathrm{E}-06$ & $2.00 \mathrm{E}-06$ & $3.33 \mathrm{E}-06$ & $1.33 \mathrm{E}-05$ & $1.20 \mathrm{E}-05$ & $1.43 \mathrm{E}-05$ \\
\hline V3ave & 262.33 & $6.67 \mathrm{E}-06$ & $4.00 \mathrm{E}-06$ & $9.00 \mathrm{E}-06$ & $3.00 \mathrm{E}-06$ & $2.00 \mathrm{E}-06$ & 3.33E-06 & $2.20 \mathrm{E}-05$ & $2.00 \mathrm{E}-05$ & $2.43 \mathrm{E}-05$ \\
\hline Vtotave & 245.11 & $6.00 \mathrm{E}-06$ & $3.67 \mathrm{E}-06$ & $8.33 \mathrm{E}-06$ & $2.67 \mathrm{E}-06$ & $2.00 \mathrm{E}-06$ & $3.22 \mathrm{E}-06$ & $1.86 \mathrm{E}-05$ & $1.69 \mathrm{E}-05$ & $2.04 \mathrm{E}-05$ \\
\hline
\end{tabular}

\section{Zenith Velocity}

\begin{tabular}{|c|c|c|c|c|c|c|c|c|c|c|}
\hline Version & $\begin{array}{l}\text { Number of } \\
\text { Impacts }\end{array}$ & Mean & $\begin{array}{l}95 \% \text { CI for } \\
\text { Mean, Low }\end{array}$ & $\begin{array}{c}95 \% \text { CI for } \\
\text { Mean, } \\
\text { High }\end{array}$ & Median & $\begin{array}{l}95 \% \text { CI for } \\
\text { Median, } \\
\text { Low }\end{array}$ & $\begin{array}{l}95 \% \text { CI for } \\
\text { Median, } \\
\text { High }\end{array}$ & StDev & $\begin{array}{c}95 \% \text { CI for } \\
\text { StDev, } \\
\text { Low }\end{array}$ & $\begin{array}{c}95 \% \text { CI for } \\
\text { Stdev, } \\
\text { High }\end{array}$ \\
\hline V11 & 196.00 & 23.71 & 22.24 & 25.19 & 23.00 & 21.00 & 25.00 & 10.45 & 9.51 & 11.61 \\
\hline V12 & 229.00 & 23.55 & 22.21 & 24.89 & 23.00 & 21.00 & 25.00 & 10.31 & 9.45 & 11.35 \\
\hline V13 & 217.00 & 22.30 & 20.91 & 23.90 & 23.00 & 19.00 & 25.00 & 10.39 & 9.50 & 11.47 \\
\hline V21 & 264.00 & 23.10 & 21.78 & 24.42 & 23.00 & 21.00 & 25.00 & 10.87 & 10.02 & 11.89 \\
\hline V22 & 251.00 & 22.28 & 20.80 & 23.75 & 21.00 & 21.00 & 23.00 & 11.83 & 10.88 & 12.97 \\
\hline V23 & 262.00 & 22.26 & 20.93 & 23.59 & 21.00 & 19.00 & 23.00 & 10.93 & 10.06 & 11.95 \\
\hline V31 & 274.00 & 22.24 & 21.07 & 23.41 & 23.00 & 21.00 & 23.00 & 9.85 & 9.09 & 10.75 \\
\hline V32 & 254.00 & 22.36 & 20.96 & 23.76 & 21.00 & 19.00 & 23.00 & 11.32 & 10.41 & 12.40 \\
\hline V33 & 259.00 & 23.78 & 22.41 & 25.16 & 23.00 & 23.00 & 25.00 & 11.24 & 10.34 & 12.30 \\
\hline V1ave & 214.00 & 23.19 & 21.79 & 24.66 & 23.00 & 20.33 & 25.00 & 10.38 & 9.48 & 11.48 \\
\hline V2ave & 259.00 & 22.54 & 21.17 & 23.92 & 21.67 & 20.33 & 23.67 & 11.21 & 10.32 & 12.27 \\
\hline V3ave & 262.33 & 22.79 & 21.48 & 24.11 & 22.33 & 21.00 & 23.67 & 10.80 & 9.95 & 11.81 \\
\hline Vtotave & 245.11 & 22.84 & 21.48 & 24.23 & 22.33 & 20.56 & 24.11 & 10.80 & 9.92 & 11.85 \\
\hline
\end{tabular}

Nadir Mass

\begin{tabular}{|c|c|c|c|c|c|c|c|c|c|c|}
\hline Version & $\begin{array}{l}\text { Number of } \\
\text { Impacts }\end{array}$ & Mean & $\begin{array}{l}95 \% \text { CI for } \\
\text { Mean, Low }\end{array}$ & $\begin{array}{l}95 \% \text { CI for } \\
\text { Mean, } \\
\text { High }\end{array}$ & Median & $\begin{array}{l}95 \% \text { CI for } \\
\text { Median, } \\
\text { Low }\end{array}$ & $\begin{array}{l}\text { 95\% CI for } \\
\text { Median, } \\
\text { High }\end{array}$ & StDev & $\begin{array}{c}95 \% \text { CI for } \\
\text { StDev, } \\
\text { Low }\end{array}$ & $\begin{array}{c}95 \% \text { CI for } \\
\text { Stdev, } \\
\text { High }\end{array}$ \\
\hline V11 & 296.00 & $9.00 \mathrm{E}-06$ & $5.00 \mathrm{E}-06$ & $1.20 \mathrm{E}-05$ & $3.00 \mathrm{E}-06$ & $2.00 \mathrm{E}-06$ & $3.00 \mathrm{E}-06$ & $3.10 \mathrm{E}-05$ & $2.90 \mathrm{E}-05$ & $3.40 \mathrm{E}-05$ \\
\hline V12 & 302.00 & $8.00 \mathrm{E}-06$ & $6.00 \mathrm{E}-06$ & $1.00 \mathrm{E}-05$ & $3.00 \mathrm{E}-06$ & $2.00 \mathrm{E}-06$ & $3.00 \mathrm{E}-06$ & $1.90 \mathrm{E}-05$ & $1.70 \mathrm{E}-05$ & $2.00 \mathrm{E}-05$ \\
\hline V13 & 314.00 & $1.00 \mathrm{E}-05$ & $4.00 \mathrm{E}-06$ & $1.50 \mathrm{E}-05$ & $3.00 \mathrm{E}-06$ & $2.00 \mathrm{E}-06$ & $4.00 \mathrm{E}-06$ & $5.31 \mathrm{E}-03$ & $4.70 \mathrm{E}-05$ & $5.50 \mathrm{E}-05$ \\
\hline V21 & 245.00 & $8.00 \mathrm{E}-06$ & $1.00 \mathrm{E}-06$ & $1.40 \mathrm{E}-05$ & $2.00 \mathrm{E}-06$ & $2.00 \mathrm{E}-06$ & $3.00 \mathrm{E}-06$ & $5.20 \mathrm{E}-05$ & $4.80 \mathrm{E}-05$ & $5.70 \mathrm{E}-05$ \\
\hline V22 & 284.00 & $7.00 \mathrm{E}-06$ & $4.00 \mathrm{E}-06$ & $9.00 \mathrm{E}-06$ & $2.00 \mathrm{E}-06$ & $2.00 \mathrm{E}-06$ & $3.00 \mathrm{E}-06$ & $2.00 \mathrm{E}-05$ & $1.90 \mathrm{E}-05$ & $2.20 \mathrm{E}-05$ \\
\hline V23 & 286.00 & $1.00 \mathrm{E}-05$ & $4.00 \mathrm{E}-06$ & $1.60 \mathrm{E}-05$ & $3.00 \mathrm{E}-06$ & $2.00 \mathrm{E}-06$ & $3.00 \mathrm{E}-06$ & $5.30 \mathrm{E}-05$ & $4.90 \mathrm{E}-05$ & $5.80 \mathrm{E}-05$ \\
\hline V31 & 254.00 & $7.00 \mathrm{E}-06$ & $5.00 \mathrm{E}-06$ & $8.00 \mathrm{E}-06$ & $3.00 \mathrm{E}-06$ & $2.00 \mathrm{E}-06$ & $3.00 \mathrm{E}-06$ & $1.40 \mathrm{E}-05$ & $1.30 \mathrm{E}-05$ & $1.50 \mathrm{E}-05$ \\
\hline V32 & 288.00 & $6.00 \mathrm{E}-06$ & $4.00 \mathrm{E}-06$ & $7.00 \mathrm{E}-06$ & $3.00 \mathrm{E}-06$ & $2.00 \mathrm{E}-06$ & $3.00 \mathrm{E}-06$ & $1.20 \mathrm{E}-05$ & $1.10 \mathrm{E}-05$ & $1.30 \mathrm{E}-05$ \\
\hline V33 & 273.00 & $7.00 \mathrm{E}-06$ & $3.00 \mathrm{E}-06$ & $1.20 \mathrm{E}-05$ & $2.00 \mathrm{E}-06$ & $2.00 \mathrm{E}-06$ & $3.00 \mathrm{E}-06$ & $3.70 \mathrm{E}-05$ & $3.50 \mathrm{E}-05$ & $4.10 \mathrm{E}-05$ \\
\hline V1ave & 304.00 & $9.00 \mathrm{E}-06$ & $5.00 \mathrm{E}-06$ & $1.23 \mathrm{E}-05$ & $3.00 \mathrm{E}-06$ & $2.00 \mathrm{E}-06$ & $3.33 \mathrm{E}-06$ & $1.79 \mathrm{E}-03$ & $3.10 \mathrm{E}-05$ & $3.63 \mathrm{E}-05$ \\
\hline V2ave & 271.67 & $8.33 \mathrm{E}-06$ & $3.00 \mathrm{E}-06$ & $1.30 \mathrm{E}-05$ & $2.33 \mathrm{E}-06$ & $2.00 \mathrm{E}-06$ & $3.00 \mathrm{E}-06$ & $4.17 \mathrm{E}-05$ & $3.87 \mathrm{E}-05$ & $4.57 \mathrm{E}-05$ \\
\hline V3ave & 271.67 & $6.67 \mathrm{E}-06$ & $4.00 \mathrm{E}-06$ & $9.00 \mathrm{E}-06$ & $2.67 \mathrm{E}-06$ & $2.00 \mathrm{E}-06$ & $3.00 \mathrm{E}-06$ & $2.10 \mathrm{E}-05$ & $1.97 \mathrm{E}-05$ & $2.30 \mathrm{E}-05$ \\
\hline Vtotave & 282.44 & $8.00 \mathrm{E}-06$ & $4.00 \mathrm{E}-06$ & $1.14 \mathrm{E}-05$ & $2.67 \mathrm{E}-06$ & $2.00 \mathrm{E}-06$ & $3.11 \mathrm{E}-06$ & $6.16 \mathrm{E}-04$ & $2.98 \mathrm{E}-05$ & $3.50 \mathrm{E}-05$ \\
\hline
\end{tabular}


Nadir Velocity

\begin{tabular}{|c|c|c|c|c|c|c|c|c|c|c|}
\hline Version & $\begin{array}{c}\text { Number of } \\
\text { Impacts }\end{array}$ & Mean & $\begin{array}{l}95 \% \text { CI for } \\
\text { Mean, Low }\end{array}$ & $\begin{array}{c}95 \% \text { CI for } \\
\text { Mean, } \\
\text { High }\end{array}$ & Median & $\begin{array}{l}95 \% \text { CI for } \\
\text { Median, } \\
\text { Low }\end{array}$ & $\begin{array}{l}95 \% \text { CI for } \\
\text { Median, } \\
\text { High }\end{array}$ & StDev & $\begin{array}{c}95 \% \text { CI for } \\
\text { StDev, } \\
\text { Low }\end{array}$ & $\begin{array}{c}95 \% \text { CI for } \\
\text { Stdev, } \\
\text { High }\end{array}$ \\
\hline V11 & 296.00 & 21.45 & 20.23 & 22.68 & 21.00 & 19.00 & 23.00 & 10.72 & 9.92 & 11.66 \\
\hline V12 & 302.00 & 20.52 & 19.32 & 21.71 & 21.00 & 19.00 & 23.00 & 10.56 & 9.78 & 11.48 \\
\hline V13 & 314.00 & 21.82 & 20.69 & 22.96 & 21.00 & 21.00 & 23.00 & 10.22 & 9.48 & 11.09 \\
\hline V21 & 245.00 & 20.94 & 19.64 & 22.25 & 21.00 & 19.00 & 23.00 & 10.35 & 9.51 & 11.35 \\
\hline V22 & 284.00 & 20.88 & 19.58 & 22.18 & 19.00 & 17.00 & 21.00 & 11.10 & 10.26 & 12.10 \\
\hline V23 & 286.00 & 21.53 & 20.20 & 22.86 & 21.00 & 19.00 & 23.00 & 11.42 & 10.55 & 12.44 \\
\hline V32 & 288.00 & 21.25 & 19.99 & 22.51 & 21.00 & 19.00 & 23.00 & 10.84 & 10.02 & 11.81 \\
\hline V33 & 273.00 & 20.64 & 19.36 & 21.93 & 21.00 & 19.00 & 23.00 & 10.79 & 9.95 & 11.78 \\
\hline V1ave & 304.00 & 21.26 & 20.08 & 22.45 & 21.00 & 19.67 & 23.00 & 10.50 & 9.73 & 11.41 \\
\hline V2ave & 271.67 & 21.12 & 19.81 & 22.43 & 20.33 & 18.33 & 22.33 & 10.95 & 10.10 & 11.96 \\
\hline V3ave & 271.67 & 21.24 & 19.94 & 22.54 & 21.00 & 19.00 & 23.00 & 10.89 & 10.04 & 11.89 \\
\hline Vtotave & 282.44 & 21.21 & 19.94 & 22.47 & 20.78 & 19.00 & 22.78 & 10.78 & 9.96 & 11.75 \\
\hline
\end{tabular}

Earth Mass

\begin{tabular}{|c|c|c|c|c|c|c|c|c|c|c|}
\hline Version & $\begin{array}{l}\text { Number of } \\
\text { Impacts }\end{array}$ & Mean & $\begin{array}{l}95 \% \text { CI for } \\
\text { Mean, Low }\end{array}$ & $\begin{array}{c}95 \% \text { CI for } \\
\text { Mean, } \\
\text { High }\end{array}$ & Median & $\begin{array}{l}95 \% \text { CI for } \\
\text { Median, } \\
\text { Low }\end{array}$ & $\begin{array}{l}95 \% \text { CI for } \\
\text { Median, } \\
\text { High }\end{array}$ & StDev & $\begin{array}{c}95 \% \text { CI for } \\
\text { StDev, } \\
\text { Low }\end{array}$ & $\begin{array}{c}95 \% \text { CI for } \\
\text { Stdev, } \\
\text { High }\end{array}$ \\
\hline V11 & 63.00 & $5.00 \mathrm{E}-06$ & $3.00 \mathrm{E}-06$ & $8.00 \mathrm{E}-06$ & $3.00 \mathrm{E}-06$ & $2.00 \mathrm{E}-06$ & $4.00 \mathrm{E}-06$ & $1.20 \mathrm{E}-05$ & $1.00 \mathrm{E}-05$ & $1.40 \mathrm{E}-05$ \\
\hline V12 & 61.00 & $6.00 \mathrm{E}-06$ & $3.00 \mathrm{E}-06$ & $9.00 \mathrm{E}-06$ & $4.00 \mathrm{E}-06$ & $3.00 \mathrm{E}-06$ & $5.00 \mathrm{E}-06$ & $1.20 \mathrm{E}-05$ & $1.00 \mathrm{E}-05$ & $1.50 \mathrm{E}-05$ \\
\hline V13 & 70.00 & $7.00 \mathrm{E}-06$ & $3.00 \mathrm{E}-06$ & $1.00 \mathrm{E}-05$ & $2.00 \mathrm{E}-06$ & $1.00 \mathrm{E}-06$ & $4.00 \mathrm{E}-06$ & $1.50 \mathrm{E}-05$ & $1.30 \mathrm{E}-05$ & $1.80 \mathrm{E}-05$ \\
\hline V21 & 78.00 & $5.00 \mathrm{E}-06$ & $3.00 \mathrm{E}-06$ & $7.00 \mathrm{E}-06$ & $2.00 \mathrm{E}-06$ & $2.00 \mathrm{E}-06$ & $4.00 \mathrm{E}-06$ & $7.00 \mathrm{E}-06$ & $6.00 \mathrm{E}-06$ & $9.00 \mathrm{E}-06$ \\
\hline V22 & 82.00 & $6.00 \mathrm{E}-06$ & $4.00 \mathrm{E}-06$ & $8.00 \mathrm{E}-06$ & $3.00 \mathrm{E}-06$ & $2.00 \mathrm{E}-06$ & $4.00 \mathrm{E}-06$ & $9.00 \mathrm{E}-06$ & $8.00 \mathrm{E}-06$ & $1.00 \mathrm{E}-05$ \\
\hline $\mathrm{V} 23$ & 83.00 & $7.00 \mathrm{E}-06$ & $4.00 \mathrm{E}-06$ & $1.00 \mathrm{E}-05$ & $3.00 \mathrm{E}-06$ & $2.00 \mathrm{E}-06$ & $4.00 \mathrm{E}-06$ & $1.40 \mathrm{E}-05$ & $1.20 \mathrm{E}-05$ & $1.60 \mathrm{E}-05$ \\
\hline V32 & 91.00 & $6.00 \mathrm{E}-06$ & $4.00 \mathrm{E}-06$ & $7.00 \mathrm{E}-06$ & $2.00 \mathrm{E}-06$ & $2.00 \mathrm{E}-06$ & $4.00 \mathrm{E}-06$ & $8.00 \mathrm{E}-06$ & $7.00 \mathrm{E}-06$ & $1.00 \mathrm{E}-05$ \\
\hline V33 & 74.00 & $4.00 \mathrm{E}-06$ & $3.00 \mathrm{E}-06$ & $5.00 \mathrm{E}-06$ & $3.00 \mathrm{E}-06$ & $2.00 \mathrm{E}-06$ & $4.00 \mathrm{E}-06$ & $5.00 \mathrm{E}-06$ & $4.00 \mathrm{E}-06$ & $6.00 \mathrm{E}-06$ \\
\hline V1ave & 64.67 & $6.00 \mathrm{E}-06$ & $3.00 \mathrm{E}-06$ & $9.00 \mathrm{E}-06$ & $3.00 \mathrm{E}-06$ & $2.00 \mathrm{E}-06$ & $4.33 \mathrm{E}-06$ & $1.30 \mathrm{E}-05$ & $1.10 \mathrm{E}-05$ & $1.57 \mathrm{E}-05$ \\
\hline V2ave & 81.00 & $6.00 \mathrm{E}-06$ & $3.67 \mathrm{E}-06$ & $8.33 \mathrm{E}-06$ & $2.67 \mathrm{E}-06$ & $2.00 \mathrm{E}-06$ & $4.00 \mathrm{E}-06$ & $1.00 \mathrm{E}-05$ & $8.67 \mathrm{E}-06$ & $1.17 \mathrm{E}-05$ \\
\hline V3ave & 84.33 & $5.33 \mathrm{E}-06$ & $3.67 \mathrm{E}-06$ & $7.00 \mathrm{E}-06$ & $2.67 \mathrm{E}-06$ & $2.00 \mathrm{E}-06$ & $4.33 \mathrm{E}-06$ & $8.00 \mathrm{E}-06$ & $7.00 \mathrm{E}-06$ & $9.67 \mathrm{E}-06$ \\
\hline Vtotave & 76.67 & $5.78 \mathrm{E}-06$ & $3.44 \mathrm{E}-06$ & $8.11 \mathrm{E}-06$ & $2.78 \mathrm{E}-06$ & $2.00 \mathrm{E}-06$ & $4.22 \mathrm{E}-06$ & $1.03 \mathrm{E}-05$ & $8.89 \mathrm{E}-06$ & $1.23 \mathrm{E}-05$ \\
\hline
\end{tabular}

Earth Velocity

\begin{tabular}{|c|c|c|c|c|c|c|c|c|c|c|}
\hline Version & $\begin{array}{c}\text { Number of } \\
\text { Impacts }\end{array}$ & Mean & $\begin{array}{c}\text { 95\% CI for } \\
\text { Mean, Low }\end{array}$ & $\begin{array}{c}\text { 95\% CI for } \\
\text { Mean, } \\
\text { High }\end{array}$ & Median & $\begin{array}{c}\text { Median, } \\
\text { Low }\end{array}$ & $\begin{array}{c}\text { M5\% CI for } \\
\text { Median, } \\
\text { High }\end{array}$ & $\begin{array}{c}\text { 95\% CI for } \\
\text { StDev, } \\
\text { Low }\end{array}$ & $\begin{array}{c}\text { 95\% CI for } \\
\text { Stdev, } \\
\text { High }\end{array}$ \\
\hline V11 & 63.00 & 23.25 & 21.16 & 25.35 & 23.00 & 21.00 & 25.00 & 8.31 & 7.07 & 10.08 \\
\hline V12 & 61.00 & 23.00 & 20.83 & 25.17 & 23.00 & 19.81 & 25.00 & 8.47 & 7.19 & 10.31 \\
\hline V13 & 70.00 & 23.20 & 21.25 & 25.15 & 23.00 & 19.00 & 25.00 & 8.18 & 7.01 & 9.82 \\
\hline V21 & 78.00 & 24.15 & 22.25 & 26.06 & 23.00 & 22.75 & 25.00 & 8.46 & 7.31 \\
\hline V22 & 82.00 & 25.29 & 23.31 & 27.28 & 26.00 & 21.00 & 27.64 & 9.02 & 7.82 & 10.05 \\
\hline V23 & 83.00 & 21.99 & 20.06 & 23.91 & 21.00 & 19.00 & 25.00 & 8.81 & 7.64 & 10.40 \\
\hline V31 & 88.00 & 2.34 & 20.62 & 24.07 & 23.00 & 21.00 & 25.00 & 8.15 & 7.10 & 9.57 \\
\hline V32 & 91.00 & 23.07 & 21.15 & 24.98 & 23.00 & 19.00 & 25.60 & 9.19 & 8.02 & 10.76 \\
\hline V33 & 74.00 & 22.76 & 20.97 & 24.55 & 23.00 & 21.00 & 25.00 & 7.72 & 6.65 & 9.21 \\
\hline V1ave & 64.67 & 23.15 & 21.08 & 25.22 & 23.00 & 19.94 & 25.00 & 8.32 & 7.09 & 10.07 \\
\hline V2ave & 81.00 & 23.81 & 21.87 & 25.75 & 23.33 & 20.92 & 25.88 & 8.77 & 7.59 & 10.37 \\
\hline V3ave & 84.33 & 16.05 & 20.91 & 24.53 & 23.00 & 20.33 & 25.20 & 8.35 & 7.25 & 9.85 \\
\hline Vtotave & 76.67 & 21.01 & 21.29 & 25.17 & 23.11 & 20.40 & 25.36 & 8.48 & 7.31 & 10.10 \\
\hline
\end{tabular}


Sun Mass

\begin{tabular}{|c|c|c|c|c|c|c|c|c|c|c|}
\hline Version & $\begin{array}{l}\text { Number of } \\
\text { Impacts }\end{array}$ & Mean & $\begin{array}{l}95 \% \text { CI for } \\
\text { Mean, Low }\end{array}$ & $\begin{array}{l}95 \% \text { CI for } \\
\text { Mean, } \\
\text { High }\end{array}$ & Median & $\begin{array}{l}95 \% \text { CI for } \\
\text { Median, } \\
\text { Low }\end{array}$ & $\begin{array}{l}95 \% \text { CI for } \\
\text { Median, } \\
\text { High }\end{array}$ & StDev & $\begin{array}{c}95 \% \text { CI for } \\
\text { StDev, } \\
\text { Low }\end{array}$ & $\begin{array}{c}95 \% \text { CI for } \\
\text { Stdev, } \\
\text { High }\end{array}$ \\
\hline V11 & 190.00 & $5.00 \mathrm{E}-06$ & $4.00 \mathrm{E}-06$ & $7.00 \mathrm{E}-06$ & $3.00 \mathrm{E}-06$ & $2.00 \mathrm{E}-06$ & $4.00 \mathrm{E}-06$ & $1.10 \mathrm{E}-05$ & $1.00 \mathrm{E}-05$ & $1.20 \mathrm{E}-05$ \\
\hline V12 & 217.00 & $5.00 \mathrm{E}-06$ & $4.00 \mathrm{E}-06$ & $7.00 \mathrm{E}-06$ & $3.00 \mathrm{E}-06$ & $2.00 \mathrm{E}-06$ & $3.00 \mathrm{E}-06$ & $1.10 \mathrm{E}-05$ & $1.00 \mathrm{E}-06$ & $1.20 \mathrm{E}-05$ \\
\hline V13 & 209.00 & $6.00 \mathrm{E}-06$ & $4.00 \mathrm{E}-06$ & $8.00 \mathrm{E}-06$ & $3.00 \mathrm{E}-06$ & $2.00 \mathrm{E}-06$ & $3.00 \mathrm{E}-06$ & $1.30 \mathrm{E}-05$ & $1.20 \mathrm{E}-05$ & $1.40 \mathrm{E}-05$ \\
\hline V21 & 239.00 & $8.00 \mathrm{E}-06$ & $4.00 \mathrm{E}-06$ & $1.20 \mathrm{E}-05$ & $3.00 \mathrm{E}-06$ & $2.00 \mathrm{E}-06$ & $4.00 \mathrm{E}-06$ & $3.40 \mathrm{E}-05$ & $3.10 \mathrm{E}-05$ & $3.70 \mathrm{E}-05$ \\
\hline V22 & 287.00 & $6.00 \mathrm{E}-06$ & $4.00 \mathrm{E}-06$ & $8.00 \mathrm{E}-06$ & $2.00 \mathrm{E}-06$ & $2.00 \mathrm{E}-06$ & $3.00 \mathrm{E}-06$ & $1.60 \mathrm{E}-05$ & $1.50 \mathrm{E}-05$ & $1.70 \mathrm{E}-05$ \\
\hline V23 & 284.00 & $5.00 \mathrm{E}-06$ & $4.00 \mathrm{E}-06$ & $6.00 \mathrm{E}-06$ & $3.00 \mathrm{E}-06$ & $2.00 \mathrm{E}-06$ & $3.00 \mathrm{E}-06$ & $1.00 \mathrm{E}-05$ & $9.00 \mathrm{E}-06$ & $1.00 \mathrm{E}-05$ \\
\hline V31 & 267.00 & $5.00 \mathrm{E}-06$ & $4.00 \mathrm{E}-06$ & $6.00 \mathrm{E}-06$ & $3.00 \mathrm{E}-06$ & $2.00 \mathrm{E}-06$ & $3.00 \mathrm{E}-06$ & $1.00 \mathrm{E}-05$ & $1.00 \mathrm{E}-05$ & $1.10 \mathrm{E}-05$ \\
\hline V32 & 273.00 & $8.00 \mathrm{E}-06$ & $4.00 \mathrm{E}-06$ & $1.30 \mathrm{E}-05$ & $3.00 \mathrm{E}-06$ & $2.00 \mathrm{E}-06$ & $3.00 \mathrm{E}-06$ & $3.90 \mathrm{E}-05$ & $3.60 \mathrm{E}-05$ & $4.30 \mathrm{E}-05$ \\
\hline V33 & 257.00 & $6.00 \mathrm{E}-06$ & $4.00 \mathrm{E}-06$ & 7.00E-06 & $3.00 \mathrm{E}-06$ & $2.00 \mathrm{E}-06$ & $3.00 \mathrm{E}-06$ & $1.30 \mathrm{E}-05$ & $1.20 \mathrm{E}-05$ & $1.40 \mathrm{E}-05$ \\
\hline V1ave & 205.33 & $5.33 \mathrm{E}-06$ & $4.00 \mathrm{E}-06$ & 7.33E-06 & $3.00 \mathrm{E}-06$ & $2.00 \mathrm{E}-06$ & $3.33 \mathrm{E}-06$ & $1.17 \mathrm{E}-05$ & 7.67E-06 & $1.27 \mathrm{E}-05$ \\
\hline V2ave & 270.00 & $6.33 \mathrm{E}-06$ & $4.00 \mathrm{E}-06$ & 8.67E-06 & $2.67 \mathrm{E}-06$ & $2.00 \mathrm{E}-06$ & $3.33 \mathrm{E}-06$ & $2.00 \mathrm{E}-05$ & $1.83 \mathrm{E}-05$ & $2.13 \mathrm{E}-05$ \\
\hline V3ave & 265.67 & $6.33 \mathrm{E}-06$ & $4.00 \mathrm{E}-06$ & $8.67 \mathrm{E}-06$ & $3.00 \mathrm{E}-06$ & $2.00 \mathrm{E}-06$ & $3.00 \mathrm{E}-06$ & $2.07 \mathrm{E}-05$ & $1.93 \mathrm{E}-05$ & $2.27 \mathrm{E}-05$ \\
\hline Vtotave & 247.00 & $6.00 \mathrm{E}-06$ & $4.00 \mathrm{E}-06$ & $8.22 \mathrm{E}-06$ & $2.89 \mathrm{E}-06$ & $2.00 \mathrm{E}-06$ & $3.22 \mathrm{E}-06$ & $1.74 \mathrm{E}-05$ & $1.51 \mathrm{E}-05$ & $1.89 \mathrm{E}-05$ \\
\hline
\end{tabular}

Sun Velocity

\begin{tabular}{|c|c|c|c|c|c|c|c|c|c|c|}
\hline Version & $\begin{array}{c}\text { Number of } \\
\text { Impacts }\end{array}$ & Mean & $\begin{array}{l}95 \% \text { CI for } \\
\text { Mean, Low }\end{array}$ & $\begin{array}{c}95 \% \text { CI for } \\
\text { Mean, } \\
\text { High }\end{array}$ & Median & $\begin{array}{l}95 \% \text { CI for } \\
\text { Median, } \\
\text { Low }\end{array}$ & $\begin{array}{c}95 \% \text { CI for } \\
\text { Median, } \\
\text { High }\end{array}$ & StDev & $\begin{array}{c}95 \% \text { CI for } \\
\text { StDev, } \\
\text { Low }\end{array}$ & $\begin{array}{c}95 \% \text { CI for } \\
\text { Stdev, } \\
\text { High }\end{array}$ \\
\hline V11 & 190.00 & 22.75 & 21.29 & 24.21 & 21.00 & 19.00 & 23.00 & 10.20 & 9.26 & 11.34 \\
\hline V12 & 217.00 & 24.32 & 22.87 & 25.78 & 25.00 & 21.00 & 27.00 & 10.80 & 9.87 & 11.92 \\
\hline V13 & 209.00 & 23.05 & 21.68 & 24.41 & 23.00 & 21.00 & 25.00 & 10.01 & 9.13 & 11.07 \\
\hline V21 & 239.00 & 21.94 & 20.55 & 23.32 & 21.00 & 19.00 & 23.00 & 10.85 & 9.96 & 11.92 \\
\hline V22 & 287.00 & 21.93 & 20.69 & 23.17 & 21.00 & 19.00 & 23.00 & 10.67 & 9.87 & 11.63 \\
\hline V23 & 284.00 & 22.75 & 21.42 & 24.09 & 23.00 & 21.00 & 25.00 & 11.44 & 10.57 & 12.47 \\
\hline V31 & 267.00 & 21.70 & 20.34 & 23.07 & 21.00 & 19.00 & 23.00 & 11.31 & 10.43 & 12.36 \\
\hline V32 & 273.00 & 20.66 & 19.44 & 21.89 & 21.00 & 19.00 & 23.00 & 10.26 & 9.46 & 11.20 \\
\hline V33 & 257.00 & 22.30 & 20.89 & 23.71 & 21.00 & 19.00 & 23.00 & 11.47 & 10.56 & 12.56 \\
\hline V1ave & 205.33 & 23.37 & 21.95 & 24.80 & 23.00 & 20.33 & 25.00 & 10.34 & 9.42 & 11.45 \\
\hline V2ave & 270.00 & 22.21 & 20.89 & 23.53 & 21.67 & 19.67 & 23.67 & 10.99 & 10.13 & 12.01 \\
\hline V3ave & 265.67 & 21.56 & 20.22 & 22.89 & 21.00 & 19.00 & 23.00 & 11.01 & 10.15 & 12.04 \\
\hline Vtotave & 247.00 & 22.38 & 21.02 & 23.74 & 21.89 & 19.67 & 23.89 & 10.78 & 9.90 & 11.83 \\
\hline
\end{tabular}

\section{Antisun Mass}

\begin{tabular}{|c|c|c|c|c|c|c|c|c|c|c|}
\hline Version & $\begin{array}{l}\text { Number of } \\
\text { Impacts }\end{array}$ & Mean & $\begin{array}{l}95 \% \text { CI for } \\
\text { Mean, Low }\end{array}$ & $\begin{array}{c}95 \% \text { CI for } \\
\text { Mean, } \\
\text { High }\end{array}$ & Median & $\begin{array}{l}95 \% \text { CI for } \\
\text { Median, } \\
\text { Low }\end{array}$ & $\begin{array}{l}\text { 95\% CI for } \\
\text { Median, } \\
\text { High }\end{array}$ & StDev & $\begin{array}{c}95 \% \text { CI for } \\
\text { StDev, } \\
\text { Low }\end{array}$ & $\begin{array}{c}95 \% \text { CI for } \\
\text { Stdev, } \\
\text { High }\end{array}$ \\
\hline V11 & 315.00 & $6.00 \mathrm{E}-06$ & $4.00 \mathrm{E}-06$ & $8.00 \mathrm{E}-06$ & $2.00 \mathrm{E}-06$ & $2.00 \mathrm{E}-06$ & $3.00 \mathrm{E}-06$ & $1.40 \mathrm{E}-05$ & $1.30 \mathrm{E}-05$ & $1.50 \mathrm{E}-05$ \\
\hline V12 & 315.00 & $6.00 \mathrm{E}-06$ & $5.00 \mathrm{E}-06$ & $8.00 \mathrm{E}-06$ & $3.00 \mathrm{E}-06$ & $2.00 \mathrm{E}-06$ & $3.00 \mathrm{E}-06$ & $1.40 \mathrm{E}-05$ & $1.30 \mathrm{E}-05$ & $1.50 \mathrm{E}-05$ \\
\hline V13 & 292.00 & $8.00 \mathrm{E}-06$ & $3.00 \mathrm{E}-06$ & $1.40 \mathrm{E}-05$ & $3.00 \mathrm{E}-06$ & $2.00 \mathrm{E}-06$ & $3.00 \mathrm{E}-06$ & $4.80 \mathrm{E}-05$ & $4.40 \mathrm{E}-05$ & $5.20 \mathrm{E}-05$ \\
\hline V21 & 290.00 & $5.00 \mathrm{E}-06$ & $4.00 \mathrm{E}-06$ & $6.00 \mathrm{E}-06$ & $3.00 \mathrm{E}-06$ & $2.00 \mathrm{E}-06$ & $3.00 \mathrm{E}-06$ & $1.00 \mathrm{E}-05$ & $9.00 \mathrm{E}-06$ & $1.10 \mathrm{E}-05$ \\
\hline V22 & 276.00 & $5.00 \mathrm{E}-06$ & $4.00 \mathrm{E}-06$ & $6.00 \mathrm{E}-06$ & $2.00 \mathrm{E}-06$ & $2.00 \mathrm{E}-06$ & $3.00 \mathrm{E}-06$ & $8.00 \mathrm{E}-06$ & $8.00 \mathrm{E}-06$ & $9.00 \mathrm{E}-06$ \\
\hline V23 & 275.00 & $8.00 \mathrm{E}-06$ & $5.00 \mathrm{E}-06$ & $1.00 \mathrm{E}-05$ & $3.00 \mathrm{E}-06$ & $2.00 \mathrm{E}-06$ & $3.00 \mathrm{E}-06$ & $2.30 \mathrm{E}-05$ & $2.10 \mathrm{E}-05$ & $2.50 \mathrm{E}-05$ \\
\hline V31 & 268.00 & $9.00 \mathrm{E}-06$ & $4.00 \mathrm{E}-06$ & $1.40 \mathrm{E}-05$ & $3.00 \mathrm{E}-06$ & $2.00 \mathrm{E}-06$ & $3.00 \mathrm{E}-06$ & $4.40 \mathrm{E}-05$ & $4.10 \mathrm{E}-05$ & $4.90 \mathrm{E}-05$ \\
\hline V32 & 272.00 & $8.00 \mathrm{E}-06$ & $4.00 \mathrm{E}-06$ & $1.20 \mathrm{E}-05$ & $3.00 \mathrm{E}-06$ & $2.00 \mathrm{E}-06$ & $3.00 \mathrm{E}-06$ & $3.20 \mathrm{E}-05$ & $2.90 \mathrm{E}-05$ & $3.50 \mathrm{E}-05$ \\
\hline V33 & 273.00 & $5.00 \mathrm{E}-06$ & $4.00 \mathrm{E}-06$ & $6.00 \mathrm{E}-06$ & $3.00 \mathrm{E}-06$ & $3.00 \mathrm{E}-06$ & $3.00 \mathrm{E}-06$ & $1.00 \mathrm{E}-05$ & $9.00 \mathrm{E}-06$ & $1.10 \mathrm{E}-05$ \\
\hline V1ave & 307.33 & $6.67 \mathrm{E}-06$ & $4.00 \mathrm{E}-06$ & $1.00 \mathrm{E}-05$ & $2.67 \mathrm{E}-06$ & $2.00 \mathrm{E}-06$ & $3.00 \mathrm{E}-06$ & $2.53 \mathrm{E}-05$ & $2.33 \mathrm{E}-05$ & $2.73 \mathrm{E}-05$ \\
\hline V2ave & 280.33 & $6.00 \mathrm{E}-06$ & $4.33 \mathrm{E}-06$ & 7.33E-06 & $2.67 \mathrm{E}-06$ & $2.00 \mathrm{E}-06$ & $3.00 \mathrm{E}-06$ & $1.37 \mathrm{E}-05$ & $1.27 \mathrm{E}-05$ & $1.50 \mathrm{E}-05$ \\
\hline V3ave & 271.00 & $7.33 \mathrm{E}-06$ & $4.00 \mathrm{E}-06$ & $1.07 \mathrm{E}-05$ & $3.00 \mathrm{E}-06$ & $2.33 \mathrm{E}-06$ & $3.00 \mathrm{E}-06$ & $2.87 \mathrm{E}-05$ & $2.63 \mathrm{E}-05$ & $3.17 \mathrm{E}-05$ \\
\hline Vtotave & 286.22 & $6.67 \mathrm{E}-06$ & $4.11 \mathrm{E}-06$ & $9.33 \mathrm{E}-06$ & $2.78 \mathrm{E}-06$ & $2.11 \mathrm{E}-06$ & $3.00 \mathrm{E}-06$ & $2.26 \mathrm{E}-05$ & $2.08 \mathrm{E}-05$ & $2.47 \mathrm{E}-05$ \\
\hline
\end{tabular}




\section{Antisun Velocity}

\begin{tabular}{|c|c|c|c|c|c|c|c|c|c|c|}
\hline Version & $\begin{array}{l}\text { Number of } \\
\text { Impacts }\end{array}$ & Mean & $\begin{array}{l}95 \% \text { CI for } \\
\text { Mean, Low }\end{array}$ & $\begin{array}{c}95 \% \text { CI for } \\
\text { Mean, } \\
\text { High }\end{array}$ & Median & $\begin{array}{l}95 \% \text { CI for } \\
\text { Median, } \\
\text { Low }\end{array}$ & $\begin{array}{l}95 \% \text { CI for } \\
\text { Median, } \\
\text { High }\end{array}$ & StDev & $\begin{array}{c}95 \% \text { CI for } \\
\text { StDev, } \\
\text { Low }\end{array}$ & $\begin{array}{c}95 \% \text { CI for } \\
\text { Stdev, } \\
\text { High }\end{array}$ \\
\hline V11 & 315.00 & 20.66 & 19.42 & 21.91 & 21.00 & 17.00 & 21.00 & 11.21 & 10.40 & 12.16 \\
\hline V12 & 315.00 & 20.57 & 19.41 & 21.73 & 19.00 & 19.00 & 21.00 & 10.45 & 9.70 & 11.34 \\
\hline V13 & 292.00 & 20.59 & 19.42 & 21.76 & 20.00 & 19.00 & 21.00 & 10.17 & 9.41 & 11.07 \\
\hline V21 & 290.00 & 20.53 & 19.34 & 21.73 & 21.00 & 19.00 & 21.00 & 10.33 & 9.55 & 11.24 \\
\hline V22 & 276.00 & 20.25 & 18.96 & 21.54 & 19.00 & 17.48 & 21.00 & 10.90 & 10.06 & 11.90 \\
\hline V23 & 275.00 & 20.34 & 19.09 & 21.59 & 19.00 & 17.00 & 21.00 & 10.53 & 9.72 & 11.49 \\
\hline V32 & 272.00 & 20.72 & 19.51 & 21.93 & 21.00 & 19.00 & 21.00 & 10.16 & 9.37 & 11.09 \\
\hline V33 & 273.00 & 21.50 & 20.20 & 22.80 & 21.00 & 19.00 & 23.00 & 10.89 & 10.05 & 11.89 \\
\hline V1ave & 307.33 & 20.61 & 19.42 & 21.80 & 20.00 & 18.33 & 21.00 & 10.61 & 9.83 & 11.52 \\
\hline V2ave & 280.33 & 20.37 & 19.13 & 21.62 & 19.67 & 17.83 & 21.00 & 10.59 & 9.78 & 11.54 \\
\hline V3ave & 271.00 & 21.01 & 19.75 & 22.26 & 20.33 & 19.00 & 21.67 & 10.52 & 9.70 & 11.49 \\
\hline Vtotave & 286.22 & 20.66 & 19.43 & 21.89 & 20.00 & 18.39 & 21.22 & 10.57 & 9.77 & 11.52 \\
\hline
\end{tabular}

\section{Hohmann2}

Ram Mass

\begin{tabular}{|c|c|c|c|c|c|c|c|c|c|c|}
\hline Version & $\begin{array}{l}\text { Number of } \\
\text { Impacts }\end{array}$ & Mean & $\begin{array}{l}95 \% \text { CI for } \\
\text { Mean, Low }\end{array}$ & $\begin{array}{l}\text { 95\% CI for } \\
\text { Mean, High }\end{array}$ & Median & $\begin{array}{l}\text { 95\% CI for } \\
\text { Median, } \\
\text { Low }\end{array}$ & $\begin{array}{c}95 \% \text { CI for } \\
\text { Median, } \\
\text { High }\end{array}$ & StDev & $\begin{array}{l}95 \% \text { CI for } \\
\text { StDev, } \\
\text { Low }\end{array}$ & $\begin{array}{c}95 \% \text { CI for } \\
\text { Stdev, } \\
\text { High }\end{array}$ \\
\hline V11 & 236.00 & $6.00 \mathrm{E}-06$ & $4.00 \mathrm{E}-06$ & $7.00 \mathrm{E}-06$ & $2.00 \mathrm{E}-06$ & $2.00 \mathrm{E}-06$ & $3.00 \mathrm{E}-06$ & $1.20 \mathrm{E}-05$ & $1.10 \mathrm{E}-05$ & $1.30 \mathrm{E}-05$ \\
\hline V12 & 224.00 & $1.10 \mathrm{E}-05$ & $3.00 \mathrm{E}-06$ & $1.90 \mathrm{E}-05$ & $3.00 \mathrm{E}-06$ & $2.00 \mathrm{E}-06$ & $3.00 \mathrm{E}-06$ & $6.10 \mathrm{E}-05$ & $5.60 \mathrm{E}-05$ & $6.70 \mathrm{E}-05$ \\
\hline V13 & 219.00 & $7.00 \mathrm{E}-06$ & $3.00 \mathrm{E}-06$ & $1.20 \mathrm{E}-05$ & $2.00 \mathrm{E}-06$ & $2.00 \mathrm{E}-06$ & $3.00 \mathrm{E}-06$ & $3.50 \mathrm{E}-05$ & $3.20 \mathrm{E}-05$ & $3.90 \mathrm{E}-05$ \\
\hline V21 & 256.00 & $9.00 \mathrm{E}-06$ & $3.00 \mathrm{E}-06$ & $1.50 \mathrm{E}-05$ & $3.00 \mathrm{E}-06$ & $2.00 \mathrm{E}-06$ & $3.00 \mathrm{E}-06$ & $4.80 \mathrm{E}-05$ & $4.40 \mathrm{E}-05$ & $5.20 \mathrm{E}-05$ \\
\hline V22 & 224.00 & $7.00 \mathrm{E}-06$ & $4.00 \mathrm{E}-06$ & $9.00 \mathrm{E}-06$ & $3.00 \mathrm{E}-06$ & $2.00 \mathrm{E}-06$ & $3.00 \mathrm{E}-06$ & $1.80 \mathrm{E}-05$ & $1.70 \mathrm{E}-05$ & $2.00 \mathrm{E}-05$ \\
\hline V23 & 224.00 & $5.00 \mathrm{E}-06$ & $3.00 \mathrm{E}-06$ & $6.00 \mathrm{E}-06$ & $2.00 \mathrm{E}-06$ & $2.00 \mathrm{E}-06$ & $3.00 \mathrm{E}-06$ & $1.10 \mathrm{E}-05$ & $1.00 \mathrm{E}-05$ & $1.20 \mathrm{E}-05$ \\
\hline V31 & 267.00 & $9.00 \mathrm{E}-06$ & $4.00 \mathrm{E}-06$ & $1.50 \mathrm{E}-05$ & $3.00 \mathrm{E}-06$ & $2.00 \mathrm{E}-06$ & $3.00 \mathrm{E}-06$ & $4.30 \mathrm{E}-05$ & $4.00 \mathrm{E}-05$ & $4.70 \mathrm{E}-05$ \\
\hline V32 & 245.00 & $6.00 \mathrm{E}-06$ & $5.00 \mathrm{E}-06$ & $8.00 \mathrm{E}-06$ & $3.00 \mathrm{E}-06$ & $2.00 \mathrm{E}-06$ & $3.00 \mathrm{E}-06$ & $1.30 \mathrm{E}-05$ & $1.20 \mathrm{E}-05$ & $1.40 \mathrm{E}-05$ \\
\hline V33 & 260.00 & $4.00 \mathrm{E}-06$ & $4.00 \mathrm{E}-06$ & $5.00 \mathrm{E}-06$ & $3.00 \mathrm{E}-06$ & $2.00 \mathrm{E}-06$ & $3.00 \mathrm{E}-06$ & $7.00 \mathrm{E}-06$ & $6.00 \mathrm{E}-06$ & $7.00 \mathrm{E}-06$ \\
\hline V1ave & 226.33 & $8.00 \mathrm{E}-06$ & $3.33 \mathrm{E}-06$ & $1.27 \mathrm{E}-05$ & $2.33 \mathrm{E}-06$ & $2.00 \mathrm{E}-06$ & $3.00 \mathrm{E}-06$ & $3.60 \mathrm{E}-05$ & $3.30 \mathrm{E}-05$ & $3.97 \mathrm{E}-05$ \\
\hline V2ave & 234.67 & $7.00 \mathrm{E}-06$ & $3.33 \mathrm{E}-06$ & $1.00 \mathrm{E}-05$ & $2.67 \mathrm{E}-06$ & $2.00 \mathrm{E}-06$ & $3.00 \mathrm{E}-06$ & $2.57 \mathrm{E}-05$ & $2.37 \mathrm{E}-05$ & $2.80 \mathrm{E}-05$ \\
\hline V3ave & 257.33 & $6.33 \mathrm{E}-06$ & $4.33 \mathrm{E}-06$ & $9.33 \mathrm{E}-06$ & $3.00 \mathrm{E}-06$ & $2.00 \mathrm{E}-06$ & $3.00 \mathrm{E}-06$ & $2.10 \mathrm{E}-05$ & $1.93 \mathrm{E}-05$ & $2.27 \mathrm{E}-05$ \\
\hline Vtotave & 239.44 & $7.11 \mathrm{E}-06$ & $3.67 \mathrm{E}-06$ & $1.07 \mathrm{E}-05$ & $2.67 \mathrm{E}-06$ & $2.00 \mathrm{E}-06$ & $3.00 \mathrm{E}-06$ & $2.76 \mathrm{E}-05$ & $2.53 \mathrm{E}-05$ & $3.01 \mathrm{E}-05$ \\
\hline
\end{tabular}

Ram Velocity

\begin{tabular}{|c|c|c|c|c|c|c|c|c|c|c|}
\hline Version & $\begin{array}{l}\text { Number of } \\
\text { Impacts }\end{array}$ & Mean & $\begin{array}{l}95 \% \text { CI for } \\
\text { Mean, Low }\end{array}$ & $\begin{array}{c}95 \% \text { CI for } \\
\text { Mean, } \\
\text { High }\end{array}$ & Median & $\begin{array}{l}\text { 95\% CI for } \\
\text { Median, } \\
\text { Low }\end{array}$ & $\begin{array}{l}\text { 95\% CI for } \\
\text { Median, } \\
\text { High }\end{array}$ & StDev & $\begin{array}{l}95 \% \text { CI for } \\
\text { StDev, } \\
\text { Low }\end{array}$ & $\begin{array}{c}95 \% \text { CI for } \\
\text { Stdev, } \\
\text { High }\end{array}$ \\
\hline V11 & 236.00 & 22.50 & 20.84 & 24.16 & 21.00 & 19.00 & 23.00 & 12.96 & 11.88 & 14.24 \\
\hline V12 & 224.00 & 23.32 & 21.71 & 24.93 & 23.00 & 21.00 & 23.00 & 12.23 & 11.19 & 13.48 \\
\hline V13 & 219.00 & 24.08 & 22.35 & 25.81 & 23.00 & 21.00 & 25.00 & 13.01 & 11.90 & 14.36 \\
\hline V21 & 256.00 & 23.20 & 21.75 & 24.66 & 23.00 & 21.00 & 25.00 & 11.83 & 10.89 & 12.95 \\
\hline V22 & 224.00 & 23.28 & 21.57 & 24.98 & 23.00 & 20.70 & 25.00 & 12.94 & 11.84 & 14.27 \\
\hline V23 & 224.00 & 24.40 & 22.65 & 26.15 & 23.00 & 21.00 & 25.00 & 13.40 & 12.18 & 14.67 \\
\hline V32 & 245.00 & 22.07 & 20.63 & 23.51 & 21.00 & 19.00 & 23.00 & 11.42 & 10.49 & 12.53 \\
\hline V33 & 260.00 & 20.55 & 19.20 & 21.91 & 21.00 & 19.00 & 21.55 & 11.08 & 10.20 & 12.12 \\
\hline V1ave & 226.33 & 23.30 & 21.63 & 24.97 & 22.33 & 20.33 & 23.67 & 12.73 & 11.66 & 14.03 \\
\hline V2ave & 234.67 & 23.63 & 21.99 & 25.26 & 23.00 & 20.90 & 25.00 & 12.72 & 11.64 & 13.96 \\
\hline V3ave & 257.33 & 21.45 & 20.02 & 22.87 & 21.00 & 19.00 & 22.52 & 11.61 & 10.68 & 12.71 \\
\hline Vtotave & 239.44 & 22.79 & 21.21 & 24.37 & 22.11 & 20.08 & 23.73 & 12.35 & 11.33 & 13.57 \\
\hline
\end{tabular}


Wake Mass

\begin{tabular}{|c|c|c|c|c|c|c|c|c|c|c|}
\hline Version & $\begin{array}{l}\text { Number of } \\
\text { Impacts }\end{array}$ & Mean & $\begin{array}{l}95 \% \text { CI for } \\
\text { Mean, Low }\end{array}$ & $\begin{array}{c}95 \% \text { CI for } \\
\text { Mean, } \\
\text { High }\end{array}$ & Median & $\begin{array}{l}95 \% \text { CI for } \\
\text { Median, } \\
\text { Low }\end{array}$ & $\begin{array}{l}95 \% \text { CI for } \\
\text { Median, } \\
\text { High }\end{array}$ & StDev & $\begin{array}{c}95 \% \text { CI for } \\
\text { StDev, } \\
\text { Low }\end{array}$ & $\begin{array}{c}95 \% \text { CI for } \\
\text { Stdev, } \\
\text { High }\end{array}$ \\
\hline V11 & 27.00 & $5.00 \mathrm{E}-06$ & $4.00 \mathrm{E}-06$ & $7.00 \mathrm{E}-06$ & $4.00 \mathrm{E}-06$ & $3.00 \mathrm{E}-06$ & $6.00 \mathrm{E}-06$ & $4.00 \mathrm{E}-06$ & $3.00 \mathrm{E}-06$ & $5.00 \mathrm{E}-06$ \\
\hline V12 & 26.00 & $3.00 \mathrm{E}-06$ & $2.00 \mathrm{E}-06$ & $3.00 \mathrm{E}-06$ & $2.00 \mathrm{E}-06$ & $2.00 \mathrm{E}-06$ & $3.00 \mathrm{E}-06$ & $2.00 \mathrm{E}-06$ & $1.00 \mathrm{E}-06$ & $3.00 \mathrm{E}-06$ \\
\hline V13 & 31.00 & $3.00 \mathrm{E}-06$ & $2.00 \mathrm{E}-06$ & $4.00 \mathrm{E}-06$ & $2.00 \mathrm{E}-06$ & $2.00 \mathrm{E}-06$ & $3.00 \mathrm{E}-06$ & $2.00 \mathrm{E}-06$ & $2.00 \mathrm{E}-06$ & $3.00 \mathrm{E}-06$ \\
\hline V21 & 33.00 & $4.00 \mathrm{E}-06$ & $1.00 \mathrm{E}-06$ & $7.00 \mathrm{E}-06$ & $2.00 \mathrm{E}-06$ & $1.00 \mathrm{E}-06$ & $2.00 \mathrm{E}-06$ & $9.00 \mathrm{E}-06$ & $7.00 \mathrm{E}-06$ & $1.10 \mathrm{E}-05$ \\
\hline V22 & 27.00 & $7.00 \mathrm{E}-06$ & $2.00 \mathrm{E}-06$ & $1.10 \mathrm{E}-05$ & $4.00 \mathrm{E}-06$ & $2.00 \mathrm{E}-06$ & $6.00 \mathrm{E}-06$ & $1.10 \mathrm{E}-05$ & $9.00 \mathrm{E}-06$ & $1.50 \mathrm{E}-05$ \\
\hline V23 & 29.00 & $8.00 \mathrm{E}-06$ & $0.00 \mathrm{E}+00$ & $1.70 \mathrm{E}-05$ & $1.00 \mathrm{E}-06$ & $1.00 \mathrm{E}-06$ & $2.00 \mathrm{E}-06$ & $2.20 \mathrm{E}-05$ & $1.70 \mathrm{E}-05$ & $2.90 \mathrm{E}-05$ \\
\hline V32 & 32.00 & $4.00 \mathrm{E}-06$ & $3.00 \mathrm{E}-06$ & $4.00 \mathrm{E}-06$ & $3.00 \mathrm{E}-06$ & $1.00 \mathrm{E}-06$ & $4.00 \mathrm{E}-06$ & $3.00 \mathrm{E}-06$ & $2.00 \mathrm{E}-06$ & $4.00 \mathrm{E}-06$ \\
\hline V33 & 26.00 & $5.00 \mathrm{E}-06$ & $1.00 \mathrm{E}-06$ & $1.00 \mathrm{E}-05$ & $2.00 \mathrm{E}-06$ & $1.00 \mathrm{E}-06$ & $3.00 \mathrm{E}-06$ & $1.20 \mathrm{E}-05$ & $9.00 \mathrm{E}-06$ & $1.60 \mathrm{E}-05$ \\
\hline V1ave & 28.00 & $3.67 \mathrm{E}-06$ & $2.67 \mathrm{E}-06$ & $4.67 \mathrm{E}-06$ & $2.67 \mathrm{E}-06$ & $2.33 \mathrm{E}-06$ & $4.00 \mathrm{E}-06$ & $2.67 \mathrm{E}-06$ & $2.00 \mathrm{E}-06$ & $3.67 \mathrm{E}-06$ \\
\hline V2ave & 29.67 & $6.33 \mathrm{E}-06$ & $1.00 \mathrm{E}-06$ & $1.17 \mathrm{E}-05$ & $2.33 \mathrm{E}-06$ & $1.33 \mathrm{E}-06$ & $3.33 \mathrm{E}-06$ & $1.40 \mathrm{E}-05$ & $1.10 \mathrm{E}-05$ & $1.83 \mathrm{E}-05$ \\
\hline V3ave & 25.33 & $4.00 \mathrm{E}-06$ & $1.67 \mathrm{E}-06$ & $6.00 \mathrm{E}-06$ & $2.00 \mathrm{E}-06$ & $1.00 \mathrm{E}-06$ & $3.00 \mathrm{E}-06$ & $6.00 \mathrm{E}-06$ & $4.33 \mathrm{E}-06$ & $8.00 \mathrm{E}-06$ \\
\hline Vtotave & 27.67 & $4.67 \mathrm{E}-06$ & $1.78 \mathrm{E}-06$ & 7.44E-06 & $2.33 \mathrm{E}-06$ & $1.56 \mathrm{E}-06$ & $3.44 \mathrm{E}-06$ & $7.56 \mathrm{E}-06$ & $5.78 \mathrm{E}-06$ & $1.00 \mathrm{E}-05$ \\
\hline
\end{tabular}

Wake Velocity

\begin{tabular}{|c|c|c|c|c|c|c|c|c|c|c|}
\hline Version & $\begin{array}{c}\text { Number of } \\
\text { Impacts }\end{array}$ & Mean & $\begin{array}{c}\text { 95\% CI for } \\
\text { Mean, Low }\end{array}$ & $\begin{array}{c}\text { 95\% CI for } \\
\text { Mean, } \\
\text { High }\end{array}$ & Median & $\begin{array}{c}\text { Median, } \\
\text { Low }\end{array}$ & $\begin{array}{c}\text { M5\% CI for } \\
\text { Median, } \\
\text { High }\end{array}$ & $\begin{array}{c}\text { 95\% CI for } \\
\text { StDev, } \\
\text { Low }\end{array}$ & $\begin{array}{c}\text { 95\% CI for } \\
\text { Stdev, } \\
\text { High }\end{array}$ \\
\hline V11 & 27.00 & 13.37 & 9.76 & 16.98 & 11.00 & 6.94 & 17.06 & 9.13 & 7.19 & 12.52 \\
\hline V12 & 26.00 & 18.23 & 13.53 & 22.94 & 16.00 & 11.00 & 23.70 & 11.65 & 9.14 & 16.08 \\
\hline V13 & 31.00 & 16.36 & 12.54 & 20.17 & 17.00 & 9.00 & 19.00 & 10.41 & 8.32 & 13.92 \\
\hline V21 & 33.00 & 17.24 & 13.55 & 20.93 & 19.00 & 8.00 & 23.00 & 10.40 & 8.37 & 13.76 \\
\hline V22 & 27.00 & 21.37 & 16.87 & 25.87 & 19.00 & 15.00 & 27.12 & 11.37 & 8.95 & 15.58 \\
\hline V23 & 29.00 & 15.62 & 11.58 & 19.66 & 13.00 & 7.00 & 21.00 & 10.61 & 8.42 & 14.35 \\
\hline V31 & 18.00 & 19.44 & 13.81 & 25.08 & 19.00 & 10.04 & 31.96 & 11.33 & 8.50 & 16.98 \\
\hline V32 & 32.00 & 17.06 & 13.09 & 21.03 & 16.00 & 7.00 & 25.00 & 11.01 & 8.82 & 14.63 \\
\hline V33 & 26.00 & 15.69 & 12.10 & 19.29 & 16.00 & 10.30 & 19.00 & 8.91 & 6.99 & 12.30 \\
\hline V1ave & 28.00 & 15.99 & 11.94 & 20.03 & 14.67 & 8.98 & 19.92 & 10.40 & 8.22 & 14.17 \\
\hline V2ave & 29.67 & 18.08 & 14.00 & 22.15 & 17.00 & 10.00 & 23.71 & 10.79 & 8.58 & 14.56 \\
\hline V3ave & 25.33 & 17.40 & 13.00 & 21.80 & 17.00 & 9.11 & 25.32 & 10.41 & 8.10 & 14.64 \\
\hline Vtotave & 27.67 & 17.15 & 12.98 & 21.33 & 16.22 & 9.36 & 22.98 & 10.53 & 8.30 & 14.46 \\
\hline
\end{tabular}

Port Mass

\begin{tabular}{|c|c|c|c|c|c|c|c|c|c|c|}
\hline Version & $\begin{array}{l}\text { Number of } \\
\text { Impacts }\end{array}$ & Mean & $\begin{array}{l}95 \% \text { CI for } \\
\text { Mean, Low }\end{array}$ & $\begin{array}{c}95 \% \text { CI for } \\
\text { Mean, } \\
\text { High }\end{array}$ & Median & $\begin{array}{l}95 \% \text { CI for } \\
\text { Median, } \\
\text { Low }\end{array}$ & $\begin{array}{l}\text { 95\% CI for } \\
\text { Median, } \\
\text { High }\end{array}$ & StDev & $\begin{array}{c}95 \% \text { CI for } \\
\text { StDev, } \\
\text { Low }\end{array}$ & $\begin{array}{c}95 \% \text { CI for } \\
\text { Stdev, } \\
\text { High }\end{array}$ \\
\hline V11 & 135.00 & $6.00 \mathrm{E}-06$ & $4.00 \mathrm{E}-06$ & $8.00 \mathrm{E}-06$ & $2.00 \mathrm{E}-06$ & $2.00 \mathrm{E}-06$ & $3.00 \mathrm{E}-06$ & $1.20 \mathrm{E}-05$ & $1.10 \mathrm{E}-05$ & $1.40 \mathrm{E}-05$ \\
\hline V12 & 156.00 & $8.00 \mathrm{E}-06$ & $1.00 \mathrm{E}-06$ & $1.40 \mathrm{E}-05$ & $2.00 \mathrm{E}-06$ & $2.00 \mathrm{E}-06$ & $3.00 \mathrm{E}-06$ & $4.00 \mathrm{E}-05$ & $3.60 \mathrm{E}-05$ & $4.60 \mathrm{E}-05$ \\
\hline V13 & 146.00 & $8.00 \mathrm{E}-06$ & $3.00 \mathrm{E}-06$ & $1.20 \mathrm{E}-05$ & $3.00 \mathrm{E}-06$ & $2.00 \mathrm{E}-06$ & $4.00 \mathrm{E}-06$ & $2.60 \mathrm{E}-05$ & $2.40 \mathrm{E}-05$ & $3.00 \mathrm{E}-05$ \\
\hline V21 & 151.00 & $8.00 \mathrm{E}-06$ & $3.00 \mathrm{E}-06$ & $1.40 \mathrm{E}-05$ & $3.00 \mathrm{E}-06$ & $2.00 \mathrm{E}-06$ & $3.00 \mathrm{E}-06$ & $3.40 \mathrm{E}-05$ & $3.10 \mathrm{E}-05$ & $3.80 \mathrm{E}-05$ \\
\hline V22 & 143.00 & $6.00 \mathrm{E}-06$ & $4.00 \mathrm{E}-06$ & $8.00 \mathrm{E}-06$ & $3.00 \mathrm{E}-06$ & $2.00 \mathrm{E}-06$ & $4.00 \mathrm{E}-06$ & $1.20 \mathrm{E}-05$ & $1.10 \mathrm{E}-05$ & $1.30 \mathrm{E}-05$ \\
\hline V23 & 134.00 & $1.10 \mathrm{E}-05$ & $2.00 \mathrm{E}-06$ & $2.00 \mathrm{E}-05$ & $3.00 \mathrm{E}-06$ & $2.00 \mathrm{E}-06$ & $3.00 \mathrm{E}-06$ & $5.30 \mathrm{E}-05$ & $4.80 \mathrm{E}-05$ & $6.10 \mathrm{E}-05$ \\
\hline V31 & 173.00 & $7.00 \mathrm{E}-06$ & $4.00 \mathrm{E}-06$ & $9.00 \mathrm{E}-06$ & $3.00 \mathrm{E}-06$ & $2.00 \mathrm{E}-06$ & $3.00 \mathrm{E}-06$ & $1.80 \mathrm{E}-05$ & $1.70 \mathrm{E}-05$ & $2.10 \mathrm{E}-05$ \\
\hline V32 & 146.00 & $9.00 \mathrm{E}-06$ & $1.00 \mathrm{E}-06$ & $1.80 \mathrm{E}-05$ & $3.00 \mathrm{E}-06$ & $2.00 \mathrm{E}-06$ & $4.00 \mathrm{E}-06$ & $5.00 \mathrm{E}-05$ & $4.50 \mathrm{E}-05$ & $5.70 \mathrm{E}-05$ \\
\hline V33 & 155.00 & $7.00 \mathrm{E}-06$ & $5.00 \mathrm{E}-06$ & $9.00 \mathrm{E}-06$ & $3.00 \mathrm{E}-06$ & $2.00 \mathrm{E}-06$ & $4.00 \mathrm{E}-06$ & $1.40 \mathrm{E}-05$ & $1.20 \mathrm{E}-05$ & $1.60 \mathrm{E}-05$ \\
\hline V1ave & 145.67 & 7.33E-06 & $2.67 \mathrm{E}-06$ & $1.13 \mathrm{E}-05$ & $2.33 \mathrm{E}-06$ & $2.00 \mathrm{E}-06$ & $3.33 \mathrm{E}-06$ & $2.60 \mathrm{E}-05$ & $2.37 \mathrm{E}-05$ & $3.00 \mathrm{E}-05$ \\
\hline V2ave & 142.67 & $8.33 \mathrm{E}-06$ & $3.00 \mathrm{E}-06$ & $1.40 \mathrm{E}-05$ & $3.00 \mathrm{E}-06$ & $2.00 \mathrm{E}-06$ & $3.33 \mathrm{E}-06$ & $3.30 \mathrm{E}-05$ & $3.00 \mathrm{E}-05$ & $3.73 \mathrm{E}-05$ \\
\hline V3ave & 158.00 & $7.67 \mathrm{E}-06$ & $3.33 \mathrm{E}-06$ & $1.20 \mathrm{E}-05$ & $3.00 \mathrm{E}-06$ & $2.00 \mathrm{E}-06$ & $3.67 \mathrm{E}-06$ & $2.73 \mathrm{E}-05$ & $2.47 \mathrm{E}-05$ & $3.13 \mathrm{E}-05$ \\
\hline Vtotave & 148.78 & $7.78 \mathrm{E}-06$ & $3.00 \mathrm{E}-06$ & $1.24 \mathrm{E}-05$ & $2.78 \mathrm{E}-06$ & $2.00 \mathrm{E}-06$ & $3.44 \mathrm{E}-06$ & $2.88 \mathrm{E}-05$ & $2.61 \mathrm{E}-05$ & $3.29 \mathrm{E}-05$ \\
\hline
\end{tabular}


Port Velocity

\begin{tabular}{|c|c|c|c|c|c|c|c|c|c|c|}
\hline Version & $\begin{array}{l}\text { Number of } \\
\text { Impacts }\end{array}$ & Mean & $\begin{array}{l}95 \% \text { CI for } \\
\text { Mean, Low }\end{array}$ & $\begin{array}{l}95 \% \text { CI for } \\
\text { Mean, } \\
\text { High }\end{array}$ & Median & $\begin{array}{l}95 \% \text { CI for } \\
\text { Median, } \\
\text { Low }\end{array}$ & $\begin{array}{l}95 \% \mathrm{CI} \text { for } \\
\text { Median, } \\
\text { High }\end{array}$ & StDev & $\begin{array}{c}95 \% \text { CI for } \\
\text { StDev, } \\
\text { Low }\end{array}$ & $\begin{array}{c}95 \% \text { CI for } \\
\text { Stdev, } \\
\text { High }\end{array}$ \\
\hline V11 & 135.00 & 21.13 & 19.46 & 22.81 & 19.00 & 17.00 & 21.00 & 9.85 & 8.80 & 11.19 \\
\hline V12 & 156.00 & 20.92 & 19.11 & 22.73 & 19.00 & 17.00 & 23.00 & 11.44 & 10.29 & 12.87 \\
\hline V13 & 146.00 & 21.49 & 19.68 & 23.31 & 21.00 & 18.39 & 23.00 & 11.08 & 9.94 & 12.52 \\
\hline V21 & 151.00 & 19.83 & 18.13 & 21.54 & 19.00 & 17.00 & 21.00 & 10.61 & 9.54 & 11.97 \\
\hline V22 & 143.00 & 20.93 & 19.91 & 22.77 & 21.00 & 17.00 & 23.00 & 11.12 & 9.97 & 12.59 \\
\hline V23 & 134.00 & 21.37 & 19.46 & 23.29 & 21.00 & 17.36 & 23.00 & 11.22 & 10.02 & 12.75 \\
\hline V31 & 173.00 & 19.43 & 17.86 & 20.99 & 19.00 & 17.00 & 20.75 & 10.43 & 9.44 & 11.66 \\
\hline V32 & 146.00 & 21.40 & 19.50 & 23.29 & 19.00 & 17.00 & 23.61 & 11.60 & 10.40 & 13.10 \\
\hline V33 & 155.00 & 22.82 & 20.95 & 24.69 & 21.00 & 19.00 & 25.00 & 11.77 & 10.59 & 13.25 \\
\hline V1ave & 145.67 & 21.18 & 19.42 & 22.95 & 19.67 & 17.46 & 22.33 & 10.79 & 9.68 & 12.20 \\
\hline V2ave & 142.67 & 20.71 & 19.16 & 22.53 & 20.33 & 17.12 & 22.33 & 10.98 & 9.84 & 12.43 \\
\hline V3ave & 158.00 & 21.21 & 19.44 & 22.99 & 19.67 & 17.67 & 23.12 & 11.27 & 10.14 & 12.67 \\
\hline Vtotave & 148.78 & 21.04 & 19.34 & 22.82 & 19.89 & 17.42 & 22.60 & 11.01 & 9.89 & 12.43 \\
\hline
\end{tabular}

Starboard Mass

\begin{tabular}{|c|c|c|c|c|c|c|c|c|c|c|}
\hline Version & $\begin{array}{c}\text { Number of } \\
\text { Impacts }\end{array}$ & Mean & $\begin{array}{l}95 \% \text { CI for } \\
\text { Mean, Low }\end{array}$ & $\begin{array}{l}95 \% \text { CI for } \\
\text { Mean, } \\
\text { High }\end{array}$ & Median & $\begin{array}{l}95 \% \text { CI for } \\
\text { Median, } \\
\text { Low }\end{array}$ & $\begin{array}{l}95 \% \text { CI for } \\
\text { Median, } \\
\text { High }\end{array}$ & StDev & $\begin{array}{c}95 \% \text { CI for } \\
\text { StDev, } \\
\text { Low } \\
\end{array}$ & $\begin{array}{c}95 \% \text { CI for } \\
\text { Stdev, } \\
\text { High }\end{array}$ \\
\hline V11 & 148.00 & $6.00 \mathrm{E}-06$ & $4.00 \mathrm{E}-06$ & $7.00 \mathrm{E}-06$ & $3.00 \mathrm{E}-06$ & $3.00 \mathrm{E}-06$ & $4.00 \mathrm{E}-06$ & $9.00 \mathrm{E}-06$ & $8.00 \mathrm{E}-06$ & $1.00 \mathrm{E}-05$ \\
\hline V12 & 162.00 & $2.30 \mathrm{E}-05$ & $-1.30 \mathrm{E}-05$ & $6.00 \mathrm{E}-05$ & $3.00 \mathrm{E}-06$ & $2.00 \mathrm{E}-06$ & $3.00 \mathrm{E}-06$ & $2.35 \mathrm{E}-04$ & $2.12 \mathrm{E}-04$ & $2.64 \mathrm{E}-04$ \\
\hline V13 & 172.00 & $8.00 \mathrm{E}-06$ & $4.00 \mathrm{E}-06$ & $1.10 \mathrm{E}-05$ & $2.00 \mathrm{E}-06$ & $2.00 \mathrm{E}-06$ & $4.00 \mathrm{E}-06$ & $2.50 \mathrm{E}-05$ & $2.20 \mathrm{E}-05$ & $2.80 \mathrm{E}-05$ \\
\hline V21 & 151.00 & $1.10 \mathrm{E}-05$ & $4.00 \mathrm{E}-06$ & $1.80 \mathrm{E}-05$ & $3.00 \mathrm{E}-06$ & $3.00 \mathrm{E}-06$ & $4.00 \mathrm{E}-06$ & $4.30 \mathrm{E}-05$ & $3.80 \mathrm{E}-05$ & $4.80 \mathrm{E}-05$ \\
\hline V22 & 163.00 & $5.00 \mathrm{E}-06$ & $4.00 \mathrm{E}-06$ & $7.00 \mathrm{E}-06$ & $3.00 \mathrm{E}-06$ & $2.00 \mathrm{E}-06$ & $3.00 \mathrm{E}-06$ & $1.00 \mathrm{E}-05$ & $9.00 \mathrm{E}-06$ & $1.10 \mathrm{E}-05$ \\
\hline V23 & 168.00 & $5.00 \mathrm{E}-06$ & $3.00 \mathrm{E}-06$ & $6.00 \mathrm{E}-06$ & $3.00 \mathrm{E}-06$ & $2.00 \mathrm{E}-06$ & $4.00 \mathrm{E}-06$ & $8.00 \mathrm{E}-06$ & $7.00 \mathrm{E}-06$ & $9.00 \mathrm{E}-06$ \\
\hline V32 & 178.00 & $5.00 \mathrm{E}-06$ & $4.00 \mathrm{E}-06$ & $7.00 \mathrm{E}-06$ & $2.00 \mathrm{E}-06$ & $2.00 \mathrm{E}-06$ & $3.00 \mathrm{E}-06$ & $1.10 \mathrm{E}-05$ & $1.00 \mathrm{E}-05$ & $1.20 \mathrm{E}-05$ \\
\hline V33 & 162.00 & $5.00 \mathrm{E}-06$ & $4.00 \mathrm{E}-06$ & $7.00 \mathrm{E}-06$ & $2.00 \mathrm{E}-06$ & $2.00 \mathrm{E}-06$ & $3.00 \mathrm{E}-06$ & $1.00 \mathrm{E}-05$ & $9.00 \mathrm{E}-06$ & $1.20 \mathrm{E}-05$ \\
\hline V1ave & 160.67 & $1.23 \mathrm{E}-05$ & $-1.67 \mathrm{E}-06$ & $2.60 \mathrm{E}-05$ & $2.67 \mathrm{E}-06$ & $2.33 \mathrm{E}-06$ & $3.67 \mathrm{E}-06$ & $8.97 \mathrm{E}-05$ & $8.07 \mathrm{E}-05$ & $1.01 \mathrm{E}-04$ \\
\hline V2ave & 160.67 & 7.00E-06 & $3.67 \mathrm{E}-06$ & $1.03 \mathrm{E}-05$ & $3.00 \mathrm{E}-06$ & $2.33 \mathrm{E}-06$ & $3.67 \mathrm{E}-06$ & $2.03 \mathrm{E}-05$ & $1.80 \mathrm{E}-05$ & $2.27 \mathrm{E}-05$ \\
\hline V3ave & 173.00 & 5.33E-06 & $4.00 \mathrm{E}-06$ & 7.33E-06 & $2.33 \mathrm{E}-06$ & $2.00 \mathrm{E}-06$ & $3.00 \mathrm{E}-06$ & $1.17 \mathrm{E}-05$ & $1.07 \mathrm{E}-05$ & $1.30 \mathrm{E}-05$ \\
\hline Vtotave & 164.78 & $8.22 \mathrm{E}-06$ & $2.00 \mathrm{E}-06$ & $1.46 \mathrm{E}-05$ & $2.67 \mathrm{E}-06$ & $2.22 \mathrm{E}-06$ & $3.44 \mathrm{E}-06$ & $4.06 \mathrm{E}-05$ & $3.64 \mathrm{E}-05$ & $4.54 \mathrm{E}-05$ \\
\hline
\end{tabular}

\section{Starboard Velocity}

\begin{tabular}{|c|c|c|c|c|c|c|c|c|c|c|}
\hline & $\begin{array}{c}\text { Number of } \\
\text { Impacts }\end{array}$ & Mean & $\begin{array}{c}\text { 95\% CI for } \\
\text { Mean, Low }\end{array}$ & $\begin{array}{c}\text { 95\% CI for } \\
\text { Mean, } \\
\text { High }\end{array}$ & Median & $\begin{array}{c}\text { Median, } \\
\text { Low }\end{array}$ & $\begin{array}{c}\text { M5\% CI for } \\
\text { Median, } \\
\text { High }\end{array}$ & $\begin{array}{c}\text { 95\% CI for } \\
\text { StDev, } \\
\text { Lersion }\end{array}$ & $\begin{array}{c}\text { 95\% CI for } \\
\text { Stdev, } \\
\text { High }\end{array}$ \\
\hline V11 & 148.00 & 19.30 & 17.68 & 20.91 & 19.00 & 17.00 & 21.00 & 9.95 & 8.93 & 11.23 \\
\hline V12 & 162.00 & 20.44 & 18.66 & 22.23 & 19.00 & 19.00 & 23.00 & 11.54 & 10.40 & 12.95 \\
\hline V13 & 172.00 & 20.08 & 18.37 & 21.80 & 19.00 & 17.00 & 21.00 & 11.40 & 10.30 & 12.75 \\
\hline V21 & 151.00 & 20.23 & 18.33 & 22.14 & 19.00 & 15.00 & 23.00 & 11.85 & 10.65 & 13.36 \\
\hline V22 & 163.00 & 19.74 & 18.08 & 21.39 & 19.00 & 17.00 & 21.00 & 10.69 & 9.64 & 12.00 \\
\hline V23 & 168.00 & 18.98 & 17.36 & 20.60 & 17.00 & 15.00 & 19.00 & 10.63 & 9.60 & 11.90 \\
\hline V31 & 179.00 & 19.92 & 18.14 & 21.70 & 17.00 & 17.00 & 19.00 & 12.07 & 10.94 & 13.47 \\
\hline V32 & 178.00 & 20.80 & 18.97 & 22.63 & 19.00 & 17.00 & 21.00 & 12.39 & 11.22 & 13.83 \\
\hline V33 & 162.00 & 19.09 & 17.43 & 20.74 & 17.00 & 15.06 & 20.94 & 10.68 & 9.63 & 11.99 \\
\hline V1ave & 160.67 & 19.94 & 18.23 & 21.65 & 19.00 & 17.67 & 21.67 & 10.96 & 9.88 & 12.31 \\
\hline V2ave & 160.67 & 19.65 & 17.92 & 21.37 & 18.33 & 15.67 & 21.00 & 11.06 & 9.96 & 12.42 \\
\hline V3ave & 173.00 & 19.93 & 18.18 & 21.69 & 17.67 & 16.35 & 20.31 & 11.71 & 10.60 & 13.10 \\
\hline Vtotave & 164.78 & 19.84 & 18.11 & 21.57 & 18.33 & 16.56 & 20.99 & 11.24 & 10.15 & 12.61 \\
\hline
\end{tabular}




\section{Zenith Mass}

\begin{tabular}{|c|c|c|c|c|c|c|c|c|c|c|}
\hline Version & $\begin{array}{l}\text { Number of } \\
\text { Impacts }\end{array}$ & Mean & $\begin{array}{l}95 \% \text { CI for } \\
\text { Mean, Low }\end{array}$ & $\begin{array}{l}95 \% \text { CI for } \\
\text { Mean, } \\
\text { High }\end{array}$ & Median & $\begin{array}{l}95 \% \text { CI for } \\
\text { Median, } \\
\text { Low }\end{array}$ & $\begin{array}{l}95 \% \text { CI for } \\
\text { Median, } \\
\text { High }\end{array}$ & StDev & $\begin{array}{c}95 \% \text { CI for } \\
\text { StDev, } \\
\text { Low }\end{array}$ & $\begin{array}{c}95 \% \text { CI for } \\
\text { Stdev, } \\
\text { High }\end{array}$ \\
\hline V11 & 172.00 & $5.00 \mathrm{E}-06$ & $4.00 \mathrm{E}-06$ & $6.00 \mathrm{E}-06$ & $3.00 \mathrm{E}-06$ & $2.00 \mathrm{E}-06$ & $3.00 \mathrm{E}-06$ & $9.00 \mathrm{E}-06$ & $8.00 \mathrm{E}-06$ & $1.00 \mathrm{E}-05$ \\
\hline V12 & 179.00 & $5.00 \mathrm{E}-06$ & $4.00 \mathrm{E}-06$ & $7.00 \mathrm{E}-06$ & $3.00 \mathrm{E}-06$ & $2.00 \mathrm{E}-06$ & $3.00 \mathrm{E}-06$ & $1.20 \mathrm{E}-05$ & $1.10 \mathrm{E}-05$ & $1.30 \mathrm{E}-05$ \\
\hline V13 & 173.00 & $9.00 \mathrm{E}-06$ & $3.00 \mathrm{E}-06$ & $1.40 \mathrm{E}-05$ & $3.00 \mathrm{E}-06$ & $2.00 \mathrm{E}-06$ & $3.00 \mathrm{E}-06$ & $3.50 \mathrm{E}-05$ & $3.20 \mathrm{E}-05$ & $3.90 \mathrm{E}-05$ \\
\hline V21 & 161.00 & $1.10 \mathrm{E}-05$ & $3.00 \mathrm{E}-06$ & $1.80 \mathrm{E}-05$ & $3.00 \mathrm{E}-06$ & $2.00 \mathrm{E}-06$ & $4.00 \mathrm{E}-06$ & $4.90 \mathrm{E}-05$ & $4.40 \mathrm{E}-05$ & $5.50 \mathrm{E}-05$ \\
\hline V22 & 175.00 & $6.00 \mathrm{E}-06$ & $4.00 \mathrm{E}-06$ & $7.00 \mathrm{E}-06$ & $2.00 \mathrm{E}-06$ & $2.00 \mathrm{E}-06$ & $3.00 \mathrm{E}-06$ & $1.20 \mathrm{E}-05$ & $1.10 \mathrm{E}-05$ & $1.40 \mathrm{E}-05$ \\
\hline V23 & 183.00 & $5.00 \mathrm{E}-06$ & $4.00 \mathrm{E}-06$ & $7.00 \mathrm{E}-06$ & $3.00 \mathrm{E}-06$ & $2.00 \mathrm{E}-06$ & $3.00 \mathrm{E}-06$ & $9.00 \mathrm{E}-06$ & $8.00 \mathrm{E}-06$ & $1.00 \mathrm{E}-05$ \\
\hline V31 & 166.00 & $2.30 \mathrm{E}-05$ & $-1.30 \mathrm{E}-05$ & $5.90 \mathrm{E}-05$ & $2.00 \mathrm{E}-06$ & $2.00 \mathrm{E}-06$ & $3.00 \mathrm{E}-06$ & $2.33 \mathrm{E}-04$ & $2.10 \mathrm{E}-04$ & $2.61 \mathrm{E}-04$ \\
\hline V32 & 181.00 & $6.00 \mathrm{E}-06$ & $4.00 \mathrm{E}-06$ & $8.00 \mathrm{E}-06$ & $3.00 \mathrm{E}-06$ & $2.00 \mathrm{E}-06$ & $3.00 \mathrm{E}-06$ & $1.30 \mathrm{E}-05$ & $1.20 \mathrm{E}-05$ & $1.40 \mathrm{E}-05$ \\
\hline V33 & 189.00 & $5.00 \mathrm{E}-06$ & $4.00 \mathrm{E}-06$ & 7.00E-06 & $2.00 \mathrm{E}-06$ & $2.00 \mathrm{E}-06$ & $3.00 \mathrm{E}-06$ & $1.10 \mathrm{E}-05$ & $1.00 \mathrm{E}-05$ & $1.30 \mathrm{E}-05$ \\
\hline V1ave & 174.67 & $6.33 \mathrm{E}-06$ & $3.67 \mathrm{E}-06$ & $9.00 \mathrm{E}-06$ & $3.00 \mathrm{E}-06$ & $2.00 \mathrm{E}-06$ & $3.00 \mathrm{E}-06$ & $1.87 \mathrm{E}-05$ & $1.70 \mathrm{E}-05$ & $2.07 \mathrm{E}-05$ \\
\hline V2ave & 173.00 & 7.33E-06 & $3.67 \mathrm{E}-06$ & $1.07 \mathrm{E}-05$ & $2.67 \mathrm{E}-06$ & $2.00 \mathrm{E}-06$ & $3.33 \mathrm{E}-06$ & $2.33 \mathrm{E}-05$ & $2.10 \mathrm{E}-05$ & $2.63 \mathrm{E}-05$ \\
\hline V3ave & 178.67 & $1.13 \mathrm{E}-05$ & $-1.67 \mathrm{E}-06$ & $2.47 \mathrm{E}-05$ & $2.33 \mathrm{E}-06$ & $2.00 \mathrm{E}-06$ & $3.00 \mathrm{E}-06$ & $8.57 \mathrm{E}-05$ & 7.73E-05 & $9.60 \mathrm{E}-05$ \\
\hline Vtotave & 175.44 & $8.33 \mathrm{E}-06$ & $1.89 \mathrm{E}-06$ & $1.48 \mathrm{E}-05$ & $2.67 \mathrm{E}-06$ & $2.00 \mathrm{E}-06$ & $3.11 \mathrm{E}-06$ & $4.26 \mathrm{E}-05$ & $3.84 \mathrm{E}-05$ & 4.77E-05 \\
\hline
\end{tabular}

\section{Zenith Velocity}

\begin{tabular}{|c|c|c|c|c|c|c|c|c|c|c|}
\hline Version & $\begin{array}{c}\text { Number of } \\
\text { Impacts }\end{array}$ & Mean & $\begin{array}{c}\text { 95\% CI for } \\
\text { Mean, Low }\end{array}$ & $\begin{array}{c}\text { 95\% CI for } \\
\text { Mean, } \\
\text { High }\end{array}$ & Median & $\begin{array}{c}\text { Median, } \\
\text { Low }\end{array}$ & $\begin{array}{c}\text { M5\% CI for } \\
\text { Median, } \\
\text { High }\end{array}$ & $\begin{array}{c}\text { 95\% CI for } \\
\text { StDev, } \\
\text { Low }\end{array}$ & $\begin{array}{c}\text { 95\% CI for } \\
\text { Stdev, } \\
\text { High }\end{array}$ \\
\hline V11 & 172.00 & 23.70 & 22.33 & 25.07 & 23.00 & 22.36 & 25.00 & 9.12 & 8.25 & 10 \\
\hline V12 & 179.00 & 22.75 & 21.26 & 24.25 & 21.00 & 19.00 & 23.00 & 10.14 & 9.13 & 11.31 \\
\hline V13 & 173.00 & 23.79 & 22.33 & 25.25 & 23.00 & 21.00 & 25.00 & 9.72 & 8.79 & 10.87 \\
\hline V21 & 161.00 & 22.24 & 20.75 & 23.74 & 21.00 & 21.00 & 23.00 & 9.61 & 8.66 & 100 \\
\hline V22 & 175.00 & 23.48 & 22.04 & 24.92 & 23.00 & 21.00 & 27.00 & 9.67 & 8.75 & 10.80 \\
\hline V23 & 183.00 & 23.85 & 22.48 & 25.23 & 23.00 & 21.00 & 27.00 & 9.42 & 8.55 & 10.50 \\
\hline V31 & 166.00 & 23.05 & 21.57 & 24.53 & 23.00 & 21.00 & 25.00 & 9.66 & 8.72 & 10.82 \\
\hline V32 & 181.00 & 23.75 & 22.14 & 25.36 & 23.00 & 23.00 & 25.00 & 10.98 & 9.95 & 12.24 \\
\hline V33 & 189.00 & 23.49 & 22.25 & 24.73 & 23.00 & 21.00 & 25.00 & 8.65 & 7.86 & 9.63 \\
\hline V1ave & 174.67 & 23.41 & 21.97 & 24.85 & 22.33 & 20.79 & 24.33 & 9.66 & 8.72 & 10.79 \\
\hline V2ave & 173.00 & 23.19 & 21.75 & 24.63 & 22.33 & 21.00 & 25.67 & 9.57 & 8.65 & 10.70 \\
\hline V3ave & 178.67 & 23.43 & 21.99 & 24.87 & 23.00 & 21.67 & 25.00 & 9.76 & 8.84 & 10.90 \\
\hline Vtotave & 175.44 & 23.34 & 21.90 & 24.79 & 22.56 & 21.15 & 25.00 & 9.66 & 8.74 & 10.79 \\
\hline
\end{tabular}

Nadir Mass

\begin{tabular}{|c|c|c|c|c|c|c|c|c|c|c|}
\hline Version & $\begin{array}{l}\text { Number of } \\
\text { Impacts }\end{array}$ & Mean & $\begin{array}{l}95 \% \text { CI for } \\
\text { Mean, Low }\end{array}$ & $\begin{array}{l}95 \% \text { CI for } \\
\text { Mean, } \\
\text { High }\end{array}$ & Median & $\begin{array}{l}95 \% \text { CI for } \\
\text { Median, } \\
\text { Low }\end{array}$ & $\begin{array}{l}95 \% \text { CI for } \\
\text { Median, } \\
\text { High }\end{array}$ & StDev & $\begin{array}{c}95 \% \text { CI for } \\
\text { StDev, } \\
\text { Low }\end{array}$ & $\begin{array}{c}95 \% \text { CI for } \\
\text { Stdev, } \\
\text { High }\end{array}$ \\
\hline V11 & 289.00 & $7.00 \mathrm{E}-06$ & $4.00 \mathrm{E}-06$ & $1.10 \mathrm{E}-05$ & $3.00 \mathrm{E}-06$ & $2.00 \mathrm{E}-06$ & $4.00 \mathrm{E}-06$ & $3.10 \mathrm{E}-05$ & $2.80 \mathrm{E}-05$ & $3.30 \mathrm{E}-05$ \\
\hline V12 & 272.00 & $2.70 \mathrm{E}-05$ & $-1.60 \mathrm{E}-05$ & $7.00 \mathrm{E}-05$ & $3.00 \mathrm{E}-06$ & $3.00 \mathrm{E}-06$ & $3.00 \mathrm{E}-06$ & $3.64 \mathrm{E}-04$ & $3.35 \mathrm{E}-04$ & $3.97 \mathrm{E}-04$ \\
\hline V13 & 310.00 & $7.00 \mathrm{E}-06$ & $4.00 \mathrm{E}-06$ & $9.00 \mathrm{E}-06$ & $3.00 \mathrm{E}-06$ & $2.00 \mathrm{E}-06$ & $3.00 \mathrm{E}-06$ & $2.00 \mathrm{E}-05$ & $1.90 \mathrm{E}-05$ & $2.20 \mathrm{E}-05$ \\
\hline V21 & 295.00 & $8.00 \mathrm{E}-06$ & $3.00 \mathrm{E}-06$ & $1.20 \mathrm{E}-05$ & $3.00 \mathrm{E}-06$ & $2.00 \mathrm{E}-06$ & $3.00 \mathrm{E}-06$ & $4.20 \mathrm{E}-05$ & $3.90 \mathrm{E}-05$ & $4.50 \mathrm{E}-05$ \\
\hline V22 & 249.00 & $6.00 \mathrm{E}-06$ & $3.00 \mathrm{E}-06$ & $9.00 \mathrm{E}-06$ & $2.00 \mathrm{E}-06$ & $2.00 \mathrm{E}-06$ & $3.00 \mathrm{E}-06$ & $2.40 \mathrm{E}-05$ & $2.20 \mathrm{E}-05$ & $2.60 \mathrm{E}-05$ \\
\hline V23 & 309.00 & $8.00 \mathrm{E}-06$ & $3.00 \mathrm{E}-06$ & $1.40 \mathrm{E}-05$ & $2.00 \mathrm{E}-06$ & $2.00 \mathrm{E}-06$ & $3.00 \mathrm{E}-06$ & $5.30 \mathrm{E}-05$ & $4.90 \mathrm{E}-05$ & $5.80 \mathrm{E}-05$ \\
\hline V32 & 286.00 & $7.00 \mathrm{E}-06$ & $4.00 \mathrm{E}-06$ & $9.00 \mathrm{E}-06$ & $3.00 \mathrm{E}-06$ & $3.00 \mathrm{E}-06$ & $3.00 \mathrm{E}-06$ & $2.10 \mathrm{E}-05$ & $1.90 \mathrm{E}-05$ & $2.30 \mathrm{E}-05$ \\
\hline V33 & 317.00 & $6.00 \mathrm{E}-06$ & $4.00 \mathrm{E}-06$ & $7.00 \mathrm{E}-06$ & $3.00 \mathrm{E}-06$ & $2.00 \mathrm{E}-06$ & $3.00 \mathrm{E}-06$ & $1.20 \mathrm{E}-05$ & $1.10 \mathrm{E}-05$ & $1.30 \mathrm{E}-05$ \\
\hline V1ave & 290.33 & 1.37E-05 & $-2.67 \mathrm{E}-06$ & $3.00 \mathrm{E}-05$ & $3.00 \mathrm{E}-06$ & $2.33 \mathrm{E}-06$ & 3.33E-06 & $1.38 \mathrm{E}-04$ & $1.27 \mathrm{E}-04$ & $1.51 \mathrm{E}-04$ \\
\hline V2ave & 284.33 & 7.33E-06 & $3.00 \mathrm{E}-06$ & $1.17 \mathrm{E}-05$ & $2.33 \mathrm{E}-06$ & $2.00 \mathrm{E}-06$ & $3.00 \mathrm{E}-06$ & $3.97 \mathrm{E}-05$ & $3.67 \mathrm{E}-05$ & $4.30 \mathrm{E}-05$ \\
\hline V3ave & 299.67 & $7.00 \mathrm{E}-06$ & $4.00 \mathrm{E}-06$ & $9.00 \mathrm{E}-06$ & $2.67 \mathrm{E}-06$ & $2.33 \mathrm{E}-06$ & $3.00 \mathrm{E}-06$ & $2.23 \mathrm{E}-05$ & $2.03 \mathrm{E}-05$ & $2.43 \mathrm{E}-05$ \\
\hline Vtotave & 291.44 & $9.33 \mathrm{E}-06$ & $1.44 \mathrm{E}-06$ & $1.69 \mathrm{E}-05$ & $2.67 \mathrm{E}-06$ & $2.22 \mathrm{E}-06$ & $3.11 \mathrm{E}-06$ & $6.68 \mathrm{E}-05$ & $6.14 \mathrm{E}-05$ & $7.27 \mathrm{E}-05$ \\
\hline
\end{tabular}


Nadir Velocity

\begin{tabular}{|c|c|c|c|c|c|c|c|c|c|c|}
\hline Version & $\begin{array}{c}\text { Number of } \\
\text { Impacts }\end{array}$ & Mean & $\begin{array}{l}95 \% \text { CI for } \\
\text { Mean, Low }\end{array}$ & $\begin{array}{c}95 \% \text { CI for } \\
\text { Mean, } \\
\text { High }\end{array}$ & Median & $\begin{array}{l}95 \% \text { CI for } \\
\text { Median, } \\
\text { Low }\end{array}$ & $\begin{array}{l}95 \% \text { CI for } \\
\text { Median, } \\
\text { High }\end{array}$ & StDev & $\begin{array}{c}95 \% \text { CI for } \\
\text { StDev, } \\
\text { Low }\end{array}$ & $\begin{array}{c}95 \% \text { CI for } \\
\text { Stdev, } \\
\text { High }\end{array}$ \\
\hline V11 & 289.00 & 20.86 & 19.64 & 22.09 & 21.00 & 19.00 & 23.00 & 10.58 & 9.78 & 11.52 \\
\hline V12 & 272.00 & 21.10 & 19.81 & 22.38 & 21.00 & 19.00 & 23.00 & 10.77 & 9.93 & 11.76 \\
\hline V13 & 310.00 & 19.35 & 18.26 & 20.44 & 19.00 & 17.00 & 21.00 & 9.73 & 9.02 & 10.56 \\
\hline V21 & 295.00 & 20.77 & 19.58 & 21.96 & 21.00 & 19.00 & 21.00 & 10.41 & 9.63 & 11.33 \\
\hline V22 & 249.00 & 20.50 & 19.17 & 21.83 & 19.00 & 18.14 & 21.00 & 10.67 & 9.81 & 11.70 \\
\hline V23 & 309.00 & 20.68 & 19.48 & 21.89 & 21.00 & 19.00 & 23.00 & 10.74 & 9.95 & 11.66 \\
\hline V32 & 286.00 & 20.44 & 19.16 & 21.72 & 19.00 & 19.00 & 21.00 & 10.98 & 10.15 & 11.96 \\
\hline V33 & 317.00 & 19.86 & 18.65 & 21.08 & 19.00 & 17.00 & 21.00 & 11.03 & 10.23 & 11.96 \\
\hline V1ave & 290.33 & 20.44 & 19.24 & 21.63 & 20.33 & 18.33 & 22.33 & 10.36 & 9.58 & 11.28 \\
\hline V2ave & 284.33 & 20.65 & 19.41 & 21.89 & 20.33 & 18.71 & 21.67 & 10.61 & 9.80 & 11.56 \\
\hline V3ave & 299.67 & 20.38 & 19.17 & 21.59 & 19.67 & 18.33 & 21.00 & 10.62 & 9.84 & 11.55 \\
\hline Vtotave & 291.44 & 20.49 & 19.27 & 21.71 & 20.11 & 18.46 & 21.67 & 10.53 & 9.74 & 11.46 \\
\hline
\end{tabular}

Earth Mass

\begin{tabular}{|c|c|c|c|c|c|c|c|c|c|c|}
\hline Version & $\begin{array}{l}\text { Number of } \\
\text { Impacts }\end{array}$ & Mean & $\begin{array}{l}95 \% \text { CI for } \\
\text { Mean, Low }\end{array}$ & $\begin{array}{c}95 \% \text { CI for } \\
\text { Mean, } \\
\text { High }\end{array}$ & Median & $\begin{array}{l}95 \% \text { CI for } \\
\text { Median, } \\
\text { Low }\end{array}$ & $\begin{array}{l}95 \% \text { CI for } \\
\text { Median, } \\
\text { High }\end{array}$ & StDev & $\begin{array}{l}95 \% \text { CI for } \\
\text { StDev, } \\
\text { Low }\end{array}$ & $\begin{array}{c}95 \% \text { CI for } \\
\text { Stdev, } \\
\text { High }\end{array}$ \\
\hline V11 & 80.00 & $2.70 \mathrm{E}-05$ & $3.00 \mathrm{E}-06$ & $5.20 \mathrm{E}-05$ & $3.00 \mathrm{E}-06$ & $2.00 \mathrm{E}-06$ & $4.00 \mathrm{E}-06$ & $1.10 \mathrm{E}-04$ & $9.50 \mathrm{E}-05$ & $1.30 \mathrm{E}-04$ \\
\hline V12 & 57.00 & $2.10 \mathrm{E}-05$ & $-1.40 \mathrm{E}-05$ & $5.60 \mathrm{E}-05$ & $2.00 \mathrm{E}-06$ & $1.00 \mathrm{E}-06$ & $3.00 \mathrm{E}-06$ & $1.32 \mathrm{E}-04$ & $1.12 \mathrm{E}-04$ & $1.62 \mathrm{E}-04$ \\
\hline V13 & 66.00 & $8.00 \mathrm{E}-06$ & $4.00 \mathrm{E}-06$ & $1.20 \mathrm{E}-05$ & $2.00 \mathrm{E}-06$ & $2.00 \mathrm{E}-06$ & $3.00 \mathrm{E}-06$ & $1.60 \mathrm{E}-05$ & $1.40 \mathrm{E}-05$ & $2.00 \mathrm{E}-05$ \\
\hline V21 & 66.00 & $3.00 \mathrm{E}-06$ & $2.00 \mathrm{E}-06$ & $4.00 \mathrm{E}-06$ & $2.00 \mathrm{E}-06$ & $2.00 \mathrm{E}-06$ & $3.00 \mathrm{E}-06$ & $3.00 \mathrm{E}-06$ & $2.00 \mathrm{E}-06$ & $4.00 \mathrm{E}-06$ \\
\hline V22 & 56.00 & $8.00 \mathrm{E}-06$ & $3.00 \mathrm{E}-06$ & $1.20 \mathrm{E}-06$ & $3.00 \mathrm{E}-06$ & $2.00 \mathrm{E}-06$ & $4.00 \mathrm{E}-06$ & $1.70 \mathrm{E}-05$ & $1.40 \mathrm{E}-05$ & $2.10 \mathrm{E}-05$ \\
\hline $\mathrm{V} 23$ & 71.00 & $5.00 \mathrm{E}-06$ & $3.00 \mathrm{E}-06$ & $6.00 \mathrm{E}-06$ & $2.00 \mathrm{E}-06$ & $1.00 \mathrm{E}-06$ & $3.00 \mathrm{E}-06$ & $7.00 \mathrm{E}-06$ & $6.00 \mathrm{E}-06$ & $9.00 \mathrm{E}-06$ \\
\hline V32 & 69.00 & $5.00 \mathrm{E}-06$ & $2.00 \mathrm{E}-06$ & $8.00 \mathrm{E}-06$ & $2.00 \mathrm{E}-06$ & $2.00 \mathrm{E}-06$ & $3.00 \mathrm{E}-06$ & $1.30 \mathrm{E}-05$ & $1.10 \mathrm{E}-05$ & $1.50 \mathrm{E}-05$ \\
\hline V33 & 76.00 & $4.00 \mathrm{E}-06$ & $3.00 \mathrm{E}-06$ & $5.00 \mathrm{E}-06$ & $2.00 \mathrm{E}-06$ & $1.00 \mathrm{E}-06$ & $2.00 \mathrm{E}-06$ & $4.00 \mathrm{E}-06$ & $3.00 \mathrm{E}-06$ & $5.00 \mathrm{E}-06$ \\
\hline V1ave & 67.67 & $1.87 \mathrm{E}-05$ & $-2.33 \mathrm{E}-06$ & $4.00 \mathrm{E}-05$ & $2.33 \mathrm{E}-06$ & $1.67 \mathrm{E}-06$ & $3.33 \mathrm{E}-06$ & $8.60 \mathrm{E}-05$ & $7.37 \mathrm{E}-05$ & $1.04 \mathrm{E}-04$ \\
\hline V2ave & 64.33 & $5.33 \mathrm{E}-06$ & $2.67 \mathrm{E}-06$ & $3.73 \mathrm{E}-06$ & $2.33 \mathrm{E}-06$ & $1.67 \mathrm{E}-06$ & $3.33 \mathrm{E}-06$ & $9.00 \mathrm{E}-06$ & $7.33 \mathrm{E}-06$ & $1.13 \mathrm{E}-05$ \\
\hline V3ave & 72.33 & $6.33 \mathrm{E}-06$ & $1.33 \mathrm{E}-06$ & $1.13 \mathrm{E}-05$ & $2.33 \mathrm{E}-06$ & $1.67 \mathrm{E}-06$ & $3.00 \mathrm{E}-06$ & $2.13 \mathrm{E}-05$ & $1.80 \mathrm{E}-05$ & $2.53 \mathrm{E}-05$ \\
\hline Vtotave & 68.11 & $1.01 \mathrm{E}-05$ & $5.56 \mathrm{E}-07$ & $1.84 \mathrm{E}-05$ & $2.33 \mathrm{E}-06$ & $1.67 \mathrm{E}-06$ & $3.22 \mathrm{E}-06$ & $3.88 \mathrm{E}-05$ & $3.30 \mathrm{E}-05$ & 4.69E-05 \\
\hline
\end{tabular}

Earth Velocity

\begin{tabular}{|c|c|c|c|c|c|c|c|c|c|c|}
\hline Version & $\begin{array}{c}\text { Number of } \\
\text { Impacts }\end{array}$ & Mean & $\begin{array}{c}\text { 95\% CI for } \\
\text { Mean, Low }\end{array}$ & $\begin{array}{c}\text { 95\% CI for } \\
\text { Mean, } \\
\text { High }\end{array}$ & Median & $\begin{array}{c}\text { Median, } \\
\text { Low }\end{array}$ & $\begin{array}{c}\text { M5\% CI for } \\
\text { Median, } \\
\text { High }\end{array}$ & $\begin{array}{c}\text { 95\% CI for } \\
\text { StDev, } \\
\text { Low }\end{array}$ & $\begin{array}{c}\text { 95\% CI for } \\
\text { Stdev, } \\
\text { High }\end{array}$ \\
\hline V11 & 80.00 & 21.63 & 19.72 & 23.53 & 21.00 & 19.00 & 23.44 & 8.57 & 7.42 & 10.15 \\
\hline V12 & 57.00 & 21.18 & 19.06 & 23.29 & 21.00 & 19.00 & 25.00 & 7.97 & 6.73 & 9.77 \\
\hline V13 & 66.00 & 22.42 & 20.02 & 24.83 & 23.00 & 18.20 & 25.00 & 9.78 & 8.35 & 11.80 \\
\hline V21 & 66.00 & 24.73 & 22.59 & 26.86 & 25.00 & 22.20 & 27.80 & 8.68 & 7.41 \\
\hline V22 & 56.00 & 20.71 & 18.15 & 23.28 & 21.00 & 17.41 & 22.59 & 9.59 & 8.09 & 10.48 \\
\hline V23 & 71.00 & 21.62 & 19.63 & 23.62 & 23.00 & 19.00 & 25.00 & 8.43 & 7.23 & 10.10 \\
\hline V31 & 72.00 & 22.47 & 20.21 & 24.73 & 23.00 & 19.00 & 25.00 & 9.61 & 8.26 & 11.50 \\
\hline V32 & 69.00 & 23.17 & 21.07 & 25.28 & 23.00 & 21.00 & 25.00 & 8.78 & 7.52 & 10.55 \\
\hline V33 & 76.00 & 23.16 & 21.13 & 25.19 & 23.00 & 21.00 & 25.00 & 8.90 & 7.67 & 10.59 \\
\hline V1ave & 67.67 & 21.74 & 19.60 & 23.88 & 21.67 & 18.73 & 24.48 & 8.77 & 7.50 & 10.58 \\
\hline V2ave & 64.33 & 22.35 & 20.12 & 24.59 & 23.00 & 19.54 & 25.13 & 8.90 & 7.58 & 10.79 \\
\hline V3ave & 72.33 & 22.93 & 20.80 & 25.07 & 23.00 & 20.33 & 25.00 & 9.09 & 7.82 & 10.88 \\
\hline Vtotave & 68.11 & 22.34 & 20.17 & 24.51 & 22.56 & 19.53 & 24.87 & 8.92 & 7.63 & 10.75 \\
\hline
\end{tabular}


Sun Mass

\begin{tabular}{|c|c|c|c|c|c|c|c|c|c|c|}
\hline Version & $\begin{array}{l}\text { Number of } \\
\text { Impacts }\end{array}$ & Mean & $\begin{array}{l}95 \% \text { CI for } \\
\text { Mean, Low }\end{array}$ & $\begin{array}{c}95 \% \text { CI for } \\
\text { Mean, } \\
\text { High }\end{array}$ & Median & $\begin{array}{l}95 \% \text { CI for } \\
\text { Median, } \\
\text { Low }\end{array}$ & $\begin{array}{l}95 \% \text { CI for } \\
\text { Median, } \\
\text { High }\end{array}$ & StDev & $\begin{array}{c}95 \% \text { CI for } \\
\text { StDev, } \\
\text { Low }\end{array}$ & $\begin{array}{c}95 \% \text { CI for } \\
\text { Stdev, } \\
\text { High }\end{array}$ \\
\hline V11 & 178.00 & $5.00 \mathrm{E}-06$ & $4.00 \mathrm{E}-06$ & $7.00 \mathrm{E}-06$ & $3.00 \mathrm{E}-06$ & $2.00 \mathrm{E}-06$ & $4.00 \mathrm{E}-06$ & $9.00 \mathrm{E}-06$ & $8.00 \mathrm{E}-06$ & $1.00 \mathrm{E}-05$ \\
\hline V12 & 145.00 & $6.00 \mathrm{E}-06$ & $4.00 \mathrm{E}-06$ & $8.00 \mathrm{E}-06$ & $3.00 \mathrm{E}-06$ & $2.00 \mathrm{E}-06$ & $4.00 \mathrm{E}-06$ & $1.30 \mathrm{E}-05$ & $1.10 \mathrm{E}-05$ & $1.40 \mathrm{E}-05$ \\
\hline V13 & 162.00 & $5.00 \mathrm{E}-06$ & $4.00 \mathrm{E}-06$ & $6.00 \mathrm{E}-06$ & $3.00 \mathrm{E}-06$ & $2.00 \mathrm{E}-06$ & $3.00 \mathrm{E}-06$ & $9.00 \mathrm{E}-06$ & $8.00 \mathrm{E}-06$ & $1.00 \mathrm{E}-05$ \\
\hline V21 & 177.00 & $1.10 \mathrm{E}-05$ & $1.00 \mathrm{E}-06$ & $2.10 \mathrm{E}-05$ & $3.00 \mathrm{E}-06$ & $2.00 \mathrm{E}-06$ & $3.00 \mathrm{E}-06$ & $6.80 \mathrm{E}-05$ & $6.10 \mathrm{E}-05$ & $7.60 \mathrm{E}-05$ \\
\hline V22 & 160.00 & $6.00 \mathrm{E}-06$ & $2.00 \mathrm{E}-06$ & $1.00 \mathrm{E}-05$ & $2.00 \mathrm{E}-06$ & $2.00 \mathrm{E}-06$ & $3.00 \mathrm{E}-06$ & $2.50 \mathrm{E}-05$ & $2.20 \mathrm{E}-05$ & $2.80 \mathrm{E}-05$ \\
\hline V23 & 170.00 & $2.00 \mathrm{E}-05$ & $-3.00 \mathrm{E}-06$ & $4.40 \mathrm{E}-05$ & $3.00 \mathrm{E}-06$ & $2.00 \mathrm{E}-06$ & $4.00 \mathrm{E}-06$ & $1.56 \mathrm{E}-04$ & $1.41 \mathrm{E}-04$ & $1.75 \mathrm{E}-04$ \\
\hline V31 & 179.00 & $6.00 \mathrm{E}-06$ & $4.00 \mathrm{E}-06$ & $8.00 \mathrm{E}-06$ & $3.00 \mathrm{E}-06$ & $2.00 \mathrm{E}-06$ & $3.00 \mathrm{E}-06$ & $1.20 \mathrm{E}-05$ & $1.10 \mathrm{E}-05$ & $1.40 \mathrm{E}-05$ \\
\hline V32 & 205.00 & $9.00 \mathrm{E}-06$ & $3.00 \mathrm{E}-06$ & $1.50 \mathrm{E}-05$ & $3.00 \mathrm{E}-06$ & $2.00 \mathrm{E}-06$ & $3.00 \mathrm{E}-06$ & $4.40 \mathrm{E}-05$ & $4.00 \mathrm{E}-05$ & $4.80 \mathrm{E}-05$ \\
\hline V33 & 191.00 & $8.00 \mathrm{E}-06$ & $5.00 \mathrm{E}-06$ & $1.20 \mathrm{E}-05$ & $3.00 \mathrm{E}-06$ & $2.00 \mathrm{E}-06$ & $3.00 \mathrm{E}-06$ & $2.50 \mathrm{E}-05$ & $2.30 \mathrm{E}-05$ & $2.80 \mathrm{E}-05$ \\
\hline V1ave & 161.67 & $5.33 \mathrm{E}-06$ & $4.00 \mathrm{E}-06$ & $7.00 \mathrm{E}-06$ & $3.00 \mathrm{E}-06$ & $2.00 \mathrm{E}-06$ & $3.67 \mathrm{E}-06$ & $1.03 \mathrm{E}-05$ & $9.00 \mathrm{E}-06$ & $1.13 \mathrm{E}-05$ \\
\hline V2ave & 169.00 & $1.23 \mathrm{E}-05$ & $0.00 \mathrm{E}+00$ & $2.50 \mathrm{E}-05$ & $2.67 \mathrm{E}-06$ & $2.00 \mathrm{E}-06$ & $3.33 \mathrm{E}-06$ & $8.30 \mathrm{E}-05$ & 7.47E-05 & $9.30 \mathrm{E}-05$ \\
\hline V3ave & 191.67 & 7.67E-06 & $4.00 \mathrm{E}-06$ & $1.17 \mathrm{E}-05$ & $3.00 \mathrm{E}-06$ & $2.00 \mathrm{E}-06$ & $3.00 \mathrm{E}-06$ & $2.70 \mathrm{E}-05$ & $2.47 \mathrm{E}-05$ & $3.00 \mathrm{E}-05$ \\
\hline Vtotave & 174.11 & 8.44E-06 & $2.67 \mathrm{E}-06$ & $1.46 \mathrm{E}-05$ & $2.89 \mathrm{E}-06$ & $2.00 \mathrm{E}-06$ & 3.33E-06 & $4.01 \mathrm{E}-05$ & $3.61 \mathrm{E}-05$ & $4.48 \mathrm{E}-05$ \\
\hline
\end{tabular}

Sun Velocity

\begin{tabular}{|c|c|c|c|c|c|c|c|c|c|c|}
\hline Version & $\begin{array}{c}\text { Number of } \\
\text { Impacts }\end{array}$ & Mean & $\begin{array}{c}\text { 95\% CI for } \\
\text { Mean, Low }\end{array}$ & $\begin{array}{c}\text { 95\% CI for } \\
\text { Mean, } \\
\text { High }\end{array}$ & Median & $\begin{array}{c}\text { Median, } \\
\text { Low }\end{array}$ & $\begin{array}{c}\text { M5\% CI for } \\
\text { Median, } \\
\text { High }\end{array}$ & $\begin{array}{c}\text { 95\% CI for } \\
\text { StDev, } \\
\text { Low }\end{array}$ & $\begin{array}{c}\text { 95\% CI for } \\
\text { Stdev, } \\
\text { High }\end{array}$ \\
\hline V11 & 178.00 & 24.58 & 23.23 & 25.94 & 25.00 & 23.00 & 27.00 & 9.15 & 8.29 & 10.22 \\
\hline V12 & 145.00 & 22.88 & 21.23 & 24.52 & 21.00 & 19.00 & 23.00 & 10.02 & 8.99 & 11.33 \\
\hline V13 & 162.00 & 23.16 & 21.81 & 24.52 & 23.00 & 21.00 & 25.00 & 8.73 & 7.88 & 9.80 \\
\hline V21 & 177.00 & 22.85 & 21.32 & 24.39 & 23.00 & 21.00 & 25.00 & 10.35 & 9.37 & 11.56 \\
\hline V22 & 160.00 & 22.93 & 21.52 & 24.33 & 23.00 & 21.00 & 24.76 & 8.97 & 8.09 & 10.08 \\
\hline V23 & 170.00 & 22.48 & 21.05 & 23.92 & 21.00 & 19.00 & 23.00 & 9.49 & 8.57 & 10.62 \\
\hline V31 & 179.00 & 22.73 & 21.38 & 24.09 & 21.00 & 19.00 & 23.00 & 9.19 & 8.33 & 10.25 \\
\hline V32 & 205.00 & 22.54 & 21.26 & 23.82 & 23.00 & 21.00 & 23.00 & 9.30 & 8.48 & 10.30 \\
\hline V33 & 191.00 & 22.84 & 21.49 & 24.20 & 21.00 & 19.00 & 25.00 & 9.48 & 8.62 & 10.54 \\
\hline V1ave & 161.67 & 23.54 & 22.09 & 24.99 & 23.00 & 21.00 & 25.00 & 9.30 & 8.38 & 10.45 \\
\hline V2ave & 169.00 & 22.75 & 21.30 & 24.21 & 22.33 & 20.33 & 24.25 & 9.60 & 8.68 & 10.75 \\
\hline V3ave & 191.67 & 22.71 & 21.38 & 24.04 & 21.67 & 19.67 & 23.67 & 9.32 & 8.47 & 10.36 \\
\hline Vtotave & 174.11 & 23.00 & 21.59 & 24.41 & 22.33 & 20.33 & 24.31 & 9.41 & 8.51 & 10.52 \\
\hline
\end{tabular}

Antisun Mass

\begin{tabular}{|c|c|c|c|c|c|c|c|c|c|c|}
\hline Version & $\begin{array}{l}\text { Number of } \\
\text { Impacts }\end{array}$ & Mean & $\begin{array}{l}\text { 95\% CI for } \\
\text { Mean, Low }\end{array}$ & $\begin{array}{c}95 \% \text { CI for } \\
\text { Mean, } \\
\text { High }\end{array}$ & Median & $\begin{array}{l}95 \% \text { CI for } \\
\text { Median, } \\
\text { Low }\end{array}$ & $\begin{array}{l}\text { 95\% CI for } \\
\text { Median, } \\
\text { High }\end{array}$ & StDev & $\begin{array}{l}95 \% \text { CI for } \\
\text { StDev, } \\
\text { Low }\end{array}$ & $\begin{array}{c}95 \% \text { CI for } \\
\text { Stdev, } \\
\text { High }\end{array}$ \\
\hline V11 & 325.00 & $6.00 \mathrm{E}-06$ & $4.00 \mathrm{E}-06$ & $7.00 \mathrm{E}-06$ & $2.00 \mathrm{E}-06$ & $2.00 \mathrm{E}-06$ & $3.00 \mathrm{E}-06$ & $1.20 \mathrm{E}-05$ & $1.10 \mathrm{E}-05$ & $1.30 \mathrm{E}-05$ \\
\hline V12 & 321.00 & $5.00 \mathrm{E}-06$ & $3.00 \mathrm{E}-06$ & $7.00 \mathrm{E}-06$ & $2.00 \mathrm{E}-06$ & $2.00 \mathrm{E}-06$ & $3.00 \mathrm{E}-06$ & $1.80 \mathrm{E}-05$ & $1.70 \mathrm{E}-05$ & $2.00 \mathrm{E}-05$ \\
\hline V13 & 300.00 & $6.00 \mathrm{E}-06$ & $4.00 \mathrm{E}-06$ & $8.00 \mathrm{E}-06$ & $3.00 \mathrm{E}-06$ & $2.00 \mathrm{E}-06$ & $3.00 \mathrm{E}-06$ & $1.60 \mathrm{E}-05$ & $1.40 \mathrm{E}-05$ & $1.70 \mathrm{E}-05$ \\
\hline V21 & 323.00 & $8.00 \mathrm{E}-06$ & $3.00 \mathrm{E}-06$ & $1.40 \mathrm{E}-05$ & $3.00 \mathrm{E}-06$ & $2.00 \mathrm{E}-06$ & $3.00 \mathrm{E}-06$ & $5.10 \mathrm{E}-05$ & $4.70 \mathrm{E}-05$ & $5.50 \mathrm{E}-05$ \\
\hline V22 & 282.00 & $6.00 \mathrm{E}-06$ & $4.00 \mathrm{E}-06$ & $7.00 \mathrm{E}-06$ & $3.00 \mathrm{E}-06$ & $2.00 \mathrm{E}-06$ & $3.00 \mathrm{E}-06$ & $1.10 \mathrm{E}-05$ & $1.00 \mathrm{E}-05$ & $1.20 \mathrm{E}-05$ \\
\hline V23 & 321.00 & $5.00 \mathrm{E}-06$ & $4.00 \mathrm{E}-06$ & $6.00 \mathrm{E}-06$ & $2.00 \mathrm{E}-06$ & $2.00 \mathrm{E}-06$ & $3.00 \mathrm{E}-06$ & $1.10 \mathrm{E}-05$ & $1.00 \mathrm{E}-05$ & $1.20 \mathrm{E}-05$ \\
\hline V32 & 305.00 & $6.00 \mathrm{E}-06$ & $5.00 \mathrm{E}-06$ & $8.00 \mathrm{E}-06$ & $3.00 \mathrm{E}-06$ & $2.00 \mathrm{E}-06$ & $3.00 \mathrm{E}-06$ & $1.30 \mathrm{E}-05$ & $1.20 \mathrm{E}-05$ & $1.40 \mathrm{E}-05$ \\
\hline V33 & 317.00 & $5.00 \mathrm{E}-06$ & $4.00 \mathrm{E}-06$ & $6.00 \mathrm{E}-06$ & $3.00 \mathrm{E}-06$ & $2.00 \mathrm{E}-06$ & $3.00 \mathrm{E}-06$ & $8.00 \mathrm{E}-06$ & $7.00 \mathrm{E}-06$ & $9.00 \mathrm{E}-06$ \\
\hline V1ave & 315.33 & $5.67 \mathrm{E}-06$ & $3.67 \mathrm{E}-06$ & $7.33 \mathrm{E}-06$ & $2.33 \mathrm{E}-06$ & $2.00 \mathrm{E}-06$ & $3.00 \mathrm{E}-06$ & $1.53 \mathrm{E}-05$ & $1.40 \mathrm{E}-05$ & $1.67 \mathrm{E}-05$ \\
\hline V2ave & 308.67 & $6.33 \mathrm{E}-06$ & $3.67 \mathrm{E}-06$ & $9.00 \mathrm{E}-06$ & $2.67 \mathrm{E}-06$ & $2.00 \mathrm{E}-06$ & $3.00 \mathrm{E}-06$ & $2.43 \mathrm{E}-05$ & $2.23 \mathrm{E}-05$ & $2.63 \mathrm{E}-05$ \\
\hline V3ave & 305.33 & $5.67 \mathrm{E}-06$ & $4.33 \mathrm{E}-06$ & $7.00 \mathrm{E}-06$ & $3.00 \mathrm{E}-06$ & $2.00 \mathrm{E}-06$ & $3.00 \mathrm{E}-06$ & $1.03 \mathrm{E}-05$ & $9.33 \mathrm{E}-06$ & $1.13 \mathrm{E}-05$ \\
\hline Vtotave & 309.78 & $5.89 \mathrm{E}-06$ & $3.89 \mathrm{E}-06$ & $7.78 \mathrm{E}-06$ & $2.67 \mathrm{E}-06$ & $2.00 \mathrm{E}-06$ & $3.00 \mathrm{E}-06$ & $1.67 \mathrm{E}-05$ & $1.52 \mathrm{E}-05$ & $1.81 \mathrm{E}-05$ \\
\hline
\end{tabular}

\section{Antisun Velocity}




\begin{tabular}{|c|c|c|c|c|c|c|c|c|c|c|}
\hline Version & $\begin{array}{l}\text { Number of } \\
\text { Impacts }\end{array}$ & Mean & $\begin{array}{l}95 \% \text { CI for } \\
\text { Mean, Low }\end{array}$ & $\begin{array}{l}95 \% \text { CI for } \\
\text { Mean, } \\
\text { High }\end{array}$ & Median & $\begin{array}{l}95 \% \text { CI for } \\
\text { Median, } \\
\text { Low }\end{array}$ & $\begin{array}{l}95 \% \text { CI for } \\
\text { Median, } \\
\text { High }\end{array}$ & StDev & $\begin{array}{l}95 \% \text { CI for } \\
\text { StDev, } \\
\text { Low }\end{array}$ & $\begin{array}{c}95 \% \text { CI for } \\
\text { Stdev, } \\
\text { High }\end{array}$ \\
\hline V11 & 325.00 & 18.89 & 17.78 & 20.00 & 17.00 & 17.00 & 21.00 & 10.18 & 9.45 & 11.03 \\
\hline V12 & 321.00 & 20.75 & 19.54 & 21.95 & 21.00 & 19.00 & 21.00 & 11.00 & 10.21 & 11.93 \\
\hline V13 & 300.00 & 19.32 & 18.15 & 20.49 & 19.00 & 17.00 & 21.00 & 10.30 & 9.54 & 11.20 \\
\hline V21 & 323.00 & 19.96 & 18.81 & 21.12 & 21.00 & 19.00 & 23.00 & 10.55 & 9.80 & 11.44 \\
\hline V22 & 282.00 & 19.84 & 18.61 & 21.65 & 19.00 & 17.10 & 21.00 & 10.48 & 9.68 & 11.42 \\
\hline V23 & 321.00 & 20.46 & 19.25 & 21.67 & 21.00 & 19.00 & 21.00 & 11.03 & 10.24 & 11.95 \\
\hline V32 & 305.00 & 20.78 & 19.58 & 21.97 & 19.00 & 17.00 & 21.00 & 10.60 & 9.83 & 11.51 \\
\hline V33 & 317.00 & 20.21 & 19.05 & 21.36 & 21.00 & 19.00 & 21.00 & 10.42 & 9.67 & 11.30 \\
\hline V1ave & 315.33 & 19.65 & 18.49 & 20.81 & 19.00 & 17.67 & 21.00 & 10.49 & 9.73 & 11.38 \\
\hline V2ave & 308.67 & 20.09 & 18.89 & 21.48 & 20.33 & 18.37 & 21.67 & 10.69 & 9.90 & 11.60 \\
\hline V3ave & 305.33 & 20.53 & 19.36 & 21.70 & 20.33 & 18.33 & 21.00 & 10.37 & 9.61 & 11.27 \\
\hline Vtotave & 309.78 & 20.09 & 18.91 & 21.33 & 19.89 & 18.12 & 21.22 & 10.52 & 9.75 & 11.42 \\
\hline
\end{tabular}




\section{Appendix D Monolithic Impact Result Plots}

Below is the full set of plots created for the Monolithic section. The mass points on the $\mathrm{Y}$ axis are 54 masses ranging incrementally from $1 * 10^{-6}$ grams up to 0.9 grams $\left(\mathrm{ex} .8^{*} 10^{-6}, 9^{*} 10^{-6}, 1 * 10^{-5}, 2 * 10^{-6}\right.$, etc). The green areas are free from spallation, the yellow and red have incipient and detached spalling respectively, and the blue has perforation.

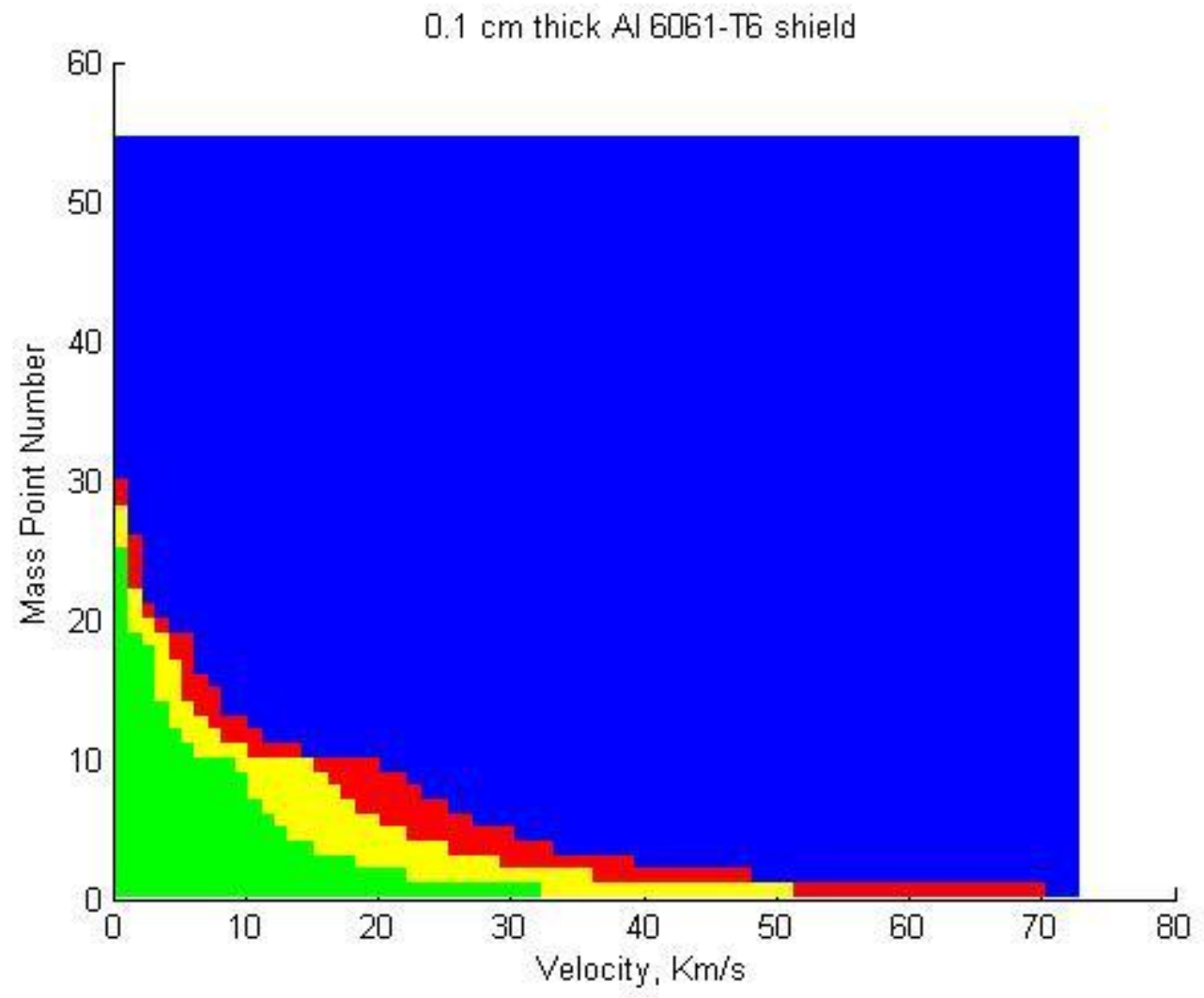



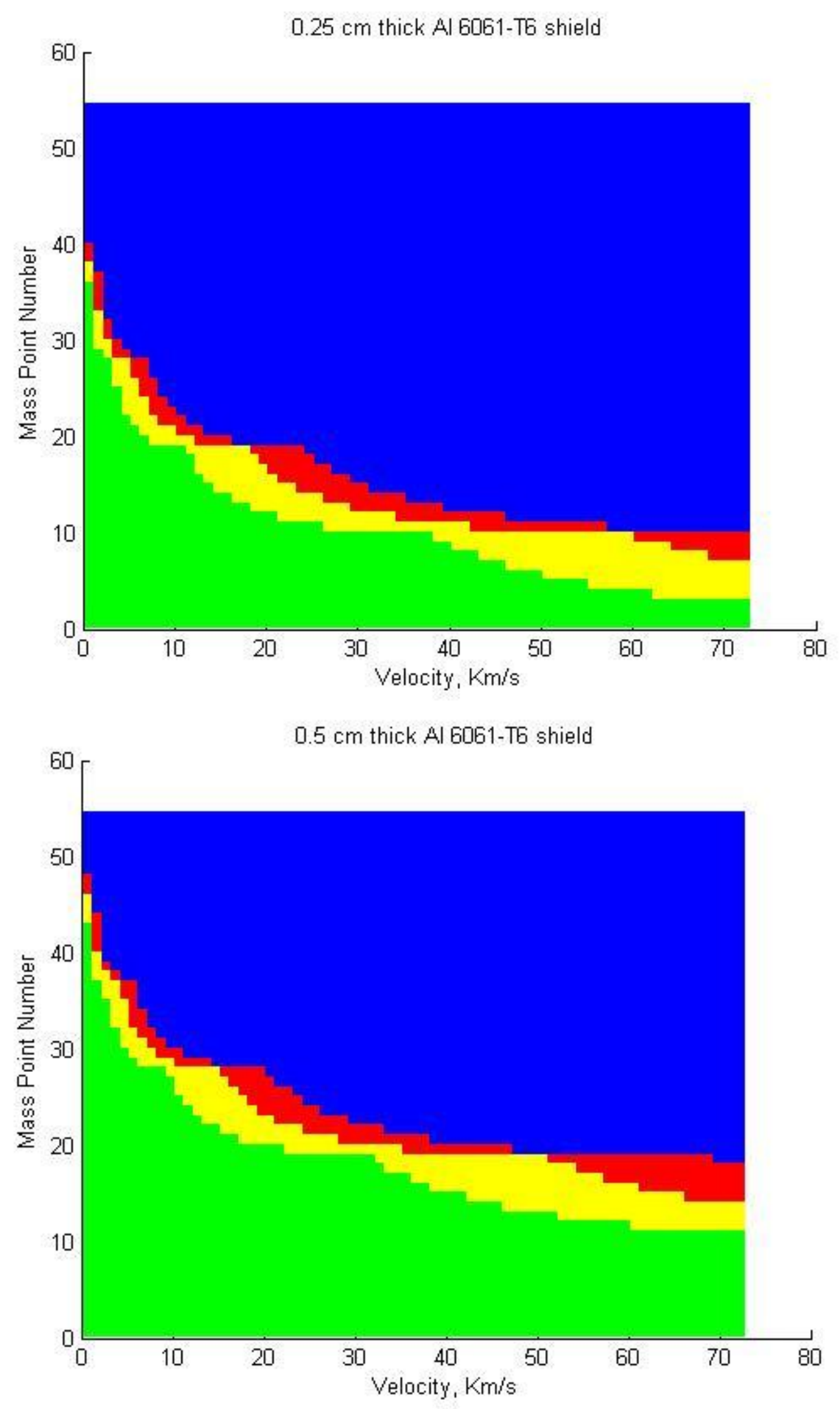

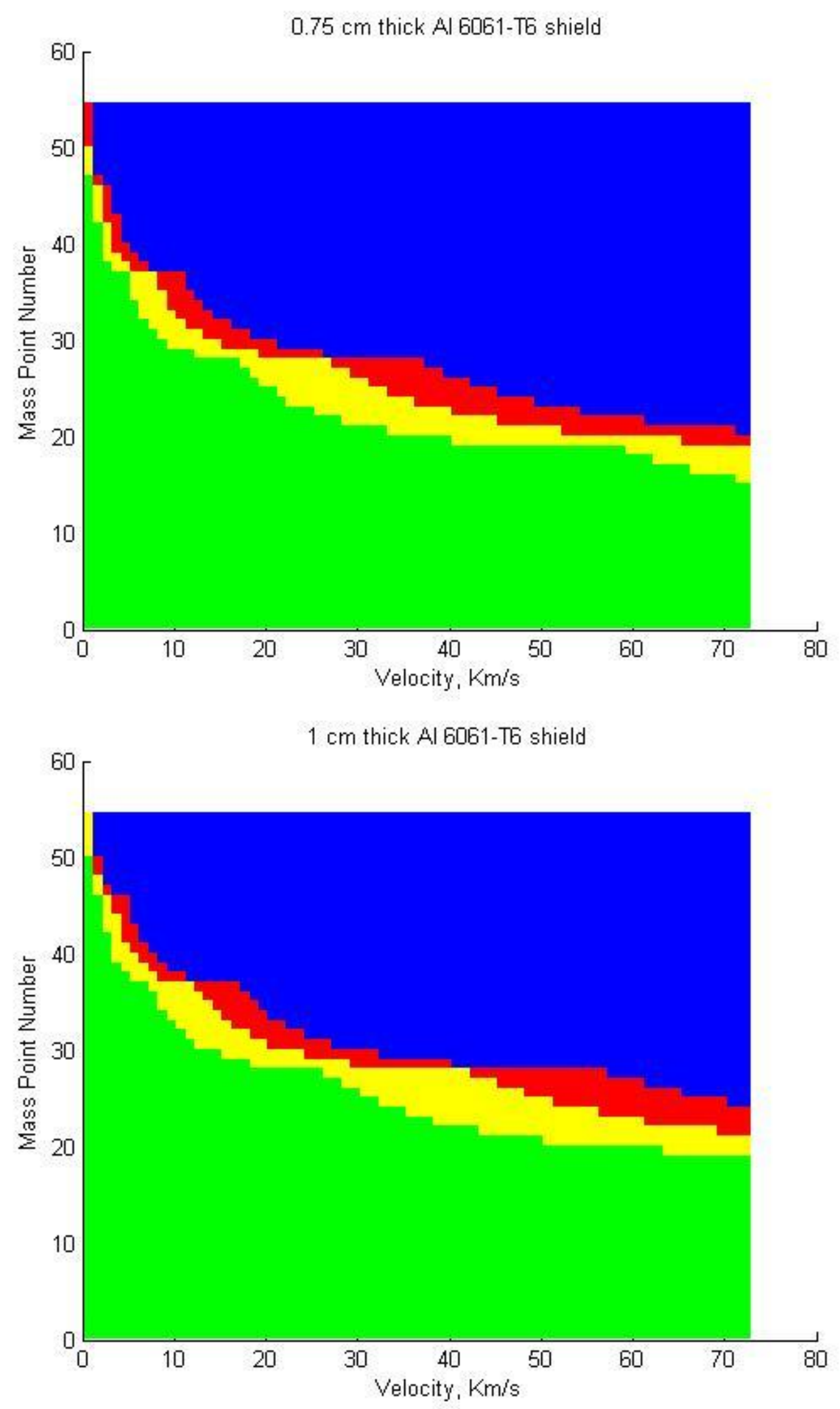

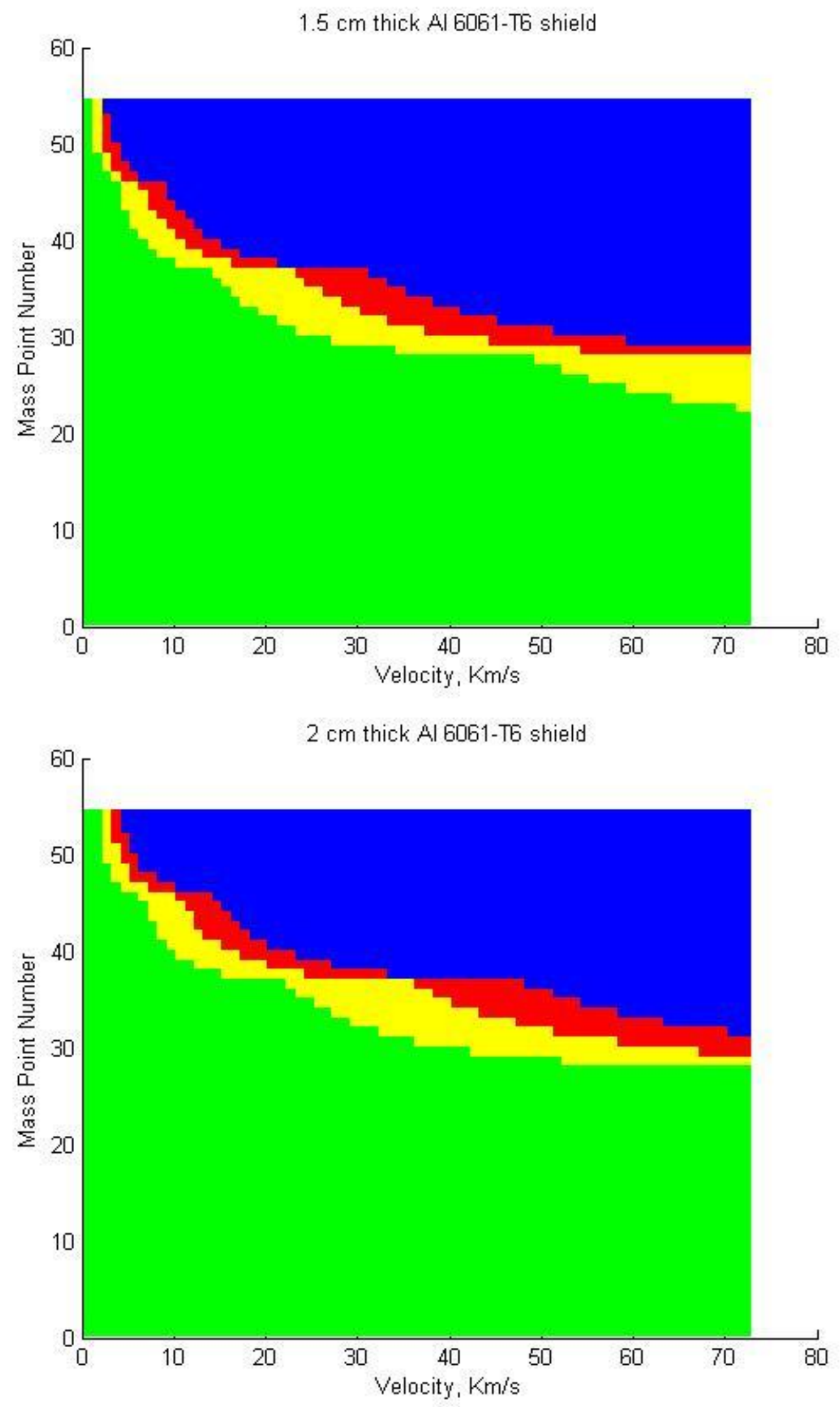

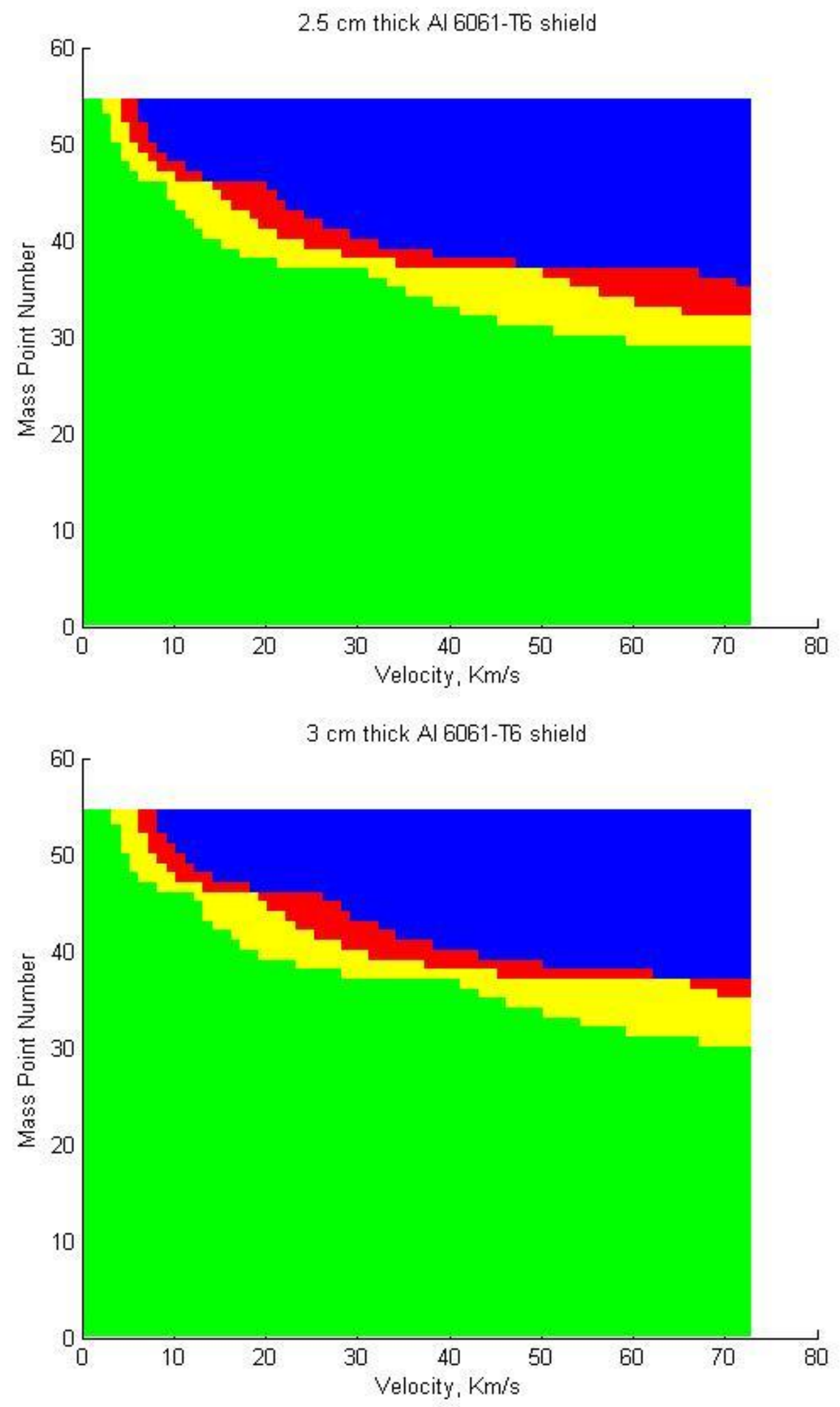

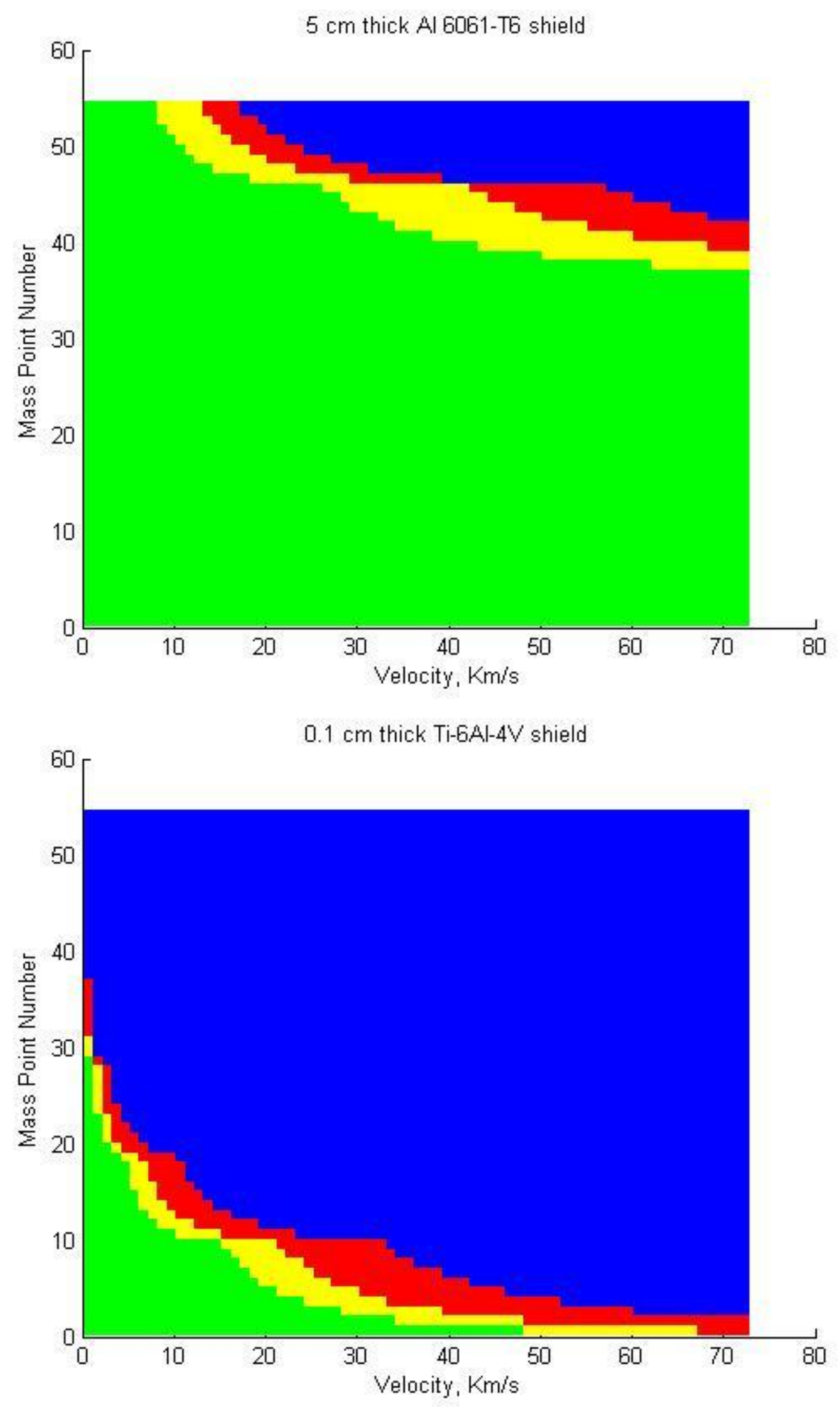

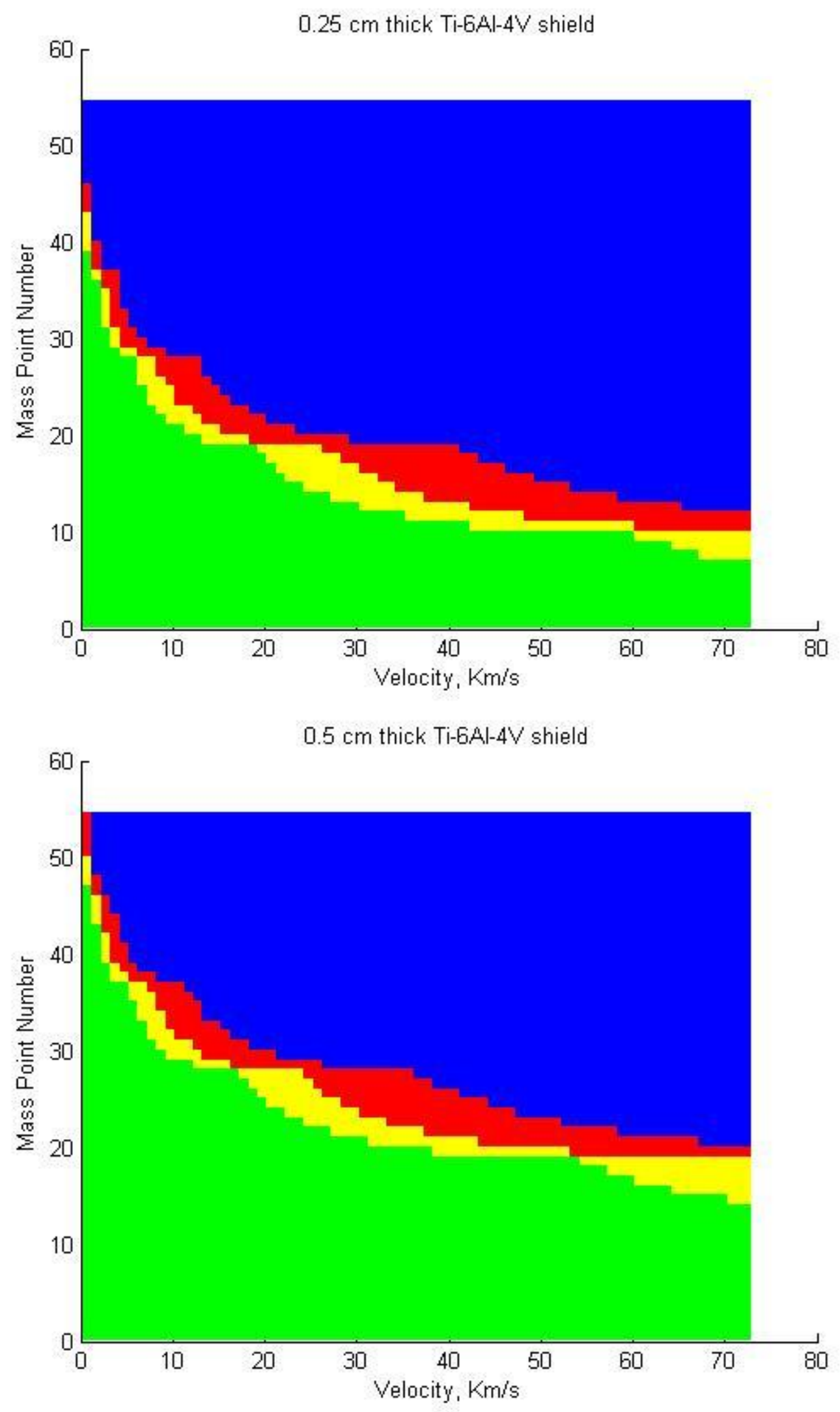

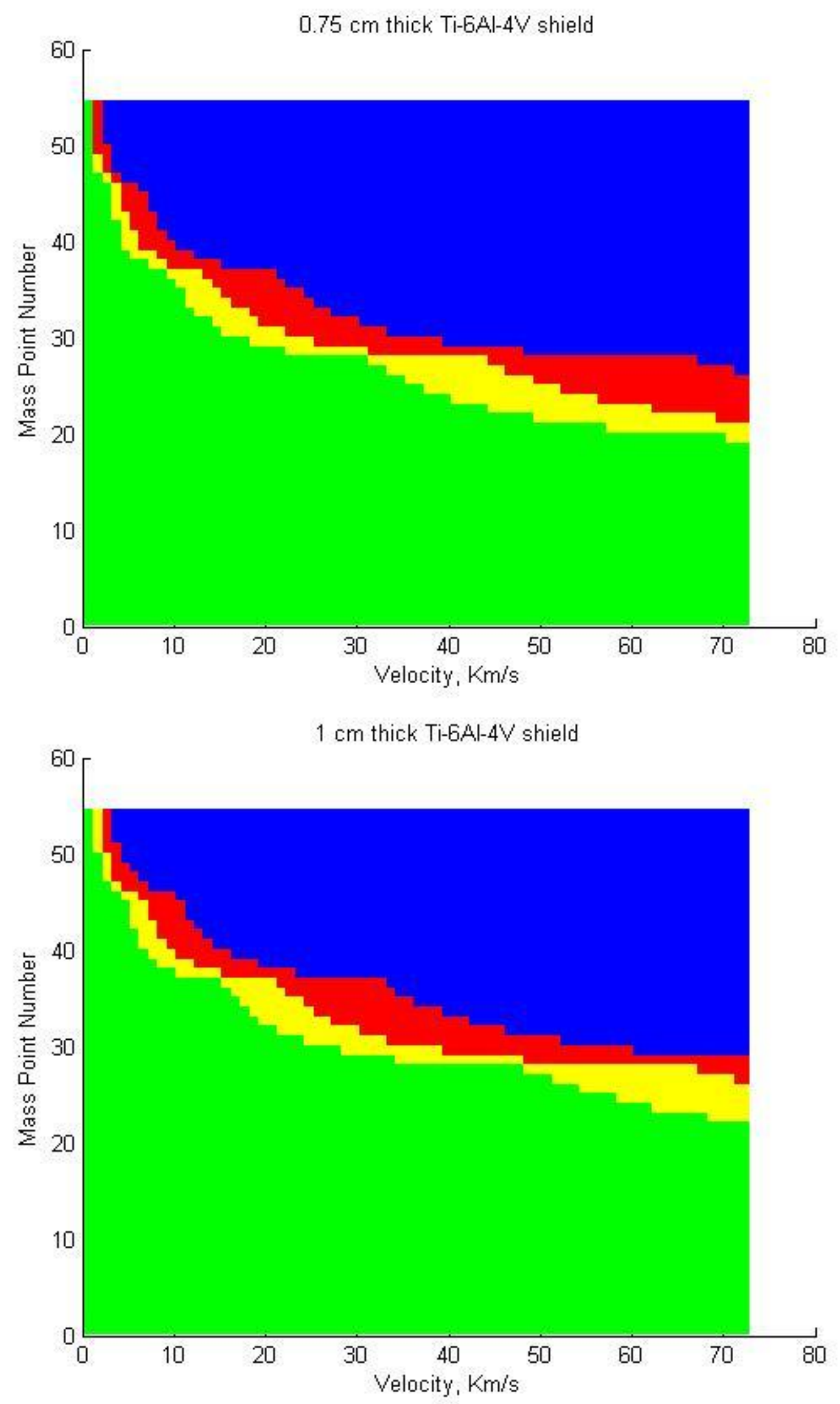

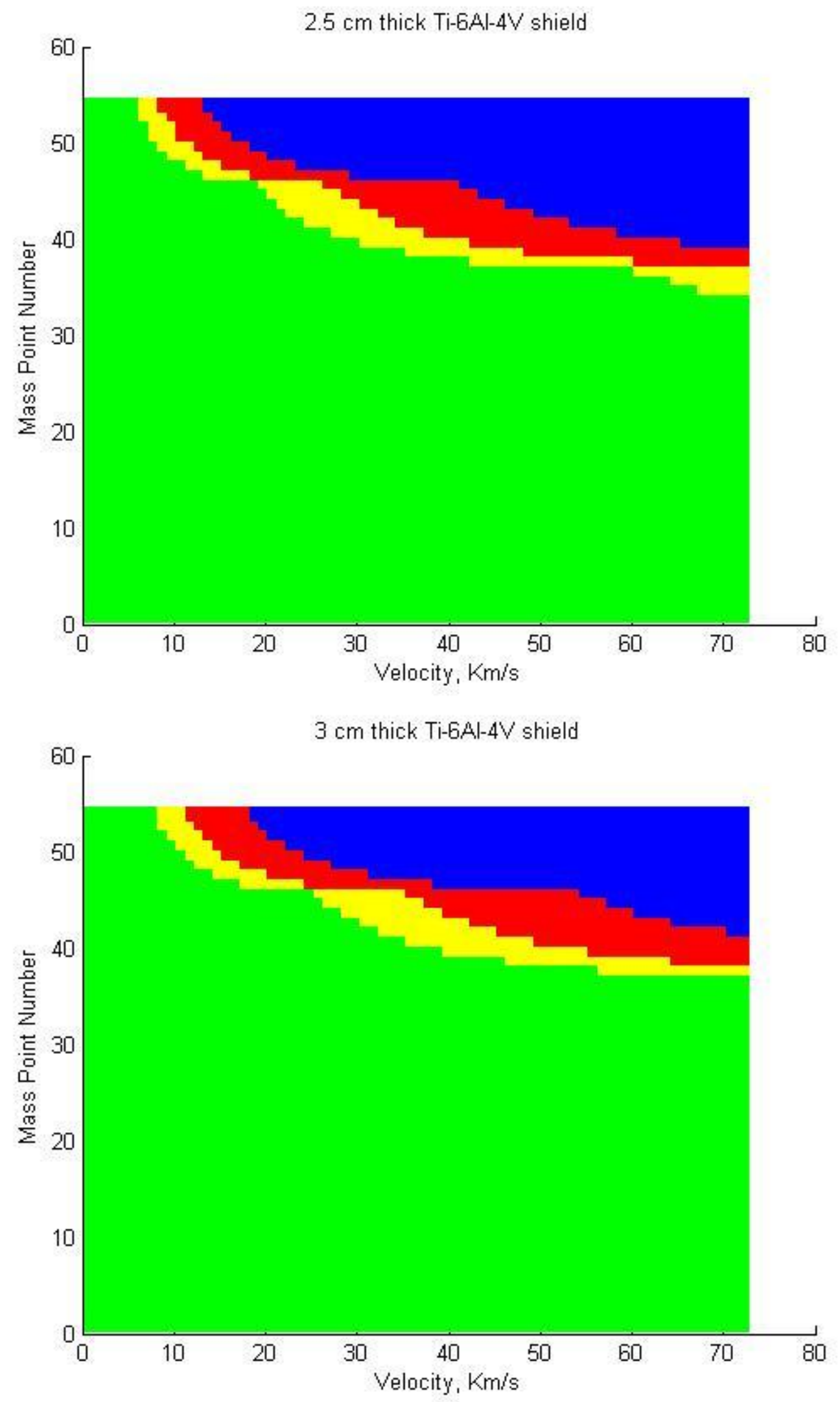


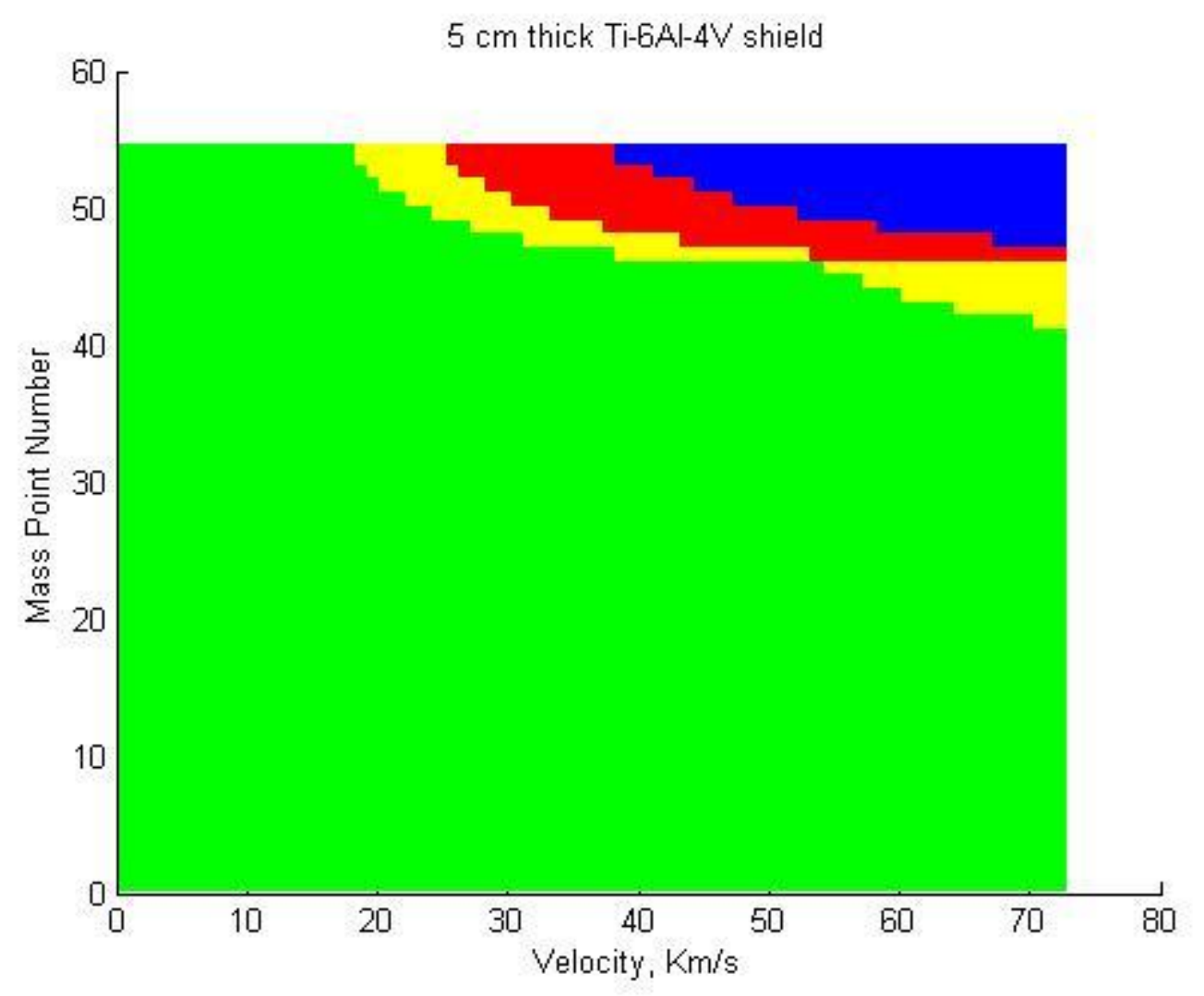




\section{Appendix E Whipple Impact Critical Diameter Plots}

The following plots show the changes in critical particle diameter as velocity and spacing between the bumper and wall increase. The first set shows the effects of increasing bumper thickness while keeping wall thickness constant. The second set shows the reverse, wall thickness varying with constant bumper thickness. The constant part of the shield was always $0.5 \mathrm{~cm}$ in thickness. Below is a color guide table, where $\mathrm{X}$ is the critical particle diameter.

\begin{tabular}{|c|c|}
\hline Color & Critical Particle Diameter \\
\hline Blue & $X>=2$ \\
\hline Green & $2>X>=1$ \\
\hline Yellow & $1>X>=0.5$ \\
\hline Red & $0.5>X>=0.1$ \\
\hline Black & $X<0.1$ \\
\hline
\end{tabular}

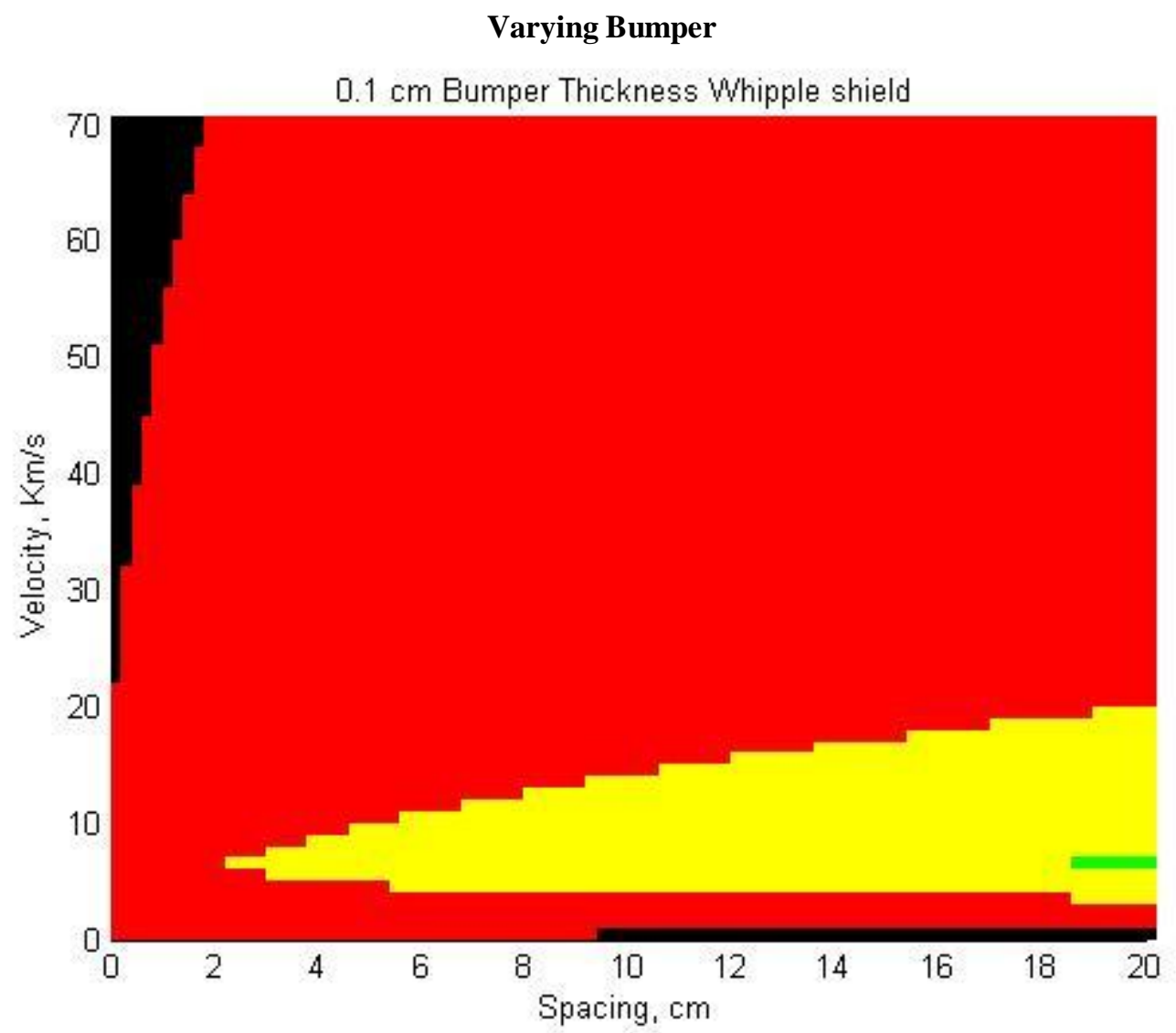



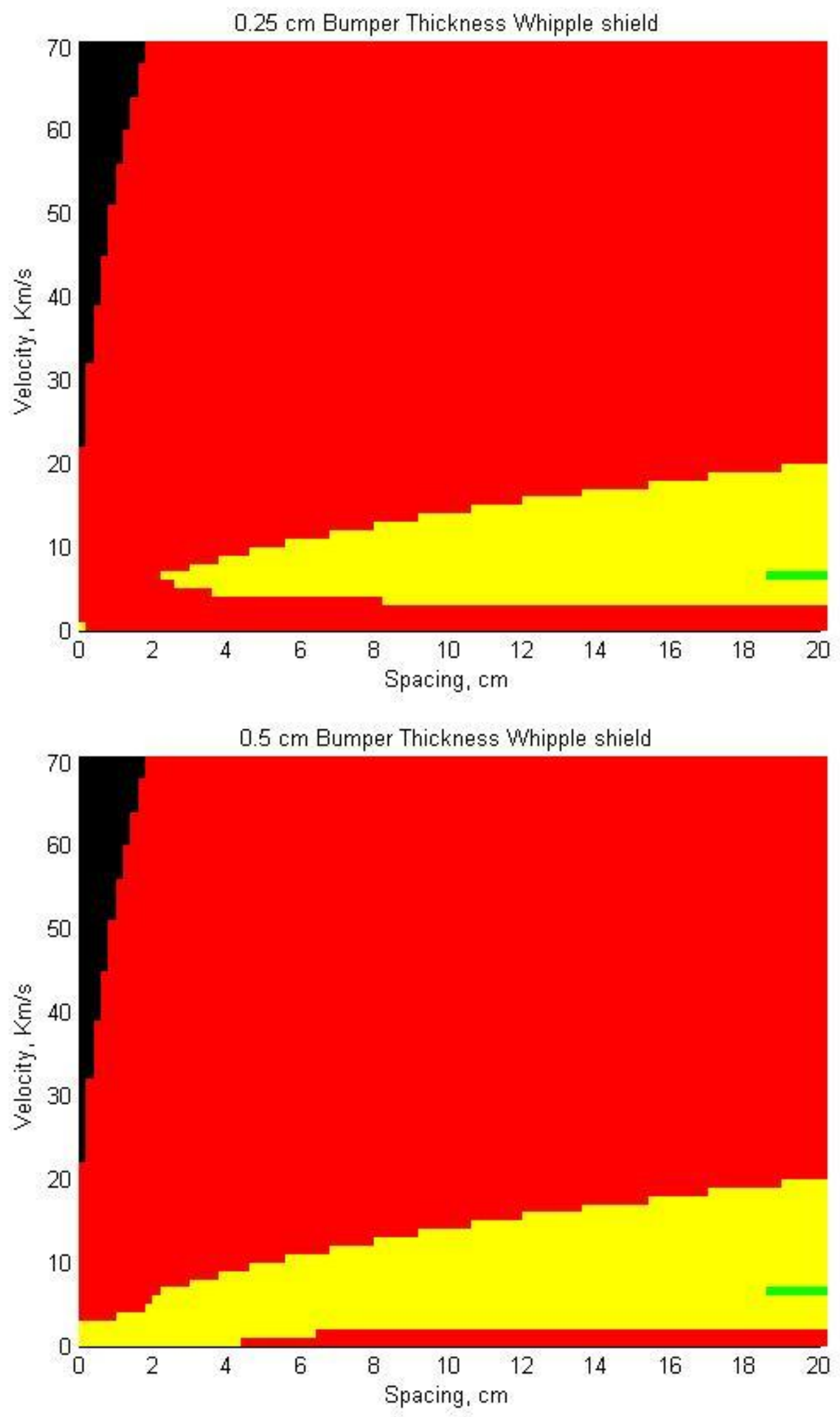

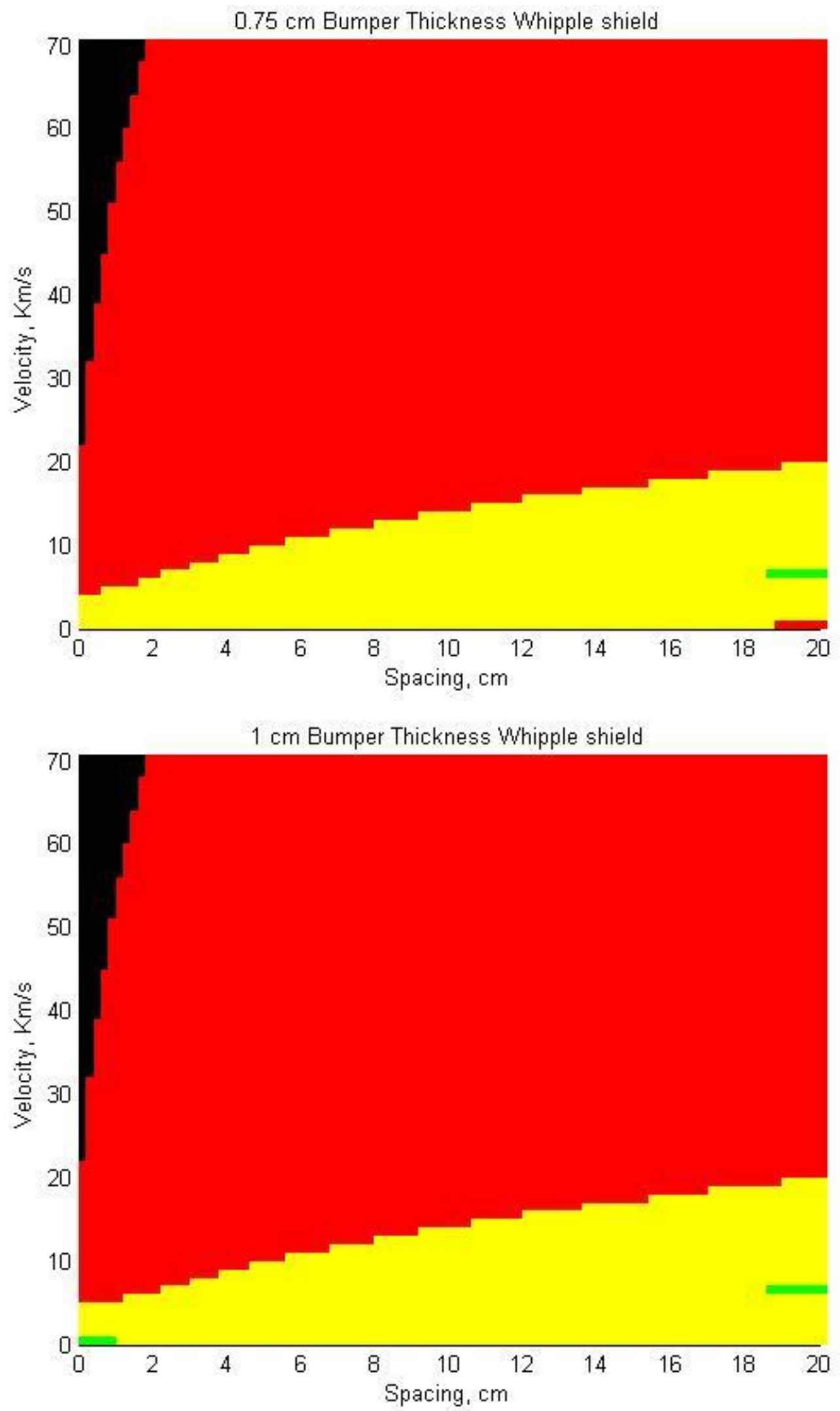

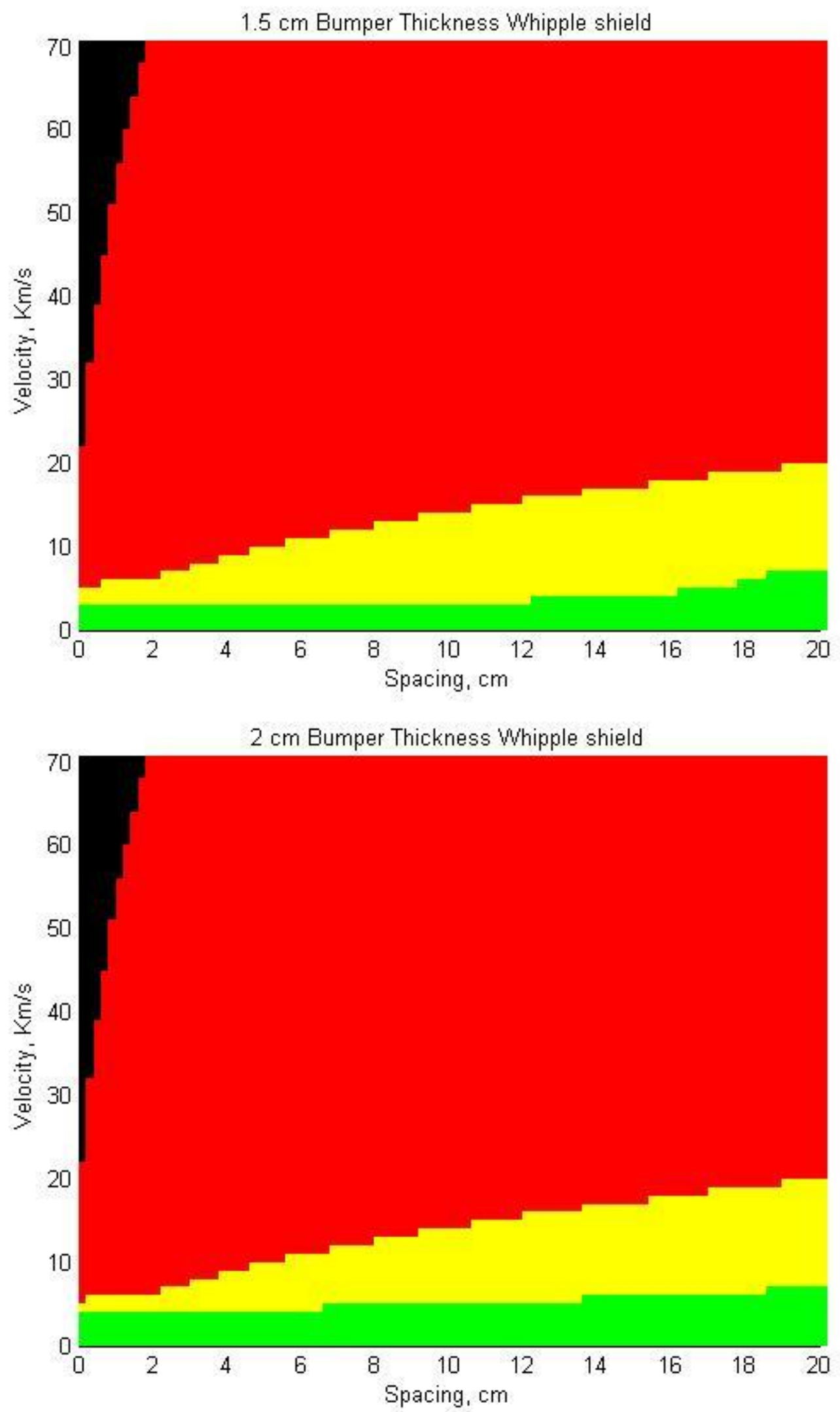

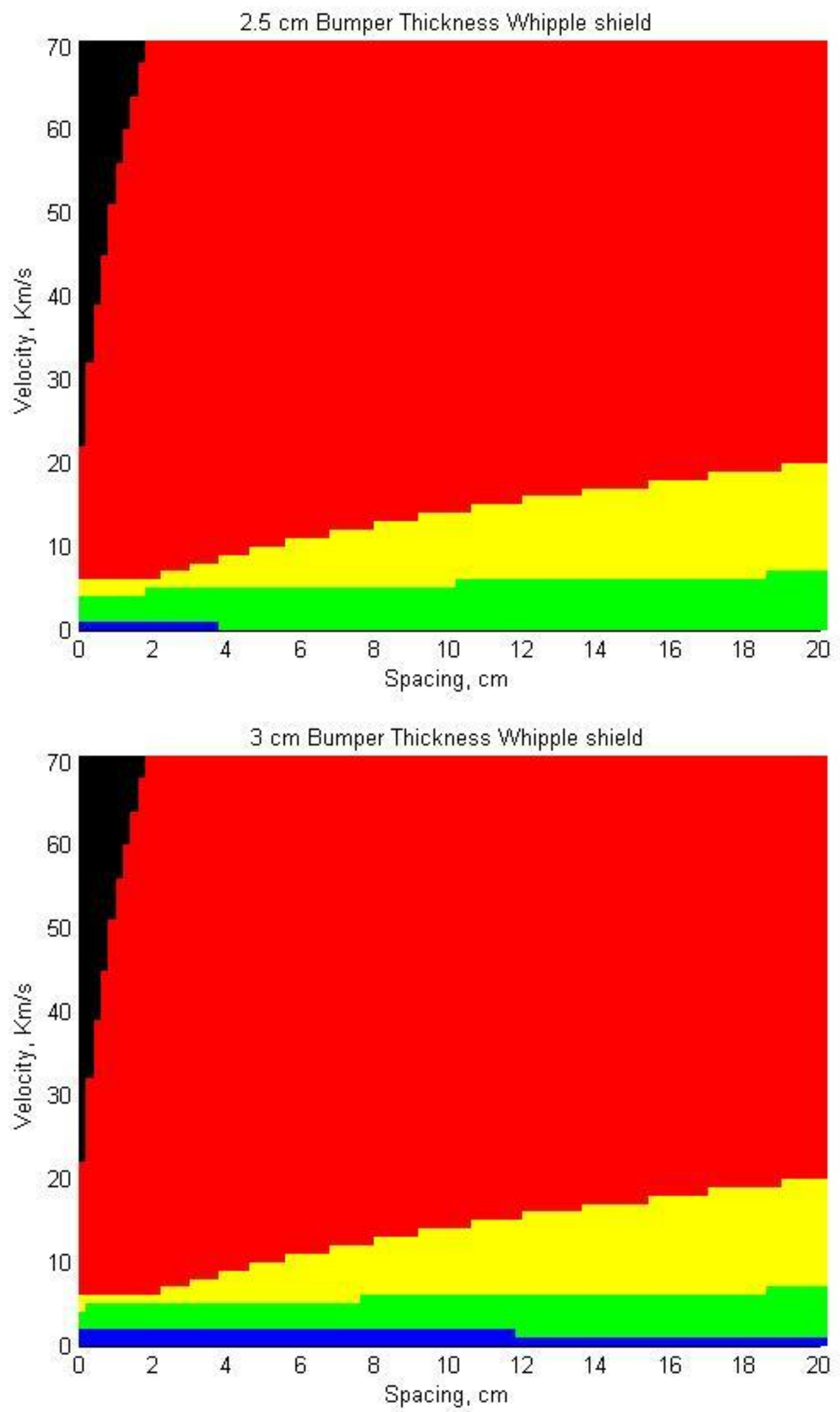


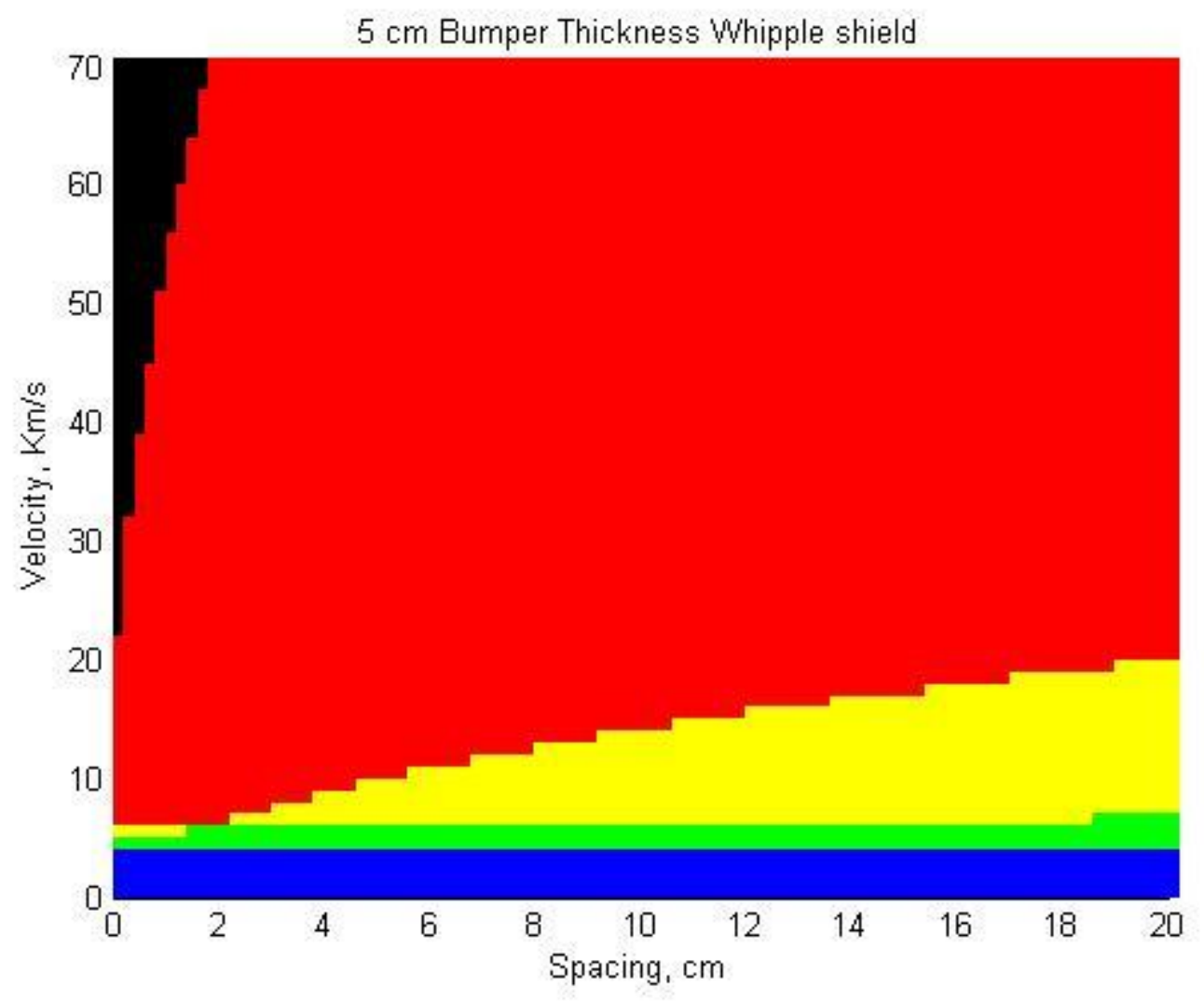



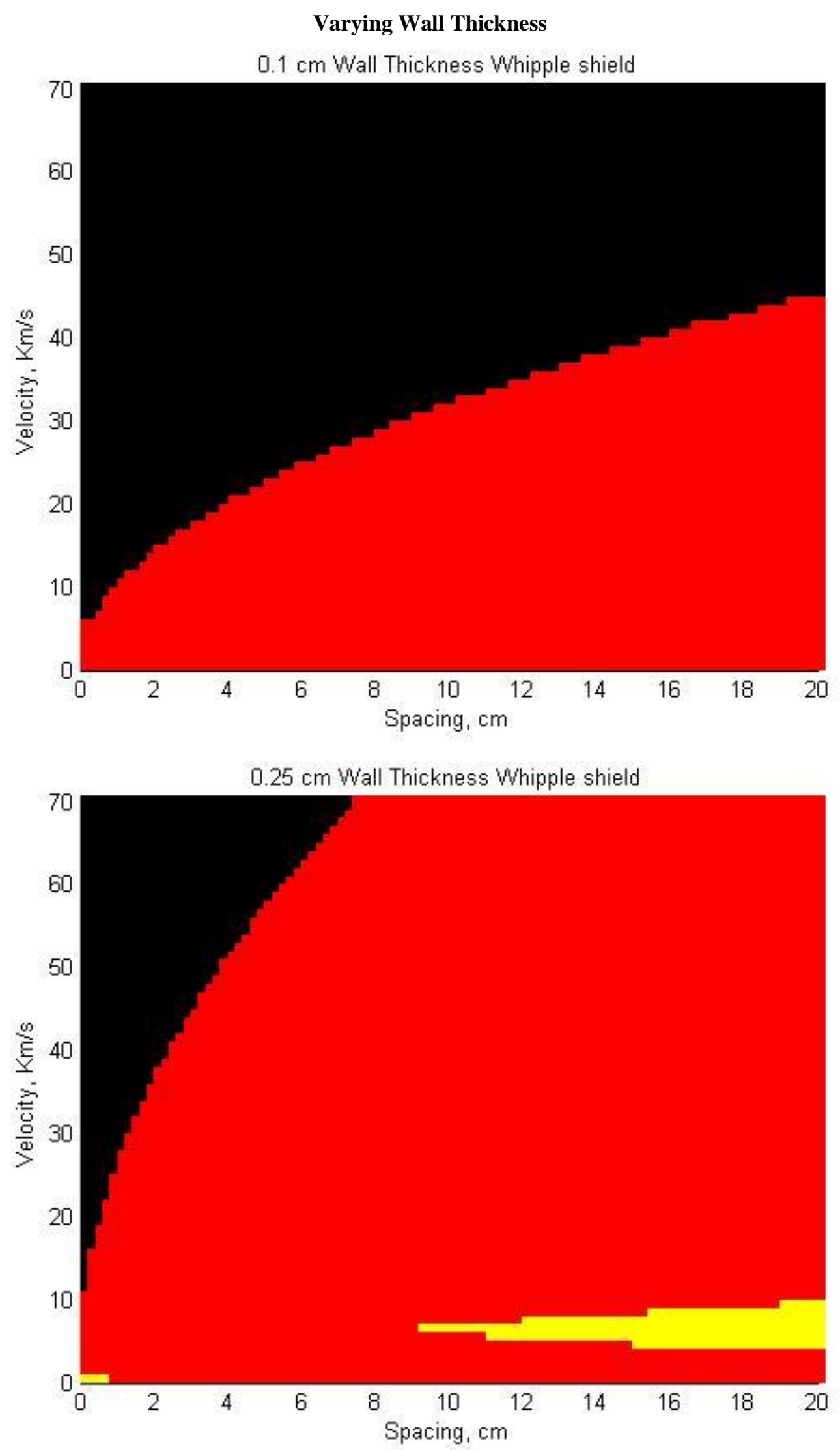

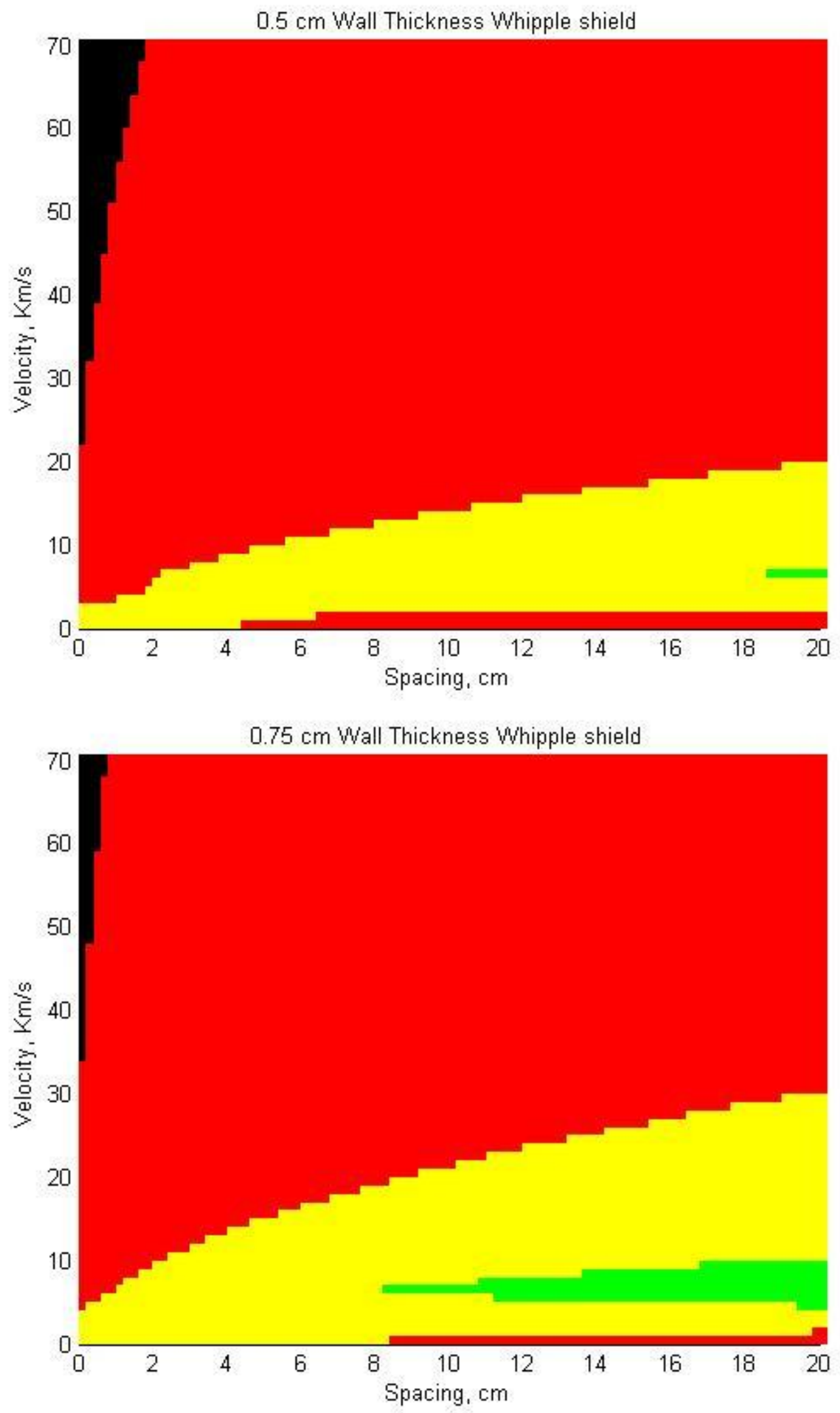

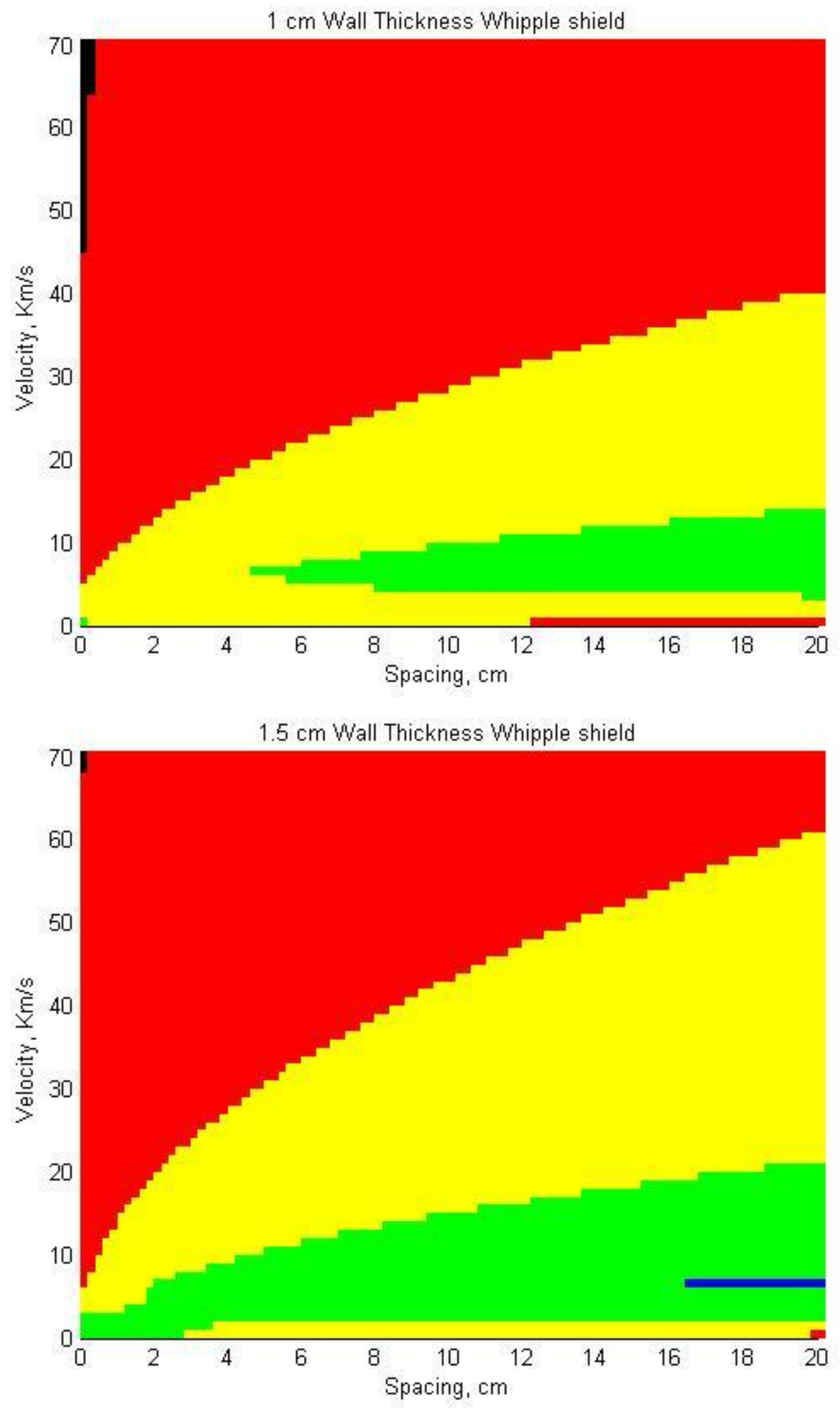

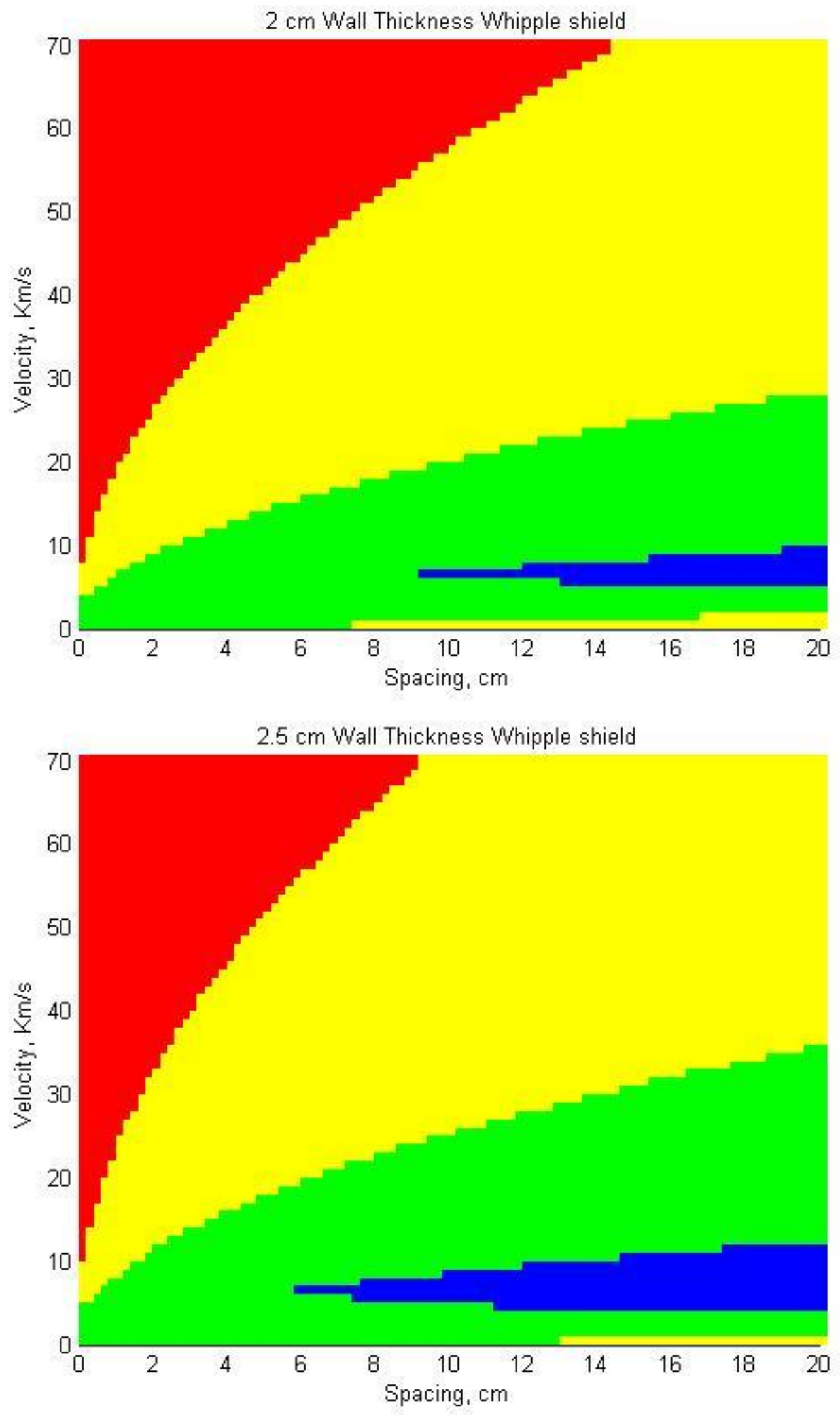

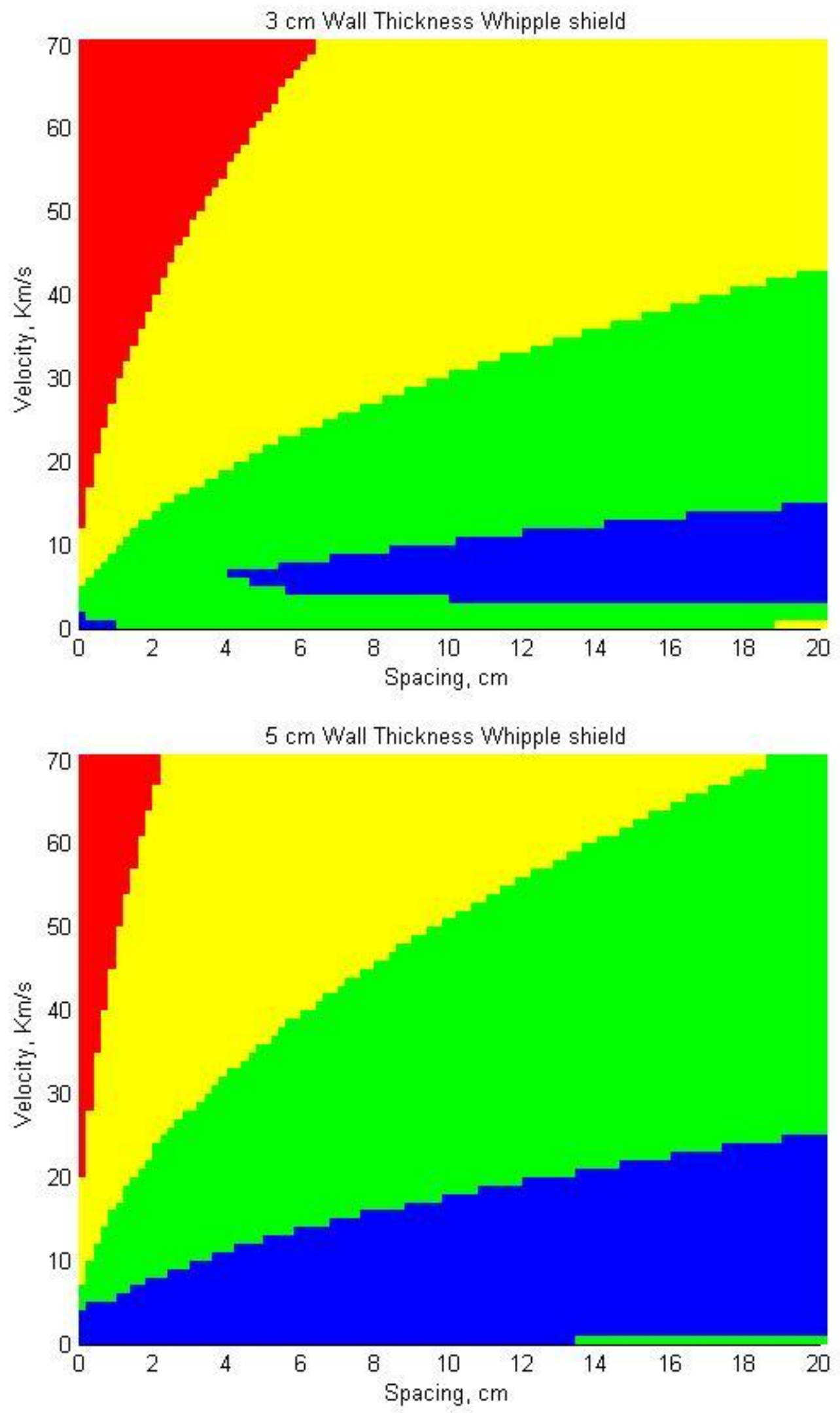
Appendix F Full Set of Effect of Minimum Mass Plots

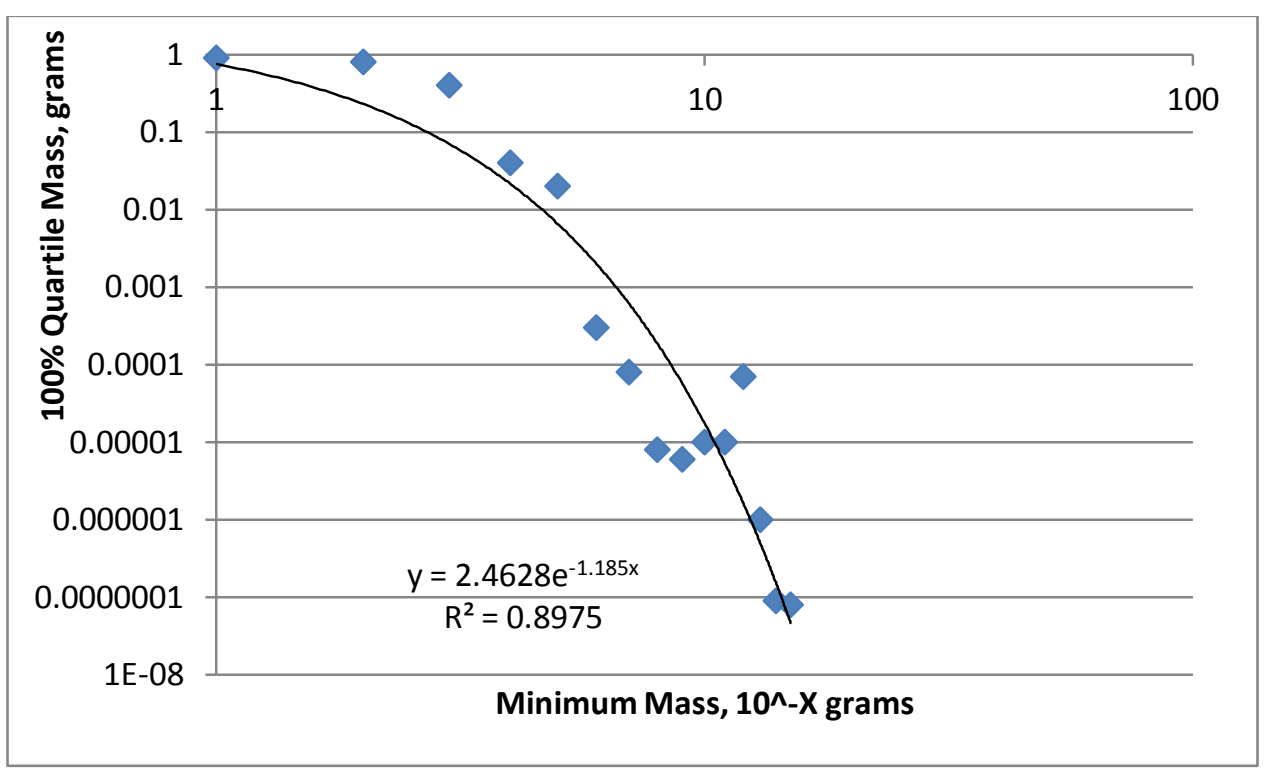

a) $100 \%$

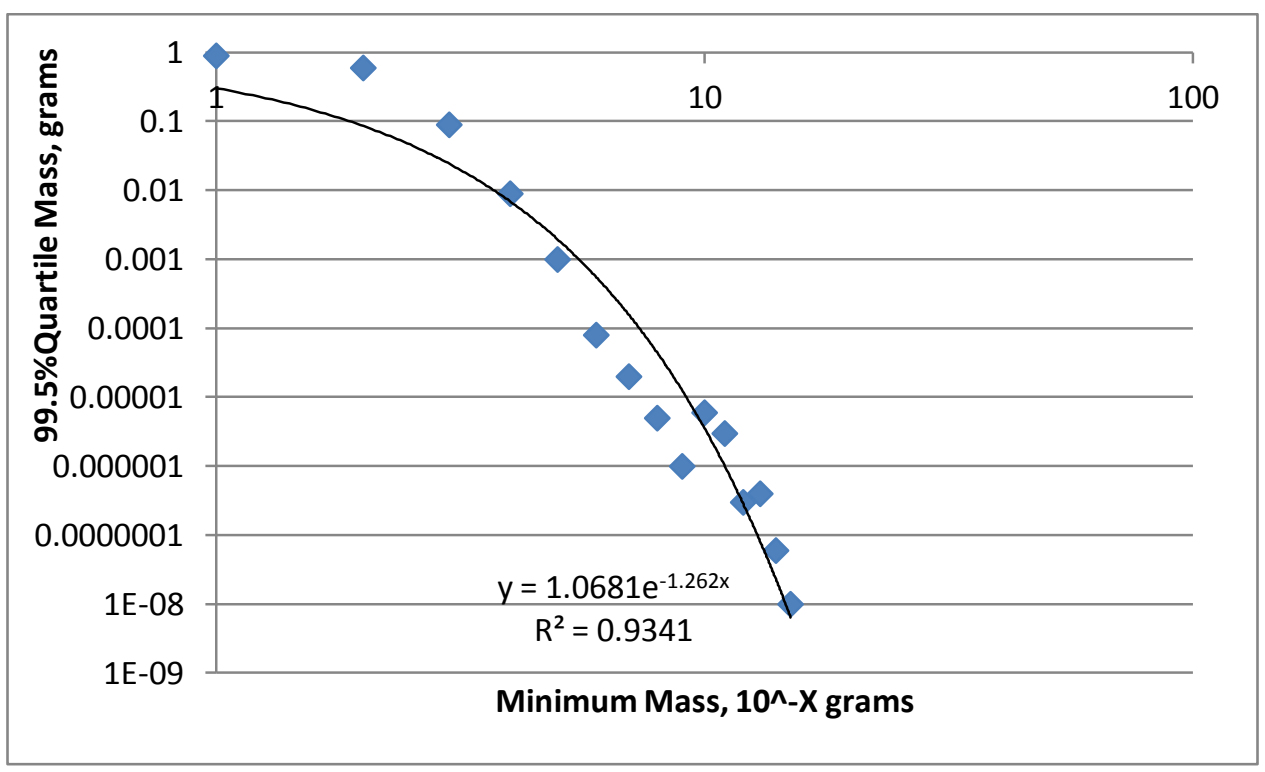

b) $99.5 \%$ 


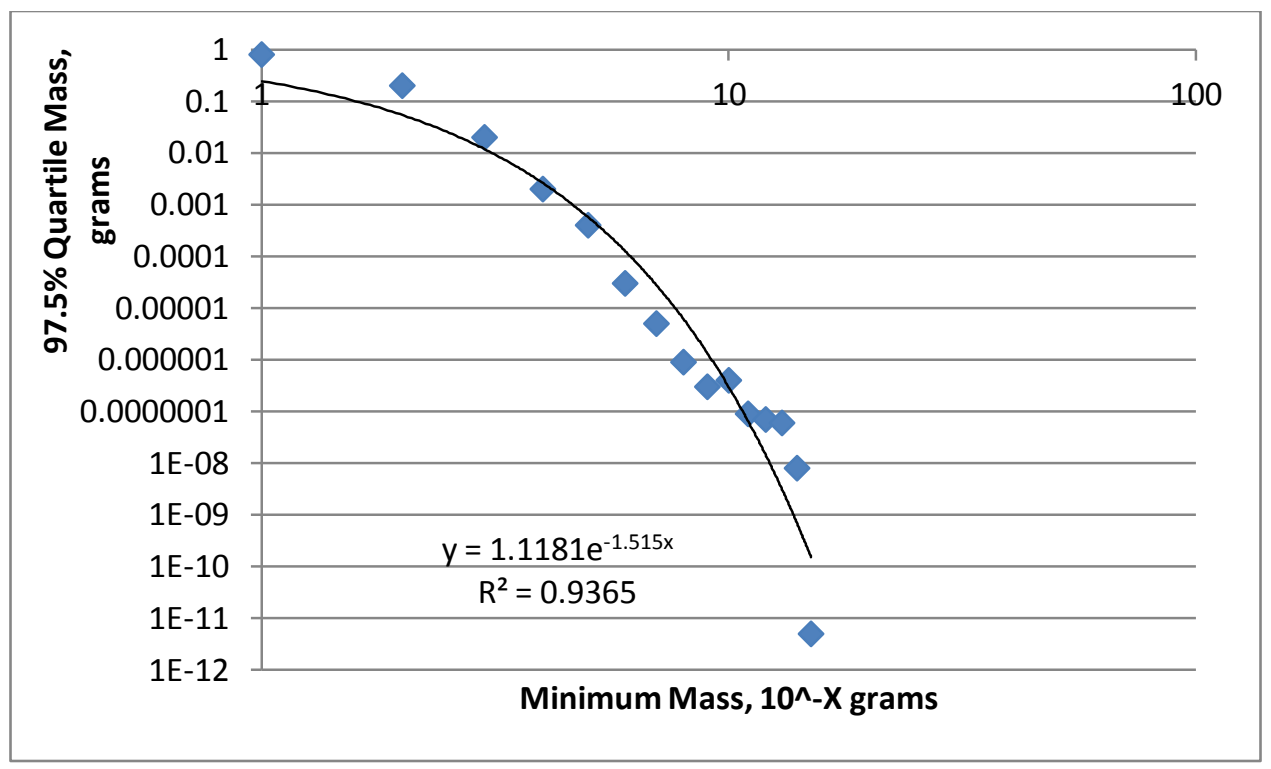

c) $97.5 \%$

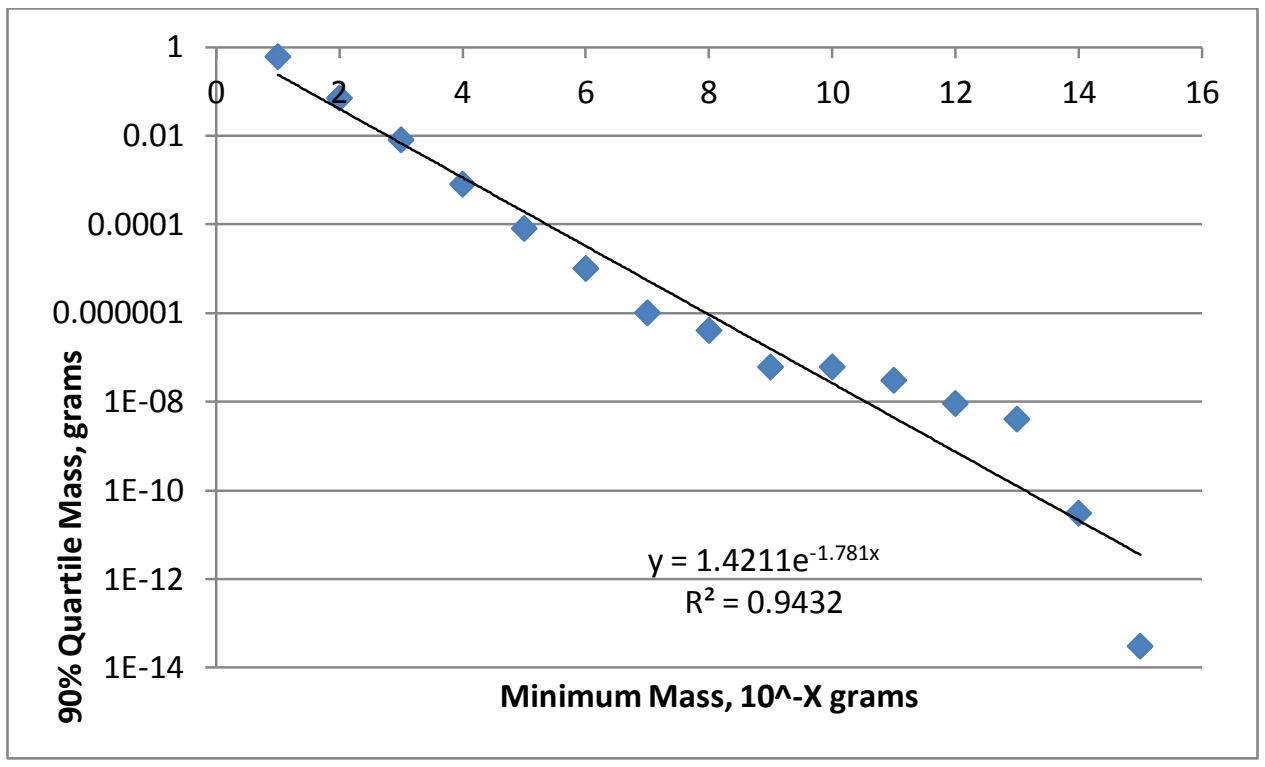

d) $90 \%$ 


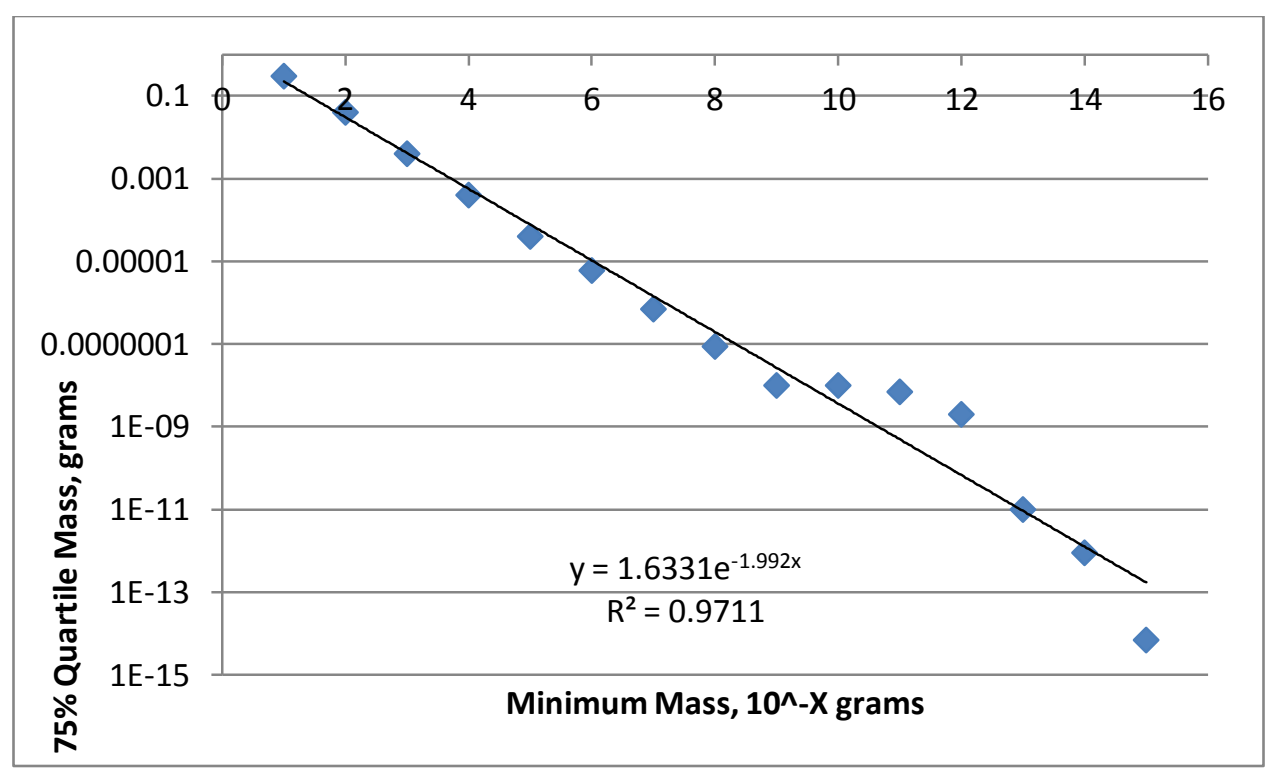

e) $75 \%$

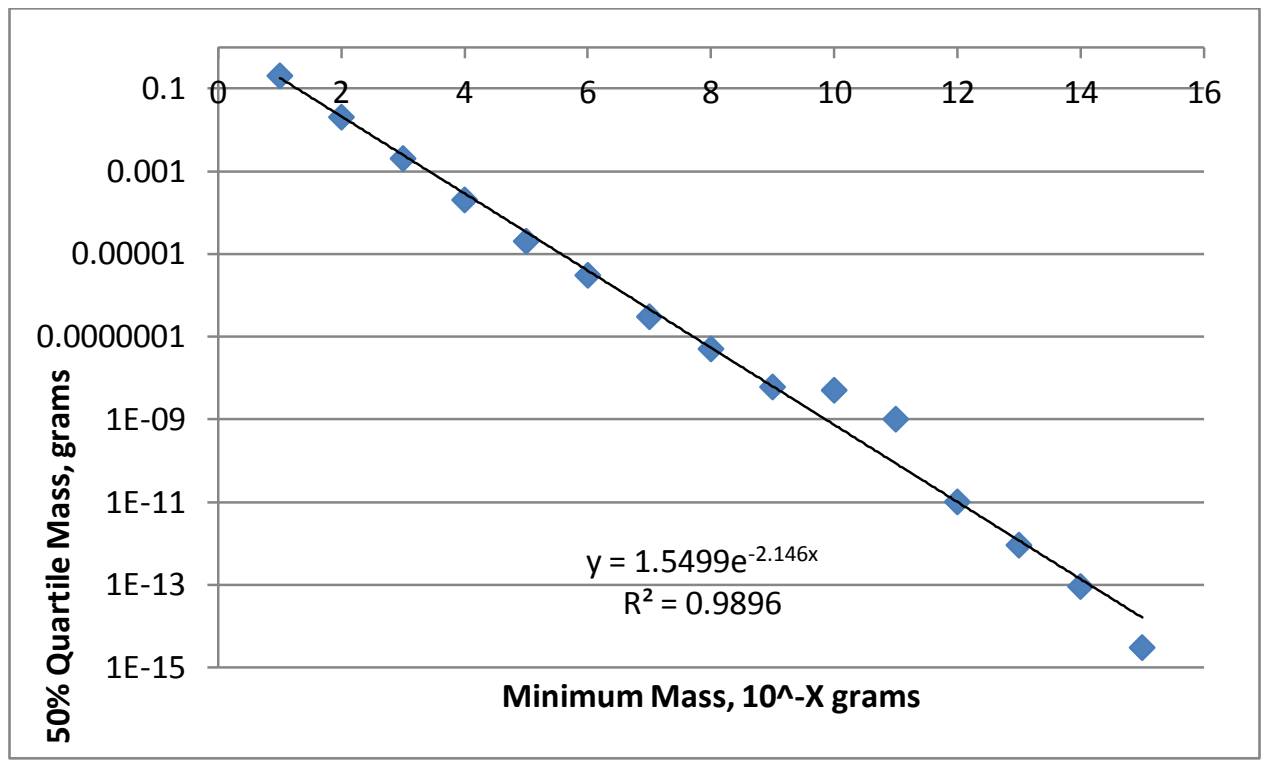

f) $\mathbf{5 0 \%}$ 


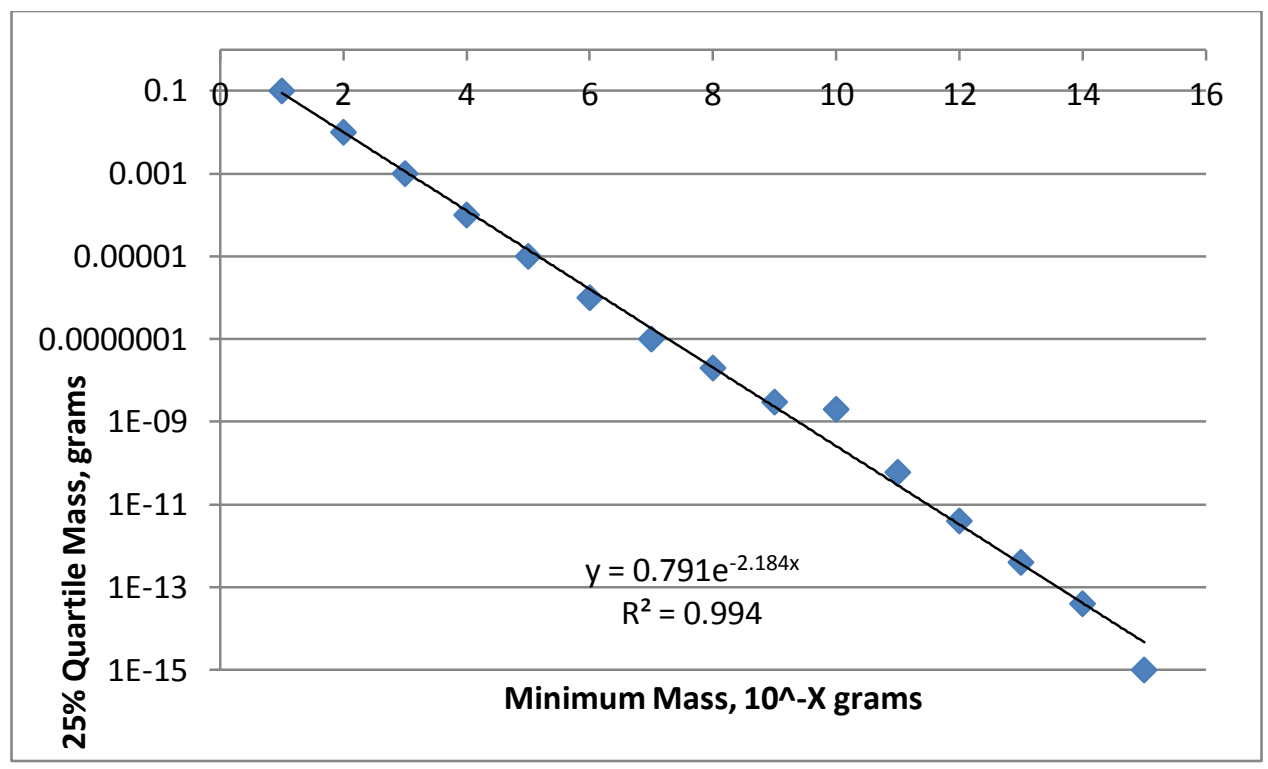

g) $25 \%$

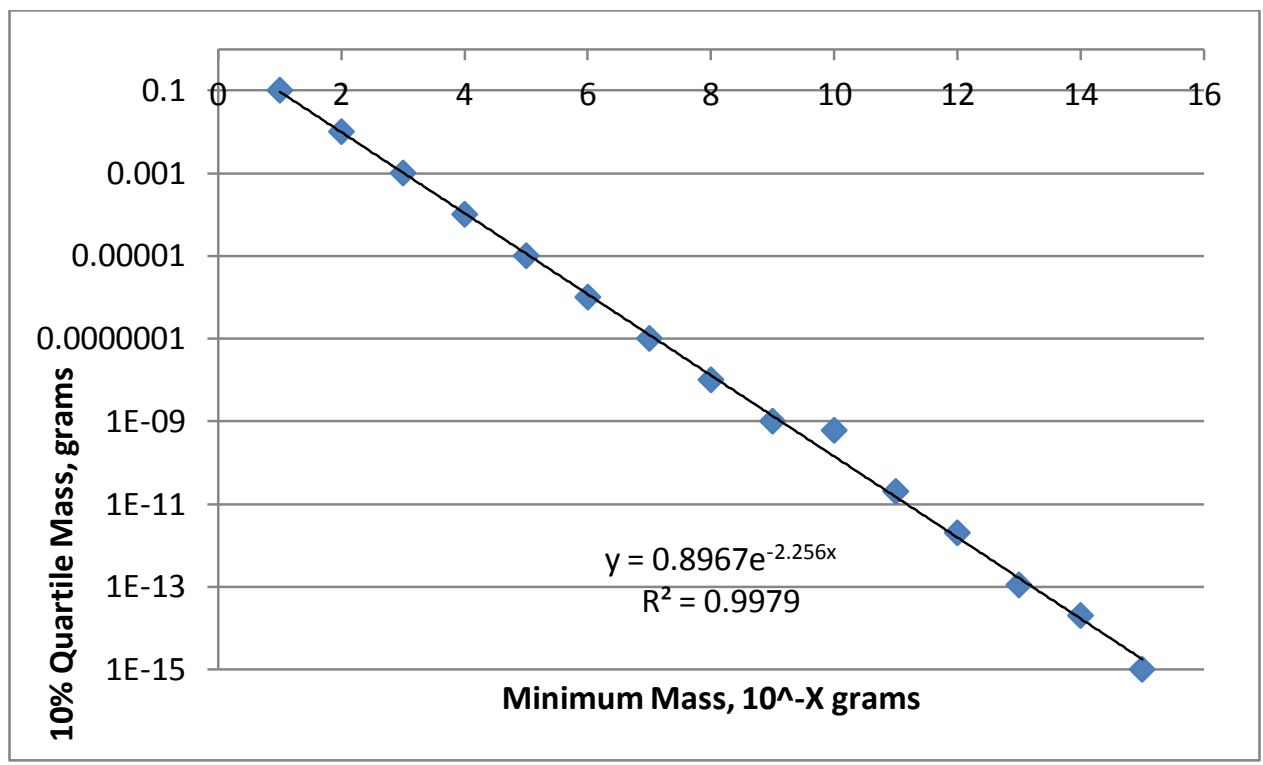

h) $10 \%$ 


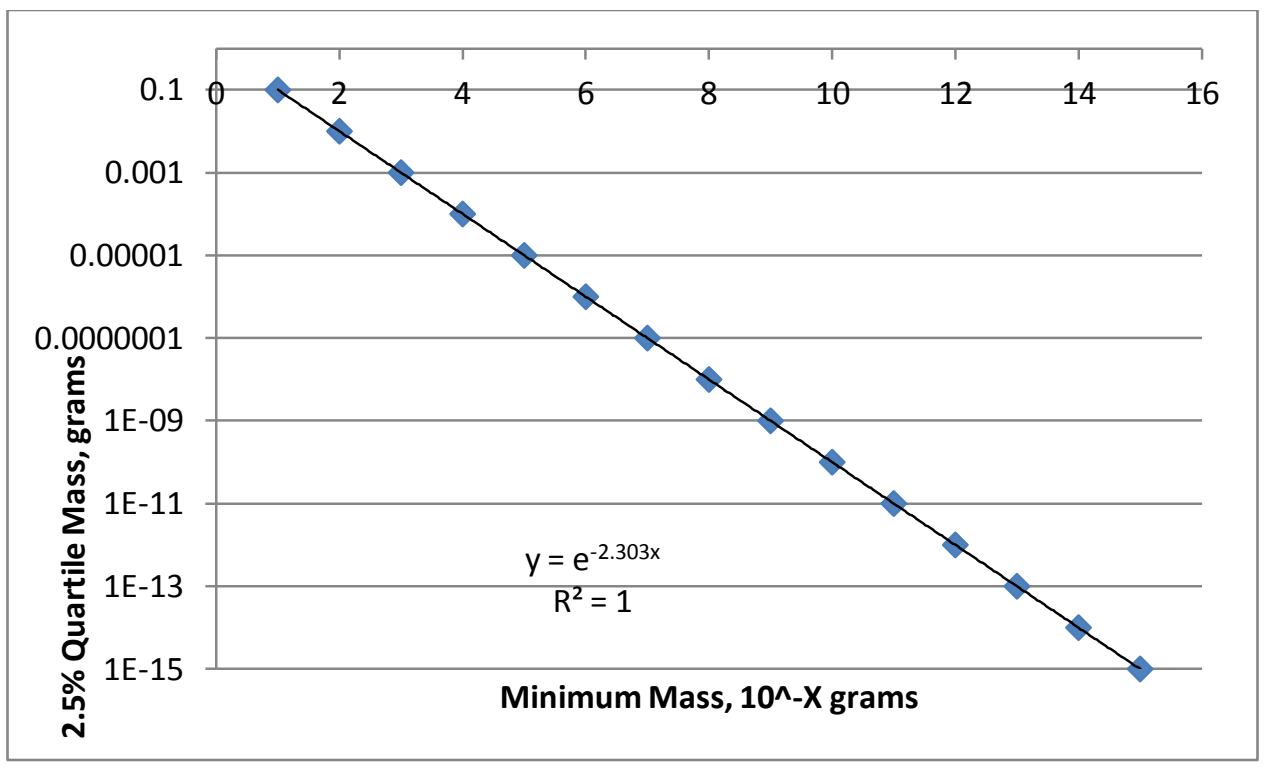

i) $2.5 \%$

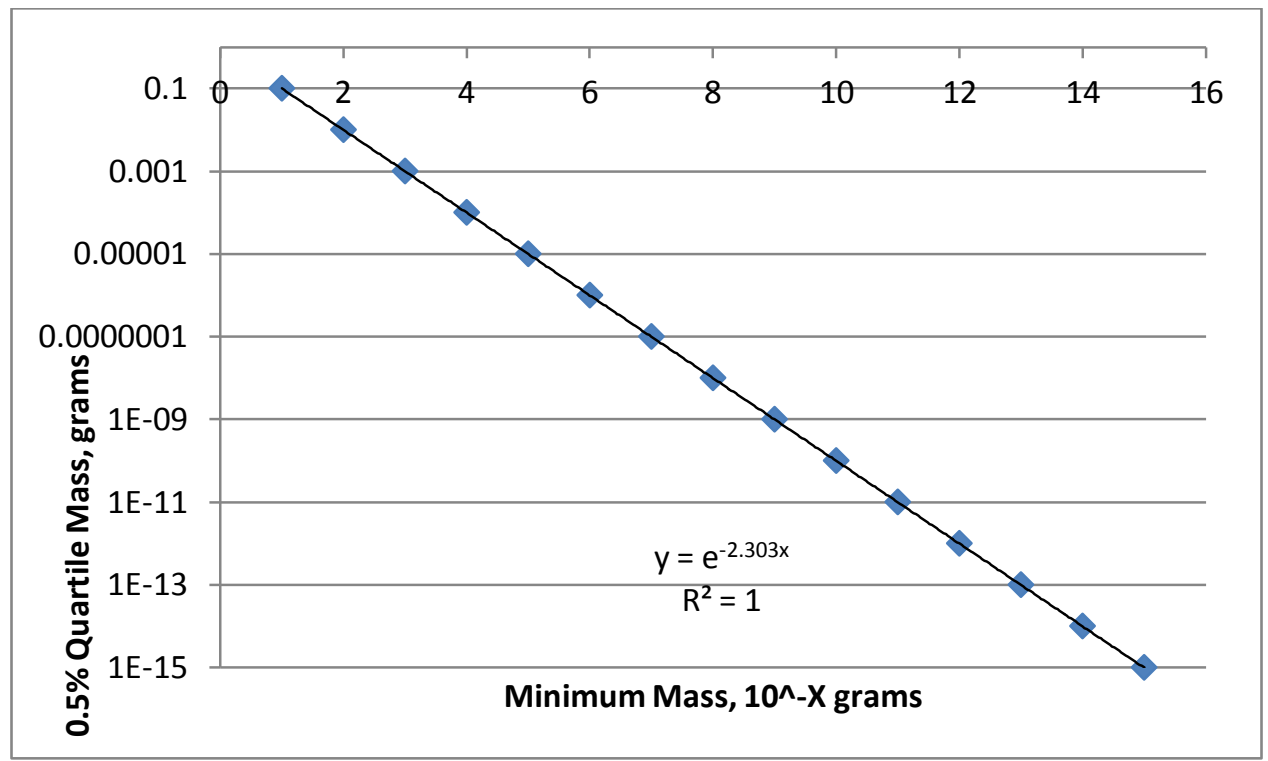

j) $0.5 \%$ 


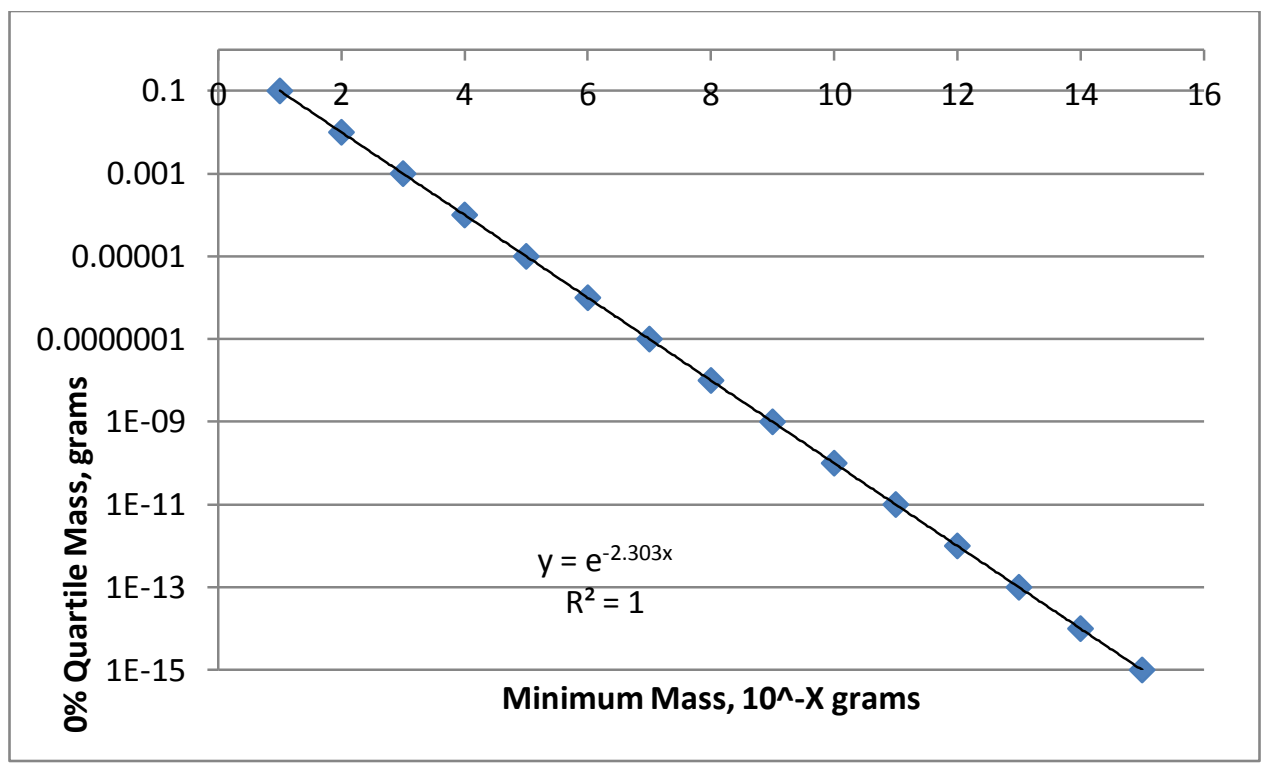

k) $0 \%$

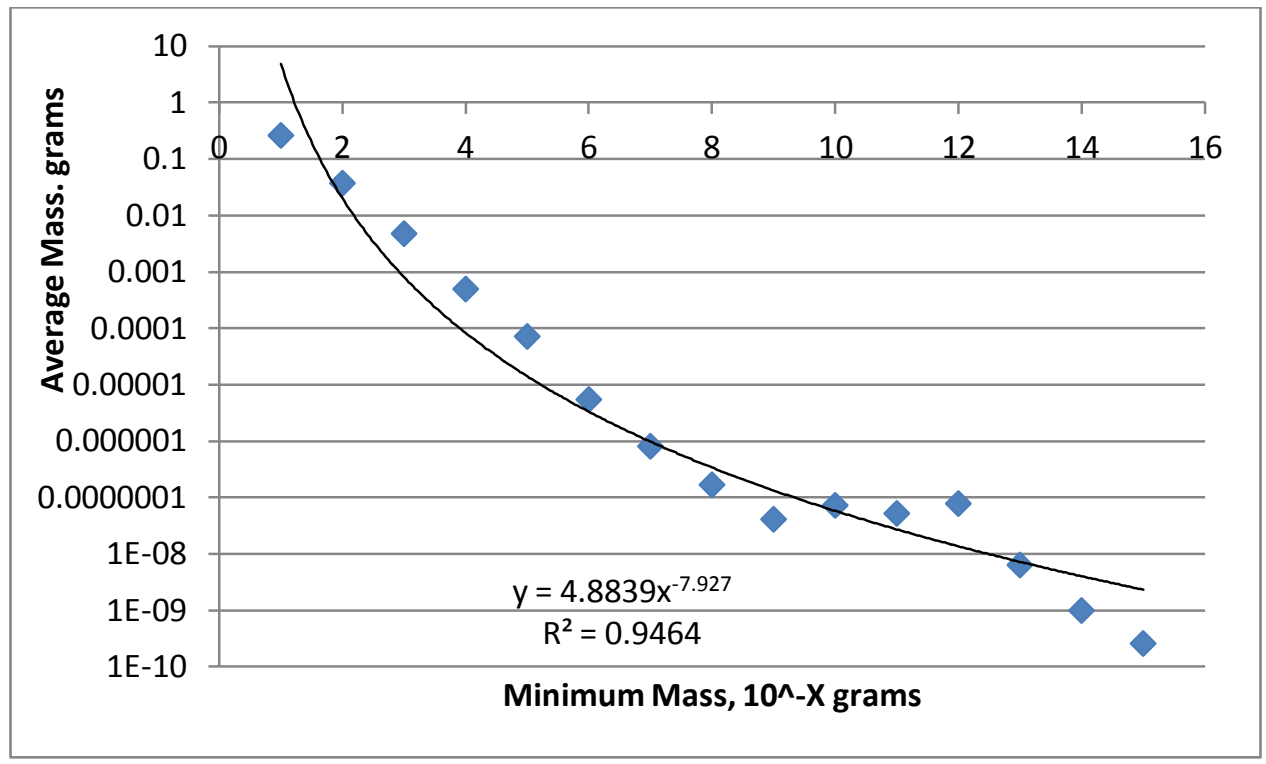

l) Mean 


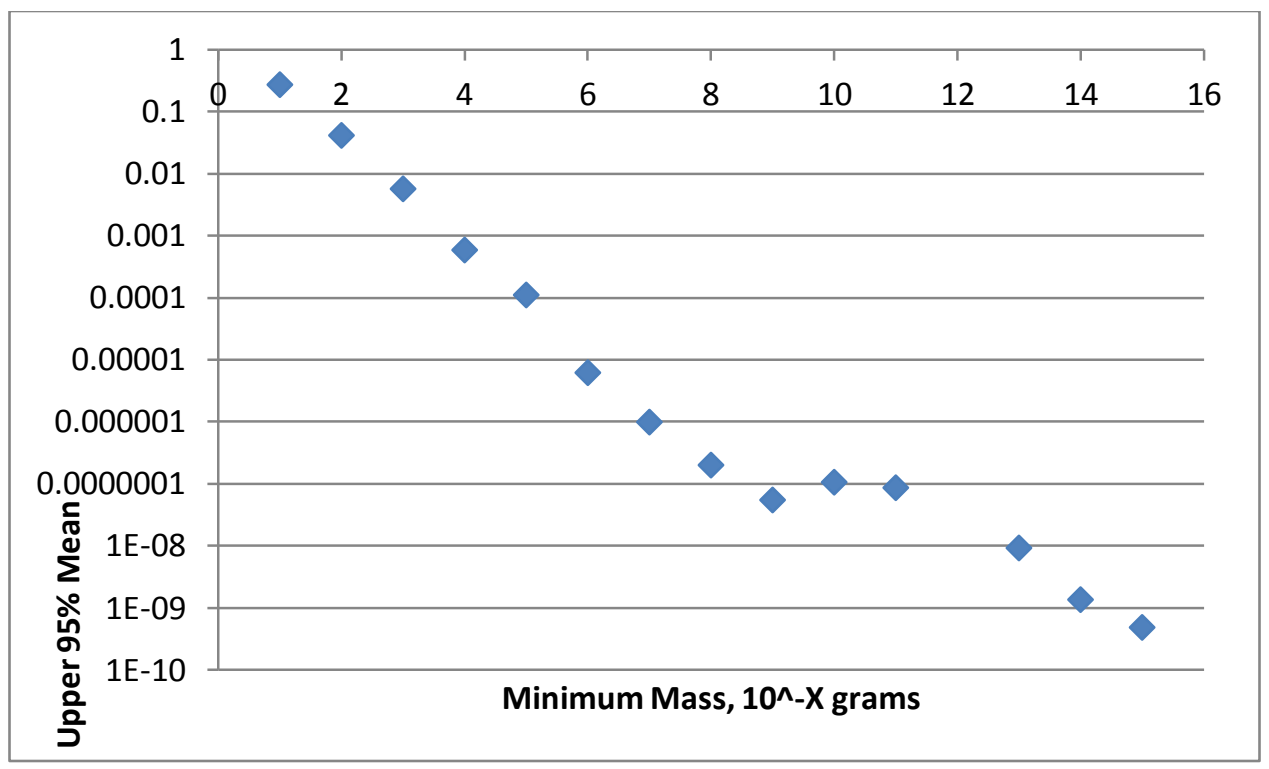

m) Upper 95\% Mean

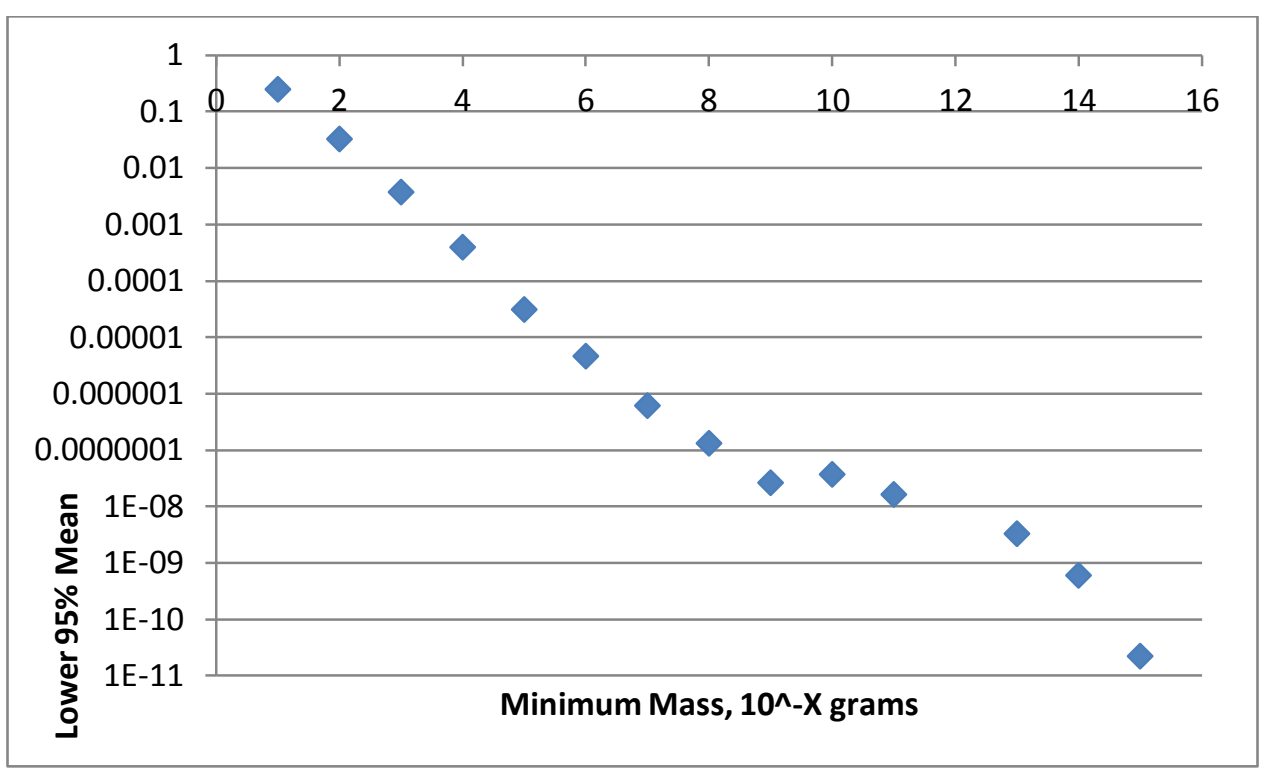

n) Lower 95\% Mean 


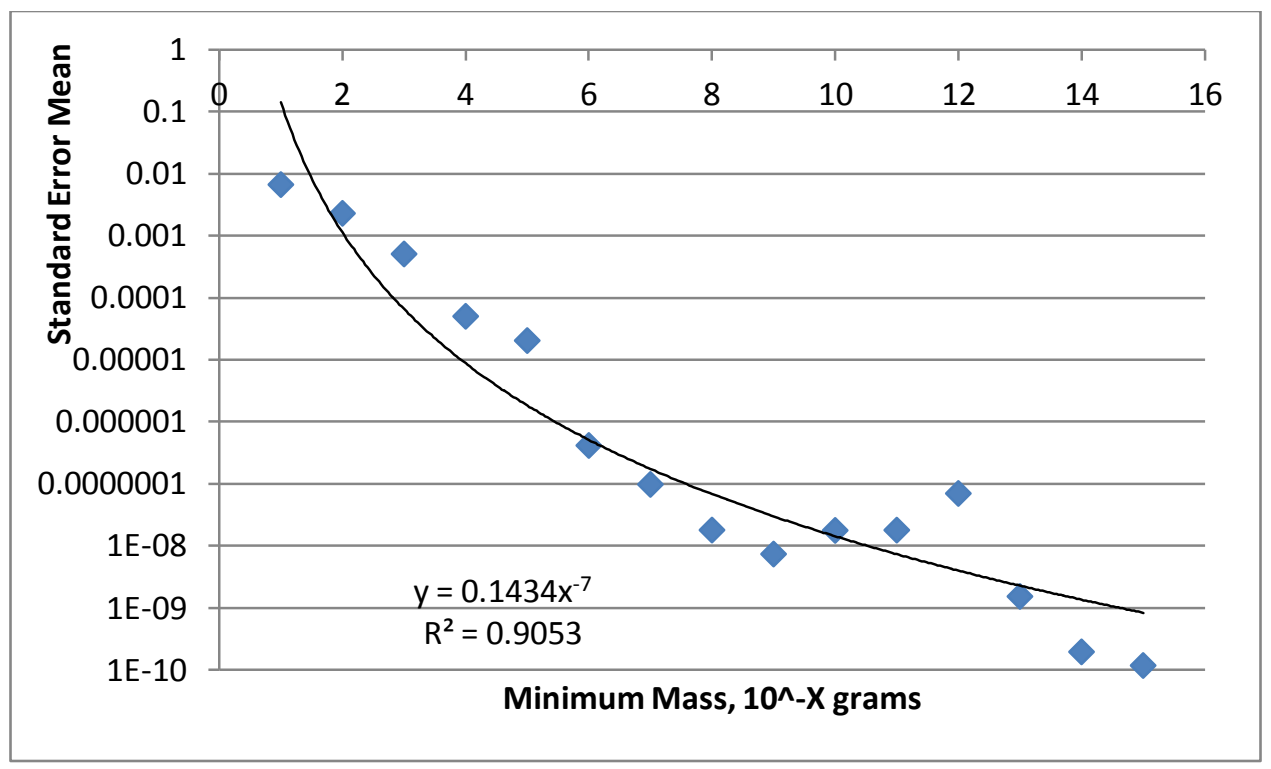

o) Standard Deviation

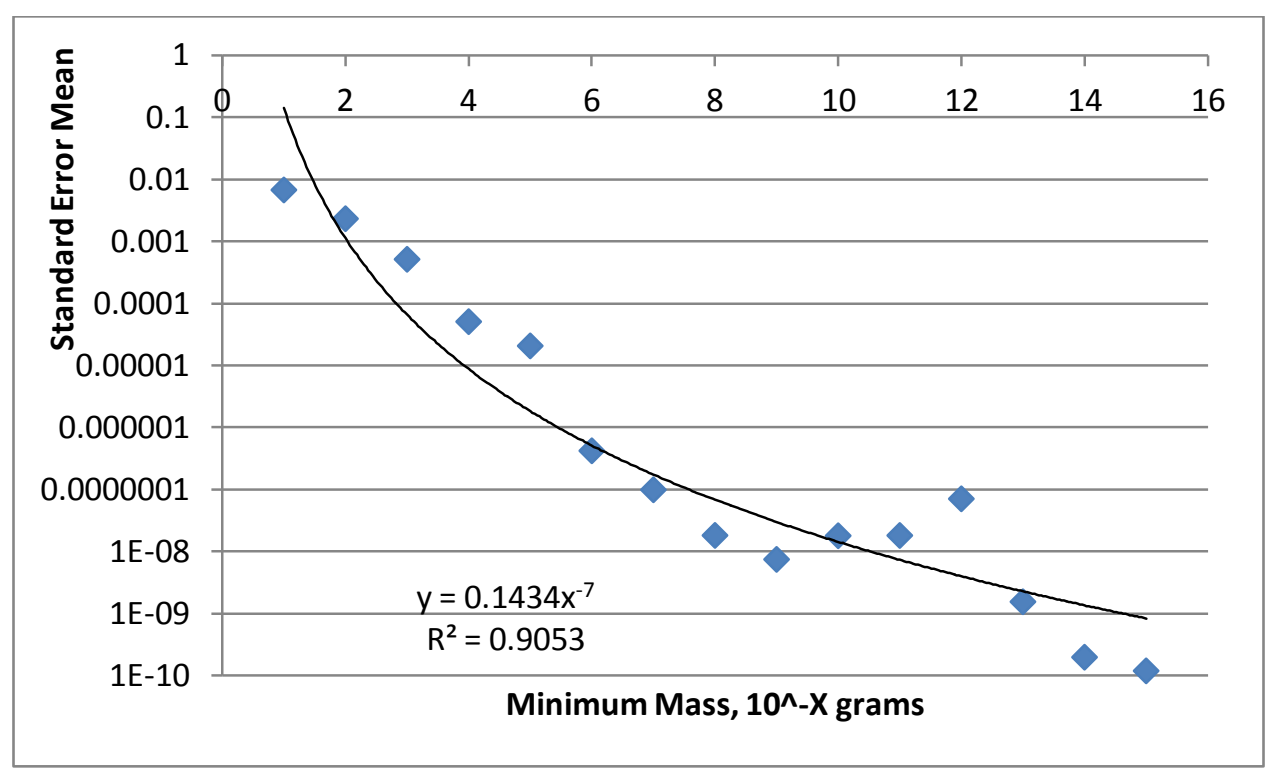

p) Standard Error Mean 